The Twentieth Century in European Memory 


\title{
European Studies
}

\section{AN INTERDISCIPLINARY SERIES IN EUROPEAN CULTURE, HISTORY AND POLITICS}

\author{
Series Editor \\ Menno Spiering (University of Amsterdam)
}

Board Members

Robert Harmsen (Université du Luxembourg)

Joep Leerssen (University of Amsterdam)

Thomas M. Wilson (Binghamton University, State University of New York)

VOLUME 34

The titles published in this series are listed at brill.com/es 


\title{
The Twentieth Century in European Memory
}

\section{Transcultural Mediation and Reception}

\author{
Edited by
}

Tea Sindbæk Andersen

Barbara Törnquist-Plewa

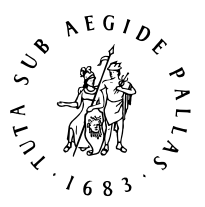

B R I L L

LEIDEN | BOSTON 
This is an open access title distributed under the terms of the CC-BY-NC License, which permits any non-commercial use, distribution, and reproduction in any medium, provided the original author(s) and source are credited.

This book is based upon work from cost Action In Search of Transcultural Memory in Europe, supported by cost (European Cooperation in Science and Technology).

COsT (European Cooperation in Science and Technology) is a funding agency for research and innovation networks. Our Actions help connect research initiatives across Europe and enable scientists to grow their ideas by sharing them with their peers. This boosts their research, career and innovation. www.cost.eu
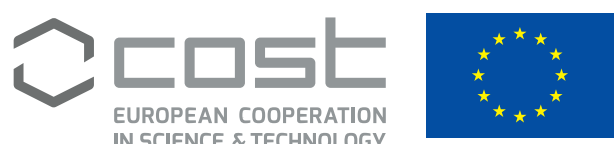

Funded by the Horizon 2020 Framework Programme of the European Union IN SCIENCE \& TECHNOLOGY

The Library of Congress Cataloging-in-Publication Data is available online at http://catalog.loc.gov

Typeface for the Latin, Greek, and Cyrillic scripts: “Brill”. See and download: brill.com/brill-typeface.

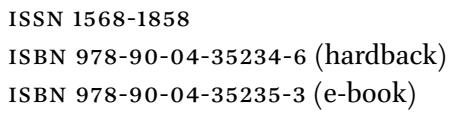

Copyright 2017 by the Editors and Authors.

This work is published by Koninklijke Brill NV. Koninklijke Brill NV incorporates the imprints Brill, Brill Hes \& De Graaf, Brill Nijhoff, Brill Rodopi and Hotei Publishing.

Koninklijke Brill NV reserves the right to protect the publication against unauthorized use and to authorize dissemination by means of offprints, legitimate photocopies, microform editions, reprints, translations, and secondary information sources, such as abstracting and indexing services including databases. Requests for commercial re-use, use of parts of the publication, and/or translations must be addressed to Koninklijke Brill NV.

This book is printed on acid-free paper and produced in a sustainable manner. 


\section{Contents}

Preface VII

List of Illustrations VIII

Notes on Contributors $\mathrm{X}$

1 Introduction: On Transcultural Memory and Reception 1

Barbara Törnquist-Plewa, Tea Sindbck Andersen and Astrid Erll

\section{PART 1}

Actors and Practices in Transcultural Transmission and Reception

2 Cross-Border Collaboration and the Construction of Memory Narratives in Europe $\quad 27$

SaraJones

3 The Polish Elites' Struggle for Recognition of the Experience of Communism in the European Union 56

Magdalena Góra and Zdzisław Mach

4 Answering Back to Presumed Accusations: Serbian First World War Memories and the Question of Historical Responsibility 83

Ismar Dedović and Tea Sindbrek Andersen

5 Beyond Local Memories: Exhumations of Francoism's Victims as

Counter-discourse during the Spanish Transition to Democracy 104

Zoé de Kerangat

6 Double Victims and Agents of Change in Europe's Margins: Estonian

Emigrants Sharing 'Their' Repressive Soviet Past in the Netherlands 122 Inge Melchior

\section{PART 2}

Content and Media in Transcultural Transmission and Reception

7 Commemorating a War That Never Came: The Cold War as

Counter-factual War Memory 149

Rosanna Farbøl 
8 Jews and the Holocaust in Poland's Memoryscapes: An Inquiry Into Transcultural Amnesia 170 Slawomir Kapralski

9 Neither Rupture nor Continuity: Memorializing the Dawn of the Space Age in Contemporary Russian Cinematography 198 Natalija Majsova

10 Literary Mediation and Reception of Memories of War: Hallgrímur Hallgrímsson's 'Under the Republic's Flag' 220 Daisy Neijmann and Gunnthorunn Gudmundsdottir

11 The Italian Hall Tragedy, 1913: A Hundred Years of Remediated Memories 240

Anne Heimo

12 How Does This Monument Make You Feel? Measuring Emotional Responses to War Memorials in Croatia 268 Vjeran Pavlaković and Benedikt Perak

13 Transnational Holocaust Memory, Digital Culture and the End of Reception Studies 305 Wulf Kansteiner

Index 345 


\title{
Preface
}

This volume is the final outcome of the research network In Search of Transcultural Memory in Europe (ISTME) which ran from 2012 to 2016. Funded by the EU COST (Cooperation in Science and Technology) programme, the network was able to bring together scholars from 33 European countries and a variety of disciplinary backgrounds. The goal of the network was to go beyond what we saw as tendencies within memory studies to be too nationally orientated and to reify the bonds between culture, nation and memory. The ambition was to investigate transcultural dynamics of memory in Europe with special attention paid to memories of the troubled twentieth century, and how they have been transmitted and received across the continent. Moreover, the network aimed to develop European memory studies theoretically and methodologically by focusing on transculturality and reception. It is why this volume is centred on these issues.

We would like to express our gratitude to the EU COST programme for its generous support, both during the four years of our network's activities and for the special grant that made the publication of this book possible.

We also want to thank all our colleagues across Europe who helped us run the project, especially the leaders of the Working Groups, the members of the STSM-committee, and last but not least, the local organizers of our conferences, workshops and PhD courses in Krakow, Skopje, Budapest, Kaunas, Dubrovnik, Sofia and Dublin. Many thanks for your commitment!

\author{
Barbara Törnquist-Plewa and Tea Sindbcek Andersen \\ Chair and Vice-chair of ISTME \\ Lund - Copenhagen, 2017
}




\section{List of Illustrations}

\section{Figures}

5.1 Arnedo (La Rioja, Spain), 4 May $1980 \quad 110$

5.2 Arnedo (La Rioja, Spain), 4 May 1980111

6.1 Remembering the Soviet deportations on the Dam square in central Amsterdam, 25 March $2011 \quad 139$

11.1 [S]howbet's YouTube video also includes clippings from local newspapers. Family and friends of Finnish victims held their funeral service at the local Finnish church 247

11.2 Several photos of the Italian hall memorial have been published on TripAdvisor $\quad 25^{2}$

11.3 Search words "italian hall 1913" offer a variety of different types of videos concerning the tragedy $25^{8}$

11.4 The tragedy continues to be discussed on various Facebook sites 261

12.1 The Jasenovac monument by Bogdan Bogdanović during a commemoration in $2014 \quad 279$

12.2 Cover of right-wing weekly Hrvatski tjednik referring to the Jasenovac commemoration as a 'Demonic Dance of Red Bandits' 282

12.3 Image of the Jasenovac monument used to elicit reactions in subjects 286

12.4 Igor Vukić 289

12.5 Zoran Milanović 289

12.6 Aleksandar Vučić 289

\section{Tables}

2.1 Top nine actors in Hohenschönhausen network (excluding Hohenschönhausen) according to degree centrality 37

2.2 Top nine actors in BStU network (excluding BStU) according to degree centrality 39

2.3 Top five actors in BStU 'Arab Spring' component according to degree centrality 40

8.1 Changing perception of Auschwitz-Birkenau in Polish society 184

12.1 The structure of the participants in the Jasenovac study 284

12.2 The results of emotional engagement and cognitive appraisal elicited by the Jasenovac monument representation $\quad 287$ 
12.3 The aggregate mean results for all three groups (Milanović, Vukić, Vučić) after exposing the subjects to the illustration of the Jasenovac monument 288

12.4 Attitudes towards the speaker and the message expressed in measures of mean and standard deviation (SD) 291

12.5 Effects of affective engagement and cognitive appraisal after the speeches by Milanović, Vukić and Vučić, as well as their aggregate effects 295

12.6 An illustration of the effects after the speeches by Milanović, Vukić, and Vučić as measured by t-test 296

12.7 Statistically significant effects sizes after Milanović's speech 298

12.8 Statistically significant effects sizes after Vukić's interview 299

12.9 Statistically significant effects sizes after Vučić's speech 299

12.10 Statistically significant effects sizes after the speeches for the aggregate data set 299 


\section{Notes on Contributors}

\section{Barbara Törnquist-Plewa}

is professor of Eastern and Central European Studies and head of the Centre for European Studies at Lund University in Sweden. Her research focuses on nationalism, identity and collective memories in Eastern and Central Europe. She has participated in numerous international research projects, most recently (2012-2016) as chair of the European research network "In Search for Transcultural Memory in Europe" (financed by the EU's cosT-programme). Among her recent publications are: Whose Memory? Which Future? Remembering Ethnic Cleansing And Lost Cultural Diversity in Eastern, Central and Southeastern Europe (Berghahn 2016) and The Europeanization of Heritage and Memories in Poland and Sweden (edited with Krzysztof Kowalski) Krakow 2016.

\section{Tea Sindbcek Andersen}

is Assistant Professor of Balkan Studies at the Department of Cross-cultural and Regional Studies, University of Copenhagen. Tea's research focuses on the contemporary history of Southeastern Europe, especially on issues related to uses of history, cultural memory, identity politics and popular culture in the Yugoslav area. 2012-2016 she acted as vice-chair of the European research network "In Search for Transcultural Memory in Europe" (financed by the Eu's cost-programme). She is the author of Usable History? Representations of Yugoslavia's difficult past from 1945 to 2002 (Aarhus University Press 2012) and, with Barbara Törnquist-Plewa, editor of Disputed Memory. Emotions and memory politics in Central, Eastern and South-eastern Europe (De Gruyter 2016).

\section{Astrid Erll}

is Professor of Anglophone Literatures and Cultures at Goethe-University Frankfurt (Germany). She has worked on memories of the First World War, the Spanish Civil War, British colonialism in India, the Iraq wars, and the Vietnam war. She is general editor of the book series Media and Cultural Memory (de Gruyter, since 2004), co-editor of A Companion to Cultural Memory Studies (with A. Nünning, 2010), Mediation, Remediation, and the Dynamics of Cultural Memory (with A. Rigney, 2009), Audiovisual Memory and the (Re-)Making of Europe (Image [\&] Narrative, with A. Rigney, 2017), and author of Memory in Culture (Palgrave 2011), an introduction to memory studies.

\section{SaraJones}

is a Senior Lecturer at the University of Birmingham. Her research focuses on European cultural and political memory, particularly of post-socialism. She is 
author of a series of articles and chapters around these themes and two monographs: Complicity, Censorship and Criticism: Negotiating Space in the GDR Literary Sphere (Berlin: de Gruyter, 2011) and The Media of Testimony: Remembering the East German Stasi in the Berlin Republic (Basingstoke: Palgrave, 2014)

\section{Zdzistaw Mach}

is professor in sociology and anthropology at the Jagiellonian University. Founder and former head of the Institute for European Studies at the Jagiellonian University, and one of the main authors of the European Studies curriculum in Poland. Currently the Dean of the Faculty of International and Political studies of the JU. His research interests cover identity issues such as nationalism, minorities and ethnicity, the development of European citizenship, migration and the reconstruction of identity, the ethnic origin of a nation and construction of identities as well as the development of the idea of Europe.

\section{Magdalena Góra}

earned her degree in Political Science from Jagiellonian University (MA 2000). Her Ph.D. (2007) was on the relations between Poland and Israel after the Second World War. From 2007 onwards she has been researcher at the Institute of European Studies of the Jagiellonian University, primarily concentrating her work on the external relations of the European Union, the changes in foreign policy and international relations in Central and Eastern Europe as well as on collective identification changes in the European Union after enlargement. She studied and worked at academic institutions in several countries (Poland, the United Kingdom, Sweden, Norway, the USA).

\section{Ismar Dedović}

is a Doctoral Candidate at the SAxo Institute at the University of Copenhagen. He studied history at the University of Copenhagen where his got his BA (2009) and MA (2012). His research interests concentrate on Yugoslav and post-Yugoslav history as well as on memory and uses of history in the Yugoslav region. He has published several scholarly articles on the cultural memory of World War One history. His current research project is titled: Our War? Their War? What War? Transnational Discussions on the Great War in BiH, Croatia and Serbia.

\section{Zoé de Kerangat}

is a researcher at the Spanish National Research Council (CSIC) and a PhD candidate in Contemporary History at Universidad Autónoma de Madrid (UAM), writing her thesis about Civil War mass grave exhumations in Spain in the 70s and 8 os. She is a member of the project "The underground past: exhumations 
and memory politics in contemporary Spain in transnational and comparative perspective" CSO 2015-66104-R, funded by the Spanish Ministry of Economy and Competitiveness, and of the project "UNREST Unsettling Remembering and Social Cohesion in Transnational Europe", funded by the European Commission program H2020-REFLECTIVE-SOCIETY-2015.

\section{Inge Melchior}

defended her PhD thesis titled "Guardians of living history: the persistence of the past in post-Soviet Estonia" at the vU University Amsterdam in 2015. As a sociologist and anthropologist, she focuses on the social practice of collectively remembering of the Second World War and the Soviet period among Estonians, both on the personal/familial and the political level. Her research is primarily based on ethnographic fieldwork, combined with statistical analyses of representative survey data. She has presented her work on the memory reception of grassroots agents on various international conferences and in peer reviewed journals and edited volumes.

\section{Rosanna Farbøl}

holds a PhD in History from Aarhus University, Denmark. In her thesis she examined how narratives of the Cold War were used in the post-Cold War era as cultural imaginary, and political and moral compass. Her latest publications include "Commemoration of a cold war. The politics of history and heritage at Cold War memory sites in Denmark", Cold War History 2015, 15(4) and "Framing the past, shaping the future. Political uses of the foreign policy tradition in contemporary Danish politics" in Ingimundarson \& Magnusdottír (eds.): Nordic Cold War Cultures: Ideological Promotion, Public Reception, and East-west Interactions Aleksanteri Cold War Series, 2015.

\section{Slawomir Kapralski}

$\mathrm{PhD}$, is Professor of Sociology at the Pedagogical University of Krakow and Recurrent Visiting Lecturer at the Center for Social Studies in Warsaw. He graduated from the Jagiellonian University in Krakow and has for several years been associated with the Central European University. He was Senior Fellow at the Wiener Wiesenthal Institut für Holocaust-Studien and in 2016-2017 he is Senior EURIAS Fellow at the Swedish Collegium for Advanced Study in Uppsala. He publishes, conducts research and participates in educational initiatives in the field of Polish-Jewish relations and among Roma communities of East/ Central Europe.

\section{Natalija Majsova}

received her PhD (2015) in cultural studies from the University of Ljubljana. She is currently assistant professor and researcher at ERUDIO Business School 
(Ljubljana). Since 2012, she has also worked as a researcher and teaching assistant at the Department of Cultural Studies of the University of Ljubljana, and has been expert associate to the Cultural Centre of European Space Technologies (KSEVT Vitanje). Her monograph, which provides a cultural studies approach to space-themed cinema, The Cosmonauts Are Among Us: Outer Space in 21st Century Russian Cinema, which will be published by Založba FDV (University of Ljubljana) in 2017.

\section{Daisy Neijmann}

received her PhD from the Vrije Universiteit in Amsterdam in 1994. She was Assistant Professor in Icelandic-Canadian Studies at the University of Manitoba and Reader in Icelandic at UCL. She currently teaches Icelandic literature and culture at the University of Iceland. She is the author of The Icelandic Voice in Canadian Letters and Colloquial Icelandic (2000, rev. edn. 2013), editor of $A$ History of Icelandic Literature (2006), and has published widely on IcelandicCanadian literature, modern Icelandic fiction, Icelandic literary historiography, war memory and trauma texts, and Icelandic as a second and heritage language.

\section{Gunnthorunn Gudmundsdottir}

received her PhD from the University of London in 2000 and is Professor of Comparative Literature at the University of Iceland. She has published widely on contemporary life writing and memory studies including her two books, Borderlines: Autobiography and Fiction in Postmodern and Life Writing (Rodopi 2003) and Representations of Forgetting in Life Writing and Fiction (Palgrave Macmillan 2016).

\section{Anne Heimo}

is senior researcher at the School of History, Culture and Arts Studies, University of Turku, Finland. Her research interests include everyday memory practices online and offline, family narratives and reading and writing below. Her research has focused especially on the memories of the 1918 Finnish Civil War and memories of migration. She is chair of the Finnish Oral History Network and co-chair of the EssHC Oral history and life stories network. She has recently co-edited the special issue of Oral History on Nordic-Baltic oral history (2016).

\section{Vjeran Pavlaković}

is an associate professor at the Department of Cultural Studies at the University of Rijeka. He received his Ph.D. in History in 2005 from the University of Washington, and has written on cultural memory, transitional justice in the former Yugoslavia, and the Spanish Civil War. Recent publications include 
"Remembering War the European Way: Croatia's Commemorative Culture on the Eve of Eu Membership" in Pero Maldini and Davor Pauković, eds., Croatia and the European Union: Changes and Development (2015) and Yugoslav Volunteers in the Spanish Civil War (2014). He is also the lead researcher on the project FRAMnAT funded by the Croatian Science Foundation (HRZZ).

\section{Benedikt Perak}

is a senior assistant at the Department of Cultural Studies, University of Rijeka. His main fields of research include the conceptualization and communication of emotions, subjective states, and complex semantic processes of construction of social identity. His research is based on system theory, embodied cognition theory, graph theory and methodology of cognitive and corpus linguistics and natural language processing. He is a currently a researcher on the projects "Repository of Croatian Metaphor Repository" and "Framing the Nation and Collective Identity in Croatia: Political Rituals and the Cultural Memory of 2oth Century Traumas" funded by the Croatian Science Foundation.

\section{Wulf Kansteiner}

is Professor of History at Aarhus University and has published in the fields of media history, memory studies, historical theory, and Holocaust studies. His research focuses on representations of history in visual culture, especially TV representations of Nazism and the Holocaust; the narrative structures of historical writing; and the methods and theories of memory studies. He is the author of In Pursuit of German Memory: History, Television, and Politics after Auschwitz (2006) and, most recently, co-editor of Probing the Ethics of Holocaust Culture (2016). He is also co-founder and co-editor of the Sage-Journal Memory Studies (published since 2008). 


\title{
Introduction: On Transcultural Memory and Reception
}

\author{
Barbara Törnquist-Plewa, Tea Sindbcek Andersen and Astrid Erll
}

In the autumn of 2012, the sculpture The Black Cone by the Spanish artist Santiago di Sierra was placed in front of the Parliament of Iceland, on Reykjavik's symbolic square Austurvöllur. The Black Cone was intended to commemorate the massive public protests, the so-called 'pots and pans revolution' in Iceland 2008-2009 against the politicians held responsible for the country's financial crash. While the majority of Reykjavik's city council in 2012 agreed to accept the artist's donation of the monument, council members were divided on the issue and it did raise controversies. ${ }^{1}$ Yet, since 2012 the monument has largely vanished from public attention. ${ }^{2}$ Perhaps its shape - a natural rock with a ridge created by a small black cone - allows it to remain unnoticed or casually overlooked as one of several organic parts of the square. How are we to understand this lack of explicit reactions to di Sierra's monument? Is it rejection, purposeful ignoring, or simply indifference? At the very least we can say that as by 2016, no one has taken ownership or re-appropriated the monument as a memorial representation for her or his own purposes. ${ }^{3}$

When in 2012 Christopher Clark published the book The Sleepwalkers. How Europe Went to War in 1914 as yet another attempt to analyze the causes of the outbreak of the First World War, reactions were numerous. Published strategically at the advent of the war's centenary by a renowned Cambridge historian, The Sleepwalkers was reviewed in newspapers and history journals across Europe, sometimes with acclaim and sometimes with lukewarm appreciation. ${ }^{4}$ Clark's account was also included in several scholarly review articles that

1 'Sierra's "Black Cone" Causes Controversy in Reykjavik,' Iceland Review Online, 5 October 2012, accessed 8 October 2016. http://icelandreview.com/news/2012/10/05/sierras-black -cone-causes-controversy-reykjavik.

2 Gunnpórunn Guðmundsdóttir, 'Memory and Memorialisation in Post-Recession Iceland' (paper presented at the conference Collapse of Memory - Memory of Collapse: Remembering the Past, Re-Constructing the Future in Periods of Crisis, Lund, 20-22 September 2016).

3 Ibid.

4 See for example Ian Pindar, 'The Sleepwalkers by Christopher Clark - review,' The Guardian, 19 July 2013, accessed 8 August 2016, https://www.theguardian.com/books/2013/jul/19/ 
traced the arguments proposed in the wave of new history books appearing in connection with the centenary of the First World War. ${ }^{5}$ Moreover, Clark made an effort to create attention around his book and held lectures in numerous German cities during the summer of 2014. Yet, for academic literature more unusually, Clark's book was also explicitly mentioned in a speech by Serbia's president Tomislav Nikolic two years after its publication, in the summer of 2014. Clark, according to Nikolić, was the primary source of a revisionism that aimed to convince the world that it was Serbs who had caused the Great War. Thus, argued Nikolić, 'the Serb struggle for freedom ... is now to be dragged through the mud'. ${ }^{6}$ Though Clark himself had, already in 2013, clearly stated that he had 'of course not wished to blame Serbia for the outbreak of the war', this was clearly how he was interpreted by Nikolić and a number of historians and commentators in Serbia. ${ }^{7}$

Thus, unlike The Black Cone, which seems to have become a silent and unengaging medium of commemoration in spite of the importance of the events it recalls, Clark's book caused very explicit reactions, both in the historical debates of several European countries and in the political sphere and commemorative activities of Serbia in 2014. As these two examples show, the effects and afterlives of memorializations and reinterpretations of the past can vary to a great extent. Trying to understand how and why individuals and communities react towards mediations of memory is a complex challenge. In an article published in 2002, Wulf Kansteiner points out that memory studies have 'not yet paid enough attention to the problem of reception both in

sleepwalkers-christopher-clark-review;Sean McMeekin, 'The Sleepwalkers. How EuropeWent to War in 1914,' History Today, 62, 12 December 2012, accessed 8 August 2016, http://www.histo rytoday.com/blog/2012/11/sleepwalkers-how-europe-went-war-1914.

5 See e.g. Hew Strachan, 'Review article: The origins of the First World War,' International Affairs 90, 2 (2014): 429-439; Andrew G. Bonnell, 'New Histories of the Origins of the First World War: What happened to the "Primacy of Domestic Politics"?' Australian Journal of Politics and History 61, 1 (2015): 121-127; William Mulligan, 'The Trail Continues: New directions in the Study of the Origins of the First World War,' English Historical Review 129, no. 538 (2014): 639-666.

6 'Govor Predesednika Reublike, sANu - Veliki rat, 13.6.2014.' (Supplied at request from the press centre at the office of the President of the Republic of Serbia). See also 'Srbija ušla u Prvi svetski rat da bi opstala,' President of the Republic of Serbia, Press centre, 13 June 2014, accessed 8 August 2016, http://www.predsednik.rs/lat/pres-centar/vesti/ srbija-usla-u-prvi-svetski-rat-da-bi-opstala.

7 'Srbi su 1914, bili sami - Evropljani,' Deutsche Welle, 11 November 2013, accessed 8 August 2016, http://www.dw.com/sr/srbi-su-1914-bili-samo-evropljani/a-17215852. See also the chapter by Dedovic and Sindbæk Andersen in this volume. 
terms of methods and sources'. Since then, the field of memory studies has developed in many important directions, but it is the contention of the editors and authors of this volume that we still struggle with the questions of how to understand and study the reception of memories. ${ }^{9}$ The aim of this book is to move forward the scholarly discussion of these questions while paying special attention to the transcultural and transnational dimensions of memory transmission and reception across Europe.

As no mediation of memory can have an impact on memory culture if it is not 'received' - seen, heard, used, appropriated, made sense of, taken as an inspiration - by a group of people, reception is indeed one of the key issues within memory studies. Collective memory is an ongoing process of mediation; it is produced by the continuous internalization and externalization of memory contents and memory forms within social groups. Whatever narratives or images about the past are externalized (via 'media' as diverse as facial expressions, orality, performance, sculpture, texts, television or the internet), they can only become a meaningful part of collective memory once they are also internalized, i.e. received by audiences, readers, listeners, users or consumers. ${ }^{10}$

Reception is a central concern of the new transcultural memory studies. If we assume that all memory 'travels' (Erll), is constantly 'on the move' (Rigney), then it clearly must move somewhere, towards a (however transitory) destination. Successful memory transmission entails reception. Transcultural memory research deals with acts of reception which are located beyond commonly assumed boundaries (national, ethnic, linguistic, religious ones, for example). For transcultural memory to actually come into existence, deterritorialized transmission must be followed by localizing reception. It does not come as a surprise, therefore, that key concepts of transcultural memory studies rely, more or less markedly, on the idea of memory reception: Levy and Sznaider's 'cosmopolitan memory' is an effect of (productive) appropriations of the

Wulf Kansteiner, 'Finding meaning in memory: A methodological critique of collective memory studies,' History and Theory 41 (2002): 180.

One indication of this is the fact that the otherwise timely collection Research Methods for Memory Studies (2013) does not feature a chapter on reception. A sustained discussion of reception from the angle of television studies is, however, provided by Ann Gray ('Televised remembering', in: Emily Keightley \& Michael Pickering, eds. Research Methods for Memory Studies. Edinburgh: Edinburgh UP 2013, 79-96).

10 On the mediation of memory and mediated memories see Astrid Erll and Ann Rigney, eds., Mediation, Remediation, and the Dynamics of Cultural Memory (Berlin/New York: de Gruyter, 2009); José van Dijck, Mediated Memories in the Digital Age (Stanford, CA: Stanford University Press, 2007); Joanne Garde-Hansen, Media and Memory (Edinburgh: Edinburgh University Press, 2011). 
globally circulating Holocaust-schema. ${ }^{11}$ Michael Rothberg's 'multidirectional memory' is based on the reception and recombination of different memories. ${ }^{12}$ Alison Landsberg's 'prosthetic memory' explicitly deals with memory reception and describes it graphically as the 'taking on' of a mediated 'memory limb'. Landsberg highlights the role of empathy as an important prerequisite of memory reception, and of solidarity as one of its potential effects. ${ }^{13}$ Studies of transgenerational transmission, too, rely on the idea that younger people 'receive' memory messages transmitted by an older generation, however implicitly. Seen in this way, Marianne Hirsch's 'postmemory' is first of all an effect of memory reception. ${ }^{14}$ But however fundamental the idea of reception may be to memory studies' current key concepts, the question of how to observe and analyse concrete acts of reception remains the major conundrum of the field.

How can memory studies address reception? One important caveat that has already been voiced by Kansteiner is that memory scholars should not conflate individual reception with receptions that are collectively relevant, i.e. that shape or change the collective memories of a group. ${ }^{15}$ It would be a 'receptional fallacy' to study reactions and memory negotiations among individuals or aggregations of individuals (for example, a group of viewers' reactions to a film) and to draw from there conclusions about collective memories. It therefore seems important to distinguish between different dimensions and scales of reception: As Halbwachs has already emphasized, individual memories are always shaped by social contexts. ${ }^{16}$ Jeffrey Olick therefore describes individual memories as "collected memories". ${ }^{17}$ Collected memories are rooted in biological and psychic processes. They need to be differentiated from the dimension of "collective memory" in the narrower sense: the media, social practices and institutions that enable people to share memories, that often substantiate the

\footnotetext{
11 Daniel Levy and Natan Sznaider, The Holocaust and Memory in the Global Age (Philadelphia: Temple University Press, 2006).

12 Michael Rothberg, Multidirectional Memory: Remembering the Holocaust in the Age of Decolonization (Stanford, CA: Stanford University Press, 2009).

13 Alison Landsberg, Prosthetic Memory: The Transformation of American Remembrance in the Age of Mass Culture (New York: Columbia University Press, 2004).

14 Marianne Hirsch, The Generation of Postmemory: Writing and Visual Culture After the Holocaust (New York: Columbia University Press, 2012).

15 Kansteiner, Finding meaning in memory.

16 Maurice Halbwachs, Les cadres sociaux de la mémoire, edited by Gérard Namer (Paris: Albin Michel, 1994 [1925]).

17 Jeffrey K. Olick, 'Collective Memory. The Two Cultures,' Sociological Theory 17, 3 (1999): 333-348.
} 
identity of a given group and that are anchored in the group's cultural life. ${ }^{18}$ Only the ongoing interaction of both, individual and socio-medial dimensions of memory can generate what Maurice Halbwachs termed la mémoire collective. Furthermore, as De Cesari and Rigney (2014) have argued, there are different 'scales' of memory, such as the intimate, the familial, the local, the urban, the regional, the national, the transnational and the global. These are also the 'scales of reception'. Of course, each scholar who studies the reception of memory mediations will - depending on disciplinary background, methodological inventory and research questions - lay emphasis on specific dimensions and scales. However, as the dynamics of memory consists in the continuous movement of contents and forms between such levels, reception research will profit greatly from multi-level analyses.

Such complex research designs are of particular relevance for studies that aim to provide (mnemo)historical insights into how changes in cultural systems of representation take place. For example, a powerful mediation of memory by an individual can influence a large group of people, and in turn, when local groups repeatedly commemorate a specific event, they may change collective memory on a national or even transnational scale. Illustrations of such cases can be found in this book in the chapters written by Heimo and de Kerangat, respectively.

The crucial question is what we mean when we speak about reception in the context of memory studies. Since cultural memories are part of human communication we can try to answer this question by going back to communication theory. According to the original mathematical models of communication, 'reception' means the decoding of a message. Early models of media communication, such as that by Shannon and Weaver, ${ }^{19}$ featured a sender, a message, a channel and a receiver (all aligned in the process from encoding to decoding). These ideas inspired linguists and literary scholars such as Roman Jakobson, who used it as a starting point to develop a sophisticated and complex model of 'communicative act'20 which is shaping ideas about reception to this day, In this model there is no room for a simplistic conception of an unambiguous message encoded in, say, a history film, that is to be effortlessly decoded by its audience. Furthermore, in the wake of cultural studies, scholars

18 See also Barbara Misztal, Theories of Social Remembering (London: Open University press, 2003), 25 .

19 Claude Elwood Shannon and Warren Weaver, The Mathematical Theory of Communication (Urbana: University of Illinois Press, 1949).

20 Roman Jakobson, 'Closing Statements: Linguistics and Poetics,' Style In Language edited by Thomas A. Sebeok, (Cambridge Massachusetts: MIT Press 1960): 350-377. 
such as Stuart Hall have emphasized that reception is an active process, which can produce diverse 'readings' or 'appropriations' of the same message. ${ }^{21}$ The insights of cultural and media studies also reveal that it is impossible to isolate reception from other constitutive elements of the communicative act such as the message (memory representation, its content and form), the medium (the channel of transmission), the sender (agents/producers of memory) and the social contexts in which mediation and reception take place. All these elements of an act of communication are interlocked. Therefore, although on a theoretical level one can speak about reception as a specific element of the communicative act, in the empirical studies and on the methodological level it seems impossible (and arguably not desirable) to isolate it from the other components of memory communication. Moreover, in memory culture the cycle of production, representation and reception becomes a perpetual spiral. Reception is not the final destination of the memory process, but can lead to further (individual and collective) productions, such as private ones (for example, the retelling of family narratives between generations ${ }^{22}$ ), semi-public ones (for example, the sharing of photos on social media platforms) or official ones (the erection of a monument as a reaction to multiply mediated memories of a specific past event or figure).

A too strong distinction between representation and reception in memory studies is therefore misleading. ${ }^{23}$ Many representations of memory emerge in response to earlier mediations of certain contents, and sometimes they may even be understood as explicit re-mediations. Thus, the analysis of a specific memory representation will often turn out to be simultaneously a study of the reception of an older memory by the producers of this new representation. An example of this can be found in this book in the chapter written by Majsova. She analyzes two films and examines them as acts of reception, because the filmmakers reinterpret, in these films, an already existing narrative dominant in their culture. Thus the filmmakers can be seen as both memory receivers (or 'consumers') of a specific memory narrative embedded in their culture, and as memory producers, since they reinterpret earlier narratives and remediate them.

\footnotetext{
21 Stuart Hall, 'Encoding/Decoding,' in Culture, Media, Language: Working Papers in Cultural Studies, 1972-79, ed. Stuart Hall, Dorothy Hobson, Andrew Lowe and Paul Willis (London: Hutchinson, 1980), 128-138.

22 Harald Welzer, 'Re-Narrations: How Pasts Change in Conversational Remembering,' Memory Studies 3, 1 (2010): 5-17.

23 Cf. Kansteiner's 2002 criticism that memory studies privileges representation over reception (Kansteiner, Finding meaning in memory.).
} 
Remediations are acts of reception. The individuals involved in the processes of remediation are 'prosumers' (both producers and consumers). ${ }^{24}$ This is especially evident in literature and the visual media, but also in the remediation of memories via so called new digital media. The chapter by Neijmann and Gudmundsdottir, as well as the chapter by Heimo in this book, deal with reception-as-remediation. In the words of Erll and Rigney, 'remediation is concerned with the ways in which the same story is recalled in new media at a later point in time and hence given a new lease of cultural life.' ${ }^{25}$ Thus, studies of the reception of memories include studies of remediation and the circulation of memories. The remediation of a specific memory narrative can be studied as a form of reception on the individual level, but at the same time, if such remediations are recurrent, they are also evidence for the reverberation of this specific memory in the cultural sphere.

In light of the issues raised so far, it seems that there are two fundamental approaches to an understanding of 'reception' in memory studies: The first concerns the reception of mediated memory in the minds of individuals. The second refers to mediated reception: remediation. Of course, both dimensions (reception in mind and media) are interlinked. Mental reception is the starting point for remediation. It is thus possible to study (mental) reception via (medial) production. Conversely, for remediations to become collectively relevant memory receptions, they need to be actualized in individual minds. However, with units of analysis so far apart - mental operations in the first case, media representations in the second - methodologies will vary greatly: The study of representations, and filiations of representations, summed up under the umbrella term of 'remediation', has a long tradition in research on influence, intertextuality, and adaptation, in 'classical reception studies', and last but not least in Aby Warburg's work on the afterlives of symbols. ${ }^{26}$ To access the reception of mediated memory in individual minds, memory studies can draw on social sciences' methodologies of qualitative interviewing, oral history and ethnographic approaches, on television studies' audience research and cultivation theory, or on literary studies' reception aesthetics and reader

24 Joanne Garde-Hansen, Andrew Hoskins and Anna Reading, eds., Save as ... digital memories (Basingstoke: Palgrave Macmillan 2009):129.

25 Astrid Erll and Ann Rigney, 'Introduction: Cultural Memory and its Dynamics,' in Mediation, Remediation and the Dynamics of Cultural Memory, edited by Astrid Erll and Ann Rigney (Berlin/New York: De Gruyter, 2009), 8.

26 Linda Hutcheon, A Theory of Adaptation (New York: Routledge, 2012); Charles Martindale and Richard F. Thomas, eds., Classics and the Uses of Reception (Malden, MA: Blackwell, 2006); Aby Warburg, Der Bilderatlas Mnemosyne, edited by Martin Warnke and Claudia Brink (Berlin: Akademie-Verlag, 200o). 
response theory. ${ }^{27}$ The social contexts of individual reception are studied by social psychology, which helps us to understand how a 'socially shared reality' is produced, for example by discursive remembering. ${ }^{28}$

Memory studies' insights into the dynamics of reception hinge on the involved disciplines bringing their methodologies to the field. To give just a few examples: Where memory research has teamed-up with social network analysis, it has enabled us to look at transnational networks of commemoration and to conduct 'influence mapping.. ${ }^{29}$ Studies located at the intersection of museum studies and memory studies have developed complex approaches to the 'mediation of memory', which pay attention to the visitors' experience of and engagement with the museum. ${ }^{30}$ Visitor studies increasingly work with 'eye tracking' methods to follow museum goers' individual attention to texts, images and objects. ${ }^{31}$ From literary and media studies perspectives, the reception of films such as Hotel Rwanda or The Downfall has been shown to be deeply influenced by individual viewers' backgrounds. ${ }^{32}$ On a collective level, the status and meaning of a 'memory film' seems to be negotiated 'outside' the film's symbolic structure, within 'plurimedial constellations.' ${ }^{33}$ The narratology of

27 Robert Perks and Alistair Thomson, eds., The Oral History Reader (London: Routledge, 1998); James Shanahan and Michael Morgan, Television and Its Viewers: Cultivation Research and Theory (Cambridge: Cambridge University Press, 1999); Wolfgang Iser, The Implied Reader: Patterns of Communication in Prose Fiction from Bunyan to Beckett (Baltimore: John Hopkins University Press, 1978); Stanley E. Fish, Is There a Text in This Class?: The Authority of Interpretive Communities (Cambridge, Mass: Harvard University Press, 1980).

28 Charles B. Stone and Lucas M. Bietti, eds., Contextualizing Human Memory: An Interdisciplinary Approach to Understanding How Individuals and Groups Remember the Past (London: Routlegde, 2016).

29 Jenny Wüstenberg. 'Vernetztes Gedenken? Netzwerkmethoden und Transnationale Erinnerungsforschung' Jahrbuch für Politik und Geschichte 6 (2016): 97-113.

30 Silke Arnold-de Simine, Mediating Memory in the Museum: Trauma, Empathy, Nostalgia (Basingstoke, Hampshire: Palgrave Macmillan, 2013); Irit Dekel, Mediation at the Holocaust Memorial in Berlin (Basingstoke, Hampshire: Palgrave Macmillan, 2013).

Silivia Filippini Fantoni, Kyle Jaebker, Daniela Bauer and Kathryn Stofer, 'Capturing Visitors' Gazes: Three Eye Tracking Studies in Museums.' In Museums and the Web 2013, edited by N. Proctor \& R. Cherry (Silver Spring, MD: Museums and the Web. Published 31 January 2013), accessed 16 December 2016, http://mw2013.museumsandtheweb.com/paper/ capturing-visitors-gazes-three-eye-tracking-studies-in-museums/.

32 Christian Gudehus, Stewart Anderson and David Keller, 'Understanding Hotel Rwanda: a Reception Study,' Memory Studies 3, 4 (2010): 344-363.

33 Astrid Erll and Stephanie Wodianka, eds., Film und kulturelle Erinnerung: Plurimediale Konstellationen (Berlin/New York: de Gruyter, 2008). 
cultural memory has shown that narratives about the past often display a 'rhetoric of collective memory' with a specific 'mnemonic potential' that may be actualized by (and thus have actual effect on) individual readers and viewers. ${ }^{34}$

Receptions are never stable, once-and-for-all understandings of collective memory. They will be shaped and reshaped across time by frameworks of discursive and otherwise mediated remembering, for example, by discussions among family and friends, by social media, and newsmedia. But are repeated, particular representations of the past in the public arena and their assimiliation into dominant discourses a sufficient indicator for their impact on collective memory in a society? The case analyzed in the chapter written by Kapralski in this book speaks against such a claim. Kapralski argues that despite a large amount of new memory narratives about Polish-Jewish relations during the Holocaust which have been repeatedly remediated in Polish culture during the last fifteen years or so, the Polish collective memory of the Holocaust has not changed tangibly, at least as evidenced by opinion polls. This case points to a difficult question about the relation between knowledge and memory. We may make a distinction between knowledge about and memory of something. 'To know something' is not the same as to internalize something to the point that it is important to one's identity, attitudes and behaviour. This distinction makes studies of reception particularly difficult and emphasizes the need to study also emotional aspects of reception, an attempt of which is made in the chapter by Pavlakovic and Perak in this volume.

How can we address this complex process of meaning-making involved in reception? How are we to answer the question put at the beginning of this introduction describing the cases of The Black Cone and The Sleepwalkers, i.e., why do some mediated (and remediated) memories take root in collective memory while others fail?

In order to come closer to responding to these issues, Kansteiner suggests that we pay particular attention to three factors: '... the intellectual and cultural traditions that frame all our representations of the past, the memory makers who selectively adopt and manipulate these traditions, and the memory consumers who use, ignore, or transform such artefacts according to their own interest'. ${ }^{35}$ This analytical model can serve as a good starting point for the analysis of reception, but it has to be substantially developed in order to catch the complexity of the reception processes. First and foremost, representation as

\footnotetext{
34 Astrid Erll, 'Literature, Film and the Mediality of Cultural Memory,' in A Companion to Cultural Memory Studies, edited by Astrid Erll \& Ansgar Nünning, 389-398. (Berlin/New York: de Gruyter, 2010).

35 Kansteiner, Finding meaning in memory, 180.
} 
such disappears in this model and should be re-introduced into it. The content of the mediated story about the past, as well as its forms (including genre, plot structure, and narrative voice) and the medium used, play a role in the process of reception. An inquiry into why some stories succeed and others do not would have to consider 'the medial framework of remembering and the specifically medial process through which memories come into the public arena and become collective. ${ }^{36}$ Media have their different kinds of logic and both media producers and consumers exploit the possibilities and are restricted by the limitations of their chosen media. For example, it matters for the reception of a certain story about the past if the medium used is seen as reliable (such as scholarly historiography), stands for immediacy of experience (such as live news) or if the mediated text or image is seen as authentic (such as seemingly 'indexical' press photography and documentary film).

Furthermore, when analysing reception it is important to pay attention to the importance of what Erll calls 'premediation' - cognitive schemata and patterns of representation that are available in a given media culture. They are 'patterns and structures of knowledge on the basis of which we make assumptions regarding specific objects, people, situations and the relation between them: ${ }^{37}$ By reducing the complexity of reality, they influence our perception of what we remember. We acquire cognitive schemata through socialization in the cultural environments we are raised in and where we encounter repertoires of medial representations of the past. ${ }^{38}$ These culturally inherited and mediated schemata and templates influence the memory producers and the representations of the past they create. They also influence memory consumers (or rather prosumers), whose reception is shaped by their own cultural schemata. ${ }^{39}$ Sindbæk Andersen and Dedovic's chapter in this volume investigates how strongly premediation may shape political responses to representations of the

$36 \quad$ Erll and Rigney, 'Introduction', 2.

37 Astrid Erll 'From "Distric Six" to District 9 and Back: The Plurimedial Production of Travelling Schemata,' in Transnational Memory. Circulation, Articulation, Scales, edited by Chiara De Cesari and Ann Rigney, (Berlin/New York: De Gruyter, 2014), 31. See also James V. Wertsch, Voices of Collective Remembering (Cambridge: Cambridge University Press, 2002).

38 On the culture-specifity of narrative schemata, see the seminal study by F.C. Bartlett, $R e-$ membering: A Study in Experimental and Social Psychology (Cambridge: Cambridge University Press, 1932).

39 Ignacio Brescó de Luna and Alberto Rosa Rivero, 'Memory, History and Narrative: Shifts of Meaning when (Re)constructing the Past,' Europe's Journal of Psychology 8, 2 (May 2012): 300-310. 
past. And Farbøl shows how the mediation of memories of one significant past may premediate the memorial framework of an altogether different past.

The cultural templates and schemata, many of them embodied, some even unconscious and often not explicitly articulated, ${ }^{40}$ create cultural constraints for memory production and reception and shape cultural frames of memory dynamics. This cultural 'programming' may help us understand why some memories evoke strong emotions and others not. As pointed out by Sara Ahmed, what is 'sticky' in terms of emotions and affect differs to a large extent from one culture to another. ${ }^{41}$ It may be justified to assume that memory representations that reverberate with specific cognitive schemata and affective patterns of reaction embedded in the culture of receivers/consumers, may have greater chance to take effect in their cultural memory. Consequently one may claim that 'the intellectual traditions', mentioned by Kansteiner are important but not enough to consider in the studies of reception. Cultural frames for memory reception include many more elements that have to be accounted for and they matter as much to memory makers as to memory consumers.

In his model Kansteiner rightly mentions the necessity to scrutinize the interests and needs of the main players in the memory field: memory makers and consumers. Such a functionalist perspective is necessary to understand the importance attached to certain memories. For what purposes are memories used? What kind of needs, and whose needs, can be met by the mediation of certain stories and interpretations of the past? Furthermore, it is vital for the study of reception to properly identify who the memory agents actually are. It makes a difference whether they possess cultural capital in terms of authority and trust in the eyes of the memory 'prosumers'. It makes a difference, too, whether the memory agents manage to identify the needs and interests of their audience and shape their narratives accordingly.

Last but not least the entire social context in which reception of the mediated narratives of the past takes place has to be considered, with special attention to power relations. Do the agents of memory and 'prosumers' have access to structural resources (such as institutions), the financial means, and power enough to direct public attention to particular memory narratives and establish them as part of the cultural canon? These kinds of questions have to be approached, because the world of memory is a world of political economy. Political scientists, sociologists, anthropologists and to some extent historians

\footnotetext{
40 For more about the embodied memories see for example Paul Connerton, How Societies Remember (Cambridge: Cambridge University Press, 1989).

41 Sara Ahmed, The Cultural Politics of Emotions (Edinburg: Edinburg University Press, 2004).
} 
are usually interested and methodologically well equipped to study these aspects. In this volume the reader will find many examples of studies focusing on such issues, especially in the chapters by Góra and Mach, Jones, Kapralski, Melchior and Farbøl.

It is the contention of the editors and authors of this book that in the studies of reception we should ideally pay attention to all elements involved in the process of memory as a communicative act and the interplay between them, avoiding an exclusive focus on memory consumers as a distinct unit. Moreover, reception in itself is a dynamic, ongoing process, one difficult to capture. A number of researchers within communication studies struggle with this problem when they want to investigate the impact of certain products (such as films, books etc.) on the audience. It may feel like chasing a moving target. A researcher can take a snap-shot of reception at a certain moment. By doing questionnaires and interviewing people before and after the act of consumption of the memorial story (viewing or reading) they can draw some conclusions about reception. ${ }^{42}$ However, this method catches the reception at a certain moment of time, gives a snap-shot of audience reactions, but these can change rather quickly in a changed social constellation and in a new context. Thus, long-term effects of memory mediation remain a difficult question. But memory scholars are particularly interested in this aspect: What 'stays'? What becomes absorbed in people's imagination?

To approach the last questions we need longitudinal studies, a diachronic perspective and a historical approach to the material. There are many cases of mediated stories about the past that fail to attract public attention at a certain moment but, remediated at a later point in time in a new social and medial context, they become highly visible in the public arena and sometimes even part of official memory. ${ }^{43}$ The last process requires, however, repetitions of the story over a longer time span and reiterations across different cultural and social platforms in the public arena, such as commemorative speeches

42 See for example the study by Jürgen Grimm, 'How do films contribute to shaping teenagers' identity' (Paper presented at the conference Mapping Memories, Kijev 2 October 2016). See also link http://www.br-online.de/jugend/izi/english/publication/ televizion/29_2016_E/Grimm-How_do_films_contribute_to_shaping_teenagers_identity .pdf (accessed 20 October 2016).

See, for example Kansteiner on the reception of the TV-miniseries Holocaust (1978) in Germany: Wulf Kansteiner, In Pursuit of German Memory: History, Television, and Politics After Auschwitz (Athens, он: Ohio University Press, 2006) or Bilj on the (re)emergence of photographs of colonial atrocity in the Netherlands: Paul Bijl, Emerging Memory: Photographs of Colonial Atrocity in Dutch Cultural Remembrance (Amsterdam: Amsterdam University Press, 2015). 
and rituals, books (including school books), images and the Internet. In this way the memory narrative can be anchored in the imagination of a community and tied to its identity. It can become part of the 'canon', or at least of the 'archive', to use Aleida Assmann's distinction. The first 'stands for the active working memory of a society that defines and supports the cultural identity of a group' 44 The second is the passive realm of cultural memory, a kind of 'store house' of the mnemonic representations that can be taken into use when there is need for them. The ongoing movements between the two, the 'mutual influx and reshuffling, ${ }^{45}$ contribute to the dynamics of memory and can make it difficult to judge as to what is 'failure' and 'success' in the process of reception of a certain memory narrative. Can we speak about a 'successful' reception of a memory if it takes root in the culture of a community and becomes a part of 'the archive', or is 'success' equal to becoming a part of a 'canon'? However, even if a memory succeeds in establishing itself as part of the 'canon' this does not necessarily mean that it is supported by a widespread consensus within the community. Despite common knowledge of a certain mnemonic narrative and despite its dominance in the public arena, individuals, even en masse, can refuse to internalize it emotionally, receiving it as a knowledge about but not a memory of a particular version of the past. As mentioned earlier, the cognitive knowledge of the past does not need to be followed by its emotional or identityrelated perception. This discrepancy is especially common in the processes of reception of the so-called 'difficult', traumatic past. The chapter by Kapralski in this book illustrates this dilemma. He summarizes it in the statement that the Holocaust can be commemorated but not remembered. ${ }^{46}$ Is this evidence of failed reception? Farbøl demonstrates in her chapter how a certain past, that of the Cold War, can be represented in museums with numerous visitors, but apparently without a surrounding memory culture and without much reaction from the audience. Another contributor to this volume, de Kerangat, complicates further our view on reception by pointing to the fact that we should be careful to interpret silence around a certain memory as a sign of indifference and thus 'a failure' in the process of memory reception. She demonstrates with the case of post-Franco Spain that silence can be a form of reception.

\footnotetext{
44 Aleida Assmann, 'Canon and Archive,' in Cultural Memory Studies. An International and Interdisciplinary Handbook, edited by Astrid Erll and Angar Nunning (Berlin/New York: de Gruyter, 2008), 106.

45 Ibid.

46 An example of previous research that paid attention to this problem is the seminal study 'Opa war kein Nazi': Nationalsozialismus und Holocaust im Familiengedächtnis by Harald Welzer, Sabine Moller and Karoline Tschugnall (Frankfurt/M.: S. Fischer, 2008).
} 
In sum, this volume shows that the processes of memory reception are extremely complex and dynamic. Studying them may involve tracing chains of reactions, mediations and re-mediations, circulations and re-circulations, re-appropriations and rejections. It includes investigating already existing memory patterns, understanding the specific dynamics of genres and fields of discourse, and trying to grasp political needs and the cultural logic of the present. Studies of reception in all these aspects require a variety of methods. Through a selection of chapters that analyze cases of transcultural transmission and reception of European memories of the twentieth century, we hope to demonstrate both the variety of questions about reception that exists, understood as entangled in all parts of the mnemonic communicative act, and the diversity of ways in which to investigate them.

The authors of the chapters in this volume apply a variety of methods in their analyses of reception. These are, among others, interviews, participant observation, opinion polls, surveys and questionnaires, close reading of specific images, films and other media text, netnography, discourse analysis of speeches and debates, as well social network analyses. Moreover, they contribute to a deeper understanding of reception from the perspective of their respective disciplines: anthropology and ethnology, cultural studies, history, sociology, literary studies, cognitive linguistics and political science.

The examples of The Black Cone and The Sleepwalkers, mentioned at the beginning of this introduction, point to the fact that Europe's twentieth century memories are inherently transcultural and, with the rise of digital communication and the radically intensified mobility of people across the national borders, increasingly so. Memory representations in Europe and in the world travel across borders: cultural, national, and linguistic ones, but also between media and genres, as well as domains of society, such as politics, popular culture, history, the arts, mass media and education. The Internet and modern mass culture have made the distribution and sharing of memory content faster and easier. ${ }^{47}$ This also allows people to engage emotionally with memories that they are not obviously connected with through personal, familial, ethnical or national ties. ${ }^{48}$ People can become part of new memory communities, subcultural, cosmopolitan or activist groups, and to (differently) imagined memory

47 Andrew Hoskins, 'Digital Network Memory', in Mediation, Remediation and the Dynamic of Cultural Memory, edited by Astrid Erll and Ann Rigney (Berlin: De Gruyter, 2009), 91-106.

48 Stef Craps and Michael Rothberg, 'Introduction: Transcultural Negotiations of Holocaust Memory,' Criticism 53, 4 (2011): 517. 
communities, such as European communities or global ones. ${ }^{49}$ Due to the multifaceted nature of our identities our individual memory is located at the intersection of multiple social frameworks and thus it is inherently transcultural. The same can be argued about cultural memories since no culture is a closed container and the entanglement of cultures and their interaction is taken for granted in today's society. Moreover, cultures are always internally heterogeneous, to a larger or lesser extent. ${ }^{50}$

These basic insights, however, have not been at the centre of attention of memory studies as they (re-)emerged in the 1980s, when 'cultural' or 'collective memory' was usually imagined as the mnemonic property of bounded cultures - the memory of a nation, an ethnic group, $a$ religious community, $a$ social class etc. In the age of Pierre Nora's lieux de mémoire, 'methodological nationalism' (U. Beck) was only the most visible aspect of the larger tendency towards 'methodological culturalism'. This tendency to see cultures as containers affected a reification of the bonds between culture and memory. However, some researchers, including Erll, Rigney and Rothberg have recently pointed to the need to direct attention to the inherent transculturality of memory. This volume contributes to this new direction in memory studies by scrutinizing one specific arena of transcultural memory practice - Europe - and by focussing on reception as a major force of the transcultural memory process.

By focusing on the transculturality of memory, the editors and authors of this book take into account that memory cultures, like cultures in general, are no homogenous unified entities but rather 'more porous than previously acknowledged'.51 Memory communities increasingly cross traditional (or traditionally perceived) cultural borders and are, like most modern cultural communities, characterized by internal differentiation and external interconnectedness. ${ }^{52}$ The concept of transculturality encompasses - and cuts transversally across - the international, the national and the local, the universalistic and the particularistic. As suggested by Astrid Erll, the term 'transcultural' can

49 For discussion about possibilities of global communities of memory see Aleida Assmann and Sebastian Conrad, eds., Memory in a Global Age. Discourses, Practices and Trajectories (New York: Palgrave, 2010).

5o See Wolfgang Welsch: 'Transculturality - the puzzling form of Cultures Today', in Spaces of Culture: City, Nation, World, edited by Mike Featherstone and Scott Lash (London: Sage, 1999), 194-213.

$5^{1} \quad$ Lucy Bond and Jessica Rapson, 'Introduction,' in The Transcultural Turn. Interrogating Memory between and beyond borders, edited by Lucy Bond and Jessica Rapson (Berlin: De Gruyter, 2014), 19.

Wolfgang Welsch, 'Transculturality - the puzzling form of cultures today'. 
be used as 'an umbrella term for what in other academic contexts might be described with concepts of the transnational, diasporic, hybrid, syncretistic, postcolonial, translocal, creolized, global or cosmopolitan. ${ }^{33}$ As the prefix of 'trans' indicates, we are looking at movements from one or more of the porous European memory communities to others, and, by focusing on reception, we are exploring the dialogues between them. What happens when memories are shared across alleged cultural borders? How are they negotiated, transformed, appropriated or rejected?

Transcultural memory according to Erll can be conceived 'as the incessant wandering of carriers, media, contents, forms and practices of memory, their continual "travels" and ongoing transformations through time and space, across social, linguistic and political borders'. ${ }^{44}$ The chapters of this book show the 'travelling' of memory and what happens in this process. Jones, Melchior, Góra and Mach demonstrate in their chapters how individuals such as migrants, politicians and activists of different organizations try to disseminate, outside their countries, the mnemonic narratives ('contents') of their national communities, seeking recognition for them among people of other nationalities in Europe. Jones points especially to how forms and practices of remembrance are shared among people from the organizations that work with politics of memory. She indicates directions of diffusion and mutual influence. The 'travelling' practices are also in the focus of the chapter by de Kerangat, who points to a transnational reception of the discourses promoting and implementing silence about the violent past. She also emphasizes the transcultural and transnational character of the practice of exhumation of the victims of mass violence as a way of remembering. Farbøl shows how memories of a past shared by an international community is translated into a decidedly quiet national narrative, whereas Sindbæk Andersen and Dedovic demonstrate how national memory politics may take the shape of a reaction to or even rejection of tendencies within international history debates. Other authors put greater focus on the travel of the specific memory contents and media across space, time and cultures (Neijmann and Gudmundsdottir, Heimo, Majsova, Kapralski, Pavlakovic and Perak). Pavlakovic and Perak also direct our attention to the important, but much less researched, intersubjective aspect of memory transmission and reception.

The chapters of the book are divided into two general sections. While all chapters study transcultural transmission and reception of memory, the chapters in the first section concentrate on the roles of memory actors and

53 Astrid Erll, 'Travelling Memory' Parallax 17, 4 (2011): 9.

54 Ibid.11. 
entrepreneurs, as well as different social and political practices in transcultural transmission and reception of memory.

The role of memory entrepreneurs and institutions in transnational sharing of memory narratives and in the processes of transmission, reception and redistribution is explored in the first chapter by Sara Jones. Using social network analysis to investigate networks of memory entrepreneurs, Jones charts the involvement of institutions, and the connections through which narratives of memory and ways of remembering are transmitted and shared within such networks. Turning our focus towards the role of memory agents, Jones introduces the concept of 'collaborative memory' in order to emphasize how networks of institutions and entrepreneurs work together across borders when constructing narratives of memory, and to explore how such narratives are received and put to use in different places.

Political mediation and use of memory in a European political arena, as well as political reception of memory politicization is the topic of the chapter by Zdzisław Mach and Magdalena Góra, who explore how Polish politicians in the European Parliament have demanded recognition for Polish, and more generally Central European, memories of the twentieth century. Analyzing debates from the European Parliament since 2004, Mach and Góra show how the Polish concerns, though partly based on domestic memory debates and divisions within Polish politics, were received largely favourably on a principal level, and requests to recognize memories of totalitarian communism were widely supported by Parliamentarians. Yet, as the chapter shows, attempts to use these memories in requests for economic concessions have been less successful.

Political agency in the form of reception and contestation of a particular interpretation of the past is studied in the third chapter by Tea Sindbæk Andersen and Ismar Dedovic. Looking at the Serbian president's reception of a historical study that reinterprets the much-discussed question of the causes of and path to the outbreak of the First World War, Sindbæk Andersen and Dedovic argues that this kind of reception reflects both a need to defend an essential part of Serbian national memory and a significant and somehow politically obliging premediation in the form of a tradition to reject Serbian responsibility for the outbreak of the Great War.

Zoé de Kerangat's chapter on exhumations of victims of Francoism by their friends and relatives investigates an example of contestation and rejection of memory politics from the side of unofficial and very local memory agents. De Kerangat shows how small memory communities have reacted to official memory politics through informal practices of contestation. Indeed, the exhumations constitute both a belated reaction to and commemoration of the crimes and a form of reception - and rejection - of official memory politics 
after the fall of the Franco regime. De Kerangat demonstrates how very local and unofficial memory entrepreneurs defy the memory politics of the state by quietly creating alternative sites and rituals of memory, thereby affirming alternative memory narratives.

The individual as memory agent, both with regard to remediation and reception, is the topic of Inge Melchior's chapter on Estonian migrants in the Netherlands. Through interviews and participant observation, Melchior explores how Estonians perceive themselves as carriers of national memory narratives that are not quite compatible with the mainstream memory framework in their new country of residence. Melchior shows how individuals feel both challenged and obliged to defend their position, but also that attitudes from both Estonians and long-time citizens of the Netherlands are dynamic and influenced by, for example, changing attitudes towards Russia in the Netherlands

The chapters in the second section focus on the functions of contents and media in the processes of transcultural transmission and reception of memory.

The way that politically contested memory is being mediated in a way that somehow minimizes contestation is studied in the section's first chapter, in which Rosanna Farbøl explores how the disputed memory of the Cold War in Denmark is being presented at several new or newly refurbished Cold War museums. Farbøl emphasizes how the museum mediation is largely framed as a re-appropriation of the internationally established Second World War memory framework, though with a strong element of the counterfactual, which allows for a degree of playfulness. Whereas the Cold War museums can certainly be understood as a reception and remediation of a Danish political Cold War discourse, Farbøl points out a surprising absence of reactions to the museums, in spite of their potentially controversial context.

Slawomir Kapralski's study of Holocaust memory in Poland questions the relationship between knowledge in the form of public presence of memory and its reception. Kapralski draws on a number of public opinion surveys to demonstrate developments in the understanding of and attitude towards the Holocaust in Poland. Based on these results, Kapralski argues that the Holocaust has indeed been commemorated publicly and officially in Poland since the fall of communism, but it has not become part of the individual remembering within members of the Polish population. Though formally present in a general Polish memoryscape, the Holocaust has not been received and included into individual and emotionally engaged memory.

The chapter by Natalija Majsova looks at the relationship between memory and cinematic aesthetics. Majsova shows how cinematic representations of memory narratives constitute a reception and remediation of society's 
established memory narratives. Investigating both the narrative representation and the formal aesthetics, Majsova demonstrates how post-Soviet films of the dawn of the space age challenge dominant memory narratives. Yet, by contrasting these readings with review examples of the films' reception by lay viewers, Majsova points out that reception is certainly diverse, as the contesting and challenging meanings are not necessarily readable or relevant to viewers.

The role of literary memory mediation and long-term reception of literary memory is studied in Daisy Neijmann and Gunthorun Gudmundsdottir's chapter on the reception and afterlife of the memoirs of an Icelandic fighter with the International Brigades in the Spanish civil war. Neijmann and Gunthorun Gudmundsdottir demonstrate how literary mediations of memory may remain in the shadow of public memory, only to return to public prominence through another literary remediation. Indeed, as Neijmann and Gudmundsdottir show, the literary reception and remediation may provide memory narratives that are otherwise absent from public memory and memorialization.

The internet as a site of transcultural memory, remediation and reception is the topic of Anne Heimo's chapter on online commemoration of the 1913 Italian hall tragedy, in which 73 people were killed at a Christmas celebration in Michigan. Heimo shows how narratives of the tragedy are being shared by individuals within online communities and openly accessible on the web. Heimo investigates how individuals as non-historians and non-professional memory entrepreneurs contribute to creating a spontaneous digital archive of such narratives, keeping the memory alive through regular remediation, and how other individuals engage and react to this.

The audience's reaction to memory mediation is the object of Vjeran Pavlaković and Benedikt Perak's chapter, which presents a methodologically innovative pilot study of how emotional reactions to memorials and political discourse may be measured. Pavlaković and Perak investigate how a group of informants react emotionally when confronted with the main monument to the victims of Croatia's Fascist Second World War regime, and how their affective reactions are influenced when primed by different types of political discourse. While the study clearly shows emotional reactions to the monument, it also demonstrates that the affective reactions are influenced by the degree to which the moral presumptions and standards of the informants are being challenged.

In the concluding essay, Wulf Kansteiner speculatively asks what has happened to the idea of cosmopolitan memory during what he calls 'the transnationalization of the Holocaust' and the export of 'the German model of memory management' as it was redistributed to and embraced by other 
European countries. Questioning to which extent people around the globe are able to feel passionately involved in transnational memory and practices of belonging, Kansteiner looks at attempts in the 21st century to create engaging Holocaust memory through different media, such as video games and Facebook. Studying the types of responses, or lack thereof, that such projects have attracted, Kansteiner's essay discusses the representation, circulation and regimentation of Holocaust memory in the digital sphere.

\section{Bibliography}

Ahmed, Sara. The Cultural Politics of Emotions. Edinburg: Edinburg University Press. 2004.

Arnold-de Simine, Silke. Mediating Memory in the Museum: Trauma, Empathy, Nostalgia. Basingstoke, Hampshire: Palgrave Macmillan, 2013.

Assmann, Aleida. 'Canon and Archive.' In Cultural Memory Studies. An International and Interdisciplinary Handbook, edited by Astrid Erll and Nunning, 97-107. Berlin/ New York: de Gruyter, 2008.

Assmann, Aleida and Sebastian Conrad, eds. Memory in a Global Age. Discourses, Practices and Trajectories, New York: Palgrave: 2010.

Bartlett, F.C., Remembering: A Study in Experimental and Social Psychology, Cambridge: Cambridge University Press, $193^{2}$.

Bijl, Paul. Emerging Memory: Photographs of Colonial Atrocity in Dutch Cultural Remembrance. Amsterdam: Amsterdam University Press, 2015.

Bond, Lucy and Jessica Rapson, 'Introduction.' In The Transcultural Turn. Interrogating Memory between and beyond borders, edited by Lucy Bond and Jessica Rapson, 1-26. Berlin: De Gruyter 2014.

Bonnell, Andrew G. 'New Histories of the Origins of the First World War: What happened to the "Primacy of Domestic Politics?"' Australian Journal of Politics and History, 61, 1 (2015): 121-127.

Brescó de Luna, Ignacio and Alberto Rosa Rivero. 'Memory, History and Narrative: Shifts of Meaning when (Re)constructing the Past.' Europe's Journal of Psychology 8, 2 (May 2012): 300-310.

Connerton, Paul. How Societies Remember. Cambridge: Cambridge University Press 1989 .

Craps, Stef and Michael Rothberg. 'Introduction: Transcultural Negotiations of Holocaust Memory.' Criticism 53, 4 (2011): 517-521.

Dekel, Irit. Mediation at the Holocaust Memorial in Berlin. Basingstoke, Hampshire: Palgrave Macmillan, 2013. 
Erll, Astrid. 'Literature, Film and the Mediality of Cultural Memory.' In A Companion to Cultural Memory Studies, edited by Astrid Erll and Ansgar Nünning, 389-398. Berlin/New York: de Gruyter, 2010.

Erll, Astrid. 'From "Distric Six" to District 9 and Back: The Plurimedial Production of Travelling Schemata.' In Transnational Memory. Circulation, Articulation, Scales, edited by Chiara De Cesari and Ann Rigney, 43-63. Berlin/New York: de Gruyter, 2014.

Erll, Astrid and Ann Rigney. 'Introduction. Cultural Memory and its Dynamics.' In $\mathrm{Me}$ diation, Remediation and the Dynamics of Cultural Memory, edited by Astrid Erll and Ann Rigney, 1-11. Berlin/New York: de Gruyter, 2009.

Erll, Astrid and Ann Rigney, eds. Mediation, Remediation, and the Dynamics of Cultural Memory. Berlin/New York: de Gruyter, 2009.

Erll, Astrid und Stephanie Wodianka, eds. Film und kulturelle Erinnerung: Plurimediale Konstellationen. Berlin/New York: de Gruyter, 2008.

Filippini Fantoni, S., K. Jaebker, D. Bauer and K. Stofer. 'Capturing Visitors' Gazes: Three Eye Tracking Studies in Museums.' In Museums and the Web, edited by N. Proctor and R. Cherry. Silver Spring, MD. Published 31 January 2013. Accessed 16 December 2016. http://mw2013.museumsandtheweb.com/paper/capturing-visitors-gazes-threeeye-tracking-studies-in-museums/.

Fish, Stanley E. Is There a Text in This Class? The Authority of Interpretive Communities. Cambridge, Mass: Harvard University Press, 1980.

Garde-Hansen, Joanne. Media and Memory. Edinburgh: Edinburgh University Press, 2011.

Garde-Hansen, Joanne, Andrew Hoskins and Anna Reading eds. Save as ... digitalmemories. Basingstoke: Palgrave Macmillan, 2009.

'Govor Presdsednika Republika, SANU - Veliki rat 13 June 2014', (Supplied at request from the press centre at the office of the President of the Republic of Serbia).

Gray, Ann, 'Televised remembering.' In Research Methods for Memory Studies, edited by Emily Keightley and Michael Pickering, 79-96. Edinburgh: Edinburgh UP 2013.

Grimm, Jürgen. 'How do films contribute to shaping teenagers' identity.' Paper presented at the conference Mapping Memories, Kijev, 2 October 2016. http://www .br-online.de/jugend/izi/english/publication/televizion/29_2016_E/Grimm-How_ do_films_contribute_to_shaping_teenagers_identity.pdf. Accessed 20 October 2016.

Gudehus, Christian, Stewart Anderson and David Keller. 'Understanding Hotel Rwanda: a Reception Study.' Memory Studies 3, 4 (2010): 344-363.

Guðmundsdóttir, Gunnpórunn. 'Memory and Memorialisation in Post-Recession Iceland.' Paper presented at the conference Collapse of Memory - Memory of Collapse: Remembering the Past, Re-Constructing the Future in Periods of Crisis, Lund, 20-22 September 2016. 
Halbwachs, Maurice. Les cadres sociaux de la mémoire. Edited by Gérard Namer. Paris: Albin Michel, 1994 (1925).

Hall, Stuart. 'Encoding/Decoding.' In Culture, Media, Language: Working Papers in Cultural Studies, 1972-79. Edited by Stuart Hall, Dorothy Hobson, Andrew Lowe and Paul Willis, 128-138. London: Hutchinson, 1980 (1973).

Hirsch, Marianne. The Generation of Postmemory: Writing and Visual Culture After the Holocaust. New York: Columbia University Press, 2012.

Hoskins, Andrew, 'Digital Network Memory.' In Mediation, Remediation and the Dynamics of Cultural Memory, edited by Astrid Erll and Ann Rigney, 91-106. Berlin/ New York: de Gruyter, 2009.

Hutcheon, Linda. A Theory of Adaptation. New York: Routledge, 2012.

Iser, Wolfgang. The Implied Reader: Patterns of Communication in Prose Fiction from Bunyan to Beckett. Baltimore: John Hopkins University Press, 1978.

Kansteiner, Wulf. 'Finding meaning in memory: A methodological critique of collective memory studies.' History and Theory 41 (2002): 179-197.

Kansteiner, Wulf. In Pursuit of German Memory: History, Television, and Politics After Auschwitz. Athens, он: Ohio University Press, 2006.

Landsberg, Alison. Prosthetic Memory: The Transformation of American Remembrance in the Age of Mass Culture. New York: Columbia University Press, 2004.

Levy, Daniel and Natan Sznaider. The Holocaust and Memory in the Global Age. Philadelphia: Temple University Press, 2006.

Martindale, Charles and Richard F. Thomas, eds. Classics and the Uses of Reception. Malden, MA: Blackwell, 2006.

McMeekin, Sean. 'The Sleepwalkers. How Europe Went to War in 1914.' History Today 62, 12 (December 2012). Accessed 8 August 2016. http://www.historytoday.com/ blog/2012/11/sleepwalkers-how-europe-went-war-1914.

Misztal, Barbara. Theories of Social Remembering. London: Open University press, 2003. Mulligan, William. 'Review-Article: The Trail Continues: New directions in the Study of the Origins of the First World War.' English Historical Review 129, 538 (2014): 639-666.

Olick, Jeffrey K. 'Collective Memory. The Two Cultures.' Sociological Theory 17, 3 (1999): 333-348.

Perks, Robert and Alistair Thomson, eds. The Oral History Reader. London: Routledge, 1998.

Pindar, Ian. 'The Sleepwalkers by Christopher Clark - review.' The Guardian, 19 July 2013. Accessed 8 August 2016. https://www.theguardian.com/books/2013/jul/19/ sleepwalkers-christopher-clark-review.

Rothberg, Michael. Multidirectional Memory: Remembering the Holocaust in the Age of Decolonization. Stanford, CA: Stanford University Press, 2009.

Shanahan, James and Michael Morgan. Television and Its Viewers: Cultivation Research and Theory. Cambridge: Cambridge University Press, 1999. 
Shannon, Claude Elwood and Warren Weaver. The Mathematical Theory of Communication. Urbana: University of Illinois Press, 1949.

'Sierra's "Black Cone" Causes Controversy in Reykjavik.' Iceland Review Online, 5 October 2012. Accessed 8 October 2016. http://icelandreview.com/news/2012/10/05/ sierras-black-cone-causes-controversy-reykjavik.

'Srbi su 1914, bili sami - Evropljani.' Deutsche Welle, 11 November 2013. Accessed 8 August 2016. http://www.dw.com/sr/srbi-su-1914-bili-samo-evropljani/a-17215852.

'Srbija ušla u Prvi svetski rat da bi opstala.' President of the Republic of Serbia, Press centre, 13 June 2014. Accessed 8 August 2016. http://www.predsednik.rs/lat/ pres-centar/vesti/srbija-usla-u-prvi-svetski-rat-da-bi-opstala.

Stone, Charles B, and Lucas M. Bietti, eds. Contextualizing Human Memory: An Interdisciplinary Approach to Understanding How Individuals and Groups Remember the Past. London: Routlegde, 2016.

Strachan, Hew. 'Review article: The origins of the First World War.' International Affairs, 90, 2 (2014): 429-439.

van Dijck, José. Mediated Memories in the Digital Age. Stanford, cA: Stanford University Press, 2007.

Warburg, Aby. Der Bilderatlas Mnemosyne, edited by Martin Warnke and Claudia Brink. Berlin: Akademie-Verlag, 2000.

Welsch, Wolfgang. 'Transculturality - the puzzling form of Cultures Today.' In Spaces of Culture: City, Nation, World, edited by Mike Featherstone and Scott Lash, 194-213. London: Sage, 1999.

Welzer, Harald, Sabine Moller and Karoline Tschugnall. 'Opa war kein Nazi': Nationalsozialismus und Holocaust im Familiengedächtnis. Frankfurt/M.: S. Fischer, 2008.

Welzer, Harald. 'Re-Narrations: How Pasts Change in Conversational Remembering.' Memory Studies, 3, 1 (2010): 5-17.

Wertsch, James V. Voices of Collective Remembering. Cambridge: Cambridge University Press, 2002.

Wüstenberg, Jenny. 'Vernetztes Gedenken? Netzwerkmethoden und Transnationale Erinnerungsforschung.' Jahrbuch für Politik und Geschichte 6 (2016): 97-113. 
-978-90-04-35235-3

Downloaded from Brill. com $04 / 26 / 2023$ 03:12:38PM via free access 


\section{PART 1}

Actors and Practices in Transcultural Transmission and Reception 
-978-90-04-35235-3

Downloaded from Brill. com $04 / 26 / 2023$ 03:12:38PM via free access 


\title{
Cross-border Collaboration and the Construction of Memory Narratives in Europe
}

\author{
SaraJones
}

The study of memory is becoming increasingly transnational, both in terms of the scholars who are engaged in it and the subjects which form their focus. Memory is being thought of not only in terms of its location in a specific national or regional context, but also with consideration to how it is situated, constructed and translated within and between different national or regional memory cultures. Scholars have attempted to conceptualize the interplay of national and transnational memories in different ways: as 'multi-directional,'1 'travelling,'2 'transcultural,'3 or even 'global.'4 Central to the study of memory across borders has been the recognition that the national and transnational are not easily separated, but remain 'deeply entangled. ${ }^{5}$

From an empirical perspective, there have also been recent efforts to chart the realms of memory beyond and between nation states. In this context, there appear to be two broad trends: in the first, the national or regional remains the primary unit of analysis, even as authors consider cross-fertilization between different memory cultures or the reception of memory narratives outside of their country of origin. ${ }^{6}$ In the second, authors examine explicitly

1 Michael Rothberg, Multidirectional Memory: Remembering the Holocaust in the Age of Decolonisation (Stanford: Stanford University Press, 2009).

2 Astrid Erll, 'Travelling Memory, Parallax 17 (2011): 4-18.

3 Lucy Bond and Jessica Rapson, eds, The Transcultural Turn: Interrogating Memory Between and Beyond Borders (Berlin: de Gruyter, 2014).

4 Aledia Assmann and Sebastian Conrad, eds, Memory in a Global Age: Discourses, Practices and Trajectories (Basingstoke: Palgrave, 2010).

5 Chiara De Cesari and Ann Rigney, 'Introduction,' in Transnational Memory: Circulation, Articulation, Scales, ed. Chiara De Cesari and Ann Rigney (Berlin: de Gruyter, 2014), 1-25.

6 For example: Erich Langenbacher, Bill Niven and Ruth Wittlinger, eds, Dynamics of Memory and Identity in Contemporary Europe (New York: Berghahn, 2012); De Cesari and Rigney, Transnational Memory; Bond and Rapson, The Transcultural Turn; Michael Bernhard and Jan Kubik, eds, Twenty Years after Communism: The Politics of Memory and Commemoration (Oxford: OuP, 2014); Małgorzata Pakier and Joanna Wawrzyniak, eds, Memory and Change in Europe: Eastern Perspectives (New York and Oxford: Berghahn, 2016). For a similar critique, 
transnational institutions, such as the European Union. ${ }^{7}$ In this regard, scholars have emphasized the complexity of remembering across borders, particularly in Europe, a continent divided by war, genocide and ideology. European institutions and actors appear preoccupied especially by questions of how to remember the right- and left-wing dictatorships of the twentieth century, the place of communism in European memory cultures, and the relationship between remembering the crimes of the Holocaust and the crimes of the gulag. ${ }^{8}$

In the last decade, a number of European institutions have put forward guidelines for developing the kind of negotiated memory that would be necessary for such a divided continent. These include: the European Parliament (EP) Resolution on 'The Future of Europe Sixty Years After the Second World War' (2005); Parliamentary Assembly of the Council of Europe Resolution 1481 (2006); the 'Prague Declaration on European Conscience and Communism' (2008); and the EP resolution on 'European Conscience and Totalitarianism' (2009). ${ }^{9}$ The Action 'Active European Remembrance' (part of the 'Europe for Citizens' program 2007-2013) aimed to support commemoration of victims of both National Socialist and Stalinist regimes by providing funding to memorialization projects and activities.

However, resolutions and guidelines do not enact themselves, and a transformation of memory cultures does not emerge from nowhere. Collective memory requires actors, both individual and institutional, to construct, transmit and support particular narratives about the past. These actors - for example, politicians, scholars, memorial managers, museum curators, historians, civil society activists and victim groups - have been described by Elisabeth

see Aline Sierp and Jenny Wüstenberg, 'Linking the Local and the Transnational: Rethinking Memory Politics in Europe,' Journal of Contemporary European Studies 23 (2015): 321-329.

7 For example, Elisabeth Kübler, Europäische Erinnerungspolitik: Der Europarat und die Erinnerung an den Holocaust (Bielefeld: transcript, 2012); Laure Neumayer, 'Integrating the Central European Past into a Common Narrative: The Mobilizations Around the "Crimes of Communism" in the European Parliament,' Journal of Contemporary European Studies 23 (2015): 344-363. Aline Sierp provides one of the few analyses that attempt to connect the national and transnational; however, she does not analyze collaboration between nation states. See Aline Sierp, History, Memory and Trans-European Identity: Unifying Divisions (New York: Routledge, 2014).

8 Aleida Assmann, Auf dem Weg zu einer europäischen Gedächtniskultur (Vienna: Picus, 2012); Claus Leggewie, Der Kampf um die europäische Erinnerung (Munich: C.H. Beck, 2011).

9 See Neumayer, 'Integrating the Central European Past' for a detailed process-tracing of the contentious development of these resolutions. 
Jelin as 'memory entrepreneurs, ${ }^{10}$ who by virtue of their power, influence, status or dedication to a cause can have an impact on public interpretations and understandings of the past. ${ }^{11}$ A study of agency and its relationship to structure is thus essential not only for understanding transnational memory politics in Europe and beyond, ${ }^{12}$ but also the dynamics of memory more broadly. Memory practices are 'always simultaneously individual and social,'13 and in order to fully comprehend the interaction between the two we need a systematic empirical analysis of institutions, actors and practices that shape discourses about the past at a local, regional, national and transnational level. ${ }^{14}$

Indeed, memory entrepreneurs have begun to collaborate across borders in increasingly formalized ways. Focusing on Europe alone, the last fifteen years have seen the creation of specific networking initiatives such as the International Holocaust Remembrance Alliance (IHRA, formerly the Task Force for International Cooperation on Holocaust Education, Remembrance and Research, 1998 - which also includes non-European members), the European Network Remembrance and Solidarity (ENRS, 2005), the European Network of Official Authorities in Charge of the Secret-Police Files (ENOA, 2008) and the Platform of European Memory and Conscience (Platform, 2011). These networks have themselves been the subject of an emerging field of research: initial contributions have considered their 'epistemic framing'15 or their interaction with the European Commission and other cross-border agencies. ${ }^{16}$ Jenny Wüstenberg has used network analysis software to map the personal

$10 \quad$ Elizabeth Jelin, State Repression and the Labors of Memory (Minneapolis: University of Minnesota Press, 2003).

11 Eşref Aksu, 'Global Collective Memory: Conceptual Difficulties of an Appealing Idea,' Global Society 23 (2009): 323 .

12 Sierp and Wüstenberg, 'Linking the Local and the Transnational'; see also Annabelle Littoz-Monnet, 'The Eu Politics of Remembrance: Can Europeans Remember Together?', West European Politics 35 (2012): 1182-1202; Neumayer, 'Integrating the Central European Past.'

13 Jeffrey K. Olick, 'From Collective Memory to the Sociology of Mnemonic Practices and Products,' in Cultural Memory Studies: An International and Interdisciplinary Handbook, ed. Astrid Erll and Ansgar Nünning (Berlin: de Gruyter, 2008), 151-161.

14 See Sierp and Wüstenberg, 'Linking the Local and the Transnational,' 323.

15 Sebastian M. Büttner and Anna Delius, 'World Culture in European Memory Politics? New European Memory Agents Between Epistemic Framing and Political Agenda Setting, Journal of Contemporary European Studies 23 (2015): 391-404.

16 Oliver Plessow, 'The Interplay of the European Commission, Researcher and Educator Networks and Transnational Agencies in the Promotion of a Pan-European Holocaust Memory,' Journal of Contemporary European Studies 23 (2015): 378-390. 
connections between individuals according to their attendance at public events associated with these prominent networks to demonstrate the key influencers in these memory-political initiatives. ${ }^{17}$

Wüstenberg's study, which combines an actor-centred approach to transnational memory with an analysis of networks as networks - that is, as a structure of relational ties - provides an important inspiration for the research presented here. Nonetheless, as I will show, it is not only within these named networks that European memory entrepreneurs collaborate across borders. They also work together outside of these structures, for example, through shared exhibitions, collaborative workshops and conferences, informationgathering exercises, and mutual funding arrangements - initiatives that are not captured in Wüstenberg's methodology. Moreover, Wüstenberg's focus on prominent individuals qua individuals, whilst undoubtedly important, risks underrepresenting the role of memorial institutions that are frequently represented in collaborative activities not by one, but by several different employees or members. In the networks listed above, for example, it is more commonly the institution, rather than the individual, who is the named participant.

In the present chapter, I use techniques drawn from social network analysis to demonstrate the networks created by and around two institutions in the period 2011-2014: the Stasi Prison Memorial at Berlin-Hohenschönhausen and the Federal Office for the Files of the State Security Service of the Former German Democratic Republic (GDR). The starting date was chosen as it is the year in which the Platform of European Memory and Conscience, of which both institutions are members, was formed. The end date, $3_{1}$ December 2014, was chosen as a cut-off to allow efficient data collection and management. However, this is not to suggest that transnational co-operation on the part of these institutions is limited to this time-frame (it evidently is not) and it should be acknowledged that the nature of these collaborative activities in terms of partners, foci, funding arrangements and so on changes over time. What is offered in this article is, therefore, a snapshot, but it is one that can function as a starting point for considering the significance of these cross-border collaborations for how we understand the construction of transnational remembering. A longitudinal study tracing shifts over time in the networks created around these institutions would represent an important extension to the work presented here.

I combine an exploration of the structural features of the networks with narrative analysis of the public presentation of the cross-border collaborations of these two significant memory-political institutions in the same timeframe. In

17 Jenny Wüstenberg, 'Vernetztes Gedenken?: "Influence Mapping” in der transnationalen Erinnerungsforschung,' Jahrbuch für Politik und Geschichte 6 (2016): 97-113. 
this way I show not only how and with whom the two institutions collaborate, but also what narratives are made available by these collaborations. These are narratives about the co-operative activity itself, but more significantly, about the national and transnational processes of working through the past and, indeed, about the past itself.

In this way, the chapter is also about reception, that is, about how the efforts towards Vergangenheitsaufarbeitung [working through the past] in one national context are received and put to use in another. As will be seen, the narratives attached to cross-border co-operations are a complex interweaving of the national and transnational, as collaborative efforts with partner institutions abroad are used to comment on (and in some cases express discord with) the memorial culture dominant in Germany, in which, as Langenbacher argues, the prominence 'of Holocaust-centre memory was never in doubt.' ${ }^{18}$ In other cases, these collaborations are used to construct a sense of a common European or indeed Eastern European past. Thus I conceive of reception not as the one-directional movement of memory, of a story about the past being 'encoded' in one context and 'decoded' in another. ${ }^{19}$ Rather, I want to think of reception from the perspective of what has been termed 'histoires croisées. ${ }^{20}$ This approach goes beyond looking at the movement of memory narratives in terms of 'a point of departure and a point of arrival'; rather it considers 'phenomena of interaction involving a variety of directions and multiple effects.' That is, it considers its subjects with regard to relationships, or what Werner and Zimmerman describe as 'intercrossings.' The researcher looks not only at the 'component elements' of these intercrossings, but also at the impact of their interaction. ${ }^{21}$

I thereby develop a new method for analyzing the strategies, interpretations and narratives that determine the public remembrance of contested pasts, which goes beyond a 'continuous inventory of lieux de mémoire.'22 More specifically, I want to introduce the concept of collaboration and collaborative memory into our discussion of how memory is constructed and communicates

18 Eric Langenbacher, 'Still the Unmasterable Past? The Impact of History and Memory in the Federal Republic of Germany,' German Politics 19 (2010): 35.

19 Stuart Hall, 'Encoding/decoding,' in Culture, Media, Language, ed. Stuart Hall et al. (London: Hutchinson, 1980), 128-138.

20 Michael Werner and Bénédicte Zimmermann, 'Beyond Comparison: Histoire Croisée and the Challenge of Reflexivity,' History and Theory 45 (2006): 30-50.

21 Werner and Zimmermann, 'Beyond Comparison,' 37 and 39.

22 Gregor Feindt, Felix Krawatzek, Daniela Mehler, Friedemann Pestel, and Rieke Trimçev, 'Entangled Memory: Toward a Third Wave in Memory Studies,' History and Theory 53 (2014): 42 . 
across borders. This idea of collaboration directs our attention away from the artifacts of memory and towards the agents. It highlights the ways in which European memory cultures are actively being shaped, not only in the sphere of civil society discussed here, but also in politics and culture. ${ }^{23}$ These 'intercrossings' have not previously been the subject of sustained analysis; yet the study of concrete examples of co-operation can show how alliances are forged in transnational memory politics and how such alliances are used to promote specific memory-political goals.

\section{The Case Studies}

GedenkstätteBerlin-Hohenschönhausen [MemorialBerlin-Hohenschönhausen] is situated in the former remand prison of the State Security Service (Stasi) in Berlin, which was the largest such facility in the GDR. The Memorial and its Director, Hubertus Knabe, have played a prominent role in debates surrounding the GDR since unification. The site has been criticized for, amongst other things, an over-emotionalized presentation of the past, overemphasis on the brutality of the 1950s, conflating Nazi and Soviet oppression, and engaging in political propaganda directed against the left, particularly against the Partei des Demokratischen Sozialismus [Party of Democratic Socialism, PDS] and DIE LINKE. ${ }^{24}$ Its growing prominence in German national memory politics has been accompanied by an increasing involvement in transnational collaborations. ${ }^{25}$ As will be discussed, these range from joint exhibitions with European

23 On the subject of co-operation in transitional justice, see Helga Welsh, 'Beyond the National: Pathways of Diffusion,' in Post-Communist Transitional Justice: Lessons from 25 Years of Experience, ed. Lavinia Stan, and Nadya Nedelsky (New York: Cambridge University Press, 2015), 167-187.

24 See, for example, Jürgen Hofmann, 'Zur Auseinandersetzung mit der Hohenschönhausener Gedenkstätte für die Opfer des Stalinismus,' UTOPIE kreativ 81/82 (1997): 158-163; Florien Kappeler and Christoph Schaub, 'Mauer durchs Herz: Inszenierungen von Zeitzeug/innen-Wissen im erinnerungspolitischen Diskurs der Gedenkstätte Berlin-Hohenschönhausen,' in NachBilder der Wende, ed. Inge Stephan and Alexandra Tacke (Cologne: Böhlau Verlag, 2008), 319-329. I offer a detailed analysis of the site's politics and aesthetics in, Sara Jones, The Media of Testimony: Remembering the East German Stasi in the Berlin Republic (Basingstoke: Palgrave, 2014).

25 See Sara Jones, 'Memory Competition or Memory Collaboration? Politics, Networks and Social Actors in Memories of Dictatorship,' in The Changing Place of Europe in Global Memory Cultures: Usable Pasts and Futures, ed. Christina Kränzle and Maria Mayr (Basingstoke: Palgrave, 2017), 63-86. 
partners, such as the Memorial to the Victims of Communism and to the Resistance in Sighetu Marmaţiei to extensive co-operations with Tunisian activists in the wake of the Arab Spring. As indicated above, Memorial Hohenschönhausen is also a member of the Platform of European Memory and Conscience.

The Bundesbeauftragte für die Unterlagen des Staatssicherheitsdienstes der ehemaligen DDR [Federal Office for the Files of the State Security Service of the Former GDR ] - or BStU - was established in 1991 to manage access to the Stasi files for victims, informants (under certain circumstances), media and researchers, according to the Stasi Records Law passed in December of that year. Alongside its involvement in lustration and file access, the BStU also has in its remit political education and remembrance. This includes the running of seminars, workshops and other events, as well as the management of regional and national exhibitions relating to the activities of the Stasi. Most recently, it has - in collaboration with the civil society group Association for Anti-Stalinist Action Normannenstrasse - opened a new large exhibition in the former Stasi headquarters in Berlin. The institution and its commissioners have played a central role in Germany's efforts to work through the history of the East German dictatorship. Nonetheless, this role is increasingly under question, as its primary function - that is, allowing file access for victims of the Stasi - draws to a close and there are plans for the files to be moved to the Federal Archive. In the period under consideration here, the BStU's international initiatives included joint exhibitions, conferences, workshops and podium discussions, and visits by foreign officials, heads of archives and other organizations dedicated to working through dictatorial pasts. The BStU is also a member of the Platform and the ENOA, and is an ENRS partner institution.

\section{Social Network Analysis}

The methods used in the first part of this paper are drawn from social network analysis. The network perspective guides our attention to the interdependence of actors, relational ties and the impact of network structure on individual action. ${ }^{26}$ The focus on relationships between actors (broadly defined

26 See, for example: Alexandra Marin and Barry Wellman, 'Social Network Analysis: An Introduction,' in The Sage Handbook of Social Network Analysis, ed. Peter J. Carrington and John Scott (Los Angeles etc.: Sage, 2011), 11-25; Christina Prell, Social Network Analysis: History, Theory \& Methodology (Los Angeles: Sage, 2012); Stanley Wasserman and Katherine Faust, Social Network Analysis: Methods and Applications (Cambridge: Cambridge University Press, 1994). 
to include both individuals and institutions), rather than exclusively on the actors themselves, is essential to study collaboration and its impact. Specifically, network analysis will be used in this paper to develop a map of transnational co-operations involving Hohenschönhausen and/or the BStU. The focus on the network surrounding a single institution - defining the boundary of the network according to the relationships of that single actor - can be described as an 'egocentric,' rather than 'whole network' approach. ${ }^{27}$ This map is used to identify key partnerships across borders and to demonstrate the structure of the network constructed by and through these memory-political institutions.

In order to generate the map, I gathered publicly available documents from each institution covering the period January 2011-December 2014 and detailing the institution's activities in that timeframe. In the case of Hohenschönhausen, this included the 2011-2012 and 2013-2014 activity reports, ${ }^{28}$ press releases available on the institution's website ( 48 documents in total) and newspaper articles detailing events hosted by the Memorial (10 documents in total). The activity reports were read in full and passages relevant to transnational collaboration highlighted. Press releases and newspaper articles were selected for analysis, if, in their title, they indicated cross-border co-operation. For the BStU, the corpus included yearly retrospectives (2011-2014), biannual activity reports (2011-2012 and 2013-2014) ${ }^{29}$ and press releases available on the website (16 documents in total). Again, the yearly retrospectives and activity reports were read in full and passages relevant to transnational collaboration highlighted. Press releases were selected for analysis, if, in their title, they indicated some form of cross-border co-operation. One limitation of the use of published material for identifying collaborations is that this might not capture every single event or cross-border relationship; that is, not every activity is necessarily reported. However, institutions are most likely to include in press releases, reports and retrospectives those activities that they deem most significant or reflective of their mission and self-understanding. Moreover, as the present research is interested in how memory entrepreneurs shape public discourse

27 See Nick Crossley et al., Social Network Analysis for Ego-Nets (Los Angeles etc.: Sage, 2015).

28 Stiftung Gedenkstätte Berlin-Hohenschönhausen, 6. Tätigkeitsbericht (2011/2012); Stiftung Gedenkstätte Berlin-Hohenschönhausen, 7. Tätigkeitsbericht (2013/2014).

29 Bundesbeauftragte für die Unterlagen des Staatssicherheitsdienstes der ehemaligen DDR, Elfter Tätigkeitsbericht des Bundesbeauftragten für die Unterlagen des Staatssicherheitsdienstes der ehemaligen Deutschen Demokratischen Republik für die Jahre 2011 und 2012; Bundesbeauftragte für die Unterlagen des Staatssicherheitsdienstes der ehemaligen DDR, Zwölfter Tätigkeitsbericht des Bundesbeauftragten für die Unterlagen des Staatssicherheitsdienstes der ehemaligen Deutschen Demokratischen Republik für die Jahre 2013 und 2014. Both accessed 30 June 2016, http://www.bstu.bund.de/DE/Wissen/Publikationen/ Reihen/Taetigkeitsberichte/taetigkeitsberichte_node.html. 
about the past and the processes of coming to terms with it, it is these publicly reported activities and relationships that are of the most relevance.

From these documents, events that indicated a 'relational tie,' that is, collaboration with a non-German partner institution, were identified and the details (participants, type of event, date) were gathered into a separate document for entry into the online influence mapping software Tartan (ㄷ 2011 Ntrepid Corporation). ${ }^{30}$ Following the observation above about the way in which an institution is frequently represented by several different individuals, where an individual's affiliation was named in the source documents, I defined the actor by the institution, rather than by the person representing that institution. For each event, both German and non-German participants were recorded. This was important in terms of allowing me to identify not only with whom Hohenschönhausen and the BStU collaborate transnationally, but also with which German actors they collaborate in order to develop these transnational links. In several cases, the individuals were not named; instead the document just indicated the group of entrepreneurs to which they belonged, for example, 'Tunisian civil society activists.' In these cases, that designation was used to define the actor.

Once the actors participating in the given event have been identified and the data entered into the program, the software allows the relationships between them to be coded according to the intensity of the interaction. If two actors were both present at a conference, for example, but there was no evidence that they had interacted, I did not create a relationship between them. However, if they had participated on a joint panel or in a smaller workshop, I considered this a ' $1+$ meeting.' On the other hand, co-organization of an exhibition or other event that would require closer and more sustained collaboration was designated a ' $2+$ meeting.' All relationships were assumed to be reciprocal, that is, 'undirected' in the terms of social network analysis. Tartan uses data provided by the researcher to create a visualization of the links between the actors and the resulting networks. It also calculates actors' centrality and influence within the network.

\section{Results: Memorial Berlin-Hohenschönhausen}

The material gathered relating Hohenschönhausen in the period 2011-2014 documents 75 events involving some form of transnational collaboration, from joint exhibitions to visits by foreign diplomats or heads of other memorial

3o I would like to thank Mat Mathews at Ntrepid Corporation for providing me with free access to Tartan, and for his invaluable assistance in negotiating the software. Wüstenberg demonstrates the benefits of Tartan for mapping the interactions between individuals involved in existing transnational memory-political networks. See, 'Vernetztes Gedenken.' 
institutions. These 75 events involved 114 stakeholders ${ }^{31}$ from 38 different countries. Collaboration was also recorded with multinational groups such as Amnesty International and Reporters without Borders. I coded 490 relationships between these stakeholders.

Tartan uses mathematic algorithms - taking into account the number of collaborative activities and the intensity or frequency of those activities (as defined above) - to calculate 'degree centrality', that is, which actors have the most direct connections to other actors and value of that number with relation to the rest of the network. In this regard, an institution or individual who is involved in one or more collaborations with multiple other actors will have a higher degree centrality than those involved in bilateral collaborations with Hohenschönhausen alone. We can thus infer that the actors at the top of the centrality list are important partners for the Memorial, not necessarily through close one-to-one collaboration, but because they are repeatedly brought in to support larger initiatives. ${ }^{32}$ Table 2.1 indicates the top nine most central actors in the network created by and through Hohenschönhausen in this period (excluding Hohenschönhausen itself).

If we ignore Hohenschönhausen itself (which, given how the data was collected, is unsurprisingly central to all collaborations), the two institutional actors with the highest degree centrality are the Konrad Adenauer Stiftung [Konrad Adenauer Foundation, KAS] and the Auswärtiges Amt [German Foreign Office]. What is interesting here is that neither of these actors is a named participant in the established networks relating to memory politics, such as the Platform or ENOA. Nor do they have memorialization or memory politics as part of their official remit. The KAS - a political foundation affiliated to the Christian Democratic Union of Germany (CDU) - is well known for its involvement in and funding of memory-political activities world-wide; however, this is not presented as part of its core mission. On its website, the foundation defines this mission as including 'democracy promotion,' but does not state explicitly that this incorporates memory of dictatorship. The Foreign Office is principally concerned with diplomacy and Germany's image in the world;

31 'Stakeholder' is the term used by Tartan to refer to the nodes or actors within a given network.

As Crossley et al. note, centrality measures (and any other 'whole network' measures) can be calculated on ego-nets, assuming that there are ties present between alters (i.e., the other actors within the network). However, we must bear in mind that the boundary has been defined according to an alter having a relationship with the ego (principal actor), so we cannot know what relationships it might have with actors beyond the ego-net. Crossley et al., Social Network Analysis for Ego-Nets, 82. 
TABLE 2.1 Top nine actors in Hohenschönhausen network (excluding Hohenschönhausen) according to degree centrality

\begin{tabular}{lll}
\hline Rank & Actor & Degree centrality strength \\
\hline 1 & Konrad Adenauer Foundation & 0.223 \\
2 & German Foreign Office & 0.214 \\
3 & Tunisian Government & 0.107 \\
4 & Contre l'oubli activists & 0.107 \\
5 & Sven Felix Kellerhoff & 0.089 \\
& (journalist) & \\
6 & Christoph Shaefgen (attorney & 0.08 \\
& general) & \\
7 & Deutschlandfunk (radio station) & 0.08 \\
8 & Institute for National Remem- & 0.071 \\
& brance (Warsaw) & \\
9 & Warsaw Rising Museum & 0.063 \\
& & \\
\hline
\end{tabular}

this involves, according to its website, promoting 'intensive exchange with the world in economics, culture, science and technology, environment, issues of development and many other themes, ${ }^{33}$ but the working through of dictatorship is not named explicitly. These are important examples of how institutions not affiliated with prominent memory networks, and without an obvious interest in memory politics, can nonetheless influence processes of remembrance across borders.

If we turn to the most central non-German actors in the Hohenschönhausen network, we can once again see the importance of looking beyond the prominent European networks and indeed beyond Europe in our analysis of transnational memory. The next two most central institutional actors are the Tunisian government and the Tunisian memorialization project, Contre l'oubli [Against Forgetting], both of which were engaged in a longer term collaboration with Hohenschönhausen between 2011 and 2014. The collaboration included repeated visits to the Hohenschönhausen Memorial by representatives of the Tunisian government and Contre l'oubli, and by representatives of Hohenschönhausen to sites and partners in Tunisia. There was also a collaborative exhibition, a

33 Unless otherwise stated, all translations from German are my own. 
joint conference, the writing of a master plan for memorialization in Tunisia and the production of a 'Handbook for Working through the Past.'

An important feature of Tartan is that it allows the user to make a stakeholder 'invisible' before modeling the network. Removing Hohenschönhausen from the modeling allows us to see if and how the other actors are connected beyond their relationship with the Memorial, that is, it breaks the network down into the 'components' in which all actors are linked by a path that does not go through the central node. ${ }^{34}$ In this way, one-off bilateral collaborations are removed and we get a clearer picture of the way in which connections between different stakeholders are made by and through Hohenschönhausen.

What is especially interesting in this case is that, despite the removal of the primary institution, the model is still of one significant network. The number of stakeholders in this network is reduced to 63, indicating that a number of collaborations are indeed bilateral between Hohenschönhausen and one other actor; ${ }^{35}$ however, the fact that the network by and large remains intact, indicates that Hohenschönhausen repeatedly works with the same partners on different projects and that these partners work repeatedly with several other actors. That is, multiple connections and relationships between memory entrepreneurs are created by and through the activities of the Memorial. As we will see this contrasts with the creation of networks around the activities of the BStU.

\section{Results: BStU}

The material gathered relating to the BStU in the period 2011-2014 documents 81 events involving some form of transnational collaboration. Again, this includes joint exhibitions and workshops, visits by foreign diplomats or the heads of other national archives or memorial sites, and travel by BStU representatives to international conferences. The 81 events involved 116 stakeholders from 39 different countries. I coded 361 relationships between these stakeholders. We can already observe from these figures that the BStU was involved in more collaborative activities, but with fewer actors in each.

Table 2.2 indicates the top nine most (degree) central actors in the network created by and through the BStU in this period (excluding the BStU itself). We can see that the actor with the highest degree centrality is once again a German institution, that is, the German Foreign Office. That this government

34 For more on 'components' and their significance see Crossley et al., Social Network Analysis for Ego-Nets, 12-13.

35 Nine other components were identified, but one of these had only three actors and the remaining eight only two, indicating that they represent one-off smaller events involving the Memorial, rather than sustained or significant collaboration. 


\begin{tabular}{lll}
\hline Rank & Actor & Degree centrality strength \\
\hline 1 & German Foreign Office & 0.132 \\
2 & Slovak Institute & 0.114 \\
3 & Czech Centre & 0.114 \\
4 & Slovak Embassy & 0.114 \\
5 & Czech Embassy & 0.114 \\
6 & Egyptian Government & 0.096 \\
7 & Tunisian Civil Rights & 0.088 \\
8 & Activists & \\
9 & Tunisian Government & 0.079 \\
& Egyptian Civil Rights & 0.079 \\
& Activists & \\
\hline
\end{tabular}

body plays a central role in the activities of both organizations under study here suggests that - at least when it comes to institutions supported by Federal funds, as is the case with both Hohenschönhausen and the BStU - other state actors might play a more active part than is commonly recognized. As the Foreign Office's contribution in both cases for the most part takes the form of funding or behind-the-scenes organization, this involvement is also partially hidden.

However, unlike the network formed by and through Memorial Hohenschönhausen, other German actors are less prominent in the BStU network. The actors with the next highest degree centrality are institutions located in Germany, but representing non-German interests. Positions two to five are occupied by the Slovak Institute, Czech Centre, Czech Embassy and Slovak Embassy respectively. Positions six to nine are taken by the Egyptian government, Tunisian civil rights activists, the Tunisian government and Egyptian civil rights activists. It is easier to see how and why these results emerge if we model the network with the BStU made 'invisible.' In contrast to the single network created by and through Hohenschönhausen, if the BStU is removed from the modeling, four significant components are produced with twenty-nine, fourteen, nine and nine stakeholders respectively. ${ }^{36}$ What this indicates is that the BStU works with discrete groups of actors in a project-style approach, rather than creating connections between different groups.

$3^{6} \quad$ A further twelve components were identified, each with only two actors. 


\begin{tabular}{lll}
\hline Rank & Actor & $\begin{array}{l}\text { Degree centrality } \\
\text { strength }\end{array}$ \\
\hline 1 & German Foreign Office & 0.5 \\
2 & Egyptian Government & 0.357 \\
3 & Tunisian Civil Rights Activists & 0.321 \\
4 & Tunisian Government & 0.286 \\
5 & Egyptian Civil Rights Activists & 0.286 \\
\hline
\end{tabular}

Analysis of the four components highlights this finding and also shows clearly what these 'projects' were. The first and largest component I will term the 'Arab Spring Network,' as it results from a concerted effort on the part of the BStU (and in a parallel with Hohenschönhausen) to contribute to the process of working through dictatorships in Middle Eastern and North African countries in the wake of the revolutionary movements in that region. Table 2.3 indicates the top five actors in terms of degree centrality.

The collaborations within this component included meetings in Cairo between BStU representatives and Egyptian government and civil society actors, visits by Egyptian, Tunisian and Yemeni activists to the BStU, and participation in a conference in Tunisia with, amongst others, Labó démocratique [Democratic Lab], who were also an important partner for Hohenschönhausen. Interestingly, this network is not only the largest; it also contains the most German institutional actors, including the German Foreign Office, other German government representatives, the KAS, Friedrich Ebert Stiftung [Friedrich Ebert Foundation], Goethe Institut [Goethe Institute], and the radio station Deutschlandfunk.

I describe the second largest component created by and through the BStU as the Czech and Slovak network. It is here that we see the collaboration with the Slovak Institute, Czech Centre, and Slovak and Czech Embassies. The component also includes the Prague Institute for Contemporary History, and Institute for the Study of Totalitarian Regimes, as well as the Institute for National Remembrance in Bratislava. However, these collaborations involve very few German memory entrepreneurs and no institutional ones. This network essentially represents the project Fokus DDR-ČsSR. Alltag und Geheimpolizei in zwei kommunistischen Diktaturen [Focus GDR - CSSR. The Everyday and the Secret Police in Two Communist Dictatorships], which ran as a collaboration between the BStU, Slovak Institute and Czech Centre, with the sponsorship of the Slovak and Czech Embassies in the period September-November 2011. 
The third component within the larger BStU network is dominated by the Institute for National Remembrance (INR) in Warsaw. The connections all run through this institutional actor, except for two additional links made through the Heinrich Böll Stiftung [Heinrich Böll Foundation]. What the shape of this third component suggests - and what is confirmed by reference to the types of event involving this actor - is that this co-operation is essentially an intensive bilateral one between the INR and the BStU. It included a collaborative workshop, visits by the President of the INR, and participation by BStU representatives in workshops organized by the INR. As both the BStU and INR are members of the ENOA, this is an example of how members of an established network might collaborate intensively both within and outside of that network.

The fourth network that emerges when the BStU is removed from the modeling indicates another example of German government actors being directly involved in memory entrepreneurship where one might not expect it. Here the central figure in the network is Joachim Gauck - former BStU Commissioner and Federal President from 2012 to 2017. However, closer examination reveals that this amounts to only two collaborations with multiple participants: the opening of the exhibition Lernt Polnisch at the Europa-Universität Viadrina in Frankfurt Oder and a visit by Gauck to the BStU regional branch in Rostock. In both cases, Gauck was accompanied by other heads of state or government representatives of other countries so could be said to be acting in his capacity as Federal President, rather than as a result of his close links with the BStU.

In sum, the network analysis shows that the Hohenschönhausen Memorial has several partners with whom it collaborates frequently on different projectsan approach that creates connections between different actors and a single broad network in and through the Memorial. The BStU, on the other hand, tends to collaborate transnationally on discrete projects each with a more defined set of actors. These co-operations may be more intensive; however, fewer connections are created between the actors taking part in the different projects, resulting in multiple smaller networks. The analysis of degree centrality also indicates the key actors within these networks and, by implication, the key partners of these two memory political institutions. What is striking is that, for both Hohenschönhausen and the BStU, institutions not normally associated with memory entrepreneurship and/or outside of Europe play a central role. This not only highlights the need to look beyond established networks and indeed beyond Europe in our analysis of transnational memory, it also raises several questions. What is the purpose of co-operations with non-European actors with very different experiences of dictatorship? How does this compare with the motivations behind collaboration between European memory entrepreneurs? Is it only German institutions who were so involved in memory 
political activities in the wake of the Arab Spring? That is, is there something special about the German case?

\section{Narratives of Memory}

In order to answer the questions raised above, we need to turn to qualitative methods to explore how these actors understand and present the cross-border collaborations in which they are involved. In view of the role of such memory entrepreneurs in constructing public narratives about the past and the processes of coming to terms with it, it is particularly the public portrayal that is of interest. In this regard, the same material used to identify the events and participants for entry into Tartan can be approached in a different way to explore what these collaborations meant for the actors involved.

The method used to explore these meanings is developed from narrative analysis. Narrative analysis has a long-standing tradition in the humanities and has become increasingly used in the social sciences, ${ }^{37}$ also leading to some fruitful cross-over between the two. ${ }^{38}$ Social network analysts have also turned to narrative to identify the meanings of relationships and ties for network members, as well as in recognition that networks themselves are narrative constructions. ${ }^{39}$ Narrative research is located firmly within a constructivist or postmodern and interpretative paradigm which looks not for a 'real, essential and objective reality reflected in narratives,' rather 'it proposes a subjective and relativist reality, largely invented by narratives. ${ }^{\prime 40}$ In our context, the researcher is not looking for information on the 'real' motivations behind cross-border collaborations or for an authentic insight into their purpose; rather she is interested in how the narrators (here the authors of the reports and press releases or those cited in them) give meaning to these co-operative activities.

37 For example, D. Jean Clandinin and F. Michael Connelly, Narrative Inquiry: Experience and Story in Qualitative Research (San Francisco: Wiley, 200o); Lynn Butler-Kisber, Qualitative Inquiry: Thematic, Narrative and Arts-Informed Perspectives (London: Sage, 2010); Molly Andrews, Corinne Squire and Maria Tamboukou, eds, Doing Narrative Research (Los Angeles etc.: Sage, 2008).

38 For example, Barbara Czarniawska, Narratives in Social Science Research (London/New Dehli: Sage, 2004).

39 For a summary of this research, see Crossley et al., Social Network Analysis for Ego-Nets, 104-125.

40 Gabriela Spector-Mersel, 'Narrative Research: Time for a Paradigm,' Narrative Inquiry 20 (2010): 208 . 
Narratives are made up of plot elements (events, people, time etc.), but importantly 'the same set of events can be organized around different plots.'41 This is especially significant when the narratives being constructed are not about the self, but about what society is, was and should be. What are being narrated in the documents under consideration here are co-operations between memory entrepreneurs in different national contexts. These are stories about the motivations of these collaborations and their outcomes, but they are also stories about the nature of the past and the processes of coming to terms with it that are located in a national and transnational political context. In this way, these narratives also relate to questions of power: these stories locate institutions, nations and regions in terms of success and failure; they give an account of which approaches to the past work and which do not; and they identify who should be listening to and learning from whom, that is, who the experts of Vergangenheitsaufarbeitung really are. In this sense, they are 'strategic narratives,' described by Miskimmon, O'Loughlin and Roselle as 'a communicative tool through which political actors [...] attempt to give determined meaning to past, present and future in order to achieve political objectives.'42 This is not to say that the narrators in this context are completely free to tell any strategic story, rather that their narratives are shaped and constrained by the political (including memory-political) and social context into which they are launched.

In order to identify the strategic narratives created in the storying of crossborder collaborations, the same documents that were selected for the network analysis through Tartan were subject to a process of discursive analysis in order to identify common patterns in terms of the motivations and positioning of the different actors involved. The documents were coded systematically with regard to narratives produced and the most common ones identified for each institution. Given the need to represent narrative holistically, ${ }^{43}$ in the presentation of results only a few examples for each narrative will be provided, which are representative of the corpus as a whole.

\section{Results: Memorial Berlin-Hohenschönhausen}

Analysis of the 75 cross-border events in which Hohenschönhausen was involved between 2011 and 2014 brought to the fore three key narratives. I will term these: 'Learning from the Germans,' 'Beyond the National/Better Together' and 'Learning from Others.' A single event is often narrated in multiple

\footnotetext{
41 Czarniawska, Narratives in Social Science Research, 7.

42 Alister Miskimmon, Ben O'Loughlin and Laura Roselle, Strategic Narratives: Communication, Power and the New World Order (New York/London: Routledge, 2013), 5 . 
ways; however, as will be seen, these three narratives are generally attached to different kinds of cross-border collaboration with different global or European partners and in the service of different political objectives.

Learning from the Germans

I borrow the term 'learning from the Germans' in this context from Andrew Beattie. Beattie uses the term to refer to the potential application of the German approach to working through conflicted pasts to the pan-European context. ${ }^{44}$ In contrast, here this narrative is most frequently (although not exclusively) constructed in relation to the cross-border co-operations of Hohenschönhausen with non-European actors, especially those collaborations which emerged in the wake of the Arab Spring. In this narrative, the Memorial is presented as representative of a German memorial culture which has developed successful strategies for working through dictatorships: collaborative activity in this account serves the purpose of sharing that expertise with those institutions and national contexts constructed as newcomers to the field.

One prominent example of the use of this narrative is in the collaboration between the Memorial and Tunisian memory entrepreneurs. In October 2011, Knabe visited the former prison of the state security service in Tunis at the invitation of the Tunisian Minister of the Interior Habib Essid. In the press release giving an account of the visit, Knabe is framed as an expert who 'called on the [Tunisian] authorities to do everything possible to ensure that the files of the state security service are retained. The reference specifically to the opening of the Stasi files sets this expertise beyond the competency of the Hohenschönhausen Memorial and its Director (who do not, after all, have responsibility for the Stasi files) and locates it instead in the wider approach to memory of the GDR in Germany. That Knabe presents himself and his institution as representatives of this broader context is also seen in his reported offer to support the Tunisian authorities in the drafting of a law to protect the state security files, alongside his recommendation to turn the prison into a Memorial. In his conversations with human rights activists who are making efforts towards working through the dictatorship in Tunisia, Knabe is reported as stating: 'in Tunisia there are also numerous efforts to work through the crimes of the past and ensure justice for the victims. Perhaps our experiences can be useful in this regard.' It is not clear, however, if 'our' refers to the Memorial itself, or to Germany.

44 Andrew H. Beattie, 'Learning from the Germans? History and Memory in German and European Projects of Integration,' PORTALJournal of Multidisciplinary International Studies, 4 (2007): 1-22, accessed 6 June 2016, http://dx.doi.org/10.5130/portal.v4i2.483. 
This rhetoric is repeated in the collaboration with Tunisian memory entrepreneurs in the context of the Contre l'oubli project described above. In a press release of the 6 March 2012, the Memorial is described as standing by experts from Tunisia 'in an advisory capacity' and as 'part of a new project, in which the experiences of Germany in the field of working through the past is passed onto state and social institutions in Tunisia.' The repetition in these documents of the vocabulary of 'support,' 'advice' and 'help' for the Tunisian colleagues constructs a unidirectional transfer of ideas and expertise from the German side to the (in this view) emerging democratic state. A similar use of language and narrative can be seen, among others, in co-operations with Peru in November 2011 (Hohenschönhausen 'advises the Peruvian truth commission' and offers 'support' and 'help' in the construction of memorials) and Cambodia in January and May 2012 (Hohenschönhausen offers 'support' to the memorials at the Toul Sleng prison and the central execution site of the Khmer Rouge). These non-European actors are not constructed as equal partners and the collaborations are not presented as a two-way exchange of expertise.

We must consider that part of this emphasis on a particular way of working through the past is a result of these documents largely serving promotional purposes. However, as seen above, this narrative does not (only) praise the Hohenschönhausen Memorial, but German memorial culture more broadly. Kaja Kaźmierska has recently argued that a dichotomy has been constructed between a 'Western and "non-Western" approach towards the issues of e.g., collective (national) identity. ${ }^{45}$ In his tracing of the similarities between German and European memory cultures, Beattie similarly argues that an inaccurate east-west dichotomy legitimizes pressure on the eastern side to conform to a seemingly unquestionable but, in fact, contested western norm. ${ }^{46}$ Here, however, we see an institution that might find itself on the eastern side of that dichotomy in terms of its memory politics (notably, the equation of Nazi and Soviet dictatorships frequently seen at the site) appropriating an idealized version of a pan-German coming to terms with the past in a way that constructs non-European contexts as not fully developed and in need of assistance.

\footnotetext{
45 Kaja Kaźmierska, 'Biographical and Collective Memory: Mutual Influences in Central and Eastern European Context,' in Pakier and Wawrzyniak, Memory and Change in Europe, 109 .

46 Beattie, 'Learning from the Germans,' 17.
} 
In the second narrative that is constructed around the cross-border collaborations of the Hohenschönhausen Memorial, this sense of German superiority in processes of coming to terms with the past disappears. Instead, the Memorial is located in either a global or a European community of remembrance. There are two slightly different versions of this narrative in the public presentation of cross-border activity. In the first, the Hohenschönhausen Memorial positions itself as part of a global network of institutions and individuals fighting for democracy and human rights. In many cases, these are what I term 'rhetorical' collaborations, that is, they construct a link with other protest movements or activists, but do not involve any actual material links with international partners. One example is the involvement of the Memorial on 20 March 2011 in an initiative of the Berlin International Literature Festival to organize worldwide readings from the work of Liu Xiaobo, recipient of the Nobel Peace Prize and principal author of Charta o8, which called for democratization in China. The press release notes that 'more than 115 institutions in 73 cities and 30 countries on all continents took part,' emphasizing Hohenschönhausen's place in this international community. Similarly, in articles in Die Tageszeitung and Berliner Zeitung dated 23 August 2012, Knabe is reported as wanting to visit the imprisoned Russian punk band Pussy Riot and as having written an open letter to the Russian Ambassador, Vladimir Grinin, in which he noted that 'as Director of the Memorial in the former central prison of the Stasi, the respect of basic rights and freedom of expression is also very important to me in today's context.' Knabe thereby positions both himself and the Memorial alongside international artists and activists who stand for democracy and freedom from authoritarian rule, but does not suggest explicitly that other nations might learn by the German example.

The second form of this narrative is generally used in reference to co-operations with European partners, which are often more extensive and involve actual contact between memory entrepreneurs from different national contexts. Here the narrative of German success frequently becomes one of a European failure against which the institutions involved in the collaboration are fighting. Notably, it is this narrative that is dominant in the public presentation of Hohenschönhausen's collaborative activities within the Platform of European Memory and Conscience. In a press release about the founding of the Platform on the 14 October 2011, Knabe is cited as explaining the reason behind the collaboration of the Memorial within the network as the need to understand education about the past as a 'European task' in need of 'European standards,' which had, he argued, up until now been lacking. The Hohenschönhausen Forum, organized by the Memorial alongside the annual meeting of 
the Platform in Berlin on the 7 November 2012, was held under the title 'Working through Communism as a European Task. In the announcement of the program, the event is framed as a step towards rectifying the perceived failure in Europe to deal with the history of communist regimes: 'as a rule, the perpetrators remain unpunished, the functionaries often occupy important positions in the democratic regime, victims are usually only minimally compensated. Has Europe failed in working through communism?'

Also outside of the official network, the Memorial's collaborations with other (Central and Eastern) European partners are narrated in a way that constructs common histories. This is seen, for example, in an extended collaboration with the House of Terror in Budapest and its co-founder and Hungarian President, János Áder. On the 11 March 2013, Áder visited the Hohenschönhausen Memorial; in a press release, he is reported as stating 'how important working through communism is - also beyond national borders.' This expressed desire for transnational co-operation is soon put into action at a high level. On the 16 June 2014, a press release reports that Gauck, Knabe and Áder have presented a German-Hungarian project which aims to collect in a register the names of all those who were politically persecuted under communism. Again, this initiative is set in the context of a European failure which can only be resolved through European collaboration: 'despite all commitments to working through the past, nobody has as yet made the effort to record by name those persecuted,' Knabe adds, 'we want to change that, not only for Germany, but for the whole of Europe.'

A third far less prominent, but still important, narrative in the presentation of the cross-border collaborations of the Hohenschönhausen Memorial is one not of European failure, but of German failure. Here the co-operation across borders is used not to suggest that others might learn from the German example, but that German memorial culture might learn from other national contexts. This narrative tends to be interwoven with that of 'learning from the Germans' or 'beyond the national/better together' described above, but its effect is to criticize what is presented as the dominant approach to the past in Germany by way of reference to other ways of dealing with dictatorship. For example, a press release reports a visit by Knabe to Czech sites of memory on 25 October 2012. On the one hand, Knabe is described as encouraging his Czech partners to create a publicly accessible memorial and not to leave the field open to commercial providers' - that is, to learn from the German example. On the other hand, Knabe is reported as stating: 'in contrast to what often happens in Germany, in the Czech Republic, National Socialism and communism are 
not seen as opposites, but as two sides of the same coin. [...] In this respect, the Czech Republic, which was a victim of both regimes, is a model for other European states.' Similarly, in a Tagesspiegel article reporting a visit by Knabe to Tunisia dated 20 May 2011, in the context of the transmission of knowledge from Germany to Tunisian partners described above, Knabe is cited as stating: 'in contrast to what happened in Germany, the Tunisians continued their revolution beyond the collapse of the ruling elite and banned the former ruling party.' The suggestion of a 'completed' revolution in Tunisia resonates with the concept of an 'unfinished revolution' in Central and Eastern Europe ${ }^{47}$ and clearly implies a need to ban the successor parties to the Socialist Unity Party, which ruled in the GDR, in order to achieve full social renewal.

\section{Results: BStU}

Analysis of the 81 cross-border events in which BStU was involved between 2011 and 2014 brings to the fore two key narratives. I will term these 'Learning from the Germans/Eastern Europeans' and 'Beyond the National/Better Together,' although they can be seen to serve slightly different purposes to the similar narratives constructed around events involving Hohenschönhausen. A third narrative also emerged from the documents, specifically in co-operations with other national archives and in particular those from non-Central and Eastern European countries. These are framed principally in terms of professional exchange and focus on issues of preservation. Although this does of course have an important political dimension in terms of the role of archives in what we remember, ${ }^{48}$ it is less explicitly related to memory politics than the first two narratives and I will not explore it in detail here.

\section{Learning from the Germans/Eastern Europeans}

It is striking that the promotional material surrounding the cross-border collaborations of the BStU also frequently suggests a narrative of these co-operations being motivated by other countries' desire to 'learn from the Germans.' Once again it is frequently in collaborations with non-European countries that this narrative emerges and it is especially prominent in the presentation of co-operations with North African and Middle Eastern countries in the wake of the Arab Spring. The eleventh activity report states that the citizens' rights activists involved in the Arab Spring 'are asking themselves similar questions

\footnotetext{
47 James Mark, The Unfinished Revolution: Making Sense of the Communist Past in CentralEastern Europe (New Haven/London: Yale UP, 2010).

48 See, for example, Dora Osborne, ed., Archive and Memory in German Literature and Visual Culture (Rochester, NY: Camden House, 2015).
} 
to the civil rights movement in the Peaceful Revolution in the GDR, and they want to learn from those experiences and from the work being done today in the Stasi Records Authority (BStU) and its legal framework.49 In this context too, the language is of 'support,' 'advice' and 'help' for the non-European partners. It is worth reminding ourselves that the network analysis indicates that it is these collaborations which most frequently incorporate the involvement of state-level German actors, such as the Foreign Office, and political foundations, whose remit does not explicitly include memory politics and whose focus is Germany's image in the world and the promotion of liberal democracy. This is also the case for several of Hohenschönhausen's collaborations with post-Arab Spring countries (for example, the project Contre l'oubli was set up at the initiative of the German Foreign Office $)^{50}$ and indicates that the involvement of actors with different stated motivations within the collaborations may also have an impact on the way in which these co-operations are narrated.

However, in the case of the BStU we see an interesting shift: learning from the Germans also becomes learning from Central and Eastern Europe. For example, the eleventh activity report notes the participation of the BStU in a workshop organized by the Bulgarian Foreign Ministry on the topic of transitional justice. The reader is informed: 'the workshop was aimed especially at participants from the countries of the "Arab Spring" and served to pass on the experiences of the countries of Central and Eastern Europe with regard to successes and failures in the working through of dictatorship. ${ }^{51}$ In many regards, this narrative appears similar to that of 'Beyond the National' in Hohenschönhausen's collaborations within the Platform and can indeed be seen as a result of co-operations between the BStU and its sister organizations within the ENOA. However, where the narrative constructed around the Platform events was more often one of the failure of Europe as a whole, here we see the idea of Central and Eastern European successes informing the decisions of activists in other post-conflict societies.

2

Beyond the National/Better Together

The narratives constructed around the cross-border collaborations of the BStU thus appear to be a complex interweaving of the national and transnational, of pride in what are perceived as German achievements and subsuming of these achievements into a story of Central and Eastern European co-operation. Indeed, the BStU promotional material in this period reports considerably more

49 BStU, Elfter Tätigkeitsbericht, 98.

50 Hohenschönhausen, 7. Tätigkeitsbericht, 81 .

$51 \quad$ BStU, Elfter Tätigkeitsbericht, 101. 
on the activities of the institution within pan-European networks, especially the ENOA, than in similar documentation relating to Hohenschönhausen. Here the sense of German superiority in working through difficult pasts disappears and is replaced by a narrative of mutual support and encouragement, as well as a focus on what unites the history of these different national contexts. One example of this phenomenon is the close collaboration of the BStU and the Polish INR to construct a common exhibition for the ENOA showcasing the history of the secret police in the different countries represented by the network members, as well as the different routes to working through the past. Differences between the national contexts are acknowledged; however, the very fact of a joint exhibition places the emphasis on commonalities. The language here is not of 'learning' and 'advice,' but of 'co-operation' and 'exchange.'

However, it is not only within these large networks that we see this narrative of a common history, but also with regard to smaller-scale, but more intensive, collaborations. This is where we see the impact of the different structure of the BStU's co-operative activity as described above. The emphasis on close collaboration with a smaller number of actors can mean a greater focus on what more concretely unites the different national histories. For example, in events developed as part of the close co-operation with the Czech Centre and Slovak Institute (supported by the Czech and Slovak embassies), the emphasis is on shared pasts and presents. In the press release for an event on 'The Czechoslovak and East German Opposition,' the author asks: 'how did the opposition movements influence one another? And what is the continued impact of the common [my emphasis] fight for freedom and democracy in today's society?' Similarly, the exhibition Lernt Polnisch developed by the BStU, but presented in collaboration with a number of Polish partners (including, for example, the Polish Ambassador in Berlin, the Head of the INR in Poland and former members of Solidarność $)^{52}$ is framed as a study into the influence of the Solidarność movement on opposition in the GDR.

The effect of this narrative is to create a Central and Eastern European community of remembrance, bringing together the partners of the ENOA, but also Central and Eastern European actors outside of this network. It is here that we can see the combining of the two narratives, as this community of Central and Eastern Europeans working 'better together' is also one from which others outside of this community might learn. We see this in the above description of the workshop organized by the Bulgarian Foreign Ministry, where the 'others' are non-European actors. However, it is also seen in interactions within broader European memory politics. On 14-15 September 2011, the BStU co-organized an 
international conference on the topic of the files of communist secret police services held at the representation of the European Commission in Berlin. The BStU's co-operation partners were the Südosteuropa-Gesellschaft [South-East Europe Society] and the Deutsche Gesellschaft für Osteuropakunde [German Society for the Study of Eastern Europe]. According to the eleventh activity report of the BStU, the conference considered 'the relevance of the approach to the legacy of the secret police in Eastern European societies and if the discussion in Eastern Europe provides impulses for a pan-European discussion about how to deal with the legacies of other twentieth-century dictatorships. ${ }^{53}$ The report goes onto list the national contexts from which speakers were drawn, mostly Central and Eastern European, 'but also [my emphasis] Greece and Spain.' We can read this as the counterpart to the 'othering' of Eastern European approaches to the past, as described by Kaźmierska and Beattie; in this narrative, it is the Western European, alongside the non-European, nations who might turn to Central and Eastern European countries and contexts (including eastern Germany) for inspiration.

\section{Towards a Collaborative Memory}

The analysis of the networks created by and through the transnational collaborations of these two organizations indicates that institutions use co-operations across borders to promote their particular approach to working through the past, to forge alliances and groupings and to use these collaborations to construct narratives that are located in the German national context, but also seek to assert a Central and Eastern European way of seeing. Moreover, the new methodology used here, the combination of network and narrative analysis, indicates the importance of looking beyond those institutions most obviously involved in memory activism to consider the complex interaction of state and civil society initiatives. In sum, these co-operations are important not only for comprehending the workings of these institutions, they also indicate something important about memory across borders and about the reception of different pasts at sites of 'intercrossing': that is, that both can be understood in terms of collaboration.

Through collaborative activity, memory entrepreneurs create accounts of the past, which are not 'de-territorialized' in Levy and Sznaider's terms. ${ }^{54}$ Rather,

53 BStU, Elfter Tätigkeitsbericht, 91.

54 Daniel Levy and Natan Sznaider, The Holocaust and Memory in a Global Age (Philadelphia, PA: Temple University Press, 2006), 10. 
they are embraced as territorial narratives of one national context, which can be used in an effort to create common pasts or even to transform the dominant memory narratives of another. This process is qualitatively different to that described by Erll in her concept of 'travelling memory' - these narratives do not 'move', as such, instead they communicate across borders, whilst remaining situated in their original context..$^{55}$ Collaborative memory is also similar to, but distinct from Michael Rothberg's concept of 'multidirectional memory.56 Like Rothberg, I wish to go beyond debates about 'collective memory as competitive memory' [emphasis in original] and to show that memory is instead 'subject to ongoing negotiation, cross-referencing, and borrowing. ${ }^{57}$ Rothberg's model also highlights the interweaving of memory narratives and demonstrates how 'groups do not simply articulate established positions but actually come into being through their dialogical interactions with others. ${ }^{58}$ However, with his focus on aesthetic representations of memory, Rothberg does not fully analyze actual collaborative activity between those elites who construct and maintain public narratives about the past. In this sense, Rothberg's work - while seminal for scholars of transcultural or transnational memory - does not take the actor-centered approach I advocated at the start of this chapter.

Indeed, the concept of 'collaborative memory' leads away from the focus on the objects of memory (or lieux de mémoire) and focuses our attention on the agents of European and transnational memory cultures. Collaborative memory incorporates acts of memory that are constructed through co-operative action between partners in different national contexts. By this I mean the cross-border events themselves, as well as the public stories about the past and the processes of coming to terms with it that are constructed around these events. Collaborative memory in this sense is emphatically not understood as a normative (that is, necessarily desirable) concept, rather one that can be used to describe and explain empirical phenomena. As seen in the analysis above, collaboration can be used in multiple ways which may not necessarily result in a progressive memory politics. Development of our memory studies conceptual toolbox towards a 'collaborative memory' might thus allow us to more fully understand these interactions at a granular level and to explain their impact on broader memory cultures.

\footnotetext{
55 Erll, 'Travelling Memory.'

$5^{6}$ Rothberg, Multidirectional Memory.

57 Rothberg, Multidirectional Memory, 3.

$5^{8}$ Rothberg, Multidirectional Memory, 5 .
} 


\section{Bibliography}

Aksu, Eşref. 'Global Collective Memory: Conceptual Difficulties of an Appealing Idea.' Global Society 23 (2009): 317-332.

Andrews, Molly, Corinne Squire and Maria Tamboukou, eds. Doing Narrative Research. Los Angeles etc.: Sage, 2008.

Assmann, Aleida. Auf dem Weg zu einer europäischen Gedächtniskultur. Vienna: Picus, 2012.

Assmann, Aledia and Sebastian Conrad, eds. Memory in a Global Age: Discourses, Practices and Trajectories. Basingstoke: Palgrave, 2010.

Beattie, Andrew H. 'Learning from the Germans? History and Memory in German and European Projects of Integration.' PORTAL Journal of Multidisciplinary International Studies 4 (2007): 1-22. Accessed 6 June 2016, http://dx.doi.org/10.513o/portal .v4i2.483.

Bernhard, Michael and Jan Kubik, eds. Twenty Years after Communism: The Politics of Memory and Commemoration. Oxford: OUP, 2014.

Bond, Lucy and Jessica Rapson, eds. The Transcultural Turn: Interrogating Memory Between and Beyond Borders. Berlin: de Gruyter, 2014.

Bundesbeauftragte für die Unterlagen des Staatssicherheitsdienstes der ehemaligen DDR. Elfter Tätigkeitsbericht des Bundesbeauftragten für die Unterlagen des Staatssicherheitsdienstes der ehemaligen Deutschen Demokratischen Republik für die Jahre 2011 und 2012. Accessed 30 June 2016. http://www.bstu.bund.de/DE/Wissen/Publikationen/Reihen/Taetigkeitsberichte/taetigkeitsberichte_node.html.

Bundesbeauftragte für die Unterlagen des Staatssicherheitsdienstes der ehemaligen DDR. Zwölfter Tätigkeitsbericht des Bundesbeauftragten für die Unterlagen des Staatssicherheitsdienstes der ehemaligen Deutschen Demokratischen Republik für die Jahre 2013 und 2014. Accessed 30 June 2016. http://www.bstu.bund.de/DE/Wissen/ Publikationen/Reihen/Taetigkeitsberichte/taetigkeitsberichte_node.html.

Butler-Kisber, Lynn. Qualitative Inquiry: Thematic, Narrative and Arts-Informed Perspectives. London: Sage, 2010.

Büttner, Sebastian M. and Anna Delius. 'World Culture in European Memory Politics? New European Memory Agents Between Epistemic Framing and Political Agenda Setting.' Journal of Contemporary European Studies 23 (2015): 391-404.

Clandinin, D. Jean an d F. Michael Connelly. Narrative Inquiry: Experience and Story in Qualitative Research. San Francisco: Wiley, 2000.

Crossley, Nick, Elisa Bellotti, Gemma Edwards, Martin G. Everett, Johan Koskinen and Mark Tranmer. Social Network Analysis for Ego-Nets. Los Angeles etc.: Sage, 2015.

Czarniawska, Barbara. Narratives in Social Science Research. London/New Dehli: Sage, 2004. 
De Cesari, Chiara and Ann Rigney. 'Introduction.' In Transnational Memory: Circulation, Articulation, Scales, edited by Chiara De Cesari and Ann Rigney, 1-22. Berlin: de Gruyter, 2014.

Erll, Astrid. 'Travelling Memory.' Parallax 17 (2011): 4-18.

Feindt, Gregor, Felix Krawatzek, Daniela Mehler, Friedemann Pestel, and Rieke Trimçev. 'Entangled Memory: Toward a Third Wave in Memory Studies.' History and Theory 53 (2014): 24-44.

Hall, Stuart. 'Encoding/decoding.' In Culture, Media, Language, edited by Stuart Hall et al, 128-138. London: Hutchinson, 1980.

Hofmann, Jürgen. 'Zur Auseinandersetzung mit der Hohenschönhausener Gedenkstätte für die Opfer des Stalinismus.' UTOPIE kreativ 81/82 (1997): 158-163.

Jelin, Elizabeth. State Repression and the Labors of Memory. Minneapolis: University of Minnesota Press, 2003.

Jones, Sara. 'Memory Competition or Memory Collaboration? Politics, Networks and Social Actors in Memories of Dictatorship.' In The Changing Place of Europe in Global Memory Cultures: Useable Pasts and Futurities, edited by Christina Kränzle and Maria Mayr, 63-86. Basingstoke: Palgrave, 2017.

Jones, Sara. The Media of Testimony: Remembering the East German Stasi in the Berlin Republic. Basingstoke: Palgrave, 2014.

Kappeler, Florien and Christoph Schaub. 'Mauer durchs Herz: Inszenierungen von Zeitzeug/innen-Wissen im erinnerungspolitischen Diskurs der Gedenkstätte Berlin-Hohenschönhausen.' In NachBilder der Wende, edited by Inge Stephan and Alexandra Tacke, 319-329. Cologne: Böhlau Verlag, 2008.

Kaźmierska, Kaja. 'Biographical and Collective Memory: Mutual Influences in Central and Eastern European Context.' In Memory and Change in Europe: Eastern Perspectives, edited by Małgorzata Pakier and Joanna Wawrzyniak, 96-112. New York and Oxford: Berghahn, 2016.

Kübler, Elisabeth. Europäische Erinnerungspolitik: Der Europarat und die Erinnerung an den Holocaust. Bielefeld: transcript, 2012.

Langenbacher, Eric. 'Still the Unmasterable Past? The Impact of History and Memory in the Federal Republic of Germany.' German Politics 19 (2010): 24-40.

Langenbacher, Erich, Bill Niven and Ruth Wittlinger, eds. Dynamics of Memory and Identity in Contemporary Europe. New York: Berghahn, 2012.

Leggewie, Claus. Der Kampf um die europäische Erinnerung. Munich: C.H. Beck, 2011.

Levy, Daniel and Natan Sznaider. The Holocaust and Memory in a Global Age. Philadelphia, PA: Temple University Press, 2006.

Littoz-Monnet, Annabelle. 'The Eu Politics of Remembrance: Can Europeans Remember Together?' West European Politics 35 (2012): 1182-1202.

Marin, Alexandra and Barry Wellman. 'Social Network Analysis: An Introduction.' In The Sage Handbook of Social Network Analysis, edited by Peter J. Carrington and John Scott, 11-25. Los Angeles etc.: Sage, 2011. 
Mark, James. The Unfinished Revolution: Making Sense of the Communist Past in Central-Eastern Europe. New Haven/London: Yale UP, 2010.

Miskimmon, Alister, Ben O'Loughlin and Laura Roselle. Strategic Narratives: Communication, Power and the New World Order. New York/London: Routledge, 2013.

Neumayer, Laure. 'Integrating the Central European Past into a Common Narrative: The Mobilizations Around the "Crimes of Communism" in the European Parliament.' Journal of Contemporary European Studies 23 (2015): 344-363.

Olick, Jeffrey K. 'From Collective Memory to the Sociology of Mnemonic Practices and Products.' In Cultural Memory Studies: An International and Interdisciplinary Handbook, edited by Astrid Erll and Ansgar Nünning, 151-161. Berlin: de Gruyter, 2008.

Osborne, Dora, ed. Archive and Memory in German Literature and Visual Culture. Rochester, NY: Camden House, 2015.

Pakier, Małgorzata and Joanna Wawrzyniak, eds. Memory and Change in Europe: Eastern Perspectives. New York and Oxford: Berghahn, 2016.

Plessow, Oliver. 'The Interplay of the European Commission, Researcher and Educator Networks and Transnational Agencies in the Promotion of a Pan-European Holocaust Memory.' Journal of Contemporary European Studies 23 (2015): 378-390.

Prell, Christina. Social Network Analysis: History, Theory \& Methodology. Los Angeles etc.: Sage, 2012.

Rothberg, Michael. Multidirectional Memory: Remembering the Holocaust in the Age of Decolonisation. Stanford: Stanford University Press, 2009.

Sierp, Aline. History, Memory and Trans-European Identity: Unifying Divisions. New York: Routledge, 2014.

Sierp, Aline and Jenny Wüstenberg. 'Linking the Local and the Transnational: Rethinking Memory Politics in Europe.' Journal of Contemporary European Studies 23 (2015): 321-329.

Spector-Mersel, Gabriela. 'Narrative Research: Time for a Paradigm.' Narrative Inquiry 20 (2010): 204-224.

Stiftung Gedenkstätte Berlin-Hohenschönhausen. 6. Tätigkeitsbericht (2011/2012).

Stiftung Gedenkstätte Berlin-Hohenschönhausen. 7. Tätigkeitsbericht (2013/2014).

Wasserman, Stanley and Katherine Faust. Social Network Analysis: Methods and Applications. Cambridge: Cambridge University Press, 1994.

Welsh, Helga. 'Beyond the National: Pathways of Diffusion.' In Post-Communist Transitional Justice: Lessons from 25 Years of Experience, edited by Lavinia Stan, and Nadya Nedelsky, 167-187. New York: Cambridge University Press, 2015.

Werner Michael and Bénédicte Zimmermann. 'Beyond Comparison: Histoire Croisée and the Challenge of Reflexivity.' History and Theory 45 (2006): 30-50.

Wüstenberg, Jenny. 'Vernetztes Gedenken?: “Influence Mapping” in der transnationalen Erinnerungsforschung.' Jahrbuch für Politik und Geschichte 6 (2016): 97-113. 


\title{
The Polish Elites' Struggle for Recognition of the Experience of Communism in the European Union
}

\author{
Magdalena Góra and Zdzistaw Mach
}

The course of history placed Poles outside the reflections on the shape of the political processes in Western Europe after the Second World War. Nevertheless, the origins of various Polish concepts and visions of the country's place in Europe can be traced back to the 15th and 16th centuries and the Golden Age of the Jagiellonian Commonwealth. Throughout the difficult years of their troubled history, the Polish elites referred to Western Europe as an important cultural source and a civilisation they belonged to. It was also during the period of Communism that - especially for the democratic opposition - Western Europe was a source of inspiration and resources. ${ }^{1}$ Europe, particularly Western Europe, was then to Poles a very significant point of reference and one which was essential for their collective identity. Whether as a paradise of wealth and higher level of consumption, for Poles who dreamt of a better life, or as a land of freedom and high culture, for those Poles who had more intellectual and cultural ambitions, Western Europe was a dreamland, on the other side of the Iron Curtain, accessible only sporadically on occasions of infrequent tourist or professional visits. When Communism ended in Poland and Central and Eastern Europe (CEE), Poles eagerly and almost immediately declared their intention to 'return to Europe'. Western Europe, or simply 'the West', as it was then commonly referred to, was seen in Poland as a largely undifferentiated, homogenized area of freedom, democracy and prosperity. Little was known about the internal diversity of Western Europe, and even less about the different problematic issues related to collective memory, sensitivities and conflicts of interpretation of European history. An example of the difficult lessons of European conflicts of attitudes and interpretations which Poles had to learn was the experience of the war against Iraq in 2003, in which some EU member states supported the USA, while others refused to participate in the invasion. In the decision of the latter group, anti-American sentiments played an important

1 Magdalena Góra and Zdzisław Mach, "Between Old Fears and New Challenges. The Polish Debate of Europe", in European Stories. Intellectual Debates in National Contexts, ed. Justine Lacroix, Kalypso Nicolaïdis (Oxford: Oxford University Press, 2010).

(C) MAGDALENA GÓRA AND ZDZISŁAW MACH, 2017 | DOI 10.1163/9789004352353_004 
role. Poles had to understand that they might have to take sides and choose between different Western countries, which, before 1989, were seen from the Polish perspective as the unified 'West'. The situation also stressed the importance of how the actions of political actors were perceived and received by Western counter partners, and it displayed the interactivity of European politics.

The research on the debate on the future of Europe highlights the fact that it has seemed very difficult for Poles, both ordinary people and intellectuals, to think in terms of a common, European 'we.' ${ }^{2}$ European interests were previously not perceived as being equal to Polish interests and solidarity did not extend beyond national borders. Poles tend to think of the EU predominantly from a national point of view. The EU is good if and when it contributes to Poland's strength, prosperity and security. One might say that Europe is seen in Poland as an instrumental value, not a value in itself. A pro-European position considers European integration as good for Poland, while an anti-European approach believes that European integration deprives Poland of values essential for its identity and well-being - mainly political sovereignty, tradition and Roman Catholicism (identified here as the essence of Polishness). At the same time, however, Poles express high levels of optimism as regards the $\mathrm{EU}$, and the European component is crucial for the Polish collective identification.

The focus of this chapter is on how the experience of Communism still shapes the behaviour of Polish elites and politicians and how they use the memory of Communism in order to claim recognition within the EU. How has the specific historical experience of Communism influenced the reflection on Europe, identification with Europe and perception of this political project in Poland? How have political actors in the EU perceived such claims? The eastern EU enlargement has challenged the established Western European notions of the memory of the Second World War and particularly the insignificance of the Communist crimes vis-à-vis those of the Nazi regime. As Maria Mälksoo claims "in spite of the institutional unification of the "two halves of Europe" after the end of the Cold War, the consolidation of the legacy of the Second World War in general, and that of the Soviet regime in Eastern Europe in particular, is long overdue. Europe has remained divided when it comes to the political, moral, and legal evaluation of the criminal inheritance of the other totalitarian tradition in the history of the twentieth century - that of Soviet Communism.' ${ }^{3}$ The problem with the recognition of the totalitarian nature of Soviet Communism

2 Góra, Mach, Between Old Fears; Magdalena Góra, "Solidarity of Citizens and of States in the European Union", Visegrad Insight 2:4 (2013).

3 Maria Mälksoo, "The Discourse of Communist Crimes in the European Memory Politics of World War II", (paper presented at the Ideology and Discourse Analysis conference 
and its crimes in CEE has already attracted attention, even though it still raises many controversies. In this chapter we will use the concept of recognition in order to analyze how it is utilized for political purposes in everyday European politics. The concept of recognition allows capturing the dialogical nature of the processes in European politics and focus not only on the claimants but also on the reception of claims.

In the following sections we will first provide a theoretical background of our analysis and present the concept of recognition and its role in contemporary European politics. In the second part we will explain how the memory of Communism and historical politics has functioned on the domestic level in Poland. In the final part we will present the analysis of debates from the European Parliament, where claims for recognition of the historical experience of Poland have stirred up fervent debates.

\section{Recognition, Collective Identity, Redistribution and Collective Memory}

Since the 1960 s scholars dealing with the functioning of contemporary societies have been increasingly focusing on the concept of recognition. The process of recognition is a crucial element of one's subjectivity and a foundation of a process of identification understood in relational terms when the other is necessarily involved in a mutual relationship. According to Charles Taylor's observation, 'our identity is partly shaped by recognition or its absence, often by the misrecognition of others, and so a person or group of people can suffer real damage, real distortion, if the people or society around them mirror back to them a confining or demeaning or contemptible picture of themselves. Nonrecognition or misrecognition can inflict harm, can be a form of oppression, imprisoning someone in a false, distorted, and reduced mode of being' ${ }^{4}$ Recognition is therefore relational and dialogical in its nature. The reception of the claims for recognition and response to it matters. Recognition is not only about 'an expectation of the confirmation of abilities and value by the other, ${ }^{5}$ it is also about socialization and social integration 'through the regulated forms

'Rethinking Political Frontiers and Democracy in a New World Order', Roskilde University, Denmark, 8-10 September 2008), 1.

4 Charles Taylor, "The Politics of Recognition", in Multiculturalism. The Examination the Politics of Recognition, ed. Amy Gutman (Princeton, New Jersey: Princeton University Press, 1994), 25.

5 Christian Lazzeri and Alain Caillé, "Recognition Today. The Theoretical, Ethical and Political Stakes of the Concept", in Recognition, Work, Politics. New Directions in French Critical Theory, ed. Jean-Philippe Deranty et al. (Leiden, Boston: Brill, 2007), 92. 
of recognition.' ${ }^{6}$ Recognition allows us then to grasp the nature of legitimized social order being such 'only to the degree that they [societies] are in a position to guarantee reliable relations of mutual recognition at various levels. ${ }^{7}$ Therefore, in the increasingly diverse societies of Western Europe, the concept of recognition has become a tool to better grasp the dynamics of relationships between various groups: ethnic and national minorities (also immigration groups), women, sexual minorities etc. Ultimately, it is worth mentioning that the thinkers who introduced and developed the concept of recognition also had a normative idea in mind, namely how to build a just, modern society. ${ }^{8}$ In this regard, the concept of recognition 'defines the conditions of a just society through the aim of recognizing the individual dignity of all individuals.'

This normative aspect has led to the emergence of the politics of recognition at least since the 196os, defined as a need to deal with the existence of multiple identities and recognition of the diversity of belongings in the contemporary world..$^{10}$ The issue of recognition becomes central in contemporary societies and assumes that it is 'a complex multilateral web of relations and their affects among actors of different types.'11 This multiplicity of dimensions and actors in turn has resulted in the introduction of the concept of recognition order, understood as 'a framework within which individuals and groups are learning to see themselves as recognised with respect to certain characteristics.' ${ }^{12}$ The recognition order was firstly conceptualized and analyzed within nation state frames of reference and in such a context the politics of recognition was mostly analyzed.

The politics of recognition deals with the question of how domestic institutions such as schools, universities, mass media, health care institutions and the army respond to and accommodate the necessity of the recognition of diverse social composition. ${ }^{13}$ It results in an important dilemma of politics of

Axel Honneth, "Recognition and Justice: Outline of a Plural Theory of Justice", Acta Sociologica $47: 4$ (2004), 354 .

7 Ibid.

8 Ibid.

9 Ibid, $35^{2}$.

10 Axel Honneth, The Struggle for Recognition: The Moral Grammar of Social Conflicts (Cambridge: Polity Press, 1995); Taylor, "The Politics".

11 James Tully, "Struggles over Recognition and Distribution", Constellations 7:4 (2001), 474.

12 Axel Honneth, "Redistribution as Recognition: A Response to Nancy Fraser", in Fraser N., Honneth A., Redistribution of recognition? A political-philosophical exchange (London, New York: Verso, 2003) quoted in John Erik Fossum, "Conceptualizing the EU's Social Constituency”, European Journal of Social Theory 8:2 (2005), 125.

13 Amy Gutman, "Introduction", in Multiculturalism. Examining the Politics of Recognition, ed. Amy Gutman (Princeton, New Jersey: Princeton University Press, 1994). 
recognition, stressing that in principle the public sphere should be 'difference blind' in order to fulfil the principle of recognition. ${ }^{14}$ Introducing reflection in the politics of recognition allows one to reconsider the fundamental condition on which contemporary liberal democracy is built in the context of increasingly diverse societies. This reflection is especially potent in the context of the politics of recognition entering the supranational arena, particularly within the EU. This will be developed further in the next section.

However, the politics of recognition also highlights the important aspect of redistribution, as famously raised by Nancy Fraser and debated with Honneth. ${ }^{15}$ Social movements demanding recognition - such as the women's or African American rights movements - have also focused on more just redistribution. Fraser argues that these are 'two dimensions of justice' in contemporary societies that need to be addressed. She claims, 'it is my general thesis that justice today requires both redistribution and recognition, as neither alone is sufficient.'. ${ }^{16}$ In order to establish what the relationship between them is, Fraser makes the assumption that recognition is a matter of justice: 'One should say, rather, that it is unjust that some individuals and groups are denied the status of full partners in social interactions simply as a consequence of institutionalized patterns of interpretation and evaluation in whose construction they have not equally participated and that disparage their distinctive characteristics or the distinctive characteristics assigned to them. ${ }^{\prime 7}$ As a consequence, misrecognition is a social phenomenon, which influences the position in social relations including the redistribution. Fraser therefore proposes a bivalent conception of justice, which 'does not treat recognition as a good to be distributed, nor distribution as an expression of recognition. Rather, a bivalent conception treats distribution and recognition as distinct perspectives on, and dimensions of, justice, while at the same time encompassing both of them within a broader, overarching framework. ${ }^{18}$ We argue that the main link between the two is through identity. ${ }^{19}$ As we have already stated above - the recognition is about including various narratives in mainstream collective identification and treating them as just and appropriate. Similarly, including certain groups

14 Taylor, "The Politics", 40.

15 Nancy Fraser and Axel Honneth, Redistribution of recognition? A Political-Philosophical Exchange (London, New York: Verso 2003).

16 Nancy Fraser, "Social Justice in the Age of Identity Politics: Redistribution, Recognition, and Participation", (the Tanner Lectures on Human Values. Delivered at Stanford University 30 April-2 May 1996), 5 .

17 Ibid., 24.

18 Ibid., 30.

19 Honneth, "Redistribution". 
in mainstream identification processes equips them with the legitimization to claim for redistribution. This two-dimensional aspect of recognition claims is connected with identity-oriented elements and economic demands within the recognition order and will serve as the theoretical basis for analyzing the aims of the recognition claims of Polish political actors within the $\mathrm{EU}$.

The debates on the politics of recognition have also entered the supranational level, especially in the context of the European integration. Scholars argue that, at least since the beginning of the 1990s, the politics of recognition developed mainly within the national framework has also entered the supranational level..$^{20}$ This is connected with the growing significance of policy-making and redistribution within the EU. Therefore, argues John Erik Fossum, the EU can become a new, broader recognition order if citizens and political actors seek recognition not only in the nation states but also in supranational arenas. ${ }^{21}$ Fossum also argues that this may lead to the creation of the EU as a social constituency, meaning that the EU will develop beyond a merely functional order and will transform into a full-fletched polity, especially for its citizens. According to him, this transformation has already started, as was specifically visible during the $2004 \mathrm{EU}$ enlargement. After the enlargement of the EU, new political actors from CEE started to express their particular, historically determined and hegemonic (in terms of distribution of power) demands of equal recognition. ${ }^{22}$ The new claims and new perspective brought by MEPs from CEE regarding the recognition of the Christian elements of European identity and politics could serve as an example. ${ }^{23}$

Such demands for recognition within the Eu serve several purposes. Firstly, they focus on the recognition of certain collective identifications within European mainstream narrative and as a result claim belonging to the European community. In the context of this chapter, political actors from CEE demand recognition of their unique historical experience of the Second World War and Communism in order to receive equal status in the EU. Secondly, derived from the identity-oriented aspect of recognition, the demand allows actors to claim fair redistribution within the EU political system. It is an especially important

2o Zenia Hellgren and Barbara Hobson, "Gender and ethnic minority claims in Swedish and EU frames. Sites of Multilevel Political Opportunities and Boundary Making”, in Gender politics in the expanding European Union: mobilization, inclusion, exclusion, ed. Silke Roth (New York, Oxford: Berghahn Books, 2008).

21 Fossum, "Conceptualizing".

22 Ibid.

23 Magdalena Góra and Katarzyna Zielińska, "Defenders of faith? Victims of secularization? Polish politicians in the European Parliament”, Religion, State, Society 42:2-3 (2014). 
aspect because within the EU new injustices may emerge and, as a result, a new axis of conflict could form. ${ }^{24}$ The important aspect of the claims for recognition is their reception. It is a dialogical, interactive construction where the success of the claimant depends on whether or not claims are received as legitimate. Therefore it is crucial not only to look at the claimants but also at the reception of the claims.

The specific aspect of theoretical debate on recognition concerns the role of the past experience of groups in their demands for recognition and redistribution. Various groups claim the recognition of their unique historical experience and heritage. As Carlos Closa puts it, 'Recognition of memory in a given community restores persons' dignity by means of policies which take into account their claims. Recognition thus is an essential component of policies of memory and politics of memory are the struggles for recognition of memory claims.25 It is an old dilemma in democratic societies how to recognize various, different and often contradicting narratives of past experiences and how to deal with the attempts to falsify history. Especially in CEE, strong conflicts of memory frequently arise. ${ }^{26}$ This is especially significant due to the role of memory in shaping dominant collective identifications in contemporary societies. In the European context, political actors from CEE demand recognition of their experience and suffering. According to this concept, if Europeans want to construct collective identity on equal terms, various historical experiences - also those of Communism - must be taken as equally valid. As Carlos Closa states, 'in the view of its [equal recognition] proponents, the dominant narrative on European history (as reflected by education, symbolic practices and awareness initiatives) reflects predominantly (and for some only exclusively) the experiences of the Western part of the continent whilst the historical experience of Central and Eastern European countries has not been included.' ${ }^{27}$ Maria Mälksoo, on the other hand, has stressed that the CEE actors make "vocal claims of "equal subjectivity" in the European mnemopolitical field as well as reverberate their increasing sense of confidence about the

24 John Erik Fossum and Marit Eldholm, "Conceptualising (and tentatively mapping) the Eu's social constituency", in Civic Resources and the Future of the European Union, ed. Ireneusz Pawel Karolewski, Viktoria Kaina (London: Routledge, 2012).

25 Closa, "Negotiating the Past", 6.

26 Siobhan Kattago, "Memory, Pluralism and the Agony of Politics", Journal of Baltic Studies 41:3 (2010); Georges Mink and Laure Neumayer, History, Memory and Politics in Central and Eastern Europe. Memory Games (Basingstoke: Plagrave Macmillan, 2013). 
density of their ties to the Euro-Atlantic security community'.28 Both scholars link 'equal' claims to the sense of belonging in community along the lines of recognition theory.

There is growing research on the content of these claims. Closa lists several elements raised in the European public sphere when equal recognition is demanded. The dominant demands are for condemnation of the communist regimes: the criminalization of the denial of so-called totalitarian crimes, the recognition of commemoration dates which are linked to facts of memory of CEE countries, and the teaching of history integrating CEE perspectives and finally focusing on memorialization policies. ${ }^{29}$ Mälksoo focuses on the demand for the recognition of the criminal nature of Soviet Communism and the recognition of its crimes as genocide. ${ }^{30}$ Other scholars analyzing the politics of memory of Polish actors on the European level stress three main areas where a unique perspective is used most frequently: the insistence of the commemoration of the Katyn massacre, the specific Polish experience under Communism, and the special relations with Poland's new Eastern neighbours (Ukraine, Belarus and Lithuania). ${ }^{31}$ Recently scholars have also focused on the way political actors from new member states became memory entrepreneurs in order to promote their claims. ${ }^{32}$

During the process of EU accession, one of the most important topics highlighted by Western actors was connected with the narrative on the Second World War. Specifically in the case of Poland it concerned the Holocaust remembrance and the reintroduction to the public discourse of the complicated relations between Poles, Jews and the Nazi and Soviet occupiers. Another topic has covered the forced transfers of population - particularly German - after the Second World War. These attempts were perceived as a Europeanization of the discourse on history in Europe. For years, however, the process of the Europeanization of historical discourse was asymmetrical - the demands were directed mostly at the CEE countries.

28 Mälksoo, "The Discourse", 7 .

29 Closa, "Negotiating the Past".

30 Mälksoo, "The Discourse".

31 Matt Killingsworth, Małgorzata Klatt and Stefan Auer, "Where Does Poland Fit in Europe? How Political Memory Influences Polish me Ps' Perceptions of Poland's place in Europe", Perspectives on European Politics and Society 11:4 (2010).

32 Laure Neumayer, "Integrating the Central European Past into a Common Narrative: The Mobilizations Around the 'Crimes of Communism' in the European Parliament”, in:Journal of Contemporary European Studies 23:3 (2015). 
In this chapter we will look at the other direction of the process of Europeanization of history discourse when political actors from CEE direct certain claims for recognition to and their reception by the Western European actors.

\section{Collective Memory and Historical Politics in Poland after Communism}

Polish national identity, collective memory, political culture and the perception of Europe are a result of Poland's unique location between East and West and specific historical processes. The geopolitical location and strong identification with Western European civilization versus the East have resulted in constant tensions in the region and developed a strong sensitivity towards the past in Poland. ${ }^{33}$ The experience of the Nazi occupation and later of the Communism rule has contributed to the sense of betrayal by the West and strengthened the endangered collective identity.

Since 1989 the issue of dealing with the past has resurfaced. First and foremost, as for previous centuries, the turn to the West as a source of security, modernization and prosperity has become a widely accepted policy priority. The initial political idea of how to deal with the heritage of Communism was the concept of a 'thick line' promoted by the first democratic Prime Minister Tadeusz Mazowiecki. He claimed: 'We split away the history of our recent past with a thick line. We will be responsible only for what we have done to help extract Poland from her current predicament, from now on'. ${ }^{34}$ It was meant to allow the focus to shift more to the current challenges of the devastated country and promote a fresh start. However, it was very soon interpreted as a call for cutting off what had happened before 1989, avoiding de-Communisation and

33 Joanna Pękacz, “'Antemurale of Europe'. From the History of National Megalomania In Poland", History of European Ideas 20:1-3 (1995); Georges Sanford, "Overcoming the Burden of History in Polish Foreign Policy", Journal of Communist Studies and Transition Politics 19:3 (2003); Janusz Tazbir, "Europejska wspólnota obronna”, in Europa. Drogi integracji, ed. Aniela. Dylus (Warszawa: Studium Generale Europa, Uniwersytet Kardynała Stefana Wyszyńskiego, 1999).

34 Tadeusz Mazowiecki, "Wnioski Prezydenta PRL o odwołaniu ze stanowiska Prezesa Rady Ministrów Czesława Kiszczaka oraz o powołanie na stanowisko Prezesa Rady Ministrów Tadeusza Mazowieckiego", in Sejm Rzeczpospolitej Polskiej X Kadencji, Sprawozdanie Stenograficzne z 6 Posiedzenia Sejmu, 23 i 24 sierpnia 1989, Warszawa 1989, accessed August 2014, http://orka2.sejm.gov.pl/StenogramyX.nsf/o/259278CD28DE3BBDC1257D20002CC6 FD/\$file/oo6_0oooo6771.pdf (authors' own translation). 
not punishing those responsible for crimes committed during Communism. Very soon the right-wing parties which emerged from the Solidarity camp started to question Mazowiecki's approach and criticize the Round Table accords as a means for the systemic transition into democracy. They perceived it as a rotten compromise allowing the Communist elites to regain power within the economic realm and they demanded lustration. There were several attempts to pursue this, none of which ever fully succeeded. ${ }^{35}$

At the end of the first democratic decade new political forces such as Prawo i Sprawiedliwość (PiS - Law and Justice), founded in 2001 and based on the previous centre-right wing parties, started to call for a new opening and the pursuit of historical politics in the country. It was a result of the harsh criticism of the first decade of democracy in Poland: 'this project consisted of several clear elements: from the idea of moral pluralism and the neutrality of the state, with the conviction of the imitative nature of the Polish transformation, the recognition of a fast modernisation as a major goal (including cultural modernisation), stemming from the lack of trust and reluctance to the national tradition, the ban on de-communisation and so on. (...) It did not pay much attention to the question of the affirmative sharpening of identity and collective memory'. ${ }^{36}$ So this affirmative shaping of Polish collective memory became a political goal to be pursued on the domestic level. Historical politics became a central element of the political programme of PiS and also became popular among other centre and right-wing parties in Poland. The content of this affirmative shaping concerned predominantly the period of the Second World War and specifically the way relations between German and Soviet occupiers, the Polish population and Jews were interpreted. A good illustration for this wasthe two fierce debates following the publication of the Jan T. Gross books in 2001 and $2006 .^{37}$

35 Natalia Letki, "Lustration and Democratisation in East-Central Europe", Europe-Asia Studies 54:4 (2002); Kieran Williams, Aleks Szczerbiak and Brigid Fowler, "Explaining Lustration in Eastern Europe: 'A Post-communist politics approach”, SEI Working Paper 62 (2003), accessed August 2014 https://www.sussex.ac.uk/webteam/gateway/file .php?name=sei-working-paper-no-62.pdf\&site=266; Lavinia Stan (ed.), Eastern Europe and the Former Soviet Union. Reckoning with the communist past (London: Routledge, 2009).

36 Zdzisław Krasnodębski, Demokracja peryferii (Gdańsk: Wydawnictwo słowo/obraz terytoria, 2005), 8 .

37 Tomasz J. Gross, Neighbours. The Destruction of the Jewish Community in Jedwabne, Poland (Princeton: Princeton University Press, 2001); Tomasz J. Gross, Fear: Anti-Semitism in Poland After Auschwitz. An Essay in Historical Interpretation (Princeton, Oxford: Princeton University Press, 2006). 
The second major focus of historical politics in Poland has been dealing with the legacy of Communism. Apart from the first attempts at lustration in 1992 and $1997 / 8$, the new post-Solidarity government initiated in 1997 the creation of Instytut Pamięci Narodowej (IPN - the Institute of National Remembrance) whose main duty was to gather documents, hold inquiries into Nazi and Communist crimes and to educate people. ${ }^{38}$ The historical politics and IPN itself raised high emotions in domestic politics: 'IPN became a most important, visible and controversial institution of contemporary Poland'. ${ }^{39}$ Yet, the additional goal of historical politics in Poland was directed outside the country, especially at the European institutions and states, with special attention to the European Parliament as the agora of the EU. As the leader of PiS (at that time in opposition) said in a debate on foreign policy in the Polish parliament in 2003:

And the next issues are very important to our status, but our activities are - let's say - not enough, if not non-existent. These are historical issues, the issue of the dignity of our nation; it is how we assess the Second World War, and all this connected with the great liberation from Communism (applause). There is tendency in Europe, not to mention the USA, where it is even stronger, to equal guilt and contributions from this period, also from the period of the Second World War. Recently such a declaration was made by the European Parliament. It is about, let's admit that, treating all equally - all suffered losses, all committed crimes. And on the other hand there is a well-known defamatory campaign against our nation as regards its "involvement", and I use inverted comas here, in holocaust; its alleged co-responsibility for this most horrible crime of the war. Now our actions to prevent this are definitely too weak. We can even talk about the participation in such defamatory actions of some - not of Polish diplomacy but - of Polish elites (applause). We need to be clear and decided, we need to undertake all possible actions in order to prevent it. ${ }^{40}$

Similar statements were made frequently, especially in debates related to the role in the EU and especially about relations with Germany. In 2005, for instance, another leader of PiS stated: 'I want to thank for those very clear and

38 Dariusz Stola, "Poland's Institute of national Remembrance: A Ministry of Memory?", in The Convolutions of Historical Politics, ed. A. Miller, M. Lipman (Budapest: Central European University Press, 2012).

39 Ibid., 48.

40 Jarosław Kaczyński, "Wypowiedź w debacie", in Informacja rządu na temat polskiej polityki zagranicznej w 2003 roku. 4 kadencja, 40 posiedzenie, 2 dzień (22 January 2003), accessed August 2014 http://orka2.sejm.gov.pl/Debata4.nsf (authors' own translation). 
so far unsaid words on the issue of historical truth and on the issue of German responsibility for the crimes committed during the Second World War. If such words were spelled out regularly and firmly, parts of the problems in PolishGerman relations would not be present today'41 Such an approach - to fight for the historically understood dignity and honour of the nation - has a long tradition in Poland. It stems from the gentry which dominated the political culture and difficult past on the one hand, and connects to the vivid memory of the glorious times of the Jagiellonian Commonwealth on the other. What is especially interesting for this chapter is that such an approach has been pursued by significant political actors in Poland not only on the domestic level but also that it also had a very clear connection to the debate on the role of Poland in the EU on the eve of its enlargement to the East. The peak of the attempts to deal with the past, especially of the Communist legacy, was reached in the first years following the EU enlargement. In 2005, PiS formed a ruling coalition (in office until the pre-term elections in 2007) with the rightwing Liga Polskich Rodzin (LPR - League of Polish Families) as well as the populist Samoobrona RP (SRP - Self-defence). As regards historical politics, the main elements of this government's approach on the domestic level were focused on lustration. A new law was adopted in 2006, amended in 2007 and later rejected by the Constitutional Court. On the international and European level, the main aim was to receive recognition of the totalitarian nature of Communism and actions against the alleged defamation of the Polish nation. It is important to note that such an approach to historical politics was supported by PiS and LPR as well as by other political parties from the centreright wing groups. The second most important party on the Polish political scene, the centre-right wing Platforma Obywatelska (PO - Civic Platform) only partially - especially its conservative wing - subscribed to such an agenda. The left wing and liberal parties and liberal circles openly opposed lustration attempts and were much more cautious about the historical politics coined in the 2005-2007 period. Ultimately, the Polish historical politics which gained attention and strength in domestic politics also become visible in the European arena, especially in the European Parliament which was perceived as an agora of the European Union.

Polish representation in the European Parliament in the 6th and 7 th term in office was the largest among the new member states and consisted of $50-54$ MEPS (depending on the term in office). In both the 2004 and 2009 elections,

41 Kazimierz M. Ujazdowski, "Wypowiedź w debacie", in Informacja Ministra Spraw Zagranicznych o zadaniach polskiej polityki zagranicznej w 2005 roku, 4 kadencja, 96 posiedzenie, 3 dzień (21 January 2005), accessed August 2014 http://orka2.sejm.gov.pl/ Debata4.nsf (authors' own translation). 
centre-right wing and right wing parties won the majority of the votes. The winner of both elections, Po, joined the Group of European People's Party (Christian Democrats) and European Democrats (EPP-ED) together with Polskie Stronnictwo Ludowe (PSL - Polish People's Party). The two other winners in 2004: LPR and PiS joined the right-wing party groups. PiS went for Union for a Europe of the Nations Group (UEN) and remained in this party for the entire term in office, while the LPR at first joined Independence and Democracy Group (Ind/DEM). Yet the party split and the majority of the ten LPR MEPS went to other national formations (mostly PiS) and, as a result, joined UEN in the EP. Similarly SRP split (four MEPS out of six left) as well as PSL (three MEPS out of four left). The left-wing parties joined Group of the Party of European Socialists (PES), and liberal formation Unia Wolności (UW - Freedom Union) joined Group of the Alliance of Liberals and Democrats for Europe (ALDE). During the elections for the 7 th EP (2009-2014) the right-wing (LPR) and populist (SRP) parties did not cross the electoral threshold. Their electorate went mostly to PiS which doubled its result in 2009. PiS joined the newly created European Conservatives and Reformists Group (ECR).

In the following we will provide an analysis of Polish MEPs' interventions in and reception of the 6 th and 7 th EP. In order to do so we have selected 11 debates devoted to topics connected with commemoration of totalitarianism, programmes financing such commemorations etc. However, we have also included debates concerning issues not directly related with collective memory or the past. These are debates focusing on issues connected with solidarity and redistribution in the EU (see Annex 1).

The purpose of this selection was to analyze the claims for recognition in the context of the debates on history and memory, but also in less obvious situations. The relevant claims were analyzed as regards their content (what should be recognized?), the addressee (by whom?) and for what reason (why should it be recognized?). Finally our interest was the reception of the claims. It must be noted, however, that the empirical material limits the way that the responses to the analyzed claims are captured. The plenary debates in the EP allow dialogical exchange of opinions, but the limited time allocated to speakers and the fact that MEPs rarely reappear during the same debate are impinging the interactivity and dialogue between MEPs.

\section{Recognition in European Parliament debates}

An analysis of the debates shows that the focus of Polish MEPs on the recognition of their historical, unique experience was most important immediately after the EU enlargement in 2004. During the 6th term in office of the EP it 
seems that debates on the crimes of Soviet Communism were more frequent and heated. The significance of these issues seems to have faded away in the EP's 7th term in office, although claims for recognition remained important. This is probably because the main purpose of the claims was, for those making them, to find and assert their own position within the EU and confirm their own identity as belonging, although equipped with a different - but equally important - historical experience. That had to change with time, and such claims became less frequent when political actors started feeling more assured in the new institutions. In other words, the discussions in the EU on the past and memory seemed to follow from the enlargement. Moreover it is important to note that the debates were initiated by the memory entrepreneurs from CEE. ${ }^{42}$

The interesting issue remains as to who raised the claims for recognition most often among Polish MEPs. The most actively involved in debates and most often using the recognition claims were MEPs from the centre and rightwing party groups in the EP - UEN, Ind/Dem, EPP-ED and ECR. The MEPs from ALDE and PES participated in these debates much less frequently and used the recognition claims even less. This is in tune with the analysis of the historical politics on the national level. The MEPs using recognition arguments came from parties that were devoted to puruse historical politics on the domestic political scene, such as PiS, LPR and partially PO.

\section{Soviet Communism Equals Totalitarianism}

One of the main claims of CEE actors immediately after the end of the Cold War was (and still is) that the atrocities of the Nazi regime be treated equally with those of Soviet Communism. This argument still causes controversies in academic discussions and raises fervent debates among politicians in Europe.

The demand for equal treatment of the Nazi and Soviet regimes is often raised by Polish MEPs in debates in the EP. The main call is for Soviet Communism to be treated in Western European historiography and politics as totalitarianism, as should the crimes committed under this system. The second most often raised claim is recognition of the crimes under Soviet Communism as genocide. These claims mostly concern the period of the Second World War and its immediate aftermath. However, they also appear in the debate on commemoration of Holodomor in Ukraine before the war. It is also important to note that some MEPs have stressed that these demands do not diminish the significance of the Nazi crimes, especially the Holocaust, as sometimes alleged by their opponents, ${ }^{43}$ but rather that the recognition of the criminal character of any

\footnotetext{
42 Neumayer "Integrating".

43 Mälksoo, "The Discourse".
} 
totalitarian regime makes European societies more immune to its devastating effects. Finally, some MEPs demand recognition of specific crimes against the Polish nation which in their opinion are not properly known and commemorated, such as the Katyń massacre. Such claims are also obviously directed to the memory politics of Russia. It is important to note that even though some MEPs call for the EU to put pressure on Russia to deal with its past, most of them are actually very moderate in their demands toward Moscow and focus rather on the $\mathrm{EU}$ and its member states and societies.

These claims are predominantly about 'inclusion of their [CEE societies] wartime experiences in the currently West-European bent understanding of the implication and ramification of this war. ${ }^{44}$ In many ME Ps' statements, their claims have a universalistic, European motivation. As one of them argued, 'individual nations had very different experiences of the Second World War, and so the debate we are holding today is perhaps the most important debate on European identity that has been held for years. If we genuinely wish to join together to form a single European spiritual community, we must all endeavour to gain a full understanding of the historical experiences of Europe's nations. In order to do so, there are certain issues about which we must speak quite frankly'45 According to Polish political actors, a European identity suitable for the societies of old and new member states is at stake, as are European values. The main motivation expressed for the recognition of the totalitarian nature of Soviet Communism is, generally speaking, a common future in the EU. One of the MEPS from UEN argued, 'The building of a democratic Europe is possible only on the foundations of truth, including the truth about anti-human communist totalitarianism. We owe remembrance and justice not only to the victims of inhuman systems; first of all we owe it to present and future generations so that this situation does not happen again.46 Many MEPs claim that this recognition should be granted in order to create a sense of belonging in the community. Another frequently raised motivation deals with European values: 'The more Europeans know about the true face of totalitarianism, the better it

44 Ibid. 2.

45 Wojciech Roszkowski (UEN), "The future of Europe sixty years after the Second World War", European Parliament plenary debate (11 May 2005) accessed August 2014, http:// www.europarl.europa.eu/sides/getDoc.do?pubRef=-02f\%2fEP\%2f\%2fTEXT\%2bCRE\%2 b20050511\%2bITEM-016\%2bDOC\%2bXML\%2bVo\%2f\%2fEN\&language=EN.

46 Mirosław Piotrowski (UEN), "Proposed hearing of the Commission on crimes of genocide, crimes against humanity and war crimes committed by totalitarian regimes" European Parliament plenary debate, (21 April 2008), accessed August 2014, http://www.europarl .europa.eu/sides/getDoc.do?pubRef=-\%2f\%2fEP\%2f\%2fTEXT\%2bCRE\%2b20080421\%2 bITEM-015\%2bDOC\%2bXML\%2bVo\%2f\%2fEN\&language=EN. 
will be for the future of the European Union. This is not a matter of celebrating the sufferings of millions of people. It is about understanding the dramatic consequences which came from and are still coming from totalitarian practices in many countries in Europe. Solidarity, freedom, empathy, toleration, dialogue - all of these values look somewhat different if we look at them from the perspective of experiences with totalitarianism. Let us remember this.' ${ }^{47}$

Another interesting aspect of the analysis of Polish MEPs' claims is to whom they direct their demands. Most often, it is Western Europe in general and its societies. Less frequently - and specifically in cases of concrete instruments of commemoration - it is EU institutions, especially the European Commission, that are the addressees of the claims. In a few instances - predominantly by MEPs from centre- and right-wing party groups - the political opponents are addressed. Specifically, claims about the totalitarian nature of Soviet Communism are frequently directed to the European Left, whom some right-wing MEPs believe relativizes the crimes of Communism for ideological reasons: 'Whoever today relativises the criminal character of totalitarianism, be it Nazi or Communist totalitarianism, stands in opposition to the traditions of a country ruled by law and to democracy. It is, by the way, characteristic that while the European Right does not relativise Nazi crimes today, the European Left does relativise Communist crimes. ${ }^{48}$ However, also voices from the Left itself albeit very few - raise this problem. As a Polish MEP from the PES declared: 'We are opposed to the manipulation of that memory, and to the insulting of that memory, where it is used today in an ideological battle, in a party fight in the European political system. We remember the victims. The victims of 2oth-century totalitarian regimes must be the foundation of today's democracy in Europe. 49

The claims for recognition of the significance of the crimes of Soviet Communism, especially during the Second World War, serve a double purpose for MEPs from Poland. Firstly, it equates the CEE experience with that of Western Europe, and therefore combats the Orientalist, essentially colonial approach of Western Europeans to this experience..$^{50}$ As a result, it paves the way for an equal position in the EU, making this experience equally important

47 Filip Kaczmarek (PPE-DE), "European conscience and totalitarianism" European Parliament plenary debate (25 March 2009) accessed August 2014, http://www.europarl.europa .eu/sides/getDoc.do?pubRef=-//EP//TEXT+CRE+20090325+ITEM-o10+DOC+XML+ Vo//EN.

48 Wojciech Roszkowski (UEN), "European conscience”.

49 Józef Pinior (PSE), "European conscience".

5o Mälksoo, "The Discourse". 
and therefore serving the emerging European identity and community of the new, united Europe. Secondly, this reaffirms their own identity as fully-fledged Europeans and secures their place in the Eu. This is also visible in less dramatic debates on the experience of living under Communism and fighting its system.

The reception of such claims resonates with its prime purpose of achieving an equal position within the community. Frequently the claims are positioned as justified. As one of the MEPs stated: 'the history of central and eastern Europe is our history. The problem for us British and for us French is that we were Stalin's allies at the end of the War. It took 30 years for the British to admit that Katyn was a Stalinist crime.'51 It is important to note that especially EPP politicians used the term of Stalinist totalitarianism in their statements: 'Although National Socialist totalitarianism was vanquished in 1945, Stalinist totalitarianism divided Europe and imposed its unjust rule on the peoples of Central, Eastern and South-Eastern Europe. Hope, though, did not desert the less happy survivors of the Second World War - the hope of a shared Europe, intellectually, morally and politically renewed, with the prospect of prosperity for all its citizens. To this hope they eventually gave shape in a peaceful revolution, the watchword for which was Solidarnosc.52 That is consistent with findings of scholars analyzing the process of mnemonic entrepreneurship that was especially successful within EPP. ${ }^{53}$

However, representatives for the radical left-wing party group (GUE/NGL) fiercely opposed during the analyzed debates, not the recognition of Stalinism as totalitarianism, but rather - in the words of an GUE/NGL MEP - 'the attempt surreptitiously to trivialise Nazism by placing it in a generic category that includes, in particular, Stalinism and even the regimes existing in central and eastern Europe prior to the fall of the Berlin Wall. ${ }^{54}$ Such arguments especially expressed by far left parties - have not changed much over time. They were reflected in the interparty conflicts as EPP MEP stressed: 'there is a further dimension to this debate. It is not only a united Europe that needs urgently to look at the entirety of the past, but the same is particularly true of the European Left'.55

\footnotetext{
51 Christopher Beazley (PPE-DE), "Proposed hearing".

52 Hans-Gert Pöttering (PPE-DE), "The future of Europe".

53 Neumayer "Integrating".

54 Francis Wurtz (GUE/NGL), "Proposed hearing".

55 Gyorgi Schöpflin (PPE-DE), "European conscience”.
} 


\section{Who Ended the Cold War and Why Does it Matter?}

A very frequent claim raised by Polish MEPs regards the significance of the experience of the opposition struggles in Poland under Communism for a united Europe. This is specifically visible when the Solidarity movement is mentioned in the EP. The main argument raised by Polish MEPs deals with the universality of values for which the Solidarity movement fought, as well as their complementarities with Western European values. The main claim was predominantly about the recognition of Poles as part of the same European family. This was - as discussed above - a concurrent theme in the discourse on the EU enlargement in Poland. It was mostly about how, due to their religion, history and values, Poles belong to the Western European civilization.

One element in statements on the Solidarity movement raised by Polish MEPS seems very interesting in the context of this chapter. It is connected with the claim for recognition of the significance of the Solidarity movement and its demands from 1980 for global, or at least European, historical processes. According to Polish MEPs, it was not Hungarian or Czech attempts to overthrow the Communist regime, nor the German demolition of the Berlin Wall which ultimately ended Communism in CEE and the world. It was the Polish Solidarity movement and its unprecedented mobilization of the people that finally became decisive. As one of the MEPs put it, 'Solidarity was instrumental in much more besides. It led to the peaceful revolution in Central and Eastern Europe. Nine years after the so-called outbreak of Solidarity, Czechoslovakia underwent the Velvet Revolution, and the fall of the Berlin Wall followed. The origins of these events can, however, be traced back to 1980 and to Gdansk, in Poland'.56 Such a position in the debate signals the need not yet fully expressed by Polish MEPs to be recognized in the Western European family as significant actors who contributed greatly to the changes in the continent. Various analyses of the Polish discourse on the Second World War highlight the collective trauma of being betrayed, left alone beyond the Iron Curtain. Passivity is alien to the Polish political and strategic culture since, at least from the period of partition, it was always important to act against the will of the stronger, rather than passively wait for a fate which was decided above their heads. This resonated in Polish politics in the interwar period and has returned with

$5^{6}$ Ryszard Czarnecki (NI), "25th Anniversary of Solidarity and its message for Europe" European Parliament plenary debate (26 September 2005) accessed August 2014, http://www.europarl.europa.eu/sides/getDoc.do?pubRef=-//EP//TEXT+CRE+ 20050926+ITEM-013+DOC+XML+Vo//EN. 
double strength since $1989 .{ }^{57}$ The Solidarity movement and its achievements are specifically important because they undo the curse of the Yalta conference. One MEP made it clear: 'Attempts had been made previously by the Czechs, Slovaks and Hungarians to overthrow that diabolical system, but it was the Poles and the Polish Pope who eventually succeeded in dismantling the agreements reached at Yalta. 58

The recognition of the constant Polish fight with Communism, which culminated during the Solidarity period, serves two main purposes for Polish MEPs. First and foremost, as stated above, it is about finding a place in the European Community and becoming a fully-fledged member thereof. This is done through claiming a strong commitment to the most important values of Europe. It is important to stress that the special experience of CEE societies under Communism, with their then much more caucious attitude towards any idealistic, utopian project and yet the particular attention to the individual freedom and liberty of which they were long deprived, could enrich the reflections on the future of Europe. Secondly, assertions about the contribution of Solidarity (and the broader Polish struggles with Communism) to the European peace after the Cold War are connected with redistribution claims. As will be discussed in the next part of the paper, assuring an equal place in community allows demands connected with fair distribution of goods.

The analysis of the reception of such claims confirms that Solidarity occupies an important place in the collective memory of the united Europe and that it was strengthened through the Polish political actors' claims. It has also been frequently asserted that the values that the Solidarity movement represented are important for European heritage: 'Solidarity symbolised then, as it does now, hope in the future, the determination of people to build better lives for themselves and their families and an unshakeable belief in the power of the human spirit'.59 However, the second function of the claims, i.e. the redistribution claims finds less response in the analyzed material. In other words, Solidarity is widely perceived, in a symbolic sense, as a significant contributor to the European experience. However, it has not yet been translated into the acceptance of the right of claimants to demand a different position as regards redistribution. That will be further elaborated in the following section of the chapter.

57 Góra, Mach, "Between Old Fears".

58 Jan Masiel (NI), "25th Anniversary".

59 Timothy Kirkhope (PPE-DE), "25th Anniversary”. 


\section{This is Why You Need to Pay}

The claims for the recognition of the experience of Communism also serve other purposes. As mentioned in the theoretical part of this paper, Nancy Fraser argues that part of the struggles for recognition is the right to be treated equally when redistribution is in question. Following this line of argumentation, some claims for the recognition of the experience of Communism provide political actors with the necessary instruments to demand either special treatment under Eu law or to bargain for redistribution.

The case of the Polish shipyards was one of the most difficult and complicated issues. The European Commission stood against the Polish government for its non-compliance with competition law since it was heavily subsidizing shipyards in Gdańsk, Gdynia and Szczecin. At the same time, this particular industrial sector occupies a special place in the Polish experience, as these were the cradles of opposition against Communist rule, and specifically the Solidarity movement. The long negotiations between the EC and Polish government proved to be extremely difficult, and the debate finally entered the European Parliament in 2007 and 2008. Ultimately, the EC and Commissioner Neelie Kroes decided against the subsidies of the Polish shipyards, arguing that state aid was illegal.

Most of the arguments in the debates were of an economic and political nature; however, many MEPs used arguments that pointed to the special character and symbolic meaning of the shipyards, and therefore the right to special treatment of them. As one of the MEPs stressed, 'The Gdansk Shipyard, the cradle of solidarity, the chief actor in the struggle against communism, a shipyard which suffered discrimination and which by the political decisions of the communists was brought to a poor financial condition, today awaits a positive decision from the European Commission' ${ }^{60}$ The crucial argument for the anticipated special treatment was that the sector had already been destroyed by the Communist economy, and that an attempt to save it was just and appropriate. Moreover, according to some MEPs, the entire EU owes its current well-being and prosperity to the struggle of workers under Communism: 'Polish shipyards, particularly the Gdansk shipyard, are a symbol of the struggle against the Communist government. They symbolise the fall of the Iron Curtain which had divided Europe in two. That is why the flagpoles, which stand outside the European Parliament buildings, and which fly flags of the Member

6o Elżbieta Tomaszewska (UEN), "Reform programme of Polish shipyards" European Parliament plenary debate (21 October 2008) accessed August 2014 http://www.europarl. europa.eu/sides/getDoc.do?pubRef=-\% 2f\%2fEP\%2f\%2fTEXT\%2bCRE\%2b20081021\%2 bITEM-016\%2bDOC\%2bXML\%2bVo\%2f\%2fEN\&language=EN. 
States, were made in the Gdansk shipyards. It is thanks to the heroic actions of Polish shipyard workers, who fought for a re-united Europe, that today we are able to meet here together. These people deserve our respect, they deserve a dignified life and a decent living' ${ }^{61}$

In the discussed debates dealing with the issues of redistribution, the topic of the recognition of past experience appears much less frequently. The main arguments link the lower level of development in former communist countries and the need for greater solidarity with the Cold War division of Europe. In special circumstances - such as in the case of the Polish shipyards - the role in the historical processes of the continent is perceived as an appropriate justification for special treatment in contemporary European politics.

The symbolic significance of shipyards was recognized in the debates although the prime interest was the economic aspects of the conflict. The leader of PES stated ultimately that 'The Polish shipyards, sites such as Gdansk and Szczecin, were an important symbol for us all, of the Polish people's democratic struggle against dictatorship. That is another reason why these yards must not be closed'. ${ }^{62}$ However, the claims that the experience of Communism and its economic heritage could be used as an argument for the non-compliance with EU regulations, were not supported. The reception of such claims was different predominantly due to the explicit, individual - often clearly economic - interest behind the demands. The case of shipyards confirms that, as much as there is an economic heritage of Communism with which new member states are struggling, it is not widely perceived as an excuse for different treatment.

\section{Conclusions}

The progress of European integration, and also the enlargement in which former communist countries joined the $\mathrm{E} \mathrm{U}$, has created a new, much broader and demanding frame of reference within which the European politics of memory and recognition can be developed. The European, enlarged space of historical debate has also become a frame for the construction of collective identities. As identity is a process of dialogue, an interaction with 'significant others', an involvement in meaningful relations with partners, the enlarged Europe has become a place of struggle for the recognition of those who have previously, in the divided Europe, not participated in the process of the construction of

\footnotetext{
61 Adam Bielan (UEN), "Reform programme".

62 Martin Schultz (PSE), "Reform programme".
} 
European memory and identity. For Poland and its people, as for other new members of the $\mathrm{EU}$, it has become crucial to make themselves heard and respected in their memories and interpretations of the past. The struggle for recognition consists in an attempt to introduce new topics into the European discourse - those which did not exist before 1989 or were only in the margins. The demand is that particular national or regional historical experiences and memories should become recognized by all Europeans and represented in mainstream European narratives. Also, Central and Eastern Europeans have tried to win recognition of their interpretations of events and processes which already exist in European memory.

It seems - based on our analysis - that the success of the struggle for recognition depends on whether Central and Eastern Europeans are able to offer their own, new interpretation of those issues which are seen as essential for the whole of Europe and not only for the region of CEE. The key problem here, however, is that new members of the EU must, in order to be accepted as equal partners in the dialogue, in order to be recognized, speak a language which is understood and respected. The concepts, metaphors, symbolic references and emotional expressions used in communication create the impression of familiarity or alienation. It is therefore important that new members of the network of communication know, understand and learn to use the language which is seen as the idiom of the European common platform of dialogue. Our analysis shows that the plenary sessions of the EP has served as a forum to express claims directed to Western Europe in its broadest sense and its societies. The EU institutions have been much less frequently addressed with such claims. Moreover, the main motivations given for such claims have been predominantly universally European, referring to European values and the future of European integration.

In order to be successful in their struggle for recognition, the new member states also need to address issues, questions and problems which are important for Europe and promise to contribute something to European common understanding. Our analysis shows that the new members have been able to introduce new topics of discussion which are seen as an important contribution to the common European heritage. Their voice is heard and their experience at least partially recognized. In particular, former communist countries will be recognized as equal if they can demonstrate not only that the experience of communism is important for them, but that it is important for the whole of Europe. As visible in our analysis, they have rather quickly learnt how to frame their demands. The well-being of Europe and the EU, as well as European values and principles, have often been used in the justifications of Polish MEPS and that has resonated well in the EP. 
Finally, we argue that the EU has become - even if only partially - a new recognition order for political actors from Poland. It has become a significant place for claims related to identity as well as for redistribution. The debates on the Polish shipyard sector show how the recognition of historical experience can be utilized in political battles to receive special treatment, in this context connected with the economic aspects of integration.

\section{Bibliography}

Closa, Carlos. "Negotiating the Past: Claims for Recognition and Policies of Memory in the EU". Working Paper. Instituto de Políticas y Bienes Públicos (IPP), ccHS-csIC, 8 (2010). http://ipp.csic.es/en/workpaper/negotiating-past-claims-recognitionandpolicies-memory-eu (accessed August 2014).

European Parliament plenary debate. "25th Anniversary of Solidarity and its message for Europe" (26 September 2005). Accessed July 2014. http://www.europarl.europa.eu/sides/getDoc.do?pubRef=-//EP//TEXT +CRE +20050926+ ITEM-013+DOC+XML+Vo//EN.

European Parliament plenary debate. "The future of Europe sixty years after the Second World War", (11 May 2005). Accessed July 2014. http://www.europarl.europa .eu/sides/getDoc.do?pubRef=-\%2f\%2fEP\%2f\%2fTEXT\%2bCRE\%2b20050511\%2bI TEM-016\%2bDOC\%2bXML\%2bVo\%2f\%2fEN\&language=EN.

European Parliament plenary debate. "Proposed hearing of the Commission on crimes of genocide, crimes against humanity and war crimes committed by totalitarian regimes", (21 April 2008). Accessed July 2014. http://www.europarl.europa.eu/ sides/getDoc.do?pubRef=-\%2f\%2fEP\%2f\%2fTEXT\%2bCRE\%2b20o80421\%2bIT EM-015\%2bDOC\%2bXML\%2bVo\%2f\%2fEN\&language=EN.

European Parliament plenary debate "Reform programme of Polish shipyards" (21 October 2008). Accessed July 2014. http://www.europarl.europa.eu/sides/getDoc .do?pubRef=-\%2f\%2fEP\%2f\%2fTEXT\%2bCRE\%2b2oo81021\%2bITEM-016\%2bDO C\%2bXML\%2bVo\%2f\%2fEN\&language=EN.

European Parliament plenary debate. "European conscience and totalitarianism" (25 March 2009). Accessed July 2014. http://www.europarl.europa.eu/sides/getDoc .do?pubRef=-//EP//TEXT+CRE+20090325+ITEM-o10+DOC+XML+Vo//EN.

Fossum, John Erik. "Conceptualizing the EU's Social Constituency." European Journal of Social Theory 8:2 (2005): 123-147.

Fossum, John Erik, and Marit Eldholm. "Conceptualising (and tentatively mapping) the EU's social constituency". In Civic Resources and the Future of the European Union, edited by Ireneusz Pawel Karolewski, Viktoria Kaina, 146-195. London: Routledge, 2012. 
Fraser, Nancy. "Social Justice in the Age of Identity Politics: Redistribution, Recognition, and Participation". The Tanner Lectures on Human Values. Delivered at Stanford University, 30 April-2 May 1996.

Fraser Nancy, and Axel Honneth. Redistribution of recognition? A political-philosophical exchange. London, New York: Verso, 2003.

Góra, Magdalena. "Solidarity of Citizens and of States in the European Union," Visegrad Insight, 2:4 (2013) 21-24.

Góra, Magdalena, and Katarzyna Zielińska. "Defenders of faith? Victims of secularization? Polish politicians in the European Parliament." Religion, State, Society 42:2-3 (2014): 211-226.

Góra, Magdalena, and Zdzisław Mach. "Between Old Fears and New Challenges. The Polish Debate of Europe," in Justine Lacroix, Kalypso Nicolaïdis, (eds), European Stories. Intellectual Debates in National Contexts, 221-256. Oxford: Oxford University Press, 2010.

Gross, Tomasz J. Neighbors: the Destruction of the Jewish Community at Jewabne, Poland, Princeton: Princeton University Press, 2001.

Gross, Tomasz J. Fear: Anti-Semitism in Poland After Auschwitz. An Essay in Historical Interpretation, Princeton, Oxford: Princeton University Press, 2006.

Gutman, Amy. "Introduction". In Multiculturalism. The Examination the Politics of Recognition, edited by Amy Gutman, 3-24. Princeton, New Jersey: Princeton University Press, 1994.

Hellgren, Zenia and Barbara Hobson. "Gender and ethnic minority claims in Swedish and Eu frames. Sites of Multilevel Political Opportunities and Boundary Making”. In Gender politics in the expanding European Union: mobilization, inclusion, exclusion, edited by Silke Roth, 211-237. New York, Oxford: Berghahn Books, 2008.

Honneth, Axel. The Struggle for Recognition: The Moral Grammar of Social Conflicts, Cambridge: Polity Press, 1995.

Honneth, Axel. "Redistribution as Recognition: A Response to Nancy Fraser". In Nancy Fraser, Axel Honneth, Redistribution of recognition? A political-philosophical exchange, London, 110-197. New York: Verso, 2003.

Honneth, Axel. "Recognition and Justice: Outline of a Plural Theory of Justice." Acta Sociologica 47:4 (2004): 351-364.

Kaczyński, Jarosław. "Wypowiedź w debacie”, in Informacja rządu na temat polskiej polityki zagranicznej w 2003 roku. 4 kadencja, 40 posiedzenie, 2 dzień (22 January 2003), http://orka2.sejm.gov.pl/Debata4.nsf (accessed August 2014).

Kattago, Siobhan. "Memory, Pluralism and the Agony of Politics." Journal of Baltic Studies, 41:3 (2010): 383-394.

Killingsworth, Matt, Małgorzata Klatt, and Stefan Auer. "Where Does Poland Fit in Europe? How Political Memory Influences Polish MEPs' Perceptions of Poland's place in Europe." Perspectives on European Politics and Society, 11:4 (2010): 358-375. 
Krasnodębski,Zdzisław. Demokracja peryferii. Gdańsk: Wydawnictwo słowo/obraz terytoria, 2005.

Lazzeri, Christian, and Alain Caillé. "Recognition Today. The Theoretical, Ethical and Political Stakes of the Concept". In Recognition, Work, Politics. New Directions in French Critical Theory, edited by Jean-Philippe Deranty, Danielle Petherbridge, John Rundell, Robert Sinnerbrink, 89-126. Leiden, Boston: Brill, 2007.

Letki, Natalia. "Lustration and Democratisation in East-Central Europe." Europe-Asia Studies 54:4 (2002): 529-552.

Mälksoo, Maria. "The Discourse of Communist Crimes in the European Memory Politics of World War II". Paper presented at the Ideology and Discourse Analysis conference 'Rethinking Political Frontiers and Democracy in a New World Order', Roskilde University, Denmark, 8-10 September 2008.

Mazowiecki, Tadeusz. "Wnioski Prezydenta PRL o odwołaniu ze stanowiska Prezesa Rady Ministrów Czesława Kiszczaka oraz o powołanie na stanowisko Prezesa Rady Ministrów Tadeusza Mazowieckiego", in Sejm Rzeczpospolitej Polskiej X Kadencji, Sprawozdanie Stenograficzne z 6 Posiedzenia Sejmu, 23 i 24 sierpnia 1989, Warszawa 1989, in http://orka2.sejm.gov.pl/StenogramyX.nsf/o/259278CD28DE3BBDC1257D2 0002CC6FD/\$file/oo6_ooooo6771.pdf (accessed August 2014).

Mink Georges, and Laure Neumayer. History, Memory and Politics in Central and Eastern Europe. Memory Games. Basingstoke: Plagrave Macmillan, 2013.

Neumayer, Laure. "Integrating the Central European Past into a Common Narrative: The Mobilizations Around the 'Crimes of Communism' in the European Parliament." Journal of Contemporary European Studies 23:3 (2015): 344-363.

Pękacz, Joanna. "'Antemurale of Europe'. From the History of National Megalomania In Poland." History of European Ideas 20:1-3 (1995): 419-424.

Sanford, Georges "Overcoming the Burden of History in Polish Foreign Policy." Journal of Communist Studies and Transition Politics 19:3 (2003): 178-203.

Stola, Dariusz. "Poland's Institute of national Remembrance: A Ministry of Memory?". In The Convolutions of Historical Politics, edited by A. Miller, M. Lipman, 45-58. Budapest: Central European University Press, 2012.

Stan, Lavinia (ed.). Eastern Europe and the Former Soviet Union. Reckoning with the communist past. London: Routledge, 2009.

Taylor, Charles. "The Politics of Recognition”. In Multiculturalism. The Examination the Politics of Recognition, edited by Amy Gutman, 25-74. Princeton, New Jersey: Princeton University Press, 1994.

Tazbir, Janusz. “Europejska wspólnota obronna”. In Europa. Drogi integracji, edited by Aniela, Dylus. Warszawa: Studium Generale Europa, Uniwersytet Kardynała Stefana Wyszyńskiego, 1999.

Tully, James. "Struggles over Recognition and Distribution," Constellations 7:4 (2000): 469-482.

Ujazdowski, Kazimierz M. "Wypowiedź w debacie”. In Informacja Ministra Spraw Zagranicznych o zadaniach polskiej polityki zagranicznej w 2005 roku, 4 kadencja, 
96 posiedzenie, 3 dzień (21 January 2005) http://orka2.sejm.gov.pl/Debata4.nsf (accessed August 2014).

Williams Kieran, Aleks Szczerbiak, and Brigid Fowler. "Explaining Lustration in Eastern Europe: 'A Post-communist politics approach”. SEI Working Paper 62 (2003), https://www.sussex.ac.uk/webteam/gateway/file.php?name=sei-working-paperno-62.pdf\&site=266 (accessed August 2014).

\section{Annex 1. List of Analyzed Plenary Debates in the European Parliament}

European Parliament plenary debate. "Anti-semitism and racism" (25 January 2005), http://www.europarl.europa.eu/sides/getDoc.do?pubRef=-\%2f\%2fEP\%2f\%2fTEX T\%2bCRE\%2b20050126\%2bITEM-008\%2bDOC\%2bXML\%2bVo\%2f\%2fPL\&langu age $=$ PL\&query $=$ INTERV \&detail $=3-149$.

European Parliament plenary debate. "The future of Europe sixty years after the Second World War", (11 May 2005). Accessed July 2014. http://www.europarl.europa .eu/sides/getDoc.do?pubRef=-\%2f\%2fEP\%2f\%2fTEXT\%2bCRE\%2b20050511\%2bI TEM-016\%2bDOC\%2bXML\%2bVo\%2f\%2fEN\&language=EN.

European Parliament plenary debate. "25th Anniversary of Solidarity and its message for Europe” (26 September 2005). http://www.europarl.europa.eu/sides/getDoc .do?pubRef=-//EP//TEXT+CRE+20050926+ITEM-013+DOC+XML+Vo//EN.

European Parliament plenary debate. "Culture 2007" (24 October 2005). http://www .europarl.europa.eu/sides/getDoc.do?pubRef=-//EP//TEXT+CRE +20051024+ ITEM-016+DOC+XML+Vo//EN.

European Parliament plenary debate. "The Human Rights and democracy clause" (14 February 2006). http://www.europarl.europa.eu/sides/getDoc.do?pubRef=-\%2f\%2f EP\%2f\%2fTEXT\%2bCRE\%2b20o6o214\%2bITEM-004\%2bDOC\%2bXML\%2bVo\%2 $\mathrm{f} \% 2 \mathrm{fEN} \&$ language $=\mathrm{EN}$.

European Parliament plenary debate. "Citizens for Europe Programme (2007-2013)" (4 April 2006). http://www.europarl.europa.eu/sides/getDoc.do?pubRef=-\%2f\%2f EP\%2f\%2fTEXT\%2bCRE\%2b20060404\%2bITEM-015\%2bDOC\%2bXML\%2bVo\%2 f\%2fEN\&language $=\mathrm{EN}$.

European Parliament plenary debate. "Risk of closure of Gdansk shipyard" (4 September 2007). http://www.europarl.europa.eu/sides/getDoc.do?pubRef=-\%2f \%2fEP\% 2f\%2fTEXT\%2bCRE\%2b20070904\%2bITEM-005\%2bDOC\%2bXML\%2bVo\%2f\%2 fEN\&language $=\mathrm{EN}$.

European Parliament plenary debate. "Proposed hearing of the Commission on crimes of genocide, crimes against humanity and war crimes committed by totalitarian regimes" (21 April 2008). http://www.europarl.europa.eu/sides/getDoc.do?pubRef=\%2f\%2fEP\%2f\%2fTEXT\%2bCRE\%2b20o80421\%2bITEM-015\%2bDOC\%2bXML\% 2bVo\% $\%$ f $\% 2 \mathrm{fEN} \&$ language $=\mathrm{EN}$. 
European Parliament plenary debate "Reform programme of Polish shipyards" (21 October 2008). http://www.europarl.europa.eu/sides/getDoc.do?pubRef=-\%2f\%2f EP\%2f\%2fTEXT\%2bCRE\%2b20081021\%2bITEM-016\%2bDOC\%2bXML\%2bVo\%2f $\%$ 2fEN\&language $=\mathrm{EN}$.

European Parliament plenary debate. "Commemoration of Holodomor" (22 October 2008). http://www.europarl.europa.eu/sides/getDoc.do?pubRef=-\%2f\%2fEP\%2f\% 2fTEXT\%2bCRE\%2b20081022\%2bITEM-014\%2bDOC\%2bXML\%2bVo\%2f\%2fEN \&language $=\mathrm{EN}$.

European Parliament plenary debate. "European conscience and totalitarianism" (25 March 2009). http://www.europarl.europa.eu/sides/getDoc.do?pubRef=-//EP// $\mathrm{TEXT}+\mathrm{CRE}+20090325+\mathrm{ITEM}-010+\mathrm{DOC}+\mathrm{XML}+\mathrm{Vo} / / \mathrm{EN}$. 


\title{
Answering Back to Presumed Accusations: Serbian First World War Memories and the Question of Historical Responsibility
}

\author{
Ismar Dedović and Tea Sindbrek Andersen
}

In the autumn of 2013, as the centenary of the First World War was looming in the near future, Tomislav Nikolić, president of Serbia, officially rejected that his country could in any way be held responsible for the beginning of that war. In an open letter published in the distinguished newspaper Politika, Nikolić wrote that voices were heard which tried to redefine the 'Vidovdan assassination', the Serbian phrase for the murder of Franz Ferdinand on 28 June 1914, as a terrorist attack. The aim of this, according to Nikolić, was to declare Serbia a priori guilty. 'Will the victorious powers allow attempts at revising history by the invention of a terrorist attack as the cause for the beginning of the First World War? Are the victims of a righteous battle for freedom in vain?' asked Nikolic, stating that 'We have no right to remain silent even if this lie were represented by one single voice.' ${ }^{\prime}$

The voices mentioned by Nikolić remain undefined and anonymous. Nevertheless, there is no doubt that Nikolić's passionate letter is composed as a response to what is perceived as accusations and attempts to blame Serbia for the beginning of the Great War. After posing his questions, Nikolić moves on to explain what he sees as the causes of the war, positioning them firmly outside Serbia, and to remind his readers of the catastrophic losses and suffering that Serbia endured during the wartime years.

While Nikolićs letter has the appearance of a reaction, the exact origin of the accusation is not mentioned in it. However, in a speech given in June 2014, at the eve of the centenary of the First World War, Nikolic clearly identifies Christopher Clark's book from 2012 The Sleepwalkers. How Europe Went to War in 1914 as the primary source of revisionist attempts to blame Serbia for the

1 Tomislav Nikolić, "budimo dostojni junačke prošlosti," Politika, 10 November 2013, accessed 15 September 2016, http://www.politika.rs/sr/clanak/275423/Budimo-dostojni-junackeproslosti. 
outbreak of the war. ${ }^{2}$ Yet, these statements from Serbia's president are certainly not the first examples of attempts to contradict or reject presumed accusations that Serbia could be held responsible for the outbreak of the First World War. A long tradition of such rejections can be detected nearly all the way through the century since the War began. Thus, while Nikolić's statements constitute a highly politicized reception of, among others, Clarke's book, they are certainly also highly premediated repetitions of an old argument. ${ }^{3}$ Yet, Nikolić is also claiming to protect Serbia's memory of the First World War, a war that cost Serbia very dearly, but also ensured the country's position among the victorious Entente powers and led to the creation of the first Yugoslav state in 1918. Indeed, Nikolićs letter is titled 'Let us be proud of our heroic past'. ${ }^{4}$

This chapter investigates Tomislav Nikolić's statements in connection to the First World War centenary, both as remediation of Serbian memories of the outbreak of the Great War and as reception of Clark's book. We trace what we see as a powerful premediation of Nikolićs statements in the tradition of rejecting Serbia's potential responsibility for the war in history books and school textbooks on history. We argue that this is an essential element of Serbia's war memory. Moreover, we propose that this tradition of rejecting war responsibility could be understood as reception of real and perceived accusations, and we suggest that the urge to stand up to these perceived accusations will render Serbia's First World War memory a certain urgency and a sense that it needs protection, which will increase its actuality and relevance in the present.

\section{Serbia and First World War Memory}

The First World War, Europe's 'great seminal catastrophe' in the words of George Kennan, ${ }^{5}$ is widely and massively commemorated throughout Europe. ${ }^{6}$

2 “Govor Predsednika Republike, SANU - Veliki Rat. 13 June 2014." (A print of the speech was kindly supplied at request from the press centre at the office of the President of the Republic of Serbia).

3 Astrid Erll, "Remembering across Time, Space and Culture: Premediation, Remediation and the 'Indian Mutiny,", in Mediation, Remediation and the Dynamic of Cultural Memory, edited by Astrid Erll and Ann Rigney (Berlin: De Gruyter, 2009), 111.

4 Nikolić, "budimo dostojni junačke prošlosti".

5 George Kennan, The Decline of Bismarck's European Order. Franco-Russian relations, 1875-189o (Pinceton: Princeton University Press, 1979), 3.

6 For example: George L. Mosse, Fallen Soldiers. Reshaping the Memory of the World Wars (Oxford: Oxford University Press, 1990); Jay Winter, Sites of Memory, Sites of Mourning. The Great War in European Cultural History (Cambridge: Cambridge University Press, 1995). 
As a hugely complex 'site of memory', the First World War is an essential focus point of both European and national collective remembrance and of historical meaning, attracting intense attention from those involved in remembering and constantly being invested with new meaning. ${ }^{7}$ Like other well-established sites of memory, it possesses a massive tradition or 'genealogy' of remediation ${ }^{8}$ across various modes of cultural memory, one of these being historiography. ${ }^{9}$ Indeed, the origins and causes of the First World War are among the most discussed historical problems of Europe's 2oth century. ${ }^{10}$

In Serbia, the First World War is a strongly established and hugely politicized site of memory. Indeed, Serbia's First World War history supplies abundant material for a heroic national narrative. Attacked in 1914 by a much stronger neighbouring Austro-Hungarian Empire, the Serbian army successfully defended the country's borders until the winter of 1915-1916 when, overpowered by the joint offensive from Germany, Bulgaria and Austria-Hungary, the army retreated together with the Serbian government and the royal house through the mountains of Albania, abandoning Serbia to be occupied by the Central Powers. When they reached the Adriatic coast, Serbia's military forces were sailed to Corfu, where they were reorganized in order to be deployed as part of the Entente forces at the Salonica front. Here they contributed to the break-through of the Bulgarian lines of defence and the reconquering of Serbia, returning to Belgrade in October 1918. Serbia thus emerged as a victorious

7 On the concept of site of memory, see Ann Rigney, "Plenitude, scarcity and the circulation of cultural memory," Journal of European Studies 35, 1 (2005): 18. See also the description by Nora, who originally coined the phrase: Pierre Nora, "Between Memory and History: Les Lieux de Mémoire," Representations 26 (1989): 7-24.

8 Astrid Erll and Ann Rigney, "Introduction: Cultural Memory and its Dynamics," in $\mathrm{Me}$ diation, Remediation and the Dynamic of Cultural Memory, edited by Astrid Erll and Ann Rigney (Berlin/New York: De Gruyter, 2009), 5 .

As Astrid Erll has pointed out, history may well be seen as "yet another mode of cultural memory" with historiography as its specific medium. Astrid Erll, "Cultural Memory Studies: An introduction," in A Companion to Cultural Memory Studies, edited by Astrid Erll and Ansgar Nünning (Berlin/New York: De Gruyter, 2010), 7.

For overviews of these discussions, see e.g. James Joll and Garton Martel, The Origins of the First World War, 3rd edition, (London: Routledge, 2007). For overviews of the wave of new studies published around the centenary of the war, see e.g. Hew Strachan, "Review article: The origins of the First World War," International Affairs 90, 2 (2014): 429-439; Andrew G. Bonnell, "New Histories of the Origins of the First World War: What happened to the 'Primacy of Domestic Politics'?" Australian Journal of Politics and History 61, 1 (2015): 121-127; William Mulligan, "Review-Article: The Trail Continues: New directions in the Study of the Origins of the First World War," English Historical Review 129, no. 538 (2014): $639-666$. 
Entente ally and played a dominant role in the creation of a new large South Slav state in 1918, when the Kingdom of Serbs, Croats and Slovenes (Yugoslavia from 1929) was established through a unification of the kingdoms of Serbia and Montenegro with the formerly Austro-Hungarian regions of Slovenia, Croatia and Bosnia. Yet, the costs of this uncompromising war effort were terrible; presumably a quarter of Serbia's pre-war population was killed fighting or died from war-related hunger or epidemics in the trenches or back home in the occupied country.11

The heroism and suffering of Serbia's army became key elements of the national mythology in the new Kingdom. Serbia's fallen soldiers on the allied side were widely commemorated with enthusiastic support, both personally and materially, from the Serbian royal house. ${ }^{12}$ From its very outset, Serbia regarded the Great War as a defensive struggle against the imperial ambitions of Austria-Hungary in the Balkans. 'Brave little Serbia', as the story went, was heroically defending its freedom against a manifold larger and stronger foe, and despite innumerable hardships it managed to survive and even triumph over the invading forces. This narrative was elaborated and institutionalized after the end of the war, becoming the official narrative of the newly formed Kingdom of Serbs, Croats and Slovenes (later called the Kingdom of Yugoslavia). ${ }^{13}$ It was during the first post-war years that several elements of the narrative template of Serbian First World War memory were first put in place: the brave, little state defending itself against the aggressions of the Austro-Hungarian Empire and managing to win spectacular victories, the suffering and patient nation, living through occupation and the terrible Albanian winter as the army

11 For an overview of Serbia's war history, see Andrej Mitrović, Serbia's Great War (London: Hurst, 2007); John R. Lampe, Yugoslavia as History. Twice there was a country (Cambridge: Cambridge University Press, 2000), 101-117; Stevan K. Pavlowitch, Serbia. The History behind the Name (London: Hurst, 2002), 93-110.

12 John Paul Newman, Yugoslavia in the Shadow of War. Veterans and the limits of State Building 1903-1945 (Cambridge: Cambridge University Press, 2015), 69; John Paul Newman, "Allied Yugoslavia: Serbian Great War Veterans and their Internationalist Ties," in The Great War and Veterans' Internationalism, edited by Julia Eichernberg and John Paul Newman (Basingstoke: Palgrave Macmillan, 2013), 110-112.

13 Danilo Šarenac, Top, Vojnik i Sećanje, Prvi Svetski Rat i Srbija 1914-20oo (Belgrade: Institut za savremenu istorju, 2014), 178-240; Olga Manojlović Pintar, Arheologija sećanje. Spomenici i identiteti i Srbiji 1918-1989 (Belgrade: Čigoja, 2014), 134-142; Ismar Dedović and Tea Sindbæk Andersen, "To Battle, go forth all heroes'. World War I Memory as a Narrative Template in Yugoslavia and Serbia," in Re-visting World War I. Interpretations and Perspectives of the Great Conflict, edited by Jaroslaw Suchoples and Stephane James (Frankfurt am Main: Peter Lang, 2016), 247-270. 
retreated to safety in Greece, and finally, the resurrection of the nation and the state as the Serbian army broke out from the front at Thessaloniki and liberated its country from Austria-Hungary and other occupiers. ${ }^{14}$

This narrative has, with modifications, dominated the perceptions of the Great War in Serbia and Yugoslavia since its establishment. Always focused primarily on the heroic Serbian side of wartime history, the narrative tended to exclude the memories of the millions of Yugoslav citizens who had experienced the war from within the Austro-Hungarian Empire or had fought in the Empire's armies. ${ }^{15}$ Yet, in spite of the strongly pro-Serbian leaning, efforts were made in the interwar Kingdom of Yugoslavia to create a more inclusive all-Yugoslav line of commemoration, for example by letting school book narratives emphasize the Yugoslav aspirations of Serbia's war effort or by constructing pro-Yugoslav monuments, such as the Monument to the Unknown Hero on mount Avala outside Belgrade. ${ }^{16}$

At the same time, the new state elevated Gavrilo Princip and his fellow conspirators to the status of national heroes and heralds of freedom for the South Slavs. This was a paradoxical move as it opened the state to international criticism for glorifying an assassin that - in the eyes of the world - put in motion a process leading to the Great War. ${ }^{17}$ But the Princip cult was at the same time a very potent symbol of the struggle of the South Slavs for their freedom. The graves of Princip and his fellows became sites of pilgrimage for young nationalists and in 1930 a memorial plaque was erected on the site of the assassination. ${ }^{18}$

14 See for example: Vladimir Ćorović, Istorija Jugoslavije (Belgrade: Narodno Delo, 1933), 6o9-618; Z. Špoljar, Povijest Hrvata, Srba i Slovenca za mladež nar. Osnovnih škola (Zagreb: Vlastita Naklada, 1927), 61-62; Dragan M. Adamović, Istorija Jugoslovena za podoficire (Zagreb: Merkantile, 1938), 137-145; Milan A. Kostić \& Mat P. Ljujić, Istorija Jugoslovena (Srba, Hrvata i Slovenaca) sa učenike II razreda osnovnih škola u Kraljevini Jugoslaviji (Belgrade: Knjižarnice Milorada P. Mihailovića, 1939), 42-43.

15 Newman, Yugoslavia in the Shadow of War; Dedović and Sindbæk Andersen, "'To Battle, go forth all heroes"'.

16 On Avala, see for example: Aleksandar Ignjatović, "From Constructed Memory to Imagined National Tradition: The Tomb of the Unknown Yugoslav Soldier (1934-38)," Slavonic and East European Review 88, 4 (2010): 624-651.

17 Paul B. Miller, "Compromising Memory: The Site of the Sarajevo Assassination," (Meeting Report 333, Woodrow Wilson Centre, Ees Noon Discussion, Sarajevo, 10 January 2007), accessed 8 August 2016, https://www.wilsoncenter.org/ publication/333-compromising-memory-the-site-the-sarajevo-assassination.

18 Muharem Bazdulj and Nebojsa Grujičić, eds., Stogodišnji rat. Sarajevskiatentat itumačenja (Beograd: Vreme, 2014), 45-47 and Selma Harrington, "The Politics of Memory: The Face and the Place of the Sarajevo Assassination," Prilozi, 43 (2014): 123. 
With the establishment of communist rule in Yugoslavia in 1945, commemoration of the Second World War, which had brought the Communist party to power, completely dominated public memory. Yet, in the background, the established memory narratives of the First World War remained, with history books and textbooks still focusing on Serbian heroism and suffering, only with a Marxist interpretation added, presenting the war as a result of the imperialist politics of Europe's great powers. ${ }^{19}$ In the socialist period, the cult of Gavrilo Princip was strengthened and received substantial official support. The Princip of the Communists became a revolutionary hero, struggling for national freedom and social justice. ${ }^{20}$

First World War memory attracted more attention in Yugoslavia after the 50 years anniversary of the War's outbreak in 1964, when new monuments were erected. ${ }^{21}$ Especially during the so-called 'outburst of history' in the 1980s, the Great War once again became an important and also controversial topic, particularly in Serbia. ${ }^{22}$ One of the strongest Serbian reassessments of First World War memory figured in Danko Popovićs hugely popular short novel The book about Milutin, which was published in 1985 . Milutin, a Serbian peasant who is being mobilized for the Serbian army, hears of the murder of Franz Ferdinand and is less than impressed: 'It is easy to kill a prince and a woman, but a war is not won by killing a prince and a wife' he thinks, wondering why Serbian peasants have to pay for this, and who will help Serbia, while the country's soldiers are fighting for the South Slavs. ${ }^{23}$ Popović thus lets Milutin undermine the heroic interpretation of Gavrilo Pincip and his fellow conspirators, and then moves on to underline the meaninglessness of the war and Serbia's huge sacrifices. In essence, Popović and other authors questioned the legitimacy and prudence in creating the common Yugoslav state, while emphasizing the suffering of Serbia for the Yugoslav cause. They also emphasized the futility of

19 See for example Ivan Božić et al., Istorija Jugoslavije (Belgrade: Prosveta, 1973), 380-397; Fuad Slipičević, Opšta i nacionalna istorija. Udžbenik za podoficire - pitomce vojnih akademija JNA (Belgrade, Kultura, 1968), 234-235; Šarlota Đuranović and Mirko Žeželj, Prošlost i sadašnjost 3. Udžbenik za viII razred osnovne škole (Zagreb: Školska knjiga, 1974), 19. Husein Serdarević and Stanko Perazić Stanko, 8 Povijest. Udžbenik za vinI razred osnovne škole (Sarajevo, Svjetlost 1977), 14.

Vera Katz, "Ideological use of Inauguration of Memorial Plaque Dedicated to Gavrilo Princip in the Raising and Education of Young Generations in BiH," Prilozi 37(2014): 99-111.

21 Olga Manojlović Pintar, "Tradicije Prvog Svetskog Rata u Srbiji," in Kultura Sjećanja 1918, edited by Tihomir Cipek \& Olivera Milosavljević (Zagreb: Disput, 2007), 159-162. Jasna Dragović-Soso, "Saviours of the Nation". Serbia's Intellectual Opposition and the Revival of Nationalism (London: Hurst, 2002), 77 and 89-100.

23 Danko Popović, Knjiga o Milutinu (Belgrade: Niro “Književne Novine”, 1986), 6. 
that sacrifice, since a majority of the other Yugoslav peoples seemed ungrateful to Serbia for liberating them in the Great War. In doing so, they rejected the Yugoslav aspect of Serbian First World War memory and paved the way for a narrowly national Serbian war memory. ${ }^{24}$

After the collapse of the Yugoslav state in 1991 the perception of the First World War in Serbia became increasingly nationalized. The country was still represented as an innocent victim, heroically defending its freedom against insurmountable odds, while the creation of the Yugoslav state was regarded as more of a problem than a positive outcome of the war.

\section{Rejecting Presumed Accusations}

It was this well-established and very national Serbian First World War memory that Tomislav Nikolić was defending in his letters and speeches in 2013 and 2014. Yet, Nikolić specifically felt the need to emphasize that Serbia could not be held responsible for the outbreak of the war. While this was at least partly a reaction to Christopher Clark's book, it still seems puzzling that the president himself must repeatedly use this somehow vague argument. However, President Nikolić was in fact repeating a pattern of discourse that can be traced back throughout Serbian (and Yugoslav) First World War history writing. As Astrid Erll has pointed out, 'existing representations which circulate in a given society provide schemata for new experience and its representation'. ${ }^{25}$ This kind of premediated schemata was one of the reasons behind Nikolić' reaction.

Since the end of the Great War, it has been an integral part of the Yugoslav (and later Serbian) memory tradition to present the war in a way that could absolve the country of the responsibility for the outbreak of war. From the establishment of the Yugoslav state, the defence against possible accusations of war guilt has taken the form of attempts to separate what were presented as the 'causes of war' from the actual 'pretext for war', the latter being the Sarajevo assassination. This rhetorical move has served to underline Serbia's innocence and justify Serbia's actions. There is a clearly distinctive 'genealogy of remediation'26 of that argument within Serbia's First World War memory.

\footnotetext{
24 See also Aleksandar Pavković, "The Serb National Idea: A Revival 1986-92," Slavonic and East European Review 72, 3 (1994), 3, 451-453; Dragović-Soso, "Saviours of the Nation", 89-100.

25 Erll, "Remembering across Time, Space and Culture," 111.

26 Erll and Rigney, 'Introduction: Cultural Memory and its Dynamics', p. 5 .
} 
According to history books from the interwar period, the causes for the war were to be sought in Austria. One book, a history teaching manual for junior officers, simply declared that 'the causes to the war lay in the great hatred that Austria felt towards Serbia.'27 History textbooks for primary and secondary school suggested that Austria-Hungary was worried by Serbia's expansion in the Balkan wars, and that the Empire wanted to prevent any further strengthening of the Serbian state. ${ }^{28}$ According to one of Serbia's leading historians in the interwar period, Vladimir Ćorović, Austria-Hungary feared a united Balkans dominated by Russia. Therefore leading circles in Vienna found that the only medicine for everything would be just to break Serbia. ${ }^{29}$ Yet, Austria needed an excuse - or a pretext - for attacking, and that was the assassination of Franz Ferdinand, even though Serbia could not at all, according to the books, be held responsible for that. A primary school textbook stated that: 'one day in the year 1914, without any just cause, Austria-Hungary declared war on little Serbia. As at that time on Vidovdan in Sarajevo the Austro-Hungarian heir to the throne was murdered by a young Serb from Bosnia, Gavrilo Princip, it [the Empire] declared that Serbs from Serbia were involved in this. And that was the pretext to declare war on Serbia. ${ }^{30}$ A secondary school textbook simply writes: 'To find an excuse for war, Austria-Hungary accused Serbia for the murder of their heir to the throne.31 And Ćorović emphasized how Austria 'without any proper documentation' accused Serbia itself for the murder of Franz Ferdinand, though Serbia was not involved. ${ }^{32}$

In history books from Yugoslavia's socialist era, this division into causes and pretexts remained clearly visible. It is present in history textbooks printed shortly after the end of the Second World War and it has been continuously remediated in various forms since then. Yet, during the socialist period this defensive rhetoric was given a different and more Marxist approach. The textbooks first present the international situation prior to the outbreak of war, emphasizing the colonial crises, the ambitions of the imperialist powers, the arms race and the inevitability of war owing to the logic of capitalism. Finally, Princip's assassination of Franz Ferdinand is presented as a mere pretext for

27 Adamović, Istorija Jugoslovena za podoficire, 136.

28 Špoljar, Povijest Hrvata, Srba i Slovenca, 61; Kostić \& Ljujić, Istorija Jugoslovena, 42; Lazarević, Istorija jugoslovena, 175.

29 Ćorović, Istorija Jugoslovije, 609.

30 Kostić \& Ljujić, Istorija Jugoslovena, 42. See also Adamović, Istorija Jugoslovea za podoficire, 137; Špoljar, Povijest Hrvata, Srba i Slovenca, 61; Ćorović, Istorija Jugoslavije, 610.

31 Lazarević, Istorija jugoslovena, 175.

32 Ćorović, Istorija Jugoslovije, 6o9-610. 
Germany or Austria-Hungary to start a war. ${ }^{33}$ An example of this is evident in an eighth grade history book from 1984. After presenting the numerous crises pre 1914, the text continues:

... the war was inevitable and both sides were putting enormous sums into armaments. Germany was the leading party in this and was just waiting for an opportune pretext to launch the war. The assassination on the Austro-Hungarian heir to the throne on 28 June 1914 was exactly this kind of opportunity. ${ }^{34}$

History books by socialist Yugoslavia's great historians also follow this pattern. Vladimir Dedijer, communist veteran from the Second World War and author of the official biography of President Tito, as well as several studies of the murder of Franz Ferdinand, wrote in 1973: 'Claiming that the Sarajevo assassination was the basic or immediate cause for the war would be an exaggeration ... the opposition between the European Great Powers were so tense, the reorganization and arming of the German armies had already reached such a level that only the smallest excuse was needed for the beginning of the conflict.'35 And according to Branko Petranovićs three-volume standard work on Yugoslav history, a war party in Vienna wanted to 'settle accounts with Serbia' and 'the murder of Archduke Franz Ferdinand gave the war party a pretext for war ...'36

All these books about the First World War clearly made an effort to emphasize that the outbreak of the war should certainly not be seen as something for which Serbia could be held responsible, as if to pre-empt any potential accusation against Serbia. One book, published for the $75^{\text {th }}$ anniversary of the Battle of Kolubara, where the hard-pressed Serbian armies successfully repelled an Austrian attack in November and December 1914, explicitly pointed to such accusations:

immediately after the assassination of Franz Ferdinand in Sarajevo ... an indictment was prepared against Serbia and the Serbian nation as

33 See for instance: Vojna akademija jugoslovenske armije, Katedra vojne istorije: Opšta vojna istorija: tekst. Sv. 2, Prvi svetski rat (Belgrade: Štamparija Vojne akademije jugoslovenske armije, 1950), 3-5; Đuranović and Žeželj, Prošlost i sadašnjost 3, 9; Tomo Čubelić and Dragutin Pavličević, Povijest XX. Stoljeća - sa odabranim povijesnim tekstovima. Udžbenik za stručne škole (Zagreb: Školska knjiga 1975), 9; Serdarević and Perazić, 8 Povijest, 14; Slipičević, Opšta i nacionalna istorija, 234-235.

34 Stanko Perazić and Husein Serdarević, Istorija - Povijest. Udžbenik za viII razred osnovne škole (Sarajevo: Svjetlost, 1984), 7.

35 Božić et al., Istorija Jugoslavija, 374.

36 Branko Petranović, Istorija Jugoslavije 1918-1988. Prva Knjiga. Kraljevina Jugoslavije (Belgrade: Nolit, 1988), 7 . 
instigators of the war, and afterwards also the historical responsibility for the European (later called the World) War was loaded on their backs. Historical research has long ago established the actual responsibility for the war, but the old accusations, invented from the side of Serbia's enemies, are still talked about and appear to be fundamental. ${ }^{37}$

The authors remind their readers that a large amount of literature repeating these accusations is still present in the libraries and issue a warning: 'we must not forget that this was used as preparation for the attack on Yugoslavia in $1941 .{ }^{\prime 28}$ The authors thus underline how potentially dangerous such a war guilt could be, thereby actualizing the need to protect the Serbian version of First World War memory and to reject any possible blame.

These arguments were continuously remediated after the fall of Yugoslavia, still serving the purpose of removing the war guilt from Serbia. Almost all postYugoslav Serbian textbooks examined for this chapter repeat the pattern of those of the socialist period: On the first page(s) of the chapter on the Great War, a more or less detailed description of the world situation prior to 1914 is given, with an emphasis on the crises and conflicts of the Great Powers. A high school textbook from 2012 writes:

The causes of the outbreak of the First World War are to be found in the imperialist interests of the great European powers and their struggle for political and economic domination over the Old Continent at the end of the 19th and beginning of the 2oth Centuries. ${ }^{39}$

In this way, it is made explicitly clear that the Great Powers would have gone to war even if the assassination in Sarajevo had never happened. Thus, they largely copy the socialist argument, even though they do not use quite the same Marxist rhetoric anymore. ${ }^{40}$

37 Dušan T. Bataković and Nikola B. Popović, Kolubarska bitka (Belgrade: Biblioteka „Litera“, 1989), 5 .

38 Ibid.

39 Đorđe Đurić and Momčilo Pavlović, Istorija - za treći razred gimnazije prirodnomatematičkog smera i četvrti razred opšteg i društveno-jezičkog smera (Belgrade, Zavod za udžbenike, 2012), 72. See also Mira Radojević, Istorija - za treći razred gimnazije prirodnomatematičkog smera i četvrti razred opšteg i društveno-jezičkog smera i opsteg tipa i četvrti razred srednje stručne škole za obrazovne profile pravni tehničar i birotehničar (Belgrade: Klett, 2014), 86.

40 Only two of the textbooks do not fit this frame neatly: they place the cause of the war in the rivalry between Austria-Hungary and Serbia from 1903 to 1914 and the unresolved national questions of the Dual Monarchy, as well as Serbia's perceived desire to expand 
Just like in the Yugoslav period, the assassination itself is presented as a 'pretext for war'. Sometimes this is clear from the text itself while in other textbooks it is done in a headline that frames the understanding of the text in advance. ${ }^{41}$ Several textbooks also emphasize that Serbia had nothing to do with the assassination and therefore the Austro-Hungarian ultimatum was unreasonable. Clearly casting Serbia in the role of the victim, a high school textbook from 2012 states: 'Although the Serbian government was not responsible for the Sarajevo assassination, war circles in Vienna immediately launched a campaign, which accused the official Serbia of carrying it out. They reasoned that a war should be waged against a manifold weaker Serbia to defeat and humiliate it militarily.'42

The question of war guilt was thus being answered in a very uniform manner in Serbia. The fact that all textbooks use the same language, pointing to 'cause' versus 'pretext' when describing the run up to the war and that all have the same basic argumentative structure in their chapters on the Great War is indicative of a broader and strongly premediated memory tradition. Indeed, this had been the language and argumentative structure of Serbia's First World War memory scheme for nearly a century by the time Christopher Clark's book shook the Serbian public opinion and prompted President Nikolić to react.

\section{Clark and Nikolić}

Christopher Clark wrote in The Sleepwalkers that 'Since Srebrenica and the siege of Sarajevo, it has become harder to think of Serbia as the mere object or victim of great power politics and easier to conceive of Serbian nationalism as

its territory to include all lands in which Serbs or South Slavs lived. It should be noted that these two textbooks, although published a few years apart and for different audiences, were written by the same pair of authors, making their view all the more a minority one among the authors of modern textbooks in Serbia. There is no question of the authors implying Serbian responsibility for the war itself. Rather, the text should probably be understood as an indictment of Austro-Hungarian aggression against Serbia. See Radoš Ljušić and Ljubodrag Dimić, Istorija 8 - udžbenik za osmi razred osnovne škole sa čitankom i radnom sveskom (Belgrade: Freska, 2012), 72 ; Radoš Ljušić and Ljubodrag Dimić, Istorija - za treći razred gimnazije prirodno-matematičkog smera i četvrti razred opšteg i društvenojezičkog smera (Belgrade: Freska, 2014), 64.

41 Radojević, Istorija - za treći razred gimnazije, 86-87.

42 Đurić and Pavlović, Istorija - za treći razred gimnazije, 73. See also: Predrag M. Bajagić and Stošić, Nenad, Istorija 8 - udžbenik za osmi razred osnovne škole (Belgrade: Klett, 2011), 74; Predrag Simić and Ivana Petrović, Istorija 8 - udžbenik za osmi razred osnovne škole sa tematskim istorijskim atlasom (Belgrade: Logos, 2016), 62. 
an historical force in its own right ... Putting Sarajevo and the Balkans back at the centre of the story does not mean demonizing the Serbs or their statesmen, nor does it dispense us from the obligation to understand the forces working on and in those Serbian politicians, officers and activists whose behaviour and decisions helped to determine what kind of consequences the shooting at Sarajevo would have.43 Thus, he certainly pointed towards Serbia in his attempt to explain the outbreak of the First World War, suggesting that both the assassins and Serbia's politicians were at least partly responsible. Moreover, Clark explicitly argued that for Austria-Hungary 'the Sarajevo murders were not a pretext for a pre-existing policy of invasion and warfare. They were a transformative event, charged with real and symbolic menace. ${ }^{44}$ Knowingly or not, Clark thus directly rejected the essential elements of Serbia's narrative of innocence, which was based on the claim that the assassination was exactly not a cause, but a mere pretext. Furthermore, Clark suggested that Serbia's heroic fighting and status as belonging within the victorious camp of the Entente had somehow prevented Western historians from looking seriously at Serbia's role in the crisis that led to the First World War, and only the infamous events during the Yugoslav wars 1991-1995 had enabled them to look critically at Serbian nationalism. While he refused to ascribe guilt to any one side, but rather located parts of the guilt with every major player in the crisis, ${ }^{45}$ Clark could hardly have made a more direct attack on Serbian First World War memory and Serbian nationalism.

In Serbia, Clark's book was met with a response which far surpassed that of any other country. Not surprisingly, this was primarily a reaction to the parts of The Sleepwalkers that concentrated on Serbia's role in both the Sarajevo assassination and in the breakout of war in general. While these analyses and conclusions were considered the methodologically and theoretically weakest parts of the book, Serbian academic circles denounced the whole study as unscientific and lacking scholarly weight, while Serbian pundits and politicians regarded the work as not only lacking in merit, but as an attack on Serbia and its sacrifices during the Great War. ${ }^{46}$

Yet, the most clear and elaborate public reaction to the arguments in Clark's The Sleepwalkers came from Serbia's president, Tomislav Nikolić. Indeed, as was

43 Christopher Clark, The Sleepwalkers. How Europe Went to War in 1914 (London: Penguin 2013), xxvi-xxvii. The book was first published by Allen Lane in 2012. It was published in Serbian in 2013 .

44 Clark, The Sleepwalkers, 559.

45 Ibid, $560-561$.

46 See for instance: Danilo Šarenac, "O knjizi Mesečari. Kako je Evropa ušla u rat 1914, profesora Kristofera Klarka," Vojnoistorijski glasnik (2013), 1: 267-280 ; Milica Jovanović, "Sukob oko velikog rata," Peščanik 10 November 2013, accessed 10 November 2016, http://pescanik. net/sukob-oko-velikog-rata/. 
already obvious from his open letter to the newspaper Politika in November 2013, Nikolić had casted himself as defender of Serbia's First World War memory. ${ }^{47}$ On 10 November 2013, just before Armistice Day, Nikolić was also present at the reburial of Serbia's famous female First World War veteran, Milunka Savić, in Belgrade. Having briefly described Savić's life and praised her courage in the Second Balkan War and the First World War, the President compared the heroine to Serbia, as being both thoroughly good, but unappreciated and misunderstood: 'Milunka Savić so resembles her country. Courageous when needed, invincible and upright, ready to help everyone, but again pushed aside when others think that she might get in the way, being so great and strong.' Indeed, according to Nikolić, Savić was a 'symbol of Serbia's struggle for freedom."48 Thus, in Nikolićs narrative, Serbia's war history was, like Savić's, pure, brave and righteous.

In June 2014, just before the centenary, the Serbian Academy for Science and Arts (SANU) organized a conference on 'Serbs and the First World War'. Speaking as a guest of honour, Nikolić summarized the significance of that war for Serbia: 'A small, brave, country entered into a just fight for freedom, by the Grace of God it achieved victories, survived a Golgotha and, like Nathalie's ramonde under a drop of rain, it rose from the ashes and was revived' 49 This is a distilled version of the official Serbian representation of the First World War and as such it is not in any way surprising to find it repeated in the Presidential address. But the real aim of Nikolićs speech was not to repeat the official Serbian narrative, but rather to reaffirm and defend it against a perceived new threat. According to Nikolić, Serbs were confronted with an 'attempt at falsification of history in relation to the causes of the breakout of the First World War'. This falsification was driven by 'individuals from the echelon of the powerful' who would 'take facts out of context, twist them, alter their meaning, dress them in a new attire and give them a new look whereby a lie will become a globally accepted truth'.50 And, Nikolić continued, this attempt at a historical revision was mainly

47 Nikolić, "budimo dostojni junačke prošlosti”.

48 "Govor Predsednika Republika na ukopu posmrtnih ostataka M. Savić u Aleji Velikana," Belgrade, 10 November 2013 (A print of the speech was kindly supplied at request from the press centre at the office of the President of the Republic of Serbia). See also E.V.N., "Milunka Savić: Nepobediva kao Srbija," Večernje novosti, 10 November 2013, accessed 10 October 2016, http://www.novosti.rs/vesti/naslovna/drustvo/aktuelno.29o.html:463025-Milunka-SavicNepobediva-kao-Srbija;"NikolićoheroiniMilunkiSavić;Njenživotjekaopričaizholivudskog filma," Blic, 10 November 2013, accessed 10 October 2016, http://www.blic.rs/vesti/drustvo/ nikolic-o-heroini-milunki-savic-njen-zivot-je-kao-prica-iz-holivudskog-filma/sonfi5y.

"Govor Predsednika Republike, sANU - Veliki Rat". Nathalie's ramonde, or Ramonda Nathaliae is a small purple flower named after Serbia's queen Natalija. It grows in the South of Serbia. Since 2012 it has been a symbol of Serbia's Armistice Day. Ibid. 
aimed at Serbia: 'The Serb struggle for freedom, which has for an entire century been a worldwide symbol of the fight for justice and truth, a great deed, is now to be dragged through the mud.' The aim of this revision, according to Nikolić, was 'to make the world believe that Serbs caused a war, which took 10,000.00o lives'. Later in his speech, President Nikolić pointed specifically to the work of Christopher Clark as the primary source of this revisionism:

'In his book, Professor Clark describes the Great Powers of the time as sleepwalkers who staggered into war, though they in fact did not wish that ... Clark even connects the assassination in Sarajevo with the crime in Srebrenica in 1995, and because of that he says it is difficult for him to see Serbia as a victim! Luckily, there is a minimal number of such extremes within science or, rather, quasi science. Nobody, and really nobody serious, accuses Serbia of being the cause of the Great War ... Serbia entered the war to survive. It entered the war because there was no alternative. ${ }^{51}$

The fact that a scholarly work is interpreted as an attack on a sovereign country is to an extent puzzling and requires further examination. The first point to note here is that President Nikolić seemingly does not understand the nature of historical research. In his speech he states that 'After the publication of the book by the famous German historian, Fritz Fischer, it was believed that the question of war guilt was finally solved. ${ }^{52}$ It seems that Nikolic does not quite understand that historical questions - especially more complex ones such as the causes of the Great War - are rarely answered once and for all and that, for this reason, it is to be expected that historians will use an opportunity like the Centennial to once more bring up this theme.

The outrage levelled against Clark's work does not seem to have the character of a mere historical argument. The emotional appeals in Nikolić's reaction are very much about the present: he talks about lies and falsifications that take place in the current moment, and he fears that Serbia's great sacrifices are now to be 'dragged through the mud'. Clark's own rather un-historical connection between the Srebrenica massacre and Serbia's role in the events leading up to the First World War obviously touches a sore point and makes his argument even more unacceptable to Nikolić, who represents a state that still finds it difficult to recognize that massacre and admit to Serbia's co-responsibility for it, and the role that Serbian forces played in it. This makes Clark's parallel particularly problematic, as it constitutes a double accusation against Serbian nationalism,

$\begin{array}{ll}5^{1} & \text { Ibid. } \\ 5^{2} & \text { Ibid. }\end{array}$


both of which Nikolić denies. What really provokes Nikolić is the suggestion that, because of Srebrenica, Serbian nationalism is no longer innocent, and thus Serbia's status as a righteous victim in the First World War is threatened.

It is unlikely that a President would address this topic if it were relevant to historians only. Indeed, Nikolić's speech was not an isolated act: in the run up to the centennial, numerous Serbian articles, op-eds etc. dealt with the issue of the outbreak of war in general and Clark's book in particular. By and large this media campaign expressed the same views as the President in his speech to members of SANU. ${ }^{53}$ Nikolićs speech thus seems to reflect and protect a dominant and widespread presentation of the Great War in Serbia. However, this does not necessarily explain why a president would chose to throw himself into the fray like Nikolić does. One explanation, suggested by the historian Dubravka Stojanović, is that the speech itself and the general debate on the war in Serbia was instrumentalized by the political elites in order to distract the populace from unpopular reforms and a faltering economy by whipping up nationalist frenzy. This would, furthermore, have the effect of signalling to nationalists in Serbia that the pro-EU course of the state was only a necessary evil while the real ambitions of Serbia were rooted in the nationalist framework and its history. ${ }^{54}$ One argument in favour of this explanation is that the First World War as a contested topic seemingly disappeared as soon as the main festivities and ceremonies were over.

53 E.g.: Zoran Radisavljević, "Gavrilo Princip je pucao u okupatora," Politika 20 September 2013, accessed 14 November 2016, http://www.politika.rs/scc/clanak/270687/GavriloPrincip-je-pucao-u-okupatora; D. Stanisić, "Kusturica: Gavrilo Princip je branio ideju slobode,", Politika 5 December 2013, accessed 14 November 2016, http://www.politika.rs/ sr/clanak/277735/Kusturica-Gavrilo-Princip-je-branio-ideju-slobode; Gradimir Aničić, "Princip nije fanatik", Politika, 10 June 2014, accessed 14 November 2016, http://www.politika.rs/sr/clanak/296051/принцип-није-фанатик.; Aleksandar Nikolić, "Srđan Koljević: Svakoj generaciji treba Princip," Blic, 29 June 2014, accessed 14 November 2016, http:// www.blic.rs/vesti/tema-dana/srdan-koljevic-svakoj-generaciji-treba-princip/sptvesc; Tatjana Nježić, "Legenda Gavrilo: Poznati srpski pisci odgovaraju na pitanje ko je bio Princip," Blic, 29 June accessed 14 November 2016, http://www.blic.rs/kultura/vesti/legenda-gavrilo-poznati-srpski-pisci-odgovaraju-na-pitanje-ko-je-bio-princip/4vn35xp; Miljana Leskovac, "Princip nije kriv za rat", Blic, 1 June 2014, accessed 14 November 2016, http://www .blic.rs/vesti/drustvo/princip-nije-kriv-za-rat/5cvjtmt; Tanjug, "Dodik: Rs ne pristaje na politizaciju Prvog svetskog rata”, Blic, 11 June 2014, accessed 14 November 2016, http://www .blic.rs/vesti/politika/dodik-rs-ne-pristaje-na-politizaciju-prvog-svetskog-rata/g813qso.

"Ljudi iz šume," Interview with Dubravka Stojanović, Peščanik, 29 November 2013, accessed 14 November 2016 http://pescanik.net/ljudi-iz-sume/, and "Mitski rat," Interview with Dubravka Stojanović, Peščanik, 27 June 2014, accessed 14 November 2016 http://pescanik.net/emisija-27-06-2014/. 
However, this functional understanding does not quite explain why Nikolić and other parts of the Serbian public reacted so strongly to Clark's rethinking of the causes for the First World War, or indeed, why the First World War as such could become such a vital topic. Why this particular history? As has been shown in this chapter, the First World War is a well-established and very present memory in Serbia. The heroic and tragic narrative of Serbia's First World War is well known and certainly has the potential to be emotionally affective. Moreover, through the century that has passed since the war, Serbian (and Yugoslav) narratives have consequently rejected that Serbia could in any way be held responsible for the war's outbreak. And while Princip and his fellow assassins have been presented as heroes, their deed has never been accepted as a cause for the war; it was, in the Serbian phrase, only a pretext. Yet, Princip's heroic status is seemingly less important than Serbia's status as an innocent and heroic victim of the war. Indeed, given the catastrophic consequences of the First World War for Serbia, with the loss of about one quarter of the country's population, it would seriously question the legitimacy of Serbian nationalism and nationalist politics if exactly that nationalism were to be seen as the main cause of that war. Thus, Nikolic confirms the established narrative that Serbia was forced into the war, and thus he defends its status as an innocent victim of Great Power politics. As such, his reaction was highly premediated; indeed he repeated an argumentative scheme that was established in the interwar period and has been remediated in Serbian and Yugoslav history books ever since.

The repeated rejection that Serbia in any way could be held responsible for the outbreak of the war inevitably had the effect of suggesting that such an accusation could indeed be made. The defensive discourse created the understanding that there was a need for Serbia to defend itself. Thus, it actualized the memory of the First World War as something that had to be protected, rendering it with certain urgency. Indeed, President Nikolić's reaction to Clark's book did have the appearance of an urgent need to protect Serbia's national memory. Moreover, the established memory narrative portrays the victory in the First World War as decisive for Serbia's existence; in Nikolićs rhetoric it was an unavoidable Golgotha of the Serbian nation, a war that Serbia entered to survive. Thus, it is the memory of a fatal and definitive event that Nikolić had taken upon himself to defend.

\section{Conclusion}

The existence of Serbia's strong tradition of First World War memory and the pervasiveness of the 'anti-war guilt rhetoric' help explain the need of Nikolić 
and other parts of Serbia's elites to react strongly to Clark's shifting of the responsibility from Germany towards Serbia. Not only was he thereby challenging the established truth on the war in Serbia; he was also adding new weight to an idea that - however unspoken - has always been present in the textbooks: namely that Serbia will always be thought of as potentially responsible for the outbreak of the war. The defensive argument is necessary to disprove such accusations.

In his speeches and statements in the run-up to the centenary of the First World War, Serbia's President Nikolić clearly confirmed and remediated a wellestablished narrative and argumentative scheme of Serbian First World War memory. Yet, his statements were also clearly a reaction to the publication of Christopher Clark's rethinking of the causes to the First World War, and as such Nikolićs speeches and letters are probably the most public and political reception of Clark's book. Nikolić's response was highly premediated; in essence he was repeating the defensive arguments that had been present in Serbian and Yugoslav history books for nearly a century. Apparently, Nikolić perceived Clark's argument as if he was stating the accusations that the Serbian tradition had been rejecting since the end of the First World War. Indeed, the fact that Clark's book fitted so neatly into the fears and argumentative patterns of Serbia's First World War memory was probably the main reason why it attracted so much attention in Serbia.

\section{Bibliography}

Adamović, Dragan M. Istorija Jugoslovena za podoficire. Zagreb: Merkantile, 1938.

Aničić, Gradimir. "Princip nije fanatik." Politika, 10 June 2014. Accessed 14 November 2016. http://www.politika.rs/sr/clanak/296051/принцип-није-фанатик.

Bajagić, Predrag M. and Nenad Stošić. Istorija 8-udžbenik za osmi razred osnovne škole. Belgrade: Klett, 2011.

Bataković, Dušan T. and Nikola B. Popović. Kolubarska bitka. Belgrade: Biblioteka, Litera, 1989.

Bazdulj, Muharem and Nebojsa Grujičić, eds. Stogodišnji rat. Sarajevski atentat $i$ tumačenja. Beograd: Vreme, 2014.

Bonnell, Andrew G. "New Histories of the Origins of the First World War: What happened to the 'Primacy of Domestic Politics'?" Australian Journal of Politics and History, 61, 1 (2015): 121-127.

Božić, Ivan et al. Istorija Jugoslavije. Belgrade: Prosveta, 1973.

Clark, Christopher. The Sleepwalkers. How Europe Went to War in 1914. London: Penguin 2013. 
Ćorović, Vladimir. Istorija Jugoslavije. Belgrade: Narodno Delo, 1933.

Čubelić, Tomo and Dragutin Pavličević. Povijest XX. Stoljeća - sa odabranim povijesnim tekstovima. Udžbenik za stručne škole. Zagreb: Školska knjiga 1975.

Dedović, Ismar and Tea Sindbæk Andersen. "To Battle, go forth all heroes'. World War I Memory as a Narrative Template in Yugoslavia and Serbia." In Re-visting World War I. Interpretations and Perspectives of the Great Conflict, edited by Jaroslaw Suchoples and Stephane James, 247-270. Frankfurt am Main: Peter Lang, 2016.

Dragović-Soso, Jasna. "Saviours of the Nation". Serbia's Intellectual Opposition and the Revival of Nationalism. London: Hurst, 2002.

Đuranović, Šarlota and Mirko Žeželj. Prošlost i sadašnjost 3. Udžbenik za VIII razred osnovne škole. Zagreb: Školska knjiga, 1974.

Đurić, Đorđe and Momčilo Pavlović, Istorija - za treći razred gimnazije prirodnomatematičkog smera $i$ četvrti razred opšteg $i$ društveno-jezičkog smera. Belgrade, Zavod za udžbenike, 2012.

Erll, Astrid. "Remembering across Time, Space and Culture: Premediation, Remediation and the 'Indian Mutiny." In Mediation, Remediation and the Dynamic of Cultural Memory, edited by Astrid Erll and Ann Rigney, 109-138. Berlin: De Gruyter, 2009.

Erll, Astrid. "Cultural Memory Studies: An introduction." In A Companion to Cultural Memory Studies, edited by Astrid Erll and Ansgar Nünning, 1-15. Berlin/New York: De Gruyter, 2010.

Erll, Astrid and Ann Rigney. "Introduction: Cultural Memory and its Dynamics." In $M e-$ diation, Remediation and the Dynamic of Cultural Memory, edited by Astrid Erll and Ann Rigney, 1-11. Berlin/New York: De Gruyter, 2009.

E.V.N. "Milunka Savić: Nepobediva kao Srbija." Večernje novosti, 10 November 2013. Accessed 10 October 2016. http://www.novosti.rs/vesti/naslovna/drustvo/aktuelno.29o.html:463025-Milunka-Savic-Nepobediva-kao-Srbija.

"Govor Predsednika Republika na ukopu posmrtnih ostataka M. Savić u Aleji Velikana," Belgrade, 10 November 2013 (A print of the speech was kindly supplied at request from the press centre at the office of the President of the Republic of Serbia).

"Govor Predsednika Republike, SANU - Veliki Rat. 13 June 2014." (A print of the speech was kindly supplied at request from the press centre at the office of the President of the Republic of Serbia).

Harrington, Selma. "The Politics of Memory: The Face and the Place of the Sarajevo Assassination." Prilozi 43 (2014):113-139.

Ignjatović, Aleksandar. "From Constructed Memory to Imagined National Tradition: The Tomb of the Unknown Yugoslav Soldier (1934-38)." Slavonic and East European Review 88, 4 2010: 624-651.

Joll, James and Garton Martel. The Origins of the First World War. 3rd edition. London: Routledge 2007.

Jovanović, Milica. "Sukob oko velikog rata." Peščanik, 10 November 2013. Accessed 10 November 2016. http://pescanik.net/sukob-oko-velikog-rata/. 
Katz, Vera. "Ideological use of Inauguration of Memorial Plaque Dedicated to Gavrilo Princip in the Raising and Education of Young Generations in BiH." Prilozi 37 (2014): 99-111.

Kennan, George. The Decline of Bismarck's European Order. Franco-Russian relations, 1875-189o. Pinceton: Princeton University Press, 1979.

Kostić, Milan A. and Mat P. Ljujić. Istorija Jugoslovena (Srba, Hrvata i Slovenaca) sa učenike III razreda osnovnih škola u Kraljevini Jugoslaviji. Belgrade: Knjižarnice Milorada P. Mihailovića, 1939.

Lampe, John R. Yugoslavia as History. Twice there was a country. Cambridge: Cambridge University Press, 2000.

Leskovac, Miljana. "Princip nije kriv za rat." Blic, 1 June 2014. Accessed 14 November 2016. http://www.blic.rs/vesti/drustvo/princip-nije-kriv-za-rat/5cvjtmt.

"Ljudi iz šume," Interview with Dubravka Stojanović. Peščanik, 29 November 2013. Accessed 14 November 2016. http://pescanik.net/ljudi-iz-sume/.

Ljušić, Radoš and Ljubodrag Dimić. Istorija 8 - udžbenik za osmi razred osnovne škole sa čitankom i radnom sveskom. Belgrade: Freska, 2012.

Ljušić, Radoš and Ljubodrag Dimić. Istorija - za treći razred gimnazije prirodnomatematičkog smera i četvrti razred opšteg i društveno-jezičkog smera. Belgrade: Freska, 2014.

Manojlović Pintar, Olga. “Tradicije Prvog Svetskog Rata u Srbiji.” In Kultura Sjećanja 1918, edited by Tihomir Cipek and Olivera Milosavljević, 155-167. Zagreb: Disput, 2007 .

Manojlović Pintar, Olga. Arheologija sećanje. Spomenici i identiteti i Srbiji 1918-1989. Belgrade: Čigoja, 2014.

Miller, Paul B. "Compromising Memory: The Site of the Sarajevo Assassination." Meeting Report 333, Woodrow Wilson Centre, EEs Noon Discussion, Sarajevo, 10 January 2007. Accessed 14 November 2016. https://www.wilsoncenter.org/ publication/333-compromising-memory-the-site-the-sarajevo-assassination.

Mitrović, Andrej. Serbia's Great War. London: Hurst, 2007.

"Mitski rat," Interview with Dubravka Stojanović. Peščanik, 27 June 2014. Accessed 14 November 2016. http://pescanik.net/emisija-27-06-2014/.

Mosse, George L. Fallen Soldiers. Reshaping the Memory of the World Wars. Oxford: Oxford University Press, 1990.

Mulligan, William. "Review-Article: The Trail Continues: New directions in the Study of the Origins of the First World War." English Historical Review 129, 538 (2014): $639-666$.

Newman, John Paul. "Allied Yugoslavia: Serbian Great War Veterans and their Internationalist Ties." In The Great War and Veterans' Internationalism, edited by Julia Eichernberg and John Paul Newman, 97-117. Basingstoke: Palgrave Macmillan, 2013.

Newman, John Paul. Yugoslavia in the Shadow of War. Veterans and the limits of State Building 1903-1945. Cambridge: Cambridge University Press, 2015. 
Nikolić, Aleksandar. "Srđan Koljević: Svakoj generaciji treba Princip." Blic, 29 June 2014. Accessed 14 November 2016. http://www.blic.rs/vesti/tema-dana/ srdan-koljevic-svakoj-generaciji-treba-princip/sptvesc.

"Nikolić o heroini Milunki Savić; Njen život je kao priča iz holivudskog filma." Blic, 10 November 2013. Accessed 10 October 2016. http://www.blic.rs/vesti/drustvo/ nikolic-o-heroini-milunki-savic-njen-zivot-je-kao-prica-iz-holivudskog-filma/ sonfi5y.

Nikolić, Tomislav. "budimo dostojni junačke prošlosti." Politika, 10 November 2013. Accessed 15 September 2016. http://www.politika.rs/sr/clanak/275423/ Budimo-dostojni-junacke-proslosti.

Nježić, Tatjana. "Legenda Gavrilo: Poznati srpski pisci odgovaraju na pitanje ko je bio Princip." Blic, 29 June. Accessed 14 November 2016. http://www.blic.rs/kultura/vesti/legenda-gavrilo-poznati-srpski-pisci-odgovaraju-na-pitanje-ko-je-bioprincip/4vn35xp.

Nora, Pierre. "Between Memory and History: Les Lieux de Mémoire." Representations, 26 (1989): 7-24.

Pavković, Aleksandar. "The Serb National Idea: A Revival 1986-92." Slavonic and East European Review, 72, 3 (1994): 440-455.

Pavlowitch, Stevan K. Serbia. The History behind the Name. London: Hurst, 2002.

Perazić, Stanko and Husein Serdarević. Istorija- Povijest. Udžbenik za VIII razred osnovne škole. Sarajevo; Svjetlost, 1984.

Petranović, Branko. Istorija Jugoslavije 1918-1988. Prva Knjiga. Kraljevina Jugoslavije. Belgrade: Nolit, 1988.

Popović, Danko. Knjiga o Milutinu. Belgrade: Niro “Književne Novine”, 1986.

Radisavljević, Zoran. "Gavrilo Princip je pucao u okupatora." Politika 20 September 2013. Accessed 14 November 2016. http://www.politika.rs/scc/clanak/270687/ Gavrilo-Princip-je-pucao-u-okupatora.

Radojević, Mira. Istorija - za treći razred gimnazije prirodno-matematičkog smera $i$ četvrti razred opšteg i društveno-jezičkog smera i opsteg tipa i četvrti razred srednje stručne škole za obrazovne profile pravni tehničar i birotehničar. Belgrade: Klett, 2014.

Rigney, Ann. "Plenitude, scarcity and the circulation of cultural memory." Journal of European Studies 35, 1 (2005): 11-28.

Šarenac, Danilo. "O knjizi Mesečari. Kako je Evropa ušla u rat 1914, profesora Kristofera Klarka.” Vojnoistorijski glasnik (2013), 1: 267-280.

Šarenac, Danilo. Top, Vojnik i Sećanje, Prvi Svetski Rat i Srbija 1914-20oo. Belgrade: Institut za savremenu istorju, 2014.

Serdarević, Husein and Stanko Perazić Stanko. 8 Povijest. Udžbenik za VIII razred osnovne škole, Sarajevo, Svjetlost 1977.

Simić, Predrag and Ivana Petrović. Istorija 8 - udžbenik za osmi razred osnovne škole sa tematskim istorijskim atlasom. Belgrade: Logos, 2016. 
Slipičević, Fuad. Opšta i nacionalna istorija. Udžbenik za podoficire - pitomce vojnih akademija JNA. Belgrade: Kultura, 1968.

Špoljar, Z. Povijest Hrvata, Srba i Slovenca za mladež nar. Osnovnih škola. Zagreb: Vlastita Naklada, 1927.

Stanisić, D. “Kusturica: Gavrilo Princip je branio ideju slobode.” Politika 5 December 2013. Accessed 14 November 2016. http://www.politika.rs/sr/clanak/277735/KusturicaGavrilo-Princip-je-branio-ideju-slobode.

Strachan, Hew. "Review article: The origins of the First World War." International Affairs, 90, 2 (2014): 429-439.

Tanjug. "Dodik: Rs ne pristaje na politizaciju Prvog svetskog rata." Blic, 11 June 2014. Accessed 14 November 2016. http://www.blic.rs/vesti/politika/dodik-rs-ne-pristajena-politizaciju-prvog-svetskog-rata/g813qso.

Vojna akademija jugoslovenske armije, Katedra vojne istorije: Opšta vojna istorija: tekst. Sv. 2, Prvi svetski rat. Belgrade: Štamparija Vojne akademije jugoslovenske armije, 1950.

Winter, Jay. Sites of Memory, Sites of Mourning. The Great War in European Cultural History. Cambridge: Cambridge University Press, 1995. 


\title{
Beyond Local Memories: Exhumations of Francoism's Victims as Counter-discourse during the Spanish Transition to Democracy
}

\author{
Zoé de Kerangat
}

The Spanish Civil War started in July 1936, when military generals conducted a coup against the Second Republic. As they failed to conquer the entire territory, the coup unfolded into the Civil War. At the start of the war, repression against civilians was dreadful. In the areas that remained loyal to the Republic, uncontrolled groups of people killed members of the clergy and landowners who were seen as exploiting the labour force. In the areas that had turned against the Republic, instructions were given to the population by rebel generals to violently repress anyone who was suspected of supporting the Republic or being left-wing. The objective was to erase the roots of the left completely. The number of civilian victims is still debated, but it is estimated that almost 60,000 were killed on the rebel side, and more than 100,000 on the side that was loyal with the Republic. ${ }^{1}$ A great proportion of those crimes took place in the first months of the war. When the Second Republic recovered control after an initial period of confusion, illegal repression against the conservatives virtually stopped and the executions became part of processes of justice. The rebels' repression continued throughout the war and the first years of dictatorship, although to a lesser extent than in the first months of the Civil War. General Francisco Franco soon became the leader of the rebel side. In April 1939, when the war ended with the Francoist victory, he became the head of the dictatorship. Most of the dead on the Francoist side were exhumed and honored directly after the end of the war, as part of the construction of the Francoist rhetoric of martyrdom. ${ }^{2}$ However, the thousands of victims of Francoism were left buried in unmarked mass graves across the Spanish territory. These mass

1 Julián Casanova, España Partida En Dos: Breve Historia de La Guerra Civil Española (Barcelona: Crítica, 2013).

2 Zira Box, España Año Cero. La Construcción Simbólica Del Franquismo (Madrid: Alianza, 2010). 
graves were part of what has been called the 'topography of terror,, ${ }^{3}$ acting as an instigator of fear in society, by reminding people about the consequences of opposing the Francoist regime.

Dictator Franco died while he was still in power in 1975. Soon after his death, the period of transition to democracy started. It was a very intense period in terms of institutional and political negotiations, but also a period of conflict, fear and uncertainty. As democracy developed, a tacit agreement among politicians was reached in order for the transition to be smooth. An amnesty law was passed in 1977, freeing the political prisoners jailed by the Francoist authorities, but also preventing the Francoist perpetrators from being prosecuted. Under the so-called 'Pact of Silence', there would be no mention of the victims of Francoist repression. Paloma Aguilar defines the 'Pact of Silence' as a 'tacit agreement during the transition to silence the crimes of the Civil War and Francoist repression'. ${ }^{4}$ In this sense, silence was intentional. However, the 'Pact of Silence' was in fact limited to the institutional sphere and not a real social agreement. What is more, according to Aguilar, ${ }^{5}$ the memory of the Civil War was indeed highly present in the sense that most Spanish people thought a new armed conflict was possible at the time. Thus, the argument not to bring the history of the repression into debate was in fact triggered by the very memory of the Civil War. The Spanish society wanted to avoid a new conflict at all costs, and - according to the discourse of consensus - to maintain peace, it was necessary to avoid looking back. The new dominant discourse of national reconciliation was hence based on intentional 'oblivion'. What was not possible, under the 'Pact of Silence', was to use the recent history of violence and demands of justice for the repressed as political leverage in the new Spanish democracy. Political actors such as the Socialists and Communists, illegal and repressed during the dictatorship, were allowed to come back from exile or clandestinity, under the condition that they would abide by this unwritten rule. Nevertheless, the limit of what was allowed was not clearly stated. As the nature of the so-called pact was tacit it was rather a try - and - see process. ${ }^{6} \mathrm{As}$

3 Francisco Ferrándiz, El Pasado Bajo Tierra: Exhumaciones Contemporáneas de La Guerra Civil (Barcelona: Anthropos, 2014), 192.

4 Paloma Aguilar, "Justice, Politics and Memory in the Spanish Transition," in The Politics of Memory. Transitional Justice in Democratizing Societies, ed. Alexandra Barahona de Brito, Carmen González Enríquez, and Paloma Aguilar (Oxford: Oxford University Press, 2008), 92-118.

5 Paloma Aguilar, Políticas de La Memoria YMemorias de La Política: El Caso Español En Perspectiva Comparada (Madrid: Alianza, 2008), 250-303.

6 Lidia Mateo Leivas and the author are currently publishing an article entitled "The limits of remembrance during the Spanish Transition: Questioning the "Pact of Oblivion" through the 
we will see in the following, in some places the recovery of the memory of the victims of Francoism went further than in others - because of the restrictions some people were faced with or the audacity some showed - and it is necessary to make the difference between what happened at State level and the local actions and initiatives across Spain.

As a result of the 'Pact of Silence', the institutional initiatives regarding reparations to the victims of past violence remained limited to the pension law of 1979. The law gave the widow/ers and children of people who died during the Civil War the right to receive a pension. This meant that the dead on the Republican side were now also taken into consideration. In order to claim the pension, the widows or relatives had to show proof of the death of their relative under the conditions contemplated by the law. ${ }^{7}$ Exhuming the remains, in some cases, was a way to produce or induce the pieces of evidence and testimonies necessary to get a death certificate, although indirectly, as no forensic identification or certification of death was issued at the time. The pension law was not the direct trigger for the exhumations of the late 70 and early $80 \mathrm{os}-$ many in fact took place before - but as the only institutional policy to deal with reparations, it is definitely a significant element to take into account.

This chapter studies the wave of mass grave openings in the late 1970s and early 1980s. The interest for this topic emerges from the realization that many exhumations in fact took place before the 'boom', starting in 2000. ${ }^{8}$ Indeed, when some of the graves were opened in the 21st century, parts of the bodies were missing, meaning that the grave had been opened before and that someone had taken the remains. On the other hand, the higher media impact of the 21st-century exhumations meant that an increasing number of people came forward to tell their story of the Civil War and of the repression, including people who had taken the initiative to exhume some of the graves decades ago. It is time to look into these exhumations as it is important to acknowledge them as one of the phases of mass grave openings since the Civil War.

analysis of a censored film and a mass grave exhumation" about the containment of memory during the Spanish Transition, in which we analyze two examples of what was allowed in terms of memory initiatives at the time.

7 "Real Decreto 2635/1979, de 16 de Noviembre, Para La Aplicación Y Cumplimiento de La Ley 5/1979, de 18 de Septiembre, Sobre Concesión de Derechos a Los Familiares de Los Españoles Fallecidos Como Consecuencia O Con Ocasión de La Pasada Guerra Civil," 16 November 1979, Agencia Estatal Boletín del Estado, https://www.boe.es/diario_boe/txt. php?id=BOE-A-1979-27535.

8 Emilio Silva, Las Fosas de Franco (Madrid: Temas de Hoy, 2005).; Ferrándiz, El Pasado Bajo Tierra: Exhumaciones Contemporáneas de La Guerra Civil. 
The research carried out in Spain is based on different kinds of material. The main sources of investigation are interviews with the people who were involved in the exhumations of the bodies from mass graves, and/or local activists who have researched the repression in their village or area and know how the victims were exhumed and later honoured. These people often have pictures, or even audio and video recordings of the events. In some cases, a few official documents are available in the local archives (such as reports of the plenary sessions at the town hall where the re-burial is discussed). We can also find informal documents people have saved, with information about the costs of the exhumations and re-burials, for example, or reports of their informal meetings. In a few cases, there are short press reports published in the local media about the ceremonies after the exhumations. Last but not least, the secondary sources on the Civil War and repression in specific areas are very helpful to gather more information, corroborate or contrast the data.

In the case of Arnedo presented in this chapter, the main source of information is an interview with Carlos Solana, a local activist who participated in activities for the recovery of memory and interviewed the people of Arnedo about the stories of their families. He also showed pictures of the ceremony of re-burial which he attended and had an audio-recording of the mass that was celebrated. Also, the book Aquí nunca pasó nada by Jesús Vicente Aguirre contains helpful information about what happened in Arnedo.

The methods used are the hermeneutical analysis of the interviews combined with the interpretation of the information given by the pictures, audio and video recordings, official documents and secondary sources. It has to be said that, as the repression and most of the exhumations of remains from mass graves we are dealing with were informal, the information is sometimes confusing or contradictory. However, the interest of this piece of research lies in analysing the meaning that was given to those initiatives of recovery of memory in a context of fear and silence, right after the end of Franco's dictatorship. In this sense, and given the type of sources analyzed in this piece of research, it can be defined as 'history from below' in Jim Sharpe's terms, ${ }^{9}$ in which the point of start is the local people and their cases of exhumations. The case-studies are then framed both in their broader political and historical context, and in the conceptual and theoretical framework developed through the analysis.

In the following, the exhumations of the Spanish transition will first be presented as part of the construction of local counter-discourses to the 'Pact of Silence'. In the second part, the framework will be expanded beyond Spain, to

9 Jim Sharpe, "Historia Desde Abajo," in Formas de Hacer Historia, ed. Peter Burke, Segunda edición (Madrid: Alianza, 2003), 39-58. 
relate the Spanish exhumations to the ones of the Greek transition in particular, showing that the local counter-discourses in fact go beyond the local sphere of memory practices and discourses. Looking at the kind of counter-discourse they produced, this chapter aims at opening up the view on grass-root memory practices such as the exhumations in Spain to new interpretations of the Spanish transition, also in connection to other cases such as the Greek one.

\section{Exhuming the Past: A Negotiated Counter-discourse to the 'Pact of Silence'}

Despite the difficult political circumstances of the transition, hundreds of people, mainly families of the victims, decided that now that Franco was dead and the dictatorship over, they could finally unearth the remains of their relatives in order to give them a proper burial and to have them rest in a dignified grave.

These processes started and remained informal, with no official policy supporting them. In fact, there was no specific policy whatsoever on what to do with the thousands of mass graves around Spain. As a result of the mostly informal nature of these processes, they did not leave much written documentation behind. When requested by the promoters of the exhumations, permissions to excavate were granted by the local authorities, but not without problems. There were threats, and concessions had to be made. To give an example, in Casas de Don Pedro in 1978, the procession for the re-burial of the remains was allowed by the Civil Governor under the condition that there would be no political slogans. ${ }^{10}$

Indeed, the conditions in which these groups of people carried out the exhumations were far from ideal. Although the dictatorship was over, fear among the population was still very present. Apart from the difficulties to find the graves and the occasional resentment of the local administration to allow the exhumation, the people involved were also despized by their fellow villagers. In some villages, the attendants were insulted during the procession. ${ }^{11}$ Moreover, they could not count on scientific support during the exhumations. There were, most probably, many mistakes made and no forensic identification. In most cases, the remains were reburied in collective vaults. What bound these groups together and formed a community was the desire to give dignity back to the victims through the re-burial of their remains.

10 Personal communication with Felisa Casatejada, Casas de Don Pedro, May 2015.

11 Josefina Campos Orduña, Los Fusilados de Peralta, La Vuelta a Casa (1936-1978). Operación Retorno (Pamplona/Iruña: Pamiela, 2008), 334. 
The transition exhumations show aspects of both resistance and compliance, as the case of Arnedo - a village in La Rioja, in the north of Spain - exemplifies. In Arnedo, 46 people were murdered during the repression of the Civil War against the left. ${ }^{12}$ They were taken in different sacas (the term used when people were taken out of jail or their homes to be killed elsewhere, most often outside the village), and murdered in different places in La Rioja or the neighboring region of Navarra, where they were buried in unmarked mass graves and left there for the entire dictatorship.

When Franco died, a movement started in Navarra and La Rioja to exhume the remains of the victims of Francoist repression. ${ }^{13}$ The phenomenon spread on both sides of the Ebro River, with the help of a group of priests who actively supported and participated in these initiatives. In Arnedo, too, families decided to go and unearth the victims' remains. They first had their meetings almost clandestinely, in the backroom of a bar. ${ }^{14}$ They were trying not to attract attention. Most of the times, they knew the place where their relatives had been buried. The location and the history of the mass graves were usually known among the population, although not talked about during the dictatorship and sometimes not even today, because of fear.

The families of Arnedo started opening the graves in 1978, with the help of diggers. They even removed the last bits of earth with spoons in order not to damage the remains. ${ }^{15}$ They exhumed bodies in various villages of La Rioja and Navarra - Ausejo, Lerín, Arnedillo or Calahorra - and they put the remains together in one coffin each time. Awaiting the funeral, the coffins with the remains were stored in the premises of the Red Cross. The mayor who was elected in the first democratic local elections in 1979 in Arnedo was a known Francoist. He was now part of Alianza Popular, the party founded by former politicians of the Francoist system after the dictatorship. However, when asked for permission to rebury the remains of the victims of Francoist repression in the cemetery of Arnedo, he was pleased with the idea. ${ }^{16} \mathrm{He}$ made things easy, and the piece of land of the cemetery where the pantheon was built was unanimously ceded to the families, at no cost and in perpetuity. In May 1980, the re-burial took place with a church funeral followed by a silent procession with the coffins to the cemetery.

12 Jesús Vicente Aguirre González, Aquí Nunca Pasó Nada. La Rioja 1936, 5 a edición (Logroño: Editorial Ochoa, 2008), 288.

13 These two were not the only regions where exhumations took place in the late 1970s, but there the grave openings had a kind of a domino effect, the word spreading from village to village that the relatives of the victims were bringing their loved ones 'back home'.

14 Personal communication with Carlos Solana, Arnedo, December 2014.

15 Ibid.

16 Ibid. 
On the one hand, despite the threats and people's fear, political symbols were present. In Arnedo, huge Republican flags were used in the streets during the procession and funeral of the victims after the exhumation (see Figure 5.1). They were even displayed at the church where the funeral took place. ${ }^{17}$ This happened when the Spanish Communist party itself had given up on displaying Republican flags during their events (and instead had adopted the official Spanish flag at the time) since $1977,^{18}$ as the party was looking for inclusion into the political system and was thus complying with the discourse of consensus and apparent silence. It seems to have been the first time those flags came back to the public space of Arnedo in such a visible way since the end of the Second Republic. ${ }^{19}$ Even though the political symbols and discourse may not have been as visible in some other cases, the very act of exhumation is

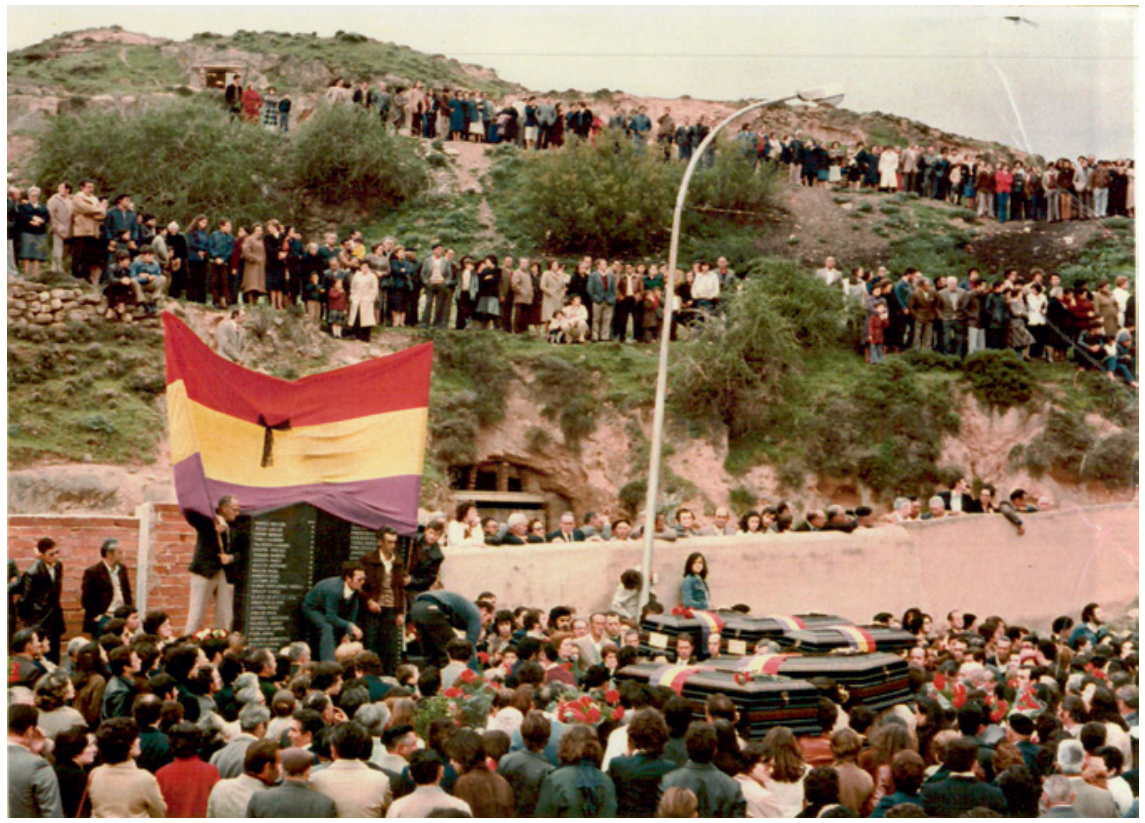

Figure 5.1 Arnedo (La Rioja, Spain), 4 May 1980

PICTURE CEDED BY CARLOS SOLANA

17 Ibid

18 Joaquín Prieto, "La Bandera Nacional Ondeará En Los Actos Del Partido Comunista de España," El País, de abril de 1977, http://elpais.com/diario/1977/04/16/ espana/229989610_850215.html.

19 Personal communication with Carlos Solana, Arnedo, December 2014. 
political, because dead bodies turn into political symbols ${ }^{20}$ when they bring a violent past into the present and as they are moved from one place to another. In short, the exhumations and the presence of these symbols were dissident in the context of the transition to democracy.

On the other hand, the processes of exhumation and re-burial were also impregnated by religion - Catholic in most Spanish cases - although the Church had taken an important part in the Francoist repression of the 1930s. Many local priests were actively involved in the exhumations. They helped searching for information and organizing funerals which were often requested by the families. In Arnedo in 1980, the local parish priest - who was apparently obliged by the Bishop ${ }^{21}$ - attended the procession and funeral (see Figure 5.2). During the funeral, another clergyman, who came from Navarra and was one of the priests who had supported all the exhumations, added something quite exceptional to the church service, given the context: he asked for forgiveness

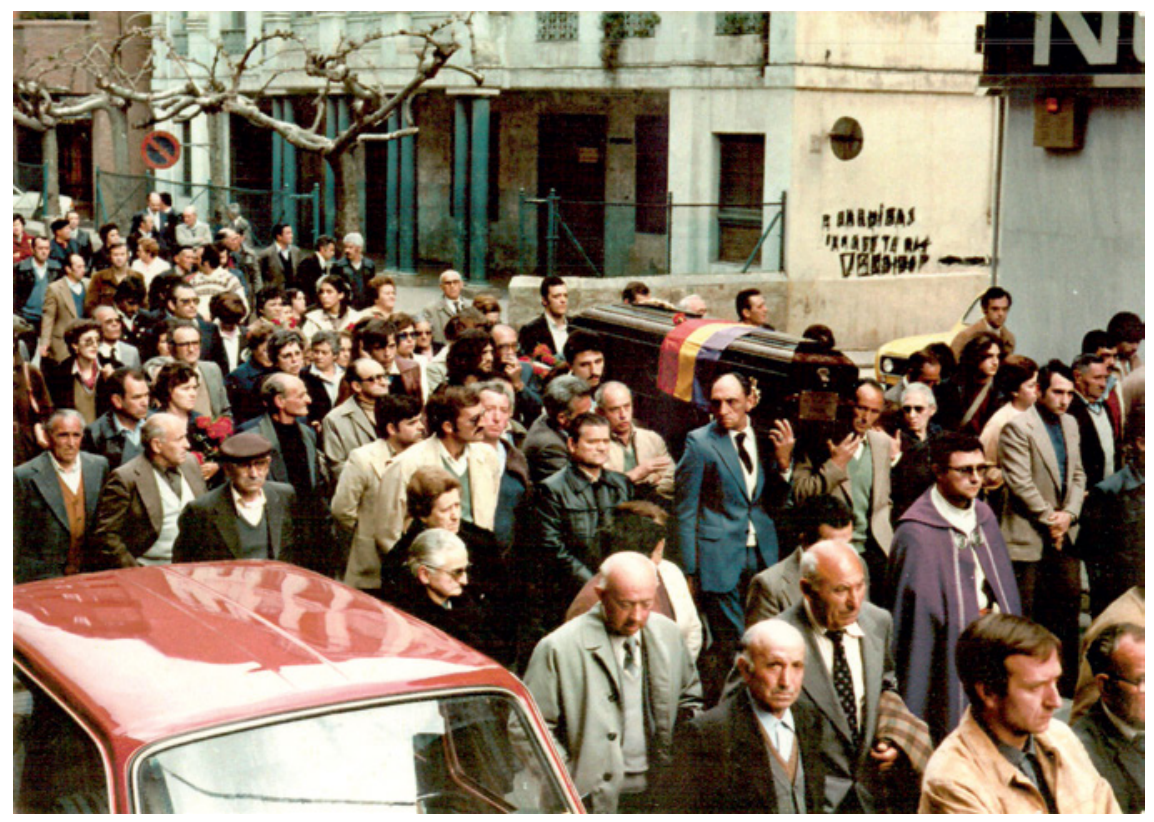

Figure 5.2 Arnedo (La Rioja, Spain), 4 May 1980

PICTURE CEDED BY CARLOS SOLANA

\footnotetext{
$20 \quad$ Katherine Verdery, The Political Lives of Dead Bodies (New York: Columbia University Press, 1999), 3.

21 Personal communication with Carlos Solana, Arnedo, December, 2014.
} 
in the name of the Church for its involvement in the repression. ${ }^{22}$ It has to be mentioned as well, that the mayor who authorized the remains to be reburied in the village cemetery thought it was a good idea to do it 'como Dios manda' [As God ordains]. ${ }^{23}$

Religious rituals and symbols were also very present. Indeed, in many of the funerals organized after the exhumations, Christian crosses were displayed and women followed the custom of wearing black clothes as a sign of mourning. The religious aspect was also part of the families' public recognition of the death of their relative as such, completing the traditional process of mourning they had been denied during the dictatorship. Basically, it was a claim for the right to comply with cultural customs: 'their' victims had a right to a funeral and decent grave. But in doing so, and by making concessions, they were also complying with the established order. That is, they were simultaneously disrupting and complying with the transitional order.

This double sense given to the exhumations gave rise to situations that may seem contradictory, such as priests taking part in a procession where Republican flags were displayed. Nevertheless, they reveal that these practices were in fact the local results of a negotiation between resistance and (self-) censorship. Although this might reflect a contradiction, we can also consider it a strategical move in order to make sure that the exhumation and reburial would actually be approved. Because the discourse of silence was enforced upon them, ${ }^{24}$ the groups of people who wanted to exhume the bodies had to be discreet to reach their goal. They adapted their practices and discourses to the circumstances, that is, the limits given by the 'Pact of Silence' within which they (thought they) could act.

Despite the concessions, these initiatives were transgressive of the established order, because they represented a crack in the discourse of silence and the consensus promoted during the transition. The transgression might not have been strong enough to worry the elites, but it was nevertheless an inflection on the dominant discourse in the public space, at a local level. They avoided a direct clash, while trying to remain as faithful as they could to the memory of the victims in their tribute. These exhumations were a form a subthe resistance to the 'Pact of Silence', as part of the 'infrapolitics of subordinate groups' defined by James Scott as 'low-profile forms of resistance that dare not

$22 \quad$ Funeral a Los Fusilados de Arnedo (Arnedo, 1980).

23 Aguirre González, Aquí Nunca Pasó Nada. La Rioja 1936, 278.

24 Andrea Davis, "Enforcing the Transition: The Demobilization of Collective Memory in Spain, 1979-1982," Bulletin of Hispanic Studies 92, no. 6 (2015): 667-689, doi:10.3828/ bhs.2015.40. 
speak in their own name..25 In this sense, mourning the dead - mourning those precise dead in that precise context - was part of a counter-discourse to the 'Pact of Silence'.

The counter-discourses were the result of the reception of the 'Pact of Silence' and of the reaction to this dominant discourse. According to Wulf Kansteiner, cultural memory is the result of three interacting factors: intellectual and cultural tradition that frames all our representations of the past, memory makers who selectively adopt and manipulate these traditions and memory consumers who use, ignore, or transform such artifacts according to their own interest. ${ }^{26}$ In this setting, the three factors interact. Memory consumers, when transforming the representations, also become memory makers as they mediate new representations of the past. In this sense, they receive memory discourses and produce new ones.

The discourse of the 'Pact of Silence' was received and consumed by many families of the victims of Francoism, who in turn became memory makers by adapting this dominant discourse to their own situation. Exhuming the remains from the mass graves contributed to the creation of a different representation of the victims than that imposed by the order of the transition. The exhumation of the bodies and their re-burial in a decent grave play a part - by turning the body into symbol - in the revaluation of the status of the victims. This diverging representation emerging from the exhumations produced a memory discourse promoting the dignification of the memory of Francoism's victims to counter the official silence about them. Without being explicit, the families demonstrated that paying a pacific tribute to the dead through the grave openings did not mean looking for another conflict. They showed it was possible - and actually fair - to dignify the victims in the context of the transition. Thus the discourse promoted was one of symbolic justice in the memory of the Civil War and the deathly repression during the dictatorship. In turn, the emergence of counter-discourses affected the dominant one, in the sense that it forced the elite to find ways of discreetly making sure those local counterdiscourses would not spread by implementing new mechanisms of containment and silencing. ${ }^{27}$

\footnotetext{
25 James Scott, Domination and the Arts of Resistance: Hidden Transcripts (New Haven and London: Yale University Press, 1990), 19.

26 Wulf Kansteiner, "Finding Meaning in Memory: A Methodological Critique of Collective Memory Studies," History and Theory 41 (2002): 180.

27 See the forthcoming article by Lidia Mateo Leivas and the author: "The limits of remembrance during the Spanish Transition: Questioning the "Pact of Oblivion" through the analysis of a censored film and a mass grave exhumation."
} 
Despite their emergence, the exhumations of the 7os and 8os received limited media attention. ${ }^{28}$ As a result of the limited media impact of the exhumations, their silencing and their relative discretion, the counter-discourses produced by these acts remained invisible to the national sphere and stayed confined to local areas at a grass-root level. They did not enter what Foucault calls the 'regime of truth': the types of discourse which society 'accepts and makes function as true. ${ }^{29}$ In this struggle of memory discourses, the different representations of the past were made visible to a very uneven degree. Although the counter-discourses did not get to be mediated in the main channels of communication and institutions, it is important to take them into account, as they offer a different point of view on the history of the transition. The transition was not indeed all about leaving the past behind. The study of grass-root actors demonstrates that the 'oblivion' of the transition is in fact one of many assumptions about that period. There was opposition to silence and it is necessary to look for it, away from the dominant discourse.

\section{Exhumations across Time and Space}

This type of local counter-discourse against silence actually fits into a larger historical and transnational discourse than that of the Spanish transition, and the grave openings should not be considered isolated events. Indeed, exhuming the victims of political violence was not anything new. The post-World War $\mathrm{I}^{30}$ and World War $\mathrm{II}^{31}$ periods saw the unearthing and moving of victims' remains across different European countries. As far as the exhumations of bodies from the Spanish Civil War mass graves are concerned, the ones carried out in the 1970s and 1980s were not the first either. The genealogy of exhumations

28 One of the exceptions in the national media is the magazine Interviú, in which thirteen reports on the mass graves were published between 1976 and 1984, although Interviú was not part of the mainstream media. For more on this topic see: Paloma Aguilar and Francisco Ferrándiz, "Memory, Media and Spectacle: Interviú's Portrayal of Civil War Exhumations in the Early Years of Spanish Democracy," Journal of Spanish Cultural Studies 17, no. 1 (2016): 1-25, doi:10.1080/14636204.2015.1135599.

29 Michel Foucault, "Truth and Power (interview with Alessandro Fontana and Pasquale Pasquino)," in The Foucault Reader, ed. Paul Rabinow, Pantheon (New York, 1984), 72-73.

$30 \quad$ Jay Winter, Sites of Memory, Sites of Mourning. The Great War in European Cultural History (Cambridge: Cambridge University Press, 1995).

31 Jean-Marc Dreyfus, "Une Renationalisation Des Corps? La Mission Française de Recherches Des Cadavres de Déportés En Allemagne, 1946-1958," in Cadavres Impensables, Cadavres Impensés, ed. Elisabeth Anstett (Paris: Pétra, 2012), 67-78. 
can be divided into the following phases: the postwar (mainly Francoist, but also Republican clandestine exhumations), the moving of thousands of bodies to Franco's future mausoleum - the Valle de los Caídos - during the dictatorship, the transition exhumations and finally the latest wave of exhumations that started in 2000. ${ }^{32}$ Each phase had its own form of necropolitics. ${ }^{33}$ If we focus on the 1970s and 1980s, Argentina was also the scene for exhumations of the victims of past violence. At the end of the Junta dictatorship, in 1984, the search for the desaparecidos - the people who had been abducted, detained and killed illegally by the military - became official. The Madres and Abuelas de la Plaza de Mayo had been looking for their children and grandchildren for years, but now that the dictatorship was over, the search was in the hands of justice. The first exhumations of bodies were conducted by the authorities, but there were many mistakes made and evidence was unintentionally destroyed. ${ }^{34}$ Soon, independent forensic anthropologists ${ }^{35}$ took over and have worked on the search for disappeared people in Argentina and across the world ever since.

All in all, exhuming the victims of violence for the purpose of dignification be it returning them to their families, as part of a State policy of honouring the 'fallen', or a justice procedure - is embedded within the so-called Western traditions. Hence, the grave openings we are dealing with in this chapter do not emerge out of nowhere.

Most interestingly, similar exhumations to that of the Spanish transition took place in Greece in the same period. ${ }^{36}$ The Greek Civil War (1946-1949) opposing the left-wing forces of the Democratic Army of Greece and the armed section of the Greek Communist party on the one hand, and the right-wing Greek government on the other, also left many unmarked graves as a result of the atrocities committed on both sides. When Greece's dictatorship was over in 1974, the policies of national reconciliation were not comprehensive and did not contemplate exhumations of the bodies in the mass graves. Katerina Stefatos and Iosif Kovras even speak of a 'subtle agreement [...] reached to silence

32 Ferrándiz, El Pasado Bajo Tierra: Exhumaciones Contemporáneas de La Guerra Civil, 148.

33 Achille Mbembe, "Necropolitics," Public Culture 15, no. 1 (2003): 11-40.

34 Mauricio Cohen Salama, Tumbas Anónimas. Informe Sobre La Identificación de Restos de Víctimas de La Represión Ilegal (Buenos Aires: Catálogos editora, 1992); Christopher Joyce and Eric Stover, Witnesses from the Grave. From Mengele to Argentina's "Disappeared" - The Stories Bones Tell (London: Grafton, 1993).

35 The Argentine Forensic Anthropology Team (EAAF in Spanish)

36 I would like to thank Iosif Kovras and Katerina Stefatos for discussing this with me and for shedding light upon the Greek case. For more information, please refer to their publication listed in the bibliography. 
certain inconvenient aspects of the violent past'. ${ }^{37}$ Indeed, the institutional memory politics of the Greek democratic consolidation share characteristics with those of the Spanish transition. It is also worth noting that both postdictatorial processes coincide in time. Another point of convergence is the politics regarding reparations to former leftist veterans of the civil war. While the Spanish pension law was passed in 1979, similar measures were adopted in Greece in 1985 with a law restoring pension rights to public servants formerly dismissed for political reasons and providing for pensions to disabled or partly disabled veterans of the resistance. ${ }^{38}$

Amid partial silence on the past from the side of the government, the Greek island of Lesvos was the scene of the very few exhumations of the bodies of former resistance and Communist fighters that had died during the civil war. Stefatos and Kovras distinguish between three periods of exhumations: secrecy in the 1950 and 1960 , the most visible wave in the 1980 s and a renewed interest for exhumations in 2009. ${ }^{39}$ Again, this sequence is reminiscent of the Spanish one. In the 1980s, the bodies from Civil War mass graves were exhumed in the Agiasos pine forest (1982), in Mytilene (1982), Lambous Mylous (1983), Aghia Paraskevi (1983) and there was an unsuccessful attempt in Eressos (1985). Similarities can be found in the practice of exhuming and dignifying the victims. In both cases, scenes of people gathering around the open coffins or the boxes containing the remains to take pictures after the exhumations can be observed. Another similarity is that there is little information about them, except for oral testimonies and material traces. Moreover, the mix of religion and politics can be found in the features of Lesvos identity, with a blend of Orthodox faith with leftist-communist convictions. ${ }^{40}$ This is reflected in the re-burial ceremonies as well: there were religious ceremonies officiated by priests and women wearing black and crying as part of the mourning process, while local Communist party members were present. The exhumations in Lesvos were also described as local and informal ones: '[...] with no official endorsement by political parties or the government. They were initiated by the local communities. ${ }^{41}$ We have to bear in mind, nevertheless, that Lesvos was an outlier case

37 Katerina Stefatos and Iosif Kovras, "Buried Silences of the Greek Civil War," in Down to Earth: Exhumations in the Contemporary World, ed. Francisco Ferrándiz and Antonius Robben (Philadelphia: University of Pennsylvania Press, 2015), 165. David Close, "The Road to Reconciliation? The Greek Civil War and the Politics of Memory in the 1980s," in The Greek Civil War. Essays on a Conflict of Exceptionalism and Silences, ed. Philip Carabott and Thanasis D. Sfikas (Aldershot: Ashgate, 2004), 266. Stefatos and Kovras, "Buried Silences of the Greek Civil War," 167-168.

$40 \quad$ Ibid., 173 .

41 Ibid. 
and that most of the mass graves of the Greek Civil War remain unopened. It does demonstrate, however, that in Greece, too, we need to look closer at the local level to find disruptions in the reception of and reaction to the dominant discourse of silence. ${ }^{42}$ The case of the Lesvos exhumations reveals a negotiated and localized counter-discourse to State silence similar to that of Spain. There too, the hegemonic silence was received and recycled into a different representation of the past, through the re-burial of the left-wing victims.

\section{Local Memories within and beyond National Silence}

During the dictatorship and to a large extent the transition period, the memories of the left were, both in Spain and in Greece, 'underground memories'.43 They were forced into public silence, but the events were not forgotten by civil society. As Michael Pollak puts it, when the past remains silent, it is often the work of memory according to its possibilities of communication. ${ }^{44}$ Silence does not mean that memory is not working behind the scenes. Silence can be the form in which memory actually expresses itself in the public sphere, because other forms are impossible at that moment. What is more, Jay Winter has argued that silence must be examined as part of the cartography of recollection and remembrance. ${ }^{45}$ As exhumations in that period show, we should not only focus on the institutional silence on the past during the Spanish and Greek transitions, but also on memory working at a local level, in the form adapted to the apparent realm of possibility.

There are striking similarities between the exhumations carried out in Spain and in Greece. However, they do not seem to be directly connected. In both cases, they were local initiatives coming from below, emerging independently from one another. This points to a transnational reception of the discourses promoting and implementing silence about the violent past from above. In this sense, we are not referring to the movement and interaction of memory discourses across space, ${ }^{46}$ but more to a common cultural and political

\footnotetext{
$42 \quad$ Ibid., 176.

43 Michael Pollak, Memoria, Olvido, Silencio. La Producción Social de Identidades Frente a Situaciones Límite. (La Plata: Ediciones Al Margen, 2006).

44 Ibid., 31.

45 Jay Winter, "Thinking about Silence," in Shadows of War. A Social History of Silence in the Twentieth Century, ed. Efrat Ben-Ze'ev, Ruth Ginio, and Jay Winter (Cambridge: Cambridge University Press, 2010), 3, http://dx.doi.org/10.1017/CBO9780511676178.002.

46 Astrid Erll, “Travelling Memory," Parallax 17, no. 4 (2011): 4-18, doi:10.1080/13534645.2011.6 05570 .
} 
ground - or intellectual and cultural tradition in Kansteiner's scheme ${ }^{47}$ - on which similar and simultaneous forms of counter-discourses to a dominant discourse are constructed.

Rituals of death and burials are culturally and historically bound, but they can also get to represent a discourse that transcends those cultural borders. The exhumations responded to a moral imperative - dignifying the dead - that is larger than the national and local cultural contexts. Although practices of dignification take different forms and cannot be generalized, the fact that local counter-discourses to State silence about violent pasts took similar forms in different places at the same time points to the greater transcendence of memory and resistance to silence. The local memory practices are entangled within a larger set of transnational practices of mourning and of memory embedded within a larger discourse based on the moral obligation to respect and honor the dead. But these practices also blend with transnational political discourses of memory and justice. As a result, the local memory discourse bypasses the national discourse of silence about the past to reach another level. In more recent periods, the human rights paradigm has been a crucial framework to develop a transnational memory discourse of truth, justice and reparation, in which the practices and terminology have become transnationally connected. ${ }^{48}$ Nevertheless, even without a clear connection and interaction, transnational discourses of the dignification of victims were at play before the globalized discourse on human rights.

Suggesting another point of view and shedding new light upon the memory practices that were hitherto not considered transgressive or dissident shows that the transitional silences on the past have actually been responded to. The reactions to the dominant discourse are not always spectacular, and sometimes they need to be made visible and recognized as part of the politics of memory, with their contradictions or particularities. ${ }^{49}$ Making those silenced voices audible also shows that they have an important role in the struggle of memory discourses, in this case revealing the transcendence of the desire to dignify one's victims.

47 Kansteiner, "Finding Meaning in Memory: A Methodological Critique of Collective Memory Studies," 180.

48 Francisco Ferrándiz, "Exhuming the Defeated: Civil War Mass Graves in 21st-Centry Spain," American Ethnologist 40, no. 1 (2013): 38-54, doi:10.1111/amet.12004.

Zoé de Kerangat, "(In)visibilidad Y Lucha Familiar: Mujeres Y Memorias de La Represión En Las Décadas de Los 70 Y 8o," in Pasados de Violencia Política. Memoria, Discurso Y Puesta En Escena, by Memorias en Red, ed. Jean-François Macé and Mario Martínez Zauner (Madrid: Anexo, 2016), 177 . 


\section{Acknowledgements}

This publication was possible thanks to the project $\mathrm{CSO}_{2015}$-66104- $\mathrm{R}$ "The underground past: exhumations and memory politics in contemporary Spain in transnational and comparative perspective" funded by the Spanish Ministry of Economy and Competitiveness, and to the project "UNREST Unsettling Remembering and Social Cohesion in Transnational Europe", funded by the European Commission program H2020-REFLECTIVE-SOCIETY-2015. I am also very thankful to both Aline Sierp and Tea Sindbæk Andersen for their insightful comments on the first version of this paper.

\section{Bibliography}

Aguilar, Paloma. "Justice, Politics and Memory in the Spanish Transition." In The Politics of Memory. Transitional Justice in Democratizing Societies, edited by Alexandra Barahona de Brito, Carmen González Enríquez, and Paloma Aguilar, 92-118. Oxford: Oxford University Press, 2008.

Aguilar, Paloma. Políticas de La Memoria YMemorias de La Política : El Caso Español En Perspectiva Comparada. Madrid: Alianza, 2008.

Aguilar, Paloma, and Francisco Ferrándiz. "Memory, Media and Spectacle: Interviú's Portrayal of Civil War Exhumations in the Early Years of Spanish Democracy." Journalof Spanish CulturalStudies 17, no.1 (2016):1-25. doi:10.1080/14636204.2015.1135599. Aguirre González, Jesús Vicente. Aquí Nunca Pasó Nada. La Rioja 1936. $5^{a}$ edición. Logroño: Editorial Ochoa, 2008.

Anonymous, Funeral a Los Fusilados de Arnedo. Arnedo, 1980.

Box, Zira. España Año Cero. La Construcción Simbólica Del Franquismo. Madrid: Alianza, 2010.

Campos Orduña, Josefina. Los Fusilados de Peralta, La Vuelta a Casa (1936-1978). Operación Retorno. Pamplona/Iruña: Pamiela, 2008.

Casanova, Julián. España Partida En Dos: Breve Historia de La Guerra Civil Española. Barcelona: Crítica, 2013.

Close, David. "The Road to Reconciliation? The Greek Civil War and the Politics of Memory in the 1980s." In The Greek Civil War. Essays on a Conflict of Exceptionalism and Silences, edited by Philip Carabott and Thanasis D. Sfikas, 257-278. Aldershot: Ashgate, 2004.

Cohen Salama, Mauricio. Tumbas Anónimas. Informe Sobre La Identificación de Restos de Víctimas de La Represión Ilegal. Buenos Aires: Catálogos editora, 1992.

Davis, Andrea. "Enforcing the Transition: The Demobilization of Collective Memory in Spain, 1979-1982." Bulletin of Hispanic Studies 92, no. 6 (2015): 667-689. doi:10.3828/ bhs.2015.40. 
De Kerangat, Zoé. “(In)visibilidad Y Lucha Familiar: Mujeres Y Memorias de La Represión En Las Décadas de Los 70 Y 8o." In Pasados de Violencia Política. Memoria, Discurso Y Puesta En Escena, by Memorias en Red, 155-179. edited by Jean-François Macé and Mario Martínez Zauner. Madrid: Anexo, 2016.

Dreyfus, Jean-Marc. "Une Renationalisation Des Corps? La Mission Française de Recherches Des Cadavres de Déportés En Allemagne, 1946-1958." In Cadavres Impensables, Cadavres Impensés, edited by Elisabeth Anstett, 67-78. Paris: Pétra, 2012.

Erll, Astrid. "Travelling Memory." Parallax 17, no. 4 (2011): 4-18. doi:10.1080/13534645.2 011.605570 .

Ferrándiz, Francisco. El Pasado Bajo Tierra: Exhumaciones Contemporáneas de La Guerra Civil. Barcelona: Anthropos, 2014.

Ferrándiz, Francisco. "Exhuming the Defeated: Civil War Mass Graves in 21st-Centry Spain." American Ethnologist 40, no. 1 (2013): 38-54. doi:10.1111/amet.12004.

Foucault, Michel. "Truth and Power (interview with Alessandro Fontana and Pasquale Pasquino)." In The Foucault Reader, edited by Paul Rabinow, Pantheon., 51-75. New York, 1984 .

Joyce, Christopher, and Eric Stover. Witnesses from the Grave. From Mengele to Argentina's "Disappeared" - The Stories Bones Tell. London: Grafton, 1993.

Kansteiner, Wulf. "Finding Meaning in Memory: A Methodological Critique of Collective Memory Studies." History and Theory 41 (2002): 179-197.

Mbembe, Achille. "Necropolitics." Public Culture 15, no. 1 (2003): 11-40.

Ministerio de Hacienda, "Real Decreto 2635/1979, de 16 de Noviembre, Para La Aplicación Y Cumplimiento de La Ley 5/1979, de 18 de Septiembre, Sobre Concesión de Derechos a Los Familiares de Los Españoles Fallecidos Como Consecuencia O Con Ocasión de La Pasada Guerra Civil," 16 November 1979. Agencia Estatal Boletín del Estado. https://www.boe.es/diario_boe/txt.php?id=BOE-A-1979-27535.

Pollak, Michael. Memoria, Olvido, Silencio. La Producción Social de Identidades Frente a Situaciones Límite. La Plata: Ediciones Al Margen, 2006.

Prieto, Joaquín. "La Bandera Nacional Ondeará En Los Actos Del Partido Comunista de España." El País, 16 April 1977. http://elpais.com/diario/1977/o4/16/ espana/229989610_850215.html.

Scott, James. Domination and the Arts of Resistance: Hidden Transcripts. New Haven and London: Yale University Press, 1990.

Sharpe, Jim. "Historia Desde Abajo." In Formas de Hacer Historia, edited by Peter Burke, Segunda edición., 39-58. Madrid: Alianza, 2003.

Silva, Emilio. Las Fosas de Franco. Madrid: Temas de Hoy, 2005.

Stefatos, Katerina, and Iosif Kovras. "Buried Silences of the Greek Civil War." In Down to Earth: Exhumations in the Contemporary World, edited by Francisco Ferrándiz and Antonius Robben, 159-183. Philadelphia: University of Pennsylvania Press, 2015. 
Verdery, Katherine. The Political Lives of Dead Bodies. New York: Columbia University Press, 1999.

Winter, Jay. Sites of Memory, Sites of Mourning. The Great War in European Cultural History. Cambridge: Cambridge University Press, 1995.

Winter, Jay. "Thinking about Silence." In Shadows of War. A Social History of Silence in the Twentieth Century, edited by Efrat Ben-Ze'ev, Ruth Ginio, and Jay Winter, 3-31. Cambridge: Cambridge University Press, 2010. http://dx.doi.org/10.1017/ CBO9780511676178.002. 


\title{
Double Victims and Agents of Change in Europe's Margins: Estonian Emigrants Sharing 'Their' Repressive Soviet Past in the Netherlands
}

\author{
Inge Melchior
}

Many [Western Europeans] do not know about the Soviet period and the deportations and about those politics. Many do not even know that Estonia exists. [...] If I am honest, I think they are not interested in what has happened here.

LINDA

Linda, born in 1942 in the Estonian Soviet Socialist Republic, recalls, while telling me her story, how Soviet soldiers entered their house in 1949 to deport her sick father to Siberia. For her, the idea that Western Europeans do not share in this memory of Soviet repression, or might not even care, is very painful. She wants to belong to Europe. Since Estonia regained its independence in 1991, the new nation-state has successfully framed its identity as 'European', as always having belonged to Europe, as an antipode to Soviet. ${ }^{1}$ Not only Estonians from the generations who actually experienced Soviet repression, but also the younger generations born in the 1970 and 1980 s, who grew up during the struggle for independence, have voiced their concerns to me about 'Western Europe not being able to comprehend' the Estonian historical experience (Sirje, 1982).

Based on previous extensive ethnographic fieldwork, I have argued that Estonians from various social groups perceive their national memory narrative to be inferior to the dominant Western European one. ${ }^{2}$ This leads to feelings of

1 Eiki Berg, "Local resistance, national identity and global swings in Post-Soviet Estonia," Europe-Asia Studies 54-1 (2002): 109-122.

2 Inge Melchior, "Guardians of Living History: The Persistence of the Past in post-Soviet Estonia" (Phd diss., vu University Amsterdam, 2015). Inge Melchior, "Forming a common European memory of wwII from a peripheral perspective: Anthropological insight into the struggle for recognition of Estonians, wwII memories in Europe," in Disputed memory: 
insecurity, of not belonging to the 'European family' and not being taken seriously as equal partners. For this chapter I have followed Estonians who moved to the Netherlands, in order to get a deeper understanding of what actually happens when the 'Estonian memory narrative' is transported into Western Europe. What do Estonian grassroots' memory agents do when they experience different reactions to/receptions of their understanding of the past? In what kind of contexts does this exchange of stories happen?

This chapter will reveal that in addition to the 'double victims' that I have described extensively in my previous work, Estonians who moved to the Netherlands present themselves sometimes as 'agents of change'. Both double victims and agents of change cannot just do 'nothing'; both feel the need to create understanding and recognition among the Dutch, to pay respect to the stories of their relatives. For many this also means they feel the need to 'defend' or at least explain their national politics, which are much entangled with their family stories. Agents of change, however, believe that they have a voice that counts in that foreign context. They believe that they can make a change, that they can teach a life lesson that their Dutch friends are unable to learn from their own 'rather uncomplicated' history.

Based on the above, this chapter will provide a deeper understanding of memory reception. I will first explore the theoretical background of memory making and reception in the context of migration. Then I will explain how and among whom I have gathered my data. In the empirical part I will show what happens when migrants share their memory narratives in a host country within a rather dominant discourse.

\section{Theory on Memory Reception}

Representations of the past are being produced in museums, textbooks, monuments by cultural, intellectual and political elites, as well as during family dinners. However, as Wulf Kansteiner has elaborately pointed out, this does not necessarily mean that these representations turn into memory; meaning that the authors/tellers successfully tie the representations to specific social groups. ${ }^{3}$ Thus, instead of 'presuppose[ing] a rarely acknowledged but not particularly surprising desire for cultural homogeneity, consistency and predictability' in

emotions and memory politics in Central, Eastern and South-Eastern Europe, eds. Tea Sindbæk Andersen et al. (Berlin: de Gruyter, 2016) pp. 203-226.

3 Wulf Kansteiner, "Finding meaning in memory: a methodological critique of collective memory studies," History and Theory 41.2 (2002): 192, 179-197. 
memory studies, we should have a closer look at what happens on the reception side of memory. ${ }^{4}$ As an anthropologist I am not interested in the direct reception of a collective representation of the past. Rather, I am interested in how individuals, who have incorporated a certain memory of the past, interact with individuals who adhere to different representations of the past. How do the traces of the past that last within people, act upon them and make them act in a context among 'others'? 5

The answer to this question depends on the context. Memories of suffering are different from other kind of traces from the past. Several memory scholars have written about such 'traumatic memory': the kind of memory that does not find meaning in a narrative and thus retains its strong and uncontrollable affective force. In those cases, speaking about the past is of immense importance for a sense of liberation from that past. Firstly, it will remind the world of its responsibility to acknowledge truths that have been denied. Secondly, it will heal the self by the very act of speaking and being heard, as it allows the birth of a narrative that provides meaning to the pain. ${ }^{6}$

The listener also plays a crucial role in the extent to which the past persists into the present. If there is no listener, the terrible event does not exist in the historic record. ${ }^{7}$ Perhaps even more painful is the 'unwitnessed event', described by psychoanalysts as the 'annihilating force when others are around and do not acknowledge the inhumanity in front of them.. ${ }^{8}$ Or as anthropologist Michael Lambek puts it: ' $[t]$ here is nothing worse than making the effort to speak of terrible things and being ignored.9 ${ }^{9}$ The empathy of the listener is not only crucial at the moment of storytelling, but also in what he/she does with the story afterwards.

Several memory scholars have argued that not only those who lived through a traumatic event have a memory that can extend into the present, but that also the post-generation can embrace the memory as their own, as

4 Kansteiner, "Finding meaning in memory," 193.

5 David Berliner, "The abuses of memory: reflections on the memory boom in anthropology," Anthropological Quarterly 78.1 (2005).

Jeffrey K. Olick \& Joyce Robbins, "Social memory studies: From 'collective memory' to the historical sociology of mnemonic practices," Annual Reviews of Sociology 24 (1998).

6 Katharine Hodgkin \& Susannah Radstone. "Remembering suffering: trauma and history," in Contested pasts: the politics of memory, ed. Katharine Hodgkin et al. (London: Routledge, 2003).

7 Nancy R. Goodman, and Marilyn B. Meyers, ed., The power of witnessing: Reflections, reverberations, and traces of the Holocaust (London/New York: Routledge, 2012), 3.

8 Goodman, The power of witnessing, 10.

9 Michael Lambek, "Foreword," in Memory and World War II: An Ethnographic Approach, ed. Francesca Cappelletto. (Oxford: University of Chicago Press, 2005), xi. 
a 'post-memory'. ${ }^{10}$ The descendants of victims - such as young generations Estonians - feel so deeply connected to the traumatic experiences of their (grand)parents, 'that they need to call that connection memory and thus that, in certain extreme circumstances, memory can be transmitted to those who were not actually there to live an event'.11 The second generation has made the stories with which they grew up their 'own' to such a large extent that the experience of the trauma extends into the present.

The desire to 'compensate' the others' losses ${ }^{12}$ is especially strong in times of uncertainty, when the wounds of the past hurt the post-generation more, and coherent stories of the past are more essential to the healing process. ${ }^{13}$ 'When identity is not in question, neither is memory.' ${ }^{14}$ In other words, in times of crisis or uncertainty the post-generation will be more likely to demand recognition for their story. The peculiarity of the Estonian post-generation on which I will focus in this chapter, is that they live in a foreign society.

Generally, migrants face more uncertainty than natives do. According to anthropologist Liisa Malkki, this is due to the fact that migrants are seen, and see themselves, as 'uprooted'. Like most people, migrants long for roots, in order to feel at home in a place and to have intimate ties with other people. Migrants face more challenges than natives in rooting themselves as they move between physical spaces and between cultural communities. They live as if they were 'in-between' cultures. They have their roots in a different society than the place where they are living. They constantly need to 'decide' to which social and cultural rules they will adhere, with whom they identify and to whom they are loyal. This makes them unpredictable and therefore they are sometimes seen as 'scary' by their host society. A strong story or narrative provides guidance in this chaos and cultural 'in-betweenness'.15 Eastmond argues that stories and narratives help people in times of migration to establish identity in their ruptured life paths. ${ }^{16}$

\footnotetext{
$10 \quad$ Marianne Hirsch, "The generation of postmemory," Poetics Today 29.1 (2008).

11 Hirsch, "Postmemory," 105-106.

12 Kansteiner, "Finding meaning in memory," 184.

Olick, "Social memory studies."

13 Hodgkin, "Remembering suffering."

14 Michael Lambek and Paul Antze, "Introduction: Forecasting memory," in Tense past: Cultural essays in trauma and memory, ed. Michael Lambek et al. (New York: Routledge, 1996), xxii.

15 Liisa H. Malkki, Purity and exile: violence, memory, and national cosmology among hutu refugees in Tanzania (Chicago: The University of Chicago Press, 1995).

16 Marita Eastmond, "Stories as Lived Experience: Narratives in Forced Migration Research," Journal of Refugee Studies 20.2 (2007).
} 
Based on the preceding paragraphs we might expect that those Estonians who live in the Netherlands and feel that their Estonian identity is under threat, are more likely to defend and demand recognition for the story of Soviet repression. In the new context where they live, that story is being challenged, and therefore can become an identity marker of Estonian national identity. For those who do not strongly identify with the victims of Soviet repression or with the Estonian nation, or who do not feel that their Estonian identity is under threat in their new homeland, we might expect the opposite: that the physical distance to the homeland creates more emotional distance to its identity markers.

I have thus singled out several contextual factors that feed into the lingering effect of the past into the present, and thus the need that people feel to share their story with others: a violent and traumatic past, the absence of an empathetic listener, a high degree of identification with the victims, as well as a strong sense of insecurity and chaos in the present. A contextual factor, which is especially important to add to this list in the case of migrants, is the power of the particular migrant(group). First of all, migrants who enter a new society through a refugee camp have completely different possibilities to turn their experiences into narratives and share them with their new compatriots, than those who integrate into an urban area. ${ }^{17}$ But even though most Estonian migrants in this chapter live in Dutch urban areas and are well educated, they face the fact that the 'established' have more power because they have better access to institutions, more knowledge about the society in which they live and a stronger social network. ${ }^{18}$ As the 'outsiders', migrants have less legitimacy to their own story in their new homeland - especially if the narrative challenges the dominant story.

In this text I will focus on the reception in the Netherlands of the Estonian grand narrative on the Soviet repressions, which challenges the Dutch narrative on the Holocaust. It concerns a violent past that lingers on in the present for many of my interviewees, in their search for an empathetic listener.

\section{Methodology}

Wulf Kansteiner argues that reception is too little studied in the field of memory studies. ${ }^{19}$ Too often do memory scholars assume that the dominant story

17 Malkki, Purity and exile.

18 Norbert Elias and John L. Scotson, The established and the outsiders (New York: The Humanities Press, 1966).

19 Margaret Archer in Kansteiner, "Finding meaning in memory," 194. 
in the media correlates with the perspective of its users, also called the 'downward conflation' of structuralism. ${ }^{19}$ Therefore, I have chosen an ethnographic fieldwork approach in order to be able to focus on the social practices of remembering and to avoid sticking solely to the level of representation and memory producers. Ethnography also enables a focus on the agency that people have and on emotions that can be found below the surface.

Since 2007, when I conducted research for my Master thesis in Estonia, I have participated in activities of the Eesti Kool [Estonian school] in the Netherlands, after returning from fieldwork. Once a month they organize 'classes' for the children of Estonian parents in order to improve their Estonian language and to nourish their Estonian identity, and they provide language lessons for adults. 1100 Estonian citizens are officially registered in the Netherlands. I participated in the language classes until they no longer contributed to my language skills. I continued to attend events such as the St John's celebration every year in June. For this text I have carried out participant observations during monthly school days and interviewed several Estonian emigrants. These Estonians have moved to the Netherlands to study, work or because they have a Dutch partner. They are thus institutional or labor migrants who emigrated voluntarily. I approached them by posting a message in the Facebook group 'Eestlased Hollandis' (Estonians in the Netherlands). The network has 1962 members (on 8 March 2016). I also invited several Estonians directly; either acquaintances from my time in Estonia who had emigrated, or people I had met during my previous participation in activities of the Estonian School. Eventually I managed to gather stories from seven Estonians, all conducted in the Estonian language, either written or by Skype interview.

This data collection should be seen as building on my previous ethnographic fieldwork research in Estonia between 2007 and 2015, where I participated in commemorations, song festivals and folk dance classes, in family dinners, berry picking excursions and relatives' graveyard visits, while conducting an extensive amount of formal and informal interviews.

I did not further select those Estonian emigrants who were willing to talk to me. After all, what I am interested in is the fact that they as Estonians live within the Dutch memory landscape, and how they deal with that. Based on my previous fieldwork I would not expect major differences between individuals, as I saw how the stories of Soviet repression mattered to my informants from all parts of society, as they all identify with the Estonian nation and feel responsible for its preservation and continuation, especially, I would expect, in a foreign context, where they live among people who adhere to different stories about the recent past. They are confronted with them on a daily basis. Reception and incorporation of the Soviet narrative might therefore be different for them than for Estonians who live in Estonia. After all, they are also 
exposed to another memory narrative of that same time period, namely the one which is dominant in the Netherlands. 2014-2016 forms a very interesting time to collect data in the Netherlands, as - I will argue - the image of Russia has recently changed, due to current political developments.

\section{The Memory Narrative of Soviet Repression}

On the 25th of March 1949 we were taken away from our house. [...] We had seen how they set everything on fire, and how they filled their pockets with the things that were useful to them. From the trip I remember mainly how those Russians were screaming at us: 'fascists'. And the cold. There was so much snow outside and people were sleeping in front of the door. We had 5 families in our cattle wagon. [...] We were in the train for about a month before we arrived.

ELIISA, 1940

Eliisa was deported to Siberia as a 9-year old girl, together with her mother. Apart from her, another 33,861 Estonians ( $=3 \%$ of the total population of 1939) have lived parts of their lives in Gulag (Soviet forced labour camps) accused of being 'enemies of the people'. ${ }^{20}$ This number excludes political prisoners sent to Russia, men mobilized into the Red Army and people arrested and murdered on the spot. In total, 134,6oo Estonians - men, women, elderly people, children, intellectuals, farmers and workers - were repressed by the Soviet regime between 1939 and 1991 in one or another way. Not only Estonian families have been deprived of their freedom by the Soviet authorities. People of all ethnicities living in Soviet territory - Russians, Ukrainians, Latvians, Georgians, Uzbeks, Jews, Chechens, etc. - were in potential danger if they did not live according to the Communist rules. ${ }^{21}$ Historians have estimated that between 1928 and 1953, about 25 million people in total had circulated through the Gulag system. ${ }^{22}$

$20 \quad$ Aigi Rahi-Tamm, "Human losses," in The white book: losses inflicted on the Estonian nation by occupation regimes 1940-1991, ed. Vello Salo et al. (Tallinn: Estonian Encyclopaedia Publishers, 2005).

21 Richard M.C. Mole, The Baltic States from the Soviet Union to the European Union: Identity, discourse and power in the post-communist transition of Estonia, Latvia and Lithuania (London: Routledge, 2012).

22 Jehanne M. Gheith and Katherine R. Jolluck, Gulag voices: Oral histories of Soviet incarceration and exile (New York: Palgrave Macmillan, 2011), 3. 
Eastern Europeans grew up in the 'bloodlands', the land between Moscow and the German border, the place where Hitler and Stalin fought each other's armies and where terror would inevitably intrude in the everyday lives of the locals at some point. ${ }^{23}$ Estonia became a kind of plaything of history, being a small country $(1,133,917$ inhabitants in 1939, source: stat.ee) with a short independent history (1920-1939) and a strategic geo-political location. In 1939, the country was annexed by the Soviet Union. In 1941 the German troops arrived and took over control. Estonian men were mobilized both into the Soviet and German army. In 1944, when the Soviet army again approached the Baltic States, ten thousands of Estonians joined the German army voluntarily in order to defend their home country. On the battlefields they faced their own brothers, fathers, friends and neighbours, men who had been recruited into the Soviet army. Eventually the Soviet authorities expelled the German rulers and stayed in control until 1991.

In those almost 50 years of the Estonian Soviet Socialist Republic (ESSR), a public memory of the deportations, as the ultimate symbol of Soviet repression, did not exist. Eliisa returned with her mother in 1958, and told me how she was not 'allowed' to talk about the deportations. First of all, former deportees had problems entering certain jobs and universities. Secondly, the public narrative framed the deportees as criminals and enemies of the state, who had been transferred to Siberia in order to safeguard the rest of society. People like Eliisa thus felt ashamed mentioning the fact that they had been one of the deportees.

Only in the late 1980s, in the period of glasnost and perestroika, did a public memory narrative of Soviet repression find daylight. In the ESSR this started with the publication of 'Maria in Siberian lands' [Maria Siberimaal]. Heino Kiik wrote this novel about his deported mother and brother and arrested father already in 1978, but it only made it to the wider public after 1985 (Eesti Päevaleht, 15 May 2009). With that, the Soviet deportations had come to occupy a place in the cultural memory of the ESSR as a narrative about the repression of innocent people rather than the punishment of criminals. The publication of this book and the first newspaper articles on this topic (for example, on 27 November 1987, historian Evald Laasi wrote an article about the Soviet deportations in the main Estonian cultural magazine Sirp ja Vasar ('Hammer and sickle')), broke a taboo in Soviet Estonian society. Similar events were taking place in Soviet Russia and other Soviet republics. ${ }^{24}$

\footnotetext{
23 Timothy Snyder, Bloodlands: Europe Between Hitler and Stalin (Philadelphia: Basic Books, 2010), vii-viii.

24 Nanci Adler, "The Gulag Survivor: Beyond the Soviet System," in On Living Through Soviet Russia, edited by Daniel Bertaux, et al. (London: Routledge, 2004).
} 
Alongside the creation of this cultural memory, politicians also began to openly create a safe space for sharing stories of Soviet repression, even though Estonia was still part of the Soviet Union and politicians were still subject to Soviet authority (more on this in Melchior, 2015, pp. 91-100 and 116-136). On 25 March 1989, exactly 40 years after the second mass deportation, head of state Arnold Rüütel held a public speech and on 14 June, the date of the 1941-deportations, three government officials made an 'Address to the people of Estonia'; both acts 'politically' recognized the victimhood of the deportees. ${ }^{25}$

This new public memory touched the former deportees deeply. Leena, who had been deported in 1949 at the age of 6, recalls in our interview what had happened to her when she first got hold of a copy of 'Maria in Siberian lands': 'I just read and cried. It tore open all the old wounds. I did not want to experience it anew [...]. When I read the book at home, my children told me not to read the book, because I just cried the whole time. But I had to read and cry anyway. When I recall that time and read some old letters from that time, my heart starts to hurt' (Leena 1949). Once the story of Soviet repression was out in the open, things developed quickly. On the radio a series was launched called 'Unwritten Memoirs' [Kirjutamata memuaare], where deportees told their stories publicly.

In addition, young and critical intellectuals founded the Heritage Society in 1987 and started to collect life-stories. In the wake of Jakob Hurt, a great Estonian folklorist and linguist from the period of National Awakening, these young intellectuals believed that real history existed in the stories of the people, untouched by politics. ${ }^{26}$ National history in Estonia was thus rewritten by intellectuals, dissidents and ordinary citizens collectively, from a non-academic and personal perspective. A broad share of the population was involved, as basically every Estonian knew someone who had been deported and/or was confronted with the wounds of the past. In the wake of the wider 'Singing Revolution' - in which those intellectuals, dissidents and the majority of Estonian-speaking citizens peacefully participated in song festivals to express their cultural strength and demand freedom - Estonian deportees were explicitly called for filling in the gaps in the official history. Former deportees received special status and became 'irreplaceable' compatriots for having the

25 Terje Anepaio, "Reception of the topic repressions in the Estonian society," Pro Ethnologia $14.9(2002): 5^{0 .}$

26 In my doctoral dissertation I dedicated a full chapter to the tracing of the mobilization of history-writing of the Estonian nation. 
knowledge that others did not have. ${ }^{27}$ It could be argued that production and reception of memory in those early 1990s were inextricable linked. 'The people' produced and 'the people' received, at least that was how my informants perceived the situation at that time. ${ }^{28}$

Obviously, this relationship changed when time passed by. The intellectuals and dissidents who had been the unofficial and ordinary leaders of the 'Estonian people' in the late 1980s, became the politicians of the new Estonian state re-established in 1991. In the late 1990s, their focus was no longer with the past but with the future, according to Anepaio. ${ }^{29}$ Society by that time had split into two: the independence winners and the losers. The losers increasingly felt that they were not being represented by the political elite. They began to share stories of the good and secure Soviet life in their personal sphere. In the 2000s, these stories of innocent Soviet nostalgia also entered the public stage, but only in the cultural (writers and film / theatre directors) and intellectual (academia) arena and the topic was very cautiously addressed. ${ }^{30}$ Attempts by intellectuals or cultural figures to talk about the 'normal' Soviet life, were easily quelled by calling them 'Communist' or 'national traitor'. On a political and legal level the memory narrative of Soviet repression never lost ground. Estonian ethnologist Kirsti Jõesalu argues that all presidents between 1991 and 2012 frame the Soviet period as a rupture, an abnormal and non-Estonian time. ${ }^{31}$ Moreover, the ideology of 'legal restorationism' implemented in Estonia in the early 1990 s frames the Soviet period in legal terms as illegal. ${ }^{32}$

Since 2004 Estonia is a member of the European Union (EU). This has posed new challenges to the memory narrative of Soviet repression. After all, 'old Europe' does not have the same historical experiences with Communism and

27 Anepaio, "Reception."

Ene Kõresaar, "Memory and history in Estonian post-Soviet life stories" (PhD diss., Tartu University, 2004).

28 See Melchior, Guardians of living history.

29 Anepaio, "Reception."

30 Kristi Grünberg, (2009). "Remembering the Soviet past in Estonia: the case of the nostalgic comedy 'the light blue wagon'," Atslegvardi / Keywords: Academic Journal for New Research in humanities and Social Sciences in the Baltic States (2009), accessed 23 August 2010 available at http://www.satori.lv/projekti/keywords/Kristi_Grunberg.pdf.

Melchior, Guardians of Living History.

31 Kirsti Jõesalu, "The role of the Soviet past in post-Soviet memory politics through examples of speeches from Estonian presidents," Europe-Asia Studies 64.6 (2012): 1007-1032.

32 Vello A. Pettai, "Framing the past as future: the power of legal restorationism in Estonia" (PhD diss., Columbia University, 2004). 
the Soviet Union as 'new Europe' has. Besides that, a common European history based on the Holocaust as a unique crime against humanity was already in the making when Estonia entered. This has incited debates in Estonian society on how to deal with their memory of Soviet repression. Can they allow a Holocaust narrative into their historical consciousness without betraying their memory of Soviet repression? And if they are expected to incorporate the Holocaust narrative dominant in the west, does that mean Estonians can expect Western Europeans to do the same with the memory of Soviet repression? Helena, one of my informants, a history teacher born in 1975, explained to me her fear: 'I am curious whether that means that France is going to learn about Estonian history as well then. Did you learn anything in school about Estonian history? [...] It is just not fair. Why do we need to learn about France and England and the Netherlands, and no one is learning about us?' (Helena 1975). Helena is afraid that within the European family, the memory narrative of Soviet repression is not strong enough to persist. At the same time, she and the majority of Estonians do not want to turn their backs to Europe either, as they very much want to belong to Europe. ${ }^{33}$ Polish sociologist Piotr Sztompka traces this 'emergence of the crippled, inferior, deficient and defensive identity of "incomplete Europeans"' to the period of modern capitalism and the Cold War, both periods in which the region lost its temporary importance in Europe. $^{34}$

This is the memory narrative of Soviet repression in which the interviewees in this chapter were raised and the story they carried with them to the Netherlands. But how do they relate to that narrative in the Netherlands? Which meaning does it have in their everyday lives in this 'foreign' context? What do they do with the story?

\section{The Story of Soviet Repression in the Netherlands}

As mentioned before, the story of Soviet repression is not 'rooted' in the Netherlands. The Netherlands was never part of the Soviet Union, nor were their citizens directly affected by the Soviet authorities due to the lack of a relevant historical or political affiliation. Soviet repression is thus not part of the collective memory of the Dutch community, which also implies that few

33 Melchior, Guardians of Living History. Melchior, Forming a common European memory.

34 Piotr Sztompka, From East Europeans to Europeans: Shifting Identities and Boundaries in the New Europe (Wassenaar: NIAs/Netherlands Institute for Advanced Study in the Humanities and Social Sciences, 2004). 
Dutchmen have knowledge of what happened behind that iron curtain. It was a far from their bed show. My informants mention that when the Soviet past comes up in a conversation, it is mostly when contemporary politics evoke a debate. The topics that most easily evoke discussion when Dutch interact with Estonians are the role of Russia and the minority rights/refugee crisis.

Siim, born in 1997, moved to Maastricht for his first years of study. He got befriended with two Estonians, one Dutch and one Slovak guy. 'Russia' and 'Putin' regularly entered their conversations: 'I would say that our thoughts and feelings were not completely different, but in the beginning I definitely noticed some differences. For example when I think of Putin's or Russia's politics I am quite negative. But they were not very excited about the theme, they were relatively neutral towards Russia and Putin' (Siim, 1997). Anna, born in 1991, studied in Utrecht for some time, and had the most serious discussion when she invited a friend from the Netherlands over to Estonia during the summer. Even though he was a history teacher and Anna expected him to understand that Estonian history is different from the Dutch one, he was posing her very critical questions about the minority question in Estonia. It gave her the feeling that he did not understand her (and the general Estonian) perspective on the matter, and that he assumed that his perspective was somehow superior.

For both Siim and Anna, the story of Soviet repression did not lose its importance because they were living far away from their homeland. It rather increased because it was constantly being challenged and they felt the need to defend their standpoint. Moreover, for Estonians, the Soviet repressions are not solely a story of their nation, as we just saw, but a family story as well, with a strong sense of loyalty towards relatives. Important to stress here is that both Siim and Anna were born in independent Estonia, are highly educated and outward-looking individuals, and yet that painful national history affects the present. Siim explained as follows why the Soviet narrative is important to him, regardless of the place he lives:

WWII and the Soviet period are very much entangled with my family and therefore this topic is of great interest to me personally. The family of my grandfather on father's side was not deported, but their suitcases were packed and they were ready to go, but fortunately no one came to knock on their door. [...] The whole family of my grandmother on father's side was deported to Siberia in March 1949, somewhere close to Omsk and Kazakhstan. My grandmother Eda turned 9 years old in that animal's wagon on the way to Siberia. [...] My great-grandfather on mother's side, Karl Vares, disappeared without a trace. One thinks that 
he died somewhere in Siberia. He had been on the side of the Germans. [...] My grandmother on mother's side was an Ingrian. Also her family has suffered a lot because of wwII. [...] the family fled the war to Russia, from where they were deported to Siberia and eventually they returned to Viljandi (Estonia).

SIIM, 1997

Seeing his family history and his interest in that family history, it is understandable why the story of Soviet repression is close to his heart and has not lost its significance in the Netherlands. Also Liisa, born in 1977, who married a Dutch man in 2000 , immediately recalls her family stories while explaining to me why the story of Soviet repression lingers in her life:

You know it is a wound (haav) and it is still fresh. We have only been free for 20 years. It still hurts. My grandfather, my own grandfather, he was on the list to be deported. He was an entrepreneur, he owned apple trees. They came to get him twice. One time he was in the swamp, the second time he was literally on top of a tree in the garden, hiding, while his wife and children were in the house. He was in danger but luckily he was never deported. You know, one evening they could come to pick you up to fight in the Soviet army and the next one - or sometimes even the same evening - for the German army. There was not a matter of choice.

LIISA, 1977

Because of its close ties with one's family, the story of Soviet repression does not lose significance in the Dutch context. Kadri (1984) moved to the Netherlands in 2009, two years after she got into a relationship with a Dutch man whom she had met in Estonia. For Kadri the Soviet repressions are not only important because of her family story but because she as a citizen is directly related to that history. 'It plays a big role in the identity of Estonians. The Soviet occupation and the Singing Revolution are at least to my generation an important part of our identity' (Kadri, 1984). Only one of the interviewees, Marii, 32 years old, mentioned that the Soviet repressions did not interest her that much. Marii, who moved to Eindhoven to pursue her $\mathrm{PhD}$ research, never asked her family for their story, and apparently her relatives did not feel the need to share it with her either. For Marii, the story does not play any role in defining who she is, as a person or as an Estonian. Except for her, all interviewees mention that the story of Soviet repression not just passively lingers on in the Dutch context, but rather seems 'activated' as it is constantly being challenged. 


\section{An Equal Listener?}

Once the Estonian emigrants share the story of Soviet repression with their Dutch classmates, neighbours and colleagues, their Dutch interlocutors either react (1) indifferently or judgmentally, or (2) with surprise and interest. As argued before, it is very important for the healing process and for establishing a fruitful relationship with others that one feels understood. ${ }^{35}$

Siim explained to me that he often felt misunderstood by his Dutch friends 'who had much more liberal worldviews' when he spoke about the danger of Russia. During these conversations he got the impression that the Dutch are not very interested in the Baltic region, or make any effort to learn more about it:

They could not place themselves in my perspective, and in general Estonia, as an Eastern European state and as neighbour of Russia, was not a topic that touched them in any way. [...] Here, I want to strongly stress that Dutch people in the beginning thought that the Baltic States, including Estonia, are 'basically Russia'. Of course I did not like this at all and I tried to explain to them, again and again, that Estonia and the other Baltic States are independent and significantly different from Russia. I would bring examples about our culture, our language, that we have the Latin alphabet, not Cyrillic and that our languages are completely different. And that we are different as a Volk. We are Finn Ugric people, not Slavic, and so forth.

SIIM, 1997

Kadri shares the same feeling that the Dutch are indifferent towards what happened in that eastern region; they do not really care:

I think that the majority of Dutch people is not interested in Estonian history and does not understand it very well. Generally they still think about Eastern Europe as one single eastern bloc and they know that those countries were once part of the Soviet Union. More nuances generally do not fit to that world view. Europe ends with the eastern border of Germany and anything that comes after that does not evoke any interest. Of course there are also people who are interested in Estonian history, but those are the people who learned about it at university.

KADRI, 1984 
Anna's Dutch friend who came to visit her in Estonia - a history teacher - was not indifferent towards Estonian history; he was rather interested and asked many questions. But like those Dutch interlocutors mentioned before, he did not give Anna the feeling that he was making an effort to understand her or 'the Estonian' perspective. He was rather judgmental in his response to her stories:

When I elaborately tried to explain Estonian history to him, I got the feeling that he did not understand it very well. Especially when we spoke about the relationship of Estonians with Russia and the Russians living here. He suggested many things and drew parallels with what was happening in the Netherlands. That people who come to the Netherlands are immediately forced to study the language, so that they will quickly integrate into their new society. It was difficult to convince him that it is not so easy to accomplish that in Estonia.

ANNA, 1991

In order to avoid the pain of being misunderstood, Saara (1970) rarely speaks with Dutch people about the Soviet past, even though the topic forms an important part of who she is. 'That is why we like to meet among Estonians, because we understand each other and we know the cultural background.' Among Estonians she does not have to defend or explain herself and they regard the Soviet repressions more or less similarly.

Liisa is one of the few who has had a different experience. The responses she sees among her Dutch interlocutors 'are mostly one of surprise. Did that happen such a short time ago? In your family? It suddenly seems near to them.' The story of Soviet repression is, like for the other interviewees, very important to Liisa because of her family history, but in contrast to the others, Liisa does not experience the same fear of contemporary Russia:

I think that what happened in the Ukraine cannot happen in Estonia, it is a different story. Dutch people ask me all the time whether I am afraid of Russia. No, I am not. It is our big brother, it will always be our neighbour and we need to have a diplomatic relationship with Russia. I also question why Russia would want to have Estonia. We do not have gold, no energy sources, nothing. We only have a good location, also in connection to the sea, but Russia, too, has that.

LIISA, 1977

The difference between the experiences of Liisa and the others illustrates how important it is to feel taken seriously and be equal partners. Because of the 
responses they got while explaining the sufferings during the Soviet period, Siim, Kadri and Anna have the feeling that they are not seen as equal partners by their Dutch compatriots. They have the feeling to be expected to respect their Dutch compatriots, whereas they cannot expect the same from them. This places them in an inferior position, which is especially hurtful in times of insecurity. Liisa, in contrast, perceives her story to be taken seriously, and talking to her Dutch compatriots as an equal.

\section{Double Victims and Agents of Change}

The inequality that Siim, Kadri and Anna perceive with the Dutch while talking about the Soviet repression, hurts not only because it misrecognizes the sufferings of their loved-ones, but also because their Soviet past excludes them from the European family. Italian anthropologist Cappelletto has referred to this phenomenon as 'double victimhood': as the post-generation they have not only become victims of the mass deportations to Siberia, they become victims for the second time because they are not being heard (in this case by 'old Europe').

The way in which Liisa relates to the story of Soviet repression is not as a 'double victim', but rather as an 'agent of change'. The latter term is coined by Iranian Dutch anthropologist Halleh Ghorashi who studied Iranian refugees who arrived in the Netherlands in the 1980 s and post-1990s. ${ }^{36}$ As an agent of change, Liisa realizes she has a voice that counts. She believes that the experience of Soviet repression should not only be seen as a burden that needs to be carried around, but also as an asset in comparison to Dutch people. She explains to me that the pain of being deported - 'a pain of a people (rahvava$l u)^{\prime}-$ also allows Estonians to put their lives into perspective to an extent that Dutch people cannot. According to Liisa, Dutch people often express: "I don't like that", "I don't want that". They are very ego-centric.' Also Marju, born in 1979 and married to a Dutch man, is able to derive positive lessons from her difficult national past:

I have noticed that my experiences and the way in which I grew up are completely different from the people here. I relate differently to food, for example. I eat even the very last piece, I don't throw anything away. Or when bread is a little bit old, I don't throw it in the bin. You have to eat

36 Halleh Ghorashi, Agents of Change or Passive Victims: The Impact of Welfare States (the Case of the Netherlands) on Refugees, Journal of Refugee Studies 18.2 (2005). 
everything. [...] the same with living space. Here people want the biggest houses and apartments, I am used to small rooms, people lived on top of each other. I don't need so much space. People here are more demanding. [...] History as such does not really trouble me here. But the fact that I have lived through it, that I have the experience of not being free, that we were becoming independent, that has been very ... that you can value what you have, that makes a big difference. And because we did not have much during my first years, I now very much value the fact that we have more than we used to have.

MARJU, 1979

Liisa and Marju thus not only share the story of Soviet repression in the Netherlands because they feel this is their responsibility towards their relatives and their compatriots, but also in order to teach their Dutch friends life lessons they are not able to derive from their own history. By doing so, they do not feel the homesickness and lack of power that double victims express. Agents of change actually feel empowered by sharing their memory of Soviet repression. They see and grasp opportunities. They believe they have the right to tell their story and that they have a voice that counts in the Netherlands.

For Liisa, one such act of grasping opportunities was establishing the 'Estonian School in the Netherlands'. Our interview took place during one of its school days: 'When we established the Estonian School in the Netherlands, it was a really emotional moment for me. You do this with all your heart. It is the language of your heart (südame keel) which speaks here. We want to pass on our culture and language to the next generation.' Instead of feeling disappointed that she could not raise her children in an Estonian context, Liisa grasped the opportunity to create this Estonian School far away from her homeland. The foundation of this school was important to her for various reasons. First of all, many Estonian emigrants find it important to raise their children with a 'national consciousness' and with an 'Estonian cultural spirit'. Estonian intellectual Jakob Hurt said already in 1870: 'We can never become great in strength and numbers, but we can become great in spirit and culture!' Since then, history has proven that culture is the strongest power tool Estonians have, manifested, for example, with the 'Singing Revolution'. Liisa and the other founders hope that the children of Estonian migrants will feel closer connected to the Estonian community by learning its language and social and cultural rules. Secondly, the Estonian school also familiarizes the Dutch with the Estonian culture and language.

Several Estonian emigrants acted as agents of change when they organized a public commemoration of the Soviet deportations in Amsterdam on 25 March 
2011, as portrayed on figure 6.1. Instead of commemorating the event in the safe space of their homes or in company of their Estonian friends, they decided to claim a central public spot (the Dam square in Amsterdam) and the right to share their story of Soviet repression in Dutch society. However, the incentive to organize a public meeting did not come from the Estonian migrants. They were invited to participate by the Estonian organization Tulipisar, which approached

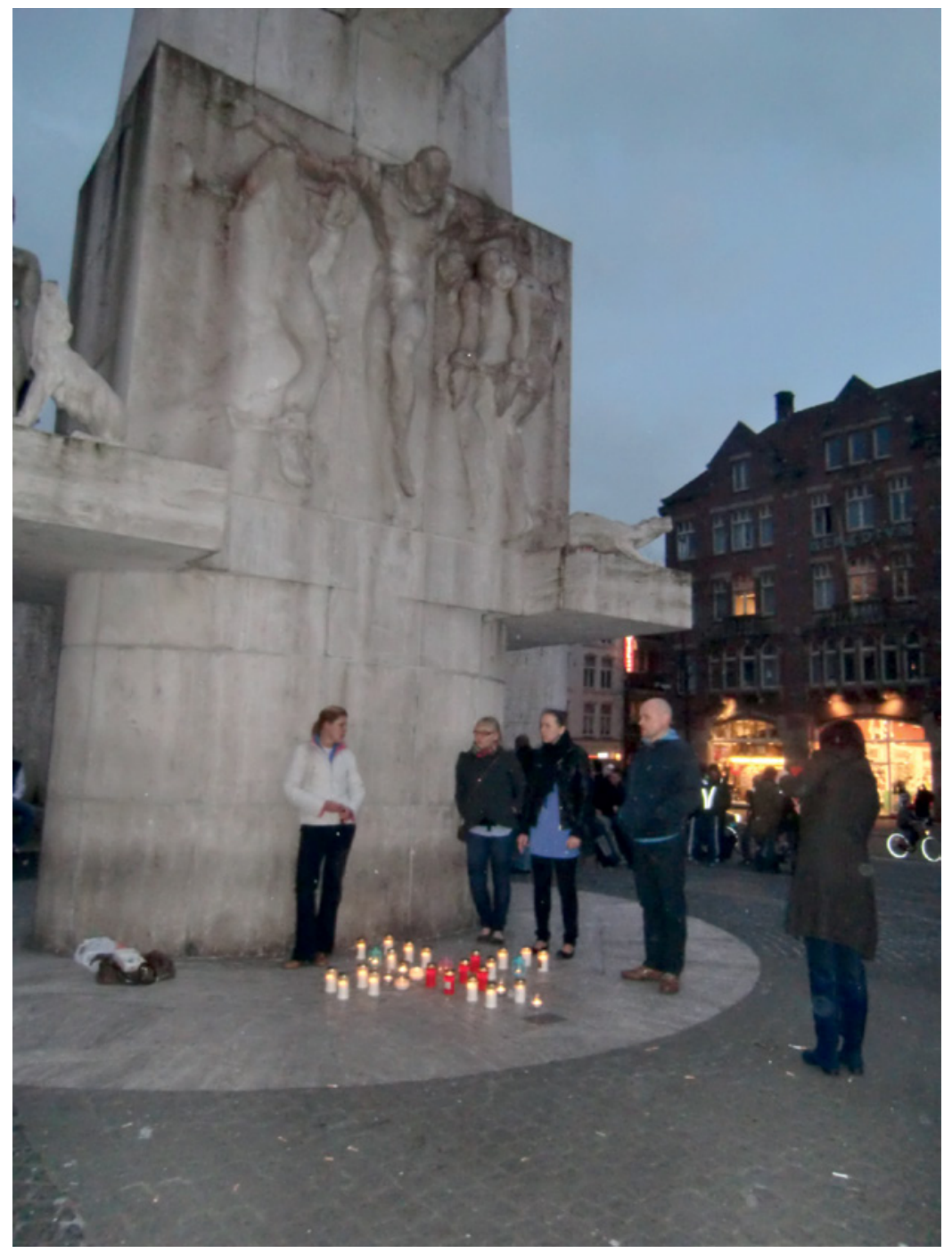

FIGURE 6.1 Remembering the Soviet deportations on the Dam square in central msterdam, 25 March 2011.

SOURCE: TULIPISAR.EE. PERMISSION GRANTED 
the Estonian School to ask if they wanted to light candles to commemorate the 22,00o Estonians who were deported to Siberia on Estonia's Remembrance Day. Estonians all over the world would join them. In Amsterdam around ten Estonians attended, while Dutch people passed by. Backed by the Estonian community all over the world, they dared to act as agents of change and make their voice heard. They lit several candles near the National Monument on Dam Square.

A particular person cannot be characterized as being either a double victim or an active agent. Of course one's personality influences how one positions oneself in a foreign context. But the context is at least as important. When Liisa's Dutch friends would unquestionably judge nationalism politics in Estonia, she might act as a double victim, feeling misunderstood by them. On other occasions, she might act as an agent of change, because she sees opportunities to teach them something new.

A good example of a recent contextual change are the political developments between the Netherlands (and other 'old Europeans') and Russia. Several interviewees mention that the public discourse in the Netherlands - and thus the 'safe space' to share their stories of Soviet repression - has changed drastically. A look into the newspaper articles that have appeared in the Dutch newspaper Volkskrant - aiming at the highly educated and slightly leftist/central population, and one of the three Dutch quality papers - reflects that change.

Right after the Baltic States entered the EU in 2004, the Dutch newspaper did not present a very understanding perspective on the fear that Estonian, Latvian and Lithuanian politicians expressed towards Russia. The fact that the presidents from Estonia, Lithuania and Georgia declined the invitation by Putin in 2005 to commemorate the end of WWII in Moscow, as the end of WWII was for them not a victory but the beginning of the subsequent Soviet occupation, the message was that emotions should not determine politics in a democratic world (Corine de Vries, Volkskrant, 10 May 2005). In the years that followed, the rational and pragmatic approach of the Dutch towards Putin's anti-democratic politics (for example his reaction to the murder of journalist Anna Politkovskaja, one of the most critical opponents of the Russian president) was praised (Bert Lanting, Volkskrant, 19 October 2006). Many EU countries depended on Russia for gas and oil, and closer cooperation was the goal. When Medvedev became Russia's new president in 2008, the EU commissioner Benita Ferrero Waldner spoke about investing in a 'partnership of equals': 'That is of great importance to our companies' (Volkskrant, 27 June 2008).

Understandably, sharing stories of Soviet repression in the Netherlands at this time dit not feel 'safe'. Especially when the five-day summer war between Georgia and Russia broke out, there was an increased wish on the part of the Estonian migrants to be understood, as they wanted to warn their Dutch 
interlocutors of the danger of Russia. They as 'experience experts' had knowledge that the Dutch did not have. However, the attempts by Polish, Lithuanian, Latvian and Estonian presidents to call upon the EU and NATO to decrease the intensity of cooperation with Moscow and to warn of the dangers of Russia, were interpreted as unrealistic fears that should not be taken too seriously (e.g. 'Polen weet wat het betekent', Volkskrant, 12 August 2008; Wim Bossema, Volkskrant, 19 January 2009). Eventually the EU chose not to enforce peace and put sanctions on Russia, but to send observers only (Theo Koelé, Volkskrant, $14 \mathrm{Au}-$ gust 2008). Afraid that their stories of Soviet repression would be interpreted in a similar way as those of the presidents, my informants found it very hard to share their stories and opinions at that time. At the same time, it was also painful to say nothing at all, with respect to their relatives who suffered.

Only three and a half years later, when the political situation in the Ukraine started to deteriorate, the fear felt by the Baltic States and Poland began to be represented as a fear that should be taken seriously. Putin had reacted quite aggressively and undemocratically to the pro-European steps that the Ukraine was taking. Especially the referendum which Putin initiated about the independence of the Crimea was presented as a farce, and the Russian soldiers sent to the Crimea as an illegal annexation that should be condemned (Hans Glaubitz, Volkskrant, 2 September 2014). The EU denied visas to Europe for certain Russian citizens and the European Commission decided to cancel the next EU-Russia summit. On 20 March 2014, the EU council concluded: 'The European Council firmly believes that there is no place for the use of force and coercion to change borders in Europe in the 21st century. The Russian actions are in clear breach of the Helsinki process, which in the past 40 years has contributed to overcoming divisions in Europe and building a peaceful and united continent.'

The EU followed the US and NATO in its condemnation of Russia's aggressive behaviour. Obama explicitly promized and sent the Eastern European countries military support and showed indefinite support for Ukraine's independence (Jan Hunin, Volkskrant, 5 June 2014). In this changing discourse, it was suddenly deemed a possibility that Putin would distort peace in Europe and send Russian jet fighters into European airspace (Stieven Ramdharie, Volkskrant, 30 October 2014). Moreover, what has changed for the Dutch since July 2014 is that emotions are allowed to play a role in the political relationship between Russia and the Netherlands, when the $\mathrm{MH}_{1}$ flight from Amsterdam to Kuala Lumpur was shut down by pro-Russian separatists on Ukrainian territory. According to Dutch minister Bert Koenders, a 'new equilibrium' should be found with Russia, but that 'business as usual is for the Netherlands no longer an option' (Theo Koelé, Volkskrant, 14 May 2015). 
In the present discourse, my Estonian interviewees have the feeling that there is more 'space' for their story of Soviet repression. It resonates better. Also, they have seen that Baltic and Polish politicians are taken more seriously by the old Europeans nowadays. The new members are acknowledged as having knowledge and experience that the Western Europeans lack. In this period, Estonian president Ilves, whose Facebook messages I closely follow, increasingly presented Estonia abroad as an 'experience expert' of Russia, that should be taken seriously: as an agent of change rather than a double victim. By taking that lead, Estonians like Liisa feel more confident sharing their stories as well. Liisa mentions that during the Ukraine referendum in the Netherlands, Dutch people started asking for her stories about Russia. Suddenly those stories resonate more with how their Dutch interlocutors and friends perceive the world. At that moment in time, Estonian emigrants felt that they could openly acknowledge their fear of Russia without the inherent need to defend that fear. It has become an increasingly common fear, instead of one of the new Europeans only.

\section{Conclusion}

In a previous extensive ethnographic study, I argued that the history of Soviet repressions is 'living' in Estonia. 'Living' here refers to the fact that Estonians from various generations are easily emotionally touched when it comes to stories of the repressive Soviet past. The memory of Soviet repression was written in the early 1990s as a 'people's story', in a time when every Estonian citizen was made and felt responsible to contribute to their small, young and newly established nation-state. Not incorporating the story of Soviet repression as part of one's identity as an Estonian is even nowadays often regarded as being a national betrayer.

By following Estonians who moved to the Netherlands (after 2000), I discovered that the Soviet repressions stay with those who have left their homeland. It can even be argued that it becomes more important, as the story is constantly being challenged by their Dutch interlocutors, who have no emotional connection to the Soviet repressions at all. The ethnographic approach taken in this chapter, combined with a focus on people who live outside of their homeland, has revealed that the 'agency' of people should not be overlooked when studying memory reception. After all, as I have found out, the Soviet repressions do not only make Estonians act upon their troubling past as 'double victims' but also as 'agents of change'.

Both within my (previous) fieldwork in Estonia and in the Netherlands, I have mostly encountered double victims. Double victims still suffer from the 
Soviet repression, because of the wounds that have not been healed and have been passed on to the next generation, and because the empathetic listener that is so essential to the healing process is not being met among the Dutch (or old Europeans in general). Many of the Estonians I spoke to - regardless of age and social background - experience a form of misunderstanding in Europe. They demand explicit external recognition as they feel 'existentially insecure' as a people; they are afraid that Estonians as a people might disappear and believe that keeping Estonian culture and history alive will prevent that from happening. ${ }^{37}$ Double victims defend the story of Soviet repression when they meet different understandings of recent history, yet at the same time they already expect 'the Other' to be unable to really understand the Estonian perspective.

In contrast, we met a few agents of change among the Estonians who live in the Dutch context. Agents of change do not defend the Soviet story as an inferior story that needs to be protected from being forgotten, but share it with their Dutch friends as a story from which they can learn something. Agents of change do not see themselves as backwards but as experience experts, not post-Soviets but equal Europeans, who can be teachers of the old Europeans, not only pupils.

The fact that I encountered possibly the first few 'agents of change' in 2015, might be related to changing public discourses, as I have pointed out in this chapter. The political relationship between the EU and Russia has become increasingly tense as the EU has condemned some of Russia's political moves. Thereby the public discourse has altered to a discourse that now resonates more with Estonian stories on the danger of Russia. Estonian emigrants, as opposed to Estonians living in Estonia, might see that there currently is a space in old Europe to share stories of Soviet repression in a sphere of equality and understanding. Moreover, Estonian emigrants might feel even more morally obliged to use the opportunities they have while living among 'the significant Other'; to share their story and educate the others with their unique knowledge. Former victims, who truly know the value of freedom in comparison to the Dutch to whom freedom is a given, become experts on Russia.

If the Estonian agents of change successfully manage to turn the Soviet sufferings from food for a European memory battlefield into important life lessons for all Europeans, then their ancestors will have suffered a little bit less in vain. Besides that, their compatriots back home might not judge them for leaving their homeland for a better life somewhere else, but praise them for being such good Estonian citizens, far away from home. 


\section{Acknowledgements}

I am grateful first and foremost to the Estonians who agreed to be interviewed for this chapter; thank you for your time and trust in my work. I also wish to thank the participants of the cosT conference 'Transcultural memory and reception in Europe' for their contribution to an earlier draft of this chapter, especially to my referent Steffi Hobuss for her extensive comments, and the cosT network for its financial contribution.

\section{Bibliography}

Adler, Nanci. “The Gulag Survivor: Beyond the Soviet System." In On Living Through Soviet Russia, edited by Daniel Bertaux, Paul Thompson and Anna Rotkirch, 212-232. London: Routledge, 2004.

Anepaio, Terje. "Reception of the topic repressions in the Estonian society." Pro Ethnologia 14.9 (2002): 47-66.

Berg, Eiki. "Local resistance, national identity and global swings in Post-Soviet Estonia." Europe-Asia Studies 54-1 (2002): 109-122.

Berliner, David. "The abuses of memory: reflections on the memory boom in anthropology." Anthropological Quarterly 78.1 (2005): 197-211.

Eastmond, Marita. "Stories as Lived Experience: Narratives in Forced Migration Research." Journal of Refugee Studies 20.2 (2007): 248-264.

Elias, Norbert and John L. Scotson. The established and the outsiders. New York: The Humanities Press, 1966.

Gheith, Jehanne M. and Katherine R. Jolluck. Gulag voices: Oral histories of Soviet incarceration and exile. New York: Palgrave Macmillan, 2011.

Ghorashi, Halleh. Agents of Change or Passive Victims: The Impact of Welfare States (the Case of the Netherlands) on Refugees. Journal of Refugee Studies 18.2 (2005): 181-198.

Goodman, Nancy R. and Marilyn B. Meyers, ed. The power of witnessing: Reflections, reverberations, and traces of the Holocaust. London/New York: Routledge, 2012.

Hirsch, Marianne. "The generation of postmemory." Poetics Today 29.1 (2008): 103-128. Hodgkin, Katharine, and Susannah Radstone. "Remembering suffering: trauma and history." In Contested pasts: the politics of memory, edited by Katharine Hodgkin and Susannah Radstone, 97-103. London: Routledge, 2003.

Jõesalu, Kirsti. "The role of the Soviet past in post-Soviet memory politics through examples of speeches from Estonian presidents." Europe-Asia Studies 64.6 (2012): 1007-1032.

Kansteiner, Wulf. "Finding meaning in memory: a methodological critique of collective memory studies." History and Theory 41.2 (2002): 179-197. 
Kõresaar, Ene. "Memory and history in Estonian post-Soviet life stories." PhD diss., Tartu University, 2004.

Lambek, Michael. "Foreword." In Memory and world war II: an ethnographic approach, edited by Francesca Cappelletto, xi-xvii. Oxford: University of Chicago Press, 2005.

Lambek, Michael and Paul Antze. "Introduction: Forecasting memory." In Tense past: Cultural essays in trauma and memory, edited by Michael Lambek and Paul Antze, xi-xxviii. New York: Routledge, 1996.

Malkki, Liisa H. Purity and exile: violence, memory, and national cosmology among hutu refugees in Tanzania. Chicago: The University of Chicago Press, 1995.

Melchior, Inge. "Guardians of Living History: The Persistence of the Past in post-Soviet Estonia." Phd diss., vU University Amsterdam, 2015.

Melchior, Inge. "Forming a common European memory of WWII from a peripheral perspective: Anthropological insight into the struggle for recognition of Estonians, WWII memories in Europe." In Disputed memory: emotions and memory politics in Central, Eastern and South-Eastern Europe, edited by Tea Sindbæk Andersen and Barbara Törnquist-Plewa, 203-226. Berlin: de Gruyter, 2016.

Mole, Richard M.C. The Baltic States from the Soviet Union to the European Union: Identity, discourse and power in the post-communist transition of Estonia, Latvia and Lithuania. London: Routledge, 2012.

Olick, Jeffrey K., and Joyce Robbins. “Social memory studies: From 'collective memory' to the historical sociology of mnemonic practices." Annual Reviews of Sociology 24 (1998): 105-140.

Pettai, Vello A. "Framing the past as future: the power of legal restorationism in Estonia." PhD diss., Columbia University, 2004.

Rahi-Tamm, Aigi. "Human losses." In The white book: losses inflicted on the Estonian nation by occupation regimes 1940-1991, edited by Vello Salo, Ülo Ennuste, Erast Parmasto, Enn Tarvel, and Peep Varju, 25-46. Tallinn: Estonian Encyclopaedia Publishers, 2005.

Snyder, Timothy. Bloodlands: Europe Between Hitler and Stalin. Philadelphia: Basic Books, 2010.

Sztompka, Piotr. From East Europeans to Europeans: Shifting Identities and Boundaries in the New Europe. Wassenaar: NIAs/Netherlands Institute for Advanced Study in the Humanities and Social Sciences, 2004. 
-978-90-04-35235-3

Downloaded from Brill. com $04 / 26 / 2023$ 03:12:38PM via free access 


\section{PART 2}

Content and Media in Transcultural Transmission and Reception 
-978-90-04-35235-3

Downloaded from Brill. com $04 / 26 / 2023$ 03:12:38PM via free access 


\title{
Commemorating a War That Never Came: The Cold War as Counter-factual War Memory
}

\author{
Rosanna Farbøl
}

The fall of the Berlin Wall made the Cold War a historical era. It does no longer exist as an ideological and security policy challenge, but as cultural memory and imaginary, political guideline and moral compass, it has a lingering contemporaneity. Still, the Cold War has not received much attention within the field of memory studies. ${ }^{1}$ Whereas scholars of this discipline have long had a strong commitment to studies of war memory and commemoration of conventional 'hot' wars, such as the First and Second World Wars, ${ }^{2}$ the Cold War has not been a popular topic. It has been argued, by among others Jan-Werner Müller, that the Cold War does not easily lend itself to commemoration because it was a cold war. ${ }^{3}$ Though it involved fierce rivalry in politics, economics, culture, and, not least, in the military arms race, it never became a war in a classical sense: declared, open and armed warfare between armies of adversarial political communities. ${ }^{4}$ To add to the Cold War's peculiar character as an absent war, it lasted half a century, it was a war without a clear and undisputed

1 David Lowe and Tony Joel: Remembering the Cold War: Global Contest and National Stories (London \& New York: Routledge, 2014). The Vietnam War is a major exception to this rule, though it is often treated as a "separate" event, and not in a Cold War context.

2 See i.e. Jay Winter, Sites of Memory, Sites of Mourning. The Great War in European Cultural History (Cambridge: Cambridge University Press, 2005 [1995]); Ashplant et al.: The Politics of War Memory and Commemoration (London \& New York: Routledge 200o); Martin Evans and Ken Lunn, eds., War and Memory in the Twentieth Century (Oxford \& New York: Berg, 1997); Winter and Sivans, eds., War and Remembrance in the Twentieth Century (Cambridge: Cambridge University Press, 1999); A. Whitmarsh: “'We Will Remember Them" Memory and Commemoration in War Museums', Journal of Conservation and Museum Studies 7 (2001), accessed 2 June 2016, doi:10.5334/jcms.7013.

3 Jan-Werner Müller: "Introduction: the power of memory, the memory of power and the power over memory" in Memory and Power in Postwar Europe. Studies in the Presence of the Past, ed. Jan-Werner Müller (Cambridge: Cambridge University Press 2002), 2.

4 This understanding is inspired by the entries 'war' in Encyclopedia Britannica, http://global .britannica.com/EBchecked/topic/635532/war and Stanford Encyclopedia of Philosophy, http://plato.stanford.edu/entries/war/ [both accessed 19 January 2015].

(C) ROSANNA FARB ØL, 2017 | DOI 10.1163/9789004352353_008

This is an open access chapter distributed under the terms of the CC-BY-NC License. 
beginning and ending, and the losing side never suffered total defeat like Nazi Germany. The Cold War, thus, lacks some of the most important and powerful lieux de mémoire, which usually function as facilitators of cultural memory and as occasions for mediating myths and narratives, thereby confirming the unity and identity of the community adhering to them. ${ }^{5}$

Yet, this article argues, in Denmark the Cold War is remembered and commemorated, to a great extent, as a war. ${ }^{6}$ And, in the proccesses of establishing this Cold War cultural memory as a war memory, it has become part of a transcultural passion for memories of traumatic pasts: war, violence, catastrophes, loss and victimhood. ${ }^{7}$ In this article, I will present a brief overview of commemoration of the Cold War as heritage, and more specifically war heritage. I highlight the notion of absence, both in relation to the character of the Cold War itself and in terms of reception, remembrance and commemoration. However, instead of considering the absence of war and destruction an obstacle that renders the Cold War unfit for memory work, I contend that this anomaly actually makes the Cold War a very usable past. I call the war memory of a war that never happened a counter-factual war memory. I also argue that the Cold War as cultural memory is multi-directional in the sense that it cannot be understood without paying attention to the Second World War as narrative and mnemonic template.

As case studies, I examine Danish museums and heritage sites. In the last decade, the Cold War has officially been embraced as Danish heritage, and concurrently there has been a remarkable multiplication of Cold War museums, many opened on the initiative of local communities. Even though 'heritage' and 'memory' tend to be treated as separate, even occasionally mutually exclusive concepts, I contend that they can fruitfully be employed in the same analysis, because 'heritage' is a form of (problematic) identity building and memory structuring. Hence, I consider heritage sites and museums powerful agents of cultural memory. The memories, narratives and interpretations endorsed at such institutions are awarded a certain legitimacy, because they are sanctioned by sites that signify knowledge, authority and power. They are,

5 Pierre Nora, "Between Memory and History: Les Lieux de Mémoire", Representations 26 (1989), 7-24.

6 This article is a development of some ideas and reflections from my $\mathrm{PhD}$ dissertation and my latest article "Commemoration of a cold war: The politics of history and heritage at Cold War memory sites in Denmark", Cold War History 15/04 (2015), 471-490.

7 On traumatic pasts as a key area of memory studies see e.g. Astrid Erll, "Traumatic pasts, literary afterlives, and transcultural memory: new directions of literary and media memory studies", Journal of aesthetics and culture, 3 (2011). 
therefore, potentially very influential in the processes of Vergangenheitsbewältigung. ${ }^{8}$ Furthermore, museums and heritage sites constitute an intersection where political, public and academic narratives meet. Thus, it is a field particularly useful for examining the construction, contestation and reception of narratives and memories of the Cold War.

My findings reveal a paradox: the museums and heritage sites in Denmark present a war narrative of the Cold War, yet, beyond these official memory institutions, I find that a public culture of war commemoration of the Cold War is largely absent; the war memory is not reflected in a larger war commemoration culture. Moreover, from a perspective of memory reception, it is remarkable that the museums and the heritage project, though popular, do not seem to foster any particular reaction in society, either from politicians or citizens. The article therefore ends with a discussion of some paradoxes of the counterfactual war memory. However, to begin with, some remarks about the context of the discussion are necessary because the commemoration of the Cold War as a war is not uncontested and consensual.

\section{Contestation of Cold War Memory in Denmark}

Despite Denmark's, for the most part rather insignificant and uncontroversial, involvement in the Cold War, a fierce debate has raged since the fall of the Wall over how to interpret the period. The Cold War is a very contested past in Denmark, not least in comparison with the other Scandinavian countries. ${ }^{9}$ The conflict has increasingly become entangled in contemporary party politics, and political and cultural elites (as well as the population) are divided into different memory communities. The tensions that have risen from memory clashes between these communities have had direct political consequences and have

8 Sharon Macdonald, Memorylands. Heritage and Identity in Europe Today (New York: Routledge 2013); Sharon Macdonald, "Introduction" in Theorizing museums, eds. Sharon Macdonald and Gordon Fyfe (Oxford: Blackwell Publishers 1996); Gaynor Kavanagh, "Making Histories, making Memories" in Making Histories in Museums, ed. Gaynor Kavanagh (London: Leicester University Press 1999), 1-15; Lucy Noakes, "Making Histories: Experiencing the Blitz in London's Museums in the 1990s" in Evans and Lunn, War and Memory, 89-105.

9 Thorsten Borring Olesen, "Truth on demand. Denmark and the Cold War", in Foreign Policy Yearbook, eds. Nanna Hvidt og Hans Mouritzen, DIIS 2006, 80-114; Tor Egil Førland, "Den danske debatt om Den Kolde Krig", Historisk Tidsskrift, hft. 2, 2002, 586-598; Tor Egil Førland, "Den kalde krigen, historikerne og ytringsfriheten", Nytt Norsk Tidsskrift, 3/31, 2014, 210-224; Rosanna Farbøl, Koldkrigere, medløbere og røde lejesvende. Den Kolde Krig i dansk historiekultur 1985-2015 (under publ). 
lead to a large scale political showdown. The Cold War was, for instance, a major part of the discussions about the Danish involvement in the war in Iraq in 2003, and more generally about the Danish foreign policy profile, and sins and errors of the past were used to legitimize contemporary policy options. The show down has also taken the form of a trend that can be called 'truth on demand': The Danish Parliament has so far commissioned specific Cold War research for more than 13.5 million euros to 'set the historical truth right'.

It is not just a simple 'right-wing versus left-wing' conflict. There are, in fact, three competing Cold War narratives. The first I call the conflict narrative. The Cold War is interpreted as an all-embracing ideological war between the good, democratic West and the evil and communist East, where neutrality was not an option. The Cold War is seen as a war against totalitarianism, and thus a continuation of the Second World War. In stark opposition, we find a protest narrative, which understands the Cold War as an ordinary geo-political and economic super power conflict (and, importantly, not a war) between two imperialist countries. Also in this narrative it is crucial that totalitarian Fascism was not beaten in 1945, but seen to have survived inside the Western so-called democratic states. In between the two narratives, there is a third, the consensus narrative that shares characteristics with both of the others. The Cold War is here understood as conflict both in terms of ideology and super power realpolitik. Denmark's role is seen as that of a balanced, responsible and morally superior small state.

These three narratives are employed by the competing memory communities to structure, interpret and make sense of the past. They also function as mobilization for actions in the present, with the past used as a guide. This became particularly apparent in Denmark in the 200os, when the then Prime Minister Anders Fogh Rasmussen re-appropriated the conflict narrative to legitimize Danish participation in the 'war on terror.10 During both the Second World War and the Cold War, he argued, Denmark had failed our allies by leading a cowardly policy of neutrality. In the eyes of Fogh Rasmussen, the war on terror was a direct continuation of the wars against totalitarianism. Because of

10 Rosanna Farbøl, "Framing the Past, Shaping the Future: the Political Uses of the Foreign Policy Tradition in Contemporary Danish Politics" in Nordic Cold War Cultures: Ideological Promotion, Public Reception, and East-West Interaction, eds. Valur Ingimundarson and Rósa Magnusdóttir (Helsinki: Aleksanteri Institute 2015), 189-206; Rasmus Brun Pedersen, "Past, present, and future: the role of the Cold War in legitimizing Danish foreign policy activism", Cold War History 16/1 (2016), 101-20. 
the 'double shame' of the past, Denmark now had the moral and political duty to assist those who had saved us twice.1

This example illustrates that Cold War remembrance and the reappropriation of it as a war can have direct political bearings. Furthermore, the contestation of narratives and competition between memory communities is of consequence for the paradoxical and counter-factual war memory examined below. Now, we will turn our attention to how the Cold War is being narrated, mediated and aestheticized as a war memory.

\section{Cold War Heritage}

In the last decade, but in particular the last three or four years, the number of Cold War related museums in Denmark has increased noticeably. There are now a total of seven Cold War museums, which is quite a large number for such a small country. ${ }^{12}$ In general, the Danish Cold War museums portray the Cold War in the way 'hot' wars usually are presented in historical tourism both nationally and internationally: with a strong focus on the political-military perspective of the conflict, on weapons, technology, soldiers and major political and military decisions (although, in contrast to other war museums, there is an obvious absence of battle decriptions). Five of the museums are even located in former Cold War military and civil defence fortifications. It is the hypothetical and counter-factual war that forms the basis of their Cold War narratives. For instance, at Odense Bunkermuseum, which is located in a former command centre, the whole exhibition is concentrated on the military and civil defence of Odense during the Cold War and, importantly, how it would operate during war. It is the 'during war' or if-perspective that rules the exhibition: the military threat scenario, the phases of state of emergency, and the procedures for how to operate during 'hot' war.

11 It should be noted that the other political parties likewise found their reasoning in their Cold War narratives. The left wing saw the whole mission as yet another result of American imperialism and desire for global dominance, whereas the advocates of the consensus narrative had some difficulties deciding whether they could support the war or not, if the UN got involved.

12 Until 1997, the Langelandsfort was the only museum dedicated to the Cold War. Stevnsfort became a museum in 2008, and in 2012 Odense Bunkermuseum and the Ejbybunker opened, followed by Panzer Museum East and Silkeborg Bunkermuseum in 2014 and Dansk Koldkrigsmuseum in 2016. 
In particular the smaller museums present an exclusively military defencedominated Cold War narrative, whereas the two largest museums, Stevnsfort and Langelandsfort, attempt to make the presentation more complex. Langelandsfort used to be a museum primarily of interest to those with an intellectual passion for military hardware. The exhibition was mainly concerned with bunkers, cannons, missiles, jet fighters and submarines. ${ }^{13}$ However, this has changed in recent years. Today, the museum is keen to situate the fort in a broader Cold War framework, connecting the island of Langeland to the NATO defence system and the development of the conflict, thus connecting local, national and global history. At present, both Langelandsfort and Stevnsfort place considerable emphasis on presenting, on both a national and international level, the cultural, social and political developments that influenced life in the forts and in Denmark. Yet, they do this without relinquishing the military perspective. The forts were built for war, crewed by marines and visited by NATO generals. Their whole existence was based on imminent war and, as such, the war is present as a master narrative.

This representation of war is important because, firstly, objects, events and interpretations are provided with a particular legitimacy when they are displayed at a museum. The history and narratives that are institutionalized in this way often have at least the potential to become dominant in the visitors' construction, adaptation and reception of memories. ${ }^{14}$ Secondly, it reflects a tendency, deliberate or not, to represent the Cold War along familiar narrative memory frames. Specifically, the representations resemble the way the Second World War is exhibited in Danish museums at, for instance, the Resistance Museum in Copenhagen and at museums in former German bunkers along the West coast of Jutland such as the Hanstholm Museum. In the way the 'war' is presented at Cold War and Second World War museums, there is much cross-referencing and borrowing of exhibition formats, aesthetics and narrative templates: the presentations of themes, soldiers, weapons and the geopolitical and military context are strikingly similar - even though the Cold War never became hot. Instead of finding a novel and original way of constructing the past as cultural memory, old templates are reused. Arguably, what we witness is the Cold War as a remediation of the Second World War. As a lieu de mémoire, it seems to refer not only to the actual event, the Cold War, but to the canon of representations of the Second World War, the 'established' way of how to represent war memory. ${ }^{15}$

13 Ole Mortensøn, Fortet og den kolde krig, Museum Langelandsfort 2006.

14 Noakes: "Making Histories", 89-105.

15 See Astrid Erll's use of the concept of remediation in "Traumatic pasts, literary afterlives, and transcultural memory: new directions of literary and media memory studies", Journal 
However, there are two major differences compared to war exhibitions in general: Firstly, the museums' representation of a war memory lacks an important characteristic of 'classical' transcultural war memory: there is no display of death, loss or suffering, and there are no victims or martyrs. Negative consequences of war are totally absent, so what remains is a purely celebratory, not a mourning, commemoration. ${ }^{16}$ The actors are presented as stereotypical heroes: brave and jolly Danish soldiers constantly on the look out for, even at times engaging with, the enemy or spies (significantly it is only occasional contact, never actual combat).

Secondly, the museums go to great lengths to make the visitors' experience transgress the lines between observing and participating. Indeed, I would argue, they go further than would be generally accepted at museums dealing with the Second World War. At Langelandsfort, for instance, a whole bunker is dedicated to a thematic exhibition of the counter-factual Third World War and the Danish preparations for it. Most spectacularly, visitors can push two buttons on a screen showing a quote by a famous lieutenant general about the possible nuclear attack on the island of Langeland: The visitor has unleashed a nuclear attack. Suddenly, hidden loud speakers in the roof make a terrible noise, the light flickers, then goes out and the floor begins to quake. The video on the screen shows footage of nuclear explosions, the blasts and the terrible destruction it causes, all the while the visitors can 'hear' the explosions and 'feel' the blast waves. ${ }^{17}$ This is a remarkably transgressive interaction with the past. Whereas it would be unthinkable that a museum would allow its visitors to interact with the Second World War to an extent that included the possibility of, for instance, denying the Holocaust or pretend to release gas over prisoners, there is apparently no similar hegemonic moral and ethical paradigm

of aesthetics and culture, 3 (2011). Also in Berlin, commemoration of the Second World War and the Cold War seem to be intricately linked, though it's arguably not directly a remediation process, see Keith R. Allen, "Wall Remains, Holocaust Memorials, and Prussian Heritage: Reflections on Cold War Commemoration in Germany", Perspectives on History, $82(2), 2014$.

16 It could be argued here, that regarding this particular aspect, Cold War commemoration at Danish museums actually resembles "old-fashioned" war commemoration practices at museums, because museums during the 2oth century developed a tradition of portraying a sanitized and glamorized version of warfare, see Andrew Whitmarsh, "We Will Remember Them: Memory and Commemoration in War Museums", Journal of Conservation and Museum Studies 7 (2001).

The visitor is not informed about where the footage comes from, or whether it is real or fake. 
concerning the loss of human lives in a nuclear apocalypse. ${ }^{18}$ I suggest this is because it is already counter-factual. Precisely because the Cold War never became a hot war, it lends itself so easily to the counter-factual play and imagination of what could fill out the absence of war if ...

Alongside the musealization of the Cold War, it was also officially declared 'Danish national heritage' in 2013 by the state Agency for Culture. This was the climax of a project, inspired by smiliar projects in Germany and the United Kingdom, that aimed to map all Danish Cold War installations and areas and subsequently designate and preserve 33 of them estimated to be of 'national significance.' The results were published in a book called Kold krig [Cold War] and online..$^{19}$ The project had been underway since the turn of the millennium with the full political, if not economic support, of the Minister of Culture 2001-08 Brian Mikkelsen (Conservative). Mikkelsen was very interested in the Cold War and had been a keen participant in Cold War related discussions in public debate. ${ }^{20}$ At a conference in 2008, the Minister explained why it was so important to him to designate this specific past 'heritage.'21 The Cold War was central to Danish identity and for the Danes' ability to manoeuvre in the contemporary world, he claimed. The Cold War had been a battle of values, and the war on terror was a continuation of that battle. Only by understanding the present conflict in a Cold War perspective could the clash between the West and Islamist terrorism be fully understood, according to Mikkelsen.

The selection and designation of heritage is a normative action. Heritage is not something that 'exists' as independent entities of the past, but something we socially and culturally create in the present by selecting objects, events and traditions (among other things) from the infinite amount of traces of the past and elevating them to a special status, heritage, because we consider them to

18 A similar counter-factual possibility for museum visitors to "drop" a nuclear bomb is found at the Lithuanian Cold War museum Plokštinè missile base.

19 Morten Stenak et al., eds., Kold Krig. 33 fortcellinger om den kolde krigs bygninger og anloeg i Danmark, Fcerøerne og Grønland, (Kulturministeriet: Kulturstyrelsen, 2013) and http:// slks.dk/kommuner-plan-arkitektur/kommune-og-turisme/kold-krig/ [acessed 19 January 2015].

$20 \quad$ Brian Mikkelsen, "Ti scener fra Den Kolde Krig”, Berlingske Tidende, 11 June 2003; Brian Mikkelsen, "Trusten fra Sovjetimperiet var reel", Jyllands-Posten, 5 September 2005; Brian Mikkelsen, "I den sorte gryde", Weekendavisen, 27 June 2003; Brian Mikkelsen, "Reagan var en helt", Jyllands-Posten, 11 June 2004; Brian Mikkelsen, "Det handler om frisind", Politiken, 4 September 2003; Brian Mikkelsen, "Kulturpolitiske visioner", Information 6 September 2008; Brian Mikkelsen, "Historien frikender ingen", Berlingske Tidende 21 January 2007.

21 www.artilleriet.dk/artikel/36o8-Historie--krigen-der-aldrig-kom.htm orlogsmuseet [accessed 8 May 2014]. 
be vital to our history and our identity. ${ }^{22}$ Like the museums, the Agency presents a master narrative of war. With the possible exception of a conscientious objector camp, all 33 areas and installations chosen were part of the 'total defence': the military and civil defence. On the list are e.g. the two major forts at Stevns and Langeland (which are now museums), the NATo head quarter in Western Denmark, a naval station, Thule air base in Greenland, barracks, control centres, depots, air defences as well as stations of civil defence. All the sites were constructed with a view to the war that never came. Some were operational during the Cold War, others were on standby, ready for the worst case scenario. In addition to the material sites, the Agency included a number of chapters in the book about Denmark's integration into NATO, war technology, protection of civilians, the intelligence services, military architecture etc. It is the (absent) nuclear, catastrophic and counter-factual war that is the symbolic and narrative structure for the Cold War experience.

Altogether, the project conveys the image that during the Cold War, in contrast to 1940, Denmark was ready to fight in the war. The Cold War is in this project reappropriated through a narrative of a heroically fighting Denmark (or at least a Denmark prepared to do so). The war narrative must be understood in light of the collective memory of the German occupation during the Second World War, of the shame of collaboration, as well as heroization of the Resistance movement. ${ }^{23}$ Since the 1970 , historians have steadily deconstructed the glorifying master narrative by breaking down myths of widespread resistance, of the strategic value of sabotage and of the heroic and democratic motives of the freedom fighters and the Danes who saved Jews. The Agency's reappropriation of a heroic narrative of a war and battle-ready Denmark can, in this light, be seen as a national redemption project.

\section{Reception of the War Memory}

Langelandsfort and Stevnsfort each has approximately 40,000 visitors per year, which is a relatively high figure for a Danish historical museum. ${ }^{24}$ The interest

22 This concerns of course not only the heritage site as an object, but rather the immaterial mythical meanings attached to it.

23 Claus Bryld and Annette Warring, Bescettelsestiden som kollektiv erindring (Frederiksberg: Roskilde Universitetsforlag, 1999); Uffe Østergaard, "Swords, Shields or Collaborators? Danish Historians and the Debate over the German Occupation of Denmark" in Nordic Narratives of the Second World War. National Historiographies Revisited, eds. Henrik Stenius, Mirja Österberg and Johan Östling (Lund: Nordic Academic Press, 2011), 31-55.

24 http://www.langelandsfortet.dk/sdu-langelandsfort_dkl.htm; https://www.kalklandet. $\mathrm{dk} /$ sites/default/files/arsberetning_2013_o.pdf. For the sake of comparison, the open-air 
in the material landscape of the Cold War is part of the constructions and negotiations for a cultural memory, and it is therefore significant that both the museums' and the Agency's efforts can be seen as an aesthetization of war memory. Moreover, this seems to be perceived and received by the public as unproblematic, convincing or even natural - or perhaps of no consequence. It does not result in any noticeable reactions from the visitors. Only Stevnsfort has made user surveys among their visitors. These are primarily statistical analyses of how satisfied the visitors are with the general experience of the museum, the exhibitions, the atmosphere, the level of service etc., as well as demographic, gender and motivation analyses of the visitors themselves. They have not made qualitative reception analyses, so in order to examine the visitors' reactions to specific exhibitions or the war narrative, we have to rely on a sparse and relatively limited source material from the public sphere, for instance newspapers or social media. On the online travel review-site TripAdvisor, only 39 Danes have rated Langelandsfort in the period 2014 (July)-2016 (October). ${ }^{25}$ The reviewers were in general excited about the museum, and in particular they mentioned the submarine, the jet fighter, the thrill of being inside military installations, as well as the pretty grounds. None of them mentioned the interactive exhibitions, and none of them reflected on what kind of Cold War narrative they had been told. ${ }^{26}$ Stevnsfort received 64 reviews on tripadvisor from 2014 (August)-2016 (October). Like the reviews of Langelandsfort, they were very positive. The visitors were especially thrilled that many of the guides were former marines who had worked at the fort. It gave them a feeling of getting a close and personal connection to history. One of the visitors called it 'a jump back to the time of war, which comes really close to you'. ${ }^{27}$ It is also noteworthy here, of course, that the visitor talks of 'the time of war'. He does not reflect on this, however. The visitors are also fascinated by the military

museum The Old Town in Aarhus had approx. 480,00o visitors and the Second World War museum in Hanstholm approx. 51,00o visitors in 2013, http://www.dst.dk/da/Statistik/emner/museer-og-kulturarv/museer.aspx [accessed 8 January 2015].

25 The earliest reviews of Langelandsfort are from 2012. However, in this research, I have focused on the period 2014-2016 because I was particularly interested in responses to the interactive exhibition that opened in 2014. However, surprisingly, this is not mentioned in the reviews.

26 https://www.tripadvisor.dk/Attraction_Review-g189521-d1137517-Reviews-or3o-Museum _ Langelandsfort-Langeland_Funen_and_Islands.html/BackUrl\#REVIEWS [accessed 29 September 2016].

27 https://www.tripadvisor.dk/ShowUserReviews-g1820371-d2234809-r407893498-Cold_ War_Museum_Stevnsfort-Roedvig_Stevns_Municipality_South_Zealand_Zealand .html\#CHECK_RATES_CONT. 
hardware, canons, tanks, missiles etc. and Stevnfort's role in NATO. Only one visitor comments directly on the war narrative he is presented with: '... exciting stories, but, as usual, with a fascination with war and military tradition.' ${ }^{28}$

With the exception of the quote above, the tripadvisor reviews represent uncritical reception and engagement with the war narrative presented at the museums. In addition, they are rather limited fora that you visit if you have been to one of the museums and have an opinion you would like to share with other visitors or, of course, with the museum staff. They speak primarily to 'those already in the know', not the general public at large, and they do not generate a public discussion of how Danish museums represent the Cold War. Such a discussion could perhaps more likely be found in newspapers, either in review articles or in letters to the editor. However, a search in the Danish online archival system for newspapers, infomedia, results in many articles about the forts, but no discussions or critical engagements with their exhibitions. The reporters and visitors seem to either just absorb and receive the war narrative uncritically or agree to an extent that they do no feel the need to critize or object to the narrative. This is, of course, a tentative conclusion as the source material is very sparse.

The museums and heritage sites are popular, but even with the above reservation in mind, it seems safe to conclude that they do not cause any significant reation or debate in society. This is perhaps surprising, when it is taken into account that the Cold War causes much conflict in the political sphere. One explanation could be that Danish museum visitors are uncritical and easily satisfied. Another is that the world of museums and heritage has succesfully managed to stay clear of the political and ideological Cold War battle. ${ }^{29} \mathrm{~A}$ third possibility is that the war narrative presented here is sufficiently vague to be acceptable to both the conflict and the consensus narrative. One the one hand, it does aestheticize the Cold War as a war and the threat as a real threat, which is a key point in the conflict narrative. On the other hand, it portrays a Denmark that was prepared to fight for sovereignty and democracy and that took its defence responsibilities seriously. Thus, it complies with the consensus narrative in stressing that Denmark was a loyal NATO ally. The Cold War as a war is acceptable, plausible and fascinating to the heritage and museum visitors.

28 https://www.tripadvisor.dk/ShowUserReviews-g1820371-d22348o9-r398799126-Cold_ War_Museum_Stevnsfort-Roedvig_Stevns_Municipality_South_Zealand_Zealand .html\#CHECK_RATES_CONT.

29 I have developed this line of argument in Rosanna Farbøl, "Commemoration of a cold war: The politics of history and heritage at Cold War memory sites in Denmark", Cold War History, 15, 2015, 471-90. 
The fascination of the Cold War as a war is matched by a generel popular interest in war history, which is reflected in the large sales of books on war history, visits to war museums etc. ${ }^{30}$ This should probably be understood in connection with the present status of Denmark as a country at war. Since the end of the Cold War, most fervently in the 200os, Denmark has assumed a new role of being at the front line of the interventions in Afghanistan, Iraq, Libya and Mali, as well as in hunting pirates on the coast of Somalia and fighting against ISIs. The current militarized foreign policy is a profound change in the country's 'small state mentality' (an expression used by, among others, former Prime Minister Fogh Rasmussen), a self-perception as a bridge-builder, the 'UN's best friend' and a stout advocate of diplomatic solutions and dialogue.

On an existential level, as humans, we often project the challenges of the present onto the past. In times of war - with the cost of dead and wounded soldiers - it comes as no surprise that we find war history interesting and relevant, because we can use the past to explore what it means to be 'at war' and how to handle this as a nation and as humans. On a more practical and political level, Liberal and Conservative politicians have repeatedly compared the war on terror with the fight against Nazism and Communism in newspapers and speeches, thus making the connection between past and present wars explicit. ${ }^{31}$ The past experiences of Communism and Nazism are reappropriated to frame and make sense of the war on terror.

Both on the existential and the political level, linking the Cold War to the Second World War is necessary in order to make the Cold War function not only as orientation and explanation (the Cold War as a universal, essential and existential war between 'good' and 'evil'), but also to mobilize action in specific contemporary settings. There was an absence of war in the Cold War, as the Western world never went to hot war for democracy and freedom - unlike in the Second World War. However, the narrative frames and memory templates

30 Niels Kayser Nielsen, Historiens forvandlinger (Aarhus: Aarhus Universitetsforlag, 2010); Lars Ole Knippel, "Museer om forsvaret: Eksplosiv interesse for krigshistorien", JyllandsPosten, 18 January 2007; Karin Dahl Hansen, "Krigshistorie på vej tilbage”, Kr. Dagblad, 26 November 2008; Mikkel Vuorela, "Den kolde krig har fået greb i danskerne", Politiken, 22 July 2013 .

31 For example in debates in the Parliament: Folketingstidende (FT) 2002-03 B 118 1. Beh; FT 2003-04 F7; FT 2003-04 B 213 2. Beh; FT 2003-04 - S 2927; FT 2004-05, 1. saml. B 42, 1+2 Beh.; 2004-05 2. saml. B 89; In newspapers see for example Anders Fogh Rasmussen "Hvad kan det nytte" Berlingske 2 March 2003; in speeches see Anders Fogh Rasmussen 4.5.05, Tale i Mindelunden 4.5.05 http://www.stm.dk/_P_750o.html [accessed 21 February 2011]; Fogh Rasmussen, Anders 15.6.05, Tale ved Folketingets åbning http://www.stm .dk/_p_7495.html [accessed 21 February 2011]. 
used to make a previous war a cultural memory are transferred to the Cold War, and the cultural memory of the Cold War becomes a remediation of the Second World War, thus the Cold War memory can be used to call for action.

\section{(Absence of a) Cold War Commemoration Culture}

However, now we encounter a paradox: On the one hand, cultural memory of Cold War is part of a transcultural fascination with war memories, and is constructed in much the same ways. On the other hand, compared to 'classic' culture of war commemoration, Danish Cold War remembrance lacks many important features. Modern wars have given rise to in many ways similar forms of cultural remembrance: memorials, traditions, national holidays etc., in the Western world. ${ }^{32}$ Danish Second World War commemoration includes all of this. However, there is nothing of that kind specifically connected to the Cold War in Denmark. There is not a Cold War commemoration culture. This is not a uniquely Danish phenomenon, though. In other countries, such as Britain and Canada, authors have noted that the Cold War is largely 'uncommemorated. ${ }^{33}$ Germany seems to be the only European country with a firmly established commemoration culture. ${ }^{34}$ In Central and Eastern Europe, the picture is more complicated. The Communist period, not the Cold War, is commemorated

32 On war memorials and commemorations of war see for instance Whitmarsh, "We Will"; Mosse, G, Fallen Soldiers: Reshaping the Memory of the World Wars, (Oxford University Press 1990); A. Gregory, The Silence of Memory: Armistice Day 1919-1946 (Oxford: Berg 1994); A. Forty, "Introduction" in The Art of Forgetting, eds. A. Forty and Küchler, S., (Oxford: Berg 1999) J. Winter, Sites of Memory, Sites of Mourning: The Great War in European Cultural History, (Cambridge: Cambridge University Press 1995); J. Winter and E. Sivan (eds.), War and Remembrance in the Twentieth Century (Cambridge: Cambridge University Press 1999); J. Young, The Texture of Memory: Holocaust Memorials and Meaning (London: Yale University Press 1993); M. Evans and K. Lunn, (eds.), War and Memory in the Twentieth Century (Oxford: Berg 1997).

33 C.S. Dobinson, J. Lake \& A.J. Schofield, "Monuments of war: Defining England's 2oth-century defence heritage", Antiquity 71.272 1997, 288-299; David Neufeld, "Commemorating the Cold War in Canada: Considering the DEw Line”, The Public Historian, Vol. 20, no. 1 (1998); Of course, the USA is an exception to this rule; American soldiers killed in Korea and Vietnam are commemorated at many memorials, memorial services, rituals, etc. In countries where the Cold War became hot, such as Korea and Vietnam, it is, not surprisingly, commemorated as an "ordinary war".

34 Keith R. Allen, "Wall Remains"; Duncan Light, "Gazing on communism: heritage tourism and post-communist identities in Germany, Hungary and Romania", Tourism Geographies 2(2), 2000, 157-176. 
and repressed at the same time. One line of explanation stresses a discourse and memory not of war but of terror and victimhood. Often, the Communist past is repressed and instead a (post-Communist) democratic identity and a return to Europe is emphasized. ${ }^{35}$ Another explanation focuses on a certain form of (n)ostalgia or disappointment with the developments following the fall of Communism that is not conducive to commemoration or anniversary celebrations. $^{36}$

What makes the Danish case interesting is that in spite of the lack of war commemoration culture, the Cold War is commemorated at museums and heritage sites and commemorated as a war. Besides the Cold War museums and the numerous Cold War installations scattered around the country, other typical physical commemoration symbols are absent. For instance, there are no memorials or statues commemorating events or people from the Cold War. ${ }^{37}$ In this way, the Cold War as cultural memory becomes both event-less and face-less. Equally strikingly absent are immaterial or temporal sites of memory; there are no traditions connected to the Cold War experience and no calendar of commemorative dates. Not even 9 November, the day of the fall of the Wall, has become a generally accepted historic date to be commemorated. Nor does Denmark celebrate 23 August as commemoration of the victims of totalitarianism.

The absence of a traditional culture of war commemoration can, I believe, be attributed to a set of interrelated factors. One of them is that national cultures of commemoration are usually unifying and homogeneous, and such commemoration is difficult to institutionalize in countries like Denmark, where there is a continuing competition between memory communities. There is no politically and publicly shared master narrative, no agreement on what or who should be commemorated, or what form the commemoration should take. Right-wing politicians have fought for the erection of a Reagan statue, which

35 Marki Lethi, "Eastern or Western, New or False? Classifying the Balts in the Post-Cold War Era", Wider Europe, Danish Institute of International Studies, 2006, 69-88; Mälksoo, "The Memory Politics of Becoming European: The East European Subalterns and the Collective Memory of Europe", European Journal of International Relations, 15/4, 2009, 653-668; C. Onken, "Memory and Democratic Pluralism in the Baltic States - Rethinking the Relationship, Journal of Baltic Studies, 41/3 Sep, 2010, 277-294; Light," Gazing.

36 Aleksandar Smolar, "History and Memory: the Revolutions of 1989-91", Journal of Democracy, Vol. 12(3), 2001, 5-19.

37 The authoritative book on Danish lieux de mémoire is Inge Adriansen, Erindringssteder i Danmark: Monumenter, mindesmcerker og mødesteder (København: Museum Tusculanum, 2010). In this book, Adriansen documents and analyzes monuments and memorials, however, none of them refer to the Cold War experience. 
would fit perfectly with the conflict narrative, but the American president and his role in the ending of the Cold War is still too disputed in Denmark to reach the necessary political consensus on the need and propriety of a celebratory commemoration. A statue would mean recognition of him as a hero, and this is incompatible with the consensus and protest narratives. The left-wing and Social Democrats cannot allow it; it would imply that they were wrong then and wrong now in their analyses of why they Cold War started, why it ended and what lessons there are to be learned and implemented today. This dispute can perhaps seem odd in a broader European context. Former Warsaw Pact capitals such as Budapest and Warsaw have erected Reagan statues. Hungary and Poland, of course, are CEE countries who quickly and successfully embarked on a 'return to Europe'. Honoring Reagan and emphasizing a national parallel to the conflict narrative seem logic in that regard.

Besides the lack of a unified Danish remembrance community in the present, another factor can be found in the historical past. One issue here is the relatively peaceful and in many ways 'un-war-like' experience of (Western) countries such as Denmark in the Cold War. War, yet alone apocalyptic war, was never part of the Danish Cold War experience. The Danes managed to participate in the conflict with the least possible effort in terms of military spending and military engagement. The country did not experience any losses, and still, in contrast to the Second World War, it was on the 'right' or winning side all the time. Commemorations of war memories often seem to be intimately connected to national catastrophe, loss, trauma, sacrifice and heroes and, in particular after the Second World War and the Holocaust, victimhood and genocide. ${ }^{38}$ The role of victimhood has, according to Lowe and Joel, become a central element in the politics of war memory: 'Once shunned as both a bitter reminder of the past or continuing domination and a signal of historical or enduring inferiority, victimhood now has become a prized commodity.' ${ }^{\prime 3}$ This transnational and transcultural obsession with victims and trauma is difficult to internalize or reappropriate to fit Danish (and Western European in general)

38 Lowe and Joel, Remembering; Jay Winter, “The Generation of Memory: Reflections on the 'Memory Boom' in Contemporary Historical Studies", G HI 27 (2000); Dominick LaCapra, History and Memory After Auschwitz (Ithaca, 1998); Paul Antze and Michael Lambek, eds, Tense Past: Cultural Essays in Trauma and Memory (London, 1996); Eltringham and Maclean, eds., Remembering Genocide (London and New York Routledge, 2014). Ashplant et al., The Politics of War Memory and Commemoration (Routledge, 2000); John R. Gillis, "Introduction" in Commemorations: the Politics of National Identity ed. John R. Gillis (Princeton University Press, 1996), 3-27; David Lowenthal, "Identity, Heritage, and History" in Gillis ed, Commemorations, 41-61; Müller, "Introduction". 
Cold War experience, because there are no losses to commemorate. Furthermore, because of the peculiar character of the Cold War as an in many ways absent war, there is no memory paradigm, such as the Holocaust paradigm, to set the limits for how and what to communicate and commemorate. This makes the counter-factual potential unlimited.

It might also be a factor that even though we live in a globalized age, Danish culture of commemoration in general still to a large degree remains intimately linked to the national state and national identity. There is no complete register of Danish memorials, but the Agency for Culture has registered more than 2,000 erected between 1830 and 2000, and they commemorate exclusively Danish historical events and persons. The, sparse, existing scholarship on the topic confirms the image that Danish commemorative culture is nationally localized and oriented. ${ }^{40}$ Many of the major Cold War events with the potential of becoming significant transcultural lieux de mémoire, such as the Berlin Wall, the uprising in Hungary 1956, the Vietnam War and the Gulag are not received and reappropriated in a Danish context and not treated as part of a common heritage. If a commemorative act that does not carry an explicit reference to Denmark is difficult to bring about in the current circumstances, there could be many ways to make international experiences part of a cultural memory in Denmark. One could have imagined, for instance, a memorial to refugees from East Germany, the German Democratic Republic, who drowned in the Baltic Sea heading for Denmark, or an exhibition about Danish communists who became victims of Stalin's purges. However, like the Holocaust, which in Danish cultural memory is seen as something that happened 'elsewhere' (whereas the Danes in cultural memory are proud to have saved (most of) the Danish Jews), the catastrophes of the Cold War were far away and not directly and unambiguously related to Denmark. It is indeed a narrow, even nationalistic, perspective, yet, because memory is closely related to identity, the past must be seen as relevant to the identification of the community in question in order to 'function' as a lieu de mémoire.

\section{Conclusions}

The last few years have witnessed a remarkable multiplication of Cold War museums in Denmark. At the same time, the state Agency forCulture hasrecognized the Cold War as national heritage. This testifies to a desire to institutionalize the

40 Adriansen, Erindringssteder. 
memory and narratives of the Cold War from 'above' and 'below' and to a fruitful merging of interests.

This article demonstrates that the Cold War is, to a large extent, commemorated as a war at these sites; war in a narrow political-military understanding. It is generally military and deference-related aspects of the war that have become institutionalized in the Cold War museums and in the official list of Cold War heritage - even if actual warfare was not part of the Danish Cold War experience. The representations centre on the hypothetical war situation, and the starting point is the total defence, which does not make sense without a war aspect. The history of the Cold War is modelled to follow the templates of the history of the Second World War, but with one crucial difference: it is a heroic and positive history without one of the most important characteristics of war commemoration of hot wars: victims, loss and sacrifice. The Danes manage to celebrate a war memory without having to deal with the unpleasant sides of warfare. There are no victims or veterans to take into consideration. ${ }^{41}$ It is an interesting commemorative strategy: reappropriation, heroization and militarization but without victimization. The public who is arguably the most interested in the Cold War apparently receives and perceives the war memory as unproblematic, if they notice it at all, in spite of the context of heated discussions about the past in the public sphere.

The article claims that the absence of war makes it a malleable and usable past, while at the same time finding a paradox in the counter-factual warmemory that becomes the result of commemorating a war that never happened. Most importantly, the article discusses the lack of a war commemoration culture. This paradox reflects, I suggest, on the one hand, the lack of a generally accepted master narrative of the Cold War in Denmark, which is a result of the continuing 'memory war', and, on the other hand, the peculiar character of the Cold War as a war that never broke out and the absence of a fixed memory paradigm.

The article has revealed a need for examining in more detail the Cold War as cultural memory, and the degree to which memory communities' competition impedes a functional commemoration culture. There remains likewise a need to embed the analyses of national cases of memory culture within a transnational or transcultural comparative framework to examine to what degree

41 The lack of fallen soldiers is, however, also an impediment to a unifying commemoration culture, as the commemoration and memory of the fallen are often used to legitimize the war effort. Benedict Anderson, Imagined Communities. Reflections on the Origin and Spread of Nationalism (London: Verso, 2006 [1983]); John R. Gillis: "Introduction" in Commemorations: The Politics of National Identity, John R. Gillis, ed., (Princeton University Press, 1996), 3-27. 
countries and communities share a similarly structured terrain of Cold War memory sites, perhaps in opposition to other memoryscapes. Also, the layers of memories and the dynamics and durability of mnemonic templates merit further examination, and provide an excellent opportunity for deepening our understanding of cultural memory.

\section{Bibliography}

Adriansen, Inge, Erindringssteder i Danmark: Monumenter, mindesmeerker og mødesteder (København: Museum Tusculanum, 2010).

Allen, Keith R. "Wall Remains, Holocaust Memorials, and Prussian Heritage: Reflections on Cold War Commemoration in Germany", Perspectives on History, 82(2), 2014.

Anderson, Benedict, Imagined Communities. Reflections on the Origin and Spread of Nationalism (London: Verso, 2006 [1983]).

Antze, Paul and Michael Lambek, eds, Tense Past: Cultural Essays in Trauma and Memory (London, 1996).

Ashplant et al: The Politics of War Memory and Commemoration (London \& New York: Routledge 2000).

Borring Olesen, Thorsten, "Truth on demand. Denmark and the Cold War", in Foreign Policy Yearbook, eds. Nanna Hvidt and Hans Mouritzen, DiIs 2006, 80-114.

Brun Pedersen, Rasmus, "Past, present, and future: the role of the Cold War in legitimising Danish foreign policy activism", Cold War History 16/1 (2016), 101-120.

Bryld, Claus and Annette Warring, Bescettelsestiden som kollektiv erindring (Frederiksberg: Roskilde Universitetsforlag, 1999).

Dahl Hansen, Karin, "Krigshistorie på vej tilbage", Kr. Dagblad, 26 November 2008.

Dobinson, C.S.; J. Lake \& A.J. Schofield, "Monuments of war: Defining England's 2othcentury defence heritage", Antiquity 71.272 1997, 288-299.

Eltringham and Maclean, eds., Remembering Genocide (London and New York Routledge, 2014).

Encyclopedia Britannica, http://global.britannica.com/EBchecked/topic/635532/war [accessed 19 January 2015].

Erll, Astrid, "Traumatic pasts, literary afterlives, and transcultural memory: new directions of literary and media memory studies", Journal of aesthetics and culture, 3 (2011).

Evans, Martin and Ken Lunn, eds., War and Memory in the Twentieth Century (Oxford \& New York: Berg, 1997).

Farbøl, Rosanna, "Framing the Past, Shaping the Future: the Political Uses of the Foreign Policy Tradition in Contemporary Danish Politics" in Nordic Cold War Cultures: Ideological Promotion, Public Reception, and East-West Interaction, eds. Valur Ingimundarson and Rósa Magnusdóttir (Helsinki: Aleksanteri Institute 2015), 189-206. 
Farbøl, Rosanna, Koldkrigere, medløbere og røde lejesvende. Den Kolde Krig i dansk historiekultur 1985-2015 (under publ.).

Farbøl, Rosanna, "Commemoration of a cold war: The politics of history and heritage at Cold War memory sites in Denmark", Cold War History, 15, 2015, 471-479.

Fogh Rasmussen, Anders, "Hvad kan det nytte", Berlingske Tidende, 26 March 2003.

Fogh Rasmussen, Anders, Tale i Mindelunden, 4 May 2005 http://www.stm.dk/_p_7500 .html [21.2.11].

Fogh Rasmussen, Anders, Tale ved Folketingets åbning, 15 June 2005 http://www.stm .dk/_p_7495.html [21.2.11].

Folketingstidende (FT) 2002-03 B 118 1. Behandling.

Forty, A., "Introduction" in The Art of Forgetting, eds. A. Forty and Küchler, S., (Oxford: Berg 1999).

Førland, Tor Egil, "Den danske debatt om Den Kolde Krig”, Historisk Tidsskrift, hft. 2, 2002, 586-598.

Førland, Tor Egil, "Den kalde krigen, historikerne og ytringsfriheten”, Nytt Norsk Tidsskrift, 3/31, 2014, 210-224.

FT 2003-04 F7 Forespørgsel til statsministeren og udenrigsministeren om betingelserne for dansk deltagelse i fremtidige krige.

FT 2003-04 B 213 Forslag til folketingsbeslutning om fortsat dansk bidrag til en multinational sikringsstyrke i Irak.

FT 2003-04-S 2927.

FT 2004-05, 1. saml. B 42 Forslag til folketingsbeslutning om fortsat dansk bidrag til en multinational sikringsstyrke i Irak.

FT 2004-05 2. saml. B 89 Forslag til folketingsbeslutning om fortsat dansk bidrag til en multinational sikringsstyrke i Irak.

Gillis, John R., "Introduction" in Commemorations: The Politics of National Identity, John R. Gillis, ed., (Princeton University Press, 1996), 3-27.

Gregory, A. The Silence of Memory: Armistice Day 1919-1946 (Oxford: Berg 1994).

http://slks.dk/kommuner-plan-arkitektur/kommune-og-turisme/kold-krig/ [accessed 19 January 2015].

http://www.dst.dk/da/Statistik/emner/museer-og-kulturarv/museer.aspx [accessed 8 January 2015].

http://www.langelandsfortet.dk/sdu-langelandsfort_dkl.htm [accessed 8January 2015]. https://www.kalklandet.dk/sites/default/files/arsberetning_2013_o.pdf.For [accessed 8 January 2015].

https://www.tripadvisor.dk/Attraction_Review-g189521-d1137517-Reviews-or3o-Museum_Langelandsfort-Langeland_Funen_and_Islands.html/BackUrl\#REVIEWS [accessed 29 September 2016].

https://www.tripadvisor.dk/ShowUserReviews-g1820371-d2234809-r407893498-Cold_ War_Museum_Stevnsfort-Roedvig_Stevns_Municipality_South_Zealand_Zealand .html\#CHECK_RATES_CONT [accessed 29 September 2016]. 
https://www.tripadvisor.dk/ShowUserReviews-g1820371-d2234809-r398799126-Cold_ War_Museum_Stevnsfort-Roedvig_Stevns_Municipality_South_Zealand_Zealand .html\#CHECK_RATES_CONT [accessed 29 September 2016].

Kavanagh, Gaynor, "Making Histories, making Memories" in Making Histories in Museums, ed. Gaynor Kavanagh (London: Leicester University Press 1999), 1-15.

Kayser Nielse, Niels, Historiens forvandlinger (Aarhus: Aarhus Universitetsforlag, 2010). Knippel, Lars Ole, "Museer om forsvaret: Eksplosiv interesse for krigshistorien", Jyllands-Posten, 18 January 182007.

LaCapra, Dominick, History and Memory After Auschwitz (Ithaca, 1998).

Lethi, Marki, "Eastern or Western, New or False? Classifying the Balts in the Post-Cold War Era”, Wider Europe, Danish Institute of International Studies, 2006, 69-88.

Light, Duncan, "Gazing on communism: heritage tourism and post-communist identities in Germany, Hungary and Romania", Tourism Geographies 2(2), 2000, 157-176.

Lowe, David and Tony Joel, Remembering the Cold War: Global Contest and National Stories (London \& New York: Routledge, 2014).

Macdonald, Sharon, "Introduction" in Theorizing museums, eds. Sharon Macdonald and Gordon Fyfe (Oxford: Blackwell Publishers 1996).

Macdonald, Sharon, Memorylands. Heritage and Identity in Europe Today (New York: Routledge 2013).

Mälksoo, "The Memory Politics of Becoming European: The East European Subalterns and the Collective Memory of Europe", European Journal of International Relations, 15 April 2009, 653-668.

Mikkelsen, Brian, “Ti scener fra Den Kolde Krig”, Berlingske Tidende, 11 June 2003.

Mikkelsen, Brian, “Det handler om frisind”, Politiken, 4 September 2003.

Mikkelsen, Brian, "Historien frikender ingen”, Berlingske Tidende 21 January 2007.

Mikkelsen, Brian, “I den sorte gryde”, Weekendavisen, 27 June 2003.

Mikkelsen, Brian, “Kulturpolitiske visioner”, Information 6 September 2008.

Mikkelsen, Brian, "Reagan var en helt", Jyllands-Posten, 11 June 2004.

Mikkelsen, Brian, "Trusten fra Sovjetimperiet var reel”, Jyllands-Posten, 5 September 2005 .

Mortensøn, Ole, Fortet og den kolde krig (Katalog for Museum Langelandsfort 2006).

Mosse, G, Fallen Soldiers: Reshaping the Memory of the World Wars, (Oxford University Press 1990).

Müller, Jan-Werner, "Introduction: the power of memory, the memory of power and the power over memory" in Memory and Power in Postwar Europe. Studies in the Presence of the Past, ed. Jan-Werner Müller (Cambridge: Cambridge University Press 2002), 1-39.

Neufeld, David, “Commemorating the Cold War in Canada: Considering the DEW Line", The Public Historian, Vol. 20, no. 1 (1998).

Noakes, Lucy, "Making Histories: Experiencing the Blitz in London's Museums in the 1990s" in Evans and Lunn, War and Memory, 89-105. 
Nora, Pierre, "Between Memory and History: Les Lieux de Mémoire", Representations 26 (1989), 7-24.

Onken, C. "Memory and Democratic Pluralism in the Baltic States - Rethinking the Relationship", Journal of Baltic Studies, 41/3 Sep, 2010, 277-294.

Østergaard, Uffe, "Swords, Shields or Collaborators? Danish Historians and the Debate over the German Occupation of Denmark" in Nordic Narratives of the Second World War. National Historiographies Revisited, eds. Henrik Stenius, Mirja Österberg and Johan Östling (Lund: Nordic Academic Press, 2011), 31-55.

Smolar, Aleksandar, "History and Memory: the Revolutions og 1989-91", Journal of Democracy, Vol. 12(3), 2001, 5-19.

Stanford Encyclopedia of Philosophy, http://plato.stanford.edu/entries/war/ [accessed 19 January 2015].

Stenak, Morten et al., eds., Kold Krig. 33 fortcellinger om den kolde krigs bygninger og anlceg i Danmark, Fcerøerne og Grønland, (Kulturministeriet: Kulturstyrelsen, 2013).

Vuorela, Mikkel, "Den kolde krig har fået greb i danskerne”, Politiken, 22 July 2013.

Whitmarsh, A.:"We Will Remember Them" Memory and Commemoration in War Museums', Journal of Conservation and Museum Studies 7 (2001), doi:10.5334/jcms.7013.

Winter and Sivans, eds, War and Remembrance in the Twentieth Century (Cambridge: Cambridge University Press, 1999).

Winter, Jay, "The Generation of Memory: Reflections on the 'Memory Boom' in Contemporary Historical Studies", GHI 27 (2000).

Winter, Jay, Sites of Memory, Sites of Mourning. The Great War in European Cultural History (Cambridge: Cambridge University Press, 2005 [1995]).

www.artilleriet.dk/artikel/36o8-Historie--krigen-der-aldrig-kom.htm orlogsmuseet [accessed 8 May 2014].

Young, J., The Texture of Memory: Holocaust Memorials and Meaning (London: Yale University Press 1993). 


\title{
Jews and the Holocaust in Poland's Memoryscapes: An Inquiry into Transcultural Amnesia
}

\author{
Slawomir Kapralski
}

The Holocaust wiped out the world of Polish Jewry. Out of a Jewish population of more than three million in pre-war Poland, only about ten percent survived and many of the survivors decided to emigrate to the West. ${ }^{1}$ The material traces of the centuries of Jewish presence in Poland were eradicated during, or after, the war and the socio-economic space once occupied by the Jews was soon filled by non-Jewish Poles as part of the radical transformation of Poland's social structure.

As a result, writes James Young, ${ }^{2}$ the non-Jewish Poles have been left with their own, uncontested, memories of the past. Post-war Polish authorities attempted to shape the country's memory to give it a new meaning according to their communist worldview while the vast majority of Polish society, reluctantly approaching the new political system, tried to safeguard its memory of the past in the private sphere of family life, supported by the structures of the Roman-Catholic Church.

The remnants of Jewish memory were therefore located in a space controlled by two frames that are conventionally called 'nationalist' and 'communist.' For the nationalists, whose ideal was an overlap of the political and cultural boundaries, ${ }^{3}$ the presence of Jews in Poland's memory proved that the latter is heterogeneous, which subverted their national project. For the communists, the ethnic and/or religious differentiation of the memory subverted their vision of history, in which ethnicity and religion supposedly had no meaning, having been replaced by economic divisions and gradually levelled by the dominant position of the working class.

Contrary to Young, it is therefore possible to say that the postwar memory of the non-Jewish Poles has not been homogeneous and uncontested. Poland

1 Michael C. Steinlauf, "Poland," in The World Reacts to the Holocaust, ed. David S. Wyman (Baltimore and London: The Johns Hopkins University Press, 1996), 109.

2 James E. Young, The Texture of Memory: Holocaust Memorials and Meaning (New Haven: Yale University Press, 1993), 116.

3 Ernest Gellner, Nations and Nationalism (Oxford: Blackwell, 1983), 1. 
has in fact been a battlefield of different visions of the past that have mutually contested one another, although not all of them have had sufficient power to significantly control public and communicative memories. But in one thing Young was right: in spite of the differences between communist and nationalist memories, there has not been any space for the Jews in either of them. What has united these otherwise opposing forms of memory has been an act of symbolic violence: an erasure of the Jewish memory, which in a way has contributed to the annihilation of the Holocaust victims.

Memory is understood here as a synthesis of mnéme (the reminiscence of the past that is stored and transmitted in the acts of remembrance), and anámnesis (a contextually conditioned re-collection of something that not necessarily forms a permanent part of our stock of memories but could be consciously commemorated). ${ }^{4}$ Memory emerges therefore as a result of two processes. The first one starts with the individual remembrances or recollections of the past events that are subsequently communicated and discussed by individuals and as such form their social memory. In the second one, the cultural frames and social institutions support (and sometimes induce or even create) certain forms of social memory (and weaken or eliminate others), deciding in this way which of the individual recollections will have a chance to become a topic of conversation, what shape they may take and what will be officially and publicly commemorated as important for the group. This officially approved vision of the past, together with commemorative practices that sustain it, forms the collective memory of a given community. ${ }^{5}$

Therefore, the crucial segment of memory is the social memory, which is a place where two genealogies meet one another, and which serves as a space of encounter of the top-down and bottom-up memory work. Sometimes a battleground, sometimes an alliance of different tendencies, social memory is the central place in the process of collective remembering.

To catch the complex nature of social memory with one word, I employ here the concept of memoryscape that refers to a material and symbolic space, in which social memory is expressed ${ }^{6}$ although here the concept will be interpreted metaphorically and without direct reference to physical places.

4 Yosef H. Yerushalmi, Zakhor: Jewish History and Jewish Memory (Seattle: University of Washington Press, 1996), 107.

5 Aleida Assmann, "Transformations between History and Memory," Social Research 1 (2008): 55 .

6 Hamzah Muzaini, and Brenda S.A. Yeoh, "War Landscapes as 'Battlefields' of Collective Memories: Reading the Reflections at Bukit Chandu, Singapore," Cultural Geographies 12 (2005): 345 . 
Memoryscapes form a matrix of possible attitudes towards the past that can be activated in the commemorative actions of individuals and groups. They are spaces of coexistence of various groups' visions of the past that could be in a symbolic conflict, precisely the way their holders could be in real conflict. For this reason, the memories contained in memoryscapes constitute an important realm of the struggle for power, understood here as the right to marginalize, exclude or even criminalize those visions of the past that diverge from the sanctioned ideal. A memoryscape is therefore a 'site of concentrated cultural practice,' in which power relations are negotiated. ${ }^{7}$

Memoryscape, however, is not only a result of power relations and past events: it, too, has the power to generate memories and amnesias. Consequently, memoryscape has a peculiar characteristic of being, in Clifford Geertz's

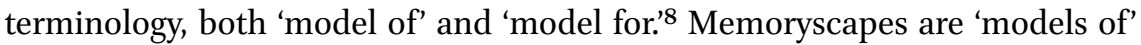
because they become, over time, representations of the remembered past. Yet, memoryscapes may also be consciously designed to emphasize and amplify those aspects and interpretations of the past desired by those with the power to shape them. In this way, memoryscapes are 'models for': they are instructions or frames for our memories in which certain recollections are more likely to emerge than others.

It is argued here that in post-war history Jews and the Holocaust have largely been absent in Poland's memoryscape, either because they have not been present in the individual remembrance (and the memoryscape has not served as a 'model of' them), or because there has not been any institutional, public commemoration of the Jewish past in Poland and its tragic end (so that the memoryscape has not served as a 'model for' them), or both. The intention of this paper is to present an interpretation of this situation and different examples of the absence of the memory of Jews and the Holocaust in Poland's social memory, with particular emphasis on the post-communist period since the $1990 \mathrm{~s}$. Since then, it is argued here, there has been an increase in the number of commemorations of the Polish Jews, but they have nevertheless remained absent in the individual remembrance (in the way the terms are understood here).

\section{Periodization of Poland's Attitude to Her Jewish Past}

Michael Steinlauf has distinguished five periods in the Polish history after the Second World War, in which Jews and the Holocaust were differently

7 William H. Jr. Sewell, Logics of History. Social Theory and Social Transformation (Chicago: The University of Chicago Press, 2005), 172.

8 Clifford Geertz, The Interpretations of Culture (New York: Basic Books, 1973), 90-91. 
remembered/forgotten: the period of 'wounded memory' (1944-1948), of 'repressed memory' (1948-1968), of 'expelled memory' (1969-1970), of 'reconstructed memory' (1970-1989) and of regained memory (1989-1995). ${ }^{9}$

In the first of them, Jewish memory was represented mainly by the Jewish survivors, in particular those who had survived the Holocaust in the USSR and returned to Poland only to face the fact that their relatives had perished and that their non-Jewish neighbors were not particularly happy with their return. On the other hand, the fate of the Jews was freshly imprinted in the memory of their neighbors, although ambiguously perceived.

The time immediately following the end of the Second World War, which for many Poles only meant the replacement of Nazi-German occupation with Soviet Communism, was characterized by the psychological states of fear, anxiety and terror, accompanied by conspiracy theories developed to ease the sense of insecurity, and by the anti-Jewish pogroms that were the consequence. ${ }^{10}$

Polish communist authorities supported the program of the Central Committee of Polish Jews that aimed at the revival of Jewish life in Poland. A manifestation of this attitude was the official commemorative activity of the Polish government regarding the Jews and the Holocaust, although treated instrumentally in order to get political legitimization and Western support. Thus the commemoration of Jewish resistance (first of all) and victimization was politically used to discredit the anti-communists who were equated with antisemites and with the Nazis in general. ${ }^{11}$

A good illustration of this attitude was the unveiling of Nathan Rapoport's Ghetto memorial on the fifth anniversary of the Warsaw Ghetto Uprising (1948), while the memorial of the 1944 Warsaw Uprising, led by the non-communist Polish resistance, had been allowed only in 1989 when communism was already on the decline.

Rapoport's monument stood alone in a vast field of rubble, easily red by Poles as a symbol of the new government's decision to honor the Jews, while consigning the Polish national struggle to the dustbin of history. Similarly, Polish secondary school textbooks of the early 1950s devote more attention to the history of anti-Semitism and the Holocaust than any subsequent versions, but the context for this information is a narrative in which the AK [Armia Krajowa = Home Army, Polish main

Michael C. Steinlauf, Bondage to the Dead. Poland and the Memory of the Holocaust (Syracuse: Syracuse University Press, 1997).

10 Marcin Zaremba, Wielka trwoga. Polska 1944-1947: ludowa reakcja na kryzys (Kraków: Wydawnictwo Znak i ISP PAN, 2012).

Steinlauf, "Poland," 111. 
non-communist anti-Nazi military organization - S.K.] is described as hindering Polish resistance. ${ }^{12}$

In the first years after the Second World War in Poland, the presence of Jewish survivors, together with relatively fresh memories of the Holocaust and official commemorative politics of the government, allowed for the remembrance and commomeration of Jews and their fate.

In the period of 'repressed memory' (1948-1968) the individual remembrance of the Holocaust by the non-Jewish Poles gradually weakened, while many Jewish survivors left Poland, together with their memories, in the wake of the wave of post-war pogroms. As for the authorities, in 1949-1956 they followed the Stalinist orientation in constructing a vision of the past, in which the entire Polish past was erased as prehistory ${ }^{13}$ and in the official Marxist-Leninist approach to history all ethnic conflicts and enmities were reduced to an epiphenomenon of class struggle and an interplay of the economic forces. Jews were thus excluded from the Communist vision of history in which, as in the Marxist dream, ethnic identities would dissolve in the fundamental economic dichotomy.

Together with the destalinization of the Polish communist regime after 1956, the authorities, although still formally adhering to the Marxist philosophy of history, started to gradually include the reference to the Polish national tradition in their legitimating efforts, attempting to present their rule as firmly rooted in Polish history and as a 'return' to the geopolitics and social homogeneity of the first Polish statehood. In the 1960s, the nationalist and often antisemitic wing of the communist party grew in importance, which eventually, together with the withdrawal of the Soviet Union's support of Israel, resulted in the state-sponsored antisemitic campaign of 1968.

The campaign, according to Steinlauf, ${ }^{14}$ marked the beginning of the period of 'expelled memory', because as a consequence many Polish Jews decided to emigrate or were in various ways forced to leave their country. The sociotechnical means used in the campaign awoke popular antisemitism, constantly present as a dormant cultural code, ${ }^{15}$ usually activated in times of crisis to give its participants an illusion of being able to intellectually control the events. As a result, from 1968 Jews and the Holocaust have neither been remembered, nor commemorated.

\footnotetext{
12 Steinlauf, "Poland," 111.

13 Steinlauf, "Poland," 111.

14 Steinlauf, Bondage to the Dead.

15 Wolfgang Benz, Anti-Semitism in Europe. Traditions, Structures, Manifestations (Uppsala: Uppsala University, 2004).
} 
The lack of remembrance and commemoration also characterized the period of 1970-1989, although relative cultural liberalization and the development of democratic opposition that established its structures in the late 1970s, and which included the attempt to reclaim memory from the communist-controlled agenda, made the Jewish past slightly more visible in Poland's memoryscape. Known as the attempt to 'fill in the blank spots' in the map of collective memory, this process contributed to the re-emergence of previously erased chapters of Polish-Jewish history. A number of official films and publications dealing with the Jewish past of Poland appeared, together with clandestine literature. Jewish history and culture became a field of study at universities. Public debates by Polish intellectuals, and the international conflict about the Carmelite Convent at Auschwitz, made a wider audience aware of the problem and helped the elites develop their arguments and revise their standpoints. In 1989 Poland entered the postcommunist period of its history with the clear knowledge, at least among the elites, that a certain part of Polish memory had been erased or manipulated and that the 'de-communization of memory' should include an attempt to re-examine Poland's Jewish past and the Holocaust. This attempt, called by Steinlauf 'reconstruction of memory,'16 has continued with greater success in postcommunist Poland.

Here, the division of postwar Jewish-Polish history presented by Steinlauf has been supplemented with two concepts: remembrance and commemoration that help convert historical periodization into sociological typology. Thus, in the period immediately following the end of the Second World War, the Jewish past and the Holocaust is individually remembered and publicly commemorated. From $195^{\circ}$ to 1968 individual remembrance weakens although is still present, while the state subdues public commemoration as contradicting the official vision of history constituted by a specific mixture of communist ideology and nationalism. With the antisemitic campaign of 1968, Poland enters a long period in which Jews and the Holocaust are neither remembered nor commemorated. This situation changes slightly in the 1980 s when the Jewish history of Poland becomes one of the motifs of the opposition's clandestine revision of the official vision of the past. Eventually, after 1989 and the collapse of communism, the institutional framework of memory radically changes and Jews and the Holocaust are commemorated again (although differently than in the past), but this commemoration, it is argued here, does not translate into individual remembrance. In post-communist Poland, Jews and the Holocaust remain commemorated but not remembered. This thesis will be developed in the subsequent part of this article. Now, however, it is necessary to go deeper into the particular nature of the relation between remembrance and

Steinlauf, Bondage to the Dead. 
commemoration to uncover less evident causes of silencing the Jewish past in postwar Polish history.

\section{The Absence of the Holocaust in Poland's Memoryscape}

To interpret the disappearance of the fate of Jews as an important element in the recollections of the past by non-Jewish Poles and in their social memory, we need to say, first of all, that in spite of being eye-witnesses, they did not have an adequate knowledge of what they had actually witnessed. The non-Jewish Poles saw what happened but did not know what happened. ${ }^{17}$ That does not mean that they were not aware of the fact that their Jewish neighbors had been murdered. But the interviews collected by the Institute of Sociology of the Jagiellonian University in the beginning of the 1990s in the project 'The Memory of Jewish Culture in Southern Poland' show that although they were able to provide details of the fate of individuals they had known (and often with compassion and sorrow), most of them had problems with acknowledging that they had witnessed a horrible, inconceivable and transforming event on a scale that surpassed previous experiences. Little empathy was expressed for the fate of Jews in general and, while on the topic, many respondents started to refer to antisemitic clichés even if they did not expose antisemitic views in other parts of the interview.

One reason for this that can be mentioned here is the separation, which was often hostile, between Jews and non-Jewish Poles. The latter lived in the same physical space and historical time as their Jewish neighbors, but the two groups did not share the same social space and time. ${ }^{18}$ Jews did not form a social community with the non-Jewish Poles. The contacts between the groups were limited to economic relations, and closer ties, friendships and social encounters were very rare among adults. Both groups formed separate worlds that existed in physical proximity, but were separated by the barrier of custom, endogamy and prejudice, and their members largely ignored each other. ${ }^{19}$ This separation was deepened by the Nazi policies of segregation and

\footnotetext{
17 Steinlauf, Bondage to the Dead.

18 Diane K. Roskies and David G. Roskies, The Shtetl Book: An Introduction to East European Jewish Life and Lore (New York: Ktav Publishing House, 1975); Slawomir Kapralski, "People of Different Times," in The Jews in Poland, Vol. 2, ed Slawomir Kapralski (Kraków: Judaica Foundation, 1999).

19 Ewa Banasiewicz-Ossowska, Między dwoma światami. Żydzi w polskiej kulturze ludowej (Wrocław: Polskie Towarzystwo Ludoznawcze, 2007), 88-89.
} 
separation of Jews into the ghettos, as well as by the differentiating approach of the Soviets occupying the eastern part of Poland in the first period of the Second World War.

Jews were therefore excluded from the Polish national/local communities. From the non-Jewish point of view, they were not part of the Polish 'Us' and therefore the memory of their tragic fate was not perceived by non-Jews as 'their' memory. The postwar exclusion of the Jews from the Polish 'mnemonic community'20 was a consequence of their previous social exclusion. Consequently, with a significant role of traditional anti-Judaism and modern prewar antisemitism, the non-Jewish Poles widely perceived Jews in the time of the Holocaust as having been 'beyond the Polish universe of obligation.'21 The postwar dissociation of the non-Jewish Poles from the memory of the Jews could show an attempt to dissolve the link between memory and continuity and, therefore, between memory and the responsibility that makes human beings capable of accountability as moral subjects. ${ }^{22}$

Generally then, the non-Jewish Poles did not perceive the fate of the Jews as something that would affect their own collective identity. They did not identify with the memory of the Holocaust because they did not identify with its victims. ${ }^{23}$ Moreover, the non-Jewish Poles themselves felt victims of Nazi terror and had good reasons to believe that: 'after the Jews and the Gypsies, the Poles were the most relentlessly victimized group in Hitler's Europe.'24 Their loss was of course not equal to the Jewish one. The non-Jewish population of Poland was decimated while ninety percent of Polish Jews perished. 'Nevertheless,' Steinlauf comments, 'nowhere else in Europe would such a comparison be necessary; nowhere else did the murder of Jews unfold amidst such slaughter of the coterritorial people. ${ }^{25}$ If we take into account the religiously tinted, messianic mythology of victimhood and suffering that since the nineteenth century has been an important part of the Polish national tradition, we may understand that the non-Jewish Poles focused on their own, enormous suffering, and perceived the suffering of the Jews as competition, largely ignored

20 Maria G. Cattell and Jacob J. Climo, "Introduction. Meaning in Social Memory and History: Anthropological Perspective," in Social Memory and History. Anthropological Perspectives, ed. Jacob J. Climo and Maria G. Cattell (Walnut Creek: Altamira Press, 2002), 35. Steinlauf, "Poland," 107.

22 W. James Booth, "The Work of Memory: Time, Identity, and Justice," Social Research 1 (2008).

23 Jeffrey C. Alexander, Trauma. A Social Theory (Cambridge: Polity, 2012), 19.

24 Steinlauf, "Poland," 81.

25 Steinlauf, "Poland," 99. 
'because of the Polish self-image of Poles as victims par excellence.' ${ }^{26}$ This perception could have been supported by the generalized experience of the first two years of the occupation when it may not have been entirely clear that Jews had it worse.'27

Another reason for silencing the memory of the Holocaust was a morally dubious profit that the non-Jewish Poles made as a result of the persecution of the Jews.

Beyond the money to be made through smuggling to and from the ghettos as well as blackmailing and informing on Jews hidden on the Aryan side, activities that involved only a small minority of Poles, the German expropriation of the property of 3.5 million Jews amounted to an economic revolution. While the Germans took the lion's share ..., the leftovers went to Poles. Throughout Poland, ownerless stores, merchandise, workshops, raw material, land, and houses quickly found new owners. ${ }^{28}$

The revolution Steinlauf writes about was, however, not only economic. It is difficult to overestimate the consequences of the expropriation for the social structure: the void in the social tissue had been quickly filled in by the nonJewish Poles for whom this was by and large a social promotion into middle class. According to Andrzej Leder, this genealogy of the ethnically Polish middle class had a tremendous impact on social memory and identity of Polish society. Members of a large segment of society, who marched to their new social position over the corpses of murdered Jews, prefer not, for obvious reasons, to reflect on their origins. They tend to repress their own sociogenesis and replace it with mythologies, in which antisemitism often plays a role of protection and justification of their uncertain identity. ${ }^{29}$

Finally, we should mention the issue of trauma that the non-Jewish Poles suffered as passive witnesses (and sometimes active co-perpetrators) of the crimes. As Steinlauf notes, "[t]he effects of witnessing murder on such a scale, at such close range, and over such a long time are of course complex. To inquire about the Polish reaction to the Holocaust is to investigate the effects of

26 Stanisław Krajewski, Poland and the Jews. Reflection of a Polish Polish Jew (Kraków: Austeria, 2005), 212.

27 Steinlauf, "Poland," 101.

28 Steinlauf, "Poland," 101.

29 Andrzej Leder, Prześniona rewolucja. Ćwiczenie z logiki historycznej (Warszawa:Wydawnictwo Krytyki Politycznej, 2014), 90-92. 
a mass psychic and moral trauma unprecedented in history. ${ }^{\prime 30}$ In the concept of trauma it is assumed that those who have participated in a horrifying event are unable to adequately react to it in a psychological sense, including lack of an adequate representation of such event in memory (assuming that such an adequate reaction and representation are possible at all, which is arguable, especially in the context of the Holocaust debate), that leads to amnesia (total or selective) or such reconstructions of the past that erase the traumatizing event. ${ }^{31}$ The memory of the event, however, continues to exist in a hidden form and unconsciously influences psychological structures of individuals and collective consciousness of groups.

The lack of adequate psychological reaction is caused simultaneously by the nature of the traumatizing event and by the lack of appropriate cultural frame, in which this event could be interpreted. ${ }^{32}$ The former process is important in studying memory in the mode of mnéme, that is when we focus on how past events form the ways they are remembered. The latter is crucial for studying memory as anámnesis, that is when the focus is on how present conditions influence the way in which past is remembered. This second approach to trauma we can find in the work of Jeffrey C. Alexander, ${ }^{33}$ for whom trauma is not a feature or a direct consequence of a historical event but of the way in which a community approaches it. In other words, trauma is a social-cultural construction that defines the way in which the community experiences past events: namely, as something that has threatened its collective identity.

Witnessing the Holocaust certainly threatened the identity of non-Jewish Poles, leaving them with questions regarding their positive self-image, moral integrity, audacity, human solidarity, religious values etc. Such questions cause discomfort and the forgetting of the situation that gave reason to ask them is a convenient way to avoid the answers. From a cognitive perspective, equally important is that to adequately remember the past, people need a classificatory scheme, a narrative, a concept that would organize their personal recollections, give them a meaning, and a language in which they could be expressed. This was clearly missing in the non-Jewish Poles' interpretation of the events they witnessed, partly because of the nature of their involvement, partly because of the lack of such a discourse.

$30 \quad$ Steinlauf, "Poland," 81.

31 Barbara A Misztal, Theories of Social Remembering (Maidenhead: Open University Press, 2003), 141.

Jeffrey Prager, Presenting the Past. Psychoanalysis and the Sociology of Misremembering (Cambridge, Massachusetts: Harvard University Press, 1998), 155-156. 
The lack of a discourse is crucial in the perspective of social trauma theory: if there is no language, in which a past experience can be expressed, the event associated with that experience cannot be properly recalled (or even, in fact, experienced). Therefore, the experience without a discourse that informs it is necessarily inadequate. To remember mass murder of Jews as the Holocaust, one needs first of all the elaborated discourse of the Holocaust. As Levy and Sznaider argue, '[ $\mathrm{f}$ ] $\mathrm{or}$ the Holocaust to be recognized as something unique, a discursive and political frame of reference needed to be put in place. ${ }^{34}$

In the first decade after the Second World War, the Polish perception was not different from the general view in Europe, the United States or Israel. 'This period was marked by silence concerning the destruction of European Jewry, which at that time did not even have a name and was broadly subsumed under the atrocities of the war. ${ }^{\prime 35}$ Of course, one cannot say that there was complete silence regarding the fate of the Jews in the years immediately following the end of the War. The memory of what had happened was retained among survivors $^{36}$ but it did not form part of the mainstream perception. Moreover, the survivors' message was largely rejected in a world that aimed to rebuild the sense of normality and to start history again, ${ }^{37}$ with 'a stable life, a steady job, and a nice family. ${ }^{\prime 3}$

In the 1960s and 1970s we may observe a desynchronization regarding the Holocaust discourse. While in this period, and for various reasons, the term 'Holocaust' becomes commonly accepted in 'the West' as describing the crucial point of history, the social consciousness in communist Poland was already controlled by different master narratives (Marxist and nationalist), in which there was neither a place for the tragedy of the Jews, nor for any subsequent universal meaning for the whole of humanity. The 'Iron Curtain' meant, among other things, the exclusion of Poland from the developing universalist Holocaust discourse as the main narrative of world's history.

Before the fall of communism, the memory of the Jews and the Holocaust was therefore absent in Poland's memoryscapes due to a number of reasons: (1) The exclusion of Jews from mnemonic community as a consequence of

34 Daniel Levy and Natan Sznaider, The Holocaust and Memory in the Global Age (Philadelphia: Temple University Press, 2006), 59.

35 Levy and Sznaider, The Holocaust, 16.

36 Hasia R. Diner, We Remember with Reverence and Love: American Jews and the Myth of Silence after the Holocaust, 1945-1962 (New York: NYU Press, 2009); David Cesarani and Eric J. Sundquist, ed., After the Holocaust: Challenging the Myth of Silence (New York: Routledge, 2012).

37 Peter Novick, The Holocaust and Collective Memory. The American Experience (London: Bloomsbury, 2001).

$3^{8} \quad$ Levy and Sznaider, The Holocaust, 57. 
(often antisemitic) social exclusion that increased during the occupation due to the segregationist Nazi policies and Soviet differential treatment of both groups. (2) The belief that the fate of the Jews had not affected the identity of the non-Jewish Poles. (3) The belief that there was something wrong with being a passive witness of the Jewish tragedy (and sometimes collaborating with the Nazi perpetrators), leading to the erasure of the memories that caused discomfort. (4) The focus of the non-Jewish Poles on their own suffering, thus neglecting the tragedy of the Jews as a competition that challenged Polish national identity. (5) The fact that large segments of the Polish society, even if unintentionally, benefited from the murder of the Jews, which lead to the erasure of the memory of the links between the Holocaust and the postwar Poland's social structure. (6) The lack of access to the Holocaust discourse in which the fate of the Jews could be expressed.

\section{The Perception of Jews and the Holocaust after the Fall of Communism}

The decade of the 1990s was marked by further intensification of the 'revival' of Jewish memory, partly assisted by the political authorities. Michael Steinlauf ${ }^{39}$ has listed a significant number of cultural and educational initiatives, publications and conferences on Jewish-Polish relations, which took place in the first years of the decade, and more recent developments have been described, for example, by Jolanta Ambrosewicz-Jacobs ${ }^{40}$ and Annamaria Orla-Bukowska. ${ }^{41}$

Most important among these developments have been changes in the school curricula and special programs addressed to teachers in the field of education about the Holocaust. In addition, a number of commemorative ceremonies with the participation of authorities have helped to focus public opinion on the previously neglected Jewish aspects of Polish history, events which have received a substantial share of attention in the mass media. The process of

39 Steinlauf, Bondage to the Dead.

40 Jolanta Ambrosewicz-Jacobs, "Memory and Civic Education: Holocaust and Coming to Terms with National History," in The Religious Roots of Contemporary European Identity, ed. Lucia Faltin and Melanie J. Wright (London: Continuum, 2007).

41 Annamaria Orla-Bukowska, "New Threads on an Old Loom. National Memory and Social Identity in Postwar and Post-Communist Poland," in The Politics of Memory in Postwar Europe, ed. Richard Ned Lebow, Wulf Kansteiner and Claudio Fogu (Durham and London: Duke University Press, 2006); Annamaria Orla-Bukowska, "Gentiles Doing Jewish Stuff. The Contribution of Polish Non-Jews to Polish Jewish Life," in Rethinking Poles and Jews: Troubled Past, Brighter Future, ed. Robert Cherry and Annamaria Orla-Bukowska (Lanham: Rowman \& Littlefield Publishers, Inc., 2007). 
change has included the area of Auschwitz-Birkenau where the museum exhibition has been refurbished with the participation of Jewish institutions to emphasize the role of the place as the symbol of the Holocaust and to clearly indicate that it was the first of the sites of mass extermination of men, women and children, sent to their deaths because they were Jewish. ${ }^{42}$

Poles started to interact more frequently with the ever greater number of Jewish visitors to Poland, which included, for example, meetings between Polish and Israeli high school students. At the same time, the revival of Jewish life in Poland includes a growing number of people who either have discovered their Jewish roots or decided to 'come out' and return to their previously repressed or rejected Jewishness. This process has been assisted by various Jewish organizations, which have become visible not only in the context of the protection of the material remnants of Jewish culture in Poland, but also as supporters of religious, cultural, and educational initiatives. Correspondingly, a number of Poles, acting out of genuine interest, curiosity or economic motives, have engaged in various initiatives, from opening a 'Jewish' restaurant and setting up a band playing Jewish music, to organizing a festival of Jewish culture, all of which have contributed to the phenomenon described by Ruth Gruber as 'virtual Jewishness': a certain form of Jewish culture produced by and addressed to non-Jews. ${ }^{43}$ The intellectual debate about Polish-Jewish relations in the time of the Shoah has continued, now free from the constraints induced by censorship. It came to a peak after the publication of Jan T. Gross's book, Sasiedzi ('Neighbors') in 2000. ${ }^{44}$ In the resulting discussion of the crime committed by the Polish inhabitants of Jedwabne on their Jewish neighbors, the 'whole of Polish society was convulsed by an extraordinary self-examination.'45 The discussion, to which I will return later, has greatly contributed to the

42 Laurence Weinbaum, The Struggle for Memory in Poland. Auschwitz, Jedwabne and Beyond (Jerusalem: Institute of the World Jewish Congress, 2001); Marek Kucia, Auschwitzjakofakt spoteczny: historia, wspótczesność i świadomość spoteczna KL Auschwitz w Polsce (Kraków: Universitas, 2005); Slawomir Kapralski, "The Role Played by the Auschwitz-Birkenau State Museum in Public Discourse and the Evolving Consciousness of the Holocaust in Polish Society," in Jewish Presence in Absence. The Aftermath of the Holocaust in Poland 1944-2010, ed. Feliks Tych and Monika Adamczyk-Garbowska (Yad Vashem, 2014).

43 Ruth E. Gruber, Virtually Jewish: Reinventing Jewish Culture in Europe (Berkeley: University of California Press, 2002).

44 Jan T. Gross, Sasiedzi. Historia zagtady żydowskiego miasteczka (Sejny: Pogranicze, 200o); published in English as Jan T. Gross, Neighbors: The Destruction of the Jewish Community in Jedwabne, Poland (Princeton: Princeton University Press, 2001).

45 Laurence Weinbaum, "Penitence and Prejudice: The Roman Catholic Church and Jedwabne," Jewish Political Studies Review 14 (2002): 3-4. 
'return of memory' of the time of the Holocaust, but it has divided various sectors of Polish society and caused a backlash that hampered the reception of the Holocaust discourse.

It would seem self-evident that the continuation of the 'memory work' in the post-communist period of Polish history must bring about growing acceptance of the truth about the history of Polish-Jewish relations and of the Holocaust. However, if we take society as a whole, this does not seem to be the case and the results of the surveys are ambiguous.

If we compare the results of sociological surveys carried out by Ireneusz Krzemiński's team in 1992, 2002 and 2012, we would see that in 1992 Poles with antisemitic attitudes (in the form of modern, political antisemitism) made up seventeen percent of the population. In 2002 their number had risen to twenty-seven percent, to eventually drop to twenty percent in 2012 - still slightly higher than in 1992. ${ }^{46}$ These results, in a country in which Jews form a tiny fraction of the population, show that in spite of the radical transformation of the cultural frames of memory, an increased educational effort, and a generational change, antisemitic beliefs still form an important part of Poland's memoryscape and indicate that antisemitism and, in general, the perception of Jews, does not really depend on the stored recollection, but on the dynamic, reconstructive memory work - anámnesis - done with reference to the present concerns, rather than to the past.

On the other hand, in the same time period we have observed a steady growth of anti-antisemitic attitudes: from eight percent in 1992, to fifteen percent in 2002, and to twenty-one percent in 2012, which may indicate a growing polarization of Polish society regarding the attitude toward Jews. ${ }^{47}$ The research by Marek Kucia and his own survey of 2010 shows a similar tendency with a more optimistic conclusion based on the fact that in that year the percentage of those with strong anti-antisemitic feelings (twenty-three percent) exceeded the percentage of strong antisemites in the modern, political sense (twenty-two percent) for the first time since such research was initiated. ${ }^{48}$ This makes the author claim that 'in the last couple of years we

46 Ireneusz Krzemiński, "Uwarunkowania i przemiany postaw antysemickich," inŻydziproblem prawdziwego Polaka. Antysemityzm, ksenofobia i stereotypy narodowe po raz trzeci, ed. Ireneusz Krzemiński (Warszawa: Wydawnictwa Uniwersytetu Warszawskiego, 2015), 24.

47 Krzemiński, “Uwarunkowania i przemiany," 24.

48 Marek Kucia, "Polacy wobec Auschwitz, Zagłady i Żydów w świetle badań socjologicznych z 2010 roku i badań wcześniejszych," in Antysemityzm, Holokaust, Auschwitz w badaniach społecznych, ed. Marek Kucia (Kraków: Wydawnictwo Uniwersytetu Jagiellońskiego, 2011), 28-29. 
have become less antisemitic and are increasingly rejecting antisemitism. ${ }^{\prime 49}$ This thesis, however, does not take into account the fluctuating nature of antisemitic attitudes and their dependency on contingent factors that do not allow us to speak about a stable tendency.

An important finding of Kucia's research is the surprisingly significant presence of 'post-Holocaust' elements of antisemitic attitudes expressed by respondents. That means that one-fifth of them agreed with the thesis that although the Holocaust was a hideous crime, it is good that it resulted in the riddance of Jews in Poland. ${ }^{50}$ One needs to add that this form of antisemitism also has the highest percentage of opponents (sixty-eight percent), but it is nevertheless an appalling result in acountry that experienced the Holocaust. Besides, a striking feature of Polish antisemitism is a relatively high proportion of educated people among the antisemites, which leads Kucia to the conclusion that an increased level of education in Polish society in the last twenty years has not been accompanied by a proportional decrease in antisemitism, and that the education about the Holocaust, introduced in Polish schools at the end of the 1990s, does not produce expected results. ${ }^{51}$

In this context it is interesting to compare the results collected by Poland's Center of Public Opinion Research regarding the changing perception of Auschwitz-Birkenau in Polish society. The results are presented in Table 8.1.

TABLE 8.1 Changing perception of Auschwitz-Birkenau in Polish society.

Auschwitz is for me predominantly the site of: (\%)

\begin{tabular}{llll}
\hline $\begin{array}{l}\text { The suffering of } \\
\text { the Polish nation }\end{array}$ & $\begin{array}{l}\text { The Holocaust } \\
\text { of the Jews }\end{array}$ & Other $\quad$ Difficult to say \\
\end{tabular}

\begin{tabular}{lllll}
\hline 2015 & 45 & 33 & 20 & 2 \\
2005 & 37 & 17 & 43 & 2 \\
1995 & 32 & 18 & 48 & 2 \\
\hline
\end{tabular}

SOURCE: CBOS. ${ }^{52}$

49 Kucia, "Polacy wobec Auschwitz," 31.

50 Kucia, "Polacy wobec Auschwitz," 27.

$5^{1}$ Kucia, "Polacy wobec Auschwitz," 33.

52 своs Centrum Badania Opinii Społecznej, Auschwitz-Birkenau w pamięci zbiorowej. Komunikat 11, (Warszawa: своs, 2015), 6. 
It turns out that in 2015, after twenty years of educational work, radical transformation of the way Auschwitz-Birkenau Museum is presenting the Holocaust, and, generally, a substantial change of the social frame of the Holocaust memory, the percentage of those who identify Auschwitz predominantly with the suffering of the Polish nation had increased. On the other hand, we may also observe an increasing percentage of the answers pointing out the Holocaust of the Jews as the first association with Auschwitz, which indicates that the educational change and transformation of the commemorative environment had yielded some effect. Taking the decreasing figure of those who have different, more universal associations with Auschwitz (for example 'site of the crime against humanity'), we may say that public opinion has become increasingly polarized regarding the issue of the meaning of Auschwitz.

However, the thesis of polarization has been challenged by the 2010 research by Marek Kucia, who allowed respondents to mention more than one association with the word 'Auschwitz.' It turned out that more than 9o percent of those to whom Auschwitz was predominantly the site of Polish suffering, associated Auschwitz also with the Holocaust of the Jews. ${ }^{53}$ It seems thus that Poles do have relevant knowledge about Auschwitz and the Holocaust and if they set aside the murder of the Jews in their enunciations it is not because of amnesia, repression or ignorance, but as a result of a conscious value-choice to focus on those with whom they identify, the people they call 'we.' Their social memory is increasingly less determined by personal recollection and transgenerational communication; instead, the external cultural frames, including education, impact the way they see the past. However, it is to a larger degree mediated by the imperatives of their attempts to build and protect their identity in difficult times, as well as by the hidden cultural codes that draw the horizon of their particular self-descriptions. Memory, at least in the mode of anámnesis, is a function of the social construction of identity. Referring to this concept, I will now try to interpret the increase in antisemitism in the 199os and the value-choices that make the Holocaust discourse, now fully accessible, only a secondary frame in the interpretation of history.

\section{Factors Influencing Poland's Memoryscape}

It seems that although Polish society, liberated from communist control, was exposed to the truth in the new social frames of memory in the decade of the 1990 and in the beginning of the twenty-first century, the information about 
the Holocaust and the Jews has not been well integrated into the existing cognitive structures.

This has partly been caused by the peculiarity of the process of 'regaining' the Jewish memory in Poland, partly by the widespread (especially in the older generation) existential insecurity and the perception of post-communist transformation as a threat to identity, and eventually by the peculiar features of the encounter of the Poles with the globalized Holocaust discourse.

\section{The Progressing Threshold of Shame}

The memoryscape of post-communist Poland, in which Jews and the Holocaust reappeared as objects of remembrance and commemoration, has been shaped by a number of public debates that have dominated Poland's intellectual life since the end of the $1980 \mathrm{os}$. The first of them, still limited by the communist control of the media, was initiated by the presentation of Claude Lanzman's Shoah on Polish TV in 1985. Although the documentary was generally perceived by the Polish audience as 'tendentious,' it nevertheless constituted the first blow to the Polish mythology of the Second World War and confronted the public with the erased issue of the Holocaust. Two years later, an essay published by Jan Błoński in the Catholic weekly Tygodnik Powszechny stirred public opinion and produced a debate about the guilt and responsibility of the Poles as passive witnesses of the Holocaust who did not express compassion and often seemed to be pleased with the Nazi persecutions of the Jews. ${ }^{54}$

The main issue debated in the years 1985-1993 was the conflict over the Carmelite convent on the site of the Auschwitz-Birkenau death camp, which lead to controversies regarding the organization of the 5oth anniversary of the liberation of the camp in 1995 and the conflict over the presence of the so-called 'Papal cross' in the area formerly designed for the convent. ${ }^{55}$ These disputes did not only expose the incompatibility of the Jewish and Catholic approaches to commemorating the tragedy of Auschwitz, but also society's reluctance to recognize the camp as a symbol for Jewish tragedy, and, consequently, the impropriety of Catholic symbols and practices in this context. Denying the propriety of religious commemoration of the victims was a shock to many Poles, leading to a series of defensive reactions, often involving a specific mixture of traditional, religiously motivated anti-Judaism (Jews as 'enemies of Christianity') and modern antisemitism (Jewish 'anti-Polish conspiracy', depriving the Poles of the right to commemorate the past in the manner accepted by their culture).

54 Jan Błoński, "Biedni Polacy patrzą na getto," Tygodnik Powszechny, 18 January 1987.

55 Geneviève Zubrzycki, The Crosses of Auschwitz. Nationalism and Religion in PostCommunist Poland (Chicago: The University of Chicago Press, 2006). 
The beginning of the twenty-first century was marked by the publication of Jan T. Gross's Neighbors (2000), which revealed to a wider audience that in 1941 the Polish inhabitants of the town of Jedwabne murdered the Jewish inhabitants of the town. This book opened up the most heated debate about PolishJewish relations during the time of the Holocaust ${ }^{56}$ and it has been fueled by other books, ${ }^{57}$ with the result that today's Poland is a place where Jews are remembered entirely differently than in the 1990s. ${ }^{58}$

The most striking feature of those debates has been the process, which I would call 'the progressing of the threshold of shame.' Each round of the debate has brought about more severe accusations and revealed more facts, with which it has been increasingly difficult to come to terms. If the general impression after Lanzman's Shoah was that some sectors of Polish society (poor, uneducated and corrupted by the time of the war) might have shown lack of compassion for the Jewish tragedy, some of the views, expressed in the 'Błoński debate', have suggested that such an attitude was far more widespread, and that it was not limited to a lack of sensitivity, but included a clear, although passive, support for the persecution of the Jews. The 'Jedwabne debate' revealed that Poles, in certain circumstances (forced or encouraged by the occupying German forces), might have been not only passive supporters of the persecutions but also active perpetrators. Subsequently, in view of the next books by Gross, the Polish readers would have to accept that after 1945 Poles did not need to be forced or encouraged by the Germans to persecute Jews.

The process of advancing the threshold of shame has two contradictory consequences. On the one hand, it has made it easier for the Poles to accept the revelations brought by the subsequent phases of the debate. A new piece of the truth has been easier to digest because of the memory work done previously. On the other hand, the gradual character of the process has also helped to develop defensive reactions. Some of those who have come to terms with the unpleasant information received at a certain stage of the debate and who have done work to revise their views might have been reluctant to accept a new challenge, treating it as an unfair continuation of demands and accusations. The rationalization which has been used in such defensive strategies could be

$5^{6}$ Antony Polonsky and Joanna B. Michlic, ed., The Neighbors Respond: The Controversy over the Jedwabne Massacre in Poland (Princeton: Princeton University Press, 2003); Joshua D. Zimmerman, Contested Memories. Poles and Jews during the Holocaust and its Aftermath (New Brunswick, New Jersey: Rutgers University Press, 2003). Jan T. Gross, Fear: Anti-Semitism in Poland after Auschwitz. An Essay in Historical Interpretation (New York: Random House, 2006); Jan T. Gross and Irena Grudzińska-Gross, Golden Harvest (New York: Oxford University Press, 2012).

$5^{8}$ Piotr Forecki, Od "Shoah" do "Strachu". Spory o polsko-żydowska przesztość i pamięć w debatach publicznych (Poznań: Wydawnictwo Poznańskie, 2010). 
summed up as: 'We did our job; what else do they want?' For the less engaged, the return of the issues previously debated might have been a source of irritation: 'do we need to go through that once again?', resulting in the broader audience shifting away from the debate.

In consequence, the different approaches by Polish people to the past split into critical re-examination of difficult aspects of the Polish-Jewish history and affirmative attitude. The latter is often defensive regarding the results of the critical work and usually intensifies in the periods of social crisis. This split took the form of the antagonistic binary opposition of memories. ${ }^{59}$ Polish debates thus proved unable to develop 'polycentric memory' in the sense advocated by Richard Sennett. This kind of memory requires that the groups involved accept that none of them is at the centre of memory and that the memory process presupposes an interaction between different centres rather than the defense of the fortress of one's own memory. Polycentric memory 'requires a social structure in which people can address others across the boundaries of difference. ${ }^{60}$ We may argue that such a social structure has not fully emerged in the course of the Polish debates, which have resulted in the fragmentation of memoryscape that continues to deepen, most recently in connection with the historical politics of the new government elected in 2015 .

\section{The Holocaust Discourse}

The fall of communism meant to Poland the opening of ideas previously blocked by the communist ideology. This included the international Holocaust discourse and coincided with the process of its 'cosmopolitanization' that Levy and Sznaider interpret as part of the effort to establish value-consensus and reorganize international cooperation. 'With the fall of the Iron Curtain ... the Holocaust has provided a political and cultural basis for establishing new sensibilities and solidarities. ${ }^{61}$

In spite of such a practical function, the Holocaust discourse was also part of contemporary postmodern culture and shared its ambiguous status. Our era, on the one hand, is often described as a post-historical period, in which history does not matter the way it did in the past. Nevertheless, contemporary 'amnesiac societies' are believed to develop a 'passion for memory, which manifests in the growing popularity of commemorative activities and the sites

59 Chantal Mouffe, Deliberative Democracy or Agonistic Pluralism (Vienna: Department of Political Science, Institute for Advanced Studies, 2000).

6o Richard Sennett, "Disturbing Memories," in Memory, ed. Patricia Fara and Karalyn Patterson (Cambridge: Cambridge University Press, 1998), 22.

61 Levy and Sznaider, The Holocaust, 17-18. 
with which they are associated, as well as in the proliferation of literature that evokes the past. ${ }^{62}$

It seems that Holocaust remembrance shares the fate of other forms of memory in our age: it is omnipresent but its relevance may be called into question. For Eva Hoffman, the memory of the Holocaust is precisely a hypermemory' in the postmodern sense of hyperreality, something that makes it in fact a 'secondary amnesia' - the 'kind of amnesia in which the Shoah is in danger not so much of vanishing into forgetfulness as expanding into an increasingly empty referent, a symbol of historical horror, an allegory of the Real, the familiar catastrophe and a stand-in for authenticity and for history.' ${ }^{63}$

This may well be one of the reasons why the Holocaust discourse has not managed to get a strong footing in post-communist Eastern Europe. The reality of the Holocaust, highly mediatized and dramatized through commemorative activities, might seem to the unprepared eye of a Polish spectator as something 'out there,' which does exist in the realm of the mass media or 'big politics,' and which may raise concern, but not for too long, as long as it does not clash with the historical narratives more familiar to the Polish audience, for example religious or nationalist narratives. Moreover, the external character of the Holocaust discourse has contributed to the feeling that the previous historical master narrative, imposed by the communist authorities, is being replaced by another one, again imposed on people who would rather prefer to avoid such impositions.

This feeling has overlapped with the widespread perception that the historical suffering of the non-Jewish East Europeans is not properly recognized in Europe (in opposition to the Jewish one). This specific form of the 'competition of victims' often corresponds with the belief that 'the focus on the Holocaust ... prevents people from investigating or taking equally seriously cases which do not appear to be exactly like it.' ${ }^{64}$

Finally, the Holocaust discourse has contributed to political divide and unrest, augmented by the transformation of social structure. According to Levy and Sznaider, globalization does not mean homogenization of standpoints but rather 'divides each national political culture into several competing worldviews, some of which are more globalized than others. The central

62 Barbara A. Misztal, "The Sacralization of Memory," European Journal of Social Theory 1 (2004): 57 .

63 Eva Hoffman, After Such Knowledge. A Meditation on the Aftermath of the Holocaust (London: Vintage, 2004), 177.

64 Dan Stone, "Beyond the Mnemosyne Institute: The Future of Memory after the Age of Commemoration," in The Future of Memory, ed. Richard Crownshaw, Jane Kilby, Antony Rowland (New York - Oxford: Berghahn Books, 2010), 28. 
characteristic of the social carriers of global memory is that their personal relationships are determined less by the nation-state than by the world of which it is a part, and this leads them to interpret the world in a different way.' ${ }^{65}$ There is also a global elite in Poland today that serves as the social carrier of the Holocaust discourse. The rejection of the Holocaust by those members of society who did not benefit from the transformation process has often taken the form of social resentment, unrelated to the actual content of what has been rejected and directed at the elites that used the Holocaust discourse to critically re-examine Poland's history and its perceptions.

\section{In Defense of Identity}

The Polish debates about the country's Jewish past and the reception of the Holocaust discourse occurred in the atmosphere of instability and insecurity that was connected with the social, political and economic transformation. They increased the 'structural trauma,' which was the response of large parts of the post-communist society to the immense change in their lives. The anxieties associated with the structural trauma of the present might sometimes have an impact on the 'historical traumas' experienced in the past and thus contribute to the deflection of memories. ${ }^{66}$ This might be the case of the large sectors of the Polish society in the 1990s: the anxieties of that time set in motion identity-protection mechanisms which largely ruled out the chance of self-critical historical examination and identification with the Jewish victims of the Holocaust. Instead, Poles preferred to recall a nostalgic image of the past that would bring some comfort into their identity crisis. ${ }^{67}$

In such a context, the attempts of the Polish intellectual elites to face the problem of the Holocaust and to include the memory of the Jews in the collective memory of Polish society did, in the eyes of many Poles, undermine the nostalgic image of the past. The attempts enforced a critical rethinking of identity, rather than the affirmation of its mythologized forms, and have thus been met with distrust. Therefore, the rejection of the Holocaust discourse by large sectors of the Polish society can be interpreted as part of the posttraumatic syndrome, bearing in mind that the trauma in question is rather the structural trauma of the post-communist transformation that evokes the historical trauma of the witnesses of the Holocaust.

65 Levy and Sznaider, The Holocaust, 18.

66 Dominick LaCapra, Writing History, Writing Trauma (Baltimore: The Johns Hopkins University Press, 2001).

67 Piotr Sztompka, "Cultural Trauma. The Other Face of Social Change," European Journal of Social Theory 4 (2000): 284 . 
It is particularly important that the memory of the Holocaust brings into question two crucial features of Polish national identity: the belief that (ethnic) Poles have been the main victims of history in general and of the Second World War in particular, and the belief in national history as the continuous unfolding of the virtues of the (ethnic) Polish nation, against all odds and plots. In the context of the identity crisis that has marked the post-communist transformation of Poland, the nation needed to be re-invented, and the continuity of its past and future had to be re-created. It goes without saying that if the future is to be anticipated with hope, the past must be constructed as a glorious one, at least if we operate within a paradigm of ethnic, particularistic nationalism, and thus the process of the post-communist recovery of memory often means 'rather the defense of a particular selection from among ... facts, one that assures its protagonists of maintaining the roles of hero or victim when faced with any other selection that might assign them a less glorious role. ${ }^{68}$

Memory as a convenient selection that serves to establish the continuity of past, present and future, and works out the essence of nationhood as unfolding in time, often focuses on the traumas of the past to reassure the pattern of survival which gives hope in overcoming the trauma of the present. This involves the 'construction of a narrative community with the dead' and the pathos of such memory work may sometime legitimate 'expiatory violence.' 69 It seems that the memory of the Holocaust has been treated by some sectors of Polish society, mostly those affected by the trauma of transformation, as interfering with the Polish memory as the celebration of nationhood (for it has questioned both the heroism of the Poles and their self-proclaimed status as the main victims), which has largely protected it from being included in Poland's memory, in spite of noble efforts, and has divided public opinion, thus leading to the polarization of standpoints revealed by the surveys' results. The time of the transformation is not the most convenient period for a critical re-examination of the past: even if it calls for the revision of mythological views, it is usually a tiny fraction of society that advances critical memory. For the remaining part, threatened in their ontological security, memories serve as trenches and myth as a protection.

68 Tzvetan Todorov, "The Uses and Abuses of Memory," in What Happens to History. The Renewal of Ethics in Contemporary Thought, ed. Howard Marchitello (New York and London: Routledge, 2001), 21.

69 William Outhwaite and Larry Ray, Social Theory and Postcommunism (Malden: Blackwell, 2005), 196. 


\section{Conclusions}

In this text the author employs Memory Studies concepts, such as memoryscape, remembrance, commemoration, mnéme, anámnesis, social and collective memory in a study of Poland's memory of Jews and the Holocaust, especially in the post-communist period. In result, Steinlauf's historical periodization has been transformed into a sociological typology, in which the period of 1944-1948 is marked by individual remembrance and public commemoration. In the period 1948-1968 individuals still keep the memory of Jews and the Holocaust alive, but they are not publically commemorated until 1956 because of the Marxist orthodoxy. Then, due to the growing nationalism within the communist party, in the period 1968-1989 there is neither remembrance nor commemoration, while after 1989 Jews and the Holocaust are publically commemorated again but with a limited impact on individual remembrance. The author's main task was therefore to explain why, in the post-communist memoryscape of Poland, Jews and the Holocaust are commemorated but not remembered.

To answer this question, the author turns firstly to the way Polish-Jewish prewar coexistence and the Holocaust have been remembered in the mode of mnéme, that is according to the perception that it is predominantly the nature of past events that has determining impact on people's future memories. Here the text focuses on the, often antisemitic, social and cultural exclusion of Jews from the prewar Polish community, which lead to the fact that the Holocaust did not affect the identity of the non-Jewish Poles, which in turn accounted for the postwar exclusion of Jews from the 'mnemonic community.' An additional factor was the suffering of the non-Jewish Poles during the Second World War that occluded in their memory the tragedy of the Jews. However, one needs to mention the trauma of witnesses (and sometimes accomplices) of the Holocaust. Although the Holocaust itself did not seem to affect the identity of the non-Jewish Poles, the witnessing of the Holocaust did. Some of the most important and often mythologized features of Polish collective identity might have been subverted by the memory of the Holocaust and thus this memory has been largely erased. Finally, one must refer to the issue of material and social benefits gained by the non-Jewish Poles as are sult of the Holocaust. For large segments of postwar Polish society the murder of Jews offered a chance to fill in the gaps in the economic and social space for social advancement. For various reasons such genealogy of the contemporary Polish middle class is usually carefully erased from memories.

A complementary way of answering the main question refers to the circumstances in which the visions of the Jewish-Polish past have been produced, i.e. 
to examine memory in the mode of anámnesis: a perception that it is mostly the nature of the present of the remembering subject(s) that determines the content of memory. Here the author follows Jeffrey Alexander's social theory of trauma as well as Levy and Sznaider's view on the importance of the Holocaust discourse. The lack of such discourse during and immediately after the war accounts for the lack of adequate recognition of the murder of Jews. Then, when the discourse was already developed, Poland was isolated behind the Iron Curtain and it did not have a significant impact as a factor that organized collective/social memory. Finally, after the collapse of communism Poland was exposed to the globalized version of the Holocaust discourse which contributed to its rejection in large segments of society.

In the post-communist Poland, the Holocaust discourse was often perceived as an instrument of cultural domination that replaced in this function the communist vision of history; moreover, as not corresponding with the need of many Poles to commemorate the (ethnically) Polish victims of Nazism and communism, something they were not allowed to do in communist Poland.

The discourse found, however, its followers among the elites, which contributed to the translation of the conflict of memory into social conflict between the beneficiaries of the neoliberal transformation of Poland's economy and politics on the one hand and, on the other hand, the impoverished sectors of the society. Therefore, the serious debates about Polish-Jewish past launched by intellectuals and artists caused defensive reactions as part of the social cleavage and also due to their internal dynamics presented in the text as the 'progressing threshold of shame.'

From a more general perspective the defensive reaction to the attempts to include Jews and the Holocaust into Poland's memoryscape can be understood as a mechanism of protecting the collective identity, already threatened by the radical social transformation, in which, as in LaCapra's model, structural trauma of the present finds its expression in the historical trauma of the past and the latter hardly accepts competition: in this case in the form of the murdered Jews and their destroyed world. In particular, the memory of having been witnesses of the Holocaust turned out to be incompatible with the mythology of the Polish nation and thus was largely rejected while the memory of Jews has been retained in the form of a, equally mythologized, nostalgic vision of peaceful multiculturality of the past.

These factors may help to understand why in post-communist Poland, in spite of serious commemorative efforts, intellectual revisions and reformed education, Jews and the Holocaust remain commemorated but not remembered in the social memory of large segments of society. Taking into account the new historical politics of the government elected in 2015, we may predict 
that in the near future the official commemoration of Poland's Jewish past will be systematically waning. This politics of memory has been clearly masterminded for those sectors of society, whose existential insecurity recently seems to have been anaesthetized by a mixture of xenophobic nationalism and populist economic programs, thus legitimizing the new rulers. The fact that for the last twenty-five years, various neoliberal governments have not managed to find a better alternative for these sectors is of course important but cannot be analyzed in detail in this paper.

\section{Bibliography}

Alexander, Jeffrey C. Trauma. A Social Theory. Cambridge: Polity, 2012.

Ambrosewicz-Jacobs, Jolanta. "Memory and Civic Education: Holocaust and Coming to Terms with National History." In The Religious Roots of Contemporary European Identity, edited by Lucia Faltin and Melanie J. Wright, 105-116. London: Continuum, 2007.

Assmann, Aleida. "Transformations between History and Memory." Social Research 1 (2008): 49-72.

Banasiewicz-Ossowska, Ewa. Między dwoma światami. Żydzi w polskiej kulturze ludowej. Wrocław: Polskie Towarzystwo Ludoznawcze, 2007.

Benz, Wolfgang. Anti-Semitism in Europe. Traditions, Structures, Manifestations. Uppsala: Uppsala University, 2004.

Błoński, Jan. "Biedni Polacy patrzą na getto." Tygodnik Powszechny, 18 January 1987.

Booth, W. James. "The Work of Memory: Time, Identity, and Justice." Social Research 1 (2008): 237-262.

Cattell Maria G., and Jacob J. Climo. "Introduction. Meaning in Social Memory and History: Anthropological Perspectives." In Social Memory and History. Anthropological Perspectives, edited by Jacob J. Climo and Maria G. Cattell, $1-36$. Walnut Creek: Altamira Press, 2002.

своs Centrum Badania Opinii Społecznej. Auschwitz-Birkenau w pamięci zbiorowej. Komunikat z badań своs. No. 11, January 2015.

Cesarani, David, and Eric J. Sundquist, eds. After the Holocaust: Challenging the Myth of Silence. New York: Routledge, 2012.

Diner, Hasia R. We Remember with Reverence and Love: American Jews and the Myth of Silence after the Holocaust, 1945-1962. New York: NYU Press, 2009.

Forecki, Piotr. Od "Shoah" do "Strachu". Spory o polsko-żydowska przesztość i pamięć w debatach publicznych. Poznań: Wydawnictwo Poznańskie, 2010.

Geertz, Clifford. The Interpretations of Culture. New York: Basic Books, 1973.

Gellner, Ernest. Nations and Nationalism. Oxford: Blackwell, 1983. 
Gross, Jan T. Fear: Anti-Semitism in Poland after Auschwitz. An Essay in Historical Interpretation. New York: Random House, 2006.

Gross, Jan T. Neighbors: The Destruction of the Jewish Community in Jedwabne, Poland. Princeton: Princeton University Press, 2001.

Gross, Jan T. Sąsiedzi. Historia zagłady żydowskiego miasteczka. Sejny: Pogranicze, 2000.

Gross, Jan T. and Irena Grudzińska-Gross. Golden Harvest. New York: Oxford University Press, 2012.

Gruber, Ruth E. Virtually Jewish: Reinventing Jewish Culture in Europe. Berkeley: University of California Press, 2002.

Hoffman, Eva. After Such Knowledge. A Meditation on the Aftermath of the Holocaust. London: Vintage, 2004.

Kapralski, Slawomir. "The Role Played by the Auschwitz-Birkenau State Museum in Public Discourse and the Evolving Consciousness of the Holocaust in Polish Society." In Jewish Presence in Absence. The Aftermath of the Holocaust in Poland 1944-2010, edited by Feliks Tych and Monika Adamczyk-Garbowska, 605-633. Jerusalem: Yad Vashem, 2014.

Kapralski, Slawomir. "People of Different Times." In The Jews in Poland, vol. 2 edited by Slawomir Kapralski, 321-338. Kraków: Judaica Foundation, 1999.

Krajewski, Stanisław. Poland and the Jews. Reflection of a Polish Polish Jew. Kraków: Austeria, 2005.

Krzemiński, Ireneusz. "Uwarunkowania i przemiany postaw antysemickich." In $\dot{Z} y d z i-$ problem prawdziwego Polaka. Antysemityzm, ksenofobia i stereotypy narodowe po raz trzeci, edited by Ireneusz Krzemiński, 21-59. Warszawa: Wydawnictwa Uniwersytetu Warszawskiego, 2015.

Kucia, Marek. "Polacy wobec Auschwitz, Zagłady i Żydów w świetle badań socjologicznych z 2010 roku i badań wcześniejszych." In Antysemityzm, Holokaust, Auschwitz w badaniach spotecznych, edited by Marek Kucia, 11-36. Kraków: Wydawnictwo Uniwersytetu Jagiellońskiego, 2011.

Kucia, Marek. Auschwitz jako fakt spoteczny: historia, wspótczesność i świadomość spoteczna KL Auschwitz w Polsce. Kraków: Universitas, 2005.

LaCapra, Dominick, Writing History, Writing Trauma. Baltimore: The Johns Hopkins University Press, 2001.

Leder, Andrzej. Prześniona rewolucja. Ćwiczenie z logiki historycznej. Warszawa: Wydawnictwo Krytyki Politycznej, 2014.

Levy, Daniel, and Natan Sznaider. The Holocaust and Memory in the Global Age. Philadelphia: Temple University Press, 2006.

Misztal, Barbara A. "The Sacralization of Memory." European Journal of Social Theory 1 (2004): 67-84.

Misztal, Barbara A. Theories of Social Remembering. Maidenhead: Open University Press, 2003. 
Mouffe, Chantal. Deliberative Democracy or Agonistic Pluralism. Vienna: Department of Political Science, Institute for Advanced Studies, 2000.

Muzaini, Hamzah, and Brenda S.A. Yeoh. "War Landscapes as 'Battlefields' of Collective Memories: Reading the Reflections at Bukit Chandu, Singapore." Cultural Geographies 12 (2005): 345-365.

Novick, Peter. The Holocaust and Collective Memory. The American Experience. London: Bloomsbury, 2001.

Orla-Bukowska, Annamaria. "Gentiles Doing Jewish Stuff. The Contribution of Polish Non-Jews to Polish Jewish Life." In Rethinking Poles and Jews: Troubled Past, Brighter Future, edited by Robert Cherry and Annamaria Orla-Bukowska, 197-214. Lanham: Rowman \& Littlefield Publishers, Inc., 2007.

Orla-Bukowska, Annamaria. "New Threads on an Old Loom. National Memory and Social Identity in Postwar and Post-Communist Poland." In The Politics of Memory in Postwar Europe, edited by Richard Ned Lebow, Wulf Kansteiner, and Claudio Fogu, 177-209. Durham and London: Duke University Press, 2006.

Outhwaite, William, and Larry Ray. Social Theory and Postcommunism. Malden: Blackwell, 2005.

Polonsky, Antony and, Joanna B. Michlic, eds. The Neighbors Respond: The Controversy over the Jedwabne Massacre in Poland. Princeton: Princeton University Press, 2003.

Prager, Jeffrey. Presenting the Past. Psychoanalysis and the Sociology of Misremembering. Cambridge, Massachusetts: Harvard University Press, 1998.

Roskies, Diane K., and David G. Roskies. The Shtetl Book: An Introduction To East European Jewish Life And Lore. New York: Ktav Publishing House, 1975.

Sennett, Richard. "Disturbing Memories." In Memory, edited by Patricia Fara and Karalyn Patterson, 10-26. Cambridge: Cambridge University Press, 1998.

Sewell, William H. Jr. Logics of History. Social Theory and Social Transformation. Chicago: The University of Chicago Press, 2005.

Steinlauf, Michael C. Bondage to the Dead. Poland and the Memory of the Holocaust. Syracuse: Syracuse University Press, 1997.

Steinlauf, Michael C. "Poland.” In The World Reacts to the Holocaust, edited by David S. Wyman, 81-155. Baltimore and London: The Johns Hopkins University Press, 1996.

Stone, Dan. "Beyond the Mnemosyne Institute: The Future of Memory after the Age of Commemoration." In The Future of Memory, edited by Richard Crownshaw, Jane Kilby, and Antony Rowland, 17-36. New York - Oxford: Berghahn Books, 2010.

Sztompka, Piotr. "Cultural Trauma. The Other Face of Social Change." European Journal of Social Theory 4 (2000): 449-466.

Todorov, Tzvetan. "The Uses and Abuses of Memory." In What Happens to History. The Renewal of Ethics in Contemporary Thought, edited by Howard Marchitello, 11-39. New York - London: Routledge, 2001.

Weinbaum, Laurence. "Penitence and Prejudice: The Roman Catholic Church and Jedwabne." Jewish Political Studies Review 3-4 (2002): 131-154. 
Weinbaum, Laurence. The Struggle for Memory in Poland. Auschwitz, Jedwabne and Beyond. Jerusalem: Institute of the World Jewish Congress, 2001.

Yerushalmi, Yosef. H. Zakhor:Jewish History and Jewish Memory. Seattle: University of Washington Press, 1996.

Young, James E. The Texture of Memory: Holocaust Memorials and Meaning. New Haven: Yale University Press, 1993.

Zaremba, Marcin. Wielka trwoga. Polska 1944-1947: ludowa reakcja na kryzys. Kraków: Wydawnictwo Znak i ISP PAN, 2012.

Zimmerman, Joshua D. Contested Memories. Poles and Jews during the Holocaust and its Aftermath. New Brunswick, New Jersey: Rutgers University Press, 2003.

Zubrzycki, Geneviève. The Crosses of Auschwitz. Nationalism and Religion in Post-Communist Poland. Chicago: The University of Chicago Press, 2006. 


\title{
Neither Rupture Nor Continuity: Memorializing the Dawn of the Space Age in Contemporary Russian Cinematography
}

\author{
Natalija Majsova
}

Around half a century after the launch of the Sputnik in 1957 and the first feats of space programmes, and a couple of decades into the so-called commercialization of outer space, scholars in the humanities and social sciences seem to be returning to the question: 'Wherein lies the significance of the space age in the first place?', a question which may hardly be addressed properly using a single theory or methodological toolbox due to its complexity. At first glance, there appears to be a general consensus on the global, if not universal, significance of the event. The dawn of the space age and its resonant events, such as the launch of the Sputnik, Gagarin's flight or the Moon-landing, are often seen as great milestones in scientific and technological progress: a symbol of humanity's unity in its terrestrial origin, a signpost signaling the humility and loneliness of life on Earth in the vast cosmic space. On the other hand, these memory narratives of the dawn of the space age mostly remain constrained to national or regional frameworks. ${ }^{1}$ Nevertheless, the general consensus persists that the aforementioned achievements are of global and transcultural relevance.

The aim of this text is to add to existent debates by exploring memory narrative reception through two particular cinematic (re)appropriations of the

1 For instance, a quick overview of existent scholarly literature shows that American space policy has, from its inception, predominantly been focused on the political, military and societal aspects of spaceflight. European space policy, on the other hand, has positioned itself in alignment with the economic and scientific benefits of space technologies, while the Russian space program has thus far devoted most attention to the cultural dimension of space exploration. Furthermore, memorialization media, such as popular globally 'iconic' imagery of/from outer space mostly involve images taken by NASA [National Aeronautis and Space Administration] and ESA [European Space Agency], and not by other space agencies; sites of memory and media of memory narrative construction, such as space history and space technologies museums around the world tend to favor local national achievements, rather than focus on the space age as a global achievement. 
narrative of the dawn of the space age. The text will examine how an audiovisual medium, such as cinema, can productively contribute to existent and persistent memory practices that mark our understanding of humanity's first tangible encounters with outer space in the late 1950 s and early 1960 s. $^{2}$ The analysis shall be limited to a particular case study: contemporary Russian cinematic production on the advent of the space age. However, it will be argued in the conclusion that such local manifestations have multifaceted significance for a potential transcultural European narrative on the issue.

Following a brief contextualization of the place of the dawn of the space age in contemporary cinema, particularly Russian cinema, the text will examine in detail two cases in point. Two case studies of contemporary Russian cinema (Kosmos kak predchuvstviye [Dreaming of Space] (dir. Alexei Uchitel', 2005) and Pervye na Lune [First on the Moon] (dir. Alexei Fedorchenko, 2004) will be used to examine the following pertinent issues. Firstly, are cinematic accounts focusing on the beginning of the space age mere reiterations of mainstream narratives about the history of space flight or do they call for reinterpretations of prevailing narratives on the significance of spaceflight? Secondly, are cinematic accounts focusing on the beginning of the space age nationally bound, i.e. do they reflect nationally specific narratives, attitudes, cinematographic canons and reference frameworks or do they appropriate and (re)interpret these narratives, attitudes, canons and reference framework in order to highlight issues of transnational significance? If the latter is true, what are these underlying issues and how do contemporary cinematic productions approach them? In addressing these questions, the text will argue that (neo)formalist film analysis - i.e. analysis particularly attentive to cinematic form ${ }^{3}$ - plays an important role in highlighting cinema's significance as a reception practice, and should supplement audience film reception analyses.

2 It has been noted by Erll and Nünning that film 'exists in a relationship to contemporary discourses of memory and illustrates functions, processes, and problems of memory in the medium of fiction through aesthetic forms' (Astrid Erll and Ansgar Nünning, "Concepts and Methods for the Study of Literature and/as Cultural Memory," Literature and Memory. Theoretical Paradigms. Genres. Functions (2006): 11-28.). In this chapter, I would like to take this argument a little further in order to suggest that cinematic fictional construction of memory narratives is also a level of reception of these narratives: cinematic adaptation may be seen as a level of memory narrative reception. Quite often, cinema intentionally plays around with officially approved memory narratives, in order to construct new ones.

3 Cf. Kristin Thompson, Breaking the glass armor: neoformalist film analysis (Princeton: Princeton University Press, 1988). 


\section{A Note on Method: Films, Memory, and Reception}

Film analysis is a tricky issue, because it involves 'translating' the cinematic audio-visual medium into text, i.e. sequences of written words. This process of interpretation is highly subjective, and reflects numerous factors, which shape the interpreter's commentary and reception. A film critic will often focus more on different aspects of a given film than a lay spectator, who is not consciously attentive to cinematic form and whose film-viewing practices are informed and shaped by a given context and daily routine. However, cinematic remediations of cultural narratives emerge precisely at this intersection of a thousand plateaus of reception practices. This chapter explores the implications of looking at different reception plateaus side by side, in order to explore the different facets of the cinematic medium that take part in memory reception processes.

While narrative analysis may be the most obvious way of looking at how films participate in cultural memory production and remediate, i.e. transpose into a different medium, re-tell, re-shape, in order to shift emphases and meanings, recent studies increasingly point to the importance of assessing other features of the cinematic medium: '/b/y communicating memories and counter-memories as well as the loss of memories the films not only share the recollections of their protagonists, and their ways of evoking certain events of their past, with the audience; they also use the cinematic apparatus and visual language to (re)present and (re)shape our understanding of memoryconstitution.' ${ }^{4}$ Films are therefore more than just motion pictures that illustrate novels and short stories. Cinematic form (lighting, mise-en-scène, music, colour, timespace construction) conveys a lot of non-verbal information about a film. Sometimes, this information is difficult to verbalize, and is only tacitly reflected in (particularly non-scholarly) film reviews: a reviewer may note that a film is 'grim' without explaining how this grimness is constructed formally. Such observations are precious comments on how films participate in memory processes: they point to divergences between narrative and form, and to ambiguities, which are key to the power of some memories; sometimes, an impression is created precisely because a certain narrative is insufficient for explaining a certain 'overall ambience' of an event. Or, in other words: 'film's impact lies less in its empirical qualities than in its powerful capacity

4 Verena Susanna Nungesser, "I Forgot to Remember (to Forget): Personal Memories in Memento (2000) and Eternal Sunshine of the Spotless Mind (2004)", in Media and Cultural Memory, ed. Astrid Erll and Ansgar Nünning (Berlin, New York: Walter de Gruyter, 2009), $31-48$. 
to influence public consciousness, mould collective memory and retrieve suppressed or marginalised histories. ${ }^{5}$ This 'powerful capacity' of film lies in its always-incomplete coalescence with verbalized film reviews.

Therefore, while considering the cinematic medium as a memory practice, and looking at how it contributes to memory reception, this text relies on several methodological remarks. The starting premise is that 'rather than assuming that the world on film should somehow adhere to the standards of written history, why not see if it has created its own standards over the last century, techniques for turning the past into history which are appropriate to the possibilities and practices of the medium, including those of drama, which is the standard way in which film tells its stories, past or present.' ${ }^{6}$ This premise allows us to consider the films themselves as memory practices and memory reception tools at the same time. In relation to memory, films are not only remediations of certain historical narratives, but also, at the same time, receptions of certain narratives: films are interpretations of narratives, constructed and approved by individual film auteurs of governance bodies that had commissioned the production of a film or both. Since this text looks closely at two auteur films, the former dimension will be considered as dominant over the latter. Therefore, cinematic interplay in memory reception processes is a 'double-bind': spectator reception is always reception of a certain reception, particularly in a case like ours, when fiction cinema is examined. Fiction cinema does not require a spectator to look for facts or coherence; it typically evokes diverse responses, only some of which note its possible contextual references.

In this text, lay spectators' reception will be juxtaposed with neoformalist analysis, which will provide insight into two issues: firstly, into the formal, aesthetic and stylistic reception of the narrative of the dawn of the space age, given by the two films, and, secondly, into the convergences and divergences between the official (verbal) narrative of the dawn of the space age and its significance, the aesthetic reception of these accounts, provided by two auteur film directors, and the reception of these cinematic accounts by lay audiences. This triple-loop will allow us to trace the subtle transformations that memory processes undergo in various phases of remediation and reception.

5 Jennie M. Carlsten and Fearghal McGarry, "Introduction", in Film, History and Memory, ed. Jennie M. Carlsten and Fearghal McGarry (London: Palgrave Macmillan, 2015), 1.

6 Jennie M. Carlsten and Fearghal McGarry, "Introduction", in Film, History and Memory, ed. Jennie M. Carlsten and Fearghal McGarry (London: Palgrave Macmillan, 2015), 6. 


\section{Memorializing the Dawn of the Space Age in the 21st Century}

Current debates on the significance of man's first indirect (satellites and spacecraft carrying plants and animals) and direct (manned spaceflight) ventures into the upper parts of Earth's atmosphere and beyond tend to focus on several key dimensions. One of them is narratives that shape our understanding of the socio-political and cultural context of these unprecedented events. These narratives typically contextualize the groundbreaking nature of the dawn of the space age within national and international frameworks, more or less narrow in scope. Narrower frameworks scale the significance of humanity's ventures into outer space down to sociopolitical, cultural and science and technological histories of spaceflight, while analyses aiming at broader horizons focus on frameworks of international and global politics. ${ }^{7}$ While such rationalist narratives that tend to focus on the political, military and economic Cold war race for primacy in outer space, as well as those that highlight man's unconditional faith in scientific progress, persist, ${ }^{8}$ they cannot fully account for the equally persistent fascination enveloping the globally resonant space-related events of the late 1950 and early 1960 .

Echoing this point, Shukaitis ${ }^{9}$ convincingly argues that the rationale guiding investments into outer space exploration (as well as space conquest and space tourism) of the 2oth and early 21st centuries can essentially be interpreted through two sequential matrices. The first, relevant for the period prior to the end of the Cold war, is a political matrix, i.e. the framework of the race for space, where dominion of the heavenly realm was seen as an analogy to political, technological, and therefore military supremacy on Earth. The second, foregrounded after the end of the Cold war and a short period of the prevalence of environmentalist arguments against investments in costly space programs, is a matrix following the logic of capitalist expansion. Here, outer space is conceptualized as a plausible solution, a welcome aid for managing structural crises of capitalism, which have to be addressed by new investments into ever

7 For a good overview, consult Roger D. Launius and Howard E. McCurdy, Imagining Space: Achievements, Predictions, Possibilities 1950-2050 (San Francisco, CA: Chronicle Books, 2005).

8 Here, I am referring to works such as Asif A. Siddiqi, The Red Rocket's Glare: Spaceflight and the Soviet Imagination, 1857-1957 (Cambridge: Cambridge University Press, 2010). and Eva Maurer, Julia Richers, Monica Ruthers and Carmen Scheide, eds., Soviet Space Culture: Cosmic Enthusiasm in Socialist Societies (London: Palgrave MacMillan, 2011) which highlight the cultural context of space enthusiasm in the Soviet Union.

9 Shukaitis, Stevphen. "Space is the (non)place: Martians, Marxists, and the outer space of the radical imagination." The Sociological Review 57 (2009): 98-113. 
further horizons. ${ }^{10}$ In both cases, outer space essentially functions as a semifictional (i.e. unknowable) horizon upon which the logic of Earthly affairs (politics, economics) is simply extrapolated with very few - if any - adjustments. Shukaitis argues that these approaches evidently ignore the unknowability of outer space, and its capacity to function as an 'imaginal machine'll expanding our horizons of thought. There appears to be little room for fascination with the unknown in the domains and language used by politics and economics.

Indeed, if anywhere, the issue of the fascination of outer space, the unknown and inherently unknowable cosmos, is addressed in sociological and media studies analyses of representations of outer space, the dawn of the space age and its future in cultural production. Starting off with this very presumption about the possibility of conceptualizing outer space and humanity's interaction with it in a different way, analyses such as Llinares'12 examination of the figure of the astronaut in popular culture and Marie Lathers' analysis of women in American science fiction, ${ }^{13}$ Rogatchevski's ${ }^{14}$ exploration of Soviet and Russian outer space cinematic production, among others, reinterpret media texts in order to demonstrate that, by and large, they fail to alter narratives on the dawn of the space age and its significance, generated by other disciplines. The first cases of manned space flight thereby remain interpreted as achievements, entirely reducible to their immediate, contextual conditions of possibility. Although several authors, such as McCurdy, Harrison, Geppert and Dick ${ }^{15}$ do acknowledge that 'imagination', a concept which here refers to

10 Shukaitis, "Space is the Non-Place", 110.

11 More precisely: 'Outer space, far from being a pure space that is always available for recomposing imaginal machines, also connects areas of political thought that veer off in strange and bizarre directions, showing that, as Deleuze and Guattari would concur in their more sober moments, absolute deterritorialization can easily end in death, insanity, or absurdity', Shukaitis, "Space is the Non-Place", 100.

12 Dario Llinares, The astronaut: Cultural mythology and idealised masculinity (Cambridge: Cambridge Scholars Publishing, 2011).

13 Marie Lathers, Space Oddities: Women and Outer Space in Popular Culture 1960-200o (New York: Continuum Books, 2010).

14 Andrei Rogatchevski, "Space Exploration in Russian and Western Popular Culture: Wishful Thinking, Conspiracy Theories and Other Related Issues." In Soviet Space Culture: Cosmic Enthusiasm in Socialist Societies, ed. Eva Maurer, Julia Richers, Monica Ruthers, Carmen Scheide (London: Palgrave Macmillan, 2011), 211-265.

15 Cf. Stephen J. Dick, "Space, Time and Aliens: The Role of Imagination in Outer Space," In Imagining Outer Space: European Astroculture in the 2oth Century, ed. Alexander C.T. Geppert, 27-45. Basinstoke, New York: Palgrave MacMillan, 2012; Alexander C.T. Geppert, ed., Imagining Outer Space: European Astroculture in the Twentieth Century (Basingstoke, New York: Palgrave Macmillan, 2012); Howard E. McCurdy, Space and the American 
the free play of human mental capacities, is an important dimension of these conditions, and proceed to link 'imagination' to the realm of aesthetics, there appear to be no analyses of contemporary artistic reflections on the narrative of the dawn of the space age that begin with, and concentrate primarily on, a formalist analysis of their aesthetics. However, as I will attempt to argue in this contribution, aesthetics is an important dimension of memory reception and reinterpretation, and should be given more emphasis in debates on cultural production of memory narratives than is currently the case.

\section{Looking for a Transcultural Narrative on the Memory of the Dawn of the Space Age through Cinematic Aesthetics}

Casting the intriguing sociopolitical, economic and technological context aside for a moment, the dawn of the space age may also be regarded as a philosophically intriguing point in history; a point of recurrence of an exceptionally old question about the place of humankind in the world at large, i.e. in the cosmos, rather than in a certain state, region or even on a certain planet. Philosophical and artistic reactions to the advent of the space age often focus on this very aspect of the event in question, testifying to its transculturality and universality ${ }^{16}$ This issue is particularly prominent in the works of Russian cubofuturists and suprematists of the early 2oth century, as well as in the works of a wide array of 2oth century philosophers of differing provenance and theoretical backgrounds (e.g. Hans Blumenberg, Günther Anders, Hanna Arendt and Jacques Lacan); ; it has also been explored performatively in science fiction literature. Today, over half of a century after humanity's first direct encounters with outer space, the question of the relevance of these encounters and their legacy for redefining humanity's conceptualizations of its place in the world, and even of life as such, is no less relevant, as demonstrated by projects at the intersection of art and science, such as Vermeulen's Seeker ${ }^{18}$ inter alia. In these projects,

Imagination. Baltimore (MA: JHU Press, 1994); Albert A. Harrison, Spacefaring: The Human Dimension (Berkeley, CA: University of California Press, 2002).

16 Cf. Christine Poggi, Inventing futurism: The Art and Politics of Artificial Optimism (Princeton, New Jersey: Princeton University Press, 2009).

17 For more on contemporary philosophical accounts on the implications of the dawn of the space age, see Natalija Majsova, "The Metaphor of the Dawn of the Space Age in Contemporary Social Sciences and Humanities," Družboslovne razprave 31 (2015): 13-30.

18 'Seeker' is artist Angelo Vermeulen's worldwide community art project creating starship prototypes, initiated in 2009. Accessed at http://www.angelovermeulen .net/?portfolio=seeker, 12 May 2016. 
aesthetics functions as a propulsive force in the domain of artistic practice. Aesthetics has the potential to drive and shift our horizons of thought, the coordinates framing our understanding of the world around us and its priorities. However, contemporary artistic production, practices and experience do not only explore the prospects of space exploration, but also address the legacy of the dawn of the space age. It is argued in this chapter that analyses of such artistic productions also need to be examined through the lens of aesthetics, in order to cast a new light on the memory narratives on the dawn of space exploration prevalent in western literature today.

Russian cinematic production is a telling case in point, and may be considered underresearched due to a lack of analyses focusing on aesthetics. Indeed, Russian cinema on outer space hinges on the tradition of Soviet cinematic production dealing with outer space, comprising genres such as scientific fantasy, ${ }^{19}$ children's scientific fantasy, popular-scientific fiction cinema, biographical dramas focusing on the lives and aspirations of prominent figures in the Soviet history of spaceflight, and even cyberpunk, as well as the commercial and dystopian science fiction which appeared during the perestroika period. Space related cinematic production, particularly fiction, of the Soviet era up until the perestroika period is of special significance, as it is positioned directly at the nexus of ideology, framing Soviet cinematic production, ${ }^{20}$ and aesthetics, so evidently dominant in films such as Tarkovsky's Solyaris [Solaris] (1972).

Comparatively, contemporary (post-2001) Russian cinematography has far greater capacities for exploring outer space and the legacy of the dawn of the space age in terms of aesthetics as it is not governed by a single aesthetic canon. Conversely, post-2001 Russian cinema on outer space is a productive medium for exploring memory practices related to the dawn of the space age, and is of analytical interest for different reasons than Soviet space related production, marked by the aforementioned tension between aesthetics and the socialist realist canon on the one hand, and an enthusiasm about space-related films, stemming from the fact that Soviet outer space supremacy was portrayed as

\footnotetext{
19 For the history of the term 'scientific fantasy' and its relation to science fiction, see Darko Suvin, Russian Science Fiction 1956-1974 (Elizabethtown, NY: Dragon Press, 1976).

20 Certainly, communist ideology and the canon of socialist realism greatly influenced outer space related fiction in other media, such as literature; however, if independent cinematic production capacities were virtually non-existent, writers and poets still had the option of resorting to, for example, samizdat. Cf. Matthias Schwartz, "Die Besiedelung der Zukunft. Zur Neubegründung der sowjetischen Science Fiction nach dem ersten Sputnikflug 1957," In Bluescreen. Visionen, Träume, Albträume und Reflexionen des Phantastischen und Utopischen, ed. Walter Delabar and Frauke Schlieckau (Bielefeld: Magazin für Literatur und Politik, Heft 43-44, 2010), 105-122.; Suvin, Russian Science Fiction 1956-1974.
} 
a building block of Soviet (supra)national identity, on the other. After the fall of the Soviet Union, which produced over 40 outer space related feature films, there were virtually no films on this topic produced in Russia until $2004 \cdot{ }^{21} \mathrm{~A}$ renewed rise of interest for outer-space-related feature film production of various genres in Russia observed after 2001 is likely to be a combination of various factors, such as a renewed political interest in the achievements of the Soviet era and its nation-building myths, increased resources for film production after the turbulent 199os, as well as an updated marketing and branding strategy of the Russian space agency, Roscosmos, which established its own television studio, Tvroscosmos, in 2006, which performs many outer-space-achievements promotion activities etc.

While it is impossible to give a complete explanation for why the rate of production of outer space related feature films has returned to that characteristic of Soviet production, amounting to more than one space related fiction feature film per annum; it is possible to give an overview of the overarching features of this production. Tvroscosmos, as well as certain other forums, insists on listing all outer space related fiction feature cinematography in one category: 'on outer space', rather than categorizing the films into more established genres such as melodrama, scientific fantasy, comedy, children's comedy etc. The archive of this category of films currently comprises ten feature films (1994-2013, with only one film produced in 1994, i.e. Chetvyortaya planeta [The Fourth Planet] (dir. Dmitry Astrakhan), including three science fiction films, two art cinema dramas, one children's science fiction film, a mockumentary, two biographical dramas and one historical drama. ${ }^{22}$ The two art cinema films (Bumazhnyi soldat [Paper soldier], 2008, dir. Alexey German Jr.) and Kosmos kak predchuvstviye [Dreaming of Space] dir. Alexey Uchitel', 2005) and the mockumentary (Pervye na Lune [First on the Moon, dir. Alexey Fedorchenko, 2004]) have thus far received the most academic and critical attention. However, none of these existent reviews and analyses seem to focus on their aesthetic impulse: reviewers focus on the fictional worlds constructed by the films, their driving dynamics and their inherent preoccupations, preferring rather to foreground their historical references (or lack of them) and overarching message (or lack thereof). The following analysis attempts to do the very contrary in order to bring out the productive, re-interpretative momentum in cinematic memorializations of an event, i.e. the dawn of the space age. This is done in order to demonstrate that, firstly, the transcultural reverberations of this event as a universally significant transformation of our reality persist, and should be ac-

21 Cf. the archives of Tvroscosmos, available at the Tvroscosmos website.

22 All information on Tvroscosmos and its archives is available on the organization's website. 
corded more emphasis if a transcultural narrative of the dawn of the space age is to emerge, and, secondly, that formalist analysis of aesthetics should be incorporated into memory narrative reception analyses, dealing with the visual arts and complementing analyses of audience reception of these films.

\section{Russian Cinematic Memories of the Dawn of the Space Age: Two Case Studies}

For the purposes of this text, case studies of two of the fiction films belonging to the category 'on outer space' delineated above shall be presented: an art film directed by Alexey Uchitel', Kosmos kak predchuvstviye [Dreaming of Space] (2005), and a mockumentary directed by Alexey Fedorchenko, Pervye na Lune [First on the Moon] (2004). Both films belong to the popular Russian cultural production on outer space, a significant percentage of which is concerned with memories of the glorious days of the Soviet space program, rather than with its future, or science fiction. ${ }^{23}$ These films are no exception. Kosmos kak predchuvstviye [Dreaming of Space] is a melancholic account about the lives of two men and two women, and their relations in the Russian North, just after the launch of the Sputnik, and before Gagarin's flight. Pervye na Lune [First on the Moon] is a mockumentary about the Soviet space program in the 193os, when a manned spacecraft was allegedly launched to the Moon, and crashed in Chile. Both films were produced with the support of the Russian Ministry of Culture, and had rather generous budgets (USD 2,000,00o in the case of Kosmos kakpredchuvstviye [Dreaming of Space] and USD 1,000,00o in the case of Pervye na Lune [First on the Moon]). Pervye na Lune [First on the Moon] received an ironic award: it was announced to be the best documentary of the year at the film festival in Venice in 2005; it also reaped the awards of the best debut and best film according to film critics at the Kinotavr festival in 2005, as well as best feature film in Zagreb in 2005. Kosmos kak predchuvstviye [Dreaming of Space] reaped numerous awards in Russia, e.g. best feature film at the Moscow International film festival in 2005, best operator and best male actor at the Nika film festival in 2006, as well as best director and best script at the 2006 Zolotoi Oryol Film festival. ${ }^{24}$

Both films were received ambiguously by the home and foreign audiences. As it will be demonstrated in the following paragraphs, despite positive expert

23 Cf. Rogatchevski, "Space Exploration in Russian and Western Popular Culture," 212-216.

24 Information on the production and reception context of the films was acquired on the films' websites and internet movie databases, in this case Kinopoisk.ru and IMDB. 
reception, online layman reviews accessible on international Russian and English-language cinema portals (Kinokultura, Kinopoisk.ru, Ruskino.ru, Kinoteatr.ru, $I M D B$ ), which frame many potential spectators' first impressions of the film and influence their decisions on whether they will proceed to watch the films or not, often fail to recognize a direct relation between these cinematic texts and the topic they claim to be addressing: memories of the dawn of the space age. In the following analysis, it will be attempted to re-establish this connection: the two films will be analyzed as reinterpretations of narratives on the key factors of the global and universal significance of the dawn of the space age.

\section{Kosmos kak predchuvstviye [Dreaming of Space]}

At the beginning of our analysis of the first of the two films in question, let us make a brief digression to the translation of the title of the film into English, in order to exemplify the aforementioned entanglements between text and its production and reception context. Had the title been translated with greater precision, Kosmos kak predchuvstviye [Dreaming of Space] would be known as 'Space as a Premonition', inaugurating the film with a slightly different connotation. Nevertheless, most reviews of the film tend to disregard the title and focus on everything but outer space. As pointed out by a reviewer on IMDB who clearly has a precise opinion about contemporary Russian cinema and its quality: ${ }^{25}$

... What is this movie really about? How bad it was to live in UssR? Or how American music was supposedly better than Russian? And what does all of that have to do with space travel? My take on this: even though made in Russia, this movie was made for the West. Why? Well, first, the story line is primitive and characters are not developed (anticipating viewers ADD and taste). A Western viewer, if he ever goes to see a foreign, or, even worse, Russian movie, expects simple things: grotesque scenes from Russian life, plump Russian girls, drunk Russian guys, 'superior'

25 The Iмдв review was accessed at http://www.imdb.com/title/tto464665/reviews?ref_=tt_ urv, 3 May 2015. It is one of five reviews on the film available at the website. All five reviews conclude that the film is, in one way or another, a reconstruction of the depicted era; only one reviewer admits that the film is also a metaphysical exploration of the way 'Homo sovieticus' has engaged with the cosmos. However, none of the reviews manage to appreciate the film beyond its contextual references to the UssR and its space program. 
American music and lifestyle, and, of course, something peculiar to Russia - in this case, Yuri Gagarin. It's too bad Mironov has degraded to movies such as this one or Pobeg. Evgenii Tsyganov's role is too simple: there's almost no acting and he is far from his best (as in 'Deti Arbata'). It would be really nice if Russian DVDs had labels such as: 'this movie was made for Westerners' or 'for Moscovites only' :), so I would know what to avoid...

An equally eloquent review on a Russian online film database Kinopoisk.ru ${ }^{26}$ is similarly skeptical:

There isn't much to criticize in this film, nor is there much to praise. It is a background movie, a collage of the aura of a bygone epoch. The atmosphere, everyday life and the way people in the 1950s thought, are presented quite credibly. It reminds me of Kuprin's novels: you open them, read them, and it seems you are breathing the air of those days. A picture comes to life. Tsyganov's performance is beyond all praise, probably one of his best roles. The episode where Horsie meets Gagarin, then a young student, who had not even dreamed about space back then, is a good shot. However, don't set your expectations too high. The film does not evoke strong emotions, doesn't make you gasp by the end. It seems that there wasn't much expected from the film in the first place. However, there is nothing to criticize. A nice, light, hearty movie. Fun to watch once. $^{27}$

Thes reviews as such are not the focus of this article, and were not chosen as representative feedback on the film in question. They are presented as illustrations of the ambiguity of the film's narrative, noted by many other reviewers of various levels of expertise; the selected two reviews succinctly sum up that it might be somewhat unproductive to analyze the film solely through the prism of its narrative or its references to historical and contemporary reality. Indeed,

26 The review was accessed at http://www.kinopoisk.ru/film/103737/, 30 March 2015. It is one of 22 reviews of the film available at the website; 10 reviewers rated the film positively, 10 were neutral, and two rated it negatively. While the vast majority of the reviewers acknowledge that the film is either a reconstruction of the Soviet epoch, an exploration of the self or an homage to the dawn of the space age, one satisfied reviewer states that the film is preoccupied with the conditions and implications of a groundbreaking scientific event - the dawn of the space age.

All translations from Russian are the work of the author of the text unless stated otherwise. 
at first glance the spectator is offered a glimpse into the life of two men in the provincial Soviet north, their relations with two women, as well as their involvement in the cosmonaut training program. Space is there, but it seems marginal, lurking in the shadows, easily mistakable for a picturesque excuse for a melodrama. However, it is possible to subvert this reading, by proposing that this film is not concerned with representation or psychology at all. Rather, I will argue that it is obsessed by an idea, which is not directly transferrable to or deducible from a character or a cinematographic technique. ${ }^{28}$

This peculiarity surfaces as soon as one attempts to dissect the film according to established analytical categories, such as character analysis. One of the protagonists, German (a possible allusion to German Titov, the cosmonaut initially intended to become the first man in space, only to be substituted by Yuri Gagarin at the very last moment), is a highly motivated fellow, who is apparently a bit too intelligent for his own good: he is studying English and apparently trying to find a way out of the UsSR, seemingly either via ship or via spaceship. His space enthusiasm is caught on by a more simple-minded creature that goes by the name of Konyok, a cook in a local restaurant - not an antagonist but simply a less intelligent and more gullible figure than German. The two men represent one subject: in the film, they do not really function without one another, and appear static and flat. Together, however, they are the driving mechanism of the film, which may thence be read as a profound and meticulous exploration of subjectivity rather than a shallow melodrama set in the Soviet north before the launch of the Sputnik.

The director employs several different techniques in order to create this double-headed subject, whose heads are facing the obscure goal that can provisionally defined as 'going to outer space', and whose body is torn apart by the differing psychological motives of the two men. Throughout the first half of the film, the camera follows Konyok who appears to be stalking German, an intriguing stranger. Around halfway through the film, the point of view changes, and the camera starts squinting at both characters, examining them from the side, in medium shots. In the final third of the film, the director intentionally, almost loudly, shifts the gaze of the camera by another quarter: a tracking shot, following someone dressed like German, suddenly is followed by a medium close-up that shows us the person en face. And the person we are suddenly faced with is not German, but Konyok, who is merely wearing German's clothes.

28 An extended version of the author's analysis of the films in question (Kosmos kak predchuvstviye and First on the Moon), focusing on the concept of the province and provinciality, is available in a vol. 10, iss. 3 . 
Apart from the gaze of the camera, other circumstances reinforce this split and illogical unity embodied by German and Konyok. For instance, there are curiosities of the fabula, which seem to drive the social-realist canonical logic of irrational connections ${ }^{29}$ to the extreme: Konyok is entirely ignorant about German's provenance, his trade, and the reasons for his interest in foreign languages and his rigorous and regular physical training. Despite all of this, he firmly decides to befriend this stranger and to follow him around everywhere he goes. He does not reconsider this decision despite German's apparent lack of enthusiasm, and despite the fact that German proceeds to coldly seduce his girlfriend. Meanwhile, the camera insists: long shots that show the coast, the bridge, a common meeting place and the forest, where Konyok often falls off his bike with a girl in the back seat - all of this is consistently fuzzy, unclear. Medium shots, on the other hand, are always in motion, they shake, shift, slide. The cinematic subject is caught somewhere between these extremes: it is captured in the medium long shot, not as a stabilization and a clarification of the image, but as a caricature: like the figure of Konyok who, once he puts on his idol's clothing, transforms into a caricature of German. He does not become German, he becomes his inefficient replica.

It can be argued that this split has nothing to do with a single person; rather, it is the split that marks the way the film is driven forward, the way it works; it enacts the film's obsession with the nearing, but faraway, imminent, but incomprehensible advent of the space age. This statement is reinforced by the relationship between the sound and the image. Most of the music in the film is diegetic, which is might be a stylistic allusion to the socialist realist tradition of Soviet cinematography. Most of the music heard in the film comes from radio transmitters on the set; and wherever there is music the source of which cannot be traced as easily, such as the music accompanying the closing credits, it is thematically directly linked to the ideas picked up on by the narrative, such as the Soviet national idea, which seems to provide explanations for inexplicable actions. However, it is not the presence and the function of the music in this particular movie that is striking; what strikes most is its loudness: compared to the dialogue, the music is exceptionally loud and sounds forced into the shots. The dialogue, on the other hand, seems to have been muted intentionally, so that it is unclear and muffled: this stylization, which foregrounds the music, creates a remarkable contrast between the visual and sonic images and the spoken word, between technology and the ambient it intrudes into.

29 Mikhail Epstein, The Paradoxes of Postmodernism and Contemporary Russian Culture (Amherst: Massachussets University Press, 1995), 180-210. 
Layered upon one another, all of these techniques almost seem excessive; yet, there is no real closure, no catharsis; the film does not make much sense if seen through a progressive or a deconstructionist lens, as demonstrated by the reviews quoted at the beginning of our analysis. However, if watched from the standpoint of post-Soviet reflections on the impending space age, the film produces a sense of uncomfortable unity, marked by the gap between the event of the dawn of the space age, and existent explanatory frameworks for it. It manages to construct a subject, which both is and is not human, which seems to be driven somewhere into the darkness, and does not have much of an ear for what might be expected of it on Earth.

\section{Pervye na Lune [First on the Moon]}

Kosmos kak predchuvstviye [Dreaming of Space] is not the only post-Soviet Russian film focusing on the beginning of the space age, which neither denies existent memory narratives nor reaffirms them, creating a fictional world driven by an altogether different logic, and therefore proposing that a new highlight be added to existent narratives on both the history of Soviet spaceflight and the history of the beginning of the space age on a more general level.

Alexey Fedorchenko's mockumentary on the memorialization of the Soviet space programme Pervye na Lune [First on the Moon], which appeared in the cinemas shortly prior to Uchitel's Kosmos kak predchuvstviye [Dreaming of Space], arguably achieves a similar result, employing a different strategy; in fact, this contrived history of the Soviet space program in the 1930s is the only humorous reference to the history of Soviet spaceflight apart from Dmitry Astrakhan's 1994 feature film Chetryortaya Planeta [The Fourth Planet].

In order to provide Pervye na Lune [First on the Moon] with a coherent, lighthearted and suggestive storyline, Fedorchenko resorts chiefly to the strategy of postmodernist deconstructive reconstruction. The film does not mock the Soviet space program as such, but rather memories and myths related to it, produced and reproduced by it. The film, also driven by a similar sort of visually explicit spatial frustration as Kosmos kak predchuvstviye [Dreaming of Space], employs most of its capacities to play around with space and time in order to focus on memory: the memory of the mythical Soviet space program. The spectators are invited to follow researchers who are investigating the unreliable evidence of the existence of the space program in the 1930s in order to track down the details of Ivan Kharlamov's flight to the Moon, which accidentally ended somewhere in Chile. 
The film abuses the authority of archival footage ${ }^{30}$ and neutral narration, as well as construed testimonies of fake witnesses to present a story of what appears to have been the logical step that had to be taken before Yuri Gagarin's first spaceflight in 1957. Many spectators were actually convinced that the director intended to ridicule the history of spaceflight, while some interpreted his intention in the very opposite way; according to certain layman reviews, the film reconstructs the mythology of the history of Soviet achievements in space exploration by adding a supplementary myth. According to an elaborate review on Kinopoisk.ru, the quality of this undertaking, whichever way one interprets it, leaves much to be desired:

... I've wanted to watch this mockumentary for a while. Finally, I managed to find an hour to do this yesterday (luckily, the film is not long). I am sorry I wasted my time on Pervye na Lune [First on the Moon]. I think everything is bad: the idea, the realization, the actors. Ok, so they shot a scene, aged the shots using scratches and blotches. Well, you might as well have done something with the sound, it obviously doesn't correspond to 1930 s chronicles. Could they at least have watched something from those times? Or they hoped their memory was good enough? This soundtrack makes one suspicious of every shot, as you no longer believe the fiction or the fake 'interviews' or the 'hidden camera' episodes. Maybe the director should have used more archive materials or watched Kuryokhin's Two Captains 2 - what a great mockumentarist! One to learn from!... Or, you could have tried to find working equipment from those times, tried to film using it, at least to understand what things were supposed to look like. ... Also, they should have read Pelevin's Omon Ra. And maybe done an adaptation of that novel, instead of coming up with their own. I'll give it a slightly higher grade than I normally would have, because my wife fell for it. ... ${ }^{31}$

30 Although seemingly full of archive materials, the film actually does not use more than 10 per cent of authentic archival footage. The rest of the shots were skillfully edited in order to appear old. (Kinopoisk.ru).

The review was accessed at http://www.kinopoisk.ru/film/16099o/, 15 May 2015, and is one of seven reviews on the film available at Kinopoisk.ru. It is an example of the only negative review of the film; the other six reviewers gave it a positive mark. However, all of these seven reviewers share the view that the film is first and foremost a mockumentary, and that it plays with the mythology of Soviet supremacy in outer space. Notably, one reviewer observes that there is a 'mystical' quality to the film, not directly related to its contents or formal qualities as such, but related to the mysticism related to the 
Indeed, the film succeeded in one matter: in creating plenty of confusion. Up until the very end, the film insists on sticking to the form of the documentary, like a persistent historian, digging through the archives and following its object of research regardless of the absurdities and illogical elements that tend to undermine the thesis set out at the beginning. The film manages to create a liminal timespace: ${ }^{32}$ it is not yet in the realm of unbelievable parody and no longer a serious conspiracy theory.

This aspect of the form of the film seems to mirror the irrational, blind persistence that guides all basic research (research for its own sake, the primary aim of which is not applicability, but scientific discovery) and that occurred before the actual beginning of the space age. This blind belief in the necessity to continue working toward success created the conditions, albeit not always the best ones, for people to stick to patterns of behaviour that might, at one point, bear results (although not necessarily): spaceflight. This is a confusing situation: the space age demanded exceptional effort from the people, and, at the same time, there was never any guarantee that, even if achieved, it would have any direct impact on the lives of the people who were workinh toward creating it. The film focuses on this confusion behind the space age, and shows confusion as crucial for the dynamics that brought about its dawn. There is, for instance, a telling sequence where horsemen ride up to the rocket before its launch. It seems that their helmets are pointing to the absurdity of the entire endeavor: why would one invest in the space program at a time when even tanks and cars were still almost the stuff of science-fiction?

Fedorchenko's film starts off with confusion, but offers no way out of it. Such incoherence often characterizes the dynamic of memory narratives, when the latter are dictated by the ideological centre (the metropolis, perceived as a mythical, unattainable centre of progressive thought, planning and lifestyle) and allowed to trickle down to the backward periphery, which always only receives and does not produce progress. ${ }^{33}$ Memory narratives received by the geographical and mythical (backward, faraway) periphery from the ideological and mythical centre are therefore often inconsistent with local

utter unknowability of the cosmos. The film was also reviewed by four IMDB users; three found it to be an amusing and humorous mockumentary, while one stated it is largely incomprehensible to a spectator not familiar with Russian and with the Soviet context of the narrative.

32 Elana Gomel, Postmodern Science-Fiction and Temporal Imagination (London, New York: Continuum, 2009), 10.

33 Cf. Aleida Assman and Linda Shortt, Memory and Political Change (New York: Palgrave MacMillan, 2012), 1-2. 
(provincial or peripheral) memories, which makes these 'instructive' memories, disseminated by the centre, seem superficial, elevated from everyday reality and therefore somewhat fairytale-like.

The film exploits the conventions of the documentary in all of their richness, often providing testimonies of the first Soviet 'cosmopilot', who allegedly flew to the Moon, had an accident in Chile, was admitted to a psychiatric ward in Chita and ended up playing the part of Prince Alexander Nevsky in a circus. His colleagues from the crew of potential cosmopilots, the constructor of the first rocket, one of the cameramen following them around instructed by the secret services, an employee from the psychiatric ward in Chita - all of them prove to be exceptionally enthusiastic respondents to the questions posed by the film crew.

'Everything that happened there got recorded. And if it was recorded, it had to be true, says one of the employees of the archives when introduced to the film crew. Humour here neutralizes the confusion generated by the film, but this at a price: we have to acknowledge that the characters involved in this burlesque are also exceptionally funny. The ex-potential cosmopilot Fattakhov, an orphan, 'raised with love by the Soviet people,' as explained by the omnipresent narrator, and now working as a guard at the zoological museum, spending his days surrounded by huge model insects; the midget who is now a performer at a midget circus, where he is filmed by the crew ... The film deconstructs a myth about a myth. The deconstruction is humorous, but allows for no empathy whatsoever, because all of the characters involved are elevated to the level of a myth and therefore deprived of everything human. The Bakhtinian carnival: the dance of bizarre, eccentric figures who once, a long time ago, participated in a common task, and are now once again brought together in its name, rendered powerful (they speak the truth, as they are witnesses) and powerless (they speak nonsense, because they are caught up in a nonsensical play of empty signifiers, awoken within the mockumentary), appears to be permanent; the carnival is the dynamics of the film. ${ }^{34}$

The visuals are accompanied by Soviet patriotic songs from various periods and Soviet sci-fi 'beeps'; the shots, on the other hand, are another bricolage of sorts: historical data is shown alongside pseudo-documentary montage and shots out of Soviet space films. The only film that is shown to be undeniable fiction, is Kosmicheskiy reys [Cosmic voyage] (dir. Vasily Zhuravlev, 1936), which also examines the possibility of flying to the Moon.

34 Cf. Michael V. Montgomery, Carnivals and Commonplaces: Bakhtin's Chronotope, Cultural Studies, and Film (New York: Peter Lang, 1994). 
The only firm anchor of the film is therefore, ironically, fiction, which does not, in postmodernist terms, replace the reality which is lost and perhaps never was, but appears as an image, pointing to a horrific void behind closed curtains. This is why the affirmatively fictional shots from Kosmicheskiy reys are important: they guarantee that there remains a little something to be trusted: at least some of the fiction is truly fictional. Other shots mainly manoeuvre between fiction and reality, such as the shots of the cameras supervising the cosmopilots. There are even excerpts from advertisements for these cameras in the movie which makes the entire film even more uncanny: everything is shown to be contrived. This is a documentary based on staged, fake evidence.

The film presents the dynamics of the myth of the Soviet space program as confused, contrived, and as a product, greatly conditioned by the tension between the centre and the periphery. It demonstrates that narratives and the imagery of memorialized events may only be perceived as objectively valid, complete accounts of events by subjects who do not fully belong to the centre.

\section{Conclusion}

The two films explored in this chapter highlight a striking ambivalence persistent in memories of the space age and space programs; an enthusiasm allegedly characteristic of the bygone era has been replaced by melancholic disillusionment. This is noted in a large proportion of layman reviews of the two films: they note that the films are reflections on the past, and that this reflection is not positive or assertive, but somewhat contrived: the past is shown in an idealized or a satirized manner; the dawn of the space age is shown as something that was highly mythologized.

On the other hand, cinematic narratives, such as those presented in Kosmos kak predchuvstviye [Dreaming of Space] and Pervye na Lune [First on the Moon] clearly state that there is something more to the space age, something that eludes rationalizations, which reduce the dawn of the space age to the political, economic or technological circumstances in which it occurred. As stated above, only some particularly meticulous reviewers note this quality of the two films. Nevertheless, closer readings of both Kosmos kak predchuvstviye [Dreaming of Space] and Pervye na Lune [First on the Moon] demonstrate that the films resonate greatly with Shukaitis's reflection on outer space as an imaginal machine, a realm offering an opportunity for humanity to radically change its coordinates of social reality instead of reiterating patterns from current affairs on Earth. Kosmos kak predchuvstviye [Dreaming of Space] highlights the ambivalence of a space-bound human subject, its premonition about impending 
change, and its anxiety in view of this change. It contextualizes the dawn of the space age in the USSR within the framework of global politics on the one hand, and with references to individual concerns, which are only partly related to political power constellations, on the other. Pervye na Lune [First on the Moon], although very different from Kosmos kak predchuvstviye [Dreaming of Space] in terms of genre and plot, highlights a very similar tension: the tension between canons of historiographical accounts, the subordination of these accounts to certain ruling political options (the Communist party, in the case of the USSR ), and the inconsistency of both of these sets of guidelines with interpretations given by the individuals involved in the actual events. Furthermore, Pervye na Lune [First on the Moon] ridicules the narrative authority of the format of the documentary, but does not necessarily do so in order to criticize it. Rather, it attracts the spectator's attention to the underlying ideas, i.e. to the idea of the necessity and imminence of the space age, and the radical nature of the transformations it might invoke. Contrasts, such as the contrast between horsemen and a space rocket, illustrate clearly what kind of a leap in thought and technology was required in order to launch the first satellite.

Therefore, both of the films discussed in this chapter are more than reinspections of an important aspect of Soviet (supra)national mythology, the myth of supremacy in the race for space. Both films not only subvert the simple narrative of this myth, which glorifies Soviet scientists, engineers, cosmonauts and politicians, but also provide reflections on a different key dimension of the dawn of the space age; they foreground the fact that it involved various efforts of common, by no means perfect individuals, who relied on the logic of scientific, mathematical language, to launch them into the unknown domain of outer space. Furthermore, the films, particularly Kosmos kak predchuvstviye [Dreaming of Space], emphasize that a transformation, such as the beginning of space exploration, entails a re-examination of the coordinates of our sociocultural and political reality, and an individual's place in it. This dimension of the two films in question is by no means nationally bound, returning our attention to the global significance of humanity's first direct encounters with outer space and ultimately arguing that humanity's space-related achievements are more than mere byproducts of technological progress and politics.

Interestingly enough, as I have attempted to demonstrate in my analysis of the films in question, a lot of analytical attention to the contextual, cultural and national details is required in order to avoid conclusions, which persist in reducing cinematography on the dawn of the space age to reiterations of nationally dominant memory narratives, such as the cited film reviews do. In order to avoid this trap, it seems relevant to return to the formal properties of the cinematic medium, and the formalist aspects of cinematic poetics. 
Supplementing narrative, thematic, character and plot analysis with an analysis focusing on formal features, such as rhythm, sequences of shots and frames, as well as composition, provides a more nuanced insight into cinematic meaning-making, and allows the spectator to enter into dialogue with the cinematic medium as both an agent in memory reception, which presents and argues for its own, original reappropriations of dominant narratives, and an agent of memory narrative production.

\section{Bibliography}

Assmann, Aleida and Linda Shortt. Memory and Political Change. New York: Palgrave MacMillan, 2012.

Carlsten, Jennie M. and Fearghal McGarry, "Introduction". In Film, History and Memory, edited by Jennie M. Carlsten and Fearghal McGarry, 1-19. London: Palgrave Macmillan, 2015.

Dick, Stephen J. "Space, Time and Aliens: The Role of Imagination in Outer Space." In Imagining Outer Space: European Astroculture in the 2oth Century. Edited by Alexander C.T. Geppert, 27-45. Basinstoke, New York: Palgrave MacMillan, 2012.

Epstein, Mikhail. The Paradoxes of Postmodernism and Contemporary Russian Culture. Amherst: Massachussets University Press, 1995.

Erll, Astrid, and Ansgar Nünning. "Concepts and Methods for the Study of Literature and/as Cultural Memory." Literature and Memory. Theoretical Paradigms. Genres. Functions (2006): 11-28.

Fedorchenko, Alexey. Pervye na Lune. Russia: Sverdlovskaya kinostudiya, 2005.

Geppert, Alexander C.T., ed. Imagining Outer Space: European Astroculture in the Twentieth Century. Basingstoke, New York: Palgrave Macmillan, 2012.

Gomel, Elana. Postmodern Science-Fiction and Temporal Imagination. London, New York: Continuum, 2009.

Harrison, Albert A. Spacefaring: The Human Dimension. Berkeley, CA: University of California Press, 2002.

Kinopoisk. Accessed 12 April 2016, http://kinopoisk.ru.

Lathers, Marie. Space Oddities: Women and Outer Space in Popular Culture 1960-20oo. New York: Continuum Books, 2010.

Launius, Roger D. in Howard E. McCurdy. Imagining Space: Achievements, Predictions, Possibilities 1950-2050. San Francisco, CA: Chronicle Books, 2001.

Llinares, Dario. The astronaut: Cultural mythology and idealised masculinity. Cambridge: Cambridge Scholars Publishing, 2011.

Majsova, Natalija. "The Metaphor of the Dawn of the Space Age in Contemporary Social Sciences and Humanities." Družboslovne razprave 31 (2015): 13-30. 
Majsova, Natalija. "The province called earth: the chronotope of the post-Soviet province explored through contemporary Russian cinema on outer space." Studies in Russian and Soviet cinema 10.3 (2016): 223-237.

Maurer, Eva, Julia Richers, Monica Ruthers, and Carmen Scheide, eds. Soviet Space Culture: Cosmic Enthusiasm in Socialist Societies. London: Palgrave MacMillan, 2011.

McCurdy, Howard E. Space and the American Imagination. Baltimore, MA: JHU Press, 1994.

Montgomery, Michael V. Carnivals and Commonplaces: Bakhtin's Chronotope, Cultural Studies, and Film. New York: Peter Lang, 1994.

Nungesser, Verena Susanna. "I Forgot to Remember (to Forget): Personal Memories in Memento (2000) and Eternal Sunshine of the Spotless Mind (2004)". In Media and Cultural Memory, edited by Astrid Erll and Ansgar Nünning, 31-48. Berlin, New York: Walter de Gruyter, 2009.

Poggi, Christine. Inventing futurism: The Art and Politics of Artificial Optimism. Princeton, New Jersey: Princeton University Press, 2009.

Rogatchevski, Andrei. "Space Exploration in Russian and Western Popular Culture: Wishful Thinking, Conspiracy Theories and Other Related Issues." In Soviet Space Culture: Cosmic Enthusiasm in Socialist Societies, edited by Eva Maurer, Julia Richers, Monica Ruthers, Carmen Scheide, 211-265. London: Palgrave Macmillan, 2011.

Schwartz, Matthias. "Die Besiedelung der Zukunft. Zur Neubegründung der sowjetischen Science Fiction nach dem ersten Sputnikflug 1957." In Bluescreen. Visionen, Träume, Albträume und Reflexionen des Phantastischen und Utopischen, edited by Walter Delabar and Frauke Schlieckau, 105-122. Bielefeld: Magazin für Literatur und Politik, Heft 43-44, 2010.

Shukaitis, Stevphen. "Space is the (non)place: Martians, Marxists, and the outer space of the radical imagination." The Sociological Review 57 (2009): 98-113.

Siddiqi, Asif A. The Red Rocket's Glare: Spaceflight and the Soviet Imagination, 1857-1957. Cambridge: Cambridge University Press, 2010.

Suvin, Darko. Russian Science Fiction 1956-1974. Elizabethtown, NY: Dragon Press, 1976. Thompson, Kristin. Breaking the glass armor: neoformalist film analysis. Princeton: Princeton University Press, 1988.

Tvroscosmos. Accessed 9 April 2016, http://tvroscosmos.ru.

Uchitel', Alexey. Kosmos kak predchuvstviye. Russia: TPO Rok, 2005. 


\title{
Literary Mediation and Reception of Memories of War: Hallgrímur Hallgrímsson's 'Under the Republic's Flag'
}

\author{
Daisy Neijmann and Gunnthorunn Gudmundsdottir
}

In 1941 a short text with an unusal story was published in Reykjavík. Its reception and afterlife in Icelandic literature are no less unusual and, we think, worth exploring as a case study in the workings of the cultural memory of a nation coming to terms with its entrance on the international stage. The text was called Undir fána lýðveldisins [Under the Republic's Flag] and was the autobiographical account of Hallgrímur Hallgrímsson (1910-1942), a young Icelandic labourer and communist, of his experiences as a member of the International Brigades in the Spanish Civil War in 1937 and 1938. This text, although it is not particularly well known today and has not been the focus of any major study, has inveigled itself into Icelandic literature on war and trauma time and again since its publication, thus becoming part of cultural memory in a particular way. In this paper we aim to address Ann Rigney's question what role literary texts play in the formation of cultural memory by tracing the trajectory and transformation of Hallgrímsson's text in Icelandic literature and public memorial culture from 1941 to 2001 and beyond, adopting Rigney's diachronic perspective into the genesis and reception of the work in order to examine its role in 'memorial dynamics'.

Hallgrímur Hallgrímsson was born in 1910 in the eastern part of Iceland. He moved to Reykjavík in 1930 and became a member of the Communist Party and a union activist. He first came to the attention of the media and the authorities when he climbed on board the German cargo ship Eider while it was moored in Reykjavík harbour in 1933 and cut down its swastika flag. He went on to fight with the International Brigades in the Spanish Civil War (1936-1939) for two years in 1937 and 1938, and on his return he wrote long articles on his experiences which were published in a left-wing newspaper. He was jailed in 1941 for his part in the so-called 'flyer-case', where Icelandic union activists distributed flyers among British soldiers occupying Iceland at the time, warning

1 Ann Rigney, "Portable Monuments: Literature, Cultural Memory, and the Case of Jeanie Deans," Poetics Today 25: 2 (Summer 2004): 362. 
them from taking on jobs while Icelandic workers were on strike. This, the government decided, amounted to inciting the soldiers to revolt against their superiors, and Hallgrímsson was jailed for his part in this for eighteen months, but was set free after eleven months in prison. It has been conjectured that the harsh sentence he received for what seems like a minor offense was in part retaliation by the government for his fighting in the Spanish Civil War, an act which the authorities had made illegal. ${ }^{2}$ While in prison, he collected his articles and turned them into a book, which was published in August 1941. Shortly after being released from prison he was a passenger on board the fishing boat Sceborg, which disappeared off the east coast of Iceland after leaving harbour and was never seen again. It is thought that it was hit by a German mine - of which there were many in Icelandic waters at the time. His short life and fate is thus intimately entwined with world events at the time.

The text of Undir fána lýdveldisins is a gripping and well-written narrative. It is clearly focused and concentrated on Hallgrímsson's journey to Spain, his experience of the war and his journey back, with a few asides about the political and global situation at the time. Hallgrímsson explains in a brief introduction to the work that he 'is not a poet' and thus has made no effort to 'fictionalize' events even though those events "could have been "imposing" if I had ridden Pegasus across the battlegrounds in the mountains of Aragon and vineyards of Catalonia.' Instead he chose to refer 'only to that which I experienced myself or had confirmed news of.' 3 Despite his protestations of not being a poet, the text is carefully written and compelling. He has a particular knack for describing people and the physical environment and is able to convey complicated turns of events during shambolic and confusing battle scenes. Although he focuses very little on his inner life, he expresses convincingly his viewpoint of people, places, war, etc., throughout. The narrative is generally in chronological order with a clear focus on events, but there are instances towards the end of the text that show a more fragmentary type of narrative, describing a dreamlike state when the experiences he has had wash over him on the slow and arduous journey back across the French border:

Not to retreat, just replaced. - Sierra Caballs in good hands. Division de Campesino. - Away from the fire, to the hinterland, al la retaguardia. - Rest, rest, Descanso. - Reorgnisacion? - Repatriacion? - Going

2 Róbert Sigurðarson, ;Viva la República! - ;Viva la libertad! La participación de islandeses en la Guerra Civil Española, BA-thesis in Spanish Studies, University of Iceland, February 2014, 34.

3 Hallgrímur Hallgrímsson, Undir fána lýðveldisins (Reykjavík: Björn Bjarnason, 1941), 7-8. All translations from Icelandic texts are ours. 
home? - Out on the hill, looking out. - The boys' state of mind. Morale. - Fighting morale, moral de combate. - A hurt mule in the valley, a kicking mule on open ground. - Machine gun fire from the summit. Rad-ad-ad-ad-ad. ${ }^{4}$

These descriptions represent disjointed but pressing memories in a mixture of Icelandic and Spanish: memories of particular events, but also the repetition of certain concepts and phrases that echo in his mind. These pages are, however, exceptions in the text. It is also interesting to note that the terms that he uses from the military and the war have carried on in other Icelandic works on the Spanish Civil War, including the novel by Álfrún Gunnlaugsdóttir discussed in this chapter. In an appendix entitled 'Explanations of military terms,' Hallgrímsson points out that when 'an Icelander reads a war book, he constantly comes across words and concepts which he either does not understand at all or to a limited degree, - because we are a nation without an army and most things military are alien to us. ${ }^{5} \mathrm{He}$ is thus acutely aware that his military experience and knowledge is highly unusual in Iceland, as will be discussed further below.

The contemporary reception of Hallgrímsson's book is highly illuminating as regards the historical and political circumstances of the time. It seems that only one review was published, in a left-wing newspaper, and that a couple of newspaper advertisements for the work appeared. However, we have not been able to find any contemporary interviews or detailed articles on the work or on Hallgrímsson's experience. His obituary, which came only a year after the book was published, is in some way part of the reception of the work. All appeared in left-wing papers and all emphasized Hallgrímsson's idealism and his commitment to the fight against fascism. Einar Olgeirsson, the leader of the Icelandic Socialist party, says in Hallgrímsson obituary: 'The Icelandic state gave him a year's time in prison and took his human rights away, this man of all people, who had risked his life, almost the only Icelander to do so, to protect human rights against the attack of fascism.' ${ }^{6}$ Thus, the circumstances of the national politics at the time, Hallgrímsson's own particular circumstances (he was in prison when the book was published), his Communist credentials, they all colour the contemporary reception of the work.

There are several aspects of the reception of the text and the public discourse relevant to it that denote particular national frameworks. First, it is often not

4 Hallgrímsson, Undir fána lýððveldisins, 206.

5 Hallgrímsson, Undir fána lýðveldisins, 237.

6 Einar Olgeirsson, "Hallgrímur Hallgrímsson," Pjóðviljinn, 1o December 1942. 
a discussion of the ideals or motivation to take up arms that is at the forefront of the reception of the writings of Icelanders who fought in the Spanish Civil War, but simply the fact that they had become soldiers - be it in the news of wounded men and how they generally fared, or in right-wing historians' notions of how they were being trained to take up arms for the communists in an expected revolution in Iceland. ${ }^{7}$ In order to understand the views and attitudes involved, we need to establish some historical facts. Iceland has never had its own military forces, and taking up arms was thus completely alien to people. During the first half of the twentieth century in particular, the idea took root that Iceland had always been a peaceful country without arms. For many people, peace and pacifism came to characterize Icelanders and Icelandic history, and they became part of collective memory and the national self-image. This idea crystallized in the 'neutrality' clause of the 1918 sovereignty agreement between Iceland and Denmark, where permanent unarmed neutrality became Iceland's official security policy. As Pétur Guðmundur Ingimarsson points out in his study on arms and security in Iceland during the struggle for national independence:

For many Icelanders there seems to have been a connection between the idea of neutrality and the idea of sovereignty. Sources from the 1930s also mention for instance the pacifism of the Icelandic general public, which the socialists were fighting for, and which included an antipathy to any kind of militarism and war. ${ }^{8}$

This also explains the complete shock of the Allied occupation of Iceland in World War II, when thousands of soldiers flooded the country.

The other point that needs to be made is that Spain was an incredibly important market for Icelandic goods before the Civil War, with a third of the country's exports from 1921 to 1935 going to Spain. Thus, as so often is the case, trade brought about transnational influences in places one would not necessarily suspect at first sight; alternative routes of memory across the Atlantic in this case. As Astrid Erll has pointed out, transnational memory not only pertains to our globalized world, but 'has a long genealogy' and it is 'a perspective of memory that can in principle be chosen with respect to all historical

7 See for instance Pór Whitehead, Sovét-Ísland: Óskalandið (Reykjavík: Ugla, 2010).

8 Pétur Guðmundur Ingimarsson, "Vopnlaus bjóð," BA-thesis in History, University of Iceland, 2011, 4. See also Guðrún Björk Guðsteinsdóttir, "Rediscovering Icelandic Canadian Pacifism," Rediscovering Canadian Difference, ed. Gudrun Björk Gudsteins (Reykjavík: University of Iceland Press, 2001), 50-60. 
periods and with a view to both the synchronic circulation of representations (e.g. of "traumatic pasts") as well as to the diachronic dimension of memory.' This very important trade also influenced the attitude toward the Falangists in the right-wing press in Iceland. The Left often accused the Right of being in the clutches of the capitalists, which meant that markets mattered more than the fight against fascism. The fish traders tried, for instance, to get the Icelandic government to acknowledge Franco's regime in early 1939, before the dissolution of the Spanish Republic, but were forced to wait until later that year. ${ }^{10} \mathrm{An}$ indication of the importance of this market (which, we have to note, had been in decline for some time before the war), was when an Icelandic official was sent to Barcelona to secure deals in the middle of the shelling of the city in 1938, and then sent over to Burgos to attempt to sell fish to the Francoists. ${ }^{11}$ The trade with Spain was thus of prime importance and obviously influenced the way in which the war was viewed, and also meant that Icelanders were better informed on Spanish politics than one may have assumed. Whether it has had any effect on how the war is remembered sixty years later is another matter.

In his study of the Spanish Civil War in contemporary newspapers in Iceland, Aitor Yraola explains that 'the civil war had both a direct and an indirect impact, which caused upheavals and changes in society in the three years the war lasted. ${ }^{\prime 2} \mathrm{He}$ also points out that news from the main events of the war was not censored or silenced, so Icelanders were relatively well informed. The ideological stance of each paper, however, dictated their sympathies with one or the other side. ${ }^{13}$ As Stefán Svavarsson notes, the Icelandic papers published sharp missives and debated the issues hotly in a manner which was later to characterize their writings during the Cold War. ${ }^{14}$ Thus, the reporting on the war was highly partisan, and the positions taken by each side, as well as the very sharp division between the Left and the Right that were to characterize Icelandic journalism and culture up until the very end of the Cold War, had already become prominent.

This is not to say that there was no censorship at all during this time. According to Yraola's account the state radio had planned to broadcast a lecture by

Astrid Erll, "Traumatic Pasts, Literary Afterlives, and Transcultural Memory: New Directions of Literary and Media Memory Studies," Journal of Aesthetics and Culture, vol 3 (2011): 5 .

Stefán Svavarsson, "Spænska borgarastríðið í íslenskum samtímaheimildum," Sagnir 26 (2006): $5^{2}$.

11 Svavarsson, "Spænska borgarastríðið," 52.

12 Aitor Yraola, “Íslensk viðbrögð við spænsku borgarastyrjöldinni," Skírnir 163 (1989): 363.

13 Yraola, "Íslensk viðbrögð," 374.

14 Svavarsson, “Spænska borgarastríðið," 52. 
Hallgrímsson on his experiences during the war in 1940, but it was postponed indefinitely as, at the time, the government was involved in negotiations with the Franco regime on the future of cod exports to Spain, and it was considered that the radio lecture might have a detrimental effect on the negotiations. ${ }^{15}$ Thus, it is evident that trade can both foster transnational memory and stifle or repress such discourse if it threatens that trade.

The third point that needs emphasizing is the stranglehold that the partisan outlook mentioned earlier had on politics, discourse and culture in Iceland in the postwar years. Claire Gorrara has pointed to the fact that, in post-war Europe generally, 'the politics of the Cold War conditioned, distorted or, in some cases, silenced processes of remembrance and commemoration of the past,' ${ }^{\prime 16}$ and Iceland was certainly no exception: almost every single discussion was framed in partisan terms, and every 'national' memory seen in those terms until 1989. And to this day, partisan historiography has the power to re-kindle the debate, as did, for instance, the publication by right-wing historian Pór Whitehead on 'Soviet-Iceland', in which he claims that those Icelanders who fought with the International Brigades had in fact been sent there by the Soviet Union in order to train them for an armed revolution in Iceland. Jón Ólafsson, a philosopher and specialist in all matters Soviet, has argued that no documents (now accessible in Russian archives) support any of these claims - and thus the contest for a definitive version of national history continues. ${ }^{17}$

\section{Fictions of Hallgrímsson}

\section{Guardian Angels}

Two years after the publication of Hallgrímsson's memories in book form, and a year after his death, the novel Verndarenglarnir [The Guardian Angels] was published, the first work of fiction to have the Allied occupation of Iceland as its main topic. The author was Jóhannes úr Kötlum (1899-1972), a poet who originally had achieved recognition for his patriotic and nature poetry but whose work had become more socially engaged and revolutionary during the Depression. Like Hallgrímsson, Jóhannes úr Kötlum was a union activist and

\footnotetext{
15 Yraola, "Íslensk viðbrögð," 373.

16 Claire Gorrara, French Crime Fiction and the Second World War (Manchester: Manchester University Press, 2012), 7.

17 Pór Whitehead, Sovét-Ísland and Jón Ólafsson, "Landráđakenning Pórs Whitehead: Nokkrar athugasemdir við ritið Sovét-Ísland: Óskalandið," Tímarit um félagsvisindi ${ }^{-6}$ (2011-2012).
} 
a member of the Communist Party, but he was also a committed nationalist and pacifist. In his highly polemical novel, which presents a fierce critique of war-mongering in general and the occupation in particular, Jóhannes úr Kötlum reworks Hallgrímsson memories and experiences through the medium of fiction, and makes them part of the anti-war, anti-colonial, anti-capitalist message underlying the work.

The story centres around an Icelandic family from a traditional Icelandic farm which acts as a synecdoche for Icelandic society as a whole, with the various family members representing different ideologies and attitudes towards the war and the occupation. The novel opens with Haraldur, one of the farmer's sons. He was a volunteer in the Spanish Civil War, fighting with the International Brigades and has recently returned, physically and mentally maimed: he is blind in one eye and suffers from amnesia and delusions. He no longer remembers his time in Spain as a soldier, but clearly suffers from survivor's guilt: he believes himself to be the one-eyed god Odin, looking for a way to bring his fallen warriors back to life. This opening scene featuring Haraldur is remarkable for several reasons. With no history of war or war literature on which to base his story, the author looks, firstly, to the old Icelandic texts relating the mythological tale of Ragnarök, where the gods fight their final battle against the forces of evil, and, secondly, to Hallgrímsson's recent experiences as a soldier in the Spanish War, which he weaves together to create the first work of fiction about the Icelandic experience of twentieth-century war. Furthermore, it represents the first attempt in Icelandic literature to mediate war trauma, an attempt that was not again pursued by an Icelandic novelist until several decades later.

As we discover in the course of the novel, Haraldur is the only survivor from a battle in which all his fellow soldiers were killed. The memory of this is so painful to him that it makes him physically ill and sets off his delusions. Clearly, he suffers from war trauma: he cannot remember the actual experience, yet he relives it over and over again through his delusions. According to trauma theory, the traumatic experience itself is beyond understanding and beyond language, it cannot be known or described, it is a memory that cannot be accessed yet continues to haunt its victim. ${ }^{18}$ The fragmented, obsessive nature of the final part of Hallgrímsson's original text quoted earlier can be seen as indicative of the traumatic nature of his memories. Lyndsey Stonebridge has pointed out that the idea that an impression can be both experienced and forgotten

18 Cathy Caruth, Unclaimed Experience: Trauma, Narrative, and History (Baltimore and London: Johns Hopkins University Press, 1996); Roger Luckhurst, The Trauma Question (London: Routledge, 2008). 
is central to trauma theory: 'trauma divides the mind not only from itself, but also splits it in time.19 Although he lives with his parents and grandmother at the farm, participating in regular farm life routine to an extent, Haraldur does not really inhabit chronological time: his every thought and individual action revolves around the obsessive search for 'his' (Odin's) ravens. It was Freud who found evidence of how the psyche 'tried to master trauma retroactively by reliving unconsciously a catastrophe which could not be experienced fully first time around. ${ }^{20}$ Haraldur needs to believe that he is Odin, so that he can return to the battlefield every night to bring his fellow soldiers back to life: this is the only way in which he can reconcile himself with what has happened.

The Icelandic experience of World War II, however, was not one of battle but of military occupation by friendly forces, which raises the question why Jóhannes úr Kötlum would include traumatic experiences of the Spanish Civil War in his novel, and in such a prominent way. The most obvious answer seems to lie in the anti-war message of the novel. Hallgrímsson's experiences in Spain provided a recent, poignant example of the horrors of modern warfare from an Icelandic perspective. They demonstrated that even Icelanders, with their centuries-old history of peace, were no longer immune from wars elsewhere: the bellicose actions of the larger powers in the world now also affected them. As was mentioned earlier, Icelanders, with only a very few exceptions, had no direct experience of war. The horrors related to them in the media had always remained abstract. The initial reactions of many Icelandic people to the occupation of their country, in some cases naive, in others opportunistic, clearly were a source of grave concern for those who felt that the British military presence represented a breach of Iceland's declared everlasting neutrality and, rather than protecting Iceland, had dragged it into the war by making it a target. While the novel's allusions to Norse mythology turn the occupation into an event of apocalyptic dimensions, its fictionalized memories of Hallgrímur Hallgrímsson become a terrifying warning of the effects of war based on Icelandic experience, a war that was brought to Iceland against its will. Haraldur is an example of what will happen to Icelanders if they become involved in war. An important aspect of war trauma is to encounter an alien part of the self, not least the part that kills others, thereby destroying the fantasy of the self as peace-time subject. ${ }^{21}$ By becoming a soldier, Haraldur becomes, by extension, a killer. Thus, Jóhannes úr Kötlum transforms Hallgrímsson’s narrative

\footnotetext{
19 Lyndsey Stonebridge, "Theories of Trauma," in The Cambridge Companion to the Literature of World War II, ed. Marina MacKay (Cambridge: Cambridge University Press, 2009), 196.

20 Stonebridge, "Theories of Trauma," 197.

21 Stonebridge, "Theories of Trauma," 197.
} 
of his personal experiences into a moralizing story, offering a powerful image of recent events 'for ethical consumption' in the present. ${ }^{22}$

Considering the strong pacifist stance of the novel's author it is noteworthy that both Hallgrímsson and the novel's character based on him, Haraldur, chose to join the Spanish Civil War as volunteers, fighting against fascism and for revolutionary change. In this respect, Hallgrímsson's model presented Jóhannes úr Kötlum with an ideological dilemma: he abhorred any form of war, but he was also a communist who strongly supported the cause of the worker and the fight for a better world. The reasons for Haraldur's participation in the war are played down in the novel. Significantly, the emphasis is, instead, not on the fight against fascism, but on the deception of the great powers, Great Britain in particular, for obvious reasons: the British were the original occupying force in Iceland. Much is made of the fact that, during the Spanish Civil War, they betrayed the International Brigades, as a result of which many were killed, among them Haraldur's fellow soldiers, and the war was lost. Great Britain and the other great powers are thus the enemy in the novel, at least on the surface: they are the symbols of belligerence, colonialism and capitalism. The Icelandic people on the other hand are their peaceful, innocent victims. This black-and-white picture is based in Icelandic partisan politics at the time. It reflects communist discourse, where the capitalist powers constituted the main enemy, but also nationalist discourse, which regarded Iceland as a powerless victim of foreign aggression throughout its history. From both perspectives, the Allied occupation of Iceland was seen as a profound betrayal of Iceland and everything it stood for.

This simplistic picture belies the complexity of the novel, however. Jóhannes úr Kötlum does not try to avoid the uncomfortable complications posed by his comrade's experience. Hallgrímur Hallgrímsson and the cause he stands for are betrayed by politics: the Spanish Civil War was lost not least because of power struggles and in-fighting among the leftist forces themselves. This is what happens in the novel as well. While the great powers and the foreign military are symbolic of an abstract enemy, the real enemy is to be found closer to home, personified in the novel by Haraldur's twin brother. Hákon is the novel's main villain: he is unrepentantly and unredeemably evil. He is not a soldier but a greedy opportunist who will support whichever cause he thinks will benefit

22 Rigney, "Portable Monuments," 380, 382. Rigney here relies in part on Hayden White's argument that there is a structural affinity between 'narrativizing' events and moralizing them, "The Value of Narrativity in the Representation of Reality," in The Content of the Form: Narrative Discourse and Historical Representation (Baltimore: Johns Hopkins University Press, 1987). 
him. Before the occupation he supported Hitler, now he is an ardent supporter of the British. He works for the occupying forces, which makes him one of the wealthiest men in Iceland. He exploits his Icelandic workers, paying them wages with which they can barely feed their families. Significantly, he does so in happy co-operation with the leader of the workers' union. To complete his villainy, he pleads with his father to sell all his farmland to the British. Thus, Hákon is the enemy inside who betrays his country and his people, including his own family, to gain power and money.

The third brother, Máni, is the character in the novel who is betrayed by his own cause and his own leaders. At the start, he is an idealistic revolutionary poet trying to compose an ode in honor of Iceland's independence. When Iceland is occupied by the British army he is overcome by anger, frustration and guilt: not only has Iceland lost its independence again before even having gained it fully, it has been drawn into a world war by the great powers, and without any Icelander standing up to defend it except a few drunks by the harbour who are quickly arrested by the Icelandic police. On the contrary, most of his countrymen seem to welcome the occupiers and are in a rush to work for them, even the workers who are opposed to the occupation, as they can hardly live off the wages paid by Icelandic companies. Máni is dismayed and tries to convince them to fight for their rights rather than pave the way for the occupying forces. He is desperate to help them in their fight and comes up with the idea of appealing to the common soldiers in the army, who are also only pawns in the power games of the capitalists. He writes a flyer urging the soldiers not to do the work of striking Icelandic workers who are fighting for a fairer deal.

Thus, Jóhannes úr Kötlum fictionalizes Hallgrímsson's fight for workers' rights at home in Iceland in the form of a separate character in the novel. Like Hallgrímsson, Máni and his friends are arrested and sent to prison - although Máni's sentence is more dramatic and symbolic: he is transported to England. On board the army ship, as he sees Iceland disappear from view, Máni ponders the betrayal of the Icelandic government, willing to sell out its citizens to a foreign prison in order to protect the interests of the rich and powerful. And it is this betrayal that eventually convinces Máni to join the Red Army as a volunteer to fight for a better world. Considering that Máni clearly is the author's representative in the novel, his decision to take up arms despite his brother Haraldur's painful experience is remarkable. The 'flyer case' plays a crucial role in this respect: the betrayal of the capitalist establishment is considered to be of such a magnitude that it convinces even a profound pacifist like Jóhannes úr Kötlum to turn his fictional alter ego into a soldier, following Hallgrímsson's example in real life. This seems to suggest that, in the end, Jóhannes úr Kötlum may have seen it as inevitable that Icelanders would eventually be driven to 
become active participants in war, now that the world and its wars had imposed itself on them. They have lost their innocence and become killers in a world characterized by deception and betrayal. This message is underlined in the rather melodramatic central tragedy of the novel, where the otherwise quiet and gentle Haraldur, in a fit of delusion, mistakes his sister's baby for a British officer and, considering it a representative of the British Empire, kills it.

Jóhannes úr Kötlum's novel thus constitutes a fictional mediation of Hallgrímur Hallgrímsson's memories and actions in the larger context of World War II and the British occupation of Iceland, all of which posed dramatic challenges to Icelandic identity and national self-image. Like Hallgrímsson's writings, the novel received few reviews, all of them political, and have since largely been forgotten. Its three original reviewers and, later, literary historians, focus primarily on the political message of the work, its anti-war critique, the communist views of the author and the nationalist polemic against the detrimental influences of a foreign military presence in Iceland, as well as its obvious flaws as a work of literature. The fact that it also constitutes the first Icelandic novel grappling with the fictional mediation of events and experiences which had not been dealt with in Icelandic literature before has gone largely unnoticed. ${ }^{23}$ Cold-war partisan politics and its aftermath have meant that the challenging questions raised by Hallgrímur Hallgrímsson's experiences have not yet become part of the general discourse, as no serious study of his work, or of the influences he has had on for instance Jóhannes úr Kötlum's work exists. Instead it disappeared from view, from cultural memory, only to reappear at the start of the next century.

\section{Across the River Ebro}

The main protagonist in Álfrún Gunnlaugsdóttir's novel Yfir Ebrofljótið [Across the River Ebro] says at the beginning of the book:

It is strange how quickly wars are forgotten, people think first and foremost about rebuilding and erasing traces and in the end it is as if nothing has happened. Horrors are at best turned into ceremonies with speeches, marching bands, and flowers. They are buried everywhere, the boys from the Republican army, and not all of them in a graveyard. It is highly unlikely that one chances upon their graves with flowers. ${ }^{24}$

23 See Daisy Neijmann, “'́boðinn gestur.' Fyrstu birtingarmyndir hernámsins í íslenskum skáldskap." Skírnir 185 (2011). Verndarenglarnir was reviewed at the time by Kristinn E. Andrésson, Sigurður Helgason, and Sverrir Kristjánsson. It has been discussed since by Kristinn Kristjánsson, Sigprúđur Gunnarsdóttir, and Dagný Kristjánsdóttir. 
Gunnlaugsdóttir's text is published in 2001, a crucial moment for 'historical memory' in Spain. It is the same year that Javier Cercas' novel Soldados de Salamina (2001; Soldiers of Salamis, 2004) is published, the first among many bestsellers in Spain on the Civil War and the Franco regime. It is also the time when, as Francisco Ferrándiz explains, Spain has 'seen the emergence of a surprisingly strong social movement, loosely founded on the idea of "recovering historical memory".' He explains that the 'recovery movement,' which has never failed to spark controversy, mostly focuses on: '(1) locating graves and exhuming corpses of the victims of Franco's repressive policies, both during the Civil War (1936-1939) and after Franco's victory, and (2) recording oral testimony from victims and relatives, mostly in digital video format. ${ }^{25}$ The exhumations have sparked controversy and debate, but the reappearance of these victims in the media through photographs has also meant that ' $[\mathrm{t}]$ he buried bodies the graves contain have turned into mute protagonists, but extraordinarily significant, in the process known as the "recuperation of historical memory" in Spain in the twenty-first century. ${ }^{26}$ The bodies have come back to haunt Spanish society, and thus opened up the past, forcing a new negotiation of remembering/forgetting.

Gunnlaugsdóttir's protagonist, directly based on Hallgrímur Hallgrímsson, is, interestingly, also called Haraldur. What is more, he addresses his story to 'Máni,' in this instance not a personal name but the Icelandic word for the moon. These names alone thus establish a direct textual link between the two earlier mediations of Hallgrímsson's experiences. This novel, however, does not view these experiences in a contemporary setting but is retrospective for the most part. Haraldur is an old man who, alone in his Reykjavík flat, revisits his memories of his time in Spain, fighting with the International Brigades during the Civil War. Like Haraldur in Verndarenglarnir, he returned from the war with physical and mental injuries. He can no longer use his left hand (is it purely a coincidence that it should be his left hand?), and he has tried to forget everything concerning the war as the memories are too painful, even though this means that he betrays his promise to his friend Andrés before he died, that he would testify to what really happened.

Having reached old age and starting to lose his memory, however, Haraldur is beginning to realize that he needs to tell his story. Thus the novel goes back

25 Francisco Ferrándiz and Alejandro Baer, "Digital Memory: The Visual Recording of Mass Grave Exhumations in Contemporary Spain," Forum: Qualitative Sozialforschung/Forum: Qualitative Social Research (Online Journal) 9.3 (2008): Art. 35, par. 10.

26 Francisco Ferrándiz, El pasado bajo tierra Exhumaciones contemporáneas de la Guerra Civil, Memoria rota. Exilios y Heterodoxias. Serie estudios 51 (Barcelona: Anthropos, 2014), 36 . 
and forth between past and present as Haraldur remembers. The descriptions of his experiences are extremely detailed, demonstrating the complexity of this war and challenging any black-and-white view. At the same time they are deeply personal, giving the reader an intimate insight into the personal experience of a large historical event which has overshadowed Haraldur's life ever since. ${ }^{27}$ The emphasis in the novel is therefore not least on the consequences of these experiences: how does one continue to live with the trauma of war, the memory of fallen friends and the betrayal of ideals? Although the fascists and Nazis are the enemy that Haraldur and his fellow soldiers are fighting on the ground, the real enemy in the novel is politics, which will betray anyone and everyone.

The Icelanders who saw the horrors of war first-hand were very few in number. Those who made it back to Iceland had to try and readjust to everyday life in a society for which the war had meant unprecedented prosperity and progress rather than atrocities, suffering and starvation. This made the readjustment all the more difficult, as their experiences did not fit into Icelandic reality. In Iceland, there was no public story or memory of war veterans, war heroes or survival against the odds. While it is true that Haraldur himself tries to forget, it is just as true that there is noone who understands, believes, or even wants to listen to his story anyway. This becomes painfully clear when his brother-in-law, who does not know the first thing about war, accuses Haraldur of having betrayed his ideals. Instead, Haraldur concludes, people 'prefer to live with deception,' for 'the truth disturbs the peace.28

One Icelander who experienced the horrors of the concentration camps was Leifur Muller. On his return he published his memories (Í fangabúðum nazista [In the Nazi concentration camps], 1945), which were re-written, expanded and re-published in 1988 (Býr Íslendingur hér? [Does an Icelander live here?], with Garðar Sverrisson). In the later edition, Muller looks back not only on his time in the camps but also remembers what it was like to live with this experience, before and after camp syndrome and PTSD became recognized. ${ }^{29}$ While Gunnlaugsdóttir relies on Hallgrímsson's memories for the descriptions of the war in Spain, she integrates Muller's experiences into Haraldur's account

27 Gunnpórunn Guðmundsdóttir, "Tregðan í frásögninni: Yfir Ebrofljótið," and Úlfhildur Dagsdóttir, "Flakkað um frásagnir: Minni, tími og stríð í skáldverkum Álfrúnar Gunnlaugsdóttur," Rúnir: greinasafn um skáldskap og frcðastörf Álfrúnar Gunnlaugsdóttur, ed. Guðni Elísson (Reykjavík: University of Iceland Press, 2010).

28 Gunnlaugsdóttir, Yfir Ebrofljótið, 436.

29 Leifur Muller, Í fangabúðum nazista (Reykjavík: Víkingsútgáfan, 1945); Garðar Sverrisson, Býr Íslendingur hér? Minningar Leifs Muller (Reykjavík: Iðunn, 1988). 
of his life after his return from the war, for instance the fact that Haraldur always has clothes ready at the end of his bed in case he needs to get up in the middle of the night and leave. ${ }^{30}$ Thus, the novel becomes, in Rigney's words, 'a fictional framework where different stories can be linked', as Gunnlaugsdóttir weaves together and re-mediates Icelandic memories of war, actual and fictionalized. ${ }^{31}$ Twenty years earlier, Gunnlaugsdóttir was the first Icelandic author after Jóhannes út Kötlum to write about traumatic war experience in an Icelandic context, in the short story 'I'. In this story, the figure of the soldier, and in particular his gun, becomes the trigger of both fascination and terror. ${ }^{32}$

With her novel and earlier short story, Álfrún Gunnlaugsdóttir contests Icelandic collective memory of both the Spanish Civil War and World War II. The Icelandic historian Guðmundur Hálfdanarson has pointed to the fact that World War II has been remarkably absent from Icelandic public consciousness and debate, and its discussion has remained quite low-key in Icelandic historiography. In Icelandic collective memory, too, World War II and the Allied occupation play only a very modest and muted role, as can be seen for instance from its virtual absence in Icelandic museum and public memorial culture. Hálfdanarson suggests this may be attributed to the fact that the Icelandic experience of World War II does not fit into the grand narrative of Icelandic history, which centres around the heroic battle for independence from foreign oppression, which in turn is considered essential for social and economic progress and welfare. During the war, however, it was in fact foreign occupation which brought wealth and modernity to the country and laid the foundation for the postwar development of Iceland as a modern nation. It is not least as a result of this that, in Hálfdanarson's words, 'interest in, or moral incentive of, rewriting the history of Iceland's participation in the Second World War, or to present an alternative narrative ... has been limited at best. ${ }^{33}$ Álfrún Gunnlaugsdóttir on the other hand focuses on personal memory of the war, particularly memories which challenge the grand national narrative of, on the one hand, a military invasion by a foreign aggressor, and, on the other hand, the 'blessed war' that

30 Gunnlaugsdóttir, Yfir Ebrófljótið, 69, 360.

31 Rigney, "Portable Monuments", 378. Gunnlaugsdóttir published an extensive article based on her research into experiences of the Nazi concentration camps as related in three published memoirs (by Leifur Muller, Primo Levi and Jorge Semprún): "Í návist dauðans: frásagnir priggja manna af dvöl sinni í fangabúðum nazista," Ritið $3 \cdot 3$ (2003).

32 Álfrún Gunnlaugsdóttir, "I", Af manna völdum (Reykjavík: Mál og menning, 1981), 7-14.

33 Guðmundur Hálfdanarson, “The Beloved War.' The Second World War and the Icelandic National Narrative," Nordic Narratives of the Second World War: National Historiographies Revisited, eds. Henrik Stenius, Mirja Österberg, and Johan Östling (Lund: Nordic Academic Press, 2011), 89. 
brought Iceland wealth, by placing it in a transnational context. In one interview after the publication of the novel, Gunnlaugsdóttir mentions the boom in memory texts in Europe and the interest in World War II at the millennium and confirms she is writing history from the inside, from the individual's perspective, through the lens of memory. As she explains:

The War had more impact on people than one thinks. People speak of the wartime lightly in Iceland, too lightly I think, because people were scared. The fear lives on with the children and has influenced the writers who want to review this period, even if simply for themselves. It is often said that people write to get rid of certain things [...] But my opinion is that if you forget the past something dies inside you. There are things that should not be forgotten, as that would be a sign of a certain type of death. ${ }^{34}$

Here, the author clearly touches upon many issues with which we are familiar in the discourse on the millennial memory boom, but that had, until then and to a large extent since, remained outside the general discourse in Iceland. Interestingly, the interview was published in the newspaper Morgunblaðið, the same right-wing paper which supported Franco during the war and which usually has had very harsh words to write about those who fought with the International Brigades.

Seen in this light, one could say that the memorial process represented in Yfir Ebrofljótið through Haraldur represents an attempt to fragment a monolithic national narrative by rendering subjective experiences of war in the larger context of transnational memory. Textual ghosts from a past the nation has chosen to forget because they did not fit into the grand narrative of Icelandic history are brought back to life. Haraldur never wanted to 'bring the past back on himself,'35 only to realize in old age that it has continued to haunt him and has alienated him from those closest to him. His decision finally to tell his story is the long overdue testimony he had promised his dying friend. By bearing witness at last, he challenges deception and demands recognition on behalf of those whose suffering has been ignored and whose experiences and sacrifices have been forgotten. Similarly, the novel, in its fictional mediation of Icelandic memories of war, bears witness to 'forgotten' stories and experiences in national history and literary history, this time in the more receptive transnational

Fríða Björk Ingvarsdóttir, “Рað veitir mér meira öryggi að leggja út í óvissuna,” interview with Álfrún Gunnlaugsdóttir, Lesbók Morgunblaðsins, 22 December 2001. 
context of the memory boom and the recognition of symptoms and long-term effects of war trauma.

It is significant that the novel ends with Haraldur, on his way home, thinking that he 'didn't know, and didn't want to know. That within a few months a world war would break out and the realm of death would take over. As it had in Spain under Franco. ${ }^{36}$ These final sentences directly link the Spanish Civil War and the Second World War, one directly following the other. These two international events catapulted Iceland into the modern age and into modern war. From this moment on, Icelanders had a share in international war, and had to face the fact that, as a nation, whether they liked it or not, they were no longer peace-time subjects 'north of war,' but participants in world events. ${ }^{37}$

The publication of Yfir Ebrofljotid in 2001, twelve years after the fall of the Berlin wall, meant that an overwhelming sense of relief of finally leaving Cold War politics behind was still palpable in the country. It is, for instance, striking that the left - right, communist - fascist discourse is barely mentioned in the work, despite its centrality to the work itself, and neither are the trade interests. Instead, the novel clearly aims to rekindle forgotten memories among new generations of readers living in a global world and exposed daily to transnational memory through media such as literature, film, popular culture, social media and the Internet. This new readership has grown up with Iceland being a participant on the international stage, and is therefore much more likely to be receptive to viewing Icelandic memory in a transnational context and to explore the reverberations of world events at home in a new light.

It comes therefore as no surprise that the reception of Gunnlaugsdóttir's novel was very different from the works of Hallgrímsson and Jóhannes úr Kötlum. Other factors of course play their part in this, notably changes in the media: the advance of new media, the fading of partisan journalism and the advances in cultural journalism. The novel was widely reviewed in newspapers, magazines, literary websites and on TV and radio. It was nominated for several literary prizes, the most prestigious of which was undoubtedly the Nordic Prize for Literature. It seems to garner continued interest, for instance as the subject of a literary program on Icelandic National Radio in 2015. Its legacy, whether it will be constitutive of war memory in Iceland, is harder to gauge at this point in time.

36 Gunnlaugsdóttir, Yfir Ebrofljótið, 456.

37 'North of war' (Norðan við strið, 1971) is the title of an Icelandic occupation novel by Indriði G. Porsteinsson which is structured on the trope of Icelanders always having believed their country to be too far removed ever to become a part of international wars. 


\section{Memorialization of Hallgrímur Hallgrímsson}

The lack of any discourse on the memory boom in Iceland might perhaps lead one to believe that the country had not witnessed such a boom. This, however, would not be quite accurate. Ketill Kristinsson has studied, mapped and investigated the history of trauma memorials in Iceland in the twentieth century. He has travelled around the country, listed the memorials, their location, the year in which they were built, and their 'character', that is, the movement as seen elsewhere from the monumental to the memorial. ${ }^{38}$ His chart of the building of memorials around the country demonstrates abundantly that Iceland followed many other countries in Europe and elsewhere in this matter. The huge increase in the building of memorials from the 1980 s and onwards is unmistakable, as is the change in their form and location. The memorials mainly memorialize fishermen and others lost at sea, as well as those killed in natural disasters, in particular in avalanches which have contributed to a great loss of life in small villages in Iceland. One such memorial is the Memorial to Drowned Seamen in the Fossvogur Cemetery in Reykjavík. The history of the memorial is interesting, as it is in part based on one of the earliest trauma memorials erected in Iceland. The original was built in 1938 on the Tomb of the Unknown Fisherman in a clear echo of tombs of the unknown soldiers erected across Europe in the wake of the Second World War. There are no Icelandic war memorials (although there are foreign war memorials in Iceland); instead Icelanders have tended to regard those lost at sea as their fallen heroes. In 1996 additional structures were added to the memorial: low walls called the Waves of Memory. Here, relatives of those lost at sea could pay for their names to be edged on the 'wave' stones under a heading with the boat's name and the year in which it perished. In 2005 the Minster of Fisheries, Árni Matthiesen, supported the initiative to add the names of those who had been lost at sea during World War II, the first time a particular group had been specifically memorialized, paid for by the public. On one of these 'waves' the ship Sceborg and its crew can be found, with the name of Hallgrímur Hallgrímsson edged in the stone. Hallgrímsson story has thus come back to haunt us, his story has become one of the stories that call on us to remember. Maybe it to a certain extent exemplifies Iceland's political, geographical and cultural situation in Europe: being very much on the margins, but nevertheless intricately involved in central events.

38 Some of the results are discussed in Ketill Kristinsson, "Eyrnamörk gleymskunnar: Nokkur orð um minnismerki," Ritið 13.1 (2013). 
It is interesting to note that, while Hallgrímur's name on the memorial awards him certain recognition, it is only for his death at sea, not for his participation in the International Brigades or his fight for workers' rights. Outside of his literary contribution he is, in other words, only recognized as a victim, not an agent, and only within the context of public memorial culture in Iceland, which is, of course, tied to the grand narrative of Icelandic history. It is the literary works, which memorialize him and his 'afterlife as textual monuments' in Rigney's terms, ${ }^{39}$ that provide the social framework for the memory of him as an active agent, a soldier, an Icelandic participant in an international conflict.

\section{Conclusion}

'Under the Republic's Flag: Memories from the Spanish Civil War' by Hallgrímur Hallgrímsson constitutes an intriguing example of a 'forgotten' text that refuses to go away. Its afterlife as a textual monument of personal memories and experiences that did not fit into the monolithic founding myth of the modern Republic of Iceland clearly demonstrates how, in Astrid Erll's words, "the nation-centredness ... approach ... "forgets" the history of exchange within Europe. ${ }^{40}$ It makes it very obvious that memory of war and occupation, as well as trauma memorials are very much under-discussed and under-researched in Iceland, and need to be brought into the discourse of the past. Icelandic historiography, collective memory and national self-image have not yet undergone the kind of revision that has happened elsewhere, and a clear tendency to view Icelandic events and experiences almost exclusively from an Icelandic point of view remains. At the same time, Hallgrímsson's text has been the source of repeated attempts at 'reactualizing' his memories at important points in Icelandic history, always contesting the dominant national version of history and claiming recognition, a place in cultural memory. The afterlife of Hallgrímsson, in the form of various re-workings and re-interpretations of his memories, constitutes a poignant example of the formative role of international events in Icelandic history, personal and national, as well as of what can be gained by integrating national and European memory.

\footnotetext{
39 Rigney, “Portable Monuments," 372.

40 Erll, "Traumatic Pasts", 1.
} 


\section{Bibliography}

Andrésson, Kristinn E., Review of Verndarenglarnir, Tímarit Máls og menningar 4.2 (1943): 228-233.

Caruth, Cathy, Unclaimed Experience: Trauma, Narrative, and History, Baltimore and London: Johns Hopkins University Press, 1996.

Dagsdóttir, Úlfhildur, “Flakkað um frásagnir: Minni, tími og stríð í skáldverkum Álfrúnar Gunnlaugsdóttur," Rúnir: greinasafn um skáldskap og fræðastörf Álfrúnar Gunnlaugsdóttur, ed. Guðni Elísson, 143-157, Reykjavík: University of Iceland Press, 2010.

Erll, Astrid, "Traumatic Pasts, Literary Afterlives, and Transcultural Memory: New Directions of Literary and Media Memory Studies," Journal of Aesthetics and Culture, vol 3 (2011): 1-5.

Ferrándiz, Francisco, El pasado bajo tierra Exhumaciones contemporáneas de la Guerra Civil, Memoria rota. Exilios y Heterodoxias. Serie estudios 51 (Barcelona: Anthropos, 2014).

Ferrándiz, Francisco and Alejandro Baer, "Digital Memory: The Visual Recording of Mass Grave Exhumations in Contemporary Spain," Forum: Qualitative Sozialforschung/Forum: Qualitative Social Research (Online Journal) 9.3 (2008): Art. 35.

Gorrara, Claire, French Crime Fiction and the Second World War. Manchester: Manchester University Press, 2012.

Guðmundsdóttir, Gunnpórunn, “Tregðan í frásögninni: Yfir Ebrofljótið,” Rúnir: greinasafn um skáldskap og fræðastörf Álfrúnar Gunnlaugsdóttur, ed. Guðni Elísson, 129-141, Reykjavík: University of Iceland Press, 2010.

Gudsteins, Gudrun Björk, "Rediscovering Icelandic Canadian Pacifism," Rediscovering Canadian Difference, ed. Gudrun Björk Gudsteins, 50-6o, The Nordic Association of Canadian Studies Text Series 17, Reykjavík: University of Iceland Press, 2001.

Gunnarsdóttir, Sigprúður, “Hér eru örlagamál á dagskrá’: menningarátök í premur skáldsögum stríðs- og eftirstríðsára," Kynlegir kvistir tíndir til heiðurs Dagnýju Kristjánsdóttur fimmtugri, ed. Soffía Auður Birgisdóttir, 53-73, Reykjavík: Uglur og ormar, 1999 .

Gunnlaugsdóttir, Álfrún, Yfir Ebrofljótið, Reykjavík: Mál og menning, 2001.

Gunnlaugsdóttir, Álfrún, “Í návist dauðans: frásagnir priggja manna af dvöl sinni í fangabúðum nazista," Ritið 3.3 (2003): 9-52.

Hálfdanarson, Guðmundur, “The Beloved War. The Second World War and the Icelandic National Narrative," Nordic Narratives of the Second World War: National Historiographies Revisited, eds. Henrik Stenius, Mirja Österberg, and Johan Östling, 79-100, Lund: Nordic Academic Press, 2011).

Hallgrímsson, Hallgrímur, Undir fána lýðveldisins, Reykjavík: Björn Bjarnason, 1941.

Helgason, Sigurður, Review of Verndarenglarnir, Menntamál 16 (1943): 90-99. 
Ingimarsson, Pétur Guðmundur, “Vopnlaus pjóð”, BA-dissertation in History, University of Iceland, 2011.

Ingvarsdóttir, Fríða Björk, "Pað veitir mér meira öryggi að leggja út í óvissuna," interview with Álfrún Gunnlaugsdóttir, Lesbók Morgunblaðsins, 22 December 2001.

Kötlum, Jóhannes úr, Verndarenglarnir, Reykjavík: Heinskringla, 1943.

Kristinsson, Ketill, "Eyrnamörk gleymskunnar: Nokkur orð um minnismerki," Ritið 13.1 (2013): 165-182.

Kristjánsdóttir, Dagný, “Árin eftir seinna stríð: Móðir Jörð,” Íslensk bókmenntasaga, vol. 4, ed. Guðmundur Andri Thorsson, 466-468, Reykjavík: Mál og menning, 2006.

Kristjánsson, Kristinn, "Konan, draumurinn og dátinn," Tímarit Máls og menningar 45.2 (1984): 194-212.

Kristjánsson, Sverrir, Review of Verndarenglarnir, Helgafell 2.4-6 (1943): 268-270.

Luckhurst, Roger, The Trauma Question, London: Routledge, 2008.

Muller, Leifur, Ífangabúðum nazista, Reykjavík: Víkingsútgáfan, 1945.

Neijmann, Daisy, “Óboðinn gestur.' Fyrstu birtingarmyndir hernámsins í íslenskum skáldskap," Skírnir 185 (2011): 64-88.

Ólafsson, Jón, "Landráðakenning Pórs Whitehead: Nokkrar athugasemdir við ritið Sovét-Ísland: Óskalandið," Tímarit um félagsvísindi (2011-2012): 47-72.

Olgeirsson, Einar, "Hallgrímur Hallgrímsson," obituary, Pjóðviljinn, 1o December 1942.

Rigney, Ann, "Portable Monuments: Literature, Cultural Memory, and the Case of Jeanie Deans," Poetics Today 25:2 (2004): 361-396.

Sigurðarson, Róbert, ¡Viva la República! - ¡Viva la libertad! La participación de islandeses en la Guerra Civil Española, BA-dissertation in Spanish Studies, University of Iceland, 2014.

Stonebridge, Lyndsey, "Theories of Trauma," The Cambridge Companion to the Literature of World War II, ed. Marina MacKay, 194-106, Cambridge: Cambridge University Press, 2009

Svavarsson, Stefán, "Spænska borgarastríðið í íslenskum samtímaheimildum," Sagnir 26 (2006): 50-55.

Sverrisson, Garðar, Býr Íslendingur hér? Minningar Leifs Muller, Reykjavík: Iðunn, 1988.

Whitehead, Pór, Sovét-Ísland: Óskalandið, Reykjavík: Ugla, 2010.

Yraola, Aitor, “Íslensk viðbrögð við spænsku borgarastyrjöldinni," Skírnir 163 (1989): $362-381$. 


\title{
The Italian Hall Tragedy, 1913: A Hundred Years of Remediated Memories
}

\author{
Anne Heimo
}

On Christmas Eve 1913 seventy-three people were crushed to death during the 1913-1914 Copper Strike in the small township of Calumet on the Keweenaw Peninsula, Upper Michigan. On Christmas Eve the local Women's Auxiliary of the Western Federation of Miners (WFM) had arranged a party for the strikers' families at the local Italian hall. At some point in the evening someone was heard to shout 'fire' and as people rushed to get out of the building they were hauled down the stairs and crushed to death. Sixty-three of the victims were children. There was no fire. Later on this tragic event became to be known as 'The Italian Hall tragedy', 'The Italian Hall disaster' or the '1913 Massacre,' and it continues to be the one most haunting event in the history of the Copper Country.

As a folklorist and oral historian, I am foremost interested in the history and memory practices of so called ordinary people in everyday situations and how they narrate about the past and events and experiences they find memorable and worth retelling. When first hearing about the tragedy a few years ago, I could not help noticing that it had all the elements for keeping a story alive. The tragedy was a worker's conflict between mining companies and miners, which resulted in the death of many innocent people, mainly children. Although the tragedy was investigated on several occasions, no one was found responsible for the deaths, and the case remains unsolved to this day. Was it a pure accident, an ill-fated prank or the deliberate work of antitrade-unionists, in other words murder? The inquiries were carried out inadequately and the documents of the coroner's inquest went missing for a half century. Even the doors of the hall have an important part in the story. While some believe that the doors were bolted from the outside to stop people from fleeing, some are sure that the doors opened inward and could not be opened, because the bodies were piling up in the front of them. In many ways the story also reminds me of historical tales concerning so called Christmas panics in churches around Finland in the eighteenth and nineteenth century. These tales often include a false fire, people suffocating in stairways trying to flee and that many of the victims are children. These tales are based on 
historical events, and because of these panics, officials ordered, already in the nineteenth century, that church doors and doors of other public buildings are to open outward. ${ }^{1}$

Now after going through dozens and dozens of versions of the story I am perhaps even more amazed by its persistence. The story has been told so many times and on so many forums, that it is nearly impossible to write about it without quoting someone else's words. But why, a century later, do people continue to retell this particular story?

Previously I have examined narrated memories and historical interpretations mainly from the perspective of the never-ending social process of history making, in which we all take part regardless of our education, profession or motivation. ${ }^{2}$ This continuous process consists of the interplay of public, popular, and scholarly histories and takes into notice the active role of non-historians and vernacular history in history making. Although people have always participated in history and memory making, new information and communication technology enable people to engage in these practices in ways that were not possible before. This shift also offers new opportunities for scholars to examine these activities, which before the digital era happened mostly within small communities and groups and could not be easily observed without long-term participant observation and interviewing.

An alternative way to look at this same process is to examine it as the remediation of transnational and transcultural memory. First, a historical event is created by the media, '... by newspaper articles, newsreels, photographs, diaries, historiographic works, poems, novels, plays, paintings, memorials, films, TV series, comics and blogs as well as Twitter and Facebook status updates' as Dagmar Brunow points out. ${ }^{3}$ After this the memory of the event will continue to travel across and beyond different borders, scales and territories and have

1 Janne Toivonen, “'Kirkko pallaa, alttari puttoo ja kivimuuri kaatuu' - joulukirkkojen tuhoisien pakokauhujen vuoksi ovet aukeavat Suomessa ulospäin," Yle uutiset, 27 December 2015, accessed 16 June 2016, http://yle.fi/uutiset/kirkko_pallaa_alttari_puttoo_ja_kivimuuri_ kaatuu_joulukirkkojen_tuhoisien_pakokauhujen_vuoksi_ovet_aukeavat_suomessa_ ulospain/8533432.

2 See e.g. Anne Heimo, Kapina Sammatissa: Vuoden 1918 paikalliset tulkinnat osana historian yhteiskunnallisen rakentamisen prosessia (Helsinki: Suomalaisen Kirjallisuuden Seura, 2010), 17-18; Anne Heimo, "The 1918 Finnish Civil War Revisited: The Digital Aftermath," Folklore 57 (2014), 142, accessed 7 June 2016, doi:10.7592/FEJF2014.57.heimo.

3 Dagmar Brunow, Remediating Transcultural Memory: Documentary Filmmaking as Archival Intervention (Berlin/Boston: De Gruyter, 2015), 4. 
new meanings attached to it at every stage. ${ }^{4}$ When the memory ceases to be remediated it has lost its meaningfulness. The same applies to all narratives. When we can no longer find meaning in a narrative, there is no point in retelling it.

Our everyday life has changed fundamentally during the last few decades. Internet technology has had a huge impact on many aspects of our lives, among them the possibility to take part in global activities, which transcend national borders. In memory studies this shift has led to the re-examining and contesting of former notions of memory, for instance the terms collective memory and national memory, which perceive groups, communities or the nation-state as certain types of containers of memory with more or less clear-cut borders. Even private and personal memories are increasingly shared in public with people whom we do not necessarily know. To overcome the problems associated with these former terms, terms like transnational memory ${ }^{5}$ and transculturalmemory ${ }^{6}$ have been introduced. Both of these terms stress the movement of memory across and between times, places, generations and media, from the private sphere to the public sphere, from individuals to communities and vice versa and beyond national (and other) borders. Additionally the acknowledging of the role of (new) media in the construction of memory has led to a shift from studying 'sites of memory' to the 'dynamics', 'flows' and 'travels' of memory. ${ }^{7}$ While an image may travel and be given new meanings without being altered, memories in narrative form will always be subject to change, and be shaped and reworked to new needs. This shaping is done according to the requirements of popular storytelling and draws on knowledge and information from the surrounding culture.

4 Chiara De Cesari and Anne Rigney, "Introduction: Beyond methodological nationalism," in Transnational Memory: Circulation, Articulation, Scales, ed. Chiara De Cesari and Anne Rigney, (Berlin/Boston: De Gruyter, 2014), 9.

5 De Cesari and Rigney, "Introduction," 3-8.

6 Astrid Erll, "Travelling Memory," Parallax 17 (2011), 9, accessed 7 June 2016, doi:10.1080/135346 45.2011.605570.

7 José Van Dijck, Mediated Memories in the Digital Age, (Palo Alto, CA: Stanford University Press, 2007), 18-19, 53-55; Astrid Erll and Ann Rigney," Introduction: Cultural Memory and its Dynamics," in Mediation, Remediation, and the Dynamics of Cultural Memory, ed. Astrid Erll and Ann Rigney, (Berlin/Boston: De Gruyter, 2009); Julia Creet, "Introduction," in Memory and migration: multidisciplinary approaches to memory studies, ed. Julia Creet and Andreas Kitzmann, (Toronto: University of Toronto Press, 2011), 9; Erll, “Travelling Memory,” 9; De Cesari and Rigney, "Introduction," 8-11. 
'New' media is often considered more democratic than 'old' media, although this is not always the case. ${ }^{8}$ It is also true that most users will rather passively follow the activities of other users or share contents created by others on the Internet than create new contents themselves. ${ }^{9}$ Nonetheless, I think that the examining of history and memory making practices online will give insight to these practices and demonstrate what people themselves find worth remembering of their past and why.

\section{Everyday Practices of Online History and Memory Making}

The Internet is full of both large institutional and small-scale private sites of memory and commemoration, which are used increasingly to showcase lost heritage sites, to commemorate historic events retrospectively or to share family memories with both local and transnational audiences. Although collaboration and participation with wider audiences is common practice among public historians working in archives, museums or oral history projects as well as a wide range of other actors, including writers, journalists, artists, film makers and activists, people will often choose to act individually on the personal level and share their memories spontaneously with their peers rather than take part in institutionally organized acts of memorialization, however impressive or well-planned they may be. ${ }^{10}$ They can become their own publishers, authors and archivists, who do not necessarily need or want expert supervision to create, manage and curate their collections. At the same time these practices result in a new kind of heritage, which is produced without outside supervision or expertise and which is more liable to change than preservation. ${ }^{11}$

See e.g. Joanne Garde-Hansen, Andrew Hoskins and Anna Reading, "Introduction", in Save as...Digital Memories, ed. Joanne Garde-Hansen, Andrew Hoskins and Anna Reading, (London \& New York: Palgrave McMillan, 2009), 8-11; Jose Van Dijck, The Culture of Connectivity: A Critical History of Social Media, (Oxford: Oxford University Press, 2013).

9 Jakob Nielsen, "The 90-9-1 Rule for Participation Inequality in Social Media and Online Communities," Nielsen Norman Group, 2006, accessed 7 June 2016, https://www.nngroup .com/articles/participation-inequality/.

10 Peter Jan Margry and Cristina Sánchez-Carretero, "Introduction: Rethinking Memorialization: The Concept of Grassroots Memorials," in Grassroots Memorials. The Politics of Memorializing Traumatic Death, ed. Peter Jan Margry and Cristina Sánchez-Carretero, (New York \& Oxford: Berghahn, 2011), 3-4; Heimo, The 1918 Finnish Civil War Revisited.

11 Elisa, Giarccardi, "Introduction: Reframing Heritage in Participatory Culture," in Heritage and Social Media: Understanding Heritage in a Participatory Culture, ed. Elisa Giarccardi, 
Participatory culture and grassroots activities are characteristics of many of these practices. Web 2.0 is often regarded a particular technology which makes interaction on the Internet (social media) possible, when it actually refers more to the way people are using the Internet than to the actual technology. ${ }^{12}$ This new mindset includes, for instance, a motivation to participate and share, to trust other users and the right to create new contents by remixing former ones, which are all features of convergence and participatory culture. Convergence refers to the circulation of media due to technological, industrial, cultural and social changes in culture and to the flow of contents across multiple media platforms. Participatory culture highlights community involvement and is ready to offer all interested an opportunity to contribute. Participatory culture is not only about production and consumption; it is also about affiliation, expression, collaboration, distribution and the disclaiming of former divisions between professionals and amateurs. ${ }^{13}$ Although participatory culture is neither only a feature of today, nor exists only on the Internet, the term is now commonly used when referring to cultural practices on the Internet. These practices may also occur offline, but are still dependent on new technology, and the creations can be distributed globally through digital networks even when they are produced personally and locally. ${ }^{14}$

The Italian Hall tragedy offers a fruitful example to examine the remediation of transcultural memory across and between different kinds of borders and times. The tragedy was immediately covered by local and national media from dissenting vantage points and photos of the site of the tragedy, the victims and their funerals, were circulated widely. However, a year later there was little or no mention of the event in public, and this is how the situation remained for decades. Even the release of Woody Guthrie's song '1913 Massacre' in 1941 did not break the silence. Nonetheless the memory of the tragedy continued to be conveyed, especially amongst those families and local ethnic

(London \& New York, Routledge, 2012), 1-10; See also Laurajane, Smith, Uses of Heritage, (Oxon, Routledge, 2006).

12 Timothy O'Reilly, "What is Web 2.o? Design Patterns and Business Models for the Next Generation of Software," Oreilly (2005), accessed 7 June 2016, http://www.oreilly.com/ pub/a/web2/archive/what-is-web-2o.html.

13 Henry Jenkins, Convergence Culture: Where Old and New Media Collide, (New York \& London: New York University Press, 2006), 2-3, 322-331; Henry Jenkins, Sam Ford and Joshua Green, Spreadable Media: Creating Value and Meaning in a Networked Culture, (New York \& London: New York University Press, 2013).

14 Joanne Garde-Hansen, Media and Memory, (Edinburgh: Edinburgh University Press, 2011), 46. 
communities which had been affected by the tragedy. When the time came, these memories surfaced again and have since been remediated in numerous ways and for various reasons. Whereas these private and personal memories used to be mostly presented and published by outsiders, such as journalists, historians and writers, today the situation is quite different. People can now share their memories on web and social media sites by themselves, without supervision. This case study also shows that over a century later the memory of the tragedy is still open for new interpretations and uses.

In the following I will first introduce Calumet, its history and multi-ethnic community and the actual tragedy. Then I will examine the memory of the tragedy from different perspectives, including the remediated memory and the transnationality and diasporic nature of the heritage site. After this I will present some examples of online commemoration and explore some of the reasons why the memory of the tragedy continues to fascinate and intrigue people.

\section{Calumet - A Multi-Ethnic Mining Community}

Copper Country was the home of the first mining boom in the United States. Copper was found on the Upper Michigan Peninsula in the 1840 and from then on, for over a century, the area was in need of a constant flow of immigrant workers. Most of the mining companies were relatively small in size and employed only a few thousand workers at the most. One of the largest mining companies was Calumet \& Hecla (C\&H), which had over 21,00o employees in 1907. Like so many other companies, also $\mathrm{C} \& \mathrm{H}$ applied a paternalistic system and built houses, shops, schools, libraries and other services for its employees. In addition to serving the needs of the company's workers, paternalism also meant that the company had control over nearly all aspects of the lives of its employees. ${ }^{15}$

From the 186os to 1920 s over 350,000 Finns immigrated to North America. In the United States large numbers of Finns ended up working in the mines in

15 Gary Kaunonen and Aaron Goings, Community in Conflict: A Working-Class History of the 1913-14 Michigan Copper Strike and the Italian Hall Tragedy, (Lansing: Michigan State University Press, 2013), 21-24, 85; Linsday E. Hiltunen, Cultural Memory and the Power of Place: One Hundred Years of Remembering the Italian Hall Tragedy and the 1913-1914 Michigan Copper Strike, (Macomb: Faculty of the Department of History of Western Illinois University, 2014), 25, accessed 7 June 2016, http://gradworks.umi.com/15/57/1557255.html. 
Copper Country in Michigan and the Iron Range in Minnesota. One of the first permanent Finnish settlements in the United States was founded in Calumet already in the 1860s and in the following decades Finns continued to move there. ${ }^{16}$ The Finnish community was only one of the many immigrant communities in the region at the time, but it was and still is the most populous ethnic community there.

Around the turn of the century socialism began to gain ground among Finnish immigrants and many 'Red Finns' took an active role in leftist politics and trade unions. ${ }^{17}$ This made the Finns the largest socialist group in the country and one of the most discriminated. All around the United States workers were forced to compete against each other, which lead to ethnic hostilities. While immigrants from English-speaking countries, Germans and Scandinavians were offered high-rank jobs, Finns, Slavs and Italians were given the most menial jobs. The differentiation between the different ethnic groups was about 'old' and 'new' immigrant groups, but it was also about racial ideology. Contrary to Scandinavians the whiteness of Finns was questioned. ${ }^{18}$

Despite the fact that Copper Country workers had been joining trade unions since the 1880 , the WFM-organized Copper Country Strike in 1913-1914 was the first major strike in the area. The strike was a multiethnic enterprise to improve working conditions, achieve union recognition and to unite immigrant communities. Many Finns were involved in the strike, both as members of the local WFM or because they held positions within the WFM. The strike began on 23 July 1913 and ended nine months later in April, 1914. The strike was not a success for the strikers, and thousands of miners moved elsewhere afterwards. ${ }^{19}$ Nonetheless, mining continued until the 196os when most of the mines were shut down in the area. The very last copper mine was shut down in 1995 .

16 Peter Kivisto, Immigrant Socialists in the United States: The Case of the Finns and the Left, (London and Toronto: Associated University Press, 1984), 72, 74-75.

17 Kivisto, Immigrant Socialists in the United States, 92-98; Ralf Kauranen and Mikko Pollari, "Transnational socialist imagination: The connections between Finnish socialists in the USA and Finland at the turn of the 2oth century," in Labouring Finns: Transnational Politics in Finland, Canada, and the United States ed. Michel S. Beaulieu, Ronald N. Harpelle and Jaimi Penney, (Turku: Institute of Migration, 2011); Kaunonen and Goings, Community in Conflict, 49-51.

18 Kivisto, Immigrant Socialists in the United States, 126-129; Kauranen and Pollari, "Transnational socialist imagination," 40-41; Kaunonen and Goings, Community in Conflict, 47-48.

19 Kivisto, Immigrant Socialists in the United States, 139; Kaunonen and Goings, Community in Conflict, 88-91, 113-114. 


\section{The Italian Hall Tragedy}

The Copper Country Strike had been going on for five months and to cheer the families and especially the children of the strikers, the Women's Auxiliary Organization of the WMF decided to arrange a party at the Italian Hall on Christmas Eve. Five to seven hundred people, a major part of them local children, were at the party enjoying themselves, when a shout of 'fire' was heard. Only a moment later people began to rush towards the stairs to get out. Tens of people found their way out, but then someone fell down the steep stairway. This caused more people to tumble down the stairs and people began to pile up on top of each other. Help arrived in a few minutes, but it took hours until people could be entangled from each other and moved from the staircase. Some of them survived with no or minor injuries, but seventy-three people were found dead. Most of the dead were children of Finnish immigrants. The victims were buried a few days later at the local Lakewood cemetery, side by side in two unmarked mass graves, one for twenty-two catholic victims and one for the forty-four protestant ones. The rest of the victims were buried in family graves. Burial and memorial services were held in six churches in several languages, with the Finnish Church among them. ${ }^{20}$

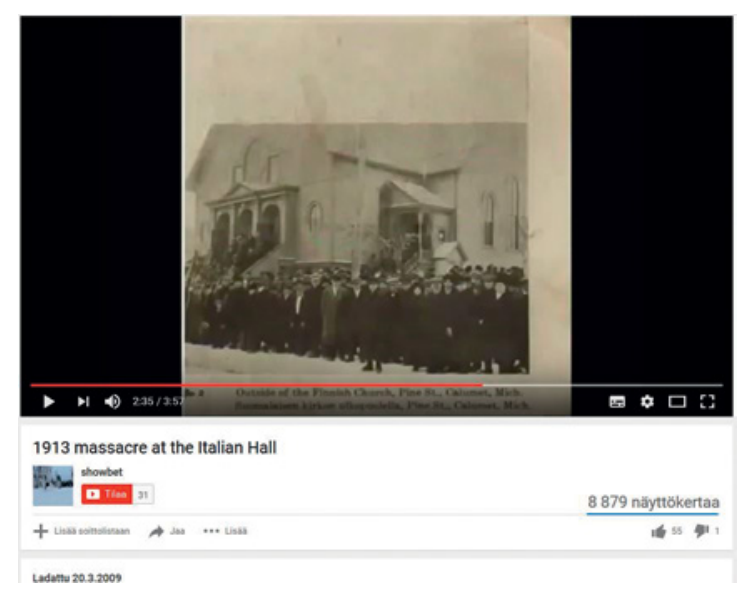

FIGURE 11.1 [s] [ ] clippings from local newspapers. Family and friends of Finnish victims held their funeral service at the local Finnish church.

(Accessed 1oJune, 2016, https://www.youtube .com/watch? $v=U g r P K 2 C N u J g$. Screenshot 4 May 2017)

$20 \quad$ Steve Lehto, Death's Door: The Truth behind Michigan's Largest Mass Murder, (Troy, MI: Momentum Books, 121-123; Hiltunen, Cultural Memory and the Power of Place, 119-120. 
Several eyewitnesses testified that a strange man wearing an anti-union Citizen Alliance button pinned to his coat had run up the stairs and shouted 'fire' and then left, but this was never officially stated. The mining companies denied having anything to do with the incident. Neither the coroner's inquest held soon after the tragedy nor the subcommittee sent by the United States Congress to investigate the tragedy a few months later found anyone guilty for the deaths. ${ }^{21}$ This led to several alternative explanations concerning the cause of the disaster. Some blamed the tragedy on a drunkard who had thought he had seen flames and some on a linguistic misunderstanding since most of the people in the hall did not share a common language. ${ }^{22}$ According to the current predominant version, which is largely based on Steve Lehto's investigations, the mining companies had wanted to disturb the party, but there is no evidence that they had actually bolted the doors or that they had planned the deed with its horrific outcome. ${ }^{23}$

For decades the doors were not considered to have anything to do with the tragedy, but at some point they became one of the main motives of the story. Some are sure that the outward opening doors had been deliberately bolted by members of the Citizen's Alliance to keep people inside, while others maintainthat the bodies piling up in front of the doors made it impossible to open the inward opening doors although documents prove that the doors did not open inward. ${ }^{24}$ In October 2015 Steve Lehto posted a newspaper clipping on the Facebook page 'The Italian Hall Disaster - Resource Center' to prove once more his point about the doors having nothing to do with the causalities. One person commented on his post: 'That's all I ever here [sic] too is about the doors. I tell them that you said the doors opened the right way and even tell them the way the staircase was they couldn't have opened in. They still don't believe me. Ugh. It's no use. LOL.'

21 Lehto, Death's Door, 124-152, 163-174.

22 Hiltunen, Cultural Memory and the Power of Place, 81; Raymond Alvar Wargelin, "Response" to Puotinen, Arthur, "Copper country Finns and the strike of 1913," in The Finnish Experience in the Western Great Lakes Region: New Perspectives, ed. Michael G. Karni, Matti E. Kaups and Douglas J. Ollila, (Turku: Migration Institute, 1975), 154.

23 Lehto, Death's Door, 207-208; Steve Lehto, Italian Hall: The Official Transcript of the Coroner's Inquest, (Troy, MI: Momentum Books, 2007).

24 Lehto, Death's Door, 175-178. Facebook, "The Italian Hall Disaster - Resource Center", accessed 10 June 2016, https://www.facebook.com/pg/The-Italian-Hall-Disaster-ResourceCenter-291845417514549/notes/?ref=page_internal. 


\section{Remediated Memories of the Italian Hall Tragedy}

The news about the tragedy at the Italian Hall was first released by the Finnish-American socialist newspaper Työmies (Worker), which published an extra edition on Christmas Day in both Finnish and English. The paper announced the death toll to be 80 and already at this stage it referred to eyewitness accounts concerning a strange man with his cap pulled down over his eyes and a Citizen's Alliance button pinned to the lapel of his coat yelling 'fire' before leaving the building. On 26 December the Työmies declared on its front page ' 83 murhattu!' ( 83 murdered!) and accused capitalists for the murder of children. The next day the first members of the staff of Työmies were arrested for their accusations. ${ }^{25}$ The news soon circulated throughout the country and abroad. Some newspapers took a neutral stance, but many sided either with or against the strikers and WFM.

A year later many had put the event behind them. On the first anniversary of the tragedy there was no mention of it in the local newspapers. The situation stayed the same for years to come. For example, in 1920 Juuso Hirvonen wrote a 120-page history of the Finns in Copper Country, but did not mention the tragedy and only briefly referred to the strike. ${ }^{26}$ The first to break the silence was Ella Reeves Bloor, one of the members of the Women's Auxiliary Organization, who had arranged the Christmas party at the Italian Hall. ${ }^{27}$ It was her autobiography which inspired Woody Guthrie to compose his song '1913 Massacre' on his album Struggle, a year later, in 1941. ${ }^{28}$ Others have also recorded the song, among them Bob Dylan who wrote his own version of the song 'Song for Woody', as a tribute to Guthrie in 1961, and Arlo Guthrie, who recorded his father's version in 1972. But in the local community the memory remained hushed and discussed only among friends and family. ${ }^{29}$

The silence was finally broken in the 1970s when the plans to tear down the Italian Hall made people alert to the possibility of losing an important local

\footnotetext{
25 Lehto, Death's Door, 110.

26 Juuso Hirvonen, Michiganin kuparialue ja suomalaiset siirtolaiset, (Duluth: Privately published, 1920).

27 Ella Reeve Bloor, We Are Many: An Autobiography of Ella Reeve Bloor, (New York: International Publishers, 1940).

28 Hiltunen, Cultural Memory and the Power of Place, 19.

29 See e.g. Lehto, Death's Door, 2; Hiltunen, Cultural Memory and the Power of Place, 15.
} 
site of memory. ${ }^{30}$ Several local stories and memoirs of the tragedy were published in the 1980s. ${ }^{31}$ A new wave of books came in the 2000s. ${ }^{32}$ Among them Deborah K. Frontiera's young adult novel Living on Sisu, which tells the story through the diary entries of a 12-year old girl. ${ }^{33}$ In 2006 attorney and author Steve Lehto published his book Death's Door: The Truth behind the Italian Hall Disaster and the Strike of $1913 .{ }^{34}$ Lehto's aim was to set the record straight so he also published the transcript of the trial. ${ }^{35}$ These have since earned him the role of expert in the history of the tragedy.

Academics have also shown an interest in the event. The tragedy has been covered in various studies on labour, social and immigrant history. One of the first of these was by Arthur Puotinen in the collection of essays The Finnish Experience in the Western Great Lakes Region: New Perspectives in $1975 .^{36}$ The most recent studies were published in the 2010s. Labor and social historians Gary Kaunonen and Aaron Goings have both examined the tragedy as part of their larger studies about the Copper Country Strike and the political activities of immigrants in the area, especially Finns. ${ }^{37}$ Linsday Hiltunen's thesis Cultural Memory and the Power of Place (2014) deals with the cultural memory of the

30 Hiltunen, Cultural Memory and the Power of Place, 104-106.

31 Wilbert B. Maki, Remembrance of a Tragedy, 1913, (sı: W.B. Maki, 1983); Arthur W. Thurner, Rebels on the Range: The Michigan Copper Miners' Strike of 19131-914, (Lake Linden, MI: John H. Forster Press, 1984); Peggy Germain, Tinsel \& Tears 2 (The Italian Hall Disaster, Calumet, Michigan), (Privately published, 1987).

32 Lawrence J. Molloy, Italian Hall: The Witnesses Speak, Great Lakes (Hubbell, MI: Great Lakes, GeoScience, 2014); Peggy Germain, False Alarm: 1913 Italian Hall Disaster and Death Certificates (Author House, 2005).

33 Deborah K. Frontiera, Living on Sisu: The 1913 Union Copper Strike Tragedy, (Bluebonnets, Boots \& Books Press, 2010).

34 Lehto, Death's Door; the second edition was published in 2013.

35 Lehto, Italian Hall.

36 Arthur Puotinen, "Copper country Finns and the strike of 1913," in The Finnish Experience in the Western Great Lakes Region: New Perspectives, ed. Michael G. Karni, Matti E. Kaups and Douglas J. Ollila, (Turku: Migration Institute, 1975); The collection also marks the beginning of ongoing collaboration between Finnish and American scholars studying Finns in the United States. See e.g. Labouring Finns: Transnational Politics in Finland, Canada, and the United States, ed. Michel S. Beaulieu, Ronald N. Harpelle and Jaimi Penney, (Turku: Institute of Migration, 2011); Finns in the United States: A History of Settlement, Dissent, and Integration, ed. Auvo Kostiainen, (East Lansing: Michigan State University Press, 2014).

37 See also Gary Kaunonen, Challenge Accepted: A Finnish Immigrant Response to Industrial America in Michigan's Copper Country, (Lansing: Michigan State University Press, 2010). 
strike and the tragedy it inflicted on the local community. A notable number of the authors mentioned above are of Finnish descent.

In 2004 the shooting of material for the documentary 1913 Massacre: A Film inspired by a Woody Guthrie Song, began. The film produced and directed by Ken Ross and Louis V. Galdieri (Dreamland Pictures LLC) came out in 2011 and has since been screened around the United States as well as in Finland. ${ }^{38}$ The documentary Red Metal: The Copper Country Strike of 1913 directed by Jonathan Silvers (Saybrook Productions LTD) premiered in December 2013 and was shown on Finnish national television a year later. ${ }^{39}$ In both of the films Woody Guthrie's song is performed, in the former by Arlo Guthrie and in the latter by Steve Earl.

\section{A Transnational Heritage Site?}

The tragedy has been commemorated in various ways including books, memoirs, films, songs, conferences, lectures, tours, concerts and even an opera. ${ }^{40}$ Yet, in spite of all the interest, there exists no permanent exhibition about the event. ${ }^{41}$ However, the Italian Hall was listed on the National Register of Historic Sites in 1980. In spite of pleas to salvage and renovate the building, The Italian Hall was pulled down in 1984. Afterwards the sandstone arch of the doorway was erected as a memorial of the tragedy at the now empty lot of the Italian Hall.

At the site there is also a marker which tells the story of the incident. The original text, which mentions the inward opening doors, was replaced in 2013 with a new text:

Michigan Historic Site, Italian Hall Tragedy

By December 1913, thousands of area copper miners had been on strike for five months. They were fighting for union recognition, safer working conditions, shorter workdays and better pay. On Christmas Eve hundreds gathered on the second floor of the Italian Hall to attend a holiday party for strikers' families. As the children filed to the stage to receive presents,

381913 Massacre: A Film inspired by a Woody Guthrie Song, accessed 7 June 2016, http://1913massacre.com/.

39 Yle, TV 1, Historia: Veristä kuparia, accessed 7 June 2016, http://yle.fi/aihe/artikkeli/2014/ 12/11/historia-verista-kuparia.

$40 \quad$ Hoagland, Unresolved; Hiltunen, Cultural Memory and the Power of Place.

41 Michigan Technological University Archives created a travelling exhibit "Turmoil \& Tragedy" with its own website for the centennial of the 1913-1914 strike: "Tumult and Tragedy: Michigan's 1913-14 Copper Strike", accessed 7 June 2016, http://www.1913strike .mtu.edu/index.html. 


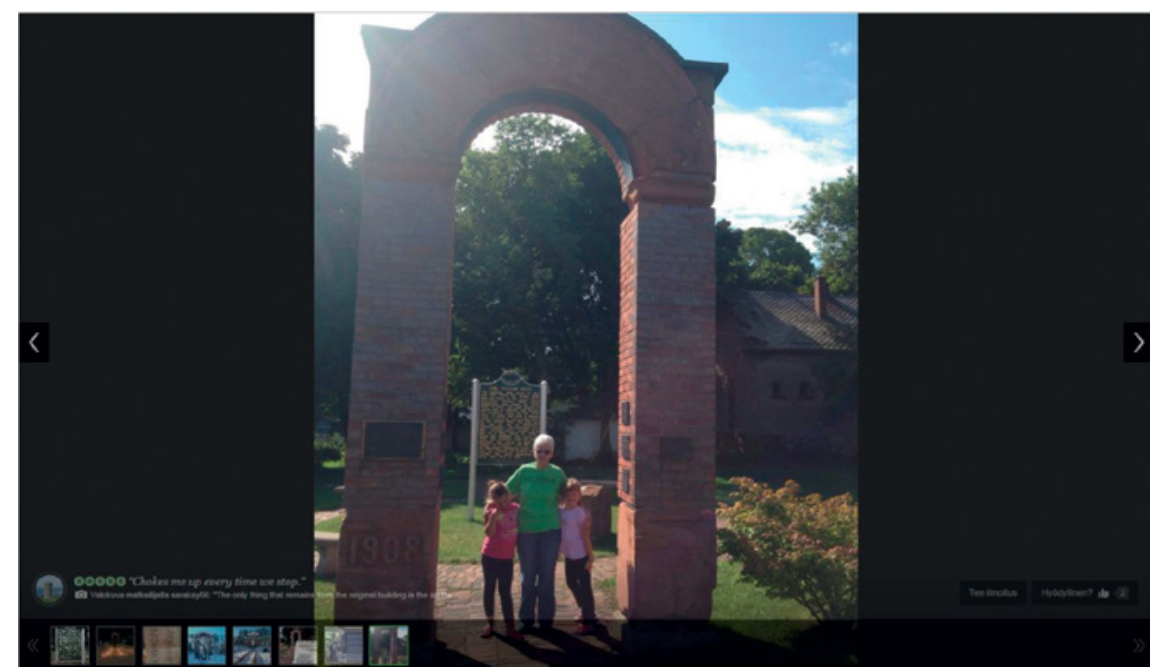

FIGURE 11.2 "Chokes me up every time we stop" commented one person on TripAdvisor after visiting the Italian Hall memorial. (Accessed 1o June, 2016, https://www.tripadvisor.com/Attraction_Review-g42038-d4557640-Reviews-Italian_Hall_Site-Calumet _Upper_Peninsula_Michigan.html.SScreenshot 4 May 2017)

someone yelled, 'Fire!' People panicked and rushed toward the exit. There was no fire. Many were trampled on the stairs. Officially seventy-three people died: more than half were children under ten. Despite a Congressional hearing and a coroner's inquest, the person whoyelled fire was never identified.

Several immigrant communities were involved in the tragedy, Finnish, Italian, Slovenian, Croatian and Polish. The marker tells the story of the tragedy, but does not list either the names of the seventy-three victims or their ethnicities. The only recognition of ethnicity is a plaque donated by the Italian American Ethnic Organization with the text 'In honor of the Italian-Americans who contributed greatly to this community'. Although the plaque is attached to the memorial arch it makes no reference to those members of the community who lost their lives in the tragedy. ${ }^{42}$ According to Lehto the reason for this is that it would raise questions and disputes about the number of victims, their names and their nationalities. Fifty-five of the victims were born in the United States, though they were identified according to the nationality of their parents. ${ }^{43}$

42 Lehto, Death's Doors, 95-97.

43 Lehto, Death's Doors, 148, 206; The Italian Hall Disaster, Calumet, Michigan, accessed 7 June 2016, http://www.genealogia.fi/emi/emizd31e.htm. 
Memory continues to travel and have new meanings attached to it. The Italian Hall memorial can be regarded as a site of 'pain and shame' as Keir Reeves and William Logan describe heritage sites that are a result of episodes which most would rather forget than remember. ${ }^{44}$ On TripAdvisor, reviewers recommend visiting the memorial to commemorate the disaster, to get acquainted with labour history and, as one reviewer notes, with 'the need for safety in all building construction safety'.45 Today it is regarded also as a more or less macabre dark heritage site and can be found in books and webpages listing examples of unsolved crimes, places of untimely death or other 'strange' or 'unusual' places. ${ }^{46}$

\section{Digital Diasporas and Diasporic Genealogy}

For dispersed migrants around the world the Internet offers various ways to connect with each other. Members of these diasporic-based online groups not only have a whole range of different sites to choose from, but their reasons to participate in these activities also vary. Michel S. Laguerre defines digital diaspora as

[a]n immigrant group or descendant of an immigrant population that uses IT connectivity to participate in virtual networks of contacts for a variety of political, economic, social, religious, and communicational purposes, that for the most part, may concern either the homeland, the host land or both, including its own trajectory abroad. ${ }^{47}$

44 William Logan and Keir Reeves, "Introduction: Remembering places of pain and shame," in Places of Pain and Shame. Dealing with Difficult Heritage, ed. William Logan and Keir Reeves, (London \& New York, Routledge, 2009), 1.

45 TripAdvisor, Italian Hall Site, Calumet, accessed 7 June 2016, https://www.tripadvisor. com/Attraction_Review-g42038-d4557640-Reviews-Italian_Hall_Site-Calumet_Upper_ Peninsula_Michigan.html.

46 Michigan's Otherside: Exploring the Strange \& Unusual in the Great Lakes State, Wicked, accessed 7 June 2016, http://michigansotherside.com/the-tragedy-at-italian-hall/; Viral Nova OMG, 25 Days of Creepy Christmas, Day 5, accessed 7 June 2016, http://www .viralnova.com/italian-hall-disaster/; Crime Magazine, America's Worst Unsolved Crime: The 1913 Italian Hall Disaster accessed 7 June 2016, http://www.crimemagazine.com/ america\%E2\%80\%99s-worst-unsolved-crime-1913-italian-hall-disaster.

47 Michel S. Laguerre, "Digital Diaspora: Definition and Models," in Diasporas in the New Media Age: Identity, Politics and Community, ed. Adoni Alonso \& Pedro J. Oiarzabal, (Las Vegas: University of Nevada Press, 2010), 50. 
Family history is one the most popular reasons to engage in history-making. ${ }^{48}$ The digital and participatory turn has meant a further increase on family history practices and what Catherine Nash (2008) refers to as diasporic genealogy, the searching for one's ancestral roots in 'the old home country' or among family members who have migrated to other parts of the world. ${ }^{49}$ In addition to searching for lost relatives and sharing family memories, people can help and assist each other in these practices on the Internet independent on where they are.

It is estimated that there are over 600,000 people in the United States who recognize their Finnish ancestry..$^{50}$ Over 4,400 of them belong to a closed Facebook group 'American Finnish people'. In addition there are Facebook pages for local Finnish American groups around the country with several hundred members in each, for example 'Finnish American Heritage Society of Cantebury, Ст' (496 likers, accessed 7 June 2016), 'Cokato Finnish American Historical Society' (426 likers, accessed 7 June 2016) and 'MN Finnish American Historical Society Duluth, MN (133 likers, accessed 7 June 2016). Most of the members of these groups are second or third generation Finns. The two most popular groups 'Finnish Genealogy' and 'Old Recipes from Our Finnish Ancestors' are closed Facebook groups dedicated to the sharing of family history and memories. 'Finnish Genealogy' was established in 2014 and the membership continues to grow (7,085 members, accessed 7 June 2016). The group members share personal documents, such as family photos, letters and documents, and help each other in translating texts, searching for information in parish registers or answering various enquires. The group 'Old Recipes from Our Finnish Ancestors' $(5,484$ members, accessed 7 June 2016) is a spin-off of the former group created in 2014 for the sole purpose of sharing old and new family recipes in order to 'connect and learn more about our Scandinavian and Finnish heritage, and to share recipes, memories and stories related to our roots, drawing us all closer through similar interest in our Scandinavian and Nordic heritage'. As a result of these activities all of these sites form archives consisting

48 For the United States see Roy Rosenzweig and David Thelen, Presence of the Past. Popular Uses of History in American Life, (New York \& Chichester, Columbia University Press, 1998), 21-22, 89-114; For Australia see Paul Ashton and Paul Hamilton, History at the Crossroads: Australians and the Past, (Sydney: Halstead Press, 2007), 27-28; For Finland see Pilvi Torsti, Suomalaiset ja historia, (Helsinki: Gaudeamus, 2012), 29-37, 40-51.

49 Catharine Nash, Of Irish Descent: Origin Stories, Genealogy, \& the Politics of Belonging, (Syracuse, Syracuse University Press, 2008), 15-16.

Kero, "Migration from Finland to North America," 53. 
of thousands of posts and hundreds and hundreds of photos, as well as some videos and text files.

I examine these types of online sites as certain types of archives, spontaneous archives, because they are also about selection, displaying and curation. But then again, compared to archives proper, spontaneous archives are dynamic, continuously evolving and often ephemeral. Spontaneous refers to the fact that these sites are often created at the spur of the moment. Therefore they may disappear or be removed without former notice or they may turn into long-lasting online archives, which may or may not be actively updated. Spontaneous also emphasizes the unofficial nature of these non-institutional memorial sites, in the same manner as vernacular and grassroots memorials are on occasion referred to as spontaneous shrines. ${ }^{51}$ Spontaneous archives may also be compared to independent community archives, but they do not require a sense of community to the same degree. ${ }^{52}$ People are drawn to spontaneous archives for various reasons. Spontaneous archives, similar to their counter parts spontaneous shrines, are the result of an emotional need to share private and public memories within a group to which one feels connected, even if the members of the group do not know each other.

Spontaneous archives come in numerous forms - blogs, YouTube videos, Flickr, Facebook etc. Spontaneous archives can be part of a larger audiovisual archive, which Brunow defines as 'the sum of images, sounds and narratives circulating in a specific society at a specific historical moment ${ }^{53}$ or a part of a digital archive such as YouTube, which also allows for the uploading of usergenerated material and therefore resembles archives in general. Spontaneous archives have also common features with creative archives or invented archives, where people publish user-generated contents for fun, as a fandom activity, school assignment, or private or public history and memory making, for example. ${ }^{54}$ Similar to creative and invented archives, spontaneous archives are created primarily for the user's own needs.

51 Jack Santino, "Performative Commemoratives: Spontaneous Shrines and the Public Memorialization of Death," in Spontaneous Shrines and the Public Memorialization of Death, ed. Jack Santino, (New York, Palgrave Macmillan, 2006).

$5^{2}$ Andrew Flinn, "Archival Activism: Independent and Community-led Archives, Radical Public History and the Heritage Professions," InterActions: UCLA Journal of Education and Information Studies, 7 (2011): xx, accessed 7 June, 2016. http://escholarship.org/uc/ item/9pt2490x.

53 Brunow, Remediating Transcultural Memory, 197.

54 Garde-Hansen, Media and Memory, 83-86. 


\section{Spontaneous Archives and Remixed Memories}

The Italian Hall tragedy continues to be commemorated and discussed on various websites and blogs. Some of these have been created by different institutions for the centennial of the Copper Country Strike $1913-1914,{ }^{55}$ by local history enthusiasts ${ }^{56}$ or political and labour organizations. ${ }^{57}$ However, most of the online discussions, sharing of post memories and commemorating takes place on public and semi-public social media sites dedicated to family, local, ethnic, migrant, or worker's history.

On blogs the event is typically commemorated through the use of both text and images. Most of the images are newspaper clippings about the tragedy and old photos which have been circulated elsewhere. But private blogs may also include family photos of family members who survived the tradegy, as well as new family photos of the descendants of the survivors. The use of images has increased immensely in recent years. Images can be used as memory tools, but also to comment on and discuss. Documentary images and family photos both function as records of the past and testify to the authenticity of the events. ${ }^{58}$

The Facebook page 'The Italian Hall Disaster - Resource Center' was created in December 2011 and had 659 members in June 2016. The page announces: 'This site is a clearinghouse for information, photos and discussion of the Italian Hall disaster of 1913. Feel free to contribute. ${ }^{59}$ The page was created and is administrated by the author of the book Death's Door, Steve Lehto. Hundreds of photos, documents and newspaper clippings have been posted on the page, some by Lehto and some by the other users of the page. Other sites have also

55 Copper Country History: History, Heritage, Memory, accessed 7 June 2016, https:// coppercountry.wordpress.com/;Finnish AmericanHistoricalArchive/FinlandiaUniversity February: 2008 Oral History Digitization Project:1913-1914Copper Strike and Italian Hall Disaster, accessed 7 June 2016, http://www.kentsgenealogy.com/finnamericanoralhistories/ CopperStrike.html; 1913-2013 Michigan Copper Miners' Strike 1913-14 Centennial, Ceremony at Italian Hall During FinnFest, accessed 7 June 2016, https://1913strike.wordpress .com/2013/06/26/ceremony-at-italian-hall-during-finnfest/.

56 Copper Country Reflections, Italian Hall Tragedy, accessed 10 June 2016, http://www .pasty.com/reflections/id228.htm; Lost in Michigan, The Italian Hall in Calumet: Michigan Historical Markers, accessed 10 June 2016, http://lostinmichigan.net/.

57 Labor and Working-Class History Association, accessed 10 June 2016, http://lawcha.org/ wordpress/2013/07/25/100-years-later-michigans-1913-14-copper-country-strike/

58 Annette Kuhn, An Everyday Magic: Cinema and Cultural Memory, (London \& New York: Tauris, 2002), 49; Van Dijck, Mediated Memories, 112-113; Brunow, Remediating Transcultural Memory, 5 .

59 Facebook, “The Italian Hall Disaster- Resource Center", accessed 10June 2016. https://www .facebook.com/The-Italian-Hall-Disaster-Resource-Center-291845417514549/?ref=br_rs 
been created on Facebook to promote other projects linked to the event, for example the documentary 1913 Massacre that has its own Facebook page with $33^{2}$ likers ${ }^{60}$ and Kaunonen's and Goings study with 95 likers. ${ }^{61}$

YouTube videos are a new medium for people to commemorate family and local history and provide thought-provoking examples of how the vernacular, institutional and commercial are mixed today. These user-generated videos are typically remixed, ${ }^{62}$ consisting of a montage of photos, archival documents, postcards, newspaper clippings etc., with a well-known song by a well-known artist playing in the background. Bruce Springsteen's song 'Youngstown' from the album 'The Ghost of Tom Joad' (1995), which tells the story of the rise and decline of this once prosperous steel town, has, for example, inspired people coming from Youngstown or similar towns to create remix videos. ${ }^{63}$ Among the twenty most-popular versions of Guthrie's song '1913 Massacre', played by Guthrie himself, his son Arlo Guthrie, Bob Dylan or by someone else on YouTube, ${ }^{64}$ there are four remix videos of the Italian Hall tragedy, which consist of Guthrie's song and a montage of photos and newspaper clippings. The most popular one of these '1913 massacre at the Italian Hall' published in 2009 by showbet had 7,658 views in June 2016, which is over a thousand more than in May 2015 when I first viewed it (6,340 views). ${ }^{65}$

For some the story of the Italian Hall tragedy is about the hardships of migrant communities and workers in general while some use it to criticize capitalism and express their political views. Some use it to stress the need for safety regulations in building constructions. Others will express their astonishment about not having any knowledge of this important event, which is related to their family or local history. Many mention in their comments that although they have no personal connection to the event or had not even known about it before, they can still relate to the experiences of those who were part of the tragedy. Over a

6o Facebook, "1913 Massacre: film", accessed 10 June 2016.

61 Facebook, "About 1913-14 Michigan Copper Strike and Italian Hall Tragedy Book Project".

62 Remix is the reworking or adaptation of an existing work. The remix may be subtle, or it may completely redefine how the work comes across. It may add elements from other works, but generally efforts are focused on creating an alternate version of the original. A mashup, on the other hand, involves the combination of two or more works that may be very different from one another.

63 Anne Heimo and Kirsi Hänninen, "Participatory, Community and Spontaneous Archives and Digitally Born Cultural Heritage," Folklore Fellows' Network 47 (2015): 8-9.

64 Search words, "woody guthrie 1913 massacre" gives 3,820 hits, "1913 massacre calumet" 127 hits, "Italian hall tragedy" 2,680, and "italian hall disaster" 5, 480 (16 June 2016).

65 YouTube, "1913 massacre at the Italian Hall", accessed 16 June 2016, https://www.youtube .com/watch?v=UgrPK2 $\mathrm{CNuJg}$. 
Suodottimet -
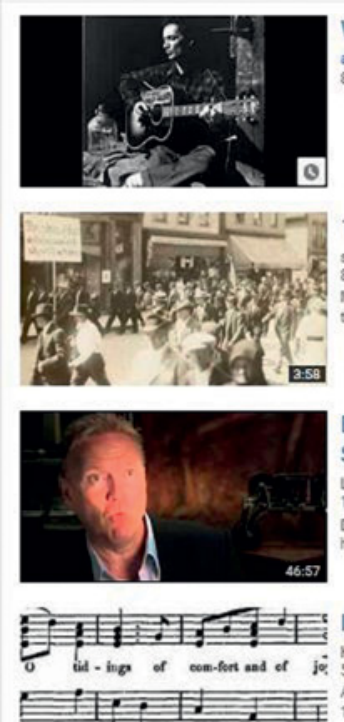

Italian Hall Disaster of 1913

Kbear586

Svuotta sitten - 1463 näyrtökertas

A brief story surrounding the Italian Hall disaster in Calumet. Michigan
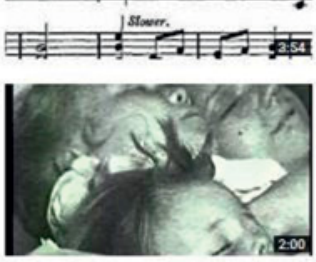

1913 massacre film to run

TV6 \& Fox UP

4 vuotta sitten $* 4013$ näyttōkertas

A film about the the Italian Hall disaster will be shown

Facebook -

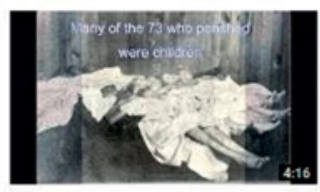

Italian Hall Disaster

\section{Karl Carter}

1 vuosi sitten - 153 näyttökertaa

1913 Massacre.

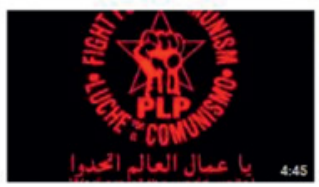

Italian Hall Massacre, 1913

PWorkers?

4 vuotta sitten - 82 näyttökertaa

Background: http://en.wikipedia.org/wiki/1913_Massacre.

FIGURE 11.3

On YouTube search words "italian hall 1913" offer a variety of different types of videos concerning the tragedy.

(Accessed 1oJune, 2016, https://www.youtube.com/results?search_ query=italian+hall+1913. Screenshot 4 May 2017)

hundred years later the remediated memories of the tragedy still evoke emotive reactions and serve as an example of prosthetic memory ${ }^{66}$ at work.

66 Alison Landsberg, Prosthetic Memory: The Transformation of American Remembrance in the Age of Mass Culture, (New York: Columbia University Press, 2004), 2-3. 
However the most popular reason to participate in the commemoration of the tragedy is when it is part of one's family or local history. ${ }^{67}$ This has to do with the fact that family history practices have become immensely popular in recent years and that people trust family memories and narratives highly as historical sources - even when they contradict facts presented in other sources. Family narratives encompass strong emotional power and vernacular authority. These features make them reliable accounts of the past and worth sharing with each other. According to folklorist Robert Howard, vernacular authority 'emerges when an individual makes appeals that rely on trust specifically because they are not institutional'. ${ }^{6}$ These appeals are backed up, for instance, by tradition - or as in this case by family memories - and not by a formally instituted social formation such as a church, a media company or an academic publication.

\section{The Power of Family Memories}

On all of the sites mentioned above people will frequently mention how the tragedy relates to their family history and where and when they learned about the event. The following family story titled 'The Hundred Year Anniversary of The Italian Hall Disaster' was published by Brita Caroline, a photographer living on the Michigan Upper Peninsula on Christmas Day, 2013:

We all grew up hearing stories. It was so horrifying. Children died. DIED. ON Christmas Eve. At a Christmas party. It was too much to take in. All of those precious little children, just trying to celebrate the season amidst a time of turmoil. We saw pictures that never left our brain. We heard all about the door that opened inwards, and we all felt anger at the man who hollered, "Fire!"

For us Eskolas, it took on a whole new meaning when we grew up with our own personal story attached to it. My Grandma Ethel is my dad's mom. She is still with us today, and we cherish her dearly. She is a special, special woman. Her father, who we call Papa Hill, was there at the Italian Hall on that fateful night. When the panic set in from the call of fire, Papa Hill was about to head to the stairs too, but his older sister stopped him and gathered him and his siblings with her to wait it out by one

67 Heimo, "The 1918 Finnish Civil War Revisited".

68 Robert Glenn Howard, “Vernacular Authority: Critically Engaging 'Tradition', in Tradition in the Twenty-First Century. Locating the Role of the Past in the Present, ed. Trevor J. Blank \& Robert Glenn Howard, (Logan: Utah State University Press, 2013), 83. 
of the windows. They stood there together, the siblings, in a tight little group, listening to the horror of it all, until finally they were led to safety through the window and down a ladder. Can you imagine?? What those kids heard?? But still, they were the lucky ones. It's impossible to imagine.

Not everyone was so lucky. A lot of young children's lives ended that night. It changed the Copper Country forever. When the Hollywood producers came a few years ago, they said that they could still feel the tragedy as they walked around the desolate streets of Calumet. Something this big doesn't just go away. It changes people forever, and it becomes who you are. This is who we are up here in the Copper Country. We fully embrace it because it makes the grief a little bit easier to bear if we all bear just a little bit of it. ${ }^{69}$

Similar to this example most family stories about the event will either include the story of how and why their grandparent or other close relative survived or that they perished. The creator of the popularYouTube video mentioned above, [s]howbet, writes: 'My great grandmother said she didn't smell any smoke, and told the children to stay put, and hold her skirt. They were some of the few to survive the trampling. My Mother [name] and her three brothers didn't believe my grandma when she told this story'. Of the thirteen comments concerning the video one mentions the death of her great-grandmother and two tell why their grandparents survived: 'My grandmother was the last living survivor. She was a daughter of a copper miner. She only survived because she went back to her seat to get her new gloves her mother had just knitted. Her best friend, [name], sitting next to her, died. She was always adamant that it was a union man that yelled, 'fire' and '... What a terrible tragedy, my dad had talked about it (his parents weren't at the hall because his older sister was sick), didn't know there was a Woody Guthrie song about it. Thanks for posting!"70 One example of this type of survival story was even presented on a product review site by a person who had purchased a copy of the film Red Metal: 'My interest in viewing and then purchasing Red Metal centres around my family's history as my Dad was one of the children at the Christmas party. The story goes that an adult

69 Brita Caroline Photograph Blog, accessed 10 June 2016 http://britacarolineblog.com; I have been granted permission to publish the story with names.

70 YouTube, "1913 massacre at the Italian Hall", accessed 16 June 2016, https://www.youtube .com/watch?v=UgrPK2CNuJg. 

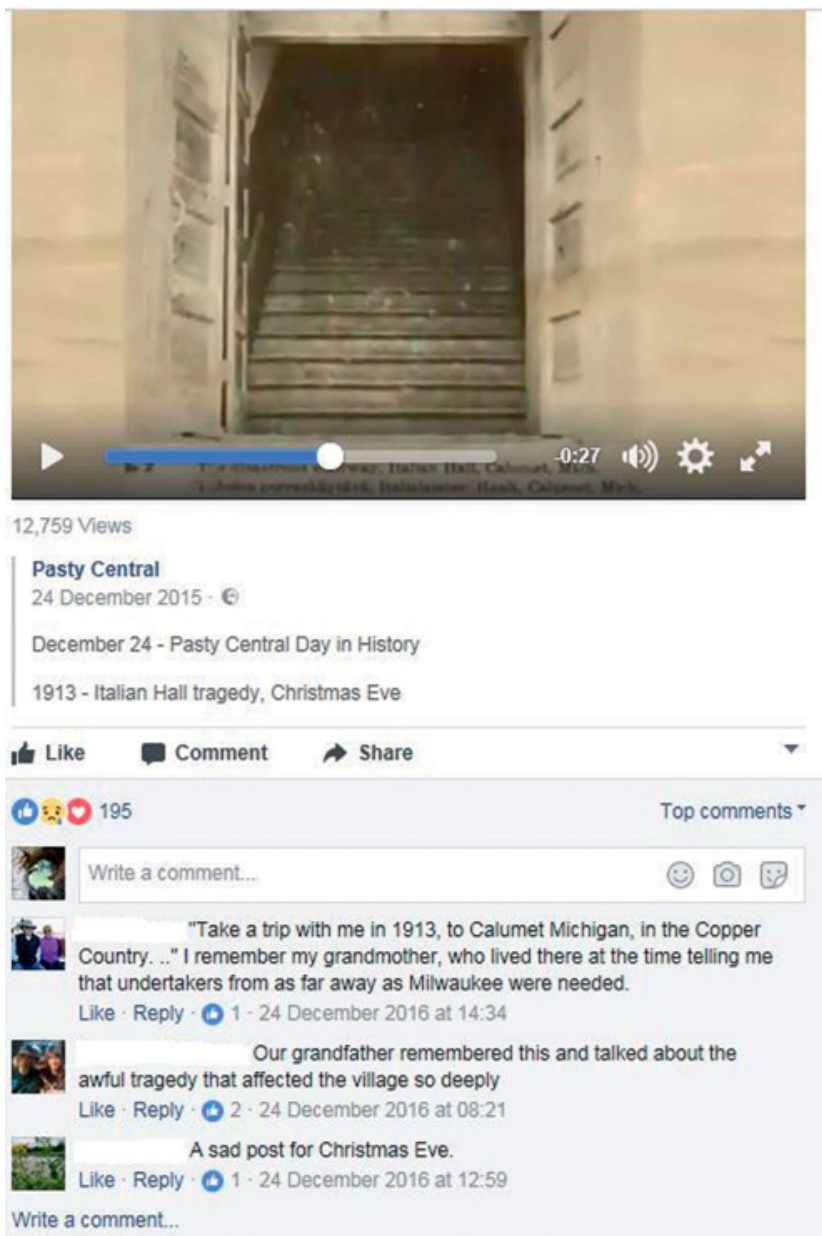

FIGURE 11.4 The tragedy continues to be discussed on various Facebook sites like on the regional site "Pasty Central" (https://www.facebook.com/PastyCentral/. Screenshot 4 May 2017)

passed him out a window to someone, thus saving his life .... ${ }^{71}$ Sometimes these survival stories leads people to ponder on the alternatives: What would it have meant for me and my family if the family members had not survived? One of

71 Shop PBs, Red Metal, Product reviews, accessed 10 June 2016, http://www.shoppbs.org/ product/index.jsp?productId=29393516. 
the blogs features a photo of the author's children with a caption: '... Imagine how [my son] might not even exist if [grandpa] would've taken those stairs.'

The names of Brita Caroline's relatives mentioned in her blog reveal that she is of Finnish descent, but she does not bring this up in her story. This is typical for most commentators. Outside the Facebook groups dedicated to Finnish-American heritage and history, people will rarely connect the event to their Finnish background. This suggests that the relevance of the story lies elsewhere.

The above examples are by no means unique or special, but illustrate how historical knowledge and memories are produced and shared (mediated) today. At first glance these family memories may seem very brief and fragmented, but actually the difference between how we share our memories online and offline does not differ much. Outside the interview situation, we rarely tell whole, coherent stories. Like Alessandro Portelli states: 'Most personal and family tales are told in pieces and episodes, when the occasion arises; we learn even the lives of our closest relatives by fragments, repetitions, hearsay. ${ }^{72}$ This is also the manner we do it online, as Henry Jenkins reminds us: 'Each of us constructs our own personal mythology from bits and fragments of information extracted from the media flow and transformed into resources through which we make sense of our everyday lives. ${ }^{73}$

\section{Conclusions}

The memory of the Italian Hall Tragedy in 1913 has been remediated for over a century in numerous forms, newspapers, journals, books, songs, autobiographies, films and, in the 200os, online. Although the memory of the disaster was forced into oblivion in the public sphere for decades, its memory has continued to be cherished in the private sphere of family. The tearing down of the Italian Hall in the 198 os followed by the centennial brought about plenty of retellings of the story. Today the memory of the tragedy also attracts tourists, especially those interested in dark tourism and dark heritage sites. A major part of the commemoration of the tragedy is institutional or academic, but the tragedy is also remembered by so-called ordinary people interested in

72 Alessandro Portelli, The Battle of Valle Giulia. Oral History and the Art of Dialogue, (Madison: The University of Wisconsin Press, 1997), 4.

73

Jenkins, Convergence Culture, 3-4. 
family and local history. Much of this remembering happens online and evokes people to share their own memories of the incident.

History and memory making and archiving are never neutral or disinterested activities. Archives can include as well as exclude, and it is often the minorities who are left out. ${ }^{74}$ Due to their small number and invisibility, Finnish immigrants are usually not accounted for in national histories of their new home countries. This applies also to those cases where they have played a significant part in the country's political history, for example in the United States and Canada. Often the experiences of immigrants go unnoticed also in their former home countries. Although more Finnish migrants died in the Italian Hall tragedy than on the Titanic, the tragedy is largely unknown in Finland.

The memory of the tragedy was never only local. The tragedy happened in a multicultural community and affected the lives of families coming from different parts of Europe. Nonetheless, much of what has been written and published about the Italian Hall tragedy has been done by people of Finnish descent, but this does not mean that they are in all cases viewing it only as a part of their family history or Finnish-American history. In the beginning of my study I assumed that spontaneous archives would offer a way for people with Finnish ancestry to bring forth their history in the United States, but my analysis shows that although much of the personal commemoration of the tragedy is intended for family and friends and the local and regional community, it offers information to anyone who has an interest in the event, for whatever reason.

The remediated memory of the Italian Hall tragedy shows that heritage no longer consists of only museum artefacts, memorials or historic sites, or that it is entirely in the hands of professionals. Due to digital technology and convergence culture people today have new kinds of possibilities to make their experiences known outside their immediate spheres to new audiences around the world, challenging in this way former notions of cultural heritage as being a product that does not change and is in need of protection, and which is controlled by experts. Instead it should be seen as a process which is dynamic, ever-evolving and ephemeral, and often curated and managed by the same people who created it or participated in the process.

74 Julia Creet, "Transnational Archives: The Canadian Case," in Journal of Aesthetics \& Culture 3, 2011; accessed 10 June 2016, doi 10.3402/jac.v3io.7216; Flinn, "Archival Activism", 3; Brunow, Remediated Transcultural Memory, 8-9. 


\section{Bibliography}

\section{Popular Books}

Bloor, Ella Reeve. We Are Many: An Autobiography of Ella Reeve Bloor. New York: International Publishers, 1940.

Frontiera, Deborah K. Living on Sisu: The 1913 Union Copper Strike Tragedy. Bluebonnets, Boots \& Books Press, 2010.

Germain, Peggy. False Alarm: 1913 Italian Hall Disaster and Death Certificates. Author House, 2005.

Germain, Peggy. Tinsel \& Tears 2 (The Italian Hall Disaster, Calumet, Michigan). Privately published, 1987 .

Hirvonen, Juuso. Michiganin kuparialue ja suomalaiset siirtolaiset. Duluth: Privately published, 1920.

Lehto, Steve. Death's Door: The Truth behind Michigan's Largest Mass Murder. Troy, MI: Momentum Books, 2006.

Lehto, Steve. Italian Hall: The Official Transcript of the Coroner's Inquest. Troy, MI: Momentum Books, 2007.

Maki, Wilbert B. Remembrance of a Tragedy, 1913. sı: W.B. Maki, 1983.

Molloy, Lawrence J. Italian Hall: The Witnesses Speak, Great Lakes. Hubbell, MI: Great Lakes, GeoScience, 2014.

Thurner, Arthur W. Rebels on the Range: The Michigan Copper Miners' Strike of 1913-1914. Lake Linden, MI:John H. Forster Press, 1984.

\section{References}

Ashton, Paul \& Hamilton, Paula, History at the Crossroads: Australians and the Past. Sydney: Halstead Press, 2007.

Brunow, Dagmar. Remediating Transcultural Memory: Documentary Filmmaking as Archival Intervention. Berlin \& Boston: De Gruyter, 2015.

Creet, Julia. "Transnational Archives: The Canadian Case." In Journal of Aesthetics \& Culture, 3, 2011. Accessed 10 June 2016, doi 10.3402/jac.v3io.7216.

Creet, Julia. "Introduction," in Memory and migration: multidisciplinary approaches to memory studies, edited by Julia Creet and Andreas Kitzmann, 3-26. Toronto: University of Toronto Press, 2011.

De Cesari, Chiara and Rigney, Anne. "Introduction: Beyond methodological nationalism." In Transnational Memory: Circulation, Articulation, Scales, edited by Chiara De Cesari and Anne Rigney, 12-41. Berlin/Boston: De Gruyter, 2014.

Erll, Astrid. "Travelling Memory." Parallax 17 (2011): 4-18. Accessed 7 June 2016. doi:10.1 080/13534645.2011.605570.

Erll, Astrid and Rigney, Ann. "Introduction: Cultural Memory and its Dynamics." In Mediation, Remediation, and the Dynamics of Cultural Memory, edited by Astrid Erll and Ann Rigney, 1-11. Berlin/Boston: De Gruyter, 2009; 
Flinn, Andrew. "Archival Activism: Independent and Community-led Archives, Radical Public History and the Heritage Professions." InterActions: UCLA Journal of Education and Information Studies, 7 (2011): 1-20. Accessed 7 June 2016. http://escholarship .org/uc/item/9pt249ox.

Garde-Hansen, Joanne. Media and Memory. Edinburgh: Edinburgh University Press, 2011.

Garde-Hansen, Joanne, Hoskins, Andrew and Reading, Anna. "Introduction.” In Save as ... Digital Memories, edited by Joanne Garde-Hansen, Andrew Hoskins and Anna Reading, 1-26. London \& New York: Palgrave McMillan, 2009.

Giarccardi, Elisa. "Introduction: Reframing Heritage in Participatory Culture." In Heritage and Social Media: Understanding Heritage in a Participatory Culture, edited by Elisa Giarccardi, 1-10, London \& New York: Routledge, 2012.

Heimo, Anne, Kapina Sammatissa. Vuoden 1918 paikalliset tulkinnat osana historian yhteiskunnallisen rakentamisen prosessia. Helsinki: Suomalaisen Kirjallisuuden Seura, 2010.

Heimo, Anne. "The 1918 Finnish Civil War Revisited: The Digital Aftermath." Folklore 57 (2014): 141-168. Accessed 7 June 2016. doi:10.7592/FEJF2014.57.heimo.

Heimo, Anne and Hänninen, Kirsi. "Participatory, Community and Spontaneous Archives and Digitally Born Cultural Heritage." Folklore Fellows' Network 47 (2015): 4-11.

Hiltunen, Linsday E. Cultural Memory and the Power of Place: One Hundred Years of Remembering the Italian Hall Tragedy and the 1913-1914 Michigan Copper Strike. Macomb: Faculty of the Department of History of Western Illinois University, 2014. Accessed 7 June 2016. http://gradworks.umi.com/15/57/1557255.html.

Hoagland, Alison K. "Unresolved: The Italian Hall Memorial in Calumet, Michigan." In Commemoration in America: Essays on Monuments, Memorialization, and Memory, edited by David Cobel and Daves Rossell. Charlottesville and London: University of Virginia Press, 2013.

Howard, Robert Glenn. “Vernacular Authority: Critically Engaging 'Tradition.”' In Tradition in the Twenty-First Century. Locating the Role of the Past in the Present edited by Trevor J. Blank \& Robert Glenn Howard, 72-99. Logan: Utah State University Press, 2013.

Jenkins, Henry. Convergence Culture: Where Old and New Media Collide. New York \& London: New York University Press, 2006.

Jenkins, Henry, Ford, Sam and Green, Joshua. Spreadable Media: Creating Value and Meaning in a Networked Culture. New York \& London:New York University Press, 2013. Kaunonen, Gary. Challenge Accepted: A Finnish Immigrant Response to Industrial American in Michigan's Copper Country. East Lansing: Michigan State University, 2010.

Kaunonen, Gary and Goings, Aaron. Community in Conflict: A Working-class History of the 1913-14 Michigan Copper Strike and the Italian Hall Tragedy. East Lansing: Michigan State University Press, 2013. 
Kauranen, Ralf, and Pollari, Mikko. "Transnational socialist imagination: The connections between Finnish socialists in the USA and Finland at the turn of the 2oth century." In Labouring Finns. Transnational Politics in Finland, Canada, and the United States, edited by Michel S. Beaulieu, Ronald N. Harpelle and Jaimi Penney, 26-49. Turku: Institute of Migration, 2011.

Kero, Reino. "Migration from Finland to North America." In Finns in the United States. A History of Settlement, Dissent, and Integration, edited by Auvo Kostiainen, 41-53. East Lansing: Michigan State University Press, 2014.

Kivisto, Peter. Immigrant Socialists in the United States: The Case of the Finns and the Left. London and Toronto: Associated University Press, 1984.

Kuhn, Annette. An Everyday Magic: Cinema and Cultural Memory. London \& New York: Tauris, 2002.

Laguerre, Michel S. "Digital Diaspora: Definition and Models." In Diasporas in the New Media Age: Identity, politics and Community, edited by Adoni Alonso \& Pedro J. Oiarzabal, 49-64. Las Vegas: University of Nevada Press, 2010.

Landsberg, Alison. Prosthetic Memory: The Transformation of American Remembrance in the Age of Mass Culture. New York: Columbia University Press, 2004.

Logan, William and Reeves, Keir. "Introduction: Remembering places of pain and shame." In Places of Pain and Shame. Dealing with Difficult Heritage, edited by William Logan and Keir Reeves, 1-14. London \& New York: Routledge, 2009.

Margry, Peter Jan \& Sánchez-Carretero, Cristina. "Introduction: Rethinking Memorialization: The Concept of Grassroots Memorials." In Grassroots Memorials. The Politics of Memorializing Traumatic Death, edited by Peter Jan Margry \& Cristina Sánchez-Carretero, 1-48. New York \& Oxford: Berghahn, 2011.

Nash, Catharine. Of Irish Descent: Origin Stories, Genealogy, \& the Politics of Belonging. Syracuse: Syracuse University Press, 2008.

Nielsen, Jakob. "The 90-9-1 Rule for Participation Inequality in Social Media and Online Communities." Nielsen Norman Group, 2006. Accessed 7 June 2016. http://www .nngroup.com/articles/participation-inequality/.

O'Reilly, Timothy. "What is Web 2.o? Design Patterns and Business Models for the Next Generation of Software." Oreilly (2005). Accessed 7 June 2016. http://www.oreilly .com/pub/a/web2/archive/what-is-web-20.html.

Portelli, Alessandro. The Battle of Valle Giulia. Oral History and the Art of Dialogue. Madison: The University of Wisconsin Press, 1997.

Puotinen, Arthur. "Copper country Finns and the strike of 1913." The Finnish Experience in the Western Great Lakes Region: New Perspectives, edited by Michael G. Karni, Matti E. Kaups and Douglas J. Ollila, 143-153. Turku: Migration Institute, 1975.

Rosenzweig, Roy and Thelen, David. Presence of the Past. Popular Uses of History in American Life. New York \& Chichester: Columbia University Press, 1998. 
Santino, Jack. "Performative Commemoratives: Spontaneous Shrines and the Public Memorialization of Death." In Spontaneous Shrines and the Public Memorialization of Death, edited by Jack Santino, 294-319. New York: Palgrave Macmillan, 2006.

Smith, Laurajane. Uses of Heritage. Oxon: Routledge, 2006.

Torsti, Pilvi. Suomalaiset ja historia. Helsinki: Gaudeamus, 2012.

Van Dijck, José. Mediated Memories in the Digital Age. Palo Alto, CA: Stanford University Press, 2007.

Van Dijck, José. The Culture of Connectivity: A Critical History of Social Media. Oxford: Oxford University Press, 2013.

Wargelin, Raymond Alvar. "Response" to Puotinen, Arthur "Copper country Finns and the strike of 1913." In The Finnish Experience in the Western Great Lakes Region: New Perspectives, edited by Michael G. Karni, Matti E. Kaups and Douglas J. Ollila. Turku: Migration Institute, 1975, 153-155. 


\title{
How Does This Monument Make You Feel? Measuring Emotional Responses to War Memorials in Croatia
}

\author{
Vjeran Pavlaković and Benedikt Perak
}

Since the collapse of communism and the disintegration of Yugoslavia, collective remembrance in all of the successor states has undergone dramatic transformations as part of nation-building projects and strategies to bolster the legitimacy of new political elites. This has included nationalist revisionism of the narratives of the Second World War and the creation of founding myths based on the bloody wars accompanying Yugoslavia's dissolution. Although there is a general agreement across the political spectrum regarding the dominant nation-building narrative in Croatia, which emphasizes its victory in the War of Independence (known as the Domovinski rat, or Homeland War, 1991-1995), there is considerably less consensus over the Second World War. ${ }^{1}$ This so-called 'red-black ideological division' in society is manifested in seemingly perpetual politicized debates over communist Partisans, fascist Ustaša, and Serb extremist Četniks, which is then additionally distorted by the more recent traumas of the 1990s conflict. The need for unity during the Homeland War led to the policy of 'national reconciliation' under the first Croatian president, Franjo Tuđman, which emphasized the struggle for statehood as one of the goals of the Croatian Partisans and concurrently whitewashed the Ustaša movement of its fascist ideology. The long-term consequences were the demonization of the antifascist struggle and the rehabilitation of Nazifascist collaborators, which was played out across the country's memoryscape: thousands of Partisan memorials have been damaged or completely destroyed

1 The results of the research project "Symbolic Strategies of Nation-building in the Western Balkans," which included a detailed opinion poll that posed questions about both the Second World War and the Homeland War, showed that the majority of respondents in Croatia held the official narrative of the latter to reflect the truth, while interpretations of the former were considerably polarized. The complete results of the opinion poll are available at http:// cultstud.ffri.hr/istrazivanje/projekti/118-symbolic-strategies. See also Vjeran Pavlaković, "Fulfilling the Thousand-Year-Old Dream: Strategies of Symbolic Nation-building in Croatia", in Pål Kolstø, ed., Strategies of Symbolic Nation-building in South Eastern Europe (Farnham: Ashgate, 2014).

(C) VJERAN PAVLAKOVIĆ AND BENEDIKT PERAK, 2017 | DOI 10.1163/9789004352353_013 
since 1991, while new monuments and public spaces have been dedicated to some of Hitler's most fervent allies. The victorious and emancipatory narrative of antifascism has slowly been replaced with an anti-communist victimization discourse perpetuated through commemorative practices at various sites of memory.

Croatia's efforts to join the European Union has meant that since 2000, its administrations have had to adopt the transnational narratives of antifascist founding myths, resulting in the partial revalorization of the Partisan struggle. Right-wing political parties have also adopted the Eu discourse on the Second World War, although by condemning communist crimes, and they have sought to equate all totalitarian systems through EU memorial days such as the Day of Remembrance for Victims of all Authoritarian and Totalitarian Regimes (23 August). After Croatia was admitted to the EU on 1 July 2013, many political observers and scholars predicted that the bitter polemics over the Second World War would play a minor role compared to the burning socio-economic issues plaguing the country. However, since the EU accession, symbolic politics centred on interpretations of the Second World War, as well as renewed debates on the Homeland War, have continued to dominate headlines and divide the political elites at a time when a unified strategy for resolving the economic crisis has been most needed. The election of a short-lived right-wing coalition in 2016 exacerbated the red-black division, particularly over cultural policies, memory politics and commemorative practices.

Previous research presented at conferences related to COST action IS1203 (In search of transnational memory in Europe) has traced the top-down strategies of rehabilitating the Ustaša in post-1990 Croatia, transnational EU discourse in Croatian memory politics and collective remembrance of communism. ${ }^{2}$ The challenge, however, is how to measure the reception of these various stages of reframing the past. As a part of the project 'Framing the Nation and Collective Identity in Croatia: Cultural Memory of 2oth Century Traumas, ${ }^{3}$ this chapter seeks to analyze to what degree perceptions of past

2 "Remembering War the European Way: Croatia's Commemorative Culture and the EU", EU Politics of Memory Conference, European University Institute, Florence, Italy (20 June 2015); "EU Narratives and the Specter of Communism in Croatia," cost Conference - Memory of Communism in Europe, Paris, France (15-16 May 2014); and "Creating Victims out of Perpetrators: Symbolic Strategies of Rehabilitating World War Two Collaborators in Croatia since the 199os," cost meeting Social Construction of Guilt and Victimhood, Krakow, Poland (16 September 2013).

3 This project is funded by the Croatian Science Foundation (HRzz - Hrvatska zaklada za znanost). 
wars are shaped by commemorative practices, monuments, political speeches and media representations of political rituals. Drawing upon the material gathered at several commemorations (including video footage of speeches, photographs of monuments and media coverage), our goal was to develop a survey to measure emotional responses to a controversial Second World War memorial in Croatia. We wanted to measure firstly the reaction to a decontextualized visual representationof the monument and secondly measure the response to the same representation but this time contextualized with various commemorative speeches imbuing the static monument with conceptualizations of meaning. The selected monument - along with a memorial complex, archive and museum - commemorates the notorious concentration camp of Jasenovac established by the Ustaša regime in the Independent State of Croatia (NDH - Nezavisna Država Hrvatska). An increasingly vocal group of right-wing historians, journalists and politicians has sought to erase, or at least radically redefine, the narratives associated with this site of memory by questioning the number of victims and rehabilitating the perpetrators. The memorial already underwent a transformation in meaning during the shift from socialist Yugoslavia to independent Croatia, and the latest efforts to undermine the accepted historical narrative are representedby an attempt to inscribe alternative meanings in line with right-wing interpretations of the Second World War. In the midst of this cacophony of state-promoted narratives and revisionist counternarratives bordering on conspiracy theories, is it possible to determine how Croatian society perceives this dark episode from the 2oth century?

One of the important questions in the research of the collective memory is the influence of the emotional and cognitive dimensions in the mechanism of social memory transmission. How successfully are the subjective qualities of the individual memories transmitted and elicited in the inter-subjective communication? What are the salient emotional and cognitive features of the narration that successfully construct a socially shared memory? Can we measure the level of affective and cognitive engagement of the receivers of the representations of the cultural memories prominent in social communication and media? Can we predict the behavioural and pragmatic tendencies based on the level of emotional and cognitive appraisal? Can we correlate the level of emotional and cognitive appraisal with the representation of a particular event in a collective memory? This chapter tackles some of the abovementioned questions by investigating the effects of a monument's representations, associated commemorative speeches, and media coverage on the individual's affective and cognitive stance about the traumatic events in Croatian collective memory. In order to formulate the reception of this multimodal representation we situate the present study on the collective memory within the theoretical 
framework of embodied cognition, ${ }^{4}$ cognitive linguistics approaches to the conceptualization of social identity, ${ }^{5}$ cultural linguistics notion of socially distributed cognition ${ }^{6}$ and componential appraisal theory of emotion. ${ }^{7}$

This theoretical framework implies that the construction of a commemorative event establishes socially distributed conceptualization networks that can involve several (conflicting) conceptualizing models. ${ }^{8}$ In other words, the same event can be construed differently by profiling different frames, resulting in specific emotional, cognitive and behavioural responses. The study presented in this article measures and compares the emotional and cognitive engagement of subjects when exposed to differently construed types of commemorative events. Its aim is to quantitatively compare the affective appraisal and cognitive responses of 'shallow conceptual' elicitation via a decontextualized static image of the monument (Figure 12.3), with the 'deep conceptual' elicitation of monument representation contextualized with the speeches delivered by the selected memory producing actors. The theoretical assumption is that the level of emotional and cognitive engagement produced by the visual conceptual elicitation via an image represents the established individual's stance to the constructed (mediated) collective memory. This 'shallow' categorical knowledge is seen as the activation of the salient conceptual patterns in the dynamic system of individual mental representation (knowledge) of the event. On the other hand, the conceptualized elicitation of the event, contextualized via political speeches, is seen as the 'deeper' framing of the individual's conceptual model. The contextualized representation engages

4 L. Barsalou, "Grounded Cognition," Annual Review of Psycholgy, (2008) 59. See also Benedikt Perak and Sanja Puljar D’Alessio, "Kultura kao emergentno svojstvo otjelovljene spoznaje," in Nenad Fanuko and Sanja Puljar D’Alessio (eds.), Avanture kulture: kulturalni studiji u lokalnom kontekstu (Zagreb: Jesenski and Turk, 2013), 77-108.

5 George Lakoff, Moral Politics: What Conservatives Know that Liberals Don't (Chicago: University of Chicago Press, 1996); George Lakoff, The Political Mind: A Cognitive Scientist's Guide to Your Brain and Its Politics (New York: Penguin Books, 2009).

6 Farzad Sharifian, "Cultural linguistics", in Farzad Sharifian, ed., The Routledge Handbook of Language and Culture (London: Routledge, 2015), 473-492; Roslyn M. Frank, "A future agenda for research on language and culture" in Sharifian, The Routledge Handbook of Language and Culture, $493-512$.

7 Klaus Scherer, 2009. "Emotions are emergent processes: they require a dynamic computational architecture," in Philosophical Transaction of the Royal Society, 364 (2009), 3459-34747; Johnny R.J. Fontaine, Klaus Scherer and Cristiana Soriano, eds., Components of emotional meaning: A sourcebook (Oxford: Oxford University Press, 2013).

8 Gabriel A. Radvansky and Jeffrey M. Zacks, Event Cognition (Oxford: Oxford University Press, 2014); George Lakoff, The political mind: A cognitive scientist's guide to your brain and its politics. (New York: Penguin, 2008). 
more processing of the affective and cognitive resources, and consequently is expected to produce a more elaborated affective appraisal and complex activation of entrenched conceptual networks for a given commemorative event. The difference in the affect response between these two types of elicitation is thus seen as an effect of the conceptualization strategies, involving change in affective stance and dynamic negotiation between individually entrenched cognitive models and socially conventionalized cultural models in the process of distributing cognition, (intergenerational) transmission, appropriation and remediation of the meaning in culture. By comparing the features of decontextualized and contextualized types of elicitation we formulated an instrument for the qualitative and quantitative description of the intersubjective dynamics of affect elicitation, cultural conceptualizations and incentives for norms of behaviour, as well as communication strategies that constitute an individual's relation to the collective identity.

In the first part of the chapter we present a historical background of the Second World War in Croatia, followed by an overview of memory politics in Croatia necessary for understanding post-socialist shifts in commemorative culture. Bleiburg, ${ }^{9} \mathrm{Srb}^{10}$ and Jasenovac represent some of the most controversial collective remembrance sites in post-1990 Croatia. The history of the Jasenovac Memorial site is thus presented along with the systematic revisionist strategies bordering on Holocaust denial pursued by various extreme Croatian nationalists in the media during 2015 and early 2016. In the second part

The commemorations in Bleiburg, located in Austria near the Slovenian border, symbolize the repression and mass killings of the defeated NDH forces, along with civilians, by the Partisans in the last phases of the Second World War and immediate post-war period. As in Jasenovac, the number of victims remains subject to manipulation and debate, and the commemoration itself has been controversial due to the rehabilitation of the NDH by many of the participants over the years. See Vjeran Pavlaković, "Deifying the Defeated: Commemorating Bleiburg since 1990," in L'Europe en Formation, No. 357 (December 2010).

10 Formerly celebrated on 27 July as the Croatian Uprising Day during socialist Yugoslavia to honour the mass uprising in response to the Ustaša terror in 1941, the commemoration has been more of a local event organized by Croatian Serb organizations and Croatian antifascist associations since 2000. However, right-wing politicians and organizations claim the uprising was not antifascist but rather led by Četniks with the goal to ethnically cleanse the area of Croats. See Vjeran Pavlaković, "Contested Pasts, Contested Red-Letter Days: Antifascist Commemorations and Ethnic Identities in Post-Communist Croatia," in Ljiljana Šarić, Karen Gammelgaard and Kjetil Ra Hauge, eds., Transforming National Holidays: Identity Discourse in the West and South Slavic Countries, 1985-2010 (London: John Benjamins Publishing, 2012). 
of the article we present the methods, results and analyses of the affect and conceptualization response study related to Jasenovac. ${ }^{11}$

\section{The Second World War in Croatia and Memory Politics}

Although the Second World War radically transformed and affected all of the republics of former Yugoslavia, the traumas and deep divisions of that conflict can be felt particularly in contemporary Croatia due to the complex relationship between state-building narratives, legacies of both right- and left-wing extremist ideologies and interethnic violence perpetrated on a massive scale. The Homeland War in the 1990s reawakened many of the unresolved issues ofthe past, which had been suppressed for decades as part of the socialist regime's efforts to maintain its monopoly over the historical narrative. The ideology of 'brotherhood and unity' was coined to emphasize the unified struggle of all of Yugoslavia's peoples against the foreign occupiers and domestic collaborators, rather than to focus on the internecine slaughter of civilians and revenge killings. The cultural memory politics of socialist Yugoslavia (with some regional differences) have reflected this interpretation of the past in commemorative practices, monument construction, official historiographies and educational systems, as well as a broad range of cultural production until the system began unraveling in the 1980s, following Tito's death.

The Second World War on the territory of former Yugoslavia was not a clearcut struggle between foreign occupiers and a revolutionary guerrilla movement, but a multisided civil war characterized by the systematic persecution of rival ethnic and religious groups for over four violent years. ${ }^{12}$ The spiral of violence was particularly brutal in the $\mathrm{NDH}$, which included not only most of today's Croatia (notably lacking the Istrian Peninsula and most of the territory on the Adriatic coast), but also present-day Bosnia-Herzegovina. Members of the Ustaša terrorist movement established the NDH on 10 April 1941, just a few days following the Axis invasion and destruction of the Interwar-era Yugoslav

11 The Srb case study will be completed as part of the ongoing FRAMNAT research project.

12 See Marko Attila Hoare, Genocide and Resistance in Hitler's Bosnia: The Partisans and the Chetniks, 1941-1943 (Oxford: Oxford University Press, 2006); Vjeran Pavlaković, "Yugoslavia," in Phillip Cooke and Ben Shepherd, eds., European Resistance in the Second World War (Barnesly: Pen \& Sword Military, 2013); Stevan K. Pavlowitch, Hitler's New Disorder: The Second World War in Yugoslavia (London: Hurst \& Company, 2008); and Jozo Tomasevich, War and Revolution in Yugoslavia, 1941-1945: Occupation and Collaboration (Stanford: Stanford University Press, 2001). 
state (1918-1941). The Ustaša leader, Ante Pavelić, who had returned from his exile in Italy, quickly established a harsh dictatorship that passed racial laws against Serbs, Jews and Roma. The regime built a system of concentration camps (the most notorious being the Jasenovac complex) and violently repressed any opposition to his regime. While many Croats initially welcomed the NDH as salvation from the Serb-dominated Interwar Yugoslav state, the totalitarian methods of the Ustaša regime quickly revolted the majority of the population. Serbs, who comprised nearly $30 \%$ of the NDH's inhabitants, were the main targets of the regime's genocidal politics. They swelled the ranks of the growing Partisan resistance movement, organized by the Communist Party of Yugoslavia under Josip Broz Tito's command. Other Serbs joined the Četniks, who fought for the restoration of royal Yugoslavia, but engaged in numerous atrocities against Croat and Muslim civilians and eventually fully collaborated with the pro-Axis forces.

The Ustaše stayed loyal to Hitler until the end, and while much of the leadership, including Pavelić, were able to escape to the West after May 1945, tens of thousands of others associated (or allegedly associated) with the regime suffered in postwar communist massacres, death marches or other types of persecution, symbolically commemorated as the Bleiburg massacre and the Way of the Cross in May every year. ${ }^{13}$ Croats in particular were saddled with the guilt of the Ustaša crimes, even though by the end of the war hundreds of thousands of ethnic Croats had fought in the Partisan ranks. The legitimacy of the post-war socialist regime was based upon the official narratives of the Partisan struggle, referred to in the historiography as the People's Liberation Struggle ( Ков - Narodnooslobodilčka borba). Although by the 1960 os Yugoslavia in many aspects was far more liberal than its neighbours in the Soviet bloc, the challenging of the state's interpretation of the past, especially the numbers of victims, was a taboo topic that could result in prison sentences. In addition to new rituals, commemorations, history books, films and cultural products which reinforced the Partisan narrative of the war, the communist regime erected thousands of monuments and memorials at important memory sites dedicated to the ideals of brotherhood and unity, socialist revolution, and sacrifice for the new Yugoslav state. ${ }^{14}$

13 Martina Grahek Ravančić, Bleiburg i križni put 1945.(Zagreb: Hrvatski institut za povijest, 2009).

14 Renata Jambrešić-Kirin, "Politička sjećanja na Drugi svjetski rat u doba medijske reprodukcije socijalističke culture," in Lada Čale Feldman and Ines Prica, eds., Devijacije $i$ promašaji: Etnografija domaćeg socijalizma (Zagreb: Institut za etnologiju i folkloristiku, 2006). 
After multiparty elections in 1990 and the rapid disintegration of communist ideology in Yugoslavia as well as Eastern Europe, the monopoly over the past crumbled along with the former political system. A proliferation of debates about the Second World War in Croatia contributed to the deterioration of Serb-Croat relations and the slide towards a new cycle of war. Slobodan Milošević, Serbia's president and architect of Yugoslavia's bloody dissolution, used his propaganda apparatus to spread fear among Croatia's Serbs of a renewed Ustaša threat. At the same time, Tuđman (himself a former Partisan officer) and his Croatian Democratic Union (HDZ - Hrvatski demokratski savez) tolerated the rehabilitation of the Ustaše in an attempt to bridge the red-black ideological divide among Croats. Despite the shameful policies during its brief existence and its inglorious end, the NDH remains romanticized in certain circles because of the predominance of the state-forming ideology (državotvornost) and ideas of 'state right' among nationalists. In their interpretation, the Ustaše had supposedly established the first independent state since the loss of national sovereignty in 1102, ignoring the fact that the NDH was divided and controlled by both Italy and Germany. Fetishization of the state led to the minimizing, and sometimes complete denial, of Ustaša crimes by émigrés who fled Tito's Yugoslavia, a trend that entered mainstream Croatian political culture after 1990. Nevertheless, the Croatian Constitution (adopted in December 1990 and amended most recently in 2010) cites the Partisan movement and zaVNoH (State Antifascist Council of the National Liberation of Croatia, the governing body of the Croatian Partisans) as part of the continuity of Croatian statehood..$^{15}$ The establishment of statehood (whether the NDH, the Socialist Republic of Croatia within a federal Yugoslavia, or independent Croatia in 1991) remains at the heart of war remembrance in Croatia. This includes speeches at sites such as Jasenovac - as described below - even though other commemorations are more relevant to the nation-building narrative.

Commemorations, along with other political rituals such as rallies, parades, anniversaries and other mass gatherings, are symbolic public activities that elites use to construct grand narratives of the national past and their own political legitimacy. 'Politics is expressed through symbolism,' asserts anthropologist David I. Kertzer, suggesting that even people in modern societies are more influenced by symbolic forms than rational calculations. ${ }^{16}$ While the majority of socialist-era monuments remained the same (those that werenot among the 3,000 damaged or destroyed ones), the content of the commemorative

\footnotetext{
15 Constitution of the Republic of Croatia, online version at http://www.zakon.hr/z/94/ Ustav-Republike-Hrvatske.

16 David I. Kertzer, Ritual, Politics, Power (New Haven: Yale University Press, 1988), 2.
} 
practices, especially the speeches, has inscribed new meanings into old sites. It is precisely the reception of what is inscribed into contested memory sites such as Jasenovac that our research is trying to analyze, two decades after the transition into multiparty democracy and the establishment of an independent nation-state.

\section{Jasenovac as a Controversial Site of Memory}

Along with the Bleiburg and Srb commemorations, the collective remembrance of Jasenovac is among the most controversial memory sites related to the Second World War in post-socialist Croatia. Unlike Bleiburg, where the small memorial is overshadowed by the chapel and outdoor altar hosting the commemorative speeches, Jasenovac is dominated by a massive monument that serves as a backdrop to the commemoration as well as an easily recognizable symbol frequently reproduced in the media (see Illustrations 2 and 3). The Jasenovac 'Flower', designed by architect Bogdan Bogdanović, represents the later trend of abstract memorial design known as Yugoslav socialist modernism. While many Partisan memorials, such as the Srb monument by sculptor Vanja Radauš, clearly depict scenes of the war in a socialist realist manner (heroic soldiers, grieving mothers, suffering civilians and murderous fascist enemies), Bogdanović's transcendent, almost alien monument does not in any way indicate that it marks the location of a brutal extermination camp. According to Bogdanović himself, "the "Flower" is an enigmatic construction. Just like the death of man is mysterious, especially in a shadowy time. The monument must be enigmatic.' ${ }^{17}$ This monument thus provides an interesting case study in trying to measure emotional reactions to a site of memory where the Yugoslav regime invested considerable resources in constructing a specific narrative of the past yet chose to do so through a memorial with ambiguous symbolism.

Unlike Auschwitz, Dachau or other former concentration camps, the Jasenovac Memorial Site lacks original buildings and is dominated by the massive concrete 'Flower' monument next to a memorial museum renovated in 2006. In contrast to the gas chambers of the Nazi death camps, victims in Jasenovac, the nearby Stara Gradiška and other Ustaša camps were often murdered

17 Interview with Bogdan Bogdanović quoted in Nataša Jovičić, "The Alchemy of the 'Flower"', in Tea Benčić Rimay, ed., Jasenovac Memorial Site, (Jasenovac: Spomen-područje Jasenovac, 2006), 229. 
through less systematic but more brutal methods. ${ }^{18}$ The estimated number of victims at Jasenovac has fluctuated wildly over the years and was subject to considerable political manipulation almost immediately after the end of the Second World War. The figure of 700,00o victims was considered sacrosanct in socialist-era Yugoslavia, and by the 1980 os some scholars inflated that number to allege that over 1 million individuals, predominantly Serbs, were killed in the camps alone. ${ }^{19}$ The reaction of Croatian nationalists, such as Franjo Tuđman, was to minimize the numbers. Even before he became president, Tuđman argued that the total death toll for all camps in Croatia was not more than 40,00o, a figure he continued to cite in the $1990 \mathrm{os}^{20}$ The museum's website currently lists just over 80,00o Serbs, Jews, Roma, Croats and individuals of other nationalities as victims, ${ }^{21}$ although scholars estimate that the final tally of victims is probably as high as $100,000 .{ }^{22}$ In her work on socialist Yugoslav monuments, historian Heike Karge has shown that the debates over the number of victims affected the decisions related to the building of a memorial at Jasenovac, including decisions at the highest political levels of the communist regime. ${ }^{23}$

As mentioned above, no original structures remain at the Jasenovac site. The Ustaše destroyed the camp and nearly all administrative records in 1945 when it became clear the war was lost, and in subsequent years the inhabitants of the town of Jasenovac scoured the ruins for building material to repair their devastated homes. In the 1950 os local officials floated the idea of creating some kind of memorial at the site, but it was not until 1963 that 1,500

18 Nataša Mataušić,Jasenovac 1941-1945 (Zagreb: Kameni cvijet, 2003); Mišo Deverić and Ivan Fumić, Hrvatska u logorima, 1941.-1945. (Zagreb: Savez antifašističkih boraca i antifašista Republike Hrvatske, 2008); and Slavko and Ivo Goldstein, Jasenovac i Bleiburg nisu isto (Zagreb: Novi liber, 2011).

19 Vladimir Žerjavić, Opsesije i megalomanije oko Jasenovca i Bleiburga (Zagreb: Globus, 1992), 11-12, 44; and Nataša Mataušić, "The Jasenovac Concentration Camp," in Rimay, ed., Jasenovac Memorial Site, 47-48.

Interview with Tuđman, reprinted in Novi list, 23 April 1996, 21. The discussion about the manipulation of the number of Jasenovac victims was featured in Franjo Tuđman's most well-known and controversial book, Bespuća povijesne zbiljnosti (1990). The notion of collective guilt was one of the central tenets of Tuđman's challenging the number of Serbian victims in the Second World War.

21 Tables identifying the victims at the Jasenovac camp by nationality can be found at www. jusp-jasenovac.hr/Default.aspx?sid=6711 (accessed 5 May 2016).

22 Archive of Javna ustanova Spomen područje (JUSP) Jasenovac, Fond SPJ - Komemoracije, A-745, Slakvo Goldstein, "Procjene o priližnom broju žrtava ustaškog logorskog sustava Jasenovac 1941-1945," 21 April 2005.

23 Heike Karge, Sećanje u kamenu - okamenjeno sećanje? Trans. Aleksandra Kostić (Belgrade: XX vek, 2014). 
people participated in a 'work action' to clear the terrain and that a decision was made to construct a monument. ${ }^{24}$ The Croatian People's Liberation War veterans' organization chose Belgrade architect Bogdan Bogdanovićs 'Flower' design (sometimes referred to as the 'Stone Flower,' Kameni cvijet, even though it is made from reinforced concrete), symbolizing 'indestructible life,' as the central monument. ${ }^{25}$ Work on the monument lasted from 1964 until the opening ceremony on $4 \mathrm{July} 1966 .{ }^{26} \mathrm{Gal} \mathrm{Kirn}$, a leading scholar on Yugoslav modernist monuments, explains that the abstract forms represent universalist values, timelessness and an antifascism that is not tied to a single nationalism. ${ }^{27}$ These memorials, even when located at the site of death camps such as Jasenovac, share the vision of modernization and education which Yugoslavia strove for but was ultimately unable to achieve due to its internal lack of cohesion. The construction ofa museum began in September 1967 and was completed in July 1968, the same year the Jasenovac Memorial Site Institution was established to administer the museum. In 1983 the Jasenovac Memorial Site was expanded to include all of the outlying camps that constituted the Jasenovac system, such as Krapje, Uštice, Stara Gradiška (the location of a women's camp) and Donja Gradina. The latter location is a massive killing field across the Sava River, an area which today belongs to Bosnia-Herzegovina (in the Republika Srpska entity). The once-united memorial site is therefore physically divided between two countries. The fragmentation of the memorial site has resulted in two radically different constructions of the past: the Croatian one, which offers a contemporary museum space and commemorative site, and a Bosnian Serb one which perpetuates the Jasenovac myths from the communist period.

In 1991 the memorial site was occupied by rebel Serb forces that devastated the museum and looted its collection. The objects ended up in a storage facility in Banja Luka (Bosnia-Herzegovina), were transferred to Washington, D.c.,

24 Duško Lončar, Deset godina spomen-područja Jasenovac (Jasenovac: Spomen-područje Jasenovac, 1977), 13-14.

25 Bogdanović stated in an interview that 'in the Jasenovac Flower I denoted life - the crimes which took place in Jasenovac were terrible, but it is important to show what comes afterwards.' Quoted in Jovičić, "The Alchemy of the 'Flower", 229.

26 Lončar, Deset godina spomen-područja Jasenovac, 13-14.

27 Gal Kirn, "A Few Critical Notes on the Destiny of the Yugoslav Partisan Memorial Sites in the Contemporary, Post-Yugoslav (Croatian) Context," in Nataša Ivančević, ed., Vojin Bakić: Lightbearing Forms - A Retrospective (Zagreb: Muzej suvremene umjetnosti, 2013), 288. See also Gal Kirn and Robert Burghardt, "Jugoslovenski partizanski spomenici: Između revolucionarne politike i apstraktnog modernizma," in Jugolink, vol. 2, no. 1 (2012), 7-20. 


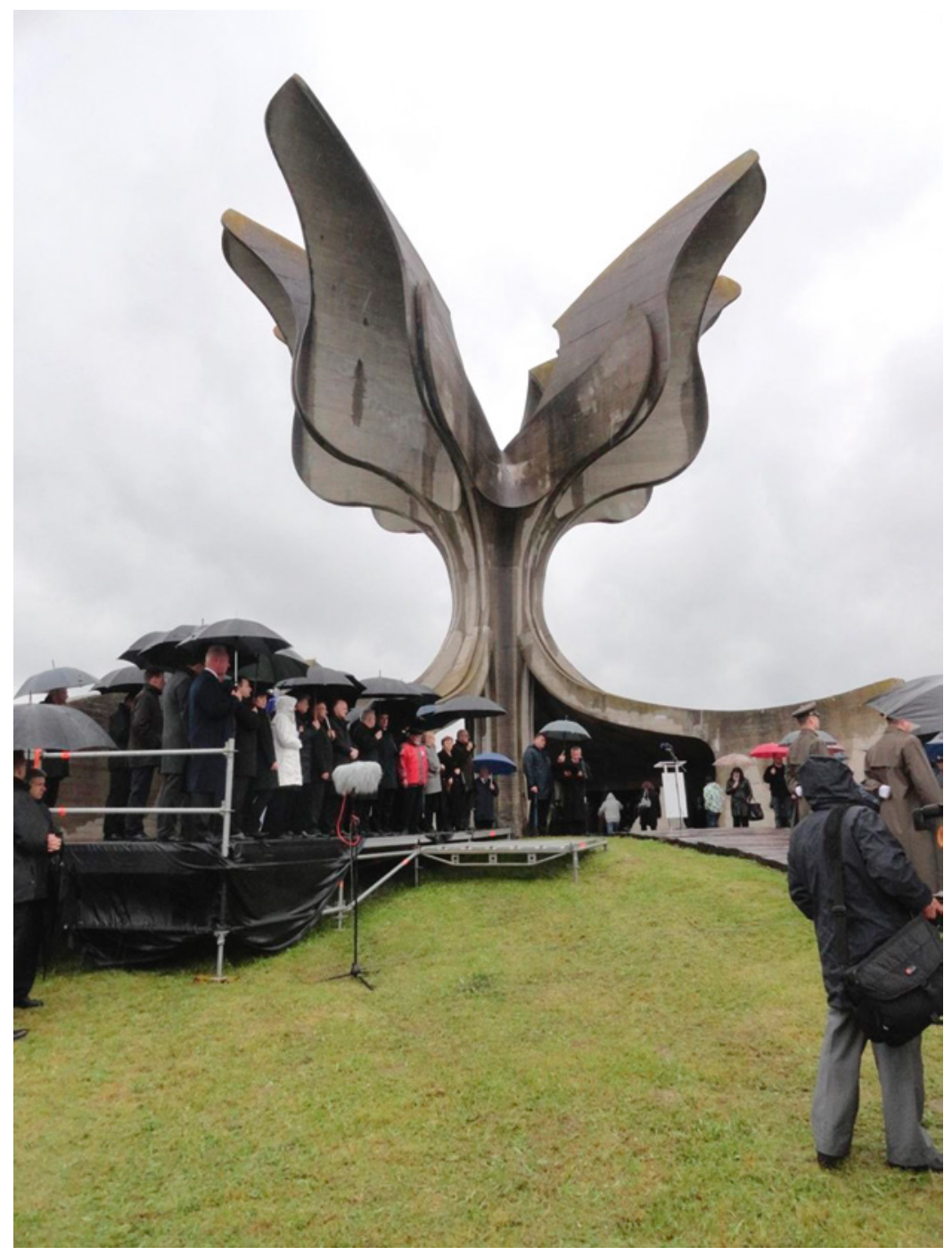

FIGURE $12.1 \quad$ The Jasenovac monument by Bogdan Bogdanović during a commemoration in 2014

PHOTO BY VJERAN PAVLAKOVIĆ

with the help of the United States Holocaust Memorial Museum in 2000, and were finally returned to Croatia in 2001 (Mataušić 2006: 54). ${ }^{28}$

28 Mataušić, "The Jasenovac Concentration Camp," 54. Croatian authorities estimate that about $30 \%$ of the collection, which in 1991 consisted of some 14,000 objects and 2,500 publications, is still missing. It is believed to be in Bosnia-Herzegovina or Serbia. 
As part of his general political platform of restoring Croatia's antifascist legacy, former president Stjepan Mesić (2000-2010) annually attended the Jasenovac commemoration (in honor of the final breakout attempt by the remaining camp prisoners on 22 April 1945), where he often gave fiery commemorative speeches praising the Partisan resistance movement and condemning attempts at rehabilitating the NDH. As Croatia drew closer to EU membership, even the HDZ, under former Prime Minister Ivo Sanader, understood that the country needed to adopt European paradigms of remembrance, particularly in relation to the Holocaust. ${ }^{29}$ In 2006 a new exhibition space was opened at the memorial site, and Sanader, Prime Minister at the time, described what Jasenovac meant to Croatia from a clear European perspective:

We must speak about a Europe without divisions precisely at Jasenovac. Because Jasenovac is a tragic measure of the depth of divisions which, in the context of the old conflicted Europe, were carved deeply into the tissue of Croatian society. Few countries in Europe felt and suffered so much from the consequences of European divisions and conflicts between ideologies and peoples. In the Homeland War we overcame those divisions, we strengthened our antifascist foundations while simultaneously condemning communist totalitarianism, and we raised the paradigm of a newly united and reconciled Croatia that is our pledge in the new Europe. That new Europe brings values that are also part of our inheritance, such as dialogue, tolerance, peace and democracy. Modern Croatia will be built on exactely those values. ${ }^{30}$

Mesić's successor, Ivo Josipović (2010-2015), and the coalition government led by the Social Democratic Party (SDP) continued the commemorative practices at Jasenovac which included explicit condemnation of the NDH and Ustaše, references to EU values, and recognition of the Croatian antifascist contribution to the Allied victory in the Second World War (see Figure 12.1).

The election of the HDz's candidate for president in 2015, Kolinda Grabar-Kitarović, precipitated a shift in the discourse used at Second World War commemorations that paralleled a more general trend in attempts by right-wing politicians and intellectuals to undermine Croatia's antifascist legacy. In April 2015, President Grabar-Kitarović chose to break the practice

29 Ljiljana Radonić, "Univerzalizacija holokausta na primjeru hrvatske politike prošlosti i spomen-područja Jasenovac," in Suvremene teme, vol. 3, no. 1 (2010).

30 Ivo Sanader at Jasenovac, 27 November 2006, https://vlada.gov.hr/vijesti/jasenovacotvoren-memorijalni-muzej-i-obrazovni-centar/5524. 
of her predecessors and did not attend the commemoration of the Jasenovac victims (she had laid a wreath at the site several days earlier). She took several other symbolic actions soon after becoming president, such as removing a bust of Tito from the presidential office (which even Tuđman had kept) and then sponsoring the Bleiburg commemoration in May, which the SDP coalition had previously stopped funding because of the perception among the Left that it contributed to the rehabilitation of the Ustaša movement. The electoral campaign prior to parliamentary elections in the fall of 2015 were notable for the HDZ's virulent anti-communist discourse, threats of imminent lustration and the decision to include parties openly sympathetic to the Ustaše in their coalition. Once the HDZ was able to form a government in early 2016, many of its initial moves seemed to confirm fears that the radical right wing of the party was pushing an ideological agenda mirroring the developments in some other Central European countries such as Hungary, Poland and Slovakia. Some of the first decisions of the new government were to appoint a controversial (some would say revisionist) historian, Zlatan Hasanbegović, as the minister of culture, restore parliamentary sponsorship over the Bleiburg commemoration, and propose to change the name of the parliament to the name it had during the NDH (Hrvatski državni Sabor).

Furthermore, the government did not react when demonstrators marched and threatened the electronic media council while shouting fascist slogans $(\mathrm{Za}$ dom spremni, the Ustaša motto meaning 'Ready for the Homeland'), because it had punished a broadcaster for hate speech against minorities, and turned a blind eye on threats and even physical attacks on representatives of the Serb minority and independent journalists. The general atmosphere was additionally poisoned by a sustained media campaign in the right-wing press discrediting the numbers of victims at Jasenovac, which included references to the annual Jasenovac commemoration as a 'Demonic Dance of Red Bandits' (see Figure 12.2). ${ }^{31}$ Right-wing weeklies, such as Hrvatski tjednik, Hrvatsko slovo and Vijenac, along with publications such as Jasenovački logori (2015), have argued that even the current numbers of victims are greatly exaggerated, andhave further claimed that the 'truth' about the concentration camp is that it allegedly continued to exist as a communist-run camp until 1952 where all of the victims were actually Croats. ${ }^{32}$

31 Hrvatski tjednik, 30 April 2015, front page. The subheading reads "Jasenovac: Magnum crimen against truth and Croatia."

32 The questionable historical methodology and clear ideological agenda of the revisionist camp prompted Slavko Goldstein to respond with his own book countering the claims of 


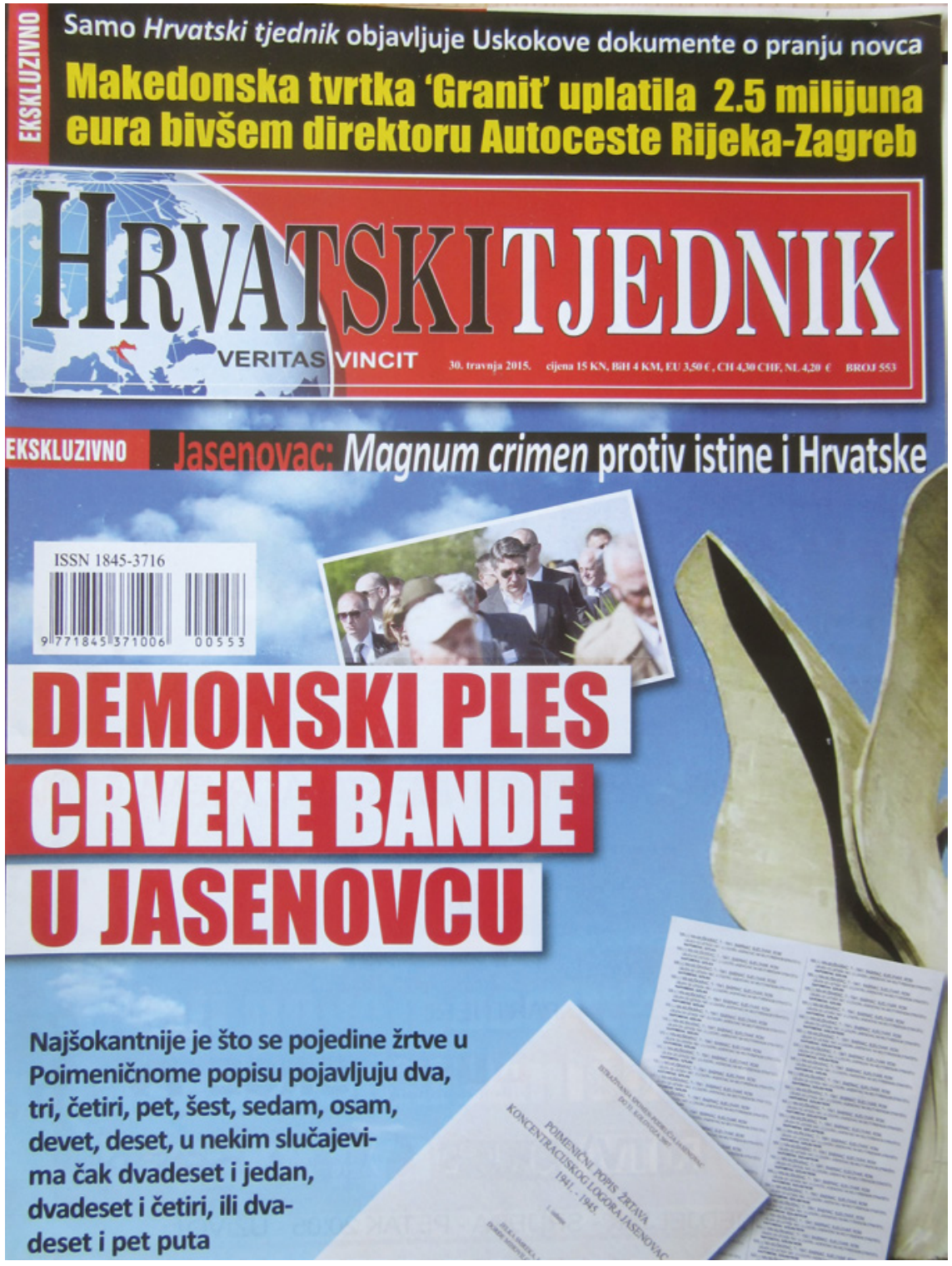

FIGURE 12.2 Cover of right-wing weekly Hrvatski tjednik referring to the Jasenovac commemoration as a 'Demonic Dance of Red Bandits'.

In April 2016, the premier of Jakov Sedlar's revisionist film, Jasenovac - Truth, which included several falsifications identified by investigative journalists, was

the Society for Jasenovac Camps (Društvo Jasenovačkih logora), titled Jasenovac: tragika, mitomanija, istina (Zagreb: Fraktura, 2016). 
the straw that broke the camel's back and spurred an outcry from human rights NGOs, the Serb minority, Roma and Jewish organizations, the antifascist association of Croatia and even the Israeli ambassador. ${ }^{33}$ Consequently, all of these groups boycotted the official commemoration, resulting in an international scandal. While the official commemoration was held on 22 April, attended primarily by government ministers and parliamentary deputies, alternative commemorations were held on 15 April (organized by Croatia's Jewish community) and on 24 April (organized by the Association of Antifascist Veterans of Croatia and the Serbian National Council), along with a protest in Zagreb organized by civil society NGOs on the same day as the official event. The rival interpretations of the nature of the Jasenovac camp were thus present not only in academic publications and the media, but in a number of commemorative rituals and official government statements. It is after this context of contested narratives in the public sphere during March and April 2016 that the respondents of the study were asked to comment on the affective and cognitive features of the Jasenovac memorial.

\section{Jasenovac Conceptualizations and Affective Engagement Case Study}

In the following sections we will present the findings of the research on emotional and cognitive responses after the exposure to the Jasenovac monument representation (Illustration 2), as well as the speeches from commemorations and media appearances given by three memory-producing actors:

a) Zoran Milanović, the former president of the Social Democratic Party of Croatia (SDP), who was, at the time of the speech at the Jasenovac commemoration (26 April 2015), Prime Minister of Croatia. ${ }^{34}$

b) Igor Vukić, a revisionist historian and contributor to the controversial book Jasenovački logori, who appeared in the talk show 'Bujica' in April $2015 .^{35}$

33 Jutarnji list, 8 April 2016, p. 5. The Israeli ambassador to Croatia, Kalay Kleitman, stated that after seeing the film she felt that it "selectively depicted history, attempted to revise many known historical facts, and offended the feelings of people who lost their loved ones in Jasenovac."

34 Link to the speech: https://www.youtube.com/watch?v=hSMyMsirFUA.

35 Link to the appearance in talk show "Bujica": https://www.youtube.com/watch?v=474 HxDhKWm8. 
TABLE 12.1 The structure of the participants in the Jasenovac study.

\begin{tabular}{llll}
\hline Sum & Milanović & Vukić & Vučić \\
\hline 126 & 57 & 41 & 18 \\
\hline
\end{tabular}

c) Aleksandar Vučić, who was, at the time of the speech at the memorial centre Donja Gradina (19 April 2015), Prime Minister of Serbia. ${ }^{36}$

In order to measure the effects of the speeches on the affective and cognitive engagement, we conducted an experimental study using a questionnaire ${ }^{37}$ with 126 participants, mostly students from the University of Rijeka, Faculty of Humanities and Social Sciences, during April 2016. They were distributed in three groups according to the approximately five minute-long speeches delivered by either Milanović, Vukić or Vučić (see Table 12.1).

This paper will focus on the results of the questionnaires from the groups who observed the speech by Milanovićs ${ }^{38}(\mathrm{M})$, the interview with Vukić39 (V) and the speech by Vučić (Vč). ${ }^{40}$ The questionnaire was conducted in the following phases: (1) general questions, (2) presentation of the monument, (3) questionnaire with 21 dimensions measuring affective appraisal and stance, (4) presentation of the speech, (5) reiteration of the questionnaire from phase 3 .

\section{Phase 1: General Questions}

The first phase of the questionnaire recorded seven categories: age, sex, education, profession, nationality, political affiliation, faith, stance on abortion and stance on gay marriage as well as stance on the theory of evolution. The average age of the participants was 21.8 years, of whom $83 \%$ were women and

36 Link to the speech: https://www.youtube.com/watch?v=lIvK8qzg-G4.

37 The questionnaires can be found on the following web-addresses:1) Vukić https://docs. google.com/forms/d/1Un5i3gKEYo_M7x7jDPQyAm3hVqoTIonog33yLoKfuk2) Milanović https://docs.google.com/forms/d/1aZodqwYREIXPQQFxjVJPkiixnjOyjCRUKNVSnson Kf 43) Vučić https://docs.google.com/forms/d/1ynhosIZIVXHwNlyoVD2FoCinywDGIDJB $5 J I_{3} m_{3} \mathrm{G}_{4} \mathrm{Qk}$.

38 The summary of the answers: https://docs.google.com/forms/d/1aZodqwYREIXPQQFxjV JPkiixnjOyjCRUKNVSnsonKf 4 /viewanalytics ).

39 The summary of the answers:https://docs.google.com/forms/d/1Un5i3gKEYo_M7x7jDPQy Am3hVqoTIonogiYyLoKfukY/viewanalytics.

40 As the results have shown, the Vučić group needs more subjects to be statistically relevant. However, we have included the results in the presentation of the study. 
$17 \%$ men. The subjects were mostly students of the University of Rijeka studying Pedagogy 25\%, Cultural Studies 30\%, Psychology 27\%, English language and literature $5 \%$, Polytechnics $6 \%$ : with $56 \%$ undergraduate, $36 \%$ graduate, and $5 \%$ doctoral studies, while $1 \%$ were high school students.

Regarding national identity, $93 \%$ of the subjects declared themselves Croats, $2 \%$ Serbs and $5 \%$ remained nationally undeclared. As to the political affiliation, $73 \%$ declared themselves undecided, $16 \%$ opted for the Social Democratic Party, $5.3 \%$ for Živi zid, $2 \%$ for MOST, and under $1 \%$ for other parties (including, interestingly, the HDz, which, at the time of writing, has the highest number of seats in the Croatian parliament). Regarding the faith, $54 \%$ declared themselves Roman Catholics, $25 \%$ Agnostics, $16 \%$ Atheists, $2 \%$ Muslims, and under $1 \%$ Buddhists and Hindus.

The last few questions were included to reveal some deeper socio-cultural aspects of the subject's belief values. On the question of abortion, $82 \%$ opted for the legalization of abortion and the freedom of a mother's choice, while $12 \%$ expressed a firm stance in favour of banning abortion with pro-life arguments. The distribution for the question on marriage issues was similar, with $90 \%$ supporting the legalization of homosexual marriages, and $9 \%$ exclusively in favour of heterosexual marriages only. On the question of evolution, $26 \%$ thought evolutionary theory to be a scientific paradigm that proves religious beliefs incorrect and is therefore unfit to be taught in schools, $50 \%$ considered the theory a paradigm that should be taught in schools on a different and separate level from religious theories, while $21 \%$ believed evolutionary theory to be equally valid to the religious creationist theory.

\section{Phase 2: Presentation of the Monument}

In the second phase of the research design we exposed the participants to a photograph of the Jasenovac monument (Figure 12.3) for a period of one minute without any additional information about the memorial site.

\section{Phase 3: Questionnaire with Sixteen Dimensions Measuring Affective Appraisal and Stance}

In order to measure the affective response to the illustration, we formulated a questionnaire with sixteen dimensions as dependent variables that indicate the level of emotional engagement and cognitive appraisal. The dimensions were selected in accordance with the theoretical assumptions of componential process model (CPM) of emotion mechanisms. ${ }^{41}$ The CPM claims emotions to

$41 \quad$ Klaus Scherer, "Emotions are emergent processes: they require a dynamic computational architecture," Philosophical Transaction of the Royal Society, 364, (2009), 3459-34747. 


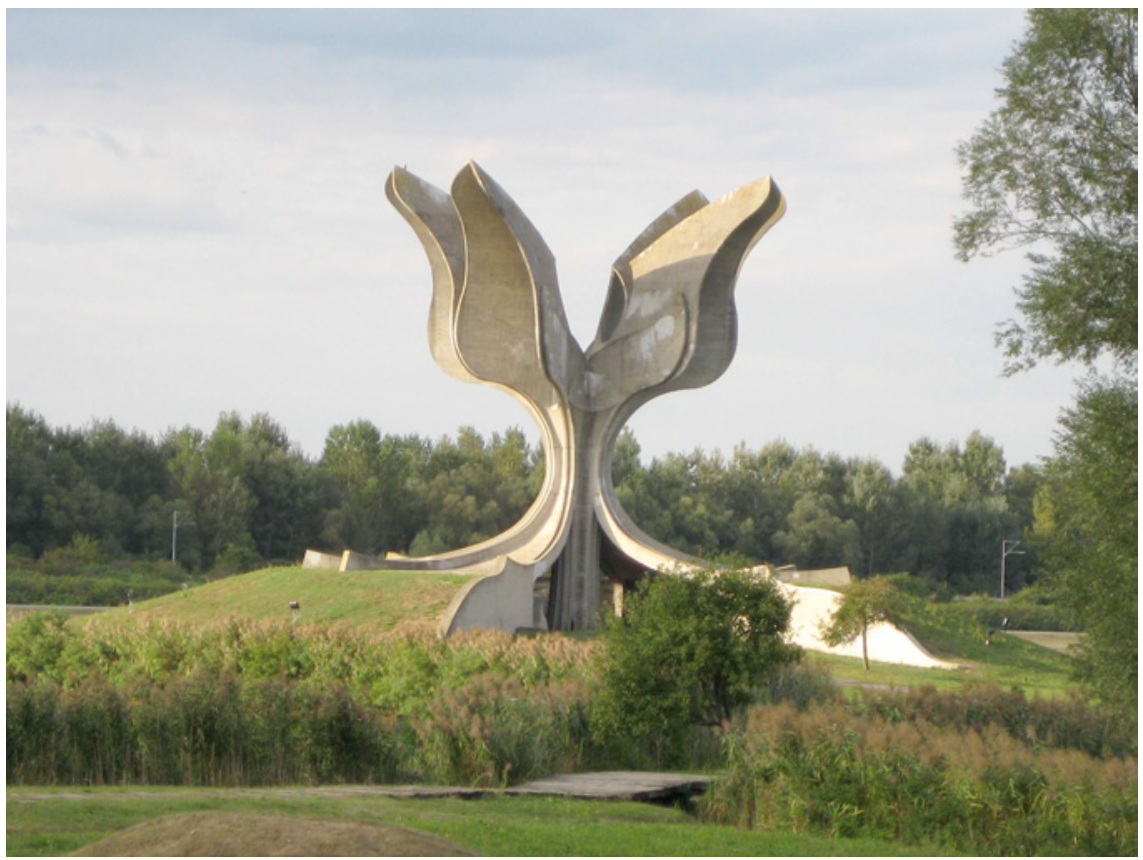

FIGURE 12.3 Image of the Jasenovac monument used to elicit reactions in subjects.

be dynamic and emergent processes arising from interaction of the organism with its environment and direct interaction with higher cognitive processes. The questions in the questionnaire are classified in features of arousal, hedonic valence with pleasantness and unpleasantness dimensions, six emotion categories of fear, shame, anger, disgust, pride, happiness, love, three normative appraisals expressing congruence of the representation with one's self values, and two behavioural tendencies to promote or to dismantle the monument (see features in Table 12.2). The question was formulated in the following manner: 'By looking at the monument I feel: X [Feature]'. The subjects evaluated the occurrence of a particular feature elicited by the representation of the monument ona five-point Likert scale with the following labels: 1 - strongly disagree, 2 - disagree, 3 - neither agree nor disagree, 4 - agree, and 5 - strongly agree. Table 12.2 presents the results of the evaluation after the initial exposure to the image of the Jasenovac monument (Figure 12.3).

The aggregate data for all three groups of subjects $(n=126)$ (Table 12.3) show that initial elicitation with the image of the Jasenovac monument resulted in the neutral activation of the behavioural tendency to keep and promote the monument $($ mean $=3.27, \mathrm{SD}=1.14)$. Slightly negative results were recorded for 
TABLE 12.2 The results of emotional engagement and cognitive appraisal elicited by the Jasenovac monument representation, measured by the five-point Likert scale for three sets ('Milanovic', 'Vukic', 'Vučic') across sixteen features. The column 'Sum' shows aggregate of all three sets. The measure of mean (or average) shows the most common value on a Likert scale, while standard deviation is a measure that quantifies the amount of variation of a set of data values.

\begin{tabular}{|c|c|c|c|c|c|c|c|c|}
\hline \multirow[b]{2}{*}{ Feature } & \multicolumn{2}{|l|}{ Sum } & \multicolumn{2}{|c|}{ Milanović } & \multicolumn{2}{|l|}{ Vukić } & \multicolumn{2}{|l|}{ Vučić } \\
\hline & Mean & SD & Mean & SD & Mean & SD & Mean & SD \\
\hline Disgust & 2.12 & 1.21 & 2.21 & 1.22 & 1.73 & 1.07 & 2.41 & 1.33 \\
\hline Love & 1.81 & 1.01 & 1.79 & 1.00 & 1.83 & 1.02 & 1.82 & 1.01 \\
\hline Anger & 2.49 & 1.37 & 2.60 & 1.28 & 2.22 & 1.37 & 2.65 & 1.46 \\
\hline Unpleasantness & 2.66 & 1.23 & 2.84 & 1.19 & 2.20 & 1.25 & 2.94 & 1.25 \\
\hline Pride & 2.18 & 1.14 & 2.28 & 1.13 & 2.07 & 1.17 & 2.18 & 1.13 \\
\hline Happiness & 1.72 & 0.94 & 1.68 & 0.95 & 1.71 & 0.84 & 1.76 & 1.03 \\
\hline Shame & 2.19 & 1.14 & 2.49 & 1.14 & 1.78 & 1.13 & 2.29 & 1.16 \\
\hline Fear & 2.10 & 1.22 & 2.30 & 1.24 & 1.76 & 1.18 & 2.24 & 1.25 \\
\hline Sadness & 2.84 & 1.39 & 2.79 & 1.28 & 2.68 & 1.46 & 3.06 & 1.43 \\
\hline Pleasantness & 2.08 & 1.03 & 2.09 & 0.95 & 2.02 & 0.96 & 2.12 & 1.17 \\
\hline Arousal & 2.44 & 1.15 & 2.33 & 1.11 & 2.46 & 1.21 & 2.53 & 1.12 \\
\hline $\begin{array}{l}\text { Monument promotes values in } \\
\text { accordance with my values }\end{array}$ & 2.41 & 1.09 & 2.67 & 1.01 & 2.39 & 1.24 & 2.18 & 1.01 \\
\hline $\begin{array}{l}\text { Monument inspires me to promote } \\
\text { my identity and values }\end{array}$ & 2.35 & 1.20 & $2.5^{8}$ & 1.13 & 2.07 & 1.10 & 2.41 & 1.37 \\
\hline $\begin{array}{l}\text { Monument inspires me to question } \\
\text { my identity and values }\end{array}$ & 2.28 & 1.29 & 2.63 & 1.28 & 1.85 & 0.99 & 2.35 & 1.62 \\
\hline $\begin{array}{l}\text { Behavioural tendency: deinstall } \\
\text { the monument }\end{array}$ & 1.75 & 0.97 & 1.93 & 1.05 & 1.68 & 0.93 & 1.65 & 0.93 \\
\hline $\begin{array}{l}\text { Behavioural tendency: keep and } \\
\text { promote the monument }\end{array}$ & 3.27 & 1.14 & 3.23 & 1.13 & 3.29 & 1.08 & 3.29 & 1.21 \\
\hline
\end{tabular}

affective arousal, emotional categories of sadness, unpleasantness and anger, as well as cognitive appraisals expressing the congruence of monument symbolic value with self-identity and social values. On the other hand, the participants disagreed that the representation elicited affective categories of disgust, love, happiness and a behavioural tendency to dismantle the monument. Overall, the initial static visual stimulus activated a somewhat expected neutral and 
TABLE 12.3 The aggregate mean results for all three groups (Milanović, Vukić, Vučić) (n=126) on the five-point Likert scale questionnaire after exposing the subjects to the illustration of the Jasenovac monument. The results are ordered in descending values. The thin lines on the histograms indicate the amount of standard deviation.

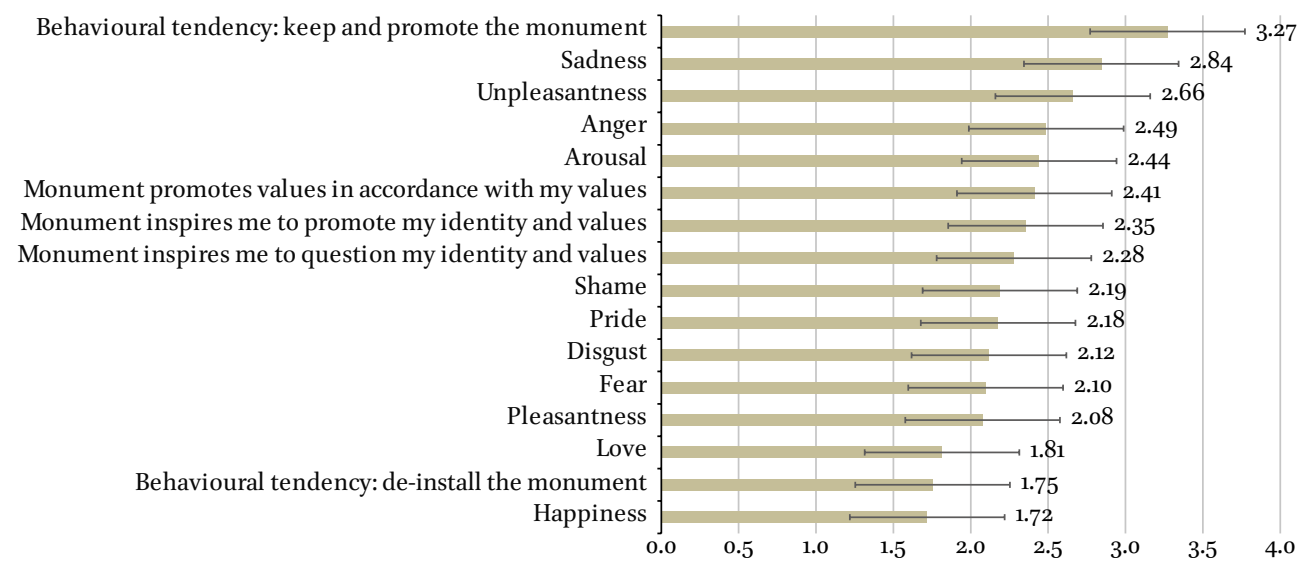

low-level affective engagement and cognitive appraisal in the respondents given the fact that the assessment was conducted in simulated experimental settings. However, the structure of the results shows the salient features of affective and cognitive dimensions elicited by the 'shallow' image representation of the Jasenovac commemoration memorial.

After this evaluation we asked the subjects whether they recognized the monument in the illustration. Around two-thirds of the participants (66\%) recognized the monument, mostly from the media (40\%), but also from elementary school (16\%), high school education (16\%), and college (4\%). Less than $1 \%$ answered that they had some personal connection to the historical events this monument represents. The rate of recognition is somewhat low considering the great historical importance of the commemoration site in Croatian history and the level of media exposure.

\section{Phase 4: Presentation of Political Speeches}

In the fourth phase of the experiment, we exposed our participants to a speech related to the Jasenovac monument by one of the following memory actors: Igor Vukić, ${ }^{42}$ Zoran Milanović ${ }^{43}$ and Aleksandar Vučić (Figure 12.4). ${ }^{44}$

\footnotetext{
42 https://www.youtube.com/watch?v=RaVpllXFi6g.

43 https://www.youtube.com/watch?v=hSMyMsirFUA.

44 https://www.youtube.com/watch?v=lIvK8qzg-G4.
} 


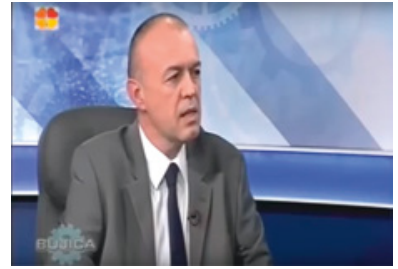

FIGURE 12.4 Igor Vukić

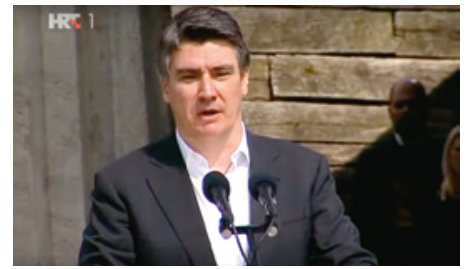

FIGURE 12.5 Zoran Milanović

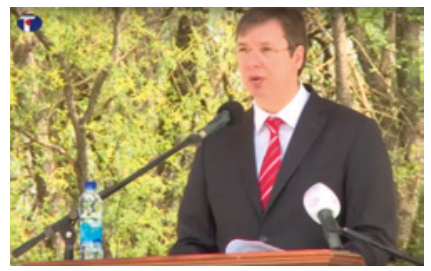

FIGURE 12.6 Aleksandar Vučić

Although the respondents had some previous knowledge of the Jasenovac memorial from either the media or school, and had an opportunity to indicate their emotions based on the visual image of the memorial, the content of the video clips of Milanović, Vukić and Vučić provided specific information of diametrically opposed interpretations of the nature of the concentration camp and its current role as a memorial space. Milanović's talk was antifascist and pro-Croatian, while Vukić's arguments could be summarized as anti-communist and pro-Croatian. Vučić's speech had strong anti-Ustaša and pro-Serbian tones.

The speech by former Prime Minister Milanović can be seen as a continuation of the narrative Croatian political elites have been transmitting at Jasenovac since 2000. He emphasized, even more than in previous years, the important role of Croatian Partisans (including Croats, Serbs and other nationalities) in defeating fascism, and cited the importance of antifascism in the Croatian Constitution. This focus on defending the legacy of antifascists from Croatia, more so than reflecting on the victims of the concentration camp, is clearly a response to the pressure from the HDz's anti-communist rhetoric and the decision of President Grabar-Kitarović to avoid the commemoration. Milanović also used the opportunity to criticize the rehabilitation of the Ustaše at the Bleiburg commemoration and the frequent chanting of the Ustaša motto 'Za dom spremni' (Ready for the Homeland) at football matches. He then ended the speech in a very fiery and patriotic manner, shouting 'Long live Croatian antifascism, long live a modern and humane Croatia!' Viewers were thus presented with a Jasenovac memorial which represented Croatian resistance to fascist ideology and a patriotism that included all regions of Croatia (Milanović repeatedly referred to various parts of the country and their contribution to the Partisan movement).

Igor Vukić's interview attempts to paint a much different picture of the Jasenovac camp than he promotes in his publications and many media appearances. Vukić and several like-minded historians claim that in addition to exaggerating the number of victims killed at Jasenovac by the Ustaše, the 
communist regime constructed lies to cover up that the true mass murders took place after 1945 when the camp was used to hold defeated Ustaše forces, and later Cominform supporters considered to be on the wrong side of the Tito-Stalin split. ${ }^{45}$ His approach is not to build upon the internationally accepted historiography, but to automatically dismiss all previous research as lies and deliberate manipulations, all with the goal of demonizing Croats and the Croatian people. He attempts to illustrate the benign nature of Jasenovac, which he claims was a work camp and not a death camp, with a story of Ustaše guards playing with his father (a Serb) when the latter was a child. This is in line with his publications ${ }^{46}$ in which he argues that witnesses do not mention seeing any Roma prisoners other than some circus performers (the approximately 8,000-15,000 Roma victims were most often immediately killed upon arriving at the camp complex), ${ }^{47}$ that many Jews were in fact protected by the Ustaša regime (a rather perverse argument considering that it was the Ustaša regime that enacted anti-Semitic laws immediately upon coming to power, resulting in an estimated 10,000-13,000 Jewish victims in the Jasenovac camp alone $)^{48}$ and that Serbs were sent to the camp only if they resisted the Ustaša regime as Četniks or Partisans (not only were the majority of Serb victims civilians, the Ustaše labelled practically all Serbs Četniks, a practice continued in Croatian nationalist circles to this day). ${ }^{49}$

Vukić's overall argument is that Jasenovac is one of the main symbols of the falsifications constructed by the communists to paint the Ustaše as mass murderers and justify their own authoritarian regime. Vukić presents the Jasenovac memorial as a place that leftist politicians use for manipulating the public in order to promote a communist, pro-Yugoslav, and anti-Croat political

45 Slavko Goldstein has convincingly debunked the conspiracy theories presented in the publications by Vukić and others who support the 'three camp theory' in his bookJasenovac: tragika, mitomanija, istina (2016).

46 Igor Vukić, "Sabirni i radni logor Jasenovac, 1941-1945," in Stjepan Razum and Igor Vukić, eds., Jasenovački logori: istraživanja (Zagreb: Društvo za istraživanje trostrukog logora Jasenovac, 2015), 132-134.

47 Narcisa Lengel-Krizman, "The Genocide Carried out on the Roma - Jasenovac 1942," in Rimay, Jasenovac, 168-169.

48 Ivo Goldstein, Holokaust u Zagrebu (Zagreb: Novi liber, 2001), 302-343.

49 Drago Roksandić, "Of Tragedy, Trauma, and Catharsis: Serbs in the Jasenovac Camp, 1941-1945," in Rimay, Jasenovac, 86-89. Roksandić notes that 'in many cases the Ustashas [sic] preferred to classify the Serbian inmates, particularly the elderly, as Chetniks, even when it was obvious they had no connections with Chetniks.' Ibid., 87 . 
agenda. The reception of the messages sent by these two opposed video clips are reflected in the second set of responses to the image of the memorial by the different emotional reactions.

Aleksandar Vučić's talk paints the opposite picture to that presented in Vukić's interview. With a rhetorically confident and emotionally conducive tone he portrays the savageness and ruthlessness of the Ustaša crimes that were committed in the Jasenovac camp against Serbs. The allegorical picture of the Serbian suffering is demonstrated by the vivid depiction in his speech at Donja Gradina of a child's head being crushed by an Ustaša guard and the use of knives to slaughter prisoners. The rhetorical twist is produced when Vučić declares that the Ustaša's extermination plan was not successful, praising the resiliency of the Serb people and their bright future, without any need for expansionism but with a need to firmly control their territory. With the skillful activation of the main conceptualizations of the Serb-Croat conflict from the perspective of Serbian politics, the main goal of this talk was to praise the Serbian people while simultaneously profiling Croatia, a geopolitical rival and EU member, in terms of Ustaša crimes.

\section{Phase 5: Stance towards the Speaker and the Message}

In the research design we included questions measuring the stance towards the speaker and his message, measuring qualitative and quantitative values. The quantitative dimensions were again measured with the same five-point Likert scale (Table 12.4).

Table 12.4 shows the mean values and standard deviation of evaluations regarding two questions: (a) do you have positive attitude towards the speaker? and (b) do you agree with the content of their message? The results indicate

TABLE 12.4 Attitudes towards the speaker and the message expressed in measures of mean and standard deviation $(S D)$.

\begin{tabular}{lllllll}
\hline & \multicolumn{2}{c}{ Milanović } & \multicolumn{2}{c}{ Vukić } & \multicolumn{3}{c}{ Vučić } \\
\cline { 2 - 7 } & Mean & SD & Mean & SD & Mean & SD \\
\hline $\begin{array}{l}\text { Positive attitude towards } \\
\text { speaker }\end{array}$ & $\mathbf{3 . 0 8}$ & $\mathbf{1 . 2 3}$ & 2.61 & 1.04 & 2.29 & 1.16 \\
$\begin{array}{l}\text { I agree with the content } \\
\text { M.56 }\end{array}$ & $\mathbf{3 . 0 2}$ & 2.46 & 1.00 & 2.94 & $\mathbf{1 . 3 4}$ \\
\hline
\end{tabular}


that the Milanovic group expressed the highest value of agreement with Milanović as a person (mean $=3.08, \mathrm{SD}=1.23$ ), as well as with the content of Milanović's antifascist message $($ mean $=3.56, \mathrm{SD}=1.02)$. Personal attitudes towards Vukić were slightly lower. Subjects in the Vučić group had the most negative attitudes regarding Serbian Prime Minister Vučić, but his message was valued as neutral. Interestingly, Vučićs anti-Ustaša message scored a relatively higher level of agreement than Vukić's pro-Ustaša revisionist message about the Jasenovac site.

In order to gain some qualitative insight about the reception of conceptualizations in the speeches we asked subjects to write down the prominent ideas they observed in the speech and the most emotive phrases they remembered. The following examples (1-3) illustrate the prominent idea detected by the subjects in Milanovićs talk.

1) Moderna Hrvatska država nije osnovana na idejama tadašnje formirane NDH, već je upravo utemeljena na otporu takvoj politici i propagandi. $\mathrm{Hr}$ vatska prema tome ne podržava veličanje nacionalizma, već za cilj ima jednakost, bez obzira na nacionalnost.

'The contemporary Croatian state is not based on the ideas of the $\mathrm{NDH}$, but on the resistance towards such politics and propaganda. Croatia, therefore, does not support nationalism but has equality as its goal, regardless of nationality.'

2) Najviše me emotivno probudilo kad je spominjao Bleiburg i Jasenovac, te kada je pričao o partizanima u svojoj obitelji, jer su i moji preci bili u partzanima.

'I was emotionally moved when he mentioned Bleiburg and Jasenovac, and when he spoke about the Partisans in his family, because my ancestors were also Partisans.'

3) živjela antifašistička Hrvatska

'Long live antifascist Croatia'

Some of the highlights from Milanovićs talk include the prototypical national messages with the aim to bolster national pride connected with the antifascist resistance (3), denunciation of the Ustaša regime (1) and recent attempts to reintegrate the Ustaša salutation 'Za dom spremni' into popular nationalist repertoire. Some of the participants have related the message with their family Partisan history (2), which made the talk more emotional and meaningful for them. However, some of the participants clearly state the need to leave this futile rhetoric and divisions in the past, perceiving it as primitive division of the Croatian people. 
Example (4) illustrates the predominant understanding of the main idea in Vukić's talk.

4) logor uJasenovcu je bio radni logor, a ne logor smrti

'The Jasenovac camp was a work camp, not a death camp.'

In Vukić's talk the most interesting conceptualization is construed by the narrative depicting his father playing with Ustaša soldiers in Jasenovac (5). This particular scene frames the whole event with an emotional flavor of cheerfulness intended to support a cognitive conceptuali of Jasenovac as a work camp, and not a death camp (4). This positive manipulation of the children's frame and its immediate affective - cognitive value is seen as especially important for the construal of the affective load necessary to superimpose the more frequent negative suffering frame connected with the Jasenovac narrative.

5) Moj se otac sjeća kako su ga ustaše nosile na ramenima i igrali se s njim! 'My father remembers how the Ustaše used to carry him on their shoulders and play with him!

The same conceptualization but with opposite affective valence is skillfully construed in Vučić's talk (6)

6) Kada se spominju djeca i način na koji su krvnici govorili kako će ih ubiti polako.

'When he mentions children and the manner in whichbutchers talk about how they are going to kill them slowly'.

Vučić channels this affective arousal into the main theme as seen by one of the subjects:

7) Nitko neće istrijebiti Srbe koji su duhovno i intelektualno nadmoćniji jer vide veličinu svojih žrtava i strahotu zločina nad svojim ljudima, a uzdižu se iznad nje - ne osvećuju se, ali pamte i prkosno stoje iznad svih!

'No one will exterminate Serbs that are spiritually and intellectually superior because they see the greatness of their own victimhood and the horror of the endured crimes and still rise above it all - they do not take revenge, but remember and dare to stand above them all!'

It is beyond the scope of this paper to delve into the intricacies of the figurative speech usage that activate the affective states and profile the pragmatic 
inferences in the listener. However, the qualitative paradigm can be noted from the previous examples. The speakers rely on the activation of the affective content and traumatic experiences by use of the embodied metonymic and metaphoric representations of horror, killing, imagery of innocence and children, vivid expressions of brutality, or the opposite heroic images of the sacrifice, pride and playfulness that are conducive to the construal of the more abstract cultural models of nationality ${ }^{50}$ with implicit rearrangement of the social norms and implications for self-identification and emergence of social identity processes. The reception of the linguistically modulated affective processes is qualitatively measured in the next phase of the questionnaire.

\section{Phase 6: Repetition of the Question from Phase 3}

After exposing our participants to the political talks we wanted to see whether the conceptualizations of the commemoration had some immediate effect on the affective and cognitive engagement regarding the Jasenovac monument. In order to determine if there was any change in the respondents' perception of the monument, the questionnaire from Phase 3 with sixteen dimensions was introduced again. This allowed us to measure the difference between pairs of affective dimensions and cognitive appraisal features after the initial decontextualized visual stimulus and then after the speech's contextualized conceptualizations. A paired-sample two-tailed t-test ${ }^{51}$ using software $\mathrm{R}^{52}$ was conducted to compare and measure significant differences in the evaluation results for the sixteen features before and after the exposure to political speeches. The mean difference was then calculated for each feature. The mean difference obtained by the t-test is taken to represent the effect of emotive engagement and appraisal caused by the profiled conceptualizations in the speech. The effects of the speeches by Milanović, Vukić and Vučić, along with the aggregate data, are represented in Table 12.5 and Table 12.6 with mean difference and p-values. ${ }^{53}$

5o Patrick Colm Hogan, Understanding Nationalism: On narrative, Cognitive Science, and Identity (Columbus: The Ohio State University Press, 2009).

$5^{1} \quad$ A paired t-test is used to compare two population means for two samples in which observations in one sample can be paired with observations in the other sample. In this case our subjects had the same set of questions evaluating the engagement with the monument before and after the speech with the five-point Likert scale.

52 https://www.r-project.org/.

53 P-value is defined as the probability of obtaining a result equal to or "more extreme" than what was actually observed, when the null hypothesis is true. If the null hypothesis is true ( $p$ value $=1$ ) means that there is no effect or difference between two measured phenomena. $\mathrm{P}$ values evaluate how well the sample data support the argument that the null hypothesis is true. Following the conventions of the asterisk rating system, we have marked the significant results with the p value $\leq 0.05$ with ${ }^{*}$, $p$ value $\leq 0.01$ with ${ }^{* *}$ and $p \leq 0.001^{* * *}$. 
TABLE 12.5 Effects of affective engagement and cognitive appraisal after the speeches by Milanović, Vukić and Vučić, as well as their aggregate effects. Values represent the mean of differences derived from two sided paired $t$-test and $p$-values $\left({ }^{*} p \leq .05\right.$, ${ }^{* *} p \leq .01,{ }^{* * *} p \leq .001$.) with a $95 \%$ confidence interval.

\begin{tabular}{|c|c|c|c|c|c|c|c|c|}
\hline \multirow[b]{2}{*}{ Feature } & \multicolumn{2}{|c|}{ Aggregate M,V,Vc } & \multicolumn{2}{|l|}{ Milanović } & \multicolumn{2}{|l|}{ Vukić } & \multicolumn{2}{|l|}{ Vučić } \\
\hline & Mean Diff & P-Value & Mean Diff & P-Value & Mean Diff & P-Value & Mean Diff & P-Value \\
\hline Disgust & $0.4^{* * *}$ & 0.0002 & 0.2632 & 0.0874 & $0.6098^{* * *}$ & 0.0003 & $0.35^{29}$ & 0.3028 \\
\hline Love & -0.0434 & 0.5807 & 0.0877 & 0.4028 & -0.0976 & 0.5117 & $-0.35^{29}$ & 0.0546 \\
\hline Anger & $0.4174^{* * *}$ & 0.0002 & $0.3158^{*}$ & 0.0431 & $0.6585^{* *}$ & 0.0033 & 0.1765 & 0.422 \\
\hline Unpleasantness & $0.4173^{* * *}$ & 0.0004 & $0.3684^{*}$ & 0.0299 & $0.6585^{* * *}$ & 0.0004 & 0.0000 & 1 \\
\hline Pride & $-0.095^{6}$ & 0.4026 & $0.05^{26}$ & 0.7636 & -0.1707 & 0.3602 & -0.4118 & 0.0895 \\
\hline Happiness & -0.1217 & 0.1086 & $-0.035^{1}$ & 0.7606 & -0.1707 & 0.1642 & -0.2941 & 0.0961 \\
\hline Shame & $0.2260^{*}$ & 0.0392 & -0.0877 & $0.5^{199}$ & $0.5854^{* *}$ & 0.0017 & 0.41176 & 0.262 \\
\hline Fear & $0.2434^{*}$ & $0.025^{2}$ & $0.035^{1}$ & 0.802 & $0.5854^{* *}$ & 0.0029 & 0.1176 & 0.7073 \\
\hline Sadness & $0.5304^{* * *}$ & $5.23^{\mathrm{E}-\mathrm{o}} 5$ & $0.5965^{* *}$ & 0.0025 & $0.5854^{* * *}$ & 0.0071 & 0.1764 & 0.5479 \\
\hline Pleasantness & $-0.2086^{*}$ & 0.0319 & -0.1228 & 0.3825 & -0.1463 & 0.3366 & $-0.6470^{*}$ & 0.0226 \\
\hline Arousal & $0.6173^{* * *}$ & $8.45^{\mathrm{E}-09}$ & $0.7544^{* * *}$ & $2.39 \mathrm{E}-07$ & $0.6829^{* * *}$ & 0.0002 & 0.0000 & 1 \\
\hline $\begin{array}{l}\text { Monument } \\
\text { promotes values } \\
\text { in accordance } \\
\text { with my values }\end{array}$ & 0.1391 & 0.1381 & $0.2807^{*}$ & 0.0410 & 0.0488 & 0.6431 & -0.1176 & 0.7498 \\
\hline $\begin{array}{l}\text { Monument } \\
\text { inspires me to } \\
\text { promote my } \\
\text { identity and } \\
\text { values }\end{array}$ & $0.1826^{*}$ & 0.04775 & 0.211 & 0.1591 & 0.1951 & 0.1031 & 0.0588 & 0.8167 \\
\hline $\begin{array}{l}\text { Monument } \\
\text { inspires me to } \\
\text { question my } \\
\text { identity and } \\
\text { values }\end{array}$ & $0.05^{217}$ & 0.6192 & 0.0175 & 0.9105 & $0.195^{1}$ & 0.198 & -0.1765 & 0.593 \\
\hline $\begin{array}{l}\text { Behavioural } \\
\text { tendency: deinstall } \\
\text { the monument }\end{array}$ & -0.0956 & 0.2506 & $-0.2281 *$ & 0.0313 & $0.073^{2}$ & $0.5^{8} 38$ & -0.0588 & 0.8484 \\
\hline $\begin{array}{l}\text { Behavioural } \\
\text { tendency: keep } \\
\text { and promote the } \\
\text { monument }\end{array}$ & $0.2347^{*}$ & 0.01947 & $0.315^{*}$ & 0.01297 & 0.2439 & 0.1242 & -0.0588 & 0.8784 \\
\hline
\end{tabular}


TABLE 12.6 An illustration of the effects after the speeches by Milanović, Vukić, and Vučić as measured by $t$-test. The effects are the difference in the mean values of the psychometric five-point Likert scale for each feature, before and after the speech. The green bars represent effects in the Milanović group, red bars in Vukić's and gray ones in the Vučić group.

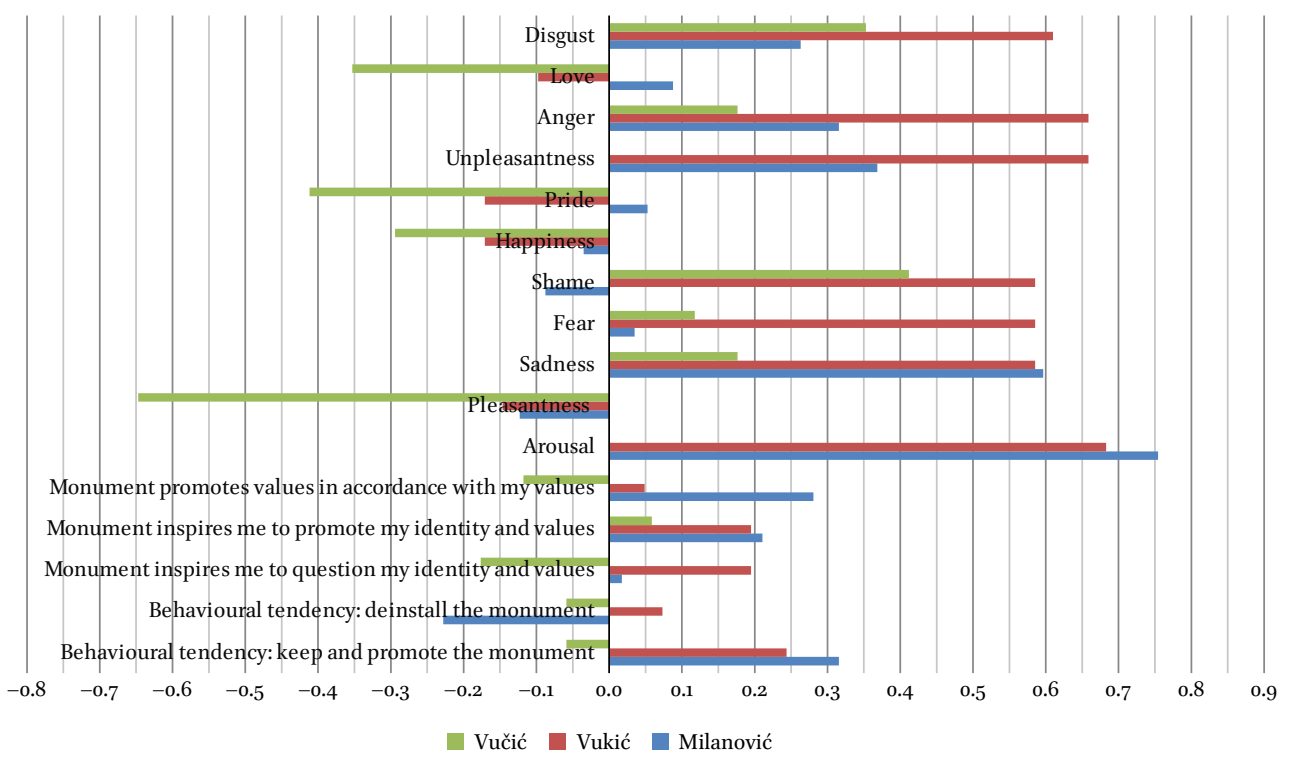

The results show the greatest and statistically significant increase in the emotional dimension of arousal and negative hedonic valence ${ }^{54}$ in three groups: unpleasantness (Tables 12.7 and 12.8), sadness (Tables 12.7 and 12.8), anger (Tables 12.7 and 12.8), fear (Table 12.8) and disgust (Table 12.8). This difference is on a scale of $0.4-0.7$ of a five-point Likert scale. This could be interpreted that, on the average, the effect of the talk was to raise arousal and negative valence by almost $15 \%$. The highest increase in these negative emotions is generated in the Vukić group implying that the revisionist message stimulated a feeling of unease, fear and repulsion, as exemplified by the statement from one of the subjects in this group (8):

8) sve izjave govornika su pobudile ljutnju

'All statements aroused anger.'

54 The ability to experience pleasant or unpleasant feelings, or to represent objects as 'positive' or 'negative', is known as representing hedonic 'valence.' 
The low arousal, negative emotion of sadness also prominently increased in all groups (Tables 12.7 and 12.8), although slightly less in the Vučić group. This difference could be due to the Vučić inability to induce emphatic discourse with his predominantly Serbian nationalistic message, as stated from the questionnaire (9):

9) hrvati su ubijali srbe u jasenovcu. oni su i dalje tu i napreduju.

'Croats killed the Serbs in Jasenovac. They are still here and continue to advance.'

In all groups the positive hedonic valence, pleasantness (Illustration 8) and happiness, decreased. The greatest negative tendency of these emotions is recorded in the Vučić group. This is probably related to the vivid depictions of the atrocities committed in Jasenovac. This is corroborated by speech observation by one of the participants in the Vučić group (10):

10) smrt, teror, ubijanje djece

'death, terror, killing of children'

It is interesting that socially complex emotions, such as pride, shame (Table 12.9) and love, have a different type of directionality in the three groups, showing more correlation with the cognitive models of self-appraisal and social standards.

The negative emotional category of shame tended to decrease after Milanović's speech. This can be seen as one of the intended effects of the commemorative ritual, related to Milanović's conceptualization of Jasenovac as a site of traumatic but transformational memory, connected with the liberation of the camp by the victorious antifascist army and the overthrow of the Ustaša regime (see example 3). The increase of the pride and love dimensions in the Milanović group can be attributed to the same kind of successful conceptualization of the traumatic history and reinforcement of these positive humanistic values in the present that are seen as congruent with self-identity and social values, and the reestablishment of one's identity.

On the other hand, shame tends to increase while love and pride decrease in the Vukić and Vučić groups. The effect of shame dimension in the Vukić group is especially prominent with a statistically significant increase over $0.5^{8}$ in terms of the five-point Likert scale, or $12 \%$. This can be interpreted as the psychological effect of how Vukić construes the Jasenovac narrative from a revisionist position that tends to highlight the two conflicting cultural models of Croatian identity: a nationalist model and an antifascist model. Both of those 
models have been imbued with atrocities committed during the Second World War or during the communist regime. This type of framing and conceptual focus on the rivaling models of the national history correlates with the decrease of pride.

The tendency to positively correlate symbolic representation of the Jasenovac monument and one's own moral values increases slightly for the Milanović group ( 0.28 or $5.6 \%)$ (Table 12.7). This is probably related to Milanović's profiling of the victorious antifascist history and progressive values that resonated with the subjects. On the other hand, questioning one's identity and values tends to be related more with the Vukić group. Vučić's depiction of theUstaša atrocities in Jasenovac seems to have effects on inhibiting identification of the monument with one's values and identity, as well as decreasing rational inquiry of the self-values and social norms.

The behavioural tendencies follow from the affective appraisal process. The Milanović group has a statistically significant increase in tendencies to keep and promote the monument ( 0.3158 or $6 \%)$. This is also observed in the Vukić group. The Vučić group, however, demonstrated a significant decrease of pleasantness and pride, as well as anincrease of shame and fear, resulting in a slight decrease of the tendency to keep and promote the monument. However, it is interesting that, although statistically not significant, the behavioural tendency to dismantle the monument was also heightened in the Vukić group. This small effect can be attributed to the accepted revisionism of the Vukić conceptualizations, but also a statistically significant increase of shame, fear, disgust and unpleasantness (Table 12.8).

In summary, the aggregate data set (Table 12.10) demonstrates that political speeches generated the largest effect size in the affective dimension

TABLE 12.7 Statistically significant effects sizes after Milanovićs speech.

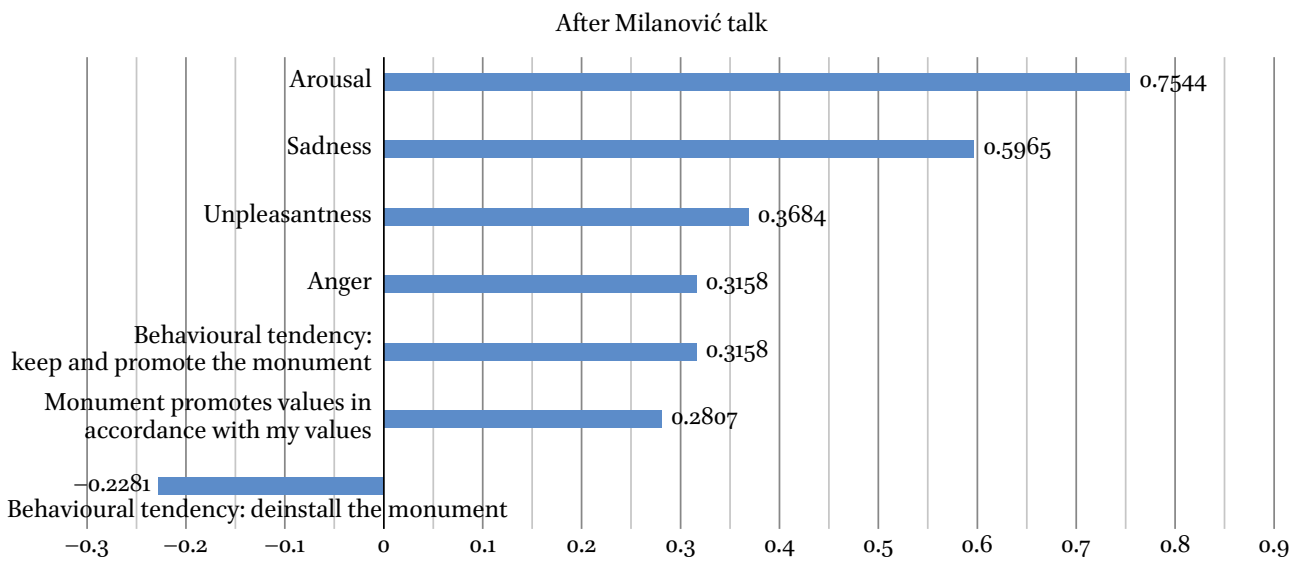


TABLE 12.8 Statistically significant effects sizes after Vukić's interview.

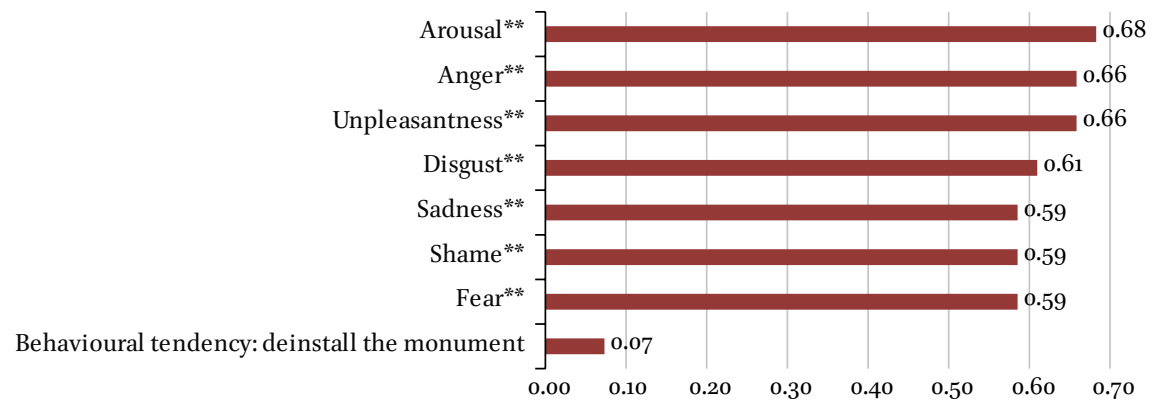

TABLE 12.9 Statistically significant effects sizes after Vučić's speech.

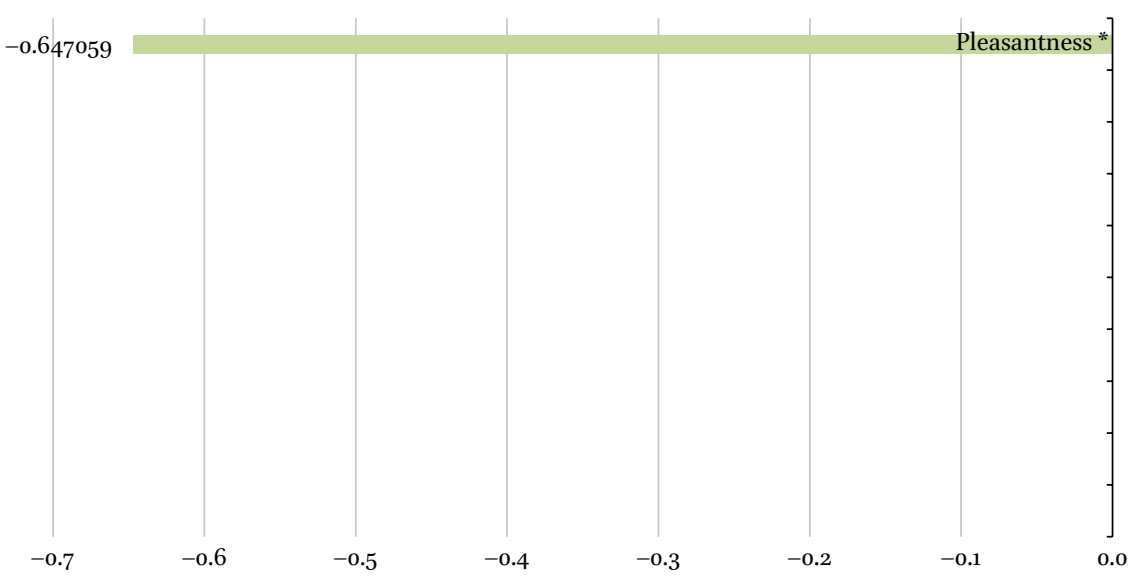

TABLE 12.10 Statistically significant effects sizes after the speeches for the aggregate data set.

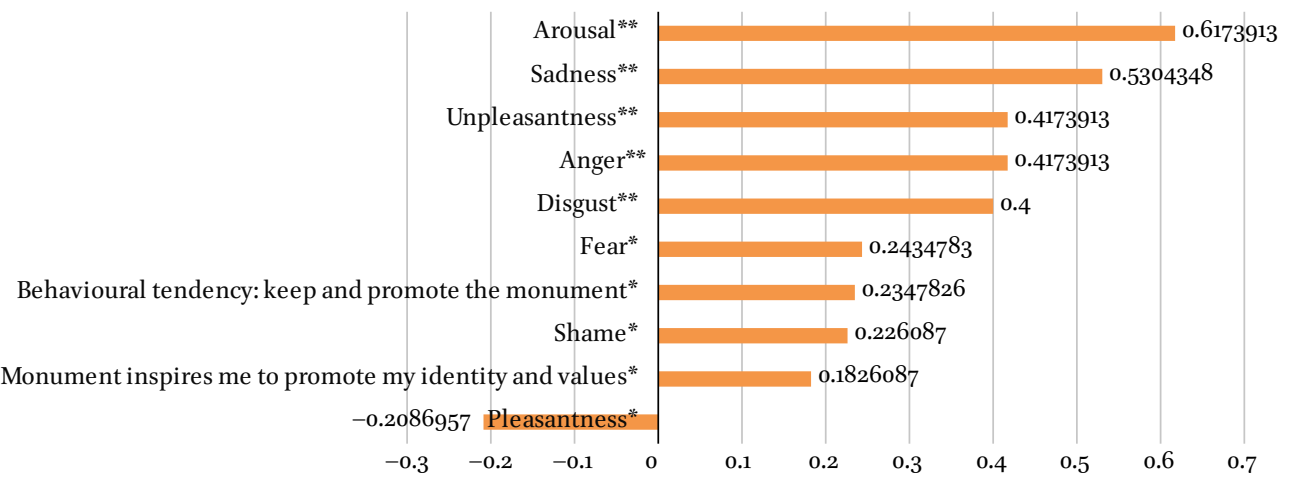


of arousal. Although qualitatively not discriminative, the value of affective arousal is correlated toactivating attention, regulating consciousness and information processing. ${ }^{55}$ The activation of attention is a key factor for the successful transmission of cultural memory, especially its transgenerational dynamics. In other words, if an event does not arouse any affective load, it is likely to be forgotten in the next generation. It can be argued that commemorative rituals have a function to capture the attention of audiences by heightening the affective dimension of arousal. The most common means of creating arousal in traumatic commemoration sites such as Jasenovac is by reconstructing vivid depictions of atrocities. Particularly Vučić, and to a certain extent Milanović, exploited these constructive strategies in their speeches, while Vukić tried to reconceptualize the prototypical Jasenovac representation by introducing the images of a safe childhood within the scenery of an alleged work camp.

The arousal is also correlated with the increase of different emotions. Not surprisingly, the effects of the commemorative speeches were to increase sadness, unpleasantness and intrinsically negative emotions such as disgust, anger, fear and shame. The effects of increased sadness can be interpreted as the measure of the intensified participant's empathy with the victims of the camp. The activation of anger and fear is especially important because of their capacity to motivate reasoning about implications and coping strategies. In our experiment we have deliberately chosen speakers that construed different causal configurations in relation to the traumatic events and implicated different type of rationalizations to channel coping with these negative feelings. Motivation and coping are an important link to framing and establishing different cultural models and social norms. The significant increase of sadness is related to successful conceptualization of the traumatic events, usually elaborated in vivid metonymic and metaphoric expressions that enable receivers to mentally recreate the distress in an embodied manner. Lastly, the contextual conceptualizations promoted the tendencies to keep the monument, implying that their symbolic significance regained new meaning.

55 The relation between arousal and attention has been the subject of extensive research in psychology. See Eysenck Michael, Attention and Arousal: Cognition and Performance (Springer Science \& Business Media, 2012); A. Hunter and J.D. Eastwood, J.D., "Does state boredom cause failures of attention? Examining the relations between trait boredom, state boredom, and sustained attention," Exp Brain Res (2016), 1-10. The CPM theory by Scherer also indicates the correlation of appraisal of relevance and attention. 


\section{Conclusion}

In this chapter we have presented a study intended to experimentally measure the psychological impact of political talks on the affective engagement and conceptualization of the collective remembrance site Jasenovac, symbolically represented by its monument. The Jasenovac site was chosen as a contested commemoration site that political agents use to construct narratives of the Croatian national past, inscribing new meanings into cultural memory through their commemorative rituals. We conducted an experiment with 126 participants and devised qualitative and quantitative methodology to empirically examine their reception of the political ritual uses of Jasenovac memory sites. The three groups of participants were exposed to the image of the Jasenovac monument and then political speeches by three memory agents (Milanović, Vukić and Vučić), all of whom are pushing different narratives about the concentration camp.

The structure of the emotional features reveals somewhat expected distribution for a commemoration event with sadness and unpleasantness in the upper ordinal range and happiness in the lower end. The results of the effect size show the greatest increase in the emotional dimension of arousal, unpleasantness, sadness, anger, fear and disgust. The range $0.4-0.7$ of a five-point Likert scale or almost $15 \%$ effect size for these important features indicates that the commemorative speeches have increased attention, motivation and reasoning about the implications of the commemoration for the national cultural model, which is one of the most important functions of commemorative rituals.

The qualitative textual analysis of political speeches and participant's observations identified narrative strategies of different speakers to construe the cultural memories of this contested memory site. The semantic analysis of responses revealed that effective inter-subjective communication of emotional qualities involved the use of embodied metonymic and metaphoric conceptualization that influence the behavioural tendencies and appraisal of the participant's self and social values. In accord with embodied cognition theory, we argue that affective and cognitive engagement elicited by the memory actors and their narrative practices are important in consolidating, reevaluating and renegotiating cognitive models, values, social identities and cultural memory. With the frequent reinforcement of the message in the media we can hypothesize that effects of this process create culturally distributed collective memory.

Due to the experimental research conditions, the effect sizes are to be taken as tendencies and not as absolute values. We can presume that direct involvement in the commemoration rituals would result in deeper 
psycho-sociological impact due to the more elaborated context. Nevertheless, this study indicates that the dynamics of a cultural memory transmission is correlated with the level of affective and cognitive engagement of the recipients. It also shows the functions of the conceptualizations activated by the memory agents in their speeches for the construal and appropriation of a cultural model and permeating the monument with new symbolic meanings.

The data we gathered enables us to seek even more correlations of dependent variables with other independent variables of age, sex, nationality and education, as well as to perform a qualitative study of the significant linguistic strategies of recreating affective engagement from the perspective of memory transmission and reception. In the future we plan to broaden the pool of respondents, including regional diversity, political orientation and age groups.

\section{Bibliography}

Assmann, Jan. Kulturno pamćenje, trans. by Vlahidin Preljavić. Zenica: Vrijeme, 2005.

Barsalou, L. "Grounded Cognition," in Annual Review of Psychology 59 (2008).

Deverić, Mišo and Fumić, Ivan. Hrvatska u logorima, 1941-1945. Zagreb: Savez antifašističkih boraca i antifašista Republike Hrvatske, 2008.

Fontaine, Johnny R.J., Scherer, Klaus R., and Soriano, Cristiana, eds. Components of emotional meaning: A sourcebook. Oxford: Oxford University Press, 2013.

Frank, Roslyn M. "A future agenda for research on language and culture" in The Routledge Handbook of Language and Culture, edited by Farzad Sharifian, 493-512. London: Routledge, 2015 .

Goldstein, Slavko. 1941. Godina koja se vraća. Zagreb: Novi Liber, 2007.

Goldstein, Slavko. Jasenovac: tragika, mitomanija, istina. Zagreb: Fraktura, 2016.

Grahek Ravančić, Martina. Bleiburg i križni put 1945. Zagreb: Hrvatski institut za povijest, 2009.

Halbwachs, Maurice. On Collective Memory. Trans. by Lewis A. Coser. Chicago: University of Illinois Press, 1992.

Hoare, Marko Attila. Genocide and Resistance in Hitler's Bosnia: The Partisans and the Chetniks, 1941-1943. Oxford: Oxford University Press, 2006.

Horvat, Ivan, Vukić, Igor, Pilić, Stipo and Matković, Blanka. Jasenovački logori: istraživanja. Zagreb: Društvo Jasenovački logori, 2015.

Jambrešić-Kirin, Renata. "Politička sjećanja na Drugi svjetski rat u doba medijske reprodukcije socijalističke culture," in Lada Čale Feldman and Ines Prica, eds. Devijacije i promašaji: Etnografija domaćeg socijalizma. Zagreb: Institut za etnologiju i folkloristiku, 2006. 
Jovičić, Nataša. "The Alchemy of the Flower," in Tea Benčić Rimay, ed.Jasenovac Memorial Site. Jasenovac: Spomen-područje Jasenovac, 2006.

Karge, Heike. Sećanje u kamenu - okamenjeno sećanje? Trans. Aleksandra Kostić. Belgrade: XX vek, 2014

Kertzer, David I. Ritual, Politics, Power. New Haven: Yale University Press, 1998.

Kirn, Gal . "A Few Critical Notes on the Destiny of the Yugoslav Partisan Memorial Sites in the Contemporary, Post-Yugoslav (Croatian) Context," in Nataša Ivančević, ed., Vojin Bakić: Lightbearing Forms - A Retrospective. Zagreb: Muzej suvremene umjetnosti, 2013.

Kirn, Gal and Burghardt, Robert. "Jugoslovenski partizanski spomenici: Između revolucionarne politike i apstraktnog modernizma," in Jugolink, 2,1 (2012).

Lakoff, George. Moral Politics: What Conservatives Know that Liberals Don't. Chicago, Ill.: University of Chicago Press, 1996.

Lakoff, George. The Political Mind: A Cognitive Scientist's Guide to Your Brain and Its Politics. New York: Penguin Books, 2009.

Lončar, Duško. Deset godina spomen-područja Jasenovac. Jasenovac: Spomen-područje Jasenovac, 1977 .

Mataušić, Nataša. 2003. Jasenovac 1941-1945. Zagreb: Kameni cvijet.

Mataušić, Nataša. 2006. “The Jasenovac Concentration Camp," in Tea Benčić Rimay, ed. Jasenovac Memorial Site. Jasenovac: Spomen-područje Jasenovac.

Pavlaković, Vjeran. 2010. "Deifying the Defeated: Commemorating Bleiburg since 1990," in L'Europe en Formation, No. 357.

Pavlaković, Vjeran. "Contested Pasts, Contested Red-Letter Days: Antifascist Commemorations and Ethnic Identities in Post-Communist Croatia," in Ljiljana Šarić, Karen Gammelgaard, and Kjetil Ra Hauge, eds., Transforming National Holidays: Identity Discourse in the West and South Slavic Countries, 1985-2010. London: John Benjamins Publishing, 2012.

Pavlaković, Vjeran. "Symbols and the culture of memory in the Republika Srpska Krajina," in Nationalities Papers, 41, 6 (2013).

Pavlaković, Vjeran. "Fulfilling the Thousand-Year-Old Dream: Strategies of Symbolic Nation-building in Croatia”, in Pål Kolstø, ed., Strategies of Symbolic Nation-building in South Eastern Europe. Farnham: Ashgate, 2014.

Pavlowitch, Stevan K. Hitler's New Disorder: The Second World War in Yugoslavia. London: Hurst \& Company, 2008.

Perak, Benedikt, Puljar D’Alessio, Sanja. “Kultura kao emergentno svojstvo otjelovljene spoznaje”, in Fanuko, Nenad i Puljar D’Alessio, Sanja (eds.) Avanture kulture: kulturalni studiji u lokalnom kontekstu. 77-108. Zagreb: Jesenski i Turk, 2013.

Radvansky, Gabriel A. and Zacks, Jeffrey M. Event Cognition. Oxford: Oxford University Press, 2014. 
Radonić, Ljiljana. "Univerzalizacija holokausta na primjeru hrvatske politike prošlosti i spomen-područja Jasenovac," in Suvremene teme, 3,1 (2010).

Ramet, Sabrina P., ed. The Independent State of Croatia, 1941-45. London: Routledge, 2007.

Rimay, Tea Benčić, ed. Jasenovac Memorial Site. Jasenovac: Spomen-područje Jasenovac, 2006.

Scherer, Klaus. "Emotions are emergent processes: they require a dynamic computational architecture" in Philosophical Transaction of the Royal Society, 364 (2009): 3459-3474.

Sharifian, Farzad. "Cultural linguistics", in Farzad Sharifian, ed., The Routledge Handbook of Language and Culture. 473-492. London: Routledge, 2015.

Svob, Connie, Brown, Norman R., Takšić, Vladimir, Katulić, Katarina and V. Žauhar. "Intergenerational Transmission of Historical Memories and Social-Distance Attitudes in Post-War Second-Generation Croatians", in Memory \& Cognition 2016.

Tomasevich, Jozo. War and Revolution in Yugoslavia, 1941-1945: Occupation and Collaboration. Stanford: Stanford University Press, 2001.

Tuđman, Franjo. Bespuća povijesne zbiljnosti: Rasprava o povijesti i filozofji zlosilja. Zagreb: Nakladni zavod Matice Hrvatske, 1990.

Tuđman, Franjo. "The Sources, Changes, and Essence of the National Question in the Socialist Federal Republic of Yugoslavia," reprinted in Peter Sugar, ed. Eastern European Nationalism in the Twentieth Century. Washington, DC: American University Press, 1995 .

Žerjavić, Vladimir. Opsesije i megalomanije oko Jasenovca i Bleiburga. Zagreb: Globus, 1992. 


\title{
Transnational Holocaust Memory, Digital Culture and the End of Reception Studies
}

\author{
Wulf Kansteiner
}

Holocaust memory and memory studies have always been intertwined. In the 2oth century, Holocaust memory advocates and memory studies scholars shared enthusiasm for politics of regret. In the 21st century, they have to share the blame for allegedly fostering Euro-centrism. ${ }^{1}$ All along the way, the conceptual infrastructure of memory studies developed in large measure through scholarly analyses of emerging memories of the Final Solution. That applies first and foremost to concepts of transnational memory which are almost synonymous with Holocaust memory scholarship. ${ }^{2}$ The marriage made both empirical and ethical sense. Holocaust memory was one of the first fully-fledged transnational collective memories traveling around the Northern hemisphere in the form of attractive imagetexts and uniting publics from different countries in appreciation of similar media events. Moreover, Holocaust memory seemed to be an unequivocal mark of political progress, helping a formerly divided continent traverse the great distance from the depths of the world wars to peaceful and prosperous cooperation in the European Union. The transformation was particularly pronounced and tangible in (West) Germany where significant segments of society recalled the crimes of the Nazi period with sincere remorse and acknowledged the suffering of their former victims under the sign of Holocaust memory. ${ }^{3}$ Given such promising realignments, memory scholars quickly connected the dots. Negative heritage in the form of Holocaust memory appeared to be the perfect moral conduit for advancing a human rights agenda in the age of globalization. After a phase of catastrophic

1 Dirk Moses, “Conceptual Blockages and Definitional Dilemmas in the 'Racial Century:' Genocides of Indigenous Peoples and the Genocide," in Colonialism and Genocide, edited by Dirk Moses and Dan Stone (Routledge: New York, 2007), 148-180.

2 Chiara De Cesari and Ann Rigney, "Introduction," in Transnational Memory: Circulation, Articulation, Scales, edited by Chiara De Cesari and Ann Rigney (Berlin: DeGryuter, 2014), 1-25, 10.

3 Jeffrey Olick, The Sins of the Fathers: Germany, Memory, Method (Chicago: University of Chicago Press, 2016). 
self-destruction in the age of nationalism, the Western world seemed to have hit upon a formula for effective moral education based on natural affinities between the economic-political dynamics of late modernity and the similarly growth-oriented forces of mediatized self-reflexive memory culture. ${ }^{4}$ Consequently, many scholars in the burgeoning field of memory studies assumed that the blessings of Holocaust memory could work wonders in a wide range of settings, including in societies with little geographical or historical proximity to the events of the Final Solution. ${ }^{5}$

In the meantime, we have left behind the optimism of cosmopolitan memory. It has become clear that a given society can cherish Holocaust memory and yet intentionally engage in serious human rights violation. Or, depending on one's interpretation of US, Israeli and EU foreign policy, one could come to the even more depressing conclusion that the presence of a mature Holocaust memory regime enhances the risk for the illegitimate and unethical use of military force. So on second look it seems that the moral effects of official Holocaust memory are a rather complicated issue. First of all, official, statesponsored Holocaust culture might increasingly look the same all across the West but has nevertheless had different memory effects in different national and institutional settings. In matters of Holocaust remembrance cultural homogeneity hides a considerable degree of political diversity. Second, official Holocaust memory only seems to have become an important moral force in societies in which transcultural Holocaust narratives and iconography became a key reference point of national self-identification. In some national settings official Holocaust memory thus temporarily assumed a truly self-critical profile; in others settings it has always been a force of national self-promotion. Third, as official Holocaust memory has become a more clearly transnationally and transculturally constituted collective memory, upheld by transnational institutions and transnational carrier groups such as academics and memory professionals, it seems to have lost some of its ability to serve as truly self-critical moral compass. Finally, while these emplotments of the history of Holocaust culture appear perfectly plausible they are difficult to prove because we have only limited insights in the reception of Holocaust culture over the course of the last four decades.

There are good reasons to assume, for instance, that the invention of popular Holocaust memory in Germany in the 1970s and 1980s, accomplished with

4 Daniel Levy and Nathan Sznaider, The Holocaust and Memory in the Global Age (Philadelphia: Temple University Press, 20o6); see also Amos Goldberg and Haim Hazan (eds.), Marking Evil: Holocaust Memory in the Global Age (New York: Berghahn, 2015).

5 Jeffrey Alexander, "The Social Construction of Moral Universals," in Alexander et al., Remembering the Holocaust: A Debate (Oxford: Oxford University Press, 2009), 3-101. 
considerable trans-Atlantic input from Hollywood, has temporarily had truly self-critical effects in (West) German society. In fact, one might speak here of an example of cultural trauma, i.e., a mediated collective agreement among significant cross sections of society perceiving a lack of collective identity and purpose caused by the realization of the extraordinary crimes committed by Germans during World War II. ${ }^{6}$ In the meantime, that productive sense of empathic unsettlement has subsided. ${ }^{7}$ After a pivot point during the 1990s, unified Germany has regained a robust sense of pride anchored, for instance, in a widely shared belief in Germany's extraordinary accomplishments in the arena of memory politics. ${ }^{8}$ One should not be surprised by this turn of events, crafted once again with generous help from abroad. Societies seem to strive (naturally, one is tempted to say) to devise and re-tool strategies of collective remembrance for the purpose of collective self-praise. The resulting memory comfort zones might invoke stories of heroism, eternal victimization or memory championship but, social, political and psychological contexts permitting, they tend to alleviate rather than exacerbate feelings of unsettlement and trauma.

Despite a general yearning for uplifting memories, self-critical strategies of collective remembrance can and have travelled widely. The combination of indigenous self-critical inquiries into shameful wwII collaboration and the export of the (West) German model of Holocaust education has resulted in phases of more or less self-critical memory in many Western European countries, including the Netherlands, France, Belgium, Norway and Austria. ${ }^{9}$ But as the transnationalization of Holocaust memory has transformed the Final Solution from a national into a transnational historical event and the task of remembrance from a German into a European obligation, culminating in the adoption of Holocaust memory as a quasi-official foundational EU memory and civic religion in Stockholm in 2000, Holocaust memory has lost a great deal of the self-critical edge it possessed in some settings. ${ }^{10}$ The new perception of the Holocaust as a European human rights catastrophe with lots of blame to go around ended decades of German exceptionalism. With the German model

6 On the concept of Cultural Trauma see Jeffrey Alexander, Cultural Trauma: A Social Theory (Cambridge: Polity, 2012).

7 For the concept of empathic unsettlement see Dominick LaCapra, Writing History, Writing Trauma (Baltimore: Johns Hopkins University Press, 2014).

8 See for example Norbert Frei's polemic comments about the student movement's collective memory in Germany, "Zum erneuten Dienstjubiläum der 'Achtundsechziger': Generation Sündenstolz," Neue Züricher Zeitung, 3/8/2008. Roni Stauber (ed.), Collaboration with the Nazis: Public Discourse after the Holocaust (New York: Routledge, 2011).

Aline Sierp, History, Memory, and Trans-European Identity: Unifying Divisions (New York: Routledge, 2014), 123-136. 
of memory management embraced across the continent and historical responsibility spread on many shoulders, unified Germany assumed a leadership position commensurate with its political and economic heft. And once again Europe followed Germany's lead, turning self-critical into merely self-reflexive memory and, in the process, shifting focus from acknowledging past crimes and making amends to exhibiting and celebrating Europe's extraordinary willingness of acknowledging past crimes and making amends. ${ }^{11}$

Therefore, one should also not be surprised that institutionalized Holocaust memory never assumed much of a self-critical edge in communities spared the onus of perpetrator status or legacies of collaboration, as for example Israel and the Us. When survivors of the Final Solution for the first time stepped into the public limelight, in the context of the Eichmann trial in Israel, the full extent of their suffering and lack of recognition of that suffering after wwII caused a temporary sense of self-doubt in Israeli society. But even in a diverse memory culture such as Israel's, official Holocaust memory has been consistently and skilfully deployed as a political asset justifying the use of force and the violation of human rights. ${ }^{12}$ There is no indication, for example, that the civil religion of Holocaust memory enshrined at Yad Vashem helped Israelis understand the historical injustice of the Nakba and embrace policies of regret and restitution. ${ }^{13}$ In the same vein, the many public institutions of Holocaust memory in the us have complemented popular culture's happy memories of WWII as the good war, rendering it all the more difficult for mainstream us society to imagine its soldiers in the role of perpetrators despite ample evidence to the contrary. ${ }^{14}$ Celebrating the liberators of World War II seems to stand in the way of coming to terms with us war crimes past and present. In this context, one may also wonder about how precisely Holocaust memory and the memory of slavery intersect in us politics and culture. Has the rise of popular Holocaust memory, from the broadcast of the TV series Holocaust in 1978 to the inauguration of the Holocaust Memorial Museum (USHMM) in 1993, delayed

11 Bill Niven, "German Victimhood Discourse in Comparative Perspective," in Dynamics of Memory and Identity in Contemporary Europe, edited by Eric Langenbacher, Bill Niven and Ruth Wittlinger (New York: Berghahn, 2012), 180-194, 185.

12 Idith Zertal, Israel's Holocaust and the Politics of Nationhood (Cambridge: Cambridge University Press, 2005).

13 Ronit Lentin, Co-Memory and Melancholia: Israelis Memorialising the Palestinian Nakba (Oxford: Oxford University Press, 2010), 28; see also Jennifer Hansen-Glucklich, Holocaust Memory Reframed: Museums and the Challenges of Representation (New Brunswick: Rutgers University Press, 2014).

14 John Bodnar, The "Good War" in American Memory (Baltimore: Johns Hopkins University Press, 2010), 221. 
the official recognition for the traumas of slavery? After all, the dark heritage of slavery only attained a permanent memory presence on the National Mall in Washington D.C. when the National African History and Culture Museum (NAHCM) opened in September 2016. ${ }^{15}$ Or, was the presence of Holocaust memory, setting a precedent for negative remembrance, an indispensable precondition for the delayed development of an increasingly self-critical official memory of slavery? Put differently, was there never an option for a direct way from the media event Roots to NAHCM, without the detour through Holocaust and USHMM?

The comparison of Holocaust and slavery memories in the US illustrates the difference between self-reflexive and self-critical sites of memory. Collective memories are self-reflexive as a matter of course; they tend to explicitly address historical events from a given collective's real or imagined past and imbed them in patterns of interpretation integrating past, present and future into meaningful story lines. The stories come in different flavours and hybrids. They might feature largely positively connoted events integrated into positive narrative trajectories, as for instance the events of the American revolution as part of an uplifting history of Us democracy; ${ }^{16}$ negatively connoted events integrated into positive narrative trajectories, for example traditional recitations of Polish suffering as part of gratifying invocations of Polish resilience; ${ }^{17}$ or negatively connoted events integrated into stories expressing collective feelings of doubt and regret as during the first decade of Holocaust culture in West Germany. The last story type is most likely to produce self-critical sites of memory, posing probing questions about past failures and their ongoing relevance in an atmosphere of relative collective insecurity. ${ }^{18}$ Phases of cultural trauma offer opportunities to inquire into the causes of past crimes and address the all-important questions of if and how a given collective can prevent its members from becoming perpetrators (again). Self-critical memory deals with one's own crimes, not the crimes of others and targets the centre of an ingroup's symbolic sense of self. Self-critical memory pursues the question of what

15 Tonya Bolden, How to Build a Museum: Smithsonian's National Museum of African American History and Culture (New York: Viking, 2016); for the memory of slavery in the us see also Ron Eyerman, Cultural Trauma: Slavery and the Formation of African American Identity (Cambridge: Cambridge University Press, 2001).

16 Janice Hume, Popular Memory and the American Revolution (New York: Routledge, 2014).

17 Ewa Ochman, Post-Communist Poland: Contested Pasts and Future Identities (New York: Routledge, 2013).

18 See in this context Jörn Rüsen's typology of historical narration and especially his concept of critical narration, Rüsen, Historik: Theorie der Geschichtswissenschaft (Cologne: Böhlau, 2013), 213. 
illegitimate or immoral acts of violence are implicated in a group's cherished accomplishments. Consequently, self-critical memories thrive along vectors of passionate identification raising the intriguing question to what extent people around the globe feel themselves passionately involved in transnational concepts and practices of collective belonging. Transnational political institutions often appear to elicit at best lukewarm responses from its constituencies and therefore do not constitute promising arenas of self-critical memory politics. In this sense, it is, for instance, unrealistic to expect that a memory institution such as the House of European History will elicit powerful feelings about Europeaness, let alone be able to channel these feelings into decidedly self-critical memory trajectories. ${ }^{19}$ In fact, it might be altogether unrealistic to expect that the kind of media that ushered in Holocaust memory 35 years ago, i.e., television, film, museums and memorials, could still provoke passionate feelings in audiences steeped in interactive digital culture and living at a point in time when the remembrance of the Final Solution transitions from the dynamic realm of communicative memory to the settled realm of cultural memory. All in all, the deck is clearly stacked against Holocaust memory serving (again) any time soon as a truly self-critical site of memory. Generational, media historical and transnational dynamics of memory culture are likely to relegate Holocaust culture-as-we-know-it to the dustbin of cultural hagiography.

If Holocaust memory can be resurrected as an emotionally and politically relevant fixture of future memory culture it would have to be in the guise of immersive, simulative and possibly also counterfactual digital memory. Gaming culture, social media networks and digitally empowered academic exchange are the kind of cultural environments where Holocaust culture might get a second lease on life as a transnationally shared, passionately pursued and possibly also self-critically inflected memory practice. A selective glance at digital Holocaust culture suggests, however, that the new media of collective remembrance are often embedded in traditional power structures and that the more innovative environments raise intriguing questions about the thematic boundaries and collective subject positions of Holocaust memory. While Holocaust allusions abound in cyberspace and established institutions of Holocaust memory make ample use of digital technologies, Holocaust memory has simply not yet arrived in the digital age - if we identify as one of the key attractions of digital culture its ability to offer users the experience of captivating historical narrative worlds combined with the compelling illusion of being able to inflect the narrative trajectories of these worlds according to their own

19 Wolfram Kaiser, "Limits of Cultural Engineering: Actors and Narratives in the European Parliament's House of European History Project," Journal of Common Market Studies 55/3 (2017), 518-534. 
aesthetic predilections. Put differently, digitized Holocaust culture features a great deal more conservative remediation of analogue and electronic media contents, formats and communication patterns than one would expect or like to see given the fact that other segments of contemporary historical culture offer fully fledged immersive and interactive historical worlds. Moreover, in light of Holocaust culture's refusal to go fully interactive and simulative, it is difficult to imagine which groups might passionately embrace Holocaust memory as a key element of their collective sense of self let alone turn it into a site of rigorous self-criticism.

\section{Gaming the Holocaust Paradigm?}

The ritual has been played out on a number of occasions in recent years: somebody greedily, provocatively or courageously develops a Holocaust themed video game and is promptly pressured to abandon the project. In 2010, a group of Wolfenstein ${ }_{3} D$ modders, led by a young Israeli, developed a technologically crude Auschwitz revenge game loosely based on the 1944 uprising of members of the Auschwitz Sonderkommando who succeeded in killing three ss-guards and setting fire to one crematorium..$^{20}$ The game that the group worked on for over three years featured Nazi violence in the camp and then turned the tables on the torturers and had players in the role of Jewish inmates go on a killing spree of the Nazi camp personnel from a first-person-shooter perspective. ${ }^{21}$ The response came quickly after the release of a pilot. ${ }^{22}$ Representatives of the Wiesenthal Center and the Anti-Defamation League rejected the project because 'the Holocaust should be off-limits for video games'. ${ }^{33}$ Citing negative media attention and attendant emotional stress, the group cancelled the game

20 The uprising has been subject to various retellings; see the measured words in Nicholas Chare/Dominic Williams, Matters of Testimony: Interpreting the Scrolls at Auschwitz (New York: Berghahn, 2016), 6-7; and compare, for instance, to Leni Yahil, The Holocaust (New York: Oxford UP, 1990), 486.

21 Michael McWherto, "Concentration Camp Game Was Meant To Be Fun," Kotaku, 10 December, 2010, http://kotaku.com/5711317/concentration-camp-game-was-meant-tobe-fun. Accessed 21 October, 2016.

22 See the pilot and additional screen shots: "Sonderkommando Revolt Wolfenstein ${ }_{3} \mathrm{D}$ mod," last updated 13 December, 2010, http://www.moddb.com/mods/sonderkommandorevolt. Accessed 21 October, 2016.

23 Brian Crecente, "Anti-Defamation League Slams 'Fun' Holocaust Video Game as Horrific and Inappropriate," Kotaku, 11 December, 2010, http://kotaku.com/5712163/anti-defamation-league-slams-fun-holocaust-video-game-as-horrific-and-inappropriate, Accessed 21 October, 2016. 
weeks before its scheduled release date. ${ }^{24}$ Apparently, violent counterfactual Jewish revenge fantasies are intriguing and prize-worthy on the big screen in, for instance, Inglourious Bastards, but unacceptable in the allegedly low-brow cultural environment of video game coding and modding. ${ }^{25}$

A New York City indie programmer has had a similar experience with a very different kind of video game project. Since 2008, Luc Bernard has worked on Imagination is the only Escape, which is set in Nazi-occupied Paris and depicts the suffering of Jews from the perspective of a young Jewish boy. The game blends history and fantasy in an effort to produce visually and narratively sophisticated historical fiction about the Shoah and has received much advance praise from game critics. Nevertheless, Bernard could not find distribution venues and most recently also failed in his efforts to raise capital through a crowdsourcing initiative. ${ }^{26}$ For a video game designer it is clearly a bad career move to invest creative efforts and many months at the screen in crafting a Holocaust-themed virtual game environment. The situation is vaguely reminiscent of Holocaust scholarship in the 1960s when the few scholars trying to write the history of the Final Solution struggled with similar prejudices. ${ }^{27}$ Today, even big players in the huge and influential video game industry are only carefully inching closer to the taboo subject matter of Holocaust gaming. In this vein, the powerful Wolfenstein franchise, now owned by Bethesda Softworks, stepped into a fictitious Nazi concentration camp in its successful 2014 release of Wolfenstein: The New Order. In the counterfactual game set in the 196os after the Nazis have won wwII, Wolfenstein hero Blazkowicz infiltrates a Nazi camp to liberate a brilliant Jewish scientist. The short episode features provocative images including a female camp commander holding a

24 Riva Gold, “Designers Pull Plug on Auschwitz Death Camp RevoltVideo Game," Haartz.com, 26 December, 2010; http://www.haaretz.com/jewish/designers-pull-plug-on-auschwitzdeath-camp-revolt-video-game-1.333022. Accessed 21 October, 2016.

25 In 2009 the ADL, for instance, praised Inglourious Basterds as "an allegory about good and evil and the no-holds barred efforts to defeat the evil personified by Hitler, his henchmen and his Nazi regime. If only it were true," "ADL Statement on Quentin Tarrantino's 'Inglourious Basterds,", archive adl.org, 18 August, 2009, http://archive.adl.org/presrele/ holna_52/5585_52.html\#.V852dBRoU6U. Accessed 21 October, 2016; for a scholarly assessments of the movie's transgressive accomplishments see Robert Dassanowsky (ed.), Quentin Tarantino's Inglourious Basterds: A Manipulation of Metacinema (New York: Continuum, 2012).

26 "Imagination Is The Only Escape," Indiegogo.com, https://www.indiegogo.com/projects/ imagination-is-the-only-escape\#/. Accessed 21 October, 2016. 
baby upside down by its leg, whip at the ready, before the 'camera' swiftly cuts to another scene. ${ }^{28}$

Critics and gamers have identified a number of reasons for the Holocaust gaming taboo. Mainstream games with attractive graphics are expensive and therefore game developers tend to copy and fine-tune previously successful formats rather than launching radically new aesthetics and content matter. Moreover, a lot of fast-paced, action-oriented video game violence thrives on simple plot structures that seem to preclude the kind of complex narrative explanations scholars use to account for events like the Final Solution. Finally, the gaming industry lacks auteur figures such as Lanzmann, Spielberg or Tarantino who can more easily transgress limits of historical taste. Consequently, as Jeff Hayton has pointed out, 'medium, genre, and economics all work as inhibiting factors steering video games away from a sustained engagement with Nazism and the Holocaust. ${ }^{29}$ Last but not least, some of the key players of the Holocaust memory establishment cannot imagine how they could successfully transfer their didactic and political mission into simulative and interactive ludic digital environments and have therefore concluded that video games and their brand of genocide/human rights education are simply incompatible with each other.

Reservations about the compatibility of the medium video game with serious historical subject matter are not limited to Holocaust themes; they also exist with regard to other topics including $9 / 11^{30}$ and slavery. ${ }^{31}$ At the same time, video games have conquered the historical imagination of many players

28 Plygon, "The New Order shows you the horror of concentration camps from the first person," YouTube, 19 May 2014, https://www.youtube.com/watch?v = DbQ3H6lEWDE. Accessed 21 October, 2016.

29 Jeff Hayton, "Beyond Good and Evil: Nazis and the Supernatural in Video Games," in Monica Black/Eric Kurlander (eds.), Revisiting the "Nazi Occult:" Histories, Realities, Legacies (Rochester: Camden House: 2015), 248-269.

30 Consider for instance the $9 / 11$ virtual reality reenactment $08: 46$ based on a student project: DarkWolfLetsPlay, "08:46/9/11 Terrorist Attack Oculus Rift Game," youtube, 19 October, 2015, https://www.youtube.com/watch?v = vd2_j8dsOsM. Accessed 21 October, 2016; and see the helpful review by Adi Robertson, "The virtual reality $9 / 11$ experience is bad, but not for the reasons you'd expect," The Verge, 30 October, 2015, http://www.theverge .com/2015/10/30/964279o/virtual-reality-9-11-experience-empathy. Accessed 21 October, 2016.

31 "Slave Trade Video Game Edited After Backlash," Huffington post, 3 September, 2015, http://www.huffingtonpost.com/entry/slave-trade-game-edited-following-backlash _us_55e848gbe4bob7a9633bdc73. Accessed 21 October, 2015. 
as games with historical themes proliferate.$^{32}$ Moreover, as a result of the development of serious gaming during the last 15 years, video games now play a decisive role in government and corporate training, education, health care and public policy. ${ }^{33}$ The gaming community is very aware of this disconnect and some game critics have already concluded that the status quo in digital Holocaust memory is untenable. Given the cultural prominence of video games in general and games with historical themes in particular it amounts to a strange case of Holocaust denial in reverse that no sophisticated game about the topic yet exists. ${ }^{34}$ That way, the field is left wide open to dubious right-wing concoctions such as KZ Manager ${ }^{35}$ and, even more importantly, the medium's extraordinary didactic potential remains untapped. As prominent history game designer Brenda Romero has emphasized, due to their interactive nature 'games convey complicity like no other medium can. ${ }^{36}$ Therefore, they

32 Matthew Kappell/Andrew Elliott (eds.), Playing with the Past:Digital Games and the Simulation of History (New York: Bloomsbury, 2014); see also Daniel Kline (ed.), Digital Gaming Re-imagines the Middle Ages (London: Routledge 2014); Chris Kempshall, The First World War in Computer Games (New York: Palgrave Macmillian, 2014); Tobias Winnerling and Florian Kerschbaumer (eds.), Early Modernity and Video Games (Newcastle: Cambridge Scholars, 2014); and Nina Huntemann and Matthew Payne (eds.), Joystick Soldiers: The Politics of Play in Military Video Games (New York: Routledge, 2010).

33 For a definition and historical overview of serious gaming see Christian Loh, Yanyan Sheng and Dirk Ilfenthaler, "Serious Games Analytics: Theoretical Framework," in Serious Games Analytics: Methodologies for Performance Measurement, Assessment, and Improvement, edited by Christian S. Loh, Yanyan Sheng and Dirk Ifenthaler (Cham: Springer, 2015), 3-29; see also Ralf Dörner, Stefan Göbel, Wolfgang Effelsberg and Josef Wiemers (eds.), Serious Games: Foundations, Concepts and Practice (Cham: Springer, 2016); and Ute Ritterfeld, Michael Cody, Peter Vorderer (eds.), Serious Games: Mechanisms and Effects (New York: Routledge, 2009).

34 Eric Day, "Why We Don't Have a Holocaust Video Game and Why We Desperately Need One," overmental.com, 5 May, 2014, http://overmental.com/content/why-we-dont-havea-holocaust-video-game-and-why-we-desperately-need-one-1303; Luke K, "wwII Games: Where is the Holocaust," Critical Gamer, http://www.criticalgamer.co.uk/2011/01/17/wwiigames-where-is-the-holocaust/. Accessed 21 October, 2016.

35 "KZ Manager," Wikipedia, last updated 21 October, 2016, https://de.wikipedia.org/wiki/ KZ_Manager. Accessed 21 October, 2016.

36 Video game designer Brenda Romero cited in Kaveh Waddell, "A Video Game That Lets You Torture Iraqi Prisoners," theatlantic.com, 1 August, 2016, http://www.theatlantic.com/ technology/archive/2016/o8/a-video-game-that-lets-you-torture-iraqi-prisoners/493379/. Accessed 21 October, 2016. Romero is also the designer of the Holocaust board game Train: Dean Takashi, "Brenda Romero's Train board game will make you ponder," venturebeat. com, 11 May, 2013, http://venturebeat.com/2013/05/11/brenda-romero-train-board-gameholocaust/. Accessed 21 October, 2016; on agency in war games see Pat Harrigan, Matthew 
seem particularly well suited for having gamers intimately explore the experiences and decisions of people living in foreign worlds, including historical narrative worlds. And that intimate knowledge of past actors, may they be victims, perpetrators or bystanders, offers in principle great potential for self-critical memory politics. ${ }^{37}$

The disconnect between a burgeoning historical gaming culture one the one hand and the lack of state-of-the-art Holocaust gaming on the other hand turns video games into an important cultural arena illustrating par excellence Andrew Hoskins' perceptive remarks about the bifurcation of memory culture in an age of digitization. Hoskins identifies a clear division of 'two media/ memory cultures: one formalized, institutionalized, regimented (including online); the other more emergent, confrontational, yet fragmented.' Obviously, both spheres of social memory are closely intertwined and influence each other with the second, more fluid and emergent culture featuring a 'virality that undermines attempts to sanitise history. 38 For Hoskins the 'immediacy, mobility, flexibility and interactivity' of the new emergent memory is the result of digital hyperconnectivity and particularly pronounced in social networks and file sharing platforms. ${ }^{39}$ Due to its scale and speed the new memory problematizes the relationship between the hitherto stable cultural constructs of 'past' and 'present,' raises anxieties about people's ability to actively shape social memory, and prompts a rush to judgment that disrupts time-tested rituals for containing and forgetting potentially unsettling pasts. The gaming industry, focused on a few particularly profitable markets and dominated by two dozen companies, clearly belongs to the regimented memory culture. In the world of Tencent, Sony and Microsoft, the formal regimes of oblivion and containment, translated into effective processes of self-censorship, are clearly (still) functioning. That raises intriguing questions about digital Holocaust memory in the more fluid and flexible cultural digital contexts of social media and academia.

Kirschenbaum and James Dunnigan (eds.), Zones of Control: Perspectives on Wargaming (Cambridge, MA: Miт Press, 2016).

Adam Chapman, Digital Games as History: How Videogames Represent the Past and Offer Access to Historical Practice (New York: Routledge, 2016).

38 Andrew Hoskins, "The Right to be Forgotten in Post-Scarcity," in, The Ethics of Memory in a Digital Age: Interrogating the Right to be forgotten, edited by Alessia Ghezzi et al. (New York: PalgraveMacmillian, 2014), 50-64, 6o; see also Andrew Hoskins, "Digital Network Memory," in Mediation, Remediation and the Dynamic of Cultural Memory, edited by Astrid Erll and Ann Rigney (Berlin: De Gruyter, 2009), , 91-106. ity: A Critical History of Social Media (Oxford: Oxford University Press, 2013). 
In crafting an identity for itself, the emerging field of digital memory studies follows in the footsteps of other academic disciplines. The proponents of the new field highlight historical developments that cannot be successfully studied by existing scholarly strategies - namely the digital revolution with the instruments of traditional memory studies - and showcase a new set of intellectual tools better suited for the job at hand. ${ }^{40}$ In short, they expose the limits of an established intellectual world and build up a new conceptual infrastructure. On the deconstructive side, all the essential binaries of memory studies become subject to critical review because digital memory requires nothing less than radically 'changing the parameters of the who, what, when, and why of remembering."41 Digital memory no longer evolves along the individualcollective axis. In the post-broadcast era there is no collective to speak of, at least not in the way in which television used to aggregate consumers into audiences through narratives and media events. For the same reason, there are also no clearly identifiable private or public spheres. Participatory digital culture features active individuals constantly posting, editing, liking and linking in pursuit of fluid 'we's' and for the purpose of crafting and exhibiting an attractive self. That job requires an intimate, affective, and symbiotic relationship to digital technology and it is often the machine that dictates the rhythm of communication. ${ }^{42}$ As a result, transhuman entities do the remembering, requiring digital memory studies to leave behind the comfortable human-non-human divide. Since transhuman selves are immersed in expansive networks always in the state of becoming, digital memory also obliterates the conventional differentiation between archives and lived historical culture with serious consequences for the social construction of time. ${ }^{43}$ In fluid networks, audiovisuals of the present rub elbows with audiovisuals from the past, rendering impossible any collectively organized, self-reflexive process of balanced remembering and forgetting. In fact, the very distinction between past and present becomes flexible with transhumans living in an 'extended now', being unable to leave

40 Karen Worcman and Joanne Garde-Hansen, Social Memory Technology: Theory, Practice, Action (New York: Routledge, 2016), esp. 46-49; Ellen Rutten, Julie Fedor and Vera Zvereva (eds.), Memory, Conflict and New Media: Web Wars in Post-Socialist States (New York: Routledge, 2013); and Joanne Garde-Hansen, Andrew Hoskins and Anna Reading (eds.), Save As ... Digital Memory (Basingstoke: Palgrave Macmillan, 2009).

Andrew Hoskins, "The Restless Past: An Introduction to Digital Memory and Media," in Digital Memory Studies: Media Pasts in Transition, edited by Andrew Hoskins (New York: Routledge, forthcoming).

43 Wolfgang Ernst, Digital Memory and the Archive (Minneapolis: University of Minnesota, 2013). 
behind the ghosts of past humiliations and battling the dystopias of eternal memory, on the one hand, and technological obsolescence and instant memory death, on the other hand. ${ }^{44}$ These fluid, transhuman 'we's' circulate on many planes including transnational and transcultural planes but it is questionable if they also attain enough cultural and political stability to support the arduous process of self-critical remembering. It might take forceful memorial anachronisms such as cosmopolitan memory with its fictions of righteous permanence to launch effective challenges of existing memory regimes. However, for those questions to become relevant Holocaust memory would first have to leave the confines of formalised, institutionalized and regimented digital memory.

\section{Digital Holocaust Education: From the Pedestrian to the Radically Multi-directional}

Given the prominence of the education theme in Holocaust memory it is not surprising that websites of applicable institutions abound with teaching guidelines, online courses and lessons plans adapted to all kinds of curricular contexts. The UK's Holocaust Memorial Day Trust (HM DT) takes, for instance, great pride in 'offering a huge range of resources to educators' although the charity's line-up of teaching tools would be best characterized as numerous rather than diverse. ${ }^{45}$ The overarching theme of Holocaust Memorial Day 2016 was 'Don't stand by' and with that catchy title HMDT invited students and teachers to become creative and craft films, launch social media campaigns or plan a HMD event in support of all sorts of deserving causes, ranging from genocide education to battling sexism and LGBT prejudice. ${ }^{46}$ But previous year's proudly mentioned initiatives and especially the HMDT teaching resources released in support of the 'Don't stand by' theme focus quite narrowly on Holocaust history, encouraging students, for instance, to draw up a character map of a British Holocaust hero, contemplating a number of survivor testimonies or celebrating resistance activities during the Holocaust. ${ }^{47}$ In addition, the teaching

44 Martin Pogacar, Media Archeologies, Micro-Archives and Story-Telling: Re-Presencing the Past (Basingstoke: Palgrave Macmillan, 2016).

45 "For Educators," Holocaust Memorial Day Trust, http://hmd.org.uk/content/for-educators. Accessed 22 October, 2016.

46 "Don't Stand By: Holocaust Memorial Day 2016: What You Can Do," http://hmd.org.uk/ sites/default/files/HMD_files/dont_stand_by_-_final.pdf. Accessed 22 October, 2016.

"Don't Stand By: Holocaust Memorial Day 2016: Lesson Activity: British Heroes of the Holocaust," http://hmd.org.uk/sites/default/files/british_heroes_of_the_holocaust_ resource.pdf. Accessed 22 October, 2016; “HMD 2016: Lesson Plan: Didn't Stand By," 
tools lack interactive depth and ambition, consisting of text PDFs and short incoherent PowerPoint presentations. ${ }^{48}$ HMDT is not an outlier in this context. Most of the established institutions provide teaching resources that are conservative, predictable and uninspiring in content and form. ${ }^{49}$

There are exceptions - some problematic, others truly innovative. Yad Vashem's website features, for instance, an interactive learning environment that describes 'the ghettos during the Holocaust from the children's perspective, and attempts to present this complex experience in a way that is accessible to children. ${ }^{50}$ One might object to the naïve drawings and small scale of the visual learning environment. Yet the platform does present a wealth of visual and historical information in an accessible albeit only rudimentary interactive format. Nevertheless, as a lot of Holocaust products for young audiences, 'Children in the Ghetto' amounts to a strange type of Holocaust denial; the tool repeatedly identifies hunger as a serious problem in the ghettos but refrains from spelling out the consequences or detailing any other problems faced by the ghetto population. ${ }^{51}$ There are excellent reasons for such reticence. As Yad Vashem points out: 'The unsupervised exposure to Holocaust history at a young age may induce trauma in children and could possibly trigger strategies of distanciation and even feelings of resentment towards the topic. 52 The word of warning contains

http://hmd.org.uk/education/hmd-2016-lesson-plan-didnt-stand. Accessed 22 October, 2016; "Life Stories," http://hmd.org.uk/resources/life-stories. Accessed 22 October, 2016.

48 HMDT is currently developing a fully interactive digital teaching tool called HMDT Eteach, but a presentation of the pilot at the BAHS Conference in July 2016 did not reveal a particularly dynamic or innovative platform. Andy Fearn, "HмDт Eteach: A new interactive, multimedia resource to support educators in teaching effectively about the Holocaust and subsequent genocides," BAHS Conference 2016, UCL 7/20/2016.

"Teaching Resources", Holocaust Educational Trust, http://www.het.org.uk/teachingpack. Accessed 22 October, 2016; "The International School for Holocaust Studies: Education Materials," Yad Vashem http://www.yadvashem.org/yv/en/education/index.asp. Accessed 22 October, 2016; "Teacher Resources: Educating Hearts and Minds," Museum of Tolerance, http://www.museumoftolerance.com/site/c.tmL6KfNVLtH/b.5052463/k .AE91/Teacher_Resources.htm. Accessed 22 October, 2016.

"International School for Holocaust Studies: Learning Environments," Yad Vashem, http:// www.yadvashem.org/yv/en/education/learning_environments/index.asp. Accessed 22 October, 2016.

For children's books with similar problems see, for instance, Phoebe Eloise Unterman, Through Eva's Eyes (Kansas City: Landmark, 2009).

$5^{2}$ In October 2016, only the German version of the online game worked. Here the words of warning in the original German: "Die unbeaufsichtigte Beschäftigung mit dem Holocaust in einem jungen Alter kann zu einem Trauma bei Kindern führen, sowie zu Distanziertheit und in manchen Fällen sogar zu einem Gefühl der Feindseligkeit im Zusammenhang 
a strange list of risks implying inadvertently that a sense of resentment towards the topic constitutes as serious a problem as trauma. In this specific case, it is not the laudable search for the new digital teaching tools which constitutes a problem, but the troublesome race to the bottom of the teaching pyramid that seeks to expand the realm of Holocaust memory by enlisting younger and younger captive audiences, for instance by way of digital technology deemed particularly attractive to children. Initiatives such as 'Children in the Ghetto' illustrate that there might indeed be some hard limits of Holocaust memory. Faced with the self-fabricated dilemma of either falsifying history or traumatizing children, silence could be an excellent temporary option.

A second exception is the pathbreaking IWitness initiative of the USC Shoah Foundation. The project is truly remarkable because it hands over editorial power over cultural memory to teachers and high school students, teaching them basic film editing skills and providing them with extensive access to the Shoah Foundation's archive of Holocaust testimonies. The students are furthermore encouraged to enter their films in the yearly IWitness Video competition. The winning entries of 2016 powerfully demonstrate that the students, giving the choice, are ready to leave behind the history of the Holocaust. Time and again, the films take a short clip from survivor testimony out of its historical context and use it as a jumping off point to engage with pressing present-day concerns such as poverty, homelessness, mental illness, animal rights, self-help and human solidarity. ${ }^{53}$ In this way, Holocaust memory becomes a tangential concern subject to powerful multi-directional forces of reframing and forgetting. ${ }^{54}$ The results of the IWitness digital film initiative are not Holocaust memory as we know it and they also do not (yet) amount to fully emergent connective memories. They represent an interesting hybrid: broadcast memories produced by members of a post-broadcast generation. The results indicate that, in an appropriate communicative-didactive setting, handing over interpretive power to transhuman memory amateurs should give less cause for ethical concern than, for example, encouraging designated memory experts to craft Holocaust curricula for young children.

mit dem Thema," see “Die Internetseite 'Kinder im Ghetto:' Kommentare für Lehrer," Yad Vashem, http://ghetto.galim.org.il/ger/about/lessons.html. Accessed 22 October, 2016.

"IWitness Video Challenge: Top Videos by Groups - 2016," University of Southern California, http://iwitness.usc.edu/SFI/IWitnessChallenge/Winners.aspx?y = 2016. Accessed 22 October, 2016.

54 On the concept of multi-directional memory see Michael Rothberg, Multidirectional Memory: Remembering the Holocaust in the Age of Decolonization (Stanford: Stanford UP, 2009). 
At the same time, the Shoah Foundation has pursued ambitious transhuman experiments designed to retain power of interpretation for the institution. For a number of years, the most digitally advanced institution of Holocaust memory has been tinkering with Holocaust holograms. The developers combine visual testimony of survivors of the Shoah, taped over the last few decades, with highly sophisticated computer software. They hope to be able to stage captivating encounters between tomorrow's school children and the holograms of yesterday's survivors in which the ghosts from the past answer the children's questions in an interactive setting and an atmosphere of pious, intergenerational respect. ${ }^{55}$ The holograms of survivors are very good at mastering the past; in simulated conversation they seemingly spontaneously provide the details of their family histories, camp ordeals, survival strategies and postwar lives. But they cannot handle the present; don't ask them what they had for breakfast today. At some point during the communicative process, the ingenious hybrid of dialogical questions and monological answers breaks down. The holograms are a fantastic attempt to stem the tide of history and decelerate the historicization of Holocaust memory. Their creators certainly understand the stakes of Holocaust memory in today's rapidly changing demographic and media environment. The culturally constructed aura of the Holocaust survivors has been a crucial component of Holocaust education in the past decades..$^{56}$ For the future of Holocaust memory it is important that that aura gets a second lease on life or is replaced by a similarly attractive memorial focus. The holograms embody the insight that Holocaust survivors as we encountered them on TV or in video testimonies represent a media figure which should, in principle, be able to survive the biological deaths of the actual survivors.

It will be interesting to follow the careers of the holograms. If their developers and the protagonists of digital memory studies read contemporary culture correctly the holograms could become exoskeletal media stars. But it is also possible that the figure of the survivor, in its new digital disguise, does not attain the same media success that its analogue predecessor enjoyed on the TV

55 For a video demonstration see itc Graphics Lab's "New Dimension in Testimony USC ICT and SFI Classroom Concept," 8 February, 2013, http://www.youtube.com/ watch? = AnF63otCiEk. Accessed 24 October, 2016; see also Sophia Stuart, "How Natural Language Tech, Holograms Are Preserving Holocaust Testimony," pcmag.com, 8 April, 2016, http://www.pcmag.com/article/343452/how-natural-language-tech-holograms-arepreserving-holocaus. Accessed 24 October, 2016.

$5^{6}$ Jeffrey Shandler, While America Watches: Televising the Holocaust (Oxford: Oxford University Press, 1999); Oren Meyers, Eyal Zandberg and Motti Neiger (eds.), Communicating Awe: Media Memory and Holocaust Commemoration (New York: Palgrave Macmillian, 2014); and, more critically, Ann Rothe, Popular Trauma Culture: Selling the Pain of Others (New Brunswick, 2011). 
screens over several decades. In the past, the aura of the survivors depended on a specific media effect. The viewers had to be able to entertain the illusion that they could meet the survivors in their everyday lives and talk to them about the extraordinary past. Through small, seemingly insignificant markers such as clothing, speech, body language, lighting and background, the coverage conveyed a powerful sense of historical simultaneity. The words and images on the screen created an atmosphere of co-presence, placing survivor and viewer in the same time frame and social universe. ${ }^{57}$ But the holograms are no longer aesthetically and narratively embedded in the present-day social context of the observer. Despite their technological sophistication, the holograms cannot be effectively and continuously brought up to date; they might always carry small, yet pervasive markers of historical non-simultaneity. Therefore, they are perhaps unable to fulfil the shuttling-service between past and present that the mediated survivors of the TV coverage of the 1980s and 1990s accomplished on a regular basis. In the era of analogue and electronic media, nobody managed to invent media aesthetics that could prevent their own historicization, but perhaps that rule no longer applies in an age of hyperconnectivity. Either way, the holograms only amount to a clever simulation of true digital interactivity. Unless the holograms are released into the wild online, its 'dialogue' partners cannot challenge the holograms' memory, the conceptual or narrative frame of Holocaust remembrance or the emotional frame of intergenerational piety. In an institutional communicative triangle comprising tomorrow's school children, the digital ghosts of Holocaust survivors, as well as heritage professionals and software developers, power is concentrated in the hands of the representatives of the Shoah Foundation although it is difficult to determine if today's and tomorrow's school children also perceive of the distribution of power in this way.

\section{Facebook Broadcasting: 'Never again without Memory'}

The tension between regimented and emergent digital memories, i.e., between institutional authorial control and the consumers' desire to engage with history on their own terms and according to their own narrative/aesthetic preferences is even more pronounced on the social media front. In August 2016, the USHMM took the Olympic Games in Brazil as an opportunity to enlighten its

57 Wulf Kansteiner, "Macht, Authentizität und die Verlockungen der Normalität: Aufstieg und Abschied der NS-Zeitzeugen in den Geschichtsdokumentationen des ZDF," in Die Geburt der Zeitzeugen nach 1945, edited by Martin Sabrow and Norbert Frei (Göttingen: Wallstein, 2013), 320-353. 
150,000 followers via Facebook about the 1936 Berlin Olympics, reporting in a series of 15 entries about the partial exclusion of Jews and the denigration of black athletes by Nazi authorities. The posts generally elicited hundreds of likes, several dozen shares and a handful of comments each. They represent a routine flow of Facebook entries primarily based on information readily available in the Usнmm's Holocaust Encyclopedia and photo archives. Occasionally, the coverage was interrupted by more current concerns. The museum marked for instance 'the second anniversary of the beginning of the Islamic State's genocide of the Yezidi' (8/2) with the help of a poster of the Free Yezidi Foundation emphasizing that the UsHMM staff had already assembled a report on the matter. ${ }^{58}$ The PR tactic of trying to fit an ongoing genocide into an anniversary obsessed memory culture in order to have somebody pay attention to the Yezidi's plight did not trigger the desired reaction. Within three weeks the post elicited an underwhelming response of a total of 117 likes/sads/ angries, 62 shares, and only one comment, whose author referred to the Nazi precedent and pointed out 'that reports are great for documentation and later trial but ... overwhelming force and unconditional surrender are the only things that stop genocide. 59

The USHMM PR officers had more luck with an entry on 11 August, deploring the suffering of civilians in the besieged city of Aleppo, Syria. Carefully chosen phrasing ('these crimes could amount to genocide') were combined with a well edited, heart-wrenching video clip showing pictures of a hospitalized five-year old boy, a victim of a Syrian government attack, who later died of his injuries. ${ }^{60}$ The clip was viewed 158,525 times and with 1,105 shares proved to be the most successful entry of the month. The 145 lively comments are particularly intriguing, documenting multi-directional memory in action as commentators addressed the important questions of who is to be blamed for and what is to be done about the war crimes in Syria. Many users voiced massive frustration with government variously highlighting the failure of local and regional

58 In June 2016 the UN officially determined that Isis is committing genocide against the Yazidis: "UN Commission of Inquiry on Syria: ISIS is committing genocide against the Yazidis," United Nations Human Rights Office of the High Commissioner, 16 June, 2016, http://www.ohchr.org/en/NewsEvents/Pages/DisplayNews.aspx?NewsID = 20113\&LangID = E. Accessed 22 October, 2016; see also "UN: Yezidi 'genocide has occurred and is ongoing," Rudaw, 16 June, 2016, http://rudaw.net/english/middleeast/16o62016. Accessed 22 October, 2016.

59 USHмm's Facebook page, 2 August, 2016, https://www.facebook.com/holocaustmuseum/. Accessed 23 August, 2016.

6o USHmM's Facebook page, 11 August, 2016, https://www.facebook.com/holocaustmuseum/. Accessed 23 August, 2016. 
leadership in the Middle East, the flawed foreign policy of the us, and, more specifically, the particular responsibility of the Obama administration. The comments, overwhelmingly coming from the Us, run the gamut from rigorous self-criticism ('The us is very much responsible for this' ${ }^{61}$ ) to determined isolationism ('No sympathy!! America has our own problems'62). In this context, commentators also discussed immigration, offered prayers and time and again deplored the suffering of innocent children. Some comments are politically incorrect ('Ya lets replace another raghead countries leader it worked so good in iraq and libya ... idiots who gives a fuc they have been slaughtering each other for thousands of years' 63 ); others are difficult to interpret even when looking at the specific context of the post ('It's time for a Muslim genocide, emoij'64). It was a lively, at times contentious discussion containing hardly any comments dealing with Holocaust history.

The successful entry about Syria raises interesting questions about the relevance of historical precedent in political communication and the role of Holocaust institutions in shaping communicative memory. The subscribers of the Ushmm feed and their Facebook friends probably share a relatively strong interest in history, but the explicit historical references included in the comments deal with the very recent past; only two commentators create analogies to WwII history. The Nazi past does not appear to resonate strongly with USHMM followers trying to make sense of the war in Syria. Moreover and more important for our purposes, having successfully triggered a debate, the USHMM stays completely silent during subsequent discussions. Throughout the month of August 2016, USHMM only once responded to a commentator providing specific historical information. Otherwise it stayed above the Facebook flow and fray even when specifically prompted by its Facebook friends to respond or take a position. ${ }^{65}$ That passivity seems to reflect the general policy of the USHMM and other Holocaust institutions whose staff members prefer

61 Dennis Howard on Ushmm's Facebook page, 20 August, 2016, https://www.facebook .com/holocaustmuseum/. Accessed 23 August, 2016.

62 Overwatch Blizzard on Us Hмm's Facebook page, 22 August, 2016, https://www.facebook .com/holocaustmuseum/. Accessed 23 August, 2016.

63 Dan Gunner on ushmm's Facebook page, 20 August, 2016, https://www.facebook.com/ holocaustmuseum/. Accessed 23 August, 2016.

64 Dylan H. Brown on Us HMm's Facebook page, 21 August, 2016, https://www.facebook.com/ holocaustmuseum/. Accessed 23 August, 2016.

65 Ron Van Cleef: "Yes, this is terrible, but I am curious if the usнmm has condemned the us bombings of civilians in Syria, Afghanistan and other places?” on ushmm's Facebook page, 11 August, 2016, https://www.facebook.com/holocaustmuseum/. Accessed 23 August, 2016. 
one-directional communication, 'broadcasting' a carefully shaped, widely acceptable message via social media, but refusing to engage further and bring their considerable expertise to bear on the difficult moral questions of how to develop an appropriate communicative memory of war crimes and what political consequences to draw from that memory. The users, for that matter, appear to expect and accept this miscommunication, perhaps because they are not looking at institutions like the UsHmM for historical and political guidance. Apparently, they simply like to be part of the group and share its values. As one user puts it: 'amazing 1099 shares wonderful.'66 For many 'subscribers,' the USHMM Facebook page seems to be a cyberspace address where they can hang out with peers, pursue their genocide memory interests by adding a thoughtful facet to their virtual selves, and then return to their comfortable lives.

Put into more abstract terms, the Facebook feed of the Us нмм is the place where the carefully balanced, politically correct cosmopolitan Holocaust memory comes in direct, dysfunctional contact with the kinds of antagonistic and agonistic memories that pervade everyday life. ${ }^{67}$ In response to the Aleppo post, some subscribers yelled at each other in an antagonistic mode, a few engaged with each other's diverging opinions in a relatively respectful agonistic fashion, and often the entries simply coexisted in cyberspace without any discernable explicit communicative link. But none of the contributions managed to penetrate the communication barrier between the institution's settled, objectifying cultural memory of genocide and the users more fluid, emergent and opinionated exchange reflecting more or less firmly held positions and prejudices. The communication strategy of the UsнmM makes perfect sense. Like their professional colleagues across the globe in the business of Holocaust memory, the managers at the USHMM are heavily dependent on government subsidies and private philanthropy. They have a lot to lose and nothing to gain by politicizing their activities, because negative press coverage would alienate sponsors, endanger their business model and jeopardize the value of their brands.

But the purposeful depolitization of genocide memory has important negative consequences. In light of the USH MM's actual communication patterns the mission of official Holocaust memory 'never again genocide' is misleading. The multifold activities of the harbingers of official memory reflect communicative aims and practices that are best summarized as 'never again Holocaust/

66 Butch Allen Seals on Ushmm's Facebook page, 26 August, 2016, https://www.facebook .com/holocaustmuseum/. Accessed 23 August, 2016.

67 Anna Bull and Hans Hansen, "On Agonistic Memory," Memory Studies 9/4 (2016), 390-404. 
genocide without memory. The overwhelming share of their investigative and communicative efforts are not geared towards identifying countries/groups at risk, assembling preventive expertise and actions and lobbying aggressively for early intervention - that would fit the motto 'never again' which represents a vital argument in justifying their sizeable budgets. Rather, the activities are fabulously well suited for preventing the kind of black hole of Holocaust memory that existed roughly between 1945 and $1975 .{ }^{68}$ Institutions such as USHMM will never again waste the memory opportunities and memory obligations that present themselves during and after genocide but they are not sure how to address the arduous task of shaping political will to action. This understandable reticence occurs at a most unfortunate moment when transhumans and their parents, representing a wide spectrum of different media biographies, need to learn how to congregate into viable we's and launch politically relevant memory cultures.

\section{YouTube, Twitter and Genocide Prevention Efforts in an Academic Bubble}

The Usнm M's leadership appears to be very aware of the disconnect between genocide memory and genocide prevention and dedicates some of its resources to engage politicians and academics in genocide prevention outreach. Unfortunately, these efforts do not seem to accomplish the desired results. The us нмм has, for example, recently enlarged and re-calibrated its Center for the Prevention of Genocide in order 'to make the prevention of genocide a core priority for leaders and academics around the world through its multi-pronged program of research, education, and public outreach. ${ }^{69} \mathrm{On} 19$ May, 2016 the new centre staged a high-profile one-day event in pursuit of these lofty goals which was ambitiously entitled Partners in Prevention: A Global Forum on Ending Genocide and featured an impressive line-up of politicians, policy experts, NGO

68 On the evolution of Holocaust culture see for instance Rebecca Jinks, Representing Genocide: The Holocaust as Paradigm? (London: Bloomsbury, 2016); and Wulf Kansteiner and Todd Presner, "Introduction: The Field of Holocaust Studies and the Emergence of Global Holocaust Culture," in Probing the Ethics of Holocaust Culture, edited by Claudio Fogu, Wulf Kansteiner and Todd Presner (Cambridge MA: Harvard University Press, 2016), 1-42.

69 "Museum Announces \$20 Million Gift to Name the Simon-Skjodt Center for the Prevention of Genocide," Usнмм, 19 February, 2015, https://www.ushmm.org/information/ press/press-releases/museum-announces-2o-million-gift-to-name-the-simon-skjodtcenter-for-the-pr. Accessed 22 October, 2016. 
leaders and academics. ${ }^{70}$ The guests spoke eloquently about the challenges of genocide prevention, for instance with regard to the warning-to-response-gap. In that context, they identified a number of strategies to be pursued further and studied more closely, including the need to work together with local elites in identifying and containing potentially particularly violent militias ('militia mapping'). Coverage of the event was widely shared through social media but appears to have triggered no substantive responses. As of 28 August, 2016, the YouTube-clip of the panel about 'Bridging the Warning-to-Response Gap' uploaded on 24 May counted 13 views. ${ }^{71}$ The enthusiastic tweets sent out during the event by Usнмм social media coordinator Kai Frazier ('Packed house for \#USH Mm's \#PreventGenocide forum' and 'I so enjoy working with these two. \#UsHmm's@NaomiKikoler \& @Qattouby of \#Syria discussing how to \#Prevent Genocide $^{72}$ ) also elicited no response.

The tweets inadvertently highlight a perfectly normal yet troublesome divide. For academics and assorted experts, discussions about genocides past and present provide a memory comfort zone ('I so enjoy working with these two'). Through meetings and connected outreach coverage they validate each other's work in an atmosphere of competitive respect and sombre performances attesting to their caring disposition and intellectual control of the subject matter. At the same time that they are crafting self-affirmative memory aesthetics they are often quite critical of other, popular strategies of genocide aesthetization. The lack of self-reflexivity is nicely illustrated by Holocaust research initiatives in the thriving and rapidly expanding transcultural terrain of the digital humanities. In 2014, after several years of path-breaking research, a team of scholars published a volume entitled Geographies of the Holocaust, marking the arrival of the spatial turn in Holocaust studies. ${ }^{73}$ With the help of relatively large quantitative data sets, they raised and answered intriguing questions about the ghettoization process, the mass murder of civilians in occupied Eastern Europe, the arrest of Jews in wartime Italy and the expansion of the ss camp system in general and Auschwitz in particular. But in their

70 "Partners in Prevention: A Global Forum on Ending Genocide," ushmm, https://www .ushmm.org/confront-genocide/speakers-and-events/all-speakers-and-events/partnersin-prevention-a-global-forum-on-ending-genocide. Accessed 22 October, 2016.

71 That number had increased to 14 by October 2016, usнmм, "Bridging the Warning-toResponse Gap," https://www.youtube.com/watch?v=iDNshd6yOns\&feature=youtu.be. Accessed 22 October, 2016.

72 Kai M. Frazier, Twitter post, 24 May, 2016, https://twitter.com/hashtag/preventgenocide. Accessed 22 October, 2016.

73 Anne Kelly Knowles, Tim Cole \& Alberto Giordano (eds.), Geographies of the Holocaust (Bloomington: Indiana UP, 2014). 
enthusiasm for the innovative methods of spatial analysis and geovisualization the authors and the publishers included in the volume a number of beautifully rendered artistic illustrations and condensations of their quantitative analyses that inadvertently channel Nazi visions of living space and geographical control. ${ }^{74}$ Put differently, the book, like so many publications in the field of Holocaust history and Holocaust studies, fails to address and acknowledge the profound sense of unease that, pace Saul Friedlander, ${ }^{75}$ should help us address the troubling parallels between the perpetrators' worldview and genocidal projects and our attempts to render them explicable and meaningful in history and memory. Considered from this perspective, the bit maps of digital humanities Holocaust scholarship are the selfies of the academic world and, as visual products in an ironic twist of analogue-digital remediation, perfectly compatible with a Nazi point of view of the camp system and deportation network. All this is not surprising. As to be expected, the digital humanities in general and scholarly Holocaust digital culture in particular primarily serve the purpose of providing new venues for the pursuit and display of transnational expert culture. There is no reason to assume that the use of digital technology in historical research would automatically inspire scholars to develop a more self-critical and politically ambitious relationship to the past.

\section{From Electronic to Digital Media Reception Studies?}

The study of Holocaust culture, including the present essay, has always channelled wide-ranging assumptions about the use of memory culture, assumptions shared by many qualitative analyses in the field of memory studies. Countless research projects advance on the reasonably sounding premise that the content and structure of the memory products under discussion correlate with the communication experiences surrounding those products. That assumption is problematic because we simply do not possess or have not extensively analysed reception data that would exhaustingly document

74 Claudio Fogu, “A 'Spatial Turn' in Holocaust Studies?” in Probing the Ethics of Holocaust Culture, edited by Claudio Fogu, Wulf Kansteiner and Todd Presner (Cambridge MA: Harvard University Press, 2016), 218-239; see also "Interview with Anne Knowles, Tim Cole, Alberto Giordano, and Paul Jaskot," in in Probing the Ethics of Holocaust Culture, edited by Claudio Fogu, Wulf Kansteiner and Todd Presner (Cambridge MA: Harvard University Press, 2016), 240-256.

75 Saul Friedländer, Years of Extermination: Nazi Germany and the Jews, 1939-1945 (New York: Harper Perennial, 2009). 
correlations between media content, media aesthetics and media use. Media archives contain a wealth of quantitative usage data but they reflect powerful commercial and political interests and often only provide rather imprecise insights into actual audience behaviour. ${ }^{76}$ Moreover, we have generally only been able to retain fragmentary qualitative reception data about electronic or digital media usage which causes serious problems for the historical studies of TV audiences. As a result of these gaps, there is a great deal of research on media effects ${ }^{77}$ but we still lack information about key audience segments, for instance of the audiences of such pervasive genres as televised sports, crime dramas $^{78}$ and historical programming. Consequently, there are good reasons to assume that indifference, ironic use, and simply unpredictable vectors of reception are systematically underreported in available audience research. With hindsight and a little remediative conceptual imagination it appears likely that the predominant reception models used to make sense of audiences in the era of film and television reveal a great deal of information about scholarly assumptions informing these models without having been able to bridge the gap between implicit and real audiences. In addition, the field of media reception studies has for a long time operated with outdated conceptual frameworks focusing first on national audiences and then on individual agency, but lacking, for instance, sophisticated concepts for the study of global media audiences. ${ }^{79}$

The limits of audience studies are all the more frustrating since Holocaust culture began with an undisputed feat of media reception studies. When the NBC TV series Holocaust was broadcast on us prime time in April 1978 to public acclaim, more than 30 countries followed suit and laid the foundation to the type of transnational Holocaust memory with which we are familiar today. In Germany, the decision to purchase and broadcast the series was widely discussed for months before the series hit the screen in January 1979. The unusual public deliberations about public TV scheduling decisions gave German media and media scholars plenty of advance warning. As a result, viewers experienced an unprecedented wave of contextualizing media coverage of the

76 Jerome Bourdon and Cecile Meadel (eds.), Television Audiences Across the World: Deconstructing the Ratings Machine (New York: Palgrave Macmillian, 2014).

77 See for example Patrick Rössler (ed.), The International Encyclopedia of Media Effects (Walden: Wiley, 2017).

78 Matt Briggs, Television, Audiences and Everyday Life (New York: Open University Press, 2010), 2.

79 Adrian Athique, Transnational Audiences: Media Reception on a Global Scale (Cambridge: Polity, 2016). 
TV event and media scholars had a chance to prepare a similarly unprecedented state-of-the-art reception analysis of the docu-drama whose possible effects on German audiences was a point of great curiosity at home and abroad.80 The research subsequently proved that the carefully scripted event had indeed a remarkable short-term and possibly also decisive long-term impact on German collective memories of the Nazi period. $50 \%$ of the West German adult population had seen at least one instalment of the series and more than 10,000 viewers wrote letters or called the station giving voice to intense feelings of shock and shame at the extent and systematicity of Nazi judeocide. ${ }^{81}$ At a time when successful prime time history fare generated on average a few hundred viewer responses, Holocaust set a stunning record that has no parallel in the history of German television.

Unfortunately, the path-breaking research strategies of 1979 remained an isolated effort. Media scholars interested in gauging the relevance of mass media programming for the development of collective memories have to content themselves with the type of reception data that public television networks generate as a matter of course and have generally no access to the archives of private networks. As a result, TV's important contributions to the task of public remembrance have to be guesstimated on the basis of quantitative ratings, a historically dwindling number of professional reviews, a handful of inconsistently selected and archived viewer responses and the occasional case study conducted by researchers in the networks or their academic peers. Under those circumstances memory scholars have a tough time reconstructing communication processes initiated and reflected by TV. More specifically, they are largely prevented from documenting multidirectional use of historical TV coverage and forced to resort to the kind of unsophisticated interpretation of mass media data often encountered in the field of memory studies. Time and again, the narrative worlds of extraordinary media events are taken to reflect dominant trends of collective remembrance without proper attention paid to television seriality and routines, complex transnational and multi-media interactions, as well as actual reception processes. ${ }^{82}$

8 Claus Wilke, "Die Fernsehserie 'Holocaust' als Medienereignis," Zeitgeschichte-online, March 2004, <http://www.zeitgeschichteonline.de/md=FSHolocaust-Wilke>.

81 Yitzhak Ahrens et al., Das Lehrstück "Holocaust:" Zur Wirkungsgeschichte eines Medienereignisses (Opladen: Westdeutscher Verlag, 1982).

82 Just as guilty as everybody else in this regard: Wulf Kansteiner, In Pursuit of German Television: History, Television, and Politics after Auschwitz (Athens, он: Ohio University Press, 2006). 
The fields of memory and media studies face familiar problems and might repeat old mistakes as they try to gauge the role of digital media in the development of 21st century historical imaginations without good empirical data. ${ }^{83} \mathrm{On}$ the one hand, fragmented digital memories are probably more dynamic and diverse than collective memories in the broadcasting era. On the other hand, digital culture offers many more opportunities for externalizing memories, for instance in social media settings, and, in principle, memory politics could therefore be studied more systematically than previously possible. But the age of television and the era of digital memory differ in another important respect. Good qualitative TV reception data did not exist in the 2oth century and had to be created at considerable expenses by researchers inside and outside the networks. In contrast, memory researchers now face a truly perverse situation of abundance and radical inaccessibility. Digital communication network providers collect and aggregate unbelievably extensive and sophisticated data about their costumers' media habits for the purpose of improving network efficiency and selling network access to advertisers and content providers. In principle, these data allows unprecedented insights in the generation of historical consciousness because multi-platform consumption of historical content and explicit generation of historical interpretation can be recorded in unprecedented depth and breadth. For the network providers, individual media biographies and crowd tastes and reflexes are open books and, if the providers were so inclined, easily captured by existing algorithms. But that treasure trough is off limits for academic researchers who are carefully shielded from the business secrets of the industry and tied to the rules of privacy laws which place strict limits on the way available data can be used for research purposes, for instant, as a result of the sound principle of informed consent. From a scholarly perspective, the transition from nationally framed public TV networks, which belatedly provided access to its extensive production and reception records, to powerful commercial corporations, which sell web access and content on a transnational scale, represents a tragic turn of events. For better or the worse, the scholarly utopia of being able to watch and reconstruct the process of historical consciousness formation in great detail and perhaps even in real time will never come to pass. In that sense, comprehensive reception analysis of narrative historical worlds, a term that might have been a misnomer from the get-go because it structurally underestimated consumers' interpretive agency, appears now less realistic than ever before. Nevertheless, exciting research opportunities abound with regard to the impact of interactive and immersive digital memory and artificial intelligence on our historical imaginations. Some

83 Michael Gray, Contemporary Debates in Holocaust Education (New York: Palgrave, 2014). 
social media, for instance Twitter, are relatively accessible for researcher trying to capture interactive historical culture in action. ${ }^{84}$ Moreover, with the help of fairly straightforward digital research techniques, for example web analytics, researchers can generate interesting insights into the use of online historical information even without access to proprietary information of network providers. ${ }^{85}$ Last but not least, there is always the option of informed consent, i.e., of cooperating with consumers, for instance by tracking their engagement with historical data on mobile devices or by observing their adventures in immersive simulative gaming environments. The collective memories of the future, including the memories of war and genocide, will be generated in thoroughly interactive, immersive, and counterfactual narrative worlds - even if it will still be difficult for researcher to observe that process, reconstruct it after the fact and really understand reception processes.

\section{Conclusion}

Holocaust culture was invented in the era of analogue media. It is a creature of photography, film, radio, television, architecture and conventional museum aesthetics and was fully developed before the rise of digital culture. When Schindler's List was released in 1993 and the Holocaust Memorial Museum in Washington D.c. opened its doors in the same year, personal mobile phones and PlayStation did not exist. Despite its long analogue history, the cosmopolitan Holocaust memory of the new millennium is synonymous with digital technology. On a few occasions, Holocaust culture has even produced pathbreaking digital advances as in the case of the Shoah Foundation's database of 53,000 survivor testimonies which are turned into superior research and teaching tools through highly innovative search engines. ${ }^{86}$ But the rigid interpretive frame and carefully moderated distribution systems of cosmopolitan Holocaust memory render it incompatible with central elements of our digitized everyday life. Official Holocaust memory is professionally managed for the purpose of safeguarding the mission and long-term interests of the respective memory institution. In its current format, official Holocaust culture

\footnotetext{
84 Katrin Weller et al., Twitter and Society (New York: Peter Lang, 2013).

85 Richard Rogers, Digital Methods (Cambridge, MA: MIT Press, 2013).

86 Todd Presner, "The Ethics of the Algorism: Close and Distant Listening to the Shoah Foundation Visual History Archive," in Probing the Ethics of Holocaust Culture, edited by Claudio Fogu, Wulf Kansteiner and Todd Presner (Cambridge MA: Harvard University Press, 2016), 175-202.
} 
therefore represents an antithesis to the nimble, decentralized exchanges of opinions driving social media communication. Moreover, with its fear of counterfactual historical representations linked to concerns about Holocaust denial intrinsic to the field, official Holocaust culture is a particular hostile environment for cutting-edge simulative and immersive virtual reality technologies. As a result, connective, emergent digital Holocaust memories exist in some social media contexts, but not in the institutional settings designed to teach Holocaust and genocide memory. Official Holocaust memory is thus poorly prepared to participate in meaningful ways in the exciting recalibration of virtual, real and embodied experiences set into motion by digital culture and especially AI technology. ${ }^{87}$ In the important memory arena of Holocaust culture, formalized, regimented standards for the deployment of digital technology have hitherto prevailed.

The International Holocaust Remembrance Alliance (IHRA), founded in Stockholm in 2000, has nicely summarized reservations about social media shared by many Holocaust educators and Holocaust memory managers. As the IHRA explicated in its 2014 guidelines for the use of social media in Holocaust education: 'Trends such as Holocaust denial, diminishment and trivialization are rampant on the Internet and using social media has the potential to introduce these topics to students and give them unwarranted prominence.' Moreover, 'social media is typically seen as platform for entertainment - the purview of pop culture, not learning and intellectual debate. ${ }^{88}$ It is not clear from the document to what extent the IHRA shares these reservations. In my view, the authors of the guidelines fail to point out that the online presence of Holocaust denial should not be equated with its popularity. There is a significant degree of Holocaust-denial-phobia in Holocaust culture, some of it instrumentalized for fund-raising purposes. The distanciation from Holocaust entertainment contains a similarly disingenuous element. All Holocaust and Ns-history learning sites, including Yad Vashem, Auschwitz, Buchenwald or the Usнмм have great, more or less intentionally crafted thanatouristic entertainment potential - otherwise they would not be as popular as they are.

The problems lie elsewhere and should be more clearly and honestly addressed. Cosmopolitan Holocaust memory and emergent digital Holocaust culture (to the degree that the latter exists) represent different, competing types

87 See the interesting historicization of virtual reality cultures in Melanie Chan, Virtual Reality: Representations in Contemporary Media (London: Bloomsbury, 2014).

88 "Using Social Media in Holocaust Education," International Holocaust Remembrance Alliance, April 2014, https://www.holocaustremembrance.com/media-room/stories/newsocial-media-guidelines. Accessed 22 October, 2016. 
of history edutainment with the emergent culture featuring a wider spectrum of narrative scripts and much more dynamic, at times unpredictable vectors of interpretive power than its well-established predecessor. Fast-paced and unscripted discussions about the politics of memory in social media, often driven by a rush to judgment, can result in powerful temporary consensus in support of official Holocaust culture. But social media also facilitate multi-directional, volatile confrontations about important problems of interpretation that defy cosmopolitan Holocaust culture. A case in point is the multi-voiced discussion about genocide, Islamophobia, and us war crimes spontaneously and collectively crafted in response to the UsHmm Facebook feed about Syria discussed above. These kinds of discussions have significant politicizing potential but are generally systematically sidestepped by risk-averse Holocaust memory institutions eager to avoid political exposure. These discussions highlight a central dilemma of cosmopolitan Holocaust culture: One cannot successfully pursue the political objective of genocide prevention while strenuously trying to avoid political risk-taking. Genocide prevention requires political courage and that is in short supply in cosmopolitan Holocaust memory.

For related reasons, official Holocaust memory keeps a careful distance from the captivating virtual environment of video game culture, observing somewhat helplessly from the sidelines the rise of a paradigm of popular entertainment that threatens its business model and allegedly also its ethical raison d'etre. Video games facilitate a new quality of absorbing, shared immersion in narrative cultural worlds, including realistically shaped historical worlds, based on rapid multi-sensory input, ludic pleasure and a significant degree of narrative and especially spatial control. It is now technologically completely realistic to recreate virtually Nazi society according to our (scholarly) ideas of how that society functioned. Or, to put a finer point to it, we can bring to virtual, interactive life our interpretations of the extreme social universe of Auschwitz and/ or any of the 42,500 other Nazi camps that covered the continent of Europe. ${ }^{89}$ The virtual camp scenario constitutes a central representational taboo of contemporary Holocaust culture. That taboo has a lot to do with taste, power and the history of Holocaust memory - and it represents perfectly legitimate concerns about the political and ethical purposes that could possibly be served by breathing a second, virtual life into the hell that was Auschwitz. Most likely, these concerns do not represent any absolute limits of representation but reflect the limits of our present-day didactic-ludic imagination. We simply do

89 Eric Lichtblau, "The Holocaust Just Got More Shocking”, New York Times, 1 March, 2013, accessed 23 October, 2016, http://www.nytimes.com/2013/o3/o3/sunday-review/the-holocaust-just-got-more-shocking.html? src = me\&ref $=$ general\&_r $=1$. 
not yet know what lines of historical interpretation and corresponding game rules a virtual Auschwitz should embody so that the gamers immersed in that truthfully recreated and therefore extremely violent world would emerge from the game with a self-reflexive democratic historical consciousness. How can the act of releasing into the world algorithms for a virtual Auschwitz support a human rights agenda of inter-cultural respect and non-violence? However, putting those legitimate concerns into writing immediately holds up a critical mirror to our familiar, comfortable cosmopolitan Holocaust experiences. How did we ever assume that a historical culture that incessantly and compulsively circles around the dark holes of torture, mass death and extreme moral depravity serves those very same objectives? Does spelling out the dark holes in virtual detail really makes all that much of an ethical difference?

While we might not yet be able to design a good Auschwitz game, that problem does not apply to other didactically valuable, ludically viable, and historically realistic Nazi game ideas. What would be wrong with designing the virtual world of Nazi-occupied Poland, France, the Netherlands or Denmark, having players assume the perspectives of Jews caught in the maelstrom, seeking out the few existing loopholes to safety and learning in the process that the vast majority of Jews were increasingly faced with choiceless choices and no hope for rescue? Such a game should be at least as capable of inducing empathy with the victims as the Holocaust movies of past decades which are probably becoming increasingly ineffective as a didactic tool for younger audiences steeped in digital culture. And why stop there? Why not work on a spin-off Aleppo 2016 game which follows the trial and tribulations of Syrian refugees on their way to Europe as the try to escape from Assad, rebel troops, Isis and Russian air strikes and try to overcome global disinterest and prejudice in very much the same way as German Jewry in the summer of 1939. If scripted intelligently such an Aleppo-game would go a long way to expose the depravity of Europe's political elite of 2016 as they tried to shed their Geneva Convention, UN Human Rights Charter and EU Convention on Human Rights obligations. ${ }^{90}$ In fact, it is difficult to imagine any video game about the topic that would be in such poor taste as the 'game' that said politicians have been playing with the

9o In fact, a successful and ethically valuable game that follows the suggested trajectory already exists. That war of mine released by a Polish developer in 2014 lets players experience the struggle for survival of a group of civilians in a fictional besieged Eastern European city. Loosely based on the 1992-96 siege of Sarajewo the game goes a long way in creating empathy with war victims, see Clark, Justin. 2014. "Counting Body like Sheep to the Rhythm of the War Drum," Gamespot, November 17, 2014. Accessed 25January, 2017, https://www.gamespot.com/reviews/this-war-of-mine-review/1900-6415963/. 
lives of millions of refugees whom they have denigrated and sought to contain in overcrowded camps outside the EU.

Simulative interactive narrative worlds exploring past and present crimes against humanity could also offer new, decidedly self-critical perspectives on perpetrator and bystander biographies. Digital game formats seem to be very well suited to have players experience in their own virtual life the slippery slope of the conformism, prejudice and fanaticism that precede genocide. In this fashion, genocide gaming could assume a self-critical quality and teach players, reflecting on their own virtual ethical failures and virtual crimes, how to recognize and counteract the early warning signs of radicalization and indifference. Since gaming with its extraordinary immersive potential offers the ambivalent (and for 'analoguers' very troublesome) experience of being simultaneously inside and outside a given simulative world, a Holocaust game could help overcome a didactic impasse that cosmopolitan Holocaust culture has thus far never been able to solve: it could complicate and possibly undermine the troublesome structural parallels between the passive bystanders of the Holocaust of the 1940 s and the relative passive consumers of official Holocaust culture of the last four decades, a culture that has taught consumers the virtues of remembering the victims (never again genocide $\mathrm{w} / \mathrm{h}$ memory) but provided little meaningful guidance in self-critically engaging with legacies of perpetration and preventing large scale victimization (never again genocide). Given the high stakes involved, the first realistic, fully immersive, interactive and simulative Holocaust game should be developed at the centre of our Holocaust culture, for instance, through a collaboration between the Shoah Foundation, ushm M, Yad Vashem, the Gedenkstättennetzwerk, the Museum of Tolerance and other interested parties. The task is too important and too expensive and has too great a didactic potential to be left exclusively to commercial enterprises or freelance outfits.

In my view, the examples of digital Holocaust culture cited above do not yet demonstrate conclusively that today's gamers, social media users and their technological devices represent a fundamentally different memory species than their electronic forbearers. At the same time, the examples indicate that the users of digital culture put a premium on becoming the narrators of their own memories and escaping the relatively narrow thematic confines of established Holocaust memory, a multi-directional desire they might share with generations of film and television consumers who simply did not have similar cultural agency.

While we are still busy trying to figure out the dynamics of mediatized human collective memories, post-human collective memory is already thriving, for example in the form of self-reflexive AI robotics. Robots are intelligent to 
the extent that they engage in self-reflexive learning, i.e., a kind of social memory leading to a degree of unpredictability and autonomy. AI learning processes and collective memories are modelled after human learning and collective memory but feature new patterns of retention and forgetting that turn AI robots into different memory agents than humans. Ironically, that makes them particularly suitable objects for media reception analysis while their interactions with humans also break the mould of anything that can be reasonably grasped with the methods of reception studies. Hence, a crucial task in the field of robotics consists of developing effective guidelines for roboethics and robot ethics preventing humans from irresponsibly using AI robotics and imbuing robots with robust circuits of self-critical memory in the hope that they will get better at this task than humans ever were. ${ }^{91}$ The response to that challenge will decisively influence the quality of post-human social relations, the future of self-critical memory, and, way down on the list of possible concerns, the need to develop new concepts of memory studies.

\section{References}

“ADL Statement on Quentin Tarrantino's 'Inglourious Basterds'” archive adl.org, 18 August, 2009. Accessed 21 October, 2016. http://archive.adl.org/presrele/ holna_52/5585_52.html\#.V852dBRoU6U.

Ahrens, Yitzhak et al., Das Lehrstück "Holocaust:" Zur Wirkungsgeschichte eines Medienereignisses. Opladen: Westdeutscher Verlag, 1982.

Alexander, Jeffrey. "The Social Construction of Moral Universals," in Remembering the Holocaust: A Debate, edited by Jeffrey Alexander et al. Oxford: Oxford University Press, 2009. 3-101.

Alexander, Jeffrey. Cultural Trauma: A Social Theory. Cambridge: Polity, 2012.

Athique, Adrian. Transnational Audiences: Media Reception on a Global Scale. Cambridge: Polity, 2016.

Bodnar, John. The "Good War" in American Memory. Baltimore: Johns Hopkins University Press, 2010.

Bolden, Tonya. How to Build a Museum: Smithsonian's National Museum of African American History and Culture. New York: Viking, 2016.

Bourdon, Jerome and Cecile Meadel, eds., Television Audiences Across the World:Deconstructing the Ratings Machine. New York: Palgrave Macmillian, 2014.

91 On roboethics and robot ethics see Gianmarco Veruggio, Fiorella Operto, George Bekey, "Roboethics: Social and Ethical Implications," Bruno Siciliano and Oussam Khatib (eds.), Handbook of Robotics (Berlin: Springer, 2016), 2135-2160. 
"Bridging the Warning-to-Response Gap." Accessed 22 October, 2016. https://www.youtube.com/watch?v=iDNshd6yOns\&feature=youtu.be.

Briggs, Matt. Television, Audiences and Everyday Life. New York: Open University Press, 2010.

Bull, Anna and Hans Hansen. “On Agonistic Memory," Memory Studies 9/4 (2016), 390-404.

LaCapra, Dominick. Writing History, Writing Trauma Baltimore: Johns Hopkins University Press, 2014.

De Cesari, Chiara and Ann Rigney. "Introduction." In Transnational Memory: Circulation, Articulation, Scales, edited by Chiara De Cesari and Rigney. Berlin: DeGryuter, 2014. 1-25.

Chan, Melanie. Virtual Reality: Representations in Contemporary Media. London: Bloomsbury, 2014.

Chapman, Adam. Digital Games as History: How Videogames Represent the Past and Offer Access to Historical Practice. New York: Routledge, 2016.

Chare, Nicholas and Dominic Williams. Matters of Testimony: Interpreting the Scrolls at Auschwitz. New York: Berghahn, 2016.

Crecente, Brian. "Anti-Defamation League Slams 'Fun' Holocaust Video Game as Horrific and Inappropriate." Kotaku, 11 December, 2010. Accessed 21 October, 2016. http://kotaku.com/5712163/anti-defamation-league-slams-fun-holocaust-video -game-as-horrific-and-inappropriate.

DarkWolfLetsPlay. “08:46/9/11 Terrorist Attack Oculus Rift Game.” YouTube, 19 October, 2015. Accessed 21 October, 2016. https://www.youtube.com/watch?v=vd2_j8dsOsM.

Dassanowsky, Robert, ed., Quentin Tarantino's Inglourious Basterds: A Manipulation of Metacinema. New York: Continuum, 2012.

Day, Eric. "Why We Don't Have a Holocaust Video Game and Why We Desperately Need One." overmental.com, 5 May, 2014. http://overmental.com/content/why-wedont-have-a-holocaust-video-game-and-why-we-desperately-need-one-1303.

“Die Internetseite 'Kinder im Ghetto:' Kommentare für Lehrer." Yad Vashem, http:// ghetto.galim.org.il/ger/about/lessons.html. Accessed 22 October, 2016.

van Dijck, José. The Culture of Connectivity: A Critical History of Social Media. Oxford: Oxford University Press, 2013.

“Don't Stand By: Holocaust Memorial Day 2016: What You Can Do," http://hmd.org. uk/sites/default/files/HMD_files/dont_stand_by_-_final.pdf. Accessed 22 October, 2016.

“Don't Stand By: Holocaust Memorial Day 2016: Lesson Activity: British Heroes of the Holocaust," http://hmd.org.uk/sites/default/files/british_heroes_of_the_holocaust _resource.pdf. Accessed 22 October, 2016.

Dörner, Ralf, Stefan Göbel, Wolfgang Effelsberg and Josef Wiemers, eds., Serious Games: Foundations, Concepts and Practice. Cham: Springer, 2016. 
Ernst, Wolfgang. Digital Memory and the Archive. Minneapolis: University of Minnesota, 2013.

Eyerman, Ron. Cultural Trauma: Slavery and the Formation of African American Identity. Cambridge: Cambridge University Press, 2001.

Fearn, Andy, "НмDт Eteach: A new interactive, multimedia resource to support educators in teaching effectively about the Holocaust and subsequent genocides," (paper presented at the BAHS Conference 2016, UCL, 20 July, 2016).

Fogu, Claudio. “A 'Spatial Turn' in Holocaust Studies?” In Probing the Ethics of Holocaust Culture, edited by Claudio Fogu, Wulf Kansteiner and Todd Presner. Cambridge MA: Harvard University Press, 2016. 218-239.

"For Educators," Holocaust Memorial Day Trust, http://hmd.org.uk/content/for-educators. Accessed 22 October, 2016.

Frazier, Kai M., Twitter post, 24 May, 2016, https://twitter.com/hashtag/preventgenocide. Accessed 22 October, 2016.

Frei, Norbert. "Zum erneuten Dienstjubiläum der 'Achtundsechziger': Generation Sündenstolz," Neue Züricher Zeitung, 3 August, 2008.

Friedländer, Saul. Years of Extermination: Nazi Germany and the Jews, 1939-1945. New York: Harper Perennial, 2009.

Garde-Hansen, Joanne, Andrew Hoskins and Anna Reading, eds., Save As ... Digital Memory. Basingstoke: Palgrave Macmillan, 2009.

Gold, Riva. "Designers Pull Plug on Auschwitz Death Camp RevoltVideo Game." Haartz. com, 26 December, 2010. Accessed 21 October, 2016. http://www.haaretz.com/ jewish/designers-pull-plug-on-auschwitz-death-camp-revolt-video-game-1.333022.

Goldberg, Amos and Haim Hazan, eds., Marking Evil: Holocaust Memory in the Global Age. New York: Berghahn, 2015.

Gray, Michael. Contemporary Debates in Holocaust Education. New York: Palgrave, 2014. Hansen-Glucklich, Jennifer. Holocaust Memory Reframed: Museums and the Challenges of Representation. New Brunswick: Rutgers University Press, 2014.

Harrigan, Pat, Matthew Kirschenbaum and James Dunnigan, eds., Zones of Control: Perspectives on Wargaming. Cambridge, MA: MIT Press, 2016.

Hayton, Jeff. "Beyond Good and Evil: Nazis and the Supernatural in Video Games." In Revisiting the "Nazi Occult:" Histories, Realities, Legacies, edited by Monica Black and Eric Kurlander. Rochester: Camden House: 2015. 248-269.

Hilberg, Raul. The Politics of Memory: The Journey of a Holocaust Historian. Ivan Dee, 1996.

“HMD 2016: Lesson Plan: Didn't Stand By," http://hmd.org.uk/education/hmd-2016 -lesson-plan-didnt-stand. Accessed 22 October, 2016.

Hoskins, Andrew. "Digital Network Memory," in Mediation, Remediation and the Dynamic of Cultural Memory, edited by Astrid Erll and Ann Rigney. Berlin: De Gruyter, 2009. 91-106. 
Hoskins, Andrew. "The Right to be Forgotten in Post-Scarcity," in , The Ethics of Memory in a Digital Age: Interrogating the Right to be forgotten, edited by Alessia Ghezzi et al. New York: PalgraveMacmillian, 2014. 50-64.

Hoskins, Andrew. "The Restless Past: An Introduction to Digital Memory and Media," in Digital Memory Studies: Media Pasts in Transition, edited by Andrew Hoskins. New York: Routledge, forthcoming.

Hume, Janice. Popular Memory and the American Revolution. New York: Routledge, 2014. Huntemann, Nina and Matthew Payne, eds., Joystick Soldiers: The Politics of Play in Military Video Games. New York: Routledge, 2010.

"Imagination Is The Only Escape." Indiegogo.com. Accessed 21 October, 2016. https:// www.indiegogo.com/projects/imagination-is-the-only-escape\#/.

"International School for Holocaust Studies: Learning Environments." Yad Vashem. http://www.yadvashem.org/yv/en/education/learning_environments/index.asp. Accessed 22 October, 2016.

"Interview with Anne Knowles, Tim Cole, Alberto Giordano, and Paul Jaskot." In Probing the Ethics, edited by Claudio Fogu, Wulf Kansteiner and Todd Presner. Cambridge MA: Harvard University Press. 240-256.

“IWitness Video Challenge: Top Videos by Groups - 2016." University of Southern California. http://iwitness.usc.edu/SFI/IWitnessChallenge/Winners.aspx?y=2016 Accessed 22 October, 2016.

Jinks, Rebecca. Representing Genocide: The Holocaust as Paradigm? London: Bloomsbury, 2016.

Justin, Clark. "Counting Body like Sheep to the Rhythm of the War Drum," Gamespot, November 17, 2014. Accessed 25 January, 2017. https://www.gamespot.com/reviews/ this-war-of-mine-review/190o-6415963/.

Kaiser, Wolfram. "Limits of Cultural Engineering: Actors and Narratives in the European Parliament's House of European History Project," Journal of Common Market Studies 55/3 (2017), 518-534.

Kansteiner, Wulf. In Pursuit of German Television: History, Television, and Politics after Auschwitz. Athens, он: Ohio University Press, 2006.

Kansteiner, Wulf. "Macht, Authentizität und die Verlockungen der Normalität: Aufstieg und Abschied der NS-Zeitzeugen in den Geschichtsdokumentationen des ZDF." In Die Geburt der Zeitzeugen nach 1945, edited by Martin Sabrow and Norbert Frei. Göttingen: Wallstein, 2013. 320-353.

Kansteiner, Wulf and Todd Presner. "Introduction: The Field of Holocaust Studies and the Emergence of Global Holocaust Culture," in Probing the Ethics of Holocaust Culture, edited by Claudio Fogu, Wulf Kansteiner and Todd Presner. Cambridge MA: Harvard University Press, 2016. 1-42.

Kappell, Matthew and Andrew Elliott, eds., Playing with the Past: Digital Games and the Simulation of History. New York: Bloomsbury, 2014. 
Kempshall, Chris. The First World War in Computer Games. New York: Palgrave Macmillian, 2014.

Kline, Daniel, ed., Digital Gaming Re-imagines the Middle Ages. London: Routledge 2014. Knowles, Anne, Tim Cole and Alberto Giordano, eds., Geographies of the Holocaust. Bloomington: Indiana UP, 2014.

"KZ Manager." Wikipedia, last updated 21 October, 2016. Accessed 21 October, 2016. https://de.wikipedia.org/wiki/KZ_Manager.

Lentin, Ronit. Co-Memory and Melancholia: Israelis Memorialising the Palestinian Nakba. Oxford: Oxford University Press, 2010.

Levy, Daniel and Nathan Sznaider. The Holocaust and Memory in the Global Age. Philadelphia: Temple University Press, 2006.

Lichtblau, Eric. “The Holocaust Just Got More Shocking”, New York Times, 1 March, 2013. Accessed 23 October, 2016, http://www.nytimes.com/2013/o3/o3/sunday-review/ the-holocaust-just-got-more-shocking.html?src=me\&ref=general\&_r=1.

"Life Stories," http://hmd.org.uk/resources/life-stories. Accessed 22 October, 2016.

Loh, Christian, Yanyan Sheng and Dirk Ilfenthaler. "Serious Games Analytics: Theoretical Framework." in Serious Games Analytics: Methodologies for Performance Measurement, Assessment, and Improvement, edited by Christian Loh, Yanyan Sheng and Dirk Ifenthaler. Cham: Springer, 2015 . 3-29.

Luke K. "WWII Games:Where is the Holocaust." Critical Gamer, 17 January, 2011. Accessed 21 October, 2016. http://www.criticalgamer.co.uk/2011/o1/17/wwii-games-where-is -the-holocaust/.

McWherto, Michael. "Concentration Camp Game Was Meant To Be Fun." Kotaku, 10 December, 2010. Accessed 21 October, 2016. http://kotaku.com/5711317/concentration -camp-game-was-meant-to-be-fun.

Meyers, Oren, Eyal Zandberg and Motti Neiger, eds., Communicating Awe:Media Memory and Holocaust Commemoration. New York: Palgrave Macmillian, 2014.

Moses, Dirk. "Conceptual Blockages and Definitional Dilemmas in the 'Racial Century:' Genocides of Indigenous Peoples and the Genocide." In Colonialism and Genocide, edited by Dirk Moses and Dan Stone. Routledge: New York, 2007. 148-180.

"Museum Announces \$20 Million Gift to Name the Simon-Skjodt Center for the Prevention of Genocide." Usнmm, 19 February, 2015. Accessed 22 October, 2016. https:// www.ushmm.org/information/press/press-releases/museum-announces-20 -million-gift-to-name-the-simon-skjodt-center-for-the-pr.

"New Dimension in Testimony - USC ICT and sfi Classroom Concept." 8 February, 2013. Accessed 24 October, 2016. http://www.youtube.com/watch?v=AnF63otCiEk.

Niven, Bill. "German Victimhood Discourse in Comparative Perspective," in Dynamics of Memory and Identity in Contemporary Europe, edited by Eric Langenbacher, Bill Niven and Ruth Wittlinger. New York: Berghahn, 2012. 180-194. 
Ochman, Ewa. Post-Communist Poland: Contested Pasts and Future Identities. New York: Routledge, 2013.

Olick, Jeffrey. The Sins of the Fathers: Germany, Memory, Method. Chicago: University of Chicago Press, 2016.

Parikka, Jussi. A Geology of Media. Minneapolis: University of Minnesota Press, 2015.

"Partners in Prevention: A Global Forum on Ending Genocide." us Hm M. Accessed 22 October, 2016. https://www.ushmm.org/confront-genocide/speakers-and-events/ all-speakers-and-events/partners-in-prevention-a-global-forum-on-ending -genocide.

Plygon. "The New Order shows you the horror of concentration camps from the first person.” YouTube, 19 May, 2014. Accessed 21 October, 2016. https://www.youtube .com/watch?v=DbQ3H6lEWDE.

Pogacar, Martin. Media Archeologies, Micro-Archives and Story-Telling: Re-Presencing the Past. Basingstoke: Palgrave Macmillan, 2016.

Presner, Todd. "The Ethics of the Algorism: Close and Distant Listening to the Shoah Foundation Visual History Archive." In Probing the Ethics of Holocaust Culture, edited by Claudio Fogu, Wulf Kansteiner and Todd Presner. Cambridge MA: Harvard University Press, 2016. 175-202.

Ritterfeld, Ute, Michael Cody, Peter Vorderer, eds., Serious Games: Mechanisms and Effects. New York: Routledge, 2009.

Robertson, Adi. "The virtual reality $9 / 11$ experience is bad, but not for the reasons you'd expect." The Verge, 30 October, 2015. Accessed 21 October, 2016. http://www .theverge.com/2015/10/30/964279o/virtual-reality-9-11-experience-empathy.

Rogers, Richard. Digital Methods. Cambridge, MA: MIT Press, 2013.

Rothberg, Michael. Multidirectional Memory: Remembering the Holocaust in the Age of Decolonization. Stanford: Stanford UP, 2009.

Rothe, Ann. Popular Trauma Culture: Selling the Pain of Others. New Brunswick, 2011.

Rüsen, Jörn. Historik: Theorie der Geschichtswissenschaft. Cologne: Böhlau, 2013.

Rutten, Ellen, Julie Fedor and Vera Zvereva, eds., Memory, Conflict and New Media: Web Wars in Post-Socialist States. New York: Routledge, 2013.

Rössler, Patrick, ed., The International Encyclopedia of Media Effects. Walden: Wiley, 2017.

Shandler, Jeffrey. While America Watches: Televising the Holocaust. Oxford: Oxford University Press, 1999.

Sierp, Aline. History, Memory, and Trans-European Identity: Unifying Divisions. New York: Routledge, 2014.

"Slave Trade Video Game Edited After Backlash." Huffington post, 3 September, 2015. Accessed 21 October, 2015. http://www.huffingtonpost.com/entry/slave-trade-game -edited-following-backlash_us_55e8489be4bob7a9633bdc73. 
"Sonderkommando Revolt Wolfenstein 3D mod." Last updated 13 December, 2010, http://www.moddb.com/mods/sonderkommando-revolt. Accessed 21 October, 2016.

Stauber, Roni, ed., Collaboration with the Nazis: Public Discourse after the Holocaust. New York: Routledge, 2011.

Stuart, Sophia. "How Natural Language Tech, Holograms Are Preserving Holocaust Testimony." pcmag.com, 8 April, 2016. Accessed 24 October, 2016. http://www.pcmag .com/article/343452/how-natural-language-tech-holograms-are-preservingholocaus.

Takashi, Dean. "Brenda Romero's Train board game will make you ponder." venturebeat. com, 11 May, 2013. Accessed 21 October, 2016. http://venturebeat.com/2013/05/11/ brenda-romero-train-board-game-holocaust/.

“Teaching Resources." Holocaust Educational Trust, http://www.het.org.uk/teachingpack. Accessed 22 October, 2016.

"Teacher Resources: Educating Hearts and Minds." Museum of Tolerance, http://www .museumoftolerance.com/site/c.tmL6KfNVLtH/b.5052463/k.AE91/Teacher_Resources.htm. Accessed 22 October, 2016.

"The International School for Holocaust Studies: Education Materials." Yad Vashem http://www.yadvashem.org/yv/en/education/index.asp. Accessed 22 October, 2016.

"UN Commission of Inquiry on Syria: ISIS is committing genocide against the Yazidis." United Nations Human Rights Office of the High Commissioner, 16 June, 2016. Accessed 22 October, 2016. http://www.ohchr.org/en/NewsEvents/Pages/DisplayNews .aspx?NewsID=20113\&LangID=E.

"UN: Yezidi 'genocide has occurred and is ongoing?." Rudaw, 16 June, 2016. Accessed 22 October, 2016. http://rudaw.net/english/middleeast/16o62016.

Unterman, Phoebe. Through Eva's Eyes. Kansas City: Landmark, 2009.

"Using Social Media in Holocaust Education." International Holocaust Remembrance Alliance, April 2014. Accessed 22 October, 2016. https://www.holocaustremembrance.com/media-room/stories/new-social-media-guidelines.

UsнmM's Facebook page, https://www.facebook.com/holocaustmuseum/. Accessed 23 August, 2016.

Veruggio, Gianmarco, Fiorella Operto and George Bekey, "Roboethics: Social and Ethical Implications." In Handbook of Robotics, edited by Bruno Siciliano and Oussam Khatib. Berlin: Springer, 2016. 2135-216o.

Waddell, Kaveh. "A Video Game That Lets You Torture Iraqi Prisoners." theatlantic.com, 1 August, 2016. Accessed 21 October, 2016. http://www.theatlantic.com/technology/ archive/2016/o8/a-video-game-that-lets-you-torture-iraqi-prisoners/493379/.

Weller, Katrin et al. Twitter and Society. New York: Peter Lang, 2013. 
Wilke, Claus. “Die Fernsehserie 'Holocaust' als Medienereignis," Zeitgeschichte-online, March 2004, http://www.zeitgeschichteonline.de/md=FSHolocaust-Wilke.

Winnerling, Tobias and Florian Kerschbaumer, eds., Early Modernity and Video Games. Newcastle: Cambridge Scholars, 2014.

Worcman, Karen and Joanne Garde-Hansen. Social Memory Technology: Theory, Practice, Action. New York: Routledge, 2016.

Yahil, Leni. The Holocaust. New York: Oxford UP, 1990.

Zertal, Idith. Israel's Holocaust and the Politics of Nationhood. Cambridge: Cambridge University Press, 2005. 
-978-90-04-35235-3

Downloaded from Brill. com $04 / 26 / 2023$ 03:12:38PM via free access 


\section{Index}

Active European Remembrance $\quad 28$

Áder, János 47

Agents of change $123,137-143$

Amnesia $\quad 170,172,179,185,188,189$

Anámnesis (memory) 171, 179, 185, 192, 193

Anders, Günther 204

Antagonistic memories 188

Antisemitism 174, 176-178, 183-186

Anti-war 226, 227, 230

Arab Spring $\quad 33,40,42,44,48,49$

Archive $\quad 255^{-256}$

Audiovisual archive $\quad 255$

Arendt, Hanna 204

Arousal 286, 288, 293, 295-301

Astrakhan, Dmitry $\quad 206$

Austria-Hungary $\quad 85-87,90-92,94$

Auswärtiges Amt [German Foreign

Office] $\quad 36-40,49$

Behavioural tendencies $\quad$ 286, 298, 301

Belarus 63

Berlin Wall 72,73

Bleiburg 272, 274, 276-277, 281, 288, 292

Blog 255, 256, 260-262

Blumenberg, Hans 204

Bogdanović, Bogdan $\quad 276,278-279$

Brunow, Dagmar 241, 255

Bundesbeauftragte für die Unterlagen des

Staatssicherheitsdienstes der ehemaligen DDR (BStU) [Federal Office for the Files of the State Security Service of the Former GDR ] 33-36, 38-41, 48-50

Burial (see also funeral) 107-109, 111-113, ${ }_{116-118}$

Capitalism 224, 226, 228, 229

Carlsten, Jennie M. 201

Carnival 215

Causes of war (WW1) 85, 89, 90, 92, 95, 96, 98,99

Censorship 224

Central and Eastern Europe (CEE) 56, 58, $61-64,69,70,71-74,77$

Cercas, Javier 231

Četniks, 268, 272, 276, 290
Civil rights activists $\quad 39,40,49$

Claims for recognition $\quad 58,62-64,68,69$, 71,75

Clark, Christopher $\quad 83-84,89-99$

Cold War 57, 69, 73, 74, 76, 149, 150-152, 156, 16o, 163-165, 202, 224, 225, 230, 235

Cold War commemoration $\quad 150,151,155$, 161-165

Cold War heritage $\quad 153,156,157,159,164$, 165

Cold War memory $\quad$ 150, 151, 161, 162, 164

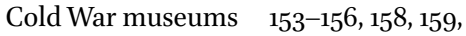
164,165

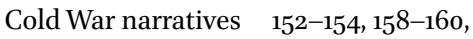
163-165

Collaboration $\quad 27-38,40-51$

Collaborative memory $\quad 31,51-5^{2}$

Collective identity $\quad 56-58,60-62,64,65,69$, $72,76-78$

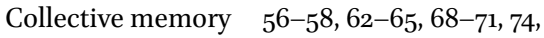
$76,77,171,192,223,233,237,242$

Collective remembrance $268,269,272$, 276, 301

Commemoration $\quad 149,155,161,162,164,165$, 171-173, 175, 184, 186, 192, 225, 270, 272, $274-276,280,283$

Communism 28, 33, 47, 56, 57, 61-64, 66, $67,72-76$

Communist 220-223, 228, 230, 235

Communist concentration camps 232,233

Communist crimes $\quad 65,66,71$

Communist Party 220, 226

Communist totalitarianism $\quad 71$

Communist vision of the past 170 , 173,174

Componential process model (CPM) $\quad 285$, 300

Consensus 105, 110, 112

Contre l'oubli [Against Forgetting] 37, 45, 49

Convergence culture 244

Copper Country $\quad 245^{-247}$

Copper Country Strike $\quad 246,247$

Co-operation $\quad 30-34,41,43-51$

Cosmopolitan memory culture $\quad 305-306$ 
Counter-discourses $\quad 107,108,113,114,117$

Counter-factual war memory $\quad 150,151,153$, $155^{-157,164,165}$

Counter-factuality $155,156,164$,

Creative archive 255

Croatia 268, 273, 275-281, 283, 285, 288, 292, 297,301

Cultural customs $\quad 112$

Cultural memory $113,150,154,158,161,164$, 200, 220, 230, 237

Cultural trauma 307

Czech Centre (Berlin) 39, 40, 50

Dark heritage, see Heritage sites

De-Communisation $\quad 64,65$

Dedijer, Vladimir 91

Desaparecidos 115

Deutschlandfunk 37,40

Diasporic genealogy 254

Dick, Stephen J. 203

Digital archive $\quad 255$

Digital diaspora 253

Digital memory studies $\quad 316-317$

Dignification/Dignity $108,113,115,118$

Double victims $\quad 123,137-143$

Egyptian government 39,40

Eider (German cargo ship) 220

Embodied cognition $\quad 271,301$

Emergent digital memory culture $\quad 315$

Emotions $\quad 285,289,296-297,300$

Erll, Astrid $\quad 223,237$

Estonian memory narrative $\quad$ 122-123

Estonian Migrants 127

E U enlargement $\quad 57,61,63,67-69$

European

European Commission $\quad 71,75$

European Conservatives and Reformists

Group (ECR) 68, 69

European identity $61,70,72,77$

European memory $\quad 28-30,32-33,41$, $45^{-46,50}$

European Parliament (EP) 58, 66-77,

European public sphere 63

European Union (EU) 6o-62, 66-73, $75^{-78}$

Europeanization $\quad 63,64$

Exhumations 106-109, 111-118

Expelled memory $\quad 173,174$
Facebook 248, 254, 256-257, 261, 262, 322

Falangists 224

Family history (see also family memories) 254, 259

Family memories (see also family history

and family stories) 259-263

Family stories (see also family memories) $260-261$

Fascism 222, 224, 228, 232, 235

Fedorchenko, Alexey 199, 206-208, 212-216

Film reception 199, 201

Film review 200, 208-209, 213

Finns in the United States $245^{-246}$, 254, 263

First World War $\quad 83,84-87$

'Flyer case' 220, 229

Franco regime 224, 231, 234, 235

Franz Ferdinand $\quad 83,88,90,91$

Freud 227

Funeral (see also burial) 109-112

Gauck, Joachim 41, 47

Gavrilo Princip $\quad 87-88,98$

Gdańsk 73

Gdańsk shipyard $\quad 75^{-76}$

Gdynia shipyard 75

Gedenkstätte Berlin-Hohenschönhausen

[Memorial Berlin-Hohenschönhausen] $30,3^{2}-41,43^{-} 5^{0}$

Genocide 69

Geppert, Alexander C. T. 203

German Democratic Republic (GDR)/East

Germany $30,32-33,40,44,48-50$

German Foreign Office $\quad 36-40,49$

German, Alexey jr. 206

Germany $31,33,36,39,44,45,47-49$, 51,66

Grass-root 108, 114

Greek transition $\quad 115^{-117}$

Gross, Jan T. 65

Group of European People's Party (Christian Democrats) and European Democrats (EPP-ED) 68, 69, 72

Group of the Alliance of Liberals and Democrats for Europe (ALDE) 68,69

Group of the Party of European Socialists (PES) 68, 69, 71

Gunnlaugsdóttir, Álfrún $\quad 222,232-235$

Guthrie, Woody $\quad 244,249,251,257$ 
Harrison, Albert A. 203

Hedonic valence $\quad 286,296-297$

Heritage $150,151,156,243,263$

Heritage sites $\quad 25 \mathbf{1}^{-253}$

Histoires croisées $\quad 31$

Historical memory 231

Historical trauma 190, 193

History books 84, 88, 90-93, 99

History making, see Social process of history making

Holocaust $\quad 28,29,31,63,66,69,155,163,164$

Holocaust discourse $\quad 179-180,181$, 188-190, 193

Holocaust Memorial Day Trust 317

Holodomor 69

Homeland War (Croatian War of

Independence) $\quad 268,269,273,286$

Hoskins, Andrew 315

House of Terror 47

Hypermemory 189

Iceland $\quad 222-237$

Icelandic politics $\quad 222,225,228,230,236$

Identity $178,179,181,186,190-193$

Imagination is the only Escape 312

Impact 12

Independence and Democracy Group

(Ind/DEM) 68, 69

Independent State of Croatia ( $\mathrm{NDH}$ ) $270,272-275,280-281,292$

Infrapolitics 112

Instytut Pamięci Narodowej (IPN - the

Institute of National Rememberance) 66

International Brigades $220,225,226,228$, 231, 234, 237

Internet technology $\quad 242,244$

Iraq war $15^{2}$

Iron Curtain $\quad 56,73,75$

Jagiellonian Commonwealth $\quad 56,67$

Jasenovac 270, 272-283, 285, 293, 297-298, 300-301

Jenkins, Henry $\quad 244,262$

Jews 63,65

Katyń massacre $\quad 63,70,72$

Knabe, Hubertus $\quad 3^{2}$

Knjiga o Milutinu [The book about Milutin] $\quad 88,89$
Konrad Adenauer Stiftung (KAS) [Konrad Adenauer Foundation] $\quad 36,37$

Kosmos kak predchuvstviye [Dreaming of Space] 206-212

Kötlum, Jóhannes úr $\quad$ 225-229, 233, 235

Kroes Neelli 75

KZ Manager 314

Lacan, Jacques 204

Laguerre, Michael S. 253

Lathers, Marie 203

Left-wing $\quad 220,222,224,228,235$

Lieu de mémoire / Lieux de mémoire (see also site of memory) 31, 52, 150, 154, 164

Liga Polskich Rodzin (LPR - League of Polish Families) $\quad 67,68,69$

Literature 226, 232-235, 237

Lithuania 63

Living history 142

Llinares, Dario 203

Local $\quad 106-109,111-113,116-118$

Long term effects p. 12

Lustration $\quad 66,67$

Mass graves 104-109, 113-117

Mazowiecki, Tadeusz 64

McCurdy, Howard E. 203

McGarry, Fearghal 201

Media 106, 114, 140-142, 231

Mediation 230, 231, 233-235

Memorial 220, 236, 237

Memorial culture 233, 237

Memorial dynamics $\quad 220,234$

Memory

Memory (personal) 222, 227, 230-233, 235, 237

Memory as anámnesis $\quad 171,179,185,192$, 193

Memory as mnéme $\quad 171,179,192$

Memory boom 234, 235, 236

Memory entrepreneurs $38,40-46,5^{1}$

Memory narrative $\quad$ 200-202, 212, 214

Memory of Communism $\quad 56-57,5^{8}$

Memory practice 200

Memoryscape $\quad 171-172,175,176,180,183,185$, $186,188,192,193$

Migrant Memory $\quad 125,132-134$

Migrants $125^{-127,132-134}$ 
Milanović, Zoran $\quad 283-283,287-289$, 291-292, 294-298, 300-301

Military 222, 223, 227, 228, 230, 233

Mnéme (memory) 171, 179, 192

Mnemonic community $177,180,192$

Monument 236, 237

Mourning 112, 113, 116, 118

Muller, Leifur 232

Multidirectional memory $27,52,150,322$

Museums 150, 151, 154

Narrative $\quad 27,28,30,32,42-52,150-152,154$, $156,221,227,228 \mathrm{n}, 233,234,237$

Nash, Catherine 254

National memory $225,235,236,242$

National memory (Iceland) 225, 235, 237

Nationalism, 170, 171, 174, 175, 189, 191-194

Nazi 232, 233

Nazi (German) occupiers $\quad 63,65$

Nazi crimes $\quad 66,69,71$

Nazi occupation 64

Nazi regime $\quad 57,69$

Nazi totalitarianism $\quad 71,72$

Nazism $\quad 72$

Necropolitics 115

Neutrality 223, 227

Newspapers 220, 222, 224, 234, 235

Nikolić, Tomislav $\quad 83-84,89-99$

Normative appraisal $\quad 286$

Nungesser, Verena Susanna 200

Oblivion 105

Occupation of Iceland 220, 223, 225-230, $233,235,237$

Odin (Norse god) 226, 227

Olgeirsson, Einar 222

Online communities and groups $\quad 253,254$

Online memory $243,254,256,259-262$

Pacifism 223, 226, 228, 229

Pact of Silence (see also silence) $\quad$ 105-107, 112,113

Participatory culture 244

Partisans 68, 72, 75, 89, 90, 92, 224, 225, 228, 230, 235

Personal memories $\quad 222,227,230-233,235$, 237

Pervye na Lune [First on the Moon] 206-208, 212-216
Petranović, Branko 91

Platform of European Memory and

Conscience (Platform) 29, 30, 33, 46, 47,49

Platforma Obywatelska (PO - Civic

Platform) $\quad 67,69$

Poland $56-58,63-77$

Poles 56, 57, 63, 73

Polish collective identity 57,64

Political symbols 110, 111

Politics 221, 228, 232

Politics of memory 193

Politics of recognition $\quad 59^{-61}$

Polskie Stronnictwo Ludowe (PSL - Polish

People's Party) 68

Polycentric memory 188

Popović, Danko 88

Portelli, Alessandro $\quad 262$

Post-memory 124-125

Post-traumatic stress disorder (PTSD) $\quad 232$

Postwar 225, 233

Prawo i Sprawiedliwość (PiS - Law and Justice) $\quad 65-69$

Premediated 84, 93, 98, 99

Premediation $\quad 10-11,84$

Pretext for war (WW1) 89-93, 94

Private memory 242

Progressing threshold of shame $\quad$ 186-188, 193

Prosthetic memory 258

PTSD (post-traumatic stress disorder) $\quad 232$

Public memory 242

Radauš, Vanja $\quad 276$

Rasmussen, Anders Fogh $\quad$ 152, 160

Reaction 271, 276, 277, 286, 291

Reappropriation / Reappropriated 153, 156, $157,160,163-165$

Reception $\quad 3-7,99,123-124,126-127,135^{-137}$, 151, 158, 159, 198-2001, 204, 207-208, 218, 222-223, 270, 276, 291-292, 294, 301

Recognition $\quad 58-64,68-78$

Recollection $\quad 171,172,176,179,183,185$

Reconciliation 105, 115

Reconstructed memory $\quad 173,175$

Redistribution $\quad 60-61,68,75$

Regained memory $\quad 173,175$

Regime of truth 114

Regimented memory culture 315

Religion or Religious $\quad 111,112,116$ 
Remains 106-109, 112-114, 116, 117

Remediation / Remediated 7-9, 84, 85, 89, 90, 92, 98, 99, 154, 155, 161, 200

Remediation of narratives 200

Remembrance $171,172,174,175,186,189,192$, 225, 232, 236

Repressed memory 173,174

Resistance (see also transgression) 109, 112, 116,118

Right-wing $\quad 223-225,234,235$

Rigney, Ann 220, 228, 233, 237

Rituals 112, 118

Rogachevski, Andrei 203

Roman Catholicism 56

Roscosmos 206

Round Table accords $\quad 65$

Russia 70

Russian cinema 199, 205, 208

Sæborg fishing boat 221

Samoobrona RP (SRP - Self-defence) 67

Sanader, Ivo 280

Savić, Milunka 95

School books (history) 87

Second World War 56, 57, 61, 65-67, 69-73, $149,150,15^{2}, 154-157,160,161,163,165$, 223, 226, 227, 229, 233-236, 268-270, 272-273, 275-277, 280, 298

Second World War commemoration $\quad 155$, 161 ,

Second World War memory $\quad 156,164$,

Second World War museums 154,155 , 158

Security policy 223

Self-critical memory $\quad 307-309$

Serbia 83-99

Shukaitis, Stevphen $\quad$ 202-203

Siddiqi, Asif A. 202

Silence or Silencing (see also Pact of Silence) $113-115,117,118$

Site of memory (see also Lieu de mémoire) 85

Sleepwalkers: How Europe went to war in 1914 83, 93-95

Slovak Institute (Berlin) $\quad 39,40,5^{0}$

Social media, see Internet technology

Social memory $\quad 171,172,192$

Social network analysis 30, 33, 35

Social network Sites, see individual site names
Social process of history making $\quad 241$

Socialist Party (Iceland) 222

Soldados de Salamina [Soldiers of Salamis] 231

Soldiers 220, 221, 223, 226-229, 236, 237

Solidarity (Solidarność) Movement in

Poland $65,72,73,74$

Soviet

Soviet Communism $\quad 57,63,69,70,71$

Soviet narratives $\quad 205^{-206,216-217}$

Soviet occupiers $\quad 63,65$

Soviet repression $\quad 122,126,128-132$

Soviet science fiction $\quad 205$

Soviet Union 225

Space age 198, 202, 217

Space age narratives $\quad 202,217$

Spain 221, 223-226, 231, 232, 235

Spanish Civil War 104, 109, 114, 220-224, 226-228, 231-233, 235

Spanish politics 224

Spanish transition $\quad 105,107-109,111-115,117$

Spontaneous archives $\quad 255,256$

Srb 272-273, 276

State Security Service of the Former GDR

(Stasi) 30, 32, 33, 44, 46, 49

Structural trauma 190, 193

Survivor holograms 321

Swastika 220

Syria $322-323$

Szczecin shipyard $\quad 75^{-76}$

Textbooks (history) 84, 88, 90-93, 99

The West 56,64

Thick line 64

Thompson, Kristin 199

Totalitarianism 68-71

Trade 223-225, 235

Transcultural memory $\quad 14-16,241-242$

Transgression or Transgressive (see also resistance) 112, 118

Transition 105, 107-109, 111-117

Transnational $27,29,30-35,37,38,41,43$, 47, 49, 51, 52, 114, 117, 118, 223, 233, 235

Transnational memory $\quad 27,29-32,41,52$, $223,225,233-235,241-242$

Trauma 178-9, 180, 190-193, 220, 223, 226-227, 231-233, 235

Trauma memorials $\quad 236,237$

Trauma theory $\quad 227$ 
Traumatic experience $\quad 226,227,233$

Traumatic memory 124, 226, 233

Traumatic past 223

Travelling memory $27,52,241-242$

TripAdvisor 252, 253

Tuđman, Franjo $\quad 268,275,277,281$

Tunisian government $37,39,40$

Uchitel', Alexey $\quad$ 199, 206-212

Ukraine $\quad 63,69$

Undir fána lýdveldisins [Under the Republic's flag] 220-223, 225, 230, 237

Unia Wolności (UW - Freedom Union) 68

Union for a Europe of the Nations Group (UEN) 68,70

United States Holocaust Memorial

Museum $\quad 321-322$

USA 56

USC Shoah Foundation $\quad 319-320$

Ustašas $\quad 268-270,272,276,281,289$, 291-293, 298

Velvet Revolution 73

Vermeulen, Angelo 204

Vernacular authority 259

Verndarenglarnir [The Guardian Angels] 225,231

Victimhood 150, 162, 163

Victimization 165 ,

Victims 104-110, 113-118, 155, 162-165, 228, 231, 237

Visible 114, 116, 118
Vučić, Aleksandar $\quad 284,287-289,291-301$

Vukić, Igor $\quad 283-284,288-290,292-298,301$

War (warfare) 220, 221, 227, 228, 230, 232, 234, 235

War commemoration $\quad 149,151,161$, 161n32, 162, 163, 165

War guilt (WW1) 92, 93, 96

War heritage 150

War literature 222, 226, 233

War memorial $\quad 236$

War memory $149,150,155,156,158$, $161-163,165,232-235,237$

War on terror $152,156,160$

War trauma $\quad 220,226,227,231,235$

Web 2.0, see Internet technology

White, Hayden 228

Wolfenstein $3 D$ mod 311

Wolfenstein: The New Order 312

World War I, see First World War

World War II, see Second World War

Wounded memory 173

Yad Vashem 318

Yalta conference 74

Yfir Ebrofljótið [Across the River Ebro] 230, 235

YouTube 247, 255, 257-258, 260

Yugoslavia $86,268,270,272-275,277-278$

Zhuravlev, Vasily $\quad 215$ 